\title{
The Problem of Enforcement in International Law
}

This book explores the contentious topic of how collective and community interests should be protected and enforced in international law. Elena Katselli Proukaki takes a detailed look at the issue of third-state countermeasures, and considers the work the International Law Commission has done in this area. The volume addresses both the theory and practice of third-state countermeasures within international law. Critically reviewing the conclusions of the International Law Commission on the non-existence of a right to third-state countermeasures, it includes consideration of examples of State practice not previously covered in the literature of this topic.

In taking a thorough view of the issues involved the author identifies among others concerns about third-state countermeasures which remain unanswered and considers the possible legal ramifications arising from a clash between a right to third-state countermeasures and obligations arising from other international norms. The Problem of Enforcement in International Law: Countermeasures, the Non-Injured State and the Idea of International Community explores questions evolving around the nature, integrity and effectiveness of international law and the role it is called to play in a contemporary context.

This book is of great interest and value not only for specialists in this area of international law, but also human rights, trade and EU lawyers, practitioners, legal advisers, and students.

Elena Katselli Proukaki is a Lecturer at Newcastle University, UK. 


\section{Routledge Research in International Law}

International Law and the Third World

Reshaping Justice

Richard Falk, Balakrishnan Rajagopal and Jacqueline Stevens

\section{International Legal Theory}

Essays and engagements, 1966-2006

Nicholas Onuf

Forthcoming titles in this series include:

International Economic Actors and Human Rights Adam McBeth

International Organisations and the Idea of Autonomy

Nigel D. White and Richard Collins

Self-Determination in the Post-9/11 Era

Elizabeth Chadwick

The Law of Consular Access

A Documentary Guide

John Quigley, William F. Aceves and Adele Shank

The Law on the Use of Force

A Feminist Analysis

Gina Heathcote 


\section{The Problem of \\ Enforcement in \\ International Law}

Countermeasures, the non-injured

state and the idea of international

community

\section{Elena Katselli Proukaki}


First published 2010

by Routledge

2 Park Square, Milton Park, Abingdon, Oxfordshire OX14 4RN

Simultaneously published in the USA and Canada

by Routledge

711 Third Avenue, New York, NY 10017

Routledge is an imprint of the Taylor $\mathcal{E}^{2}$ Francis Group, an informa business

First issued in paperback 2010

(C) 2010 Elena Katselli Proukaki

Typeset in Baskerville by

Glyph International Ltd.

The Open Access version of this book, available at www.taylorfrancis.com, has been made available under a Creative Commons Attribution-Non Commercial-No Derivatives 4.0 license.

British Library Cataloguing in Publication Data

A catalogue record for this book is available from the British Library

Library of Congress Cataloging in Publication Data

Katselli Proukaki, Elena.

The problem of enforcement in international law : countermeasures, the non-injured state and the idea of international community /

Elena Katselli Proukaki.

p. $\mathrm{cm}$.

ISBN 978-0-415-47832-8

1. Reprisals. 2. Sanctions (International law) 3. Third parties (International law) 4. Intervention (International law) 5. International obligations.

6. Justification (Law) 7. Self-defense. 8. United Nations. International Law Commission. I. Title.

KZ6364.K38 2009

$341-\mathrm{dc} 22$

2009020059

ISBN13: 978-0-415-47832-8 (hbk)

ISBN13: 978-0-415-68552-8 (pbk)

ISBN13: 978-0-203-86556-9 (ebk) 
To my parents, Andrea and Yiannoulla 



\section{Contents}

Acknowledgements xii

List of abbreviations xiii

Table of cases $\quad \mathrm{xv}$

Preface xix

Foreword $\quad \mathrm{xx}$

$\begin{array}{ll}\text { Introduction } & 1\end{array}$

1 The international community, $j u s$ cogens norms and obligations erga omnes

1 Introduction 11

2 Transition from bilateralism to the 'international community

as a whole' 12

2.1 A bilateralist approach 12

2.2 Community interests in contemporary international law 14

3 The concepts of jus cogens and obligations erga omnes 21

3.1 Peremptory norms of international law 21

3.1.1 The legal roots of peremptory norms and state consent 22

3.1.2 The scope, content and legal effect of peremptory norms 25

3.1.3 Treaty execution and indirect violations of jus cogens norms 29

3.2 Obligations erga omnes 33

3.2.1 The Barcelona Traction case 34

3.2.2 Collective interests before international bodies and legal standing for violations erga omnes 37

3.2.2.1 Standing for treaty-based obligations establishing general interests 39

3.2.2.2 The doctrine of indispensable third rights 43 


\subsubsection{Erga omnes claims before international judicial bodies 45 \\ 3.2.2.4 Concluding observations 48}

3.2.3 Scope and content of obligations erga omnes 49

4 Conclusion 52

\section{Community interests in the law on state responsibility}

1 Introduction 54

2 The ILC's mandate to codify the law on state responsibility 56

3 Content of the obligation breached and subjects entitled to invoke state responsibility 58

3.1 Early approaches to responsibility and standing 60

3.2 Approaches to responsibility and standing after World War II 62

4 State crimes in the law on state responsibility 64

5 Countermeasures as enforcement of international law 68

5.1 The progressive development of countermeasures 68

5.2 Conditions and functions of countermeasures 71

5.3 Subjects entitled to resort to countermeasures 73

6 Jus cogens norms, erga omnes obligations and third States in the 2001 Final Articles on State Responsibility 76

6.1 State crimes and serious breaches of peremptory norms 76

6.2 The injured state and states other than the injured 79

6.3 Countermeasures by states other than the injured 85

7 Conclusion 88

\section{Countermeasures in the name of community interests} in state practice

1 Introduction 90

2 Economic measures as a means of coercion 93

3 Foreign policy and human rights 96

4 European community action 99

5 Responses to violations of collective interests in state practice 102

5.1 State action not amounting to countermeasures 103

5.1.1 Soviet action against Israel (1956) 103

5.1.2 The Bonn Declaration (1978) and the hijacking incident (1981) 104

5.1.3 US action against Iraq (1980) 107

5.1.4 Denmark against Turkey (2000) 108

5.2 Countermeasures by states other than the injured in state practice 109 
5.2.1 Slavery and the United States-Great Britain Mixed Commission (1853) 110

5.2.2 Coercive action against Japan (1940-41) 113

5.2.3 US measures against North Korea and China (1950) 114

5.2.4 Organization of American States (OAS) against the Dominican Republic (1960) 114

5.2.5 Action against Greece (1967) 116

5.2.6 The Arab oil embargo (1973) 122

5.2.6.1 An introduction to the Arab-Israeli conflict 122

5.2.6.2 Legality of the oil measures in international law 123

5.2.6.3 Concluding observations 125

5.2.7 Unilateral coercive action against Portugal (1973) 126

5.2.8 US embargo against Uganda (1978) 126

5.2.9 Action against the Central African Republic (1979) 132

5.2.10 US action against Libya (1979) 133

5.2.11 Netherlands' action against Surinam (1980) 133

5.2.12 Action against Liberia (1980) 135

5.2.13 The Soviet invasion in Afghanistan (1980) 135

5.2.14 International reaction to the Teheran hostage crisis (1980) 141

5.2.15 Imposition of martial law in Poland and Soviet involvement (1981) 145

5.2.16 US action against Nicaragua (1982) 152

5.2.17 The Falklands crisis (1982) 156

5.2.18 Non-forcible action against the Soviet Union for the destruction of a civil aircraft in flight (1983) 163

5.2.19 Countermeasures against the apartheid regime in South Africa (1960-64 and 1986) 165

5.2.19.1 Introductory note 165

5.2.19.2 The Indian reaction (1946) 166

5.2.19.3 Reaction of African states 167

5.2.19.4 Calls for the imposition of an oil embargo against South Africa 168

5.2.19.5 US reaction 169

5.2.19.6 Reaction of the Dutch government 173

5.2.19.7 Canadian measures against apartheid 175

5.2.19.8 Other action 176

5.2.19.9 Concluding observations 177

5.2.20 US action against Panama (1988) 177

5.2.21 The Iraqi invasion of Kuwait and EEC response (1990) 178 
5.2.22 EC measures against Haiti (1991) 181

5.2.23 Countermeasures against Yugoslavia (1991) 182

5.2.24 Peaceful coercive measures against Nigeria (1995) 189

5.2.25 Unilateral coercive action against Burundi (1996) 190

5.2.26 US action against Sudan (1997-2005) 190

5.2.27 Coercive action against Burma/Myanmar (1997-2005) 191

5.2.28 Collective action against Mugoslavia (1998) 191

5.2.29 Legal issues arising from extradition agreements (1989 and 1991) 196

5.2.30 Unilateral coercive action against Zimbabwe (2002-2008) 197

5.2.31 US action against Syria (2003-2004) 198

5.2.32 Action against Belarus (2004-2006) 199

5.2.33 The ruling of the ECF in Kadi and Al Barakaat (2008) 199

6 Legal assessment of state practice and opinio juris 201

6.1 Elements of customary rules of international law 202

6.2 Some conclusions from the analysis of state practice 203

7 Conclusion 208

\section{Self-contained regimes, solidarity measures and the fragmentation of international law}

1 Introduction 210

2 Relationship between the law on treaties and the law on state responsibility 212

3 Lex specialis, self-contained regimes and general international law 216

3.1 Application of countermeasures and principles under general international law within self-contained regimes 222

3.1.1 The law on diplomatic immunities 222

3.1.2 The EU as a self-contained regime 222

3.1.3 Human rights treaties 225

3.2 Application of countermeasures and principles under general international law within the WTO 227

3.2.1 The WTO example 227

3.2.2 Legal nature and jurisdiction of the WTO 228

3.2.3 The general and security exceptions under Articles $X X$ and XXI of GATT 238

4 Lex specialis and self-contained regimes in the 2001 Final Articles on State Responsibility 239

5 On the risk of fragmentation of international law 241

6 Conclusion 246 
5 The principle of proportionality

1 Introduction 248

2 The principle of proportionality in the law of the EU 250

3 The concept of proportionality in national law 253

4 Proportionality in jus ad bellum and jus in bello 254

4.1 Introduction 254

4.2 Jus ad bellum 255

4.3 Jus in bello 256

4.4 Proportionality in state practice and judicial review 257

5 Proportionality in the law of countermeasures 260

5.1 In search of international enforcement 260

5.2 Legal constraints of countermeasures 263

5.3 Concept of proportionality in the work of the ILC 265

5.4 Development of proportionality in the law of countermeasures 269

6 A critical assessment of proportionality in the law on countermeasures 276

7 Conclusion 279

Conclusion

Appendix: UN and other documentation

Bibliography

Index 


\section{Acknowledgements}

My grandmother used to tell me that when a door closes it is because a big gate is waiting to open. This book is the result of a big gate that opened in my life and it is the fruit of my doctoral studies at the Department of Law, University of Durham (2002-2005). I owe this opportunity to Professor Colin Warbrick, whom I deeply admire and respect, since it was due to his efforts that the required funding to pursue my doctoral studies was found. I am also most grateful to him for entrusting the research of this fascinating topic to me. The result of this research, short of any omissions or mistakes for which the author is solely responsible, is as much his work as it is mine.

My gratitude also goes to the Law Department of the University of Durham for generously funding my doctoral studies. From this list, I cannot exclude Professor Rosa Greaves, Professor Bob Sullivan, Ms Holly Cullen and Professor Kaikobad for their friendship and support throughout my studies and work at Durham. I further want to thank my internal and external examiners, Professor Kaikobad and Sir Michael Wood, who, with their comments helped improve this work. I would also like to express my appreciation to Mr Dapo Akande and Ms Sarah Williams for their fruitful comments on my thesis, the librarians of Palace Green Library (Durham University), particularly Mrs Anne Farrow, and the librarians of Newcastle Universiy for their valuable assistance, and my friends Dr Zeray Yihdego and Chris and Alisoun Roberts. Finally I would like to thank my publishers, Routledge, and in particular Katherine Carpenter, Khanam Virjee, and Jessica Moody for their support and for bringing this monograph into fruition.

I am also grateful to Newcastle Law School and, in particular, to Mr Ashley Wilton for his continuous support. I am further indebted to Mr Ian Dawson and Dr Nick Proukakis for proofreading this book and to Mrs Avgi Proukaki for her assistance.

The chapter entitled 'Countermeasures: Concept and Substance in the Protection of Collective Interests' appearing in Kaikobad H.K. and Bohlander M., International Law and Power: Perspectives on Legal Order and Justice - Essays in Honour of Colin Warbrick is reproduced with the kind permission of Koninklijke Brill N.V.

Of course, this book would never be feasible without the support, encouragement and unconditional love of my parents, Andrea and Yiannoulla, to whom this book is dedicated, my brother Niko, who is an integral part of my life, my wonderful husband, Nick, whom I adore, and my parents-in-law, Lampis and Avgi. Professor Lampis Proukakis is greatly missed. 


\section{List of abbreviations}

ACP

AJIL

Aus.JIL

AVR

AYIL

BYIL

CLP

GFSP

CYIL

EC

ECom.HR

EConv.HR

ECHR

ECJ

ECR

ECSC

EEC

EHRLR

EJIL

EPC

EPIL

EU

FPRY

FRY

GA

GLJ

HILJ

HLR

HRLJ

HRQ

ICGPR

ICJ

ILC
African, Caribbean and Pacific group of states American Fournal of International Law

Austrian Fournal of International Law

Archiv des Völkerrechts

Australian Fournal of International Law

British Yearbook of International Law

current legal problems

common foreign and security policy

Canadian Yearbook of International Law

European Community

European Commission of Human Rights

European Convention of Human Rights

European Court of Human Rights

European Court of Justice

European Court Reports

European Coal and Steel Community

European Economic Community

European Human Rights Law Review

European Fournal of International Law

European political cooperation

Encyclopedia of Public International Law

European Union

Federal People's Republic of Yugoslavia

Federal Republic of Yugoslavia

General Assembly

German Law fournal

Harvard International Law fournal

Harvard Law Review

Human Rights Law Journal

Human Rights Quarterly

International Covenant on Civil and Political Rights

International Court of Justice

International Law Commission 


\begin{tabular}{|c|c|}
\hline ILM & International Legal Materials \\
\hline IYIL & Italian Yearbook of International Law \\
\hline JAIL & Fapanese Annual of International Law \\
\hline Max Planck YBUNL & Max Planck Yearbook of United Nations Law \\
\hline MJIL & Michigan Fournal of International Law \\
\hline NJIL & Nordic Journal of International Law \\
\hline NYIL & Netherlands Yearbook of International Law \\
\hline NYUJInt'lL\&Pol & New York University fournal of International Law and Policy \\
\hline OAS & Organization of American States \\
\hline PASIL & Proceedings of the American Society of International Law \\
\hline PGIJ & Permanent Court of International Justice \\
\hline RIAA & Reports of International Arbitral Awards \\
\hline $\mathrm{RdC}$ & Recueil des Cours de l'Académie de Droit International \\
\hline SA & South Africa \\
\hline SAYIL & South African Yearbook of International Law \\
\hline $\mathrm{SC}$ & Security Council \\
\hline SFRY & Socialist Federal Republic of Yugoslavia \\
\hline SU & Soviet Union \\
\hline TEU & Treaty of the European Union \\
\hline UN & United Nations \\
\hline UNCLT & United Nations Conference on the Law of Treaties \\
\hline UNYB & United Nations Yearbook \\
\hline UNTS & United Nations Treaty Series \\
\hline USA & United States of America \\
\hline USSR & Union of Soviet Socialist Republics \\
\hline VCLT & Vienna Convention of the Law on Treaties \\
\hline VJIL & Virginia Journal of International Law \\
\hline WCR & World Court Reports \\
\hline WLR & Weekly Law Reports \\
\hline WWI & World War One \\
\hline WWII & World War Two \\
\hline YbECHR & Tearbook of the European Convention on Human Rights \\
\hline YbILG & Tearbook of the International Law Commission \\
\hline ZaoRV & Zeitschrift für ausländisches öffentliches Recht und Völkerrecht \\
\hline
\end{tabular}




\section{Table of cases}

\section{Permanent Court of International Justice}

Case of S.S. Wimbledon, Judgment No. 1, 17 August 1923, Permanent Court of

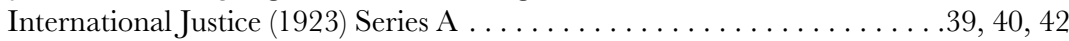

Mavrommatis Palestine Concessions (Greece v Great Britain),

Judgment No. 2, 30 August 1924, Permanent Court of International

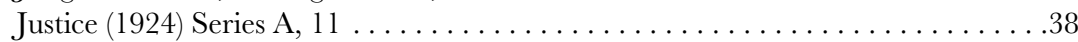

S.S. Lotus case, Judgment No. 9, 7 September 1927, Permanent

Court of International Justice (1927) Series A . . . . . . . . . . 13, 17, 18, 19, 22

Case Concerning the Factory at Chorzow, Jurisdiction, 26 July 1927,

Permanent Court of International Justice (1927) Series A, No. 9 . . . . . . . . . . . 27

Case Concerning the Factory at Chorzow, Merits, 13 September 1928,

Permanent Court of International Justice (1928) Series A, No. 17,4 . . . . . . 27, 226

Phosphates in Morocco case, Preliminary Objections, Judgment of

14 June 1938, Permanent Court of International Justice (1938)

Series A/B, No 74, 28. To be found in World Court Reports (1936-42)

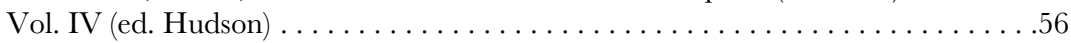

\section{International Court of Justice}

Corfu Channel case (United Kingdom of Great Britain and Northern Ireland v Albania),

Preliminary Objection, 25 March 1948, ICJ Reports (1947-48)15

Corfu Channel case (United Kingdom of Great Britain and Northern Ireland v Albania),

Merits, Judgment of 9 April 1949, ICJ Reports (1949) 4 . . . . . . . . .43, 44, 258

Reparation for Injuries Suffered in the Service of the United Nations, Advisory

Opinion, 11 April 1949, ICJ Reports (1949)174 . . . . . . . . . . . . . . 13

Asylum case (Colombia/Peru), Judgment of 20 November 1950,

ICJ Reports (1950) 266 . . . . . . . . . . . . . . . . . . . . . . . . . . . . . . 202

Case of the Monetary Gold Removed from Rome in 1943

(Italy v United Kingdom, United States, France). Pleadings,

Oral Arguments and Documents, ICJ Reports (1954) . . . . . . . . . . . . . . . 44

Case of the Monetary Gold Removed from Rome in 1943

(Italy v France, United Kingdom of Great Britain and Northern

Ireland and United States of America), Preliminary Question,

Judgment of 15 June 1954, ICJ Reports (1954) 19 . . . . . . . . . . . . . . 44

South West Africa cases (Ethiopia v South Africa) and

(Liberia v South Africa), Preliminary Objections, Judgment of

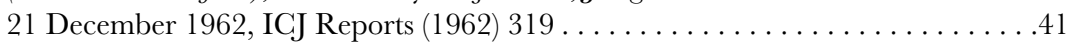


Case Concerning the Northern Cameroons (Cameroon v United Kingdom),

Preliminary Objections, Judgment of 2 December 1963,

ICJ Reports (1963) 15 . . . . . . . . . . . . . . . . . . . . . . . .41

South West Africa cases (Ethiopia v South Africa) and

(Liberia v South Africa), Second Phase, Judgment of 18 July 1966,

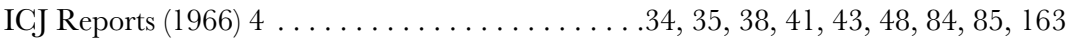

North Sea Continental Shelf cases (Federal Republic of Germany v

Denmark and the Netherlands), ICJ Reports (1969) 3. . . . . . . . . . . 202, 203

Case Concerning the Barcelona Traction, Light and Power Company, Limited (Belgium v Spain),

Judgment of 5 February 1970, ICJ Reports (1970) 4. . . . . . . . 4, 6, 7, 12,

$17,34,35,39,42,45,47,48,49,50$, $52,53,59,83,90,148,166,287$

Legal Consequences for States of the Continued Presence of South Africa in Namibia

(South West Africa) notwithstanding Security Council Resolution 276 (1970),

Advisory Opinion, 21 June 1971, ICJ Reports (1971) 4 . . . . . . 42, 166, 216, 227

Case Concerning Nuclear Tests (Australia v France) and (New Zealand v France),

Judgment of 20 December 1974, ICJ Reports (1974).. . . . . . . . . . . . .47, 48

United States Diplomatic and Consular Staff in Teheran (United States of America v Iran),

Judgment of 24 May 1980, ICJ Reports (1980) 3 . . . . . . . .48, 80, 141, 142, 219

Case Concerning Military and Paramilitary Activities in and against Nicaragua

(Nicaragua v United States of America), Jurisdiction of the

Court and admissibility of the application, Judgment of

26 November 1984, ICJ Reports (1984) 392 . . . . . . . . . . . . . . . . . . . 45, 258

Case Concerning Military and Paramilitary Activities in and against Nicaragua

(Nicaragua $v$ United States of America), Merits, Judgment of

27 June 1986, ICJ Reports (1986) 14. . . . . . . . . 27, 48, 153, 155, 202, 203, 255, 258

Case Concerning Elettronica Sicula S.p.A. (ELSI) (United States of America v Italy),

Judgment of 20 July 1989, ICJ Reports (1989) 15 . . . . . . . . . . . . . . . . .227

Case Concerning Certain Phosphate Lands in Nauru (Nauru v Australia),

Preliminary Objections, Judgment of 26 June 1992,

ICJ Reports (1992) 240

Case Concerning East Timor (Portugal v Australia), Judgment of 30 June 1995,

ICJ Reports (1995) $90 \ldots \ldots \ldots \ldots \ldots \ldots \ldots \ldots \ldots \ldots \ldots \ldots \ldots \ldots \ldots$ 44, 46, 47, 49, 50

Legality of the Threat or Use of Nuclear Weapons, Advisory Opinion,

8 July 1996, ICJ Reports (1996) I, 66 . . . . . . . . 16, 18, 19, 26, 242, 255, 259, 260

Case Concerning Application of the Convention on the Prevention and

Punishment of the Crime of Genocide (Bosnia and Herzegovina v Mugoslavia),

Order of 17 October 1997, ICJ Reports (1997) 243 . . . . . . . . . . . . . . . . 30

Case Concerning the Gabcikovo-Nagymaros Project (Hungary/Slovakia),

Judgment of 25 September 1997, ICJ Reports (1997) 7 . . . . . . . . 78, 212,

$213,214,215,216,263,272,275$

Application of the Convention on the Prevention and Punishment of the Crime of Genocide

(Bosnia and Herzegovina v Serbia and Montenegro), Merits, 26 February 2007 . . . . . . . 30

\section{International arbitration}

Case Concerning the Responsibility of Germany for Damage Caused in the

Portuguese Colonies of South Africa (Portugal v Germany) - The Naulilaa Incident, 
Arbitral Decision of 31 July 1928, 2 Reports of International

Arbitral Awards (1928). United Nations, Reports of International

Arbitral Awards (UN Publication, Sales No. 1949, v. 1), Vol. II . . . . . . . . . . .70, 269

Case Concerning the Air Service Agreement of 27 March 1946 between the

United States of America and France, Decision of 9 December 1978,

Reports of International Arbitral Awards, Volume XVIII, 417.

Also in International Law Reports 54 (1979) $304 \ldots \ldots \ldots \ldots$. . . . . 270, 272, 274 Amoco Int'l Fin. Corp. v Iran, 15 Iran-US Claims

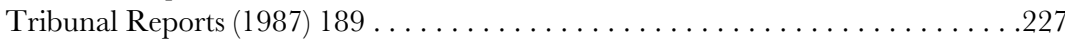

\section{International Tribunal for the Former Yugoslavia}

Martix case, The Prosecutor v Martix, Decision of 8 March 1996,

Case No IT-95-11-R61, International Tribunal for the

Former Yugoslavia, Trial Chamber I.

Ćelebici case, The Prosecutor v Delalix et al., Decision of 20 February 2001,

Case No. IT-96-21-A, International Tribunal for the Former

Yugoslavia, Appeals Chamber.

\section{World Trade Organization dispute settlement}

United States - Imports of Sugar from Nicaragua, GATT Basic Instruments and

Selected Documents, Report of the Panel adopted on 13 March 1984,

BISD/31S/67 L/5607. . . . . . . . . . . . . . . . . . . . . . . . . 153

Gasoline Case - United States - Standards for Reformulated and Conventional Gasoline,

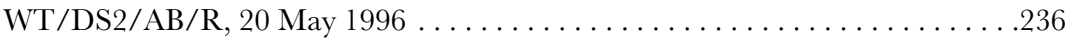

Hormones case - EC Measures Concerning Meat and Meat Products

(Hormones), WT/DS26/AB/R, January 1997 .................231

US - Certain EC Products, Panel Report, WT/DS165/R, 17 July 2000 . . . . . . . . . . .232

United States v Mexico, WT/DS308, Report of the Appellate Body

in Mexico - Tax Measures on Soft Drinks and Other Beverages,

6 March 2006.

\section{European Court of Human Rights}

Pfunders case (Austria v Italy), European Commission on Human Rights,

4 Yearbook of the European Convention on Human Rights (1961)117 . . . 117, 225

Belilos v Switzerland, 10328/83, Judgment of 29 April 1988, 1988 ECHR,

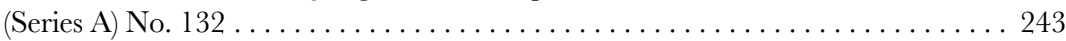

Soering v UK, 11 EHRR (1989), 439. . . . . . . . . . . . . . . . . . . . . . . 196

Chrisostomos et al. v Turkey, Human Rights Law Journal 12 (1991) . . . . . . . . . . . 119

Denmark v Turkey, Friendly Settlement of 5 April 2000,

Application No. 34382/97. . . . . . . . . . . . . . . . . . . . . . . . . . 109

McElhinney v Ireland, No. 31253/96, Judgment of 21 November 2001,

ECHR (2001) XI . . . . . . . . . . . . . . . . . . . . . . . . . . . . . . . . . . 227

Al-Adsani v United Kingdom, No. 35763/97, Judgment of 21 November 2001,

ECHR (2001) XI . . . . . . . . . . . . . . . . . . . . . . . . . . . . . . 227

Fogarty o United Kingdom, Judgment of 21 November 2001,

ECHR (2001) X . . . . . . . . . . . . . . . . . . . . . . . . . 227 
Bosphorus Hava Yollari Turizm ve Ticaret Anonim Sirketi v Ireland,

Application No. 45036/98, Grand Chamber Judgement,

30 June 2005

\section{European Commision of Human Rights}

Greek case, Commission's Report, 12 Tearbook of the

European Convention on Human Rights (1969)................ 43, 116, 117, 131

\section{European Court of Justice}

Commission v Grand Duchy of Luxembourg and Commission v Kingdom of Belgium, cases 90 and 91/63, European Court Reports (1964) 1217................223

Racke v Hauptzollamt Mainz, Judgment of 16 June 1998, Case C-162/96,

European Court Reports I (1998) Part 6, 3655 . . . . . . . . . . . 185, 186, 225

Internationale Handelsgesellschaft v Einfür- und Vorratsstelle Getreide, Case 11/70,

European Court Reports (1970) 1125 . . . . . . . . . . . . . . . . . . . . . .251

Nold v Commission, Case 4/73, European Court Reports (1974) ECR 491 . . . . . . . . .251

United Kingdom v Council, Case C-84/94, European Court Reports I

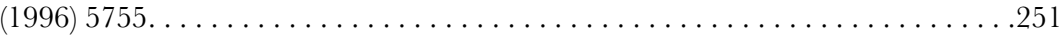

Hauer v Rheinland-Pfalz, Case 44/79, European Court Reports

(1979) 3727.

Bosphorus v Minister for Transport, Energy and Communications,

Ireland and the Attorney-General, Case C-84/95, European Court Reports I

(1996) 3953 . . . . . . . . . . . . . . . . . . . . . . . . . . . . . . . . . 252

Ebony Maritime and Boden Navigation v Prefetto della Provincia di Brindisi and Others,

Case C-177/95, European Court Reports I (1997) 1111 . . . . . . . . . . . . .252

Germany v Council, Case C-122/95 (1998) ECR I-973 . . . . . . . . . . . . . . . . . 200

Kadi and Al Barakaat International Foundation v Council of the European Union

and Commission of the European Communities, Joined Cases C-402/05 P and

C-415/05 P, Judgment 3 September 2008 . . . . . . . . . . . . . . . . . . . . . 199

Kadi $v$ Council of the European Union and Commission of the European Communities,

Opinion of Advocate General Mr Maduro, 16 January 2008,

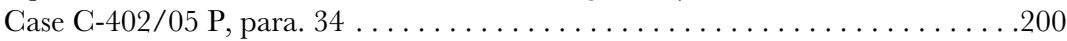

\section{Judgments of national courts}

South African Airways case (South African Airways v Dole) 817 F. 2d 119

(D.C. Cir. 1987), cert. Den., 108 S.GT. 229 . . . . . . . . . . . . . . . . . 171

C.D.S. v The State of the Netherlands, Supreme Court, 30 March 1990,

RvdW (1990) No 76; MRT (1990) 225; NJ (1991) No 249. . . . . . . . . . . . . . 197

Jugoslovenski Aerotransport v. l'État Belge, Cour d'Appel de Bruxelles

(9ème Chambre), decision of 10 June 1999 (No. 1998/KR/528)

[1999]J.T. 693. 


\section{Preface}

The evolution of the concepts of jus cogens norms and obligations owed to the international community as a whole, as developed in international legal theory and practice, has had a strong impact on the work of the International Law Commission for the codification of the law on state responsibility. The acceptance that not all primary international norms are of the same gravity or significance because of the nature of the rights they seek to protect could not but influence the legal consequences to derive from the violation of such norms. However, the categorization of internationally wrongful acts to serious and less serious raises significant questions concerning the enforcement of these 'superior' norms through countermeasures and also the subjects entitled to invoke the responsibility of the wrongdoing state in case of their infringement. This becomes even more compelling in the absence of effective and compulsory centralized mechanisms for the protection and enforcement of the most fundamental interests of the international community.

The adoption of the 2001 Final Articles on State Responsibility has far from concluded the debate over the entitlement of states other than the individually injured to resort to countermeasures, which falls at the heart of this book. While the ILC has found that state practice supporting a right to third-state countermeasures in response to the violation of these collective interests is still inconclusive, the book challenges these conclusions and demonstrates, through extensive analysis of state practice, that a right to solidarity measures has become an integral part of the international legal order.

The book starts with an analysis of how the notion of fundamental community interests emerged in international legal thinking and in the law on state responsibility, and proceeds to a detailed account of evidence in support of a right to countermeasures by third states in their protection. It further considers the interrelationship between the right to solidarity measures and obligations emanating from self-contained regimes amidst claims of risks of fragmentation of the international legal order and explores in some depth the significance of proportionality as a necessary legal restriction of such right. 


\section{Foreword}

There is a lot of talk about 'The International Community' these days but it can hardly be said that the promiscuity of the conversation has done much to enlighten us about what 'The International Community' is and how it works. It is sometimes a term of the simple realism - reflecting the fact that politicians of consequence invoke 'The International Community' as though it was a concrete thing and, accordingly, it falls to commentators to supply the unexplicated features of the concept (or concede that the statesmen are talking nonsense). This is a burden for political scientists, one which many of them are ready to assume. At the other extreme, 'The International Community' is a utopian construct; a regime of international perfection where everyone can pursue the good life in conditions of perpetual peace and security. This is a task for the imaginations of political philosophers: they also are up for the task. Not willing to be left out, there is a considerable community of international lawyers who invoke the notion of 'The International Community'. A truly realistic inquiry would reveal substantial deficiencies in sustaining the legal characteristics of 'The International Community'; a utopian prescription would lack the normative foundation which some international lawyers still regard as an essential characteristic of any system of law.

But international lawyers will not be left out. Fired by ideas of international justice (not ones wholly discerned within the rules and principles of extant international law) and appalled by the unjust conditions which prevail in so much of the world, they invoke 'The International Community' to justify some exercises of power and to demand the execution of some duties which seem to serve good ends. Those who have reservations about the project are dismissed as churls or cynics. It will be clear where I stand, though I should prefer 'cautious' and 'sceptical' as the preferred terms of use. Simply, there is a lot of work to be done to turn either the malleable, political references to 'The International Community' into a legally literate notion or to implement the high aspirations for a universally better world into the practical legal means to justify or structure the decisions necessary to do justice. The problem, of course, is States, with their central role in the international legal system and their tight control over the guns and money required to stop things getting worse and make things get better. The international legal system in which States have operated has been predominantly based on a civil or private model of legal relations - bilateral and delictual. The claims 
of 'The International Community' would introduce public law elements into these arrangements; innovations harder to adopt when the legislative powers in international law are so constrained and limited, and the supplementary initiatives which courts might take are so circumscribed by the rules on jurisdiction. It takes energetic investigation, great organisational capacity and acute legal imagination to make a positive contribution to the elucidation of the public law of public international law which might persuade States of its utility.

Dr Katselli Proukaki has brought these qualities to this much expanded and reconsidered version of her $\mathrm{PhD}$ thesis. I was her supervisor and learnt once again the lesson that supervisors soon lose control over the work of their students. Dr Katselli Proukaki has demonstrated an impressive independence in developing, maintaining and refining her ideas. She is, of course, aware of all the reservations expressed in the preceding paragraphs but she has been driven by a commitment to find what there is in the law which might be useful to her project - a peaceful world, in which human rights are broadly and widely enjoyed. The results are set out in what follows. The method is to look at the practice, some of it familiar, some not so well-known, over a long period through the lens of public law. She is not so unrealistic as to imagine a system which would fit within the paradigm of a domestic legal order but she is able to conclude that some of the more controverted limitations of international law are not so disabling to the pursuit of common interests as is sometimes maintained. She dispatches the hesitations of the International Law Commission about the legality of third-party countermeasures in response to serious breaches of peremptory norms as being unnecessarily timid, when the legal materials are examined as a whole. The attention which she gives to countermeasures is explained partly by the conceptual significance of the topic - a role for a materially uninjured State in the implementation of international law - but also because these 'serious breaches' are attacks on the values which she holds to be most important and which, in many cases, will only be prevented from being consolidated or getting even worse by actions which impose real costs on the perpetrators.

The work which Dr Katselli Proukaki has started here will keep her and many others in challenging inquiry for the remainder of their careers. One can not but admire the aspiration and, whatever one's caution, hope for the persuasiveness of the project where it matters - in the council rooms of Governments.

Colin Warbrick

Honorary Professor

Birmingham Law School 



\section{Introduction}

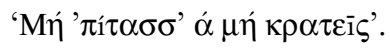

Sophocles ${ }^{1}$

In the absence of a structure equivalent to that existing in domestic legal systems, with compulsory legislative, judicial and enforcement procedures, international law has often come under attack as being not 'real' law. This seems to suggest that international law is a system of moral values and principles that vanish whenever the geostrategic, political or other interests of the stronger components of the international community are at stake. ${ }^{2}$ While law-making takes place in the international legal order in the form of customary and conventional rules and general principles and adjudication finds expression in the jurisdiction, even if consensual, of the International Court of Justice (ICJ) and other international tribunals, the lack of an automatic and compulsory enforcement mechanism remains the most striking feature of public international law. The legal loophole is not filled by the existence of the United Nations Security Council (Security Council) whose role is restricted to the safeguarding of international peace and security, which does not include enforcement of international law, although the two may at times coincide. As a consequence, compliance with international law and with fundamental principles still, and to a great extent, relies on the good will of each state.

The problem of enforcement becomes, as this book argues, compelling in the event of serious infringements of fundamental interests owed to the international community of states as a whole known as obligations erga omnes, including peremptory norms or jus cogens norms of international law derogation from which is not permitted. Indeed, it will be shown in the course of the following analysis that the evolution of

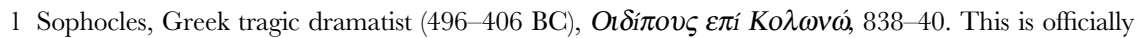
translated as 'Ne me donne pas d'ordre; tu n'es pas mon maitre' in J. C. Kamerbeek, The Plays of Sophocles: Commentaries VII The Oedipus Coloneus, 124. A more close consideration of Sophocles' words suggests that one should refrain from giving orders that he cannot observe. This is particularly true in the light of contemporary international law, which is often unable to enforce its commandments.

2 See, for this purpose, the analysis on the Austinian school of thought in M.W. Reisman, Nullity and Revision: The Review and Enforcement of International Judgments and Awards (Yale University Press: 1971) 645. Also see H. Bull, The Anarchichal Society: A Study of Order and World Politics, $2^{\text {nd }}$ ed. (Columbia:1995) 136. 


\section{Introduction}

the concept of fundamental community norms has led to the expansion of the circle of states that have a legal interest in their observance, but also in their enforcement. In view of the decentralized nature of the international legal system, but also of the principles of sovereign equality of states and state consent that hold prominent role in the system, the enforcement of such essential norms becomes problematic. The same holds true regarding the violation of interests established for the collective interest of a group of states. Although the emphasis of this book is predominantly placed on the enforcement of interests owed to the international community as a whole, the enforcement of such collective interests is not precluded from its scope either.

In such a decentralized legal system in which, as a matter of general rule, resort to the use of armed force is prohibited, the notion of countermeasures comes to fill the legal lacuna and contributes significantly towards compliance with and the enforcement of international law. As noted: 'Countermeasures are mechanisms of private justice that find their raison d'être in the failure of the institutions.' 3 In particular, this notion corresponds to peaceful measures resorted to by states, unilateral in character, taken in response to an internationally wrongful act that was previously committed by the state against whom they are turned and which, under normal circumstances, they would themselves be unlawful as infringing the rules of international law. It is accordingly imperative to distinguish the concept of countermeasures from other concepts of international law such as retorsion, in other words unfriendly but still lawful measures, sanctions authorized by an international organization, self-defence that is permitted in response to an armed attack and the suspension or termination of treaties as it will be further explored in Chapter 4 .

The concept of countermeasures finds justification in the need to restore the equality between sovereign states and to restore the balance that has been disturbed with the commission of the internationally wrongful act. Despite the fact that they are otherwise internationally wrongful acts themselves, countermeasures are justified and thus responsibility is precluded, by reasons of self-protection, reciprocity and the need to induce the defaulting state to cease the wrongful act, to offer reparation for the injury suffered by the aggrieved state and to secure guarantees for non-repetition in the future. It is also now clearly established that for countermeasures to be lawful, they must not be used as a means of revenge or punishment and their effects must be temporary. ${ }^{4}$

Nevertheless, while the right to resort to countermeasures by an injured state is undisputed, the same does not apply with the right of third states to respond with countermeasures or, as otherwise known, solidarity measures,${ }^{5}$ whenever the

3 D. Alland, 'Countermeasures of General Interest' 13 EfIL (2002) No. 5, 1221, 1226.

4 O. Elagab, The Legality of Non-forcible Countermeasures in International Law (Clarendon: 1988), 46. Also see J. Crawford, The International Law Commission's Articles on State Responsibility: Introduction, Text and Commentaries (CUP: 2002) 283.

5 M. Koskenniemi, 'Solidarity Measures: State Responsibility as a New International Order?' 71 BIIL (2001) 337, 339. For the general acceptability of the right to countermeasures by injured states see M. Spinedi, 'International Crimes of State: The Legislative History' in J. Weiler, A. Cassese, M. Spinedi (eds), International Crimes of States: A Critical Analysis of the ILC's Draft Article 19 on State Responsibility, (de Gruyter: 1989), 1, 69. 
fundamental interests of the international community as a whole or other collective interests are endangered. The recognition of a norm permitting solidarity measures, third-state countermeasures or countermeasures by states other than the injured as they are referred to in this book, has been at the heart of controversy in academic commentary but also in the work of the International Law Commission (ILC) for the codification of the law on state responsibility. This has led the ILC to leave the question of a right to such countermeasures by states not directly injured in response to violations of fundamental community and collective interests unsettled, causing yet more legal uncertainty on the matter.

The analysis that follows focuses on the question of implementation and enforcement of such interests by way of solidarity measures. Of course, the analysis could not ignore the judicial enforcement of community and collective interests and the circle of states entitled to initiate judicial proceedings seeking compliance with such norms, which is discussed extensively in Chapter 1.

Bearing in mind that in some cases of gross violations of international law there is no injured state but, rather, there are injured people, nationals of the same state committing the violation, to preclude the possibility of peaceful but nonetheless coercive action by independent components of the international community means to deny those most in need the hope of justice. Such are the cases of genocide, apartheid and torture. Furthermore, and although aggression has for long been considered as the most serious offence of international law threatening peace and security, now other violations such as the ones mentioned earlier merit equal attention. The paradox lies, however, in the fact that third states are entitled to resort to the use of armed force in the light of collective self-defence in response to an armed attack. Contrary to this, however, and according to the ILC's conclusions on the Final Articles on State Responsibility for the Commission of Internationally Wrongful Acts adopted in 2001 (hereinafter, Final Articles), the current international legal system seems not to allow third states from resorting to milder means, such as countermeasures, in reaction to serious infringements of specific international rules, including aggression.

This makes the protection of fundamental community interests weak, ineffective and subject to more abuse. It also leads to another paradox according to which while injured states are entitled to resort to countermeasures in response to 'ordinary' or less serious violations of international law, states, even if they are not directly injured by a given wrongdoing, are not entitled to do so in response to serious infringements of fundamental community or other collective interests.

In consequence, the position taken by the ILC against solidarity measures is questioned. The book, apart from the fact that it highlights the necessity of such countermeasures for the effective implementation of the rule of law particularly regarding fundamental community interests, demonstrates that the ILC's conclusions that there is no sufficient state practice in support of a right to third-state countermeasures were restricted to a very limited number of examples. These examples are by no means exhaustive or reflective of an unequivocal and clear stance on the question. The ILC did not take into consideration numerous other incidents that, in the author's view, provide evidence of well-established practice and opinio juris in this regard. 
While 8 years have passed since the adoption of the Final Articles, some of the ILC's findings remain controversial, including the question of the right to thirdstate countermeasures. Moreover, uncertainty remains regarding the status of the Final Articles and as to whether they should be incorporated in a United Nations General Assembly (General Assembly) resolution or in an international treaty. This issue is dealt with in Chapter 2.

The book discusses how the concept of third-state countermeasures evolved in international jurisprudence, the literature and also in state practice. The analysis aims to show the origins of the concept, its scope and content and how it was endorsed in international legal thinking. At the same time, it recognizes that in view of the inherent risks entailed from the recognition of a right to solidarity measures, resort to such measures must be exceptionally permitted.

It will be demonstrated in the course of this book that the concept of third-state countermeasures is closely associated with the early realization in international legal doctrine that not all internationally wrongful acts are of the same legal weight, significance and effect. Accordingly, the concept of third-state countermeasures is closely associated with some other significant legal developments concerning the emergence of the notions of peremptory norms and obligations erga omnes. These are reflected in Article 53 of the 1969 Vienna Convention on the Law of Treaties (hereinafter 1969 VCLT) and the obiter dictum of the ICJ in the Barcelona Traction case respectively. Nevertheless, these were not new notions in international legal thinking. In 1915 Professor Elihu Root, making a comparison between municipal and international law, pointed to the necessity for a distinction in the international legal order between wrongs that affected only the parties directly involved in the dispute and wrongs that inflicted a legal injury to every nation. ${ }^{6}$ This early understanding was later to have a great impact on the field of state responsibility, in other words, on the legal consequences to arise as a result of the infringement of primary international norms safeguarding fundamental community interests.

However, it was not until the end of World War II that 'a real current opinion emerged' according to which general international law provided for two different regimes of responsibility: one that would apply as a result of the breach of obligations of great significance to the international community as a whole and a second that would apply to breaches concerning obligations of less importance. ${ }^{7}$ This debate led to the realization that there may be different ways in which a state is affected by the commission of a wrongful act and that the legal consequences of certain violations do not leave unaffected the international community as a whole. It has been acknowledged, therefore, that should a violation of obligations established for the collective interest of a group of states or even of the international community as a whole occur, these states should be entitled to invoke the responsibility of the defaulting state. By what means they may be entitled to do so

6 E. Root, 'The Outlook for International Law', 10 AfIL (Jan., 1916) No. 1, 2, 9.

7 Fifth Report on State Responsibility (Ago), YbILC (1976) Vol. II, Part One, 3, 26 (80). 
has been the centre of much controversy as noted already and it forms the focus of this book.

Consequently, contemporary international law has been enriched with new principles, new rules and new concepts. In an increasingly interdependent world, community values have surfaced formulating a distinction between wrongful acts and legal consequences, simultaneously widening the spectrum of actors that have a legal interest to invoke the responsibility of the wrongdoing state. In this regard, current international law consists of more than just reciprocal obligations between two states: the recognition of interests and values placed to serve collective interests and the international community is now undisputed. Most significantly, international law is now moving towards adopting new mechanisms for its enforcement in an attempt to escape from the legal stagnation imposed by its own lack of compulsory enforcement jurisdiction over the most flagrant violations of international law. Similarly, the role of the individual in contemporary international law has been enhanced: thus, international law is not merely drafted to protect sovereign states, but also individuals and peoples.

It is with this new orientation of international law in mind that this research was carried out and which was also the result of a deep urge to shed some light to what is, and what should be, the function of international law today. In a more specific context, this book evolves predominantly around the law on state responsibility and the categorization of internationally wrongful acts, in respect of both their gravity and the international actors entitled to take action, by way of countermeasures, in order to remedy the infringement of fundamental community interests. Emphasis is therefore on the notion of solidarity measures and how this notion is accommodated in international legal doctrine today.

In this regard, the book is to be distinguished from other recent works that emphasize an extensive theoretical analysis of the scope, content and legal effects of peremptory norms of international law per se or on the general implementation of obligations erga omnes thoroughly distinguishing this notion from other concepts that have emerged in international legal doctrine. ${ }^{8}$ While the development of the concepts of peremptory norms and obligations owed to the international community as a whole hold prominent place in the scope of this book, its main focus lies on the enforcement of such fundamental norms by way of countermeasures by states other than the injured. The emphasis is accordingly placed on the evolution of such measures, including their scope, content, limits but also their relation with obligations emanating from other legal regimes. As such, the consideration of the notion of community interests is necessary for comprehending the impact that it has had on the question of standing in judicial 


\section{Introduction}

proceedings, but also, quite significantly, on the law on state responsibility generally and on the development of the law on third-state countermeasures particularly.

Furthermore, the analysis of this book is not confined to the question of whether state practice and opinio juris prove the existence of a customary norm permitting countermeasures by states other than the injured. Rather, it intends to set the background within which the concept of solidarity measures developed and the significance that the concept of community interests has had in this regard. The study demonstrates the existence of a general standing to pursue respect for such community interests through judicial means and, significantly, through countermeasures. In the scope of this analysis also lies an in-depth consideration of the legal ramifications arising from recognition of a right to solidarity measures and to identify the existing tensions between such right and obligations emanating from other legal regimes, such as self-contained or special regimes. It also looks into the legal safeguards that must be in place before resort to solidarity measures can be justified. These safeguards play a crucial role in the recognition of third-state countermeasures in order to mitigate fears of abuse by powerful states. In this regard, particular focus is given on the principle of proportionality, an issue that becomes difficult to assess especially if many states invoke their entitlement to take peaceful coercive action against the wrongdoing state in protection of fundamental community interests.

At the same time, and despite the differences in focus, this book aims to add to the existing literature regarding the implementation of fundamental community interests ${ }^{9}$ and provides further evidence in support of a customary international rule on solidarity measures. The book therefore deals with decentralized and unilateral mechanisms of enforcement of community interests and it is accordingly necessary to distinguish these mechanisms from institutionalized responses such as those authorized under a Security Council resolution adopted under Chapter VII of the United Nations Charter (UN Charter).

The examination starts in Chapter 1 with an analysis of the notion of community interests as emerged through the recognition of peremptory norms of international law in Article 53 of the 1969 VCLT and obligations erga omnes in the Barcelona Traction case. It is shown that these concepts have signified the fundamental changes the international community and international law itself have undergone with the passage from 'pure' bilateralism to the recognition of community values. It is further demonstrated that the changing nature of international law from a legal order confined to obligations of a reciprocal character to a legal order that safeguards fundamental community principles in the protection of which all states have a legal interest could hardly be disputed. In a decentralized and still rudimentary legal order such as the international one, concepts of a

9 Also see M. Dawidowicz, 'Public Law Enforcement without Public Law Safeguards? An Analysis of State Practice on Third-Party Countermeasures and their Relationship to the UN Security Council', BIIL (2006) 333. 
constitutional or quasi-constitutional nature start to make their appearance. In this context, the question of enforcement of such norms gains particular gravity and, in this regard, Chapter 1 considers the standing of states to initiate judicial proceedings seeking their protection. The research in this chapter establishes that even before the ruling of the ICJ in the Barcelona Traction case general international law recognized the entitlement of third states not directly affected by a certain wrongdoing concerning fundamental community or collective interests to make claims before judicial and other bodies seeking observance with these norms. This position becomes firmer with the obiter dictum of the ICJ on obligations erga omnes the significance of which lies in the recognition that all states are entitled to demand observance with community rules even if no direct injury has been suffered. While this does not mean circumventing any jurisdictional rules that may be in place, it establishes general judicial standing for the protection of such obligations.

The analysis made in Chapter 1 lays the foundational stone for the discussion of the main theme of this book, in other words, the question of implementation and enforcement of these fundamental norms within the law on state responsibility, particularly by way of countermeasures.

Chapter 2 builds on this analysis and turns its attention to the attempts of the ILC to codify the law on state responsibility - painstaking work that has lasted for almost five decades - and to categorize the legal consequences of a given international wrongdoing in accordance with the significance of the rule infringed. The study in Chapter 2 intends to set the background within which the need for differentiation between serious and less serious violations of international law and more specifically between 'crimes' and 'delicts' emerged in the law on state responsibility. It also intends to highlight the strong impact that the concept of community interests has had on the determination of the legal consequences to arise therefrom and of the subjects entitled to invoke the responsibility of the wrongdoing state. Indeed, the analysis in this chapter illustrates that the infringement of fundamental community interests widens the circle of states affected from the wrongful act and entitles them to invoke the responsibility of the wrongdoing state. It also considers how community interests are reflected in the Final Articles and it examines the question of third-state countermeasures and how the ILC approached the matter in concluding its work on state responsibility. As noted earlier, the conclusions of the ILC that contemporary international law does not recognize a customary rule permitting resort to solidarity measures are being put into question.

This leads to the analysis in Chapter 3, which is driven by the need to further examine the conclusions of the ILC according to which state practice permitting countermeasures by states other than the injured is sparse and embryonic. This study is mostly needed amid disagreement as to whether there is or there should be such a right in international law. Accordingly, while this chapter builds from the incidents relied on by the ILC, it provides an extensive and detailed analysis of yet more examples of solidarity measures arising from state practice and opinio juris. This work, while complementing the recent literature on the matter, goes beyond that by bringing into light some early incidents concerning solidarity measures, arguing that the question of solidarity measures was not a recent discovery 


\section{Introduction}

in international state practice. The results of this research also highlight the fact that states have often relied on community and collective interests in order to cease performance of other international obligations, such as those emanating from extradition treaties or, even more significantly, from the United Nations Charter (UN Charter) as in the recent Kadi and Al Barakaat cases. Furthermore, Chapter 3 provides additional evidence that even in those cases where states have justified their conduct on other legal justifications, a claim in support of solidarity measures could be made instead.

The purpose of the conclusions to emerge from Chapter 3 is to highlight the fact that states have often resorted to action in violation of their international commitments in response to serious violations of fundamental community and collective interests and that, therefore, a customary norm allowing third-state countermeasures is recognized in international law. Moreover, the discussion in this chapter aims to show the significance of countermeasures by states other than the injured for the enforcement of fundamental community and collective interests in the event of serious infringement. It is revealed through these observations that in the absence of other satisfactory enforcement mechanisms, such countermeasures may at times constitute the only means to respond to violations that affect community and collective interests. The recognition of such a right, with its legal constraints, is much needed in a decentralized legal order that is often unable to respond with determination to serious violations of such interests. The existence of a right to third-state countermeasures provides an opportunity for the effective enforcement of interests the violation of which is of particular gravity and significance for the international community of states as a whole. This is illustrated from the significant contribution of such measures in the exercise of pressure and the cessation of gross violations of international law such as genocide, apartheid and aggression, as the cases of Uganda, South Africa and the Arab oil embargo demonstrate.

At the same time, however, the discussion reveals that caution must be exercised in relation to the fulfilment of the conditions allowing resort to such measures. In this regard, it is argued that in some cases there was no clear identification of the norm infringed or there was uncertainty regarding whether a norm protecting community interests had indeed been infringed such as in the case of the military coup abolishing democratic rule in Haiti.

Whereas the analysis of state practice and opinio juris is by no means exhaustive, it intends to add to the existing literature and to provide a detailed and thorough analysis of the matter.

With these observations in mind and having established the existence of a customary rule on third-state countermeasures, Chapter 4 evolves around the relationship between lex specialis and so-called self-contained regimes, on the one hand, and the general law on state responsibility and countermeasures, on the other. The issue gains particular significance in view of the proliferation of agreements and autonomous legal regimes in the international legal order, thus narrowing significantly the content of the international responsibility of states, and especially of countermeasures, even whenever the most flagrant violations of 
international law are involved. This is especially true insofar as the expansion of the competences of such regimes is concerned, arguably precluding or restricting to a great extent the application of the rules of general international law. While this position is contested, the emphasis is placed, among others, on the World Trade Organization (WTO) and its position within the general framework of international law, including the law on state responsibility. It is shown in this regard that the more the WTO expands its competences the narrower the scope for countermeasures, even in response to serious violations of fundamental community interests, becomes. The analysis therefore leads to the examination of another, closely linked phenomenon, that of the fragmentation of international law. Should the international legal order be construed, as it is, as consisting of multiple 'anarchical' legal systems that exist in parallel but which at times clash between them, the danger of fragmentation then becomes evident. In this respect, legal opinion is divided with some international lawyers arguing that the specific terms of the self-contained regimes will prevail, with others arguing that such regimes are not to be seen in isolation from general international law.

As the book argues, to claim that by agreeing to join such special regimes states have given up any other means of enforcing their general rights and interests would be tantamount to refusing their having access to other possible and effective means of enforcement of international law. This is particularly important insofar as community interests are concerned.

The last chapter, and in view of the recognition that countermeasures may be used and abused especially by powerful states, turns its attention on the legal restrictions of the right to resort to countermeasures. In this context, proportionality plays a determinative role in drawing the limits between lawful and unlawful coercive action. This study is therefore carried out on the realization that the principle of proportionality constitutes an essential safeguard against the abuse of countermeasures generally and solidarity measures particularly. In fact, the danger of abuse is aggravated in the light of solidarity measures where proportionality becomes difficult to be assessed in view of the plurality of the actors and the plurality of the action taken against the defaulting state. For this purpose, the determination of the scope and content of proportionality or, in other words, the elements to be taken into account, become essential for establishing legal certainty and legal predictability, diminishing, to the extent possible, subjectivity and arbitrary and excessive use of countermeasures in the pretext of community interests. In this respect, the analysis in Chapter 5 proceeds from a brief consideration of the principle of proportionality at a national and EU level, to consideration of proportionality in the law of armed conflict, with the emphasis placed on the principle as developed in the law on state responsibility and countermeasures. It is argued in this regard that the question of proportionality in respect of solidarity measures has received little attention and that serious concerns are raised in relation to how proportionality would be assessed under such circumstances. Accordingly, it is suggested that proportionality, developed in an already narrow legal framework, must be assessed in the light of numerous relevant factors that must be taken into consideration. These relate to the seriousness of the initial 
violation, the aims and objectives pursued by the response, the significance of the rights affected both by the initial wrongful act but also by the response, the injury caused, but also the appropriateness of the measures taken to achieve the said objectives. Accordingly, while a uniform standard of proportionality may not be feasible due to the varied nature and objectives of countermeasures, which in any event must not be aimed at revenge or the punishment of the defaulting state, there must be a clear identification of the factors relevant for determining whether a certain response meets the standard of proportionality.

The analysis concludes that the principle of proportionality in the law on countermeasures is essential as it ensures clarity and legal certainty enabling the achievement of the goals of the international community and restricting further abuses.

Coming back to Sophocles' quote at the beginning of this introduction, the protection of fundamental community interests, as reflected in the concepts of $j u s$ cogens norms and obligations erga omnes, would become devoid of meaning if no enforcement mechanisms were available for their implementation. No theory regarding the 'superior' character of certain norms or the importance of certain obligations granting all states a legal interest in their observance would matter had it not been accompanied by specific rules concerning the legal consequences to arise as a result of violation of these significant rules. Most importantly, no distinction between 'ordinary', or less serious and serious violations, or between bilateral or reciprocal and community or collective interests would be necessary had this distinction not been accompanied with a more serious regime of responsibility. This could not but exercise a huge impact on the states entitled not only to invoke the responsibility of the wrongdoing state but also to resort to coercive peaceful measures in order to induce the cessation of the wrongful act and the compliance of the wrongdoing state. The changing nature of contemporary international law, the recognition of fundamental community interests, but also the absence of compulsory enforcement mechanisms advocate for alternative means of protection. In this regard, the right of not directly affected states to implement countermeasures in the name of fundamental community interests becomes necessary and essential for the effective protection and enforcement of rules owed to the international community of states as a whole. 


\section{The international community, jus cogens norms and obligations erga omnes}

\section{Introduction}

International law establishes a dynamic legal order that has progressively developed from an order of peaceful coexistence to an order of cooperation of states and from an order concerned with narrowly construed state interests to an order that promotes the interests of the international community as a whole. In parallel to these developments and while for a long time states were recognized as the only subjects of international law, the international legal order today extends its rules and protection to other subjects such as individuals and international organizations. ${ }^{10}$

These changes have had a tremendous impact on how international law is perceived in a contemporary context with its nature and aims constantly evolving from a purely state-oriented understanding to one that gives prevalence to higher interests shared by all states of the international community. The incorporation of new concepts in the international legal doctrine that, as the analysis that follows purports to show, are now well rooted, contributed much to these groundbreaking developments.

On the one hand, Article 53 of the 1969 VCLT encompasses the concept of peremptory norms of international law (jus cogens) and provides that a treaty which infringes these norms is invalid. ${ }^{11}$ The Article identifies peremptory norms as norms, which are recognized as fundamental by the international community of states as a whole as a consequence of which no derogation is permitted. Accordingly, the quality of the interests protected under such norms and their significance to the international community endow them with compelling and hierarchical authority in relation to all other rules of international law. ${ }^{12}$

On the other hand, the ICJ itself endorsed the idea of interests owed to the international community of states as a whole (obligations erga omnes) as distinct from interests of a bilateral and reciprocal nature, such as those arising from the law of diplomatic immunities. This was recognized in the Barcelona Traction case

10 For a very interesting discussion on the changing nature of international law, see M.P. Dupuy, 'International Law: Torn between Coexistence, Cooperation and Globalization. General Conclusions', 9 EfIL (1998) 278, 280. Also see M. Shaw, International Law, 6th edn (CUP: 2008) Chapter 1.

11 Vienna Convention on the Law of Treaties, 23 May 1969, 1155 UNTS 331.

12 Orakhelashvili (2006), op.cit., 8. 
and, as will be discussed later, it was again the importance of the rights protected under such obligations that prompted the Court to make this pronouncement in its now famous obiter dictum on obligations erga omnes.

In the midst of these legal events, questions emerged and still do emerge in relation to their impact on international legal thinking and the practice of states. The recognition of the concepts of peremptory norms and obligations owed to the international community as a whole, therefore, calls for a determination of their legal scope and content, their legal effects and the legal consequences that arise in the case of their infringement. In turn, and most significantly perhaps, the determination of these specific issues must unavoidably lead to the determination of the subjects entitled to rely on such concepts towards other states and of the mechanisms concerning their enforcement and implementation in the international legal arena. This is closely related to the question of standing and it will be at the heart of this work.

As will be seen, the enforcement and implementation of these community interests in a largely decentralized international legal system may take various forms and may be fulfilled by every state. ${ }^{13}$ In Chapter 1 , however, attention will be turned onto the initiation of proceedings before international judicial bodies as one way of enforcement of community interests, together with an analysis of how the notion of community interests developed in the first place and came to dominate the literature and international jurisprudence. Nevertheless, this study does not intend to exhaust the topic of community interests. Rather, it aims to set the background within which these legal concepts were conceived and their effect on judicial standing, in order to proceed in other chapters, and in particular in Chapter 2, to a thorough consideration of how these developments influenced the ILC in its work on the codification of the law on state responsibility. It will also be shown that the notion of community interests was instrumental in the introduction of another concept, that of countermeasures taken by states other than the injured, which is at the focus of this book.

\section{Transition from bilateralism to the 'international community as a whole'}

\subsection{A bilateralist approach}

Traditional international law as most recently referred to in legal writings is built on the notion of bilateralism and establishes a bipartite relation of multiple rights and obligations that together constitute 'minimal law' and are reciprocal in character. ${ }^{14}$ Within this framework, one state is the carrier of the right and the other the carrier of the duty, establishing legal relations among states identical in kind to those established under contractual law. Bilateralism is built on a strong perception of state sovereignty and the prohibition of non-interference in the domestic

13 Tams, op. cit, 6-7.

14 P. Allott, Eunomia. New Order for a New World (OUP: 1990) 324; B. Simma, 'From Bilateralism to Community Interest in International Law' $250 R d C(1994)$ VI, 217, 229. 
affairs of another state. States are legally bound by international rules only because they have themselves given their consent to restrict certain of their sovereign powers, usually because they have come to realize that it is for their own benefit to do so. As the Permanent Court of International Justice (PCIJ) has stressed: 'The rules of law binding upon States ... emanate from their own free will as expressed in conventions or by usages generally accepted as expressing principles of law.' 15

State consent is accordingly the driving force of interstate relations and international law. This position is co-related with the pacta tertiis rule, according to which no state may be bound by a treaty that it has not signed and ratified. On the same footing, under this perception of international law no state may be bound by a rule the development of which it has opposed. This extends to dispute settlement mechanisms, which require the consent of all parties involved. In this bilateral relationship, and in case of an infringement, it is solely on the carrier of the right to pursue the fulfilment of what has been refused to it and to resort to coercive measures that for a long time took the form of armed force or even to unilaterally denounce its obligations. ${ }^{16}$ The fact that it is the state to which a specific obligation is individually owed that is entitled to demand its performance is a very wellestablished principle of international law that has been upheld by the ICJ, with particular emphasis made in its Opinion concerning the Reparation for Injuries case. In this instance, the ICJ concluded that 'only the party to whom an international obligation is due can bring a claim in respect of its breach' and that the injury sustained by the UN in this case related to the violation of obligations owed to the UN itself. ${ }^{17}$ To what extent this position may have been altered by a broadening of the circle of states entitled to initiate judicial proceedings in response to violations not of rights individually owed to them, but rather of interests owed to the international community as a whole is considered in detail.

Bilateralism could also not leave unaffected the sphere of 'sanctions'. For many commentators, in the absence of a hierarchical order which was precluded by the nature of international law as a legal order of coordination rather than subordination and in the light of the principle that all states were equal actors in international affairs, 'sanctions' themselves found no place. ${ }^{18}$

Despite the fact that under bilateralism states are protected (at least in theory) from unlawful interference and there is clear identification of the injured states entitled to seek redress, it leaves enforcement to the state whose subjective rights have been infringed. Given the factual inequality of states, bilateralism weakens the position of already weak and small states which are unable to take action against the wrongdoer, no matter how serious the violation and how fundamental the right at stake. ${ }^{19}$ Furthermore, it ignores the need for certain common values essential for the

15 The S.S. Lotus case, Judgment No. 9, September 7, 1927, PCIJ, Series A, WCR (1927-32) Vol. II, $20,35$.

16 See analysis in C. Tomuschat, 'Obligations Arising for States Without or Against their Will' 241 $R d C$ (1993) IV, 195, 353-4.

17 Reparation for Injuries Suffered in the Service of the United Nations, Advisory Opinion, ICJ Reports (1949) 174, 181-2.

18 J. Delbruck, 'International Economic Sanctions and Third States' AdV(1992) 86, 88-90.

19 Simma (1994), op. cit., 232-3. 
very existence of mankind and which have to be protected even if no specific state is directly injured as a result of their infringement and independently of state consent.

Accordingly, bilateralism cannot explain current legal trends such as the fact that there may be instances where the conduct of one state may adversely affect the interests of all other states without however causing a direct injury to their rights. Neither can it explain the fact that certain issues are the concern of all states, for example, human rights and environmental considerations, the legal status of Antarctica or the legal status of the seabed that extends beyond the jurisdiction of any state. It has been pointed out in this regard that human rights and the protection of the environment for instance 'are typically the subject matter of multilateral treaties which define mutually accepted uniform standards. Their conclusion as instruments of codification or progressive development of international law weighs against a bilateral perspective which signifies a reciprocal exchange of commitments. ${ }^{20}$ While this statement relates to a treaty-based regime establishing what are known as obligations erga omnes partes, the examination in this chapter will expand its scope mainly to community interests as protected under general international law and which are the concern of all states. ${ }^{21}$

Bilateralism is therefore unable to adequately respond to the increasing need to protect certain collective principles and which, in turn, widen the circle of interested or affected actors in the international legal arena. Mosler explains in this regard that: 'International law cannot be defined solely in terms of bilateral or multilateral relations between subjects which possess legal capacity. The collection of subjects participating in the international legal order constitutes a community living according to common rules of conduct.' 22

It is therefore submitted that international law is no longer solely built upon bilateral relations among states or reciprocity. Rather, it also consists of norms intended to go beyond bilateralism and to safeguard the foundations of the international legal system as a system that aims to ensure the development of states and their subjects in conditions of peace and security. This has led to the development of the concept of community interests, considered in the next section.

\subsection{Community interests in contemporary international laze}

While bilateralism is what still significantly describes the international relations of states today, one can say with confidence that contemporary international law has also evolved to something more than just being 'minimal law' in certain areas. ${ }^{23}$ In this way, contemporary international law has moved towards an expansion of the competences of the organized community that ceases to be merely an abstract idea, on the one hand, while limiting the sovereign powers of the states,

20 G. Chinkin, Third Parties in International Law (Clarendon: 1993) 3.

21 This is a significant distinction clearly made in Tams, op. cit., 120.

22 H. Mosler, 'International Legal Community' in R. Bernhardt (ed.), 7 Encyclopedia of Public International Law (North-Holland Elsevier Science: 1984) 309-12; Chinkin (1993) op. cit., 5.

23 Allott, op. cit., 324. Also see Simma (1994), op. cit., 229. 
on the other. A contemporary understanding of international law promotes the notion of community interest to the extent that 'absolute sovereign freedom to accept or dismiss a legal rule simply appears anachronistic in the present time'. ${ }^{24}$ It has also been realized that narrowing the understanding of international law as being a system that is solely founded on state consent could not be reconciled with contemporary concerns which required an international public order with which all states would have to strictly comply. ${ }^{25}$

In his Anarchical Society, Bull argues that international society is not structured exclusively on realist or moralist/idealist theories. He rather makes the point that the international society bears characteristics of both. Therefore, while it consists of sovereign states seeking to gain power, these very states recognize the significance of peaceful cooperation and coexistence with other states. This is the intention behind the formulation of international organizations and common rules because a common interest constitutes the Gordian knot that binds all states together. ${ }^{26}$ At the present moment, the outlawing of the use of force and the protection of certain fundamental principles become the concern of all: their violation affects all states and, therefore, all states have an interest in their performance. This has increased the necessity for a strong international community and solidarity among states, the latter being described by Professor MacDonald as:

An agreement among formal equals that will all refrain from actions that would significantly interfere with the realization of common goals and fundamental interests. Solidarity requires an understanding that every member of the community must consciously and constantly conceive of its own interests as being inextricable from the interests of the whole. No State may choose to use its power to undertake actions that might threaten the integrity of the community. ${ }^{27}$

As early as 1937, three decades before the conclusion of the 1969 VCLT and its express reference to the concept of peremptory norms Verdross wrote that the international community consists of higher interests that restrict both the sovereignty and freedom of states. More specifically, he noted that 'it is the quintessence of norms of this character that they prescribe a certain, positive or

24 Tomuschat (1993) op. cit., 213.

25 S. Kirchner, 'Relative Normativity and the Constitutional Dimension of International Law: A Place for Values in the International Legal System?' 5 GLF (2004) No. 1, 47, 51. This is also evident in the case of emergence of new states in international law where the new entities enter the international legal system without the possibility of opting out from already established rules, such as the prohibition of the use of armed force. As a consequence, consent cannot always provide adequate explanation as the only source of state obligations. It is noted in this regard that while consent is required for the acceptance of specific rules, the international legal system is founded on state consensus, i.e. states accept and recognize this system as a 'general system of international law' within which they exist and develop. See in this regard Shaw, op. cit., 9-11.

26 Bull, op. cit., 13.

27 R. Macdonald, 'The Principle of Solidarity in Public International Law' in C. Dominicé, R. Patry and C. Reymond (eds) Études de droit international en l'honneur de Pierre Lalive (Helbing \& Lichtenhahn: 1993) 293 quoted in Simma (1994), op. cit., 238. 
negative behaviour unconditionally; norms of this character, therefore, cannot be derogated from by the will of the contracting parties. ${ }^{28}$

It accordingly became common ground, especially in the post-World War II era, that the sovereignty of states no longer has the absolute and exclusive character that it possessed in the past. This absolute authority was expressed in three ways. First, states enjoyed absolute freedom concerning their domestic affairs. ${ }^{29}$ Second, states possessed unrestricted power to enforce international law when a breach against them had occurred. Third, states were empowered to select the norms with which they would be bound. ${ }^{30}$ That states do no longer enjoy unlimited sovereign powers is revealed from the various state responses to serious violations of international law of an internal character, as will be illustrated later in the book. With the current growing interdependence of states, sovereignty despite the fact that it still possesses a prominent role in contemporary international law is not conceived as an absolute instrument of strength and inviolability in the hands of dictators or human rights violators. ${ }^{31}$ At the same time, and as a result of progress in international legal thinking concerning the protection of international peace and security, states recognized that it was to their benefit to avail themselves of certain international rules in the light of the realization that war and conflict could not be factors of stability and development. Hence, a new conception of the role of states in the international arena had gradually begun to unfold amid the necessity for the cooperation and peaceful coexistence of the various states of the international community. ${ }^{32}$

The appearance of the 'international community' as a legal concept changed the international legal balance in that a state which violated fundamental principles of international law would now be faced with the international community as a whole. ${ }^{33}$ The protection of certain higher interests in the name of the international community supports the idea that an international public order exists, which qualifies the scope and content of norms in the light of these superior interests. ${ }^{34}$

28 A. Verdross, 'Forbidden Treaties in International Law: Comments on Professor Garner's Report on the "Law of Treaties"' 31 AfIL(1937) No. 4, 571, 571-2. Also see N. Jorgensen, The Responsibility of States for International Crimes (OUP: 2000) 86.

29 This perhaps is best reflected in Article 2(7) of the United Nations Charter according to which member states undertake not to interfere in the domestic affairs of another state. Nevertheless, there is sufficient evidence in state practice to show that massive and gross human rights violations no longer fall within the exclusive jurisdiction of states, thus broadening the scope of this provision. See analysis in F.A. Von Geusau, 'Staying the Course: The Concept of Sovereignty in the Work of Pieter Kooijmans' in G. Kreijen (ed.), State, Sovereignty, and International Governance (OUP: 2002) 619, especially 625, 629.

30 Shaw, op. cit., 9-11.

31 Von Geusau, op. cit., 629.

32 Declaration of Judge Bedjaoui, Legality of the Threat or Use of Nuclear Weapons, Advisory Opinion, 8 July 1996, ICJ Reports (1996) I, 270 (13).

33 Although the term 'international community' is being frequently used in various contexts, it does not always have a normative character. On the significance of the concept of international community, see discussion in D. Greig, 'International Community', 'Interdependence' and All That ... Rhetorical Correctness?' in Kreijen, op. cit., 521, 563-66.

34 Orakhelashvili (2006), op. cit., 27-8. 
The reference to this concept, although not unknown before, has flourished ever since the adoption of Article 53 of the 1969 VCLT on jus cogens norms. As noted earlier, peremptory norms qualify norms that are 'accepted and recognized by the international community of States as a whole' and 'from which no derogation is permitted'. ${ }^{35}$

Not long after the adoption of Article 53, the ICJ pronounced in the Barcelona Traction case that there needed to be a distinction between obligations that derived from the law of diplomatic immunities, on the one hand, and obligations owed to the international community as a whole, on the other. ${ }^{36}$ Although the Court did not say what action could specifically be taken in response to the violation of the latter obligations, it expressly recognized a legal interest of all states in their protection. The significance of this ruling lies not only in the fact that the international community is authorized to attach an erga omnes character to certain obligations, but also on the fact that obligations of this category are owed to all states and are enforced on behalf of the international community. ${ }^{37}$ However, as Tams points out this should not be construed as meaning that individual states are not entitled to invoke the responsibility of the state that infringes such obligations or that they do not have standing to either initiate judicial proceedings or to take countermeasures under international law in protection of these obligations. ${ }^{38}$

The concept of the 'international community' has often been cited as evidence to the evolution of international law. Judge Bedjaoui, moving away from the ruling in the Lotus case according to which states have such freedom of action as long as it is not prohibited by a rule of international law, commented that:

[1] t scarcely needs to be said that the face of contemporary international society is markedly altered ... Witness the proliferation of international organizations, the gradual substitution of an international law of co-operation for the traditional international law of co-existence, the emergence of the concept of "international community" ... The resolutely positivist, voluntarist approach of international law still current at the beginning of the [twentieth] century ... has been replaced by an objective conception of international law, a law more readily seeking to reflect a collective juridical conscience and respond to the social necessities of States organized as a community. ${ }^{39}$

35 The linkage between jus cogens norms and the international community was made on a proposal submitted by the governments of Finland, Greece and Spain. Rozakis, in particular, spoke of a 'confrontation between ... growing social concerns and the ... perseverance of States in their sovereign rights'. The inclusion of the notion of peremptory norms revealed 'that the international community is rapidly heading towards some more advanced forms of organization under the rule of law and justice'. C.L. Rozakis, The Concept of Jus Cogens in the Law of Treaties (North-Holland: 1976) 194; Greig (2002), op. cit., 537.

36 Case Concerning the Barcelona Traction, Light and Power Company, Limited (Belgium v Spain), Judgment of 5 February 1970, ICJ Reports (1970) 4, 32-3, (33-4).

37 Greig (2002), op. cit., 547.

38 Tams, op. cit., 175.

39 Declaration of Judge Bedjaoui, Legality of the Threat or Use of Nuclear Weapons op. cit., 270 (13). 
The dissenting opinion of Judge Shahabudeen in the Advisory Opinion on the Legality of the Threat or Use of Nuclear Weapons also constitutes a reflection of the growing view that international law has not remained static. ${ }^{40}$ Rejecting the Lotus ruling Judge Shahabudeen addressed the question before the ICJ by pointing out that the lack of a rule, conventional or customary, to prohibit the use of nuclear weapons could not imply that the use of such weapons was lawful. Rather, it was imperative to look at more general principles, and he suggested, 'in a case of this kind, the action of a State is unlawful unless it is authorized under international law' ${ }^{41}$ According to him, since the appearance of nuclear weapons there has been no crystallized opinio juris towards the direction of outlawing what was previously allowed, or vice versa, permitting what was previously unlawful. In determining therefore whether the use of such strong weapons that could signal the end of mankind was allowed, Judge Shahabudeen suggested looking at the juridical foundations' on which a legal system, here the international legal system, is structured. He pointed in this regard to Ibn Khaldun according to whom 'laws have their reason in their purposes they are to serve', namely the preservation of civilization, and that 'injustice invites the destruction of civilization with the necessary consequence that the species will be destroyed.' ${ }^{2}$

Judge Shahabudeen concluded accordingly that since 'the preservation of the human species and of civilization constitutes the ultimate purpose of a legal system' the immense, 'clear and palpable' risks for the very survival and existence of the international community that can arise from the use of nuclear weapons, make their use unacceptable and 'repugnant to the conscience of the community.' ${ }^{3}$ Most significantly, support of the position that what is not prohibited is permitted, he said, would bring to mind the advice given by Persian judges to King Cambyses when asked if he could marry his sister. In answering the question posed by the King the judges said that 'though they could discover no law which allowed brother to marry sister, there was undoubtedly a law which permitted the King of Persia to do what he pleased.' ${ }^{44}$ Similarly, to say that the threat or use of nuclear weapons is permitted under international law 'would mean that, while the Court could discover no law allowing a State to put the planet to death, there is undoubtedly a law which permits the State to accomplish the same result through an exercise of its sovereign powers' ${ }^{45}$

Judge Shahabudeen further emphasized that even if no prohibition of nuclear weapons is found the coexistence of states in the international legal system restricts the freedom of action of each state. These restrictions define the very notion of state sovereignty, which he described as an 'objective structural framework' which 'shuts out

40 Dissenting Opinion of Judge Shahabudeen, Legality of the Threat or Use of Nuclear Weapons op. cit., 375.

41 Ibid, 377.

42 I. Khaldun, The Muqaddimah, An Introduction to History (N.J. Dawood: 1981) 40 in ibid, 381.

43 Dissenting Opinion of Judge Shahabudeen, ibid, 381 and 387.

44 Herodotus, The Histories (trans. Aubrey de Selincourt, Penguin: 1959). 187 in ibid, 392, fn6.

45 Dissenting Opinion of Judge Shahabudeen, ibid, 392, fn6. 
the right of a State to embark on a course of action which would dismantle the basis of the framework by putting an end to civilization and annihilating mankind'. ${ }^{46}$

Moreover, the conclusions to be derived from the Lotus case were improper for another reason as well. In particular, that case did not concern the possibility of the entire destruction of humanity and that since that ruling there have been significant legal developments in contemporary international legal community reflected, first, in the prohibition of the use of force and, second, in the promotion of a 'universal international community'. Both, it seems, at the expense of state sovereignty. ${ }^{47}$

These conclusions seem to reflect an earlier distinction between two kinds of international law and, in particular, between the necessary law of nations embodying the law of nature (jus strictum) and the law created by agreement and custom. According to Vattel:

Since therefore the necessary Law of Nations consists in the application of the law of nature to states - which law is immutable as being founded on the nature of things, and particularly on the nature of man - it follows, that the necessary Law of Nations is immutable. Whence as this Law is immutable, and the obligations that arise from it necessary and indispensable, nations can neither make any changes in it by their conventions, dispense with it in their own conduct, nor reciprocally release each other from the observance of it. ${ }^{48}$

The same conclusion was reached by Mosler over a century later, who emphasized that: 'The law cannot recognize any act either of one member or of several members in concert, as being legally valid if it is directed against the very foundation of law.' 49

The recognition of community interests, as reflected also in the ILC's work on state responsibility that will be discussed in the next chapter, signalled the categorization of various internationally wrongful acts based on their seriousness and the interests they affect, on the one hand, and of differentiated legal consequences, on the other. The discussion of community interests could not but influence the determination of the actors affected by a certain infringement of obligations establishing community interests, and their entitlements arising therefrom, with special attention given to whether or not they possess a right to resort to countermeasures, an issue that constitutes the kernel of this book.

Nevertheless, the recognition that contemporary international law is founded on the concept of collective interests reflected in the concepts of jus cogens norms and obligations erga omnes is not without its sceptics. Some authors have expressed their unease at accepting these 'superior' notions whose exact scope and content

46 Ibid, 392-3.

47 Ibid, 394.

48 E. Vattel, The Law of Nations or the Principles of Natural Law (tr. Charles G. Fenwick, Vol. 3, 1916) (Washington, DC: 1916), Vol. 3, Book 1, Chapter 2, Sections 16-18, lviii in Jorgensen op. cit., 86.

49 H. Mosler, 'The International Society as a Legal Community' (1980) 18 in J. Frowein, 'Reactions by Not Directly Affected States to Breaches of Public International Law' 248 Academie de Droit International, Recueil des Cours, Collected Courses (1994) IV, 345, 364. 
remains uncertain and which arguably contravene the nature and function of international law as they attempt to alter the consensual character of the international legal system and its profound horizontal structures of state equality. ${ }^{50}$ There is no doubt that the concept of jus cogens norms alters the nature of international law from being a system of norms of equal standing to a system of a hierarchy of norms to which all other norms need to comply. ${ }^{51}$

Recently, for instance, Professor Weil was warning emphatically against an international law that was moving towards a 'relative normativity' and away from the traditional principles on which it was structured. With modern international law having developed through the decentralized system of state entities that emerged from the 1648 Peace Treaty of Westphalia and which resulted in the collapse of the hierarchical structure of international society, ${ }^{52}$ the emphasis was placed on the peaceful relations and the common interests of states, equals among equals and sovereigns among sovereigns. ${ }^{53}$ Professor Weil was of the view that the essence of this Westphalian system and modern international law remained unchanged. He argued in this regard that modern international law remained a legal order deeply rooted on the principle of sovereign equality and the consent of states. ${ }^{54}$ For this reason, he described the distinction made between jus cogens and ordinary norms (a distinction that prevailed during the debates of the ILC as Chapter 2 will show) and between state crimes and delicts, as 'a key that will not fit the lock it will have to open'. ${ }^{5}$ The intrusion, he said, of ideology in the neutrality of international law, where all states are equal and therefore none could impose its own values on the others, of ill-defined notions over clearly established norms and the weakening of the consensual character of the international legal order 'might well destabilize the whole international normative system and turn it into an instrument that can no longer serve its purpose'. ${ }^{56}$ It was therefore imperative, for international law to fulfil its normative functions, to consist of norms of 'good quality'. ${ }^{57}$ Professor Weil warned against the adoption of notions which lacked definition, such as the notion of 'international community of states as a whole', simultaneously stressing that these ideas would work only were international society fundamentally to change the structures on which it was built.

It is further argued that 'international law scholarship lacks a coherent understanding of hierarchy and, in essence, nothing has been changed since Weil argued in his famous 1982 article that such a hierarchy would hinder the functioning of

50 Shaw, op. cit., 129.

51 Rozakis, op. cit., 19-20. Also see Orakhelashvili, op. cit., 14.

52 Treaty of Munster (Westphalia), Peace Treaty between the Holy Roman Emperor and the King of France and their respective Allies, 24 October 1648, 1 CTS 271.

53 O. Okafor-Obasi, The Enforcement of State Obligations to Respect and Ensure Human Rights in International Law (Universität Potsdam, Series 10: Juni 2003) 22-3.

54 P. Weil, 'Towards Relative Normativity in International Law' 77 AfIL (1983) 419.

55 Ibid, 442.

56 Ibid, 423.

57 Ibid, 413. 
international law in its main role, namely to ensure coexistence and a common aim in a fundamentally pluralistic society'. 58

Despite the scepticism that surrounds these concepts, however, it cannot be disputed that they now find express recognition in the theory and practice of contemporary international law. While one needs to be cautious in clearly identifying these significant norms and their legal consequences, these concepts have become, as the analysis that preceded aimed to establish and as the discussion that follows aims to enhance, an integral part of international legal thinking. The necessity therefore to preserve the juridical foundations of the international legal system which can be identified as the continuation of mankind in conditions of peace and security and the coexistence and cooperation of states is the driving force behind the concept of community interests. This can be no better reflected than in the absolute prohibition of genocide or torture today. States have realized that they share certain common principles and that it is in their interest to protect them even if they are not the direct victims of a certain violation. This is mostly the case when genocide is committed by one state against its own nationals. In instances such as these, there is no injured state, no violation of a bilateral relation of any kind, and yet, contemporary international law, and states themselves have outlawed such conduct as infringing fundamental community interests. This leads to the recognition that the freedom of states is not unlimited, rather, it is restricted by the freedom of other states which have the right to exist and develop in the light of equality, but also, by certain norms which are essential to protect the international legal order itself and its subjects.

\section{The concepts of jus cogens and obligations erga omnes}

\subsection{Peremptory norms of international law}

Since the adoption of Article 53, there have been several attempts to determine not only the exact scope and content of jus cogens norms, but also the legal effects that peremptory norms have both in relation to enforcement and state responsibility. ${ }^{59}$ Article 53 provides the following:

A treaty is void if, at the time of its conclusion, it conflicts with a peremptory norm of general international law. For the purposes of the present Convention, a peremptory norm of general international law is a norm accepted and recognized by the international community of States as a whole as a norm from which no derogation is permitted and which can be modified only by a subsequent norm of general international law having the same character. ${ }^{60}$

58 T. Koji, 'Emerging Hierarchy in International Human Rights and Beyond: From the Perspective of Non-derogable Rights' 12 EfIL (2001) 917, 918.

59 For a recent detailed study on peremptory norms, see the work of Orakhelashvili, op. cit.

601969 Vienna Convention on the Law of Treaties, op. cit. 
The fact that the concept of peremptory norms is entailed in an international treaty does not mean that only states parties to the 1969 VCLT are bound by it. On the contrary, Article 53 seems to reflect a concept that already existed in customary international law as it intends to safeguard norms of general international law. ${ }^{61}$

Identifying the elements that qualify a norm as one of a peremptory character is essential not least because of the serious consequences that its violation may incur such as the invalidity of a treaty, but also of other serious consequences that may arise under the law on state responsibility. The analysis in the following sections is therefore necessary, as the right to countermeasures by states other than the injured is closely related to the content of such norms as protecting fundamental community interests.

\subsubsection{The legal roots of peremptory norms and state consent}

As noted earlier, inclusion of the notion of jus cogens norms in Article 53 of the 1969 VCLT has contributed significantly, to the shift of the discussion from a bilateral, exclusively consent-based traditional international law, to the recognition of certain common values the protection of which is cherished as fundamental to the benefit of the international legal order.

One of the main difficulties concerning the concept of jus cogens norms, however, relates to how it may be reconciled with the consent theory as affirmed in the Lotus case discussed earlier, according to which states are only bound by those norms to which they have consented. The requirement of consent is problematic in the sense that no peremptory norms would ever have been developed had the consent of every state been required. This can be contrasted, for instance, with Article 103 of the UN Charter according to which Charter obligations prevail over all obligations arising from other international agreements since the hierarchy here is established by state consent. Peremptory norms therefore have an indispensable legal effect that seems to be disassociated from state consent, ${ }^{62}$ which may find explanation in the 'immutable Law of Nations' as Vattel has pointed out, or in the 'objective structural framework' of international law that cannot be dismantled as Judge Shahabudeen has argued. ${ }^{63}$

The concept of jus cogens norms corroborates the existence of an international public order that is founded on 'principles of morality' that cannot be dispensed with by any agreement. ${ }^{64}$ As noted, these are essential for the 'legal coexistence' of states within the international community ${ }^{65}$ and they are 'inherent' in every legal system, including the international one. ${ }^{66}$

61 Rozakis, op. cit., 22. Also see Orakhelashvili (2006), op. cit., 113.

62 Orakhelashvili, ibid, 106-08.

63 See section 2.2.

64 A. McNair, The Law of Treaties (Oxford: 1961) 213-14.

65 Separate Opinion of Judge Moreno Quintana, Guardianship of Infants, ICJ Reports (1958) 106-07.

66 Orakhelashvili distinguishes what he identifies as 'structural norms' such as the principle that treaties must be respected from peremptory norms in that the latter leave no choice as to the legal effect of a certain conduct in breach of such norms resulting in their invalidity. Orakhelashvili (2006), op. cit., 32, 45 . 
This has taken place amid a barrage of arguments that the evolution of the concept has sparked as some authors expressed reservations and concerns over the ability of the concept to invalidate treaties and 'interfere' with the bilateral and consent-based nature of the international legal system, but also with the principle that treaties must be observed. ${ }^{67}$ Despite the reservations expressed, Professor Tomuschat emphasized that: ' $[$ t would be wrong to assume that States as a mere juxtaposition of individual units constitute the international community. Rather, the concept denotes an overarching system which embodies a common interest of all States and, indirectly, of mankind.' 68

This may somehow also be revealed by the gradually evolved practice of the Security Council which has on some occasions directed its resolutions for arms and economic embargoes not only to those member states of the UN, but also to non-member states whenever it has felt that there has been a breach of or threat to international peace and security. ${ }^{69}$ Nevertheless, this can hardly find justification under the conventional and customary rules on the law of treaties regarding the imposition of rights or obligations to third states without their consent. ${ }^{70}$

Moreover, as becomes clear from the debates on article 53 and from the Chairman of the Drafting Committee:

$[\mathrm{T}]$ he Drafting Committee had wished to stress that there was no question of requiring a rule to be accepted and recognised as peremptory by all States. It would be enough if a very large majority did so; that would mean that if one State in isolation refused to accept the peremptory character of the rule, or if that State was supported by a very small number of States, the acceptance and recognition of the peremptory character of the rule by the international community as a whole would not be affected. ${ }^{71}$

Not only a hierarchy of norms now seems to make its appearance also in the international legal order, but also states will be bound by such norms even if they have opposed them. It then seems that the notion of jus cogens norms has deprived tradi-

67 G. Schwarzenberger, 'The Problem of International Public Policy', 18 CLP(1965) 191, 213-14.

68 Tomuschat (1993), op. cit., 227.

69 Security Council Res. 660 (1990); Security Council Res. 670 (1990); Security Council Res. 713 (1991); Security Council Res. 757 (1992). For an analysis see Tomuschat (1993), ibid, 252-5.

70 Having said that, it is also important to stress that the UN, and in particular the Security Council, does not possess a role of law enforcer in the international arena. Rather, its powers are limited to the safeguarding of international peace and security, even though a broad interpretation to this end has been attempted since the beginning of the 1990s. Moreover, the Security Council remains a political body where states' own interests still bear gravity in its decision-making process. For more analysis on the contemporary challenges the Security Council is faced with see E. Katselli, 'Holding the Security Council Accountable for Human Rights Violations', Human Rights and International Legal Discourse (2007), Vol. 1, Issue No. 2, 301-333.

71 Comment by Iraq's representative, Mr Yaseen, 80th Meeting Committee of the Whole, 21 May 1968, I, United Nations Conference on the Law of Treaties, Official Records of the United Nations Conference on the Law of Treaties, First Session, 80th meeting, UN doc. A/CONF.39/11 (1969) 472, (12) also cited in Greig (2002), op. cit., 534-5. 
tional international law of one of its most characteristic features: the understanding that international law was structured merely on the consent of states. This issue gains particular significance in the context of customary rules. In this respect Professor Sur wonders whether:

$[\mathrm{T}]$ he formation of a rule of jus cogens is identical to that of a customary rule and that jus cogens is a strengthened form of custom, a higher derivation of custom, or is there an autonomous, original mode of formation, which perhaps does not form part of practice? ${ }^{72}$

As Shelton very pointedly observed: 'The urgent need to act [...] fundamentally challenges the consensual framework of the international system by seeking to impose on dissenting States obligations, that the "international community" deems fundamental. ${ }^{73}$ Verhoeven, however, takes the view that no rule can be considered as having a peremptory character unless states agree. ${ }^{74}$ It is argued in this regard that the fact that a norm of this kind must be recognized by the international community of states as a whole indicates that consent is essential and it takes two forms: first, consent about the character of a norm under general international law and, second, consent as to its non-derogable nature. ${ }^{75}$ However, the fact that peremptory norms protect higher interests owed not to individual states but to the international community makes them independent of consent particularly if a limited number of states oppose their creation. Neither can a state invoke circumstances precluding wrongfulness for the violation of such norms. ${ }^{76}$

Moreover, Orakhelashvili wonders whether a peremptory norm 'has to be so known as recognised by the consent of States or on the basis of the norm's character'. ${ }^{77}$ While acceptance of a norm as fundamental and therefore as peremptory may rely on state consent, it may also depend on 'a belief of the international community that the interest protected by that norm is so essential that the norm binds States even if they have not consented to it'. ${ }^{78}$

72 S. Sur, 'Discussion Statement' in A. Cassese and J.H.H. Weiler (eds) Change and Stability in Intermational Law-Making (de Gruyter: 1988) 128 in Simma (1994), op. cit., 291.

73 D. Shelton, 'International Law and Relative Normativity' in M. Evans (ed.), International Law, 2nd edn (Oxford: 2006) 159, 173.

74 J. Verhoeven, "Fus Cogens and Reservations or "Counter-reservations" to the Jurisdiction of the International Court of Justice' in K. Wellens (ed.), International Law: Theory and Practice, Essays in Honour of Eric Suy (Martinus Nijhoff: 1998) 195, 196.

75 Koji, op. cit., 928-9. Once again, however, the consent theory cannot explain why a state would still be bound by a jus cogens prohibition if that state, either at the moment of its accession to the international legal order or at a later stage, withdraws its consent to be bound by such a norm. Neither does the consent theory adequately explain how a norm may acquire a peremptory character if, as it will be shown in the discussion that follows, not all states need to agree and give their consent about the peremptory character of the said norm.

76 Orakhelashvili (2006), op.cit., 69.

77 Ibid, 106.

78 Ibid, 107. 
Having considered the legal justification of peremptory norms and their relation with state consent, we next focus on the scope and content of such norms.

\subsubsection{The scope, content and legal effect of peremptory norms}

There has been much ambiguity regarding the scope and content of peremptory norms and therefore a consideration into the distinctive elements that make such norms of a prevailing and non-derogable character is essential. It was discussed in section 2.2 in this chapter that some authors have considered this ambiguity as a threat taking away the necessary certainty of the law amid fears of abuse by states that may move behind imperialistic motives for imposing their own 'moral' values on the rest of the world. ${ }^{79}$ Even though the vagueness or ambiguity of a norm cannot be said to take away its legal or peremptory character, ${ }^{80}$ we need to be careful in identifying which norms are jus cogens and which are not.

Although the 1969 VCLT does not provide a definition of peremptory norms, something that may indeed entail the risk of abuse, it incorporates three distinctive elements that may be used by way of interpretation for the determination of these norms. More specifically, Article 53 highlights that under general international law a peremptory norm is one accepted and recognized as such by the international community of states as a whole, that allows for no derogation and that can be modified only by a subsequent norm of the same character. It is noted in this regard that these characteristics differentiate jus cogens norms from other nonderogable rights, which do not have a peremptory character.

With respect to the requirement that these norms are recognized and accepted by the international community of states 'as a whole', this does not, as already noted, presuppose unanimity. Roberto Ago, the second Special Rapporteur appointed for the codification of the law on state responsibility, suggested that such a norm should be recognized by the 'basic components' of the international community such as western and eastern countries, equally developed and developing, although this position has been criticized due to the continuous evolution of the international community. ${ }^{81}$ The Drafting Committee itself clarified that this did not require acceptance of the norm by all states. ${ }^{82}$

Furthermore, the reference to obligations 'owed to the international community as a whole' should not be construed to imply that the international community is a legal person. This is due to the fact that even down to the present day where states have conferred large powers on the UN as a body to observe international peace and security with the ability to authorize armed force, states remain the main actors in international affairs and international lawmaking. Although some states suggested during the second reading of the Draft Articles on State Responsibility

79 M. Koskenniemi, 'International Law in Europe: Between Tradition and Renewal', 16 EfIL (2005) No. 1, 113, 115.

80 H.J.G.Van Hoof, Rethinking the Sources of International Law (Deventer: 1983) 165.

81 See Fifth Report on State Responsibility (Ago) 53, op. cit., (151).

82 Comment by Iraq's representative, Mr Yaseen, 472, (12) in Greig (2002), op. cit., 534-5. 
adopted by the ILC in 1996 that reference to international community as a whole should read as 'international community of States as a whole', the ILC did not consider this as being necessary. This was mainly because it was well established that states continued to have a central role in international decision making, although it is now acknowledged that apart from states, the international community now includes other entities such as the European Union (EU) and other international organizations. ${ }^{83}$

Yet the decisive requirement is the importance of the rights and the interests protected under a norm that qualifies it as peremptory. The violation of such interests is a violation towards all because they are 'universal in scope, and cannot be reduced to bundles of bilateral interstate relations'. ${ }^{84}$ However, Professor Koji tried to qualify this by saying that because jus cogens norms must be recognized as such not only by a specific group of states, even if it is the majority, but by all the essential components of the international community, the substance of the norm has a significant role to play. Consequently, 'jus cogens must include common elements among major different (legal) cultures.' 85

Significantly, due to the lack of a definition, the question of whether a specific norm qualifies as peremptory must be the subject of individual consideration. Thus, the emphasis must be placed on the substance and content of the norm, in other words, on the significance and essentiality of what is protected by it. ${ }^{86}$ This is because: 'Not all rules which are important, or even indispensable, for the existence and working of international law are peremptory.' ${ }^{27}$ Accordingly, jus cogens norms protect prevailing interests that 'do not exist to satisfy the needs of the individual states but the higher interest of the whole international community'. ${ }^{88}$ During the debates for the codification of the law of treaties, it was commented that what makes a norm of peremptory character is not merely that it is recognized as such by all states but also the nature of the interests at stake, which touch morality and the international legal order. ${ }^{89}$ However, not all rules of international law

83 J. Crawford, J. Peel and S. Olleson, 'The ILC's Articles on Responsibility of States for Internationally Wrongful Acts: Completion of the Second Reading' 12 EfIL (2001) 963, 973. Also Fourth Report on State Responsibility by Mr Crawford, UN doc. A/CN.4/517 (37).

84 J. Crawford, 'Responsibility to the International Community as a Whole', Fourth Annual Snyder Lecture, April 2000, Bloomington School of Law, Indiana University, 4, available at http://www. lcil.cam.ac.uk/media/lectures/doc/Snyderlect00(f).doc.

85 Koji, op. cit., 929.

86 Orakhelashvili (2006), op. cit., 43-4. On the legal character and effect of jus cogens norms, see Advisory Opinion on the Legality of the Threat or Use of Nuclear Weapons, op. cit., 258, (83); G. Abi-Saab, 'The Concept of Jus Cogens in International Law', 2 Lagonissi Conference: Papers and Proceedings, Vol. II, Carnegie Endowment for International Peace (Geneva: 1967) 7, 15.

87 Orakhelashvili (2006), ibid, 46.

88 A. Verdross, 'Jus Dispositivum and Fus Cogens in International Law', 60 AfIL (1966) 55, 58.

89 Third Report on the Law of Treaties (Fitzmaurice), YbILC (1958) Vol. II, 20, 40-1, (76). Also United Nations Conference on the Law of Treaties, Official Records of the United Nations Conference on the Law of Treaties, First Session, 80th meeting, UN doc. A/CONF.39/11 (1969) 472, (12). 
are of such character but on the contrary, only those that protect fundamental interests of the international community are considered as such.

Agreement seems to exist, although not always unanimous, that as jus cogens norms qualify norms concerning the prohibition of the use of armed force, the right to self-determination, the core of fundamental human rights and humanitarian law. ${ }^{90}$ Nevertheless, while international legal theory and practice reveal very few, exceptional examples of jus cogens norms, this is only a reflection of the rudimentary character of the international community. ${ }^{91}$

With respect to the non-derogability of a peremptory norm as required under Article 53, this must be distinguished from its limitations or qualifications, in other words, the scope of the norm itself. ${ }^{92}$ The significance of this becomes apparent in relation to the question of whether the prohibition of the use of armed force constitutes a jus cogens norm. According to one view, the fact that force is allowed in circumstances of self-defence or in the light of Security Council authorization makes the norm derogable. However, the other school of thought supports that these exceptions merely define the scope of the prohibition. ${ }^{93}$

It has thus far been established that jus cogens norms protect fundamental interests of the international community and that states are bound by such norms irrespective of their consent. This is particularly evident when a new state is created as it will be bound by norms such as the prohibition of the use of armed force irrespective of whether it consents or not. Nevertheless, peremptory norms are also distinguished for their aggravated legal effects. Article 53 provides in this regard that a treaty that violates a peremptory norm is void, signifying in this manner the importance of the rights protected under the infringed norm but also the seriousness of the violation itself. In addition to the legal consequences that derive from the law of treaties, and as will be discussed in depth in the next chapter, the violation of peremptory norms incurs consequences also under the law on state responsibility.

Suffice it to say here that states in breach of international norms, including jus cogens norms, have a duty, as proclaimed in the Chorzow Factory case, to provide

90 Orakhelashvili, op. cit., 50-66. In support of the jus cogens character of the prohibition of the use of armed force, see Case Concerning Military and Paramilitary Activities in and Against Nicaragua (Nicaragua v United States of America), Merits, Judgment, ICJ Reports (1986) 14, 100-101; Separate Opinion of Judge Bruno Simma, Oil Platforms (Islamic Republic of Iran v United States of America), Merits, ICJ Reports (2003), Judgment of 6 November 2003, 161, 329-30, (9). Separate Opinion of Judge Elagaby, Legal Consequences of the Construction of a Wall in the Occupied Palestinian Territory, Advisory Opinion of 9 July 2004, General List No. 131, para. 3.1. For arguments in support of the jus cogens character of at least certain human rights, see R. Higgins, 'Derogations under Human Rights Treaties', BYIL (1976-77) 281, 282; B. Simma and P. Alston, 'The Sources of Human Rights Law: Custom, Jus Cogens, and General Principles', 12 AYIL (1992) 82, 103.

91 Verhoeven, op. cit., 195, 196.

92 Orakhelashvili (2006), op. cit., 72.

93 Ibid, 72 et seq. 
reparation. ${ }^{94}$ This enables all other states to seek reparation even for the violation of a norm that protects not state interests directly but rather the rights of individuals. ${ }^{95}$ At the same time, restitution seems to be an essential and non-derogable condition of the peremptory character of the infringed violation. ${ }^{96}$ The significance of this must be particularly stressed because a violation involving the unlawful use of force, for instance, would result in a non-negotiable duty of withdrawal from the occupied territory. ${ }^{97}$ The unlawfulness created cannot be remedied by an international agreement. As a result, in the example just cited, acquisition of territory through the unlawful use of force could not become legally justified by an international agreement such as, for instance, a peace treaty. ${ }^{98}$ Moreover, the right of displaced persons to return to their homes is arguably also non-negotiable creating a duty of return. ${ }^{99}$ At the same time, a derivative effect of the peremptory character of a norm is the duty not to recognize the legal effects of conduct committed in violation of such norm.

Quite separately from the legal effects of peremptory norms, many industrialized states had made it clear that they would not ratify the 1969 VCLT unless it provided for adequate and compulsory procedures whenever the parties in a dispute regarding a specific treaty could not themselves settle the matter. By way of contrast, socialist and Third World countries opposed this idea. As a compromise, the ILC adopted Article 66, which provides that whenever a dispute regarding a peremptory norm arises under Article 53 then it must be submitted to the ICJ unless the parties agree to resort to arbitration. This means that a state which is not a party to the 1969 VCLT cannot be forced to accept the jurisdiction of the Court, as Article 66 does not reflect a customary rule of international law. However, these states would still be bound by jus cogens norms, which are accepted to have a customary character. ${ }^{100}$

After the conclusion of the 1969 VCLT, some states placed specific reservations regarding Article 66. Despite the fact that especially for the industrialized states the inclusion of Article 66 was a precondition for accepting those provisions of Part 5 that were expressive of progressive development, according to one view, such reservations could not be regarded as invalid as they did not oppose the object and the purpose of the convention. ${ }^{101}$ In such an event, states opposing reservations

94 Case Concerning the Factory at Chorzow, Merits, 13 September 1928, Permanent Court of International Justice (1928) Series A, No. 17, 4, 29.

95 Orakhelashvili (2006), op. cit., 246-48.

96 B. Graefrath, 'International Crimes and Collective Security' in Weiler, Cassese and Spinedi op. cit., 161,165.

97 Orakhelashvili (2006), op. cit., 252.

98 Ibid, 220-1.

99 Final Report on Human Rights and Population Transfer, Special Rapporteur Al-Khasawneh E/CN.4/ Sub.2/1997/23, (60-61) in ibid, 252-3.

100 Verhoeven, op. cit., 202.

101 Ibid, 197-8, 202. 
regarding Article 66 are entitled to oppose the force of the convention between themselves and the states that have expressed reservation to this provision.

Moreover, acceptance of the concept of jus cogens norms had implications in relation to whether states other than the contracting parties to a treaty in breach of a jus cogens norm would be entitled to invoke the invalidity and nullity of the said treaty. However, the 1969 VCLT in Article 65 provides that only a state which is party to the treaty may invoke its invalidity, making the two positions difficult to reconcile. ${ }^{102}$

Some states have felt that the inclusion of Article 53 would threaten the stability of treaty relations, while at the same time the attribution to the ICJ of jurisdiction to resolve issues regarding the interpretation or application of the Convention would make states more hesitant to accept the jurisdiction of the Court. ${ }^{103}$

\subsubsection{Treaty execution and indirect violations of jus cogens norms}

While Article 53 makes clear that a treaty in contravention of peremptory norms is null, it makes no reference to the status of a treaty that only indirectly contributes to the breach of a jus cogens norm and the legal consequences deriving therefrom. In fact, contemporary international law finds no examples of treaties under which two or more states agree to commit genocide or torture. ${ }^{104}$ On the contrary, in almost all cases treaties seem, as Professor Crawford put it, 'innocent' in their purpose. ${ }^{105}$ Nevertheless, it often happens that compliance with the terms of a particular treaty indirectly assists in the infringement of a peremptory norm. A question closely related to this is, therefore, whether a state which is party to a certain treaty may be entitled to either suspend or terminate that

102 G. Gaja, 'fus Cogens Beyond the Vienna Convention’ 172 RdC(1981) III, 271, 281, 283.

103 France is among those states that have not signed or ratified the 1969 VCLT. France's opposition is not against the notion of jus cogens in general; on the contrary it supports such notion with respect to certain human values accepted by all states. However, as a state that supports nuclear testing itself, France was afraid that accepting the notion without clearly identifying the criteria by which norms would be described as possessing a peremtory character, would have an impact on the stability and security of the law of treaties, but also to state sovereignty. Official Records of the United Nations Conference on the Law of Treaties, First Session, 80th meeting, Vienna, 26 March-24 May 1968, UN doc. A/CONF.39/11 (1969) 309-310; Official Records of the United Nations Conference on the Law of Treaties, Second Session, Vienna, 9 April-22 May 1969, UN doc. A/Conf.39/11/Add.1, 93-5.

104 However, one could refer to other agreements that may directly infringe peremptory norms. As an example of this, one may mention state agreements providing for the use of armed force in circumstances other than self-defence and Security Council authorization. In particular, it has been argued that the Treaty of Guarantee that is annexed as part of the London Agreement establishing the Republic of Cyprus that grants rights of 'intervention' to Greece, Turkey and the United Kingdom for the purpose of restoring legal order is in violation of the peremptory norm prohibiting the use of armed force. See Cyprus-Greece, Turkey, UK, Treaty of Guarantee of the Republic of Cyprus, 16 August 1960, 382 UNTS 3.

105 Second Report on State Responsibility (Crawford), Addendum 2 (1999), A/CN.4/498, Add. 2 (306). 
treaty or refuse to perform it under the law on state responsibility by way of countermeasures.

As will be analytically discussed in Chapter 4, Article 60 of the 1969 VCLT only permits the suspension or termination of a treaty in case of a material breach of the terms of that specific treaty. Any events occurring outside the framework of the treaty are not relevant and therefore leave unaffected the obligations of the concerned parties. As for the non-performance of the treaty by way of countermeasures it has been concluded by the ILC that current international law does not accommodate a right to third, non-injured states to resort to countermeasures. Although this conclusion will be questioned in the course of this analysis, one is left wondering as to the remedies available under international law regarding a treaty that indirectly assists in the commission of a violation of a jus cogens norm. In such cases, it is not the treaty itself that violates the norm, but rather the performance of the treaty. This can be illustrated by an example. Two states conclude a treaty for the sale of weapons and military material. The treaty, on its face, suffers no wrong. If, however, one of the parties is involved in a genocidal plan to exterminate a specific ethnic group living on its territory, the question arises as to whether the other state will still be obliged to conform to its treaty undertakings. ${ }^{106} \mathrm{Mr}$ Ago used a similar example to state that no one could actually blame a state for not observing its treaty obligations under these circumstances since in observing those obligations it would be participating in the commission of an 'international crime'. ${ }^{107}$

Professor Crawford further says in relation to this:

If a peremptory norm invalidates an inconsistent treaty, how can the obligation to perform the treaty stand against the breach of such a norm? No doubt the link between performance of the treaty obligation and breach of the peremptory norm would have to be clear and direct. But in such cases, the temporary suspension of the obligation to perform surely follows from the peremptory character of the norm that would otherwise be violated. ${ }^{108}$

Yet, Professor Crawford is of the view that in these cases of indirect conflict with a peremptory norm there is no need for the total invalidation of the treaty in question. Furthermore, in his opinion a norm having a jus cogens character should

106 On the obligation of states to prevent genocide see Application of the Convention on the Prevention and Punishment of the Crime of Genocide (Bosnia and Herzegovina o Serbia and Montenegro), Merits, 26 February 2007, (427) and (430). According to the Court, 'the obligation of each contracting State to prevent genocide is both normative and compelling', while asserting that states have 'obligation to take such action as they can to prevent genocide from occuring'. The state must accordingly take all reasonable steps within its power to prevent genocide, a duty that derives from a specific treaty, namely, the 1948 UN Convention on the Prohibition of Genocide. See in this regard, Convention on the Prevention and Punishment of the Crime of Genocide, 9 December 1948, UNTS, Vol. 78, 277.

107 Fifth Report on State Responsibility (Ago) op. cit., 18, (50).

108 Second Report on State Responsibility (Grawford), Addendum 2, op. cit., (306). 
prevail over all other international obligations that do not have the same normative effect. Therefore:

[1]n such cases the State concerned would not have the choice whether or not to comply: if there is inconsistency in the circumstances, the peremptory norm must prevail. On the other hand, the invalidation of a treaty which does not in terms conflict with any peremptory norm, but whose observance in a given case might happen to do so, seems both unnecessary and disproportionate. In such cases, the treaty obligation is, properly speaking, inoperative and the peremptory norm prevails. But if the treaty can in future have applications not inconsistent with the peremptory norm, why should it be invalidated by such an occasional conflict? ${ }^{109}$

It seems further to be the position of Professor Crawford that the obligations deriving from a jus cogens norm are to be found in the 'system of international law', but he did press for an inclusion of a provision on precluding the wrongfulness of an act if this act is required by a jus cogens norm. ${ }^{110}$ Indeed, the notion of jus cogens norms would diminish in significance if it at least did not have this effect of entitling the non-observance of a certain treaty obligation, which assists in the commission of a jus cogens violation.

Along the same lines, Professor Fitzmaurice points out that: 'A treaty obligation the observance of which is incompatible with a new rule or prohibition of international law in the nature of jus cogens will justify (and require) non-observance of any treaty obligation involving such incompatibility'. ${ }^{111}$

Nevertheless, this raises the question as to whether there are any real differences between the legal consequences that arise from the violation of a peremptory norm such as in the examples mentioned earlier and countermeasures. As noted in the introduction to this volume, as countermeasures qualify measures of a peaceful character that are in violation of international law; however, they are justified as they are taken in response to a previously committed wrongful act. It is also well established that countermeasures need not be of a reciprocal character. ${ }^{112}$ If therefore an 'inherent' effect of peremptory norms is the obligation of states not to perform their international obligations if by doing so a jus cogens norm is infringed, then this would suggest that countermeasures are not only allowed under international law, but they are also required in circumstances when a peremptory norm is at stake. Most significantly, it seems that the concept of countermeasures by states other than the injured constitutes an integral part of the concept of jus cogens norms in that states are required - in other words, they have a legal duty - not to perform their obligations under that treaty even if they are not directly affected by

109 Ibid, (311).

110 Ibid, (312).

111 Fourth report on the Law of Treaties (Fitzmaurice), YbILC (1959) Vol. II, 37, 46 in ibid, (308).

112 Also, see analysis in Chapter 5, section 5.4. 
such violation. At least it seems that this effect would apply towards those international obligations the execution of which indirectly contributes to the violation of peremptory norms. Of course, the question remains with respect to whether international law permits the non-performance of international obligations in response to violations of obligations that, while of an erga omnes character, do not amount to peremptory norms. This is a question that is central to this book.

Furthermore, states are also under an obligation not to render any aid or assistance to the state that infringes peremptory norms of international law, a duty now envisaged in Article 41 of the Final Articles. This illustrates the close relation between the two branches of international law and, in particular, the law of treaties and the law on state responsibility. While the law of treaties, and in particular Article 53, has the effect of invalidating the treaty which itself violates a peremptory rule establishing the compulsory jurisdiction of the ICJ, the law on state responsibility provides in Article 41(2) the legal consequences arising in the event of serious violations of peremptory norms whether customary or conventional in character. More specifically, it incorporates the duty not to provide any assistance to the perpetrator although there is no mechanism equivalent to that provided under the 1969 VCLT to monitor possible abuses. This leads to the conclusion that the debate is not limited to the question of whether international law recognizes a right to countermeasures by states other than the injured. In fact, the analysis thus far demonstrates that states have a legal obligation to resort to such measures by way of not performing their treaty or customary obligations in circumstances such as those just described. This necessary legal consequence is encompassed by the very notion of peremptory norms of international law.

In any event, in order to justify the non-performance of a treaty under these conditions it will be imperative to show the existence of a direct link between the observance of the treaty and the commission of an act which is in violation of peremptory norms. On this reasoning, it could be argued that the use of nuclear weapons would be directly and clearly contributing to the violation of jus cogens norms since some of the rules of international humanitarian law have been enforced with such status.

Finally, although a treaty is null when in breach of a peremptory norm, there is not much said about the legal consequences of a customary rule in violation of a jus cogens norm. However, it would be safe to conclude that such a rule will become ineffective and inoperative in the same way as in the case of treaties. ${ }^{113}$

The recognition of jus cogens norms as part of international law prepared the ground for the appearance of another notion, no less controversial - that of international state crimes, as thoroughly explored within the work of the ILC on its codification of the law on state responsibility and which will be considered in the next chapter. The realization that not all violations had the same output and the need to attach a more grave nature to some of them due to the fundamental character of the rights protected under certain international rules was the driving force for the introduction of the concept of state crimes in the international legal debate. The serious 
implications arising from the incorporation of the concept in international law, with the possibility of some states being faced with punitive measures, forced many states to look at the notion with a great amount of suspicion and disbelief. The legal consequences to derive from such violations and the states entitled to take action were among the most significant concerns that attracted legal attention, aggravated by the lack of a centralized enforcement mechanism in international law. The debate that emerged around the notion of state crimes is considered in chapter 2.

At this point, it is necessary to consider in some depth another significant concept that emerged in international law and in particular the concept of obligations owed to the international community as a whole and its association with peremptory norms.

\subsection{Obligations erga omnes}

One year after the incorporation of the notion of peremptory norms into the 1969 VCLT, and apparently influenced from the latest developments, the ICJ made a significant distinction between reciprocal and bilateral obligations arising from the law of diplomatic immunities and obligations owed to the international community of states as a whole. It will be seen, however, that despite the similarities between jus cogens norms and erga omnes obligations in that they both protect community interests and as a result they often overlap, the two concepts are not identical. While jus cogens norms establish obligations erga omnes, the same does not apply with respect to erga omnes obligations, which most of the time do not possess a peremptory character. ${ }^{114}$ Moreover, while a jus cogens norm establishes an obligation of observance derogation from which is prohibited unless so provided by a rule having the same normative effect, erga omnes obligations do not have such a strong, compulsory effect. As already discussed, jus cogens norms also preclude the conclusion of treaties that may be in violation of them, while they invalidate any treaties that have this effect. Contrariwise, obligations erga omnes do not deal with the legal consequences per se, but rather, with the question of standing in response to such a breach. ${ }^{115}$

The ICJ's ruling on obligations owed erga omnes constituted a further major turning point for the protection of community interests, despite attempts to diminish the significance of the Court's statement because of the fact that this was not part of its legal conclusions, but rather part of an obiter dictum. ${ }^{116}$ Some authors have even argued that the concept of obligations erga omnes signals the 'constitutionalization of international law'. ${ }^{117}$ Significantly, this concept contributed to the development of the rules concerning the enforcement of obligations of this nature. ${ }^{118}$

114 Jorgensen, op. cit., 97.

115 Tams, op. cit., 152.

116 See ibid, 168. For the significance of the ICJ's dictum also see Koji, op. cit., 933.

117 J. Delbruck, "Laws in the Public Interest" - Some Observations on the Foundations and Identification of Erga Omnes Norms in International Law' in Götz et al. (eds) Liber Amicorum Gunther faenicke - Zum 85. Geburtstag (1999) as cited in Tams, ibid, 3.

118 Tams, ibid, 102. 
The concept of obligations owed erga omnes, however, was not new in international legal doctrine. ${ }^{119}$ In 1957, for instance, Schwarzenberger, commenting on the legal effects of treaties on third states referred to the notion of erga omnes obligations. ${ }^{120}$ The concept also appears in the debates for the drafting of Article 62 of the VCLT concerning treaties that give rise to rights and obligations of third states. During these debates, Manfred Lachs, later judge on the ICJ and in the Barcelona Traction case, suggested that a distinction should be drawn between such treaties and 'treaties establishing objective regimes and obligations erga omnes'. ${ }^{121}$ Furthermore, Judge Jessup, a few years before the ruling in the Barcelona Traction case, observed that states might possess a general interest in the protection of values and benefits common to the international community. ${ }^{122}$

The examination that follows looks at the distinctive features of the concept of obligations owed to the international community as a whole and how this concept has influenced international jurisprudence in terms of legal standing. In other words, the significance of the analysis that follows lies in the fact that the question of whether an obligation is of an erga omnes character is interrelated with the question of standing of states not directly injured by a given breach to make a claim through judicial remedies invoking community interests. The question of whether such states have legal standing to resort to other means of enforcement such as countermeasures will be at the centre of examination in the following chapters.

\subsubsection{The Barcelona Traction case}

Nothing in the Barcelona Traction case was so widely discussed as the reference made by the ICJ to the concept of obligations erga omnes. While the Court has often been criticized for introducing a notion whose necessity was required by neither the legal issues nor the facts of the case, ${ }^{123}$ its pivotal contribution to the establishment of this idea as a general principle of international law is now generally acknowledged.

The case concerned a complaint filed by Belgium on behalf of several Belgian citizens who had been shareholders in the Barcelona Traction Company, a company registered in Canada, for damages they suffered in the hands of the Spanish authorities. Spain based its argument on the ground that the claim was of a bilateral nature involving Canada and Spain, thus precluding Belgium from any right of action on behalf of Canada or the company. The Court's dictum on erga omnes

119 Ibid, 103. See however Koji, op. cit., 931.

120 G. Schwarzenberger, International Law as Applied by International Courts and Tribunals, Vol. 1 (Stevens: 1957) 459 .

121 Summary records of the Sixteenth Session on the Law of Treaties, YbILC (1964) Vol. I, 1, 80, 83, (29) in M. Ragazzi, The Concept of International Obligations Erga Omnes (Clarendon Press: 1997) 8.

122 Dissenting Opinion of Judge Jessup, South West Africa cases (Ethiopia v South Africa) and (Liberia v South Africa), Second Phase, Judgment of 18 July 1966, ICJ Reports (1966) 373-4.

123 See in G. Gaja, 'Obligations Erga Omnes, International Crimes and fus Cogens: A Tentative Analysis of Three Related Concepts' in Weiler, Cassese and Spinedi, op. cit., 151, 154. 
was a response to Spain's reference to the possibility of invocation of state responsibility by any state for the commission of an international crime, although finally rejecting that this was the case in the present circumstances. The judgment identified two main features of the notion of erga omnes: universality, insofar as erga omnes obligations bind all states without exception and solidarity in that every state has a legal interest in their protection. ${ }^{124}$ Consequently, a two-way approach is recognized according to which the international community endorses certain obligations the compliance with, and respect for which are the concern of all states. Nevertheless, it will be established that the enforcement of these obligations is left to individual states in the absence of centralized or community enforcement mechanisms in international law. ${ }^{125}$

According to the famous dictum of the Court:

[A]n essential distinction should be drawn between obligations of a State towards the international community as a whole, and those arising vis-à-vis another State in the field of diplomatic protection. By their very nature the former are the concern of all States. In view of the importance of the rights involved, all States can be held to have a legal interest in their protection. ${ }^{126}$

The dictum in the Barcelona Traction case came only 4 years after the ruling of the ICJ in the South West Africa case. In that case, as we discuss later, the Court rejected the existence of an actio popularis in international law according to which every state would possess a right to bring a claim for violations of international law irrespective of whether there had been a violation of an individual interest. ${ }^{127}$ As already discussed, the possibility of third-state measures for the infringement of an international obligation is a notion unknown to traditional international law as no state can act as a 'world policeman'. The only state entitled to take action against another state is the one that has suffered a wrong, the state to whom the obligation was owed and the state whose rights have been disregarded. According to this view, any state claiming to be injured needs to establish the existence of a subjective legal interest. While the Court distanced itself from an absolute application of bilateralism in the Barcelona Traction case, recognizing that all states have a legal interest to demand compliance with obligations erga omnes, it went on to add in paragraph 91:

With regard more particularly to human rights, to which reference had already been made in paragraph 34 of this Judgement, it should be noted that these also include protection against denial of justice. However, on the

124 Ragazzi, op. cit., 17.

125 Also see the discussion in Tomuschat (1993), op. cit., 231. It has been noted that there was also disagreement among states regarding the existence of the international community itself, what that represented, which states and what powers did that community have in safeguarding the international legal order.

126 Case Concerning the Barcelona Traction, Light and Power Company, Limited, op. cit., 32, (33).

127 South West Africa cases, Second Phase (1966) 47, (88). 
universal level, the instruments which embody human rights do not confer on States the capacity to protect the victims of infringements of such rights irrespective of their nationality. ${ }^{128}$

This statement has provoked much controversy as setting a legal impediment in the implementation of such general interests by states and as negatively filtering the erga omnes invocation of human rights abuses by imposing an unwanted restriction on states. ${ }^{129}$ If one thinks that in most cases human rights violations occur by the state of nationality of the victim, to demand that states respect the nationality rule would be tantamount to expecting the violator to protect its own victims. Frowein interpreted the Court's approach by noting that:

Although the relationship between this paragraph and the one on obligations erga omnes is not absolutely clear, it would not seem to be correct to interpret the latter as foreclosing the possibility for States to act on the basis of obligations erga omnes. This seems to be confirmed by the difference of formulation the Court uses as far as human rights are concerned. While the Court explains in the first part that the "basic rights of the human person" form part of those norms which create obligations erga omnes, it refers to the wider spectrum of "human rights" in the latter part. ${ }^{130}$

The same position is adopted by Professor Koji who identifies two factors creating erga omnes obligations: rights that are incorporated in general international law and 'international instruments of a universal or quasi-universal character', the latter of which is absent with respect to rights referred to in paragraph 91.131 Tams reaches a similar conclusion by observing that paragraph 91 refers to international treaties as opposed to general international law where erga omnes obligations derive from. Yet Tams makes the point that the Court erred in its conclusion that at the time of its ruling such treaties did not empower states other than the state of nationality to invoke their infringement. By way of contrast, there existed at the time many examples of such treaties prohibiting for instance genocide and slavery, empowering all states parties to them to make a claim in relation to the violation of the treaty concerned. ${ }^{132}$ Moreover, as the reference in paragraph 91 concerns human rights enforcement mechanisms established under treaties, it does not extend to the enforcement of obligations erga omnes that derive from customary international law. In this regard, 'the enforcement of obligations erga omnes ... is not a matter of

128 Case Concerning the Barcelona Traction, Light and Power Company, Limited, op. cit., 47 (91).

129 For the view that paragraph 91 should not be interpreted as precluding third states from seeking protection for individuals other than their nationals, see A. de Hoogh, Obligations Erga Omnes and International Crimes (Kluwer Law International: 1996) 52.

130 Frowein (1994), op. cit., 406.

131 Koji, op. cit., 932. Gaja also notes in this regard that obligations 'concerning the basic rights of the human person' create obligations owed to all states irrespective of a direct legal interest on their part, and as a consequence, no derogation is allowed. Gaja (1981), op. cit., 281.

132 Tams, op. cit., 177. 
treaty law.' ${ }^{133}$ Significantly, this means that the implementation of community interests, particularly those emerging under customary international law, is not subject to the nationality principle that may be applicable under specific treaties and therefore it is in this light that this paragraph must be read.

Yet, the recognition of a legal interest in the observation of an obligation erga omnes does not give rise to an automatic right to initiate proceedings before international courts (locus standi) or a right to take countermeasures. On the contrary, there also has to be a distinct right of protection conferred on the state taking action. ${ }^{134}$ This rule applies to both states with a subjective right and states with a legal interest as understood under the concept of obligations owed to the international community as a whole. Simma notes in this respect that 'although the terms "legal interest" and "capacity of action" (qualité pour agir) are identical, specific international agreements may channel such qualité pour agir into appropriate procedures, thereby excluding the possibility of recourse to the classical means of self-help under general international law to a certain extent, that is, as far as these agreements can be considered self-contained.' ${ }^{35}$ As a consequence of this, the right of states to invoke the liability of the defaulting state by means of judicial remedies, which is at the scope of the examination in this chapter, may be qualified by certain procedural guarantees. This is justified by the consent-based character of the international judicial machinery that has not been defeated even with the emergence of such norms and obligations such as those qualifying as jus cogens and erga omnes respectively. However, the erga omnes character of an obligation is not precluded even in the case where states have agreed for specific requirements to be fulfilled regarding their implementation.

Moreover, it will be established that even in cases concerning the violation of obligations erga omnes, the ICJ may not disregard its own jurisdictional rules regarding the capacity of a state to bring a case before it. ${ }^{136}$ It is noted in this regard, that the ICJ, when called to determine a specific dispute between certain parties, must do so weighing its jurisdictional powers, on the one hand, and the interests of the international community, on the other. ${ }^{137}$ The question of the interests of third states that have not consented to the jurisdiction of the Court is also relevant here. In such circumstances, it is imperative that the Court finds a balance between preventing parties from making claims before it that would endanger third states' interests, and not allowing third states to prevent the Court from adjudicating issues submitted with the consent of the parties before it, a matter that will be considered in turn. ${ }^{138}$

The following sections will elaborate on the scope, content and legal effects of obligations erga omnes and, importantly, on the question of standing to bring claims

133 Ibid, 178.

134 Hoogh (1996) op. cit., 25-8. Also see ibid, 19-25; I. Scobbie, 'The Invocation of Responsibility for the Breach of "Obligations" under Peremptory Norms of General International Law' 13 EfIL (2002) 5, 1201, 1218-9.

135 Simma (1994), op. cit., 296.

136 J. Charney, 'Third State Remedies in International Law' 10 MfIL (1989) 57, 90-1.

137 Chinkin (1993), op. cit., 149.

138 Ibid, 202. 
before international courts for the protection of general community and collective interests when individual injury is lacking.

\subsubsection{Collective interests before international bodies and legal standing for violations erga omnes}

Apart from the fact that international law lacks compulsory enforcement mechanisms except where expressly provided (and therefore the existence of such mechanisms is conditioned on the initial agreement of states), it also lacks compulsory judicial jurisdiction for the resolution of disputes arising from the interpretation and implementation of international rules. Consequently, international courts, including the ICJ, do not have jurisdiction to look into a case without the consent of all parties concerned. ${ }^{139}$ Due to the fact that not all states are always willing to subject a certain dispute to the jurisdiction of the ICJ, the Court often finds it difficult to look into the substance of the questions submitted before it and is hence unable to adjudicate on significant issues of international law.

Moreover, a dispute may often involve a wider number of subjects that may be affected in numerous different ways, either directly or indirectly, and in moral, economic, legal, ideological or other terms. ${ }^{140}$ This raises the question whether all states will have a right to seek the performance of the infringed rule, a matter that gains significance in the context of obligations erga omnes. This is particularly so in light of the PCIJ's earlier ruling in the Mavrommatis case, according to which a dispute constitutes a disagreement between two states on issues of law, fact, legal views or interests, thus associating proceedings before it with bilateralism. ${ }^{141}$ Nevertheless, this narrow understanding of legal standing for the enforcement of erga omnes obligations by states not directly affected will be challenged. The attention will subsequently focus on the enforcement of such obligations by initiating proceedings before international judicial and other bodies, although, as noted already, this may not be the only way by which such rules may be enforced, including countermeasures, ${ }^{142}$ a subject that will be separately considered.

The question of standing relates to the persons entitled to give effect to a certain rule by seeking its observance and to the link they need to establish between the infringed obligation and their entitlement to make a claim. As will be shown, in the case of community interests all states have an interest in seeing the observance of the obligation concerned. How they may be able to do so will usually depend, as discussed earlier, on specific procedural and substantive requirements that may need to be satisfied. Furthermore, it will become clear that standing is recognized solely

139 See, for instance, Article 36 of Statute of the International Court of Justice, Statute of the International Court of Justice, 39 AfIL (1945) Supp. 215n.

140 Chinkin (1993), op. cit., 16, 18.

141 Mavrommatis Palestine Concessions (Greece v Great Britain), Judgment No. 2, 30 August 1924, Permanent Court of International Justice (1924) Series A, 11 in ibid, 15.

142 Tams, op. cit., 25-6. 
for those interests that are legally protected or, in other words, are veiled with legal effect. This was affirmed by the ICJ in the South West Africa case ${ }^{143}$ and, accordingly, a state that claims that it has standing to initiate judicial proceedings must establish its right or legal interest. Quite significantly, and as Tams points out, 'a State that can establish a general right to invoke another State's responsibility should be presumed to have standing to do so by way of ICJ proceedings.' ${ }^{144}$ This will often depend on the source of the infringed obligation or the gravity of the violation itself. ${ }^{145}$ At the same time, a state's right to initiate judicial proceedings even if not directly injured by a certain violation may be treaty based and may derive from the nature of certain treaties as interdependent or as establishing an objective regime. Even more so, this entitlement may derive from the nature of the infringed obligation as one that is owed to the international community as a whole.

With these preliminary observations, the analysis is now turned to the enforcement of obligations arising from treaty-based regimes and general international law and how international bodies have approached the question of disputes involving the rights of third states, but also the quest for standing in protection of general interests.

\subsubsection{STANDING FOR TREATY-BASED OBLIGATIONS ESTABLISHING} GENERAL INTERESTS

Issues relating to the notion of obligations erga omnes came to the attention of international courts and bodies a long time before the ICJ's dictum in the Barcelona Traction case. However, inconsistencies in international jurisprudence have caused confusion with respect to whether states not affected in their subjective rights are entitled to make an international claim against the wrongdoing state. In this section, the emphasis will be placed on the enforcement of rights and legal interests arising from treaty-based regimes and it will be shown that there exists sufficient evidence that supports the right of third states to instigate proceedings before international bodies in response to the violation of obligations arising from such regimes. These regimes establish a general right to all states which are parties to enforce the rights protected under them, regardless of whether they have suffered a direct injury to their individual rights. ${ }^{146}$

The PCIJ was concerned with such a case when France, Italy, Japan and the United Kingdom initiated proceedings against Germany as 'interested' powers for the violation of the Treaty of Versailles and, in particular, its obligation to allow free and open access to the Kiel Canal to the vessels of all nations at peace with Germany. The violation took place when Germany denied canal access to a British vessel chartered by a French company that was carrying military material to Poland, which at the time was at war with Russia. Germany justified its action with the 
argument that allowing access to the vessel would put its neutrality at risk. While Italy and Japan, unlike France and the United Kingdom, were not injured or specially affected states, the PCIJ accepted their claim on the basis that they all possessed 'a clear interest in the execution of the provisions relating to the Kiel Canal, since they all possessed fleets and merchant vessels flying their respective flags'. ${ }^{147}$ In particular, the Court held that these states were entitled to raise a claim against Germany because of express treaty provisions according to which 'a legal interest is deemed to be vested in all States by operation of general international law'. ${ }^{148}$ The Court, in examining Germany's entitlement to deny access to the canal, determined that with the Treaty of Versailles the parties wished to establish an 'international regime' that would benefit all nations. ${ }^{149}$ The Court's ruling was not therefore restricted to finding standing solely in favour of France and the United Kingdom as the state of registry of the vessel and as a specially affected state respectively. Rather, the Court acknowledged that under Article 386 of the Treaty of Versailles 'any interested Power' was entitled to initiate judicial proceedings for matters concerning the non-compliance with, or the interpretation of, the treaty. ${ }^{150}$

A similar question regarding the notion of 'permanent international interests' was raised in the dispute regarding the Aaland Islands. This case related to the obligations of states arising under treaties that determine territorial issues. Under these treaties, and in deviation from the principle that treaties do not create obligations for non-parties, an objective regime is established that not only states that are parties to such treaties must respect but also non-parties. ${ }^{151}$ In this particular incident, Sweden offered the Åaland Islands to Finland, then still part of Russia, in 1809, but when Russia was defeated in the Crimean War, the latter concluded an agreement in 1856 with France and Great Britain to demilitarize the islands. ${ }^{152}$ This agreement was annexed to the General Peace Treaty signed by Austria, France, Prussia, Russia, Sardinia, Turkey and Great Britain. When Finland later gained its independence in 1917 a dispute broke out between Finland and Sweden concerning, inter alia, the duty for the demilitarization of the islands. While Finland and Sweden were not parties to the demilitarization agreements, the Committee appointed by the Council of the League of Nations to examine the dispute concluded that:

The Powers have, on many occasions since 1815, and especially at the conclusion of peace treaties, tried to create true objective law, a real political

147 The S.S. Wimbledon, Judgment No. 1, August 17, 1923, Permanent Court of International Justice (1923) Series A, 20.

148 Ibid. Also see Ragazzi, op. cit., 25.

149 The S.S. Wimbledon, ibid, 28.

150 Treaty of Versailles (Treaty of Peace between the Allied and Associated Powers and Germany), 28 June 1919, 16 AfIL (1922) Supp. 1. See analysis in Tams, op. cit., 76-9.

151 Tams, ibid, 87.

1521856 Åaland Islands Convention, 15 NRG, 1st Series, 788-90. Also see ibid, 86. 
status the effects of which are felt outside the immediate circle of contracting parties. ${ }^{153}$

The Committee held in particular that 'every interested state' was empowered to seek compliance with the 1856 Convention. Indeed, the Agreements did not establish reciprocal rights, but on the contrary, the provisions relating to the prohibition of fortification intended to protect European interests by establishing 'a special international status' in the observance of which every state had an interest. ${ }^{154}$

This case too seems to recognize a general right of standing irrespective of whether an individual injury can be established. Quite distinctively however from the Wimbledon case, the Committee's findings lead to the conclusion that a claim regarding the fortification of the islands could be brought not only by the contracting parties but also by other states as well.

The ICJ reached similar conclusions in its Advisory Opinion in the Reservations to the Genocide Convention case in 1951. In particular, the Court acknowledged that the prohibition of genocide established a general public interest, irrespective of the nationality of the victim allowing therefore every state which was party to the Convention to make a claim against the wrongdoer in case of a violation. This is due to the fact that the Convention aims to protect not individual state interests but rather a common interest that benefits the international community in its entirety. ${ }^{155}$

In another case brought before the ICJ in 1963 an erga omnes claim was raised regarding certain provisions of the Trusteeship Agreement for Cameroon established for the purpose of protecting the common interests of UN member states. The ICJ was called on to determine whether each member state possessed a right of action; however, the Court never considered the substance of the case as it dismissed the action on other grounds. ${ }^{156}$

Nevertheless, in the South West Africa case, which concerned a mandate concluded in 1920 to protect the common interests of the former member states of the League of Nations, the ICJ gave rather contradictory rulings. In its ruling on the preliminary objections, the Court recognized the legal right or interest of members of the League of Nations to demand from the mandatory to comply with its obligations towards the people of the mandated territory and the League of Nations. ${ }^{157}$ The Court further acknowledged that since neither the Council nor the League of Nations was entitled to appear before it, the only route for the

153 Aaland Islands Question, 'Report of the International Committee of Jurists entrusted by the Council of the League of Nations with the task of giving an Advisory Opinion upon the legal aspects of the Åaland Islands Question', L.N.O.J., Special Supplement No. 3 (October 1920) 17 in Ragazzi, op. cit., 32.

154 Aaland Islands Question, Report, ibid, 19.

155 Reservations to the Genocide Convention case, Advisory Opinion, ICJ Rep. (1951) 15, 23.

156 Case Concerning the Northerm Cameroons (Cameroon v United Kingdom), Preliminary Objections, Judgment of 2 December 1963, ICJ Reports (1963) 15, 34-6.

157 South West Africa cases, Preliminary Objections, Judgment of 21 December 1962, ICJ Reports (1962), 319, 343. Also see C. Annacker, 'The Legal Regime of Erga Omnes Obligations in International Law' 46 Aus. fIL (1994) 133. 
protection of the rights of the people protected under the sacred trust was resort to the Court initiated by any member of the League. Despite the fact that the Court made no express reference to the notion of erga omnes obligations, it pointed out that the people of the mandated territory needed to turn to the organized international community for the achievement of the goals of the trust. According to the Court, there existed "'a sacred trust of civilisation" laid upon the League as an organized international community and upon its Members'. ${ }^{158}$

Despite these conclusions, the Court dismissed the cases at the second phase on the ground that Ethiopia and Liberia lacked a legal right or interest in the issue before it. ${ }^{159}$ More specifically, the Court, examining whether the mandate created obligations owed to other individual member states of the League of Nations, held that 'the mandatories were to be the agents of the League and not of each and every member of it individually.' ${ }^{160}$ In consequence, the League members were not considered as being directly concerned with the mandates to which they were not parties. The Court even stated that the fact that it was recognized that the mandatory was a 'sacred trust of civilization' did not endow it with a legal effect. As pointed out by the Court, the principles on which the system of mandated territories were founded reflected moral rather than legal principles and, therefore, did not establish legal rights or legal obligations that could be enforced. ${ }^{161}$ However, the Court did not reject the notion of implementation of general interests by states that have not individually suffered an injury, pointing out that such rights and interests, 'in order to exist, must be clearly vested in those who claim them, by some text or instrument, or rule of law'. ${ }^{162}$ Still, the Court's reference to the notion of actio popularis was, according to Tams, 'unnecessary' as it was not asked to do so by the parties. Instead, the Court's ruling relied on a restrictive interpretation of the rules on standing in the light of Article 7(2) of the South West Africa Mandate Agreement, according to which it did not confer a broad entitlement of initiating proceedings before the ICJ in response to a violation of the agreement's provisions. ${ }^{163}$ These conclusions of the Court cannot be reconciled with the previous ruling of the PCIJ in the Wimbledon case as discussed earlier or with the findings of the Committee of the League of Nations in the Aaland Islands incident. On the contrary, they uphold a narrow understanding of the rules on standing restricting the right to initiate judicial proceedings to those states that have directly suffered a wrongdoing unless otherwise provided.

However, in 1971, one year after its ruling in the Barcelona Traction case and a few years after its ruling in the South West Africa case, the Court was asked to give its Opinion regarding the legal consequences of the continuing presence of South Africa in South West Africa despite a Security Council resolution in 1970

158 South West Africa Cases, ibid, 329.

159 South West Africa cases, Second Phase, op.cit., 51, (99).

160 Ibid, 25 and 29, (24) and (33).

161 Ibid, 34, (49-51).

162 Ibid, 32, (44). Tams, op. cit., 67.

163 South West Africa Mandate, 17 December 1920, LNOJ 1921, 89. 
terminating the mandate. The ICJ held that (a) member states were bound not to recognize the lawfulness of South Africa's administration of South West Africa and (b) non-member states should assist the UN in its action relating to South West Africa, finding the termination of the mandate as being an obligation erga omnes. The Court did not elaborate the grounds on which a Security Council resolution was binding on non-UN member states, thus having an erga omnes effect. Different interpretations have been attempted, including the view that the obligations of all states in this particular case derived from an obligation erga omnes not to recognize a jus cogens breach, although the ICJ made no reference to this latter concept. ${ }^{164}$

In contrast to the restrictive approach followed by the ICJ in the South West Africa case in 1966, regional courts have on many occasions considered cases brought by states other than those injured. The case law of the European Court of Human Rights, for instance, reveals that for the initiation of proceedings before it, it is not a prerequisite that a state is directly injured by a violation of a right protected under the European Convention on Human Rights. An example of this kind constitutes the interstate application brought against the dictatorship in Greece by Denmark, the Netherlands, Norway and Sweden in 1967. These states justified their action on the public order established under the European Convention on Human Rights, empowering them with a legal interest in seeing the performance of the obligations arising thereunder. ${ }^{165}$

While the ICJ in the South West Africa case adopted a cautious approach restricting the right of third states to instigate proceedings before it, it has been shown that a rather broader approach was accepted a long time before the 1966 ruling for the protection of general interests that had been set up under specific treaty agreements. The significance of these examples is not to be underestimated as they enhance an argument in favour of the judicial enforcement of general interests even by states that have not been directly affected by their breach.

\subsubsection{THE DOCTRINE OF INDISPENSABLE THIRD RIGHTS}

Having considered how international bodies approached the question of standing for the protection of general interests established under specific treaties, this section aims to look at how international judicial bodies dealt with disputes that, although affecting general interests, also had an impact on the rights of third states. While the concept of community interests and obligations erga omnes gained ground in international fora, the extensive jurisprudence predominantly of the ICJ reveals a reluctance to consider cases, even when raising erga omnes considerations, whenever the rights of states not parties to the proceedings are affected. This is known as the doctrine of 'indispensable third rights'. This enhances the

164 Legal Consequences for States of the Continued Presence of South Africa in Namibia (South West Africa) notwithstanding Security Council Resolution 276 (1970), Advisory Opinion, ICJ Reports (1971) 4, 58 (133). See analysis in Ragazzi, op. cit., 169 and 171.

165 Commission's Report on the Greek case, 12 YbECHR (1969) 1. For more analysis on this incident, see Chapter 3, section 5.2.5. 
earlier submission that any relevant substantive or procedural requirements in place cannot be overlooked even if the fundamental interests of the international community are at stake.

In the dispute between Albania and the United Kingdom concerning the explosion of mines within Albanian territorial waters resulting in loss of life and damage to British warships, the ICJ was called to consider Albania's responsibility over the explosions. It was accepted by all parties to the dispute that the principles endorsed in the Hague Convention No. VIII of 18 October 1907 relating to the laying of mines, applicable in time of war, reflected principles that constituted a 'minimum international standard binding at all times on civilized States'. ${ }^{166}$ As a corollary to it, there was a duty on any state laying mines to give notification to international shipping. Therefore, the disagreement between the two parties was not one of law but, rather, one of fact: Albania claimed that it was not aware of the mines. The Court concluded that Albania must have been aware of the mines while stressing that the duty of notification established general and well-recognized principles. More specifically, it constituted a duty establishing:

elementary considerations of humanity, even more exacting in peace than in war; the principle of the freedom of maritime communication; and every State's obligation not to allow knowingly its territory to be used for acts contrary to the rights of other States. ${ }^{167}$

When Albania refused to comply with the ruling of the ICJ in the Corfu Channel case and to compensate the UK for damages it incurred as a result of the explosions, a tripartite commission was established after the end of World War II. The committee, consisting of France, the United Kingdom and the United States decided to grant seized Albanian gold to the United Kingdom. Italy initiated proceedings before the ICJ against France, the United Kingdom and the United States claiming compensation for the expropriation of the Albanian National Bank, which according to it had been built mainly with the use of Italian capital. The Court, however, declined to examine the case as it would inevitably not only affect Albania's legal interests but it would constitute the main subject matter of the proceedings with legally binding implications on Albania which was not participating in the proceedings. ${ }^{168}$ The United Kingdom, in the proceedings before the Court, justified France's and the United States' standing on the basis that all states are empowered to resort to measures that will ensure compliance with and enforcement of the judgments of the ICJ in the light of a general interest they

166 Corfu Channel case, Merits, 9 April 1949, ICJ Reports (1949) 4, 22.

167 Ibid, 22.

168 Case of the Monetary Gold Removed from Rome in 1943, 15 June 1954, ICJ Reports (1954) 19, 32. Also see C. Schulte, 'The Enforcement of Obligations Erga Omnes before the International Court of Justice, Procedural Law and the East Timor Judgment in Might and Right in International Relations' XXIII Thesaurus Acroasium (1999) 531, 538. 
possess in this regard. According to the UK's view at the time, all states are entitled to 'reasonable and legitimate steps' in order to ensure compliance with the ICJ's decisions. ${ }^{169}$ Although not expressly stated, this statement could imply a right of third states to resort even to countermeasures in response to a violation of community interests, namely the disregard of international decisions.

It is worth mentioning that, had the gold been Albania's, the action of France and the United States, as third states, to seize it could arguably be justified as a countermeasure in response to Albania's failure to comply with the earlier ruling of the ICJ, providing yet more evidence in support of a right to third-state countermeasures. Charney suggests in this regard that there is a universal right to assist in ensuring compliance with the judgments of the ICJ, ${ }^{170}$ although the ILC seems to take the view that international judgments can only be enforced by the states that are parties to the dispute. ${ }^{171}$

In the Nicaragua case, the ICJ upheld the indispensable third-right rule stressing that it would only dismiss a case that involved the rights and legal interests of a third state if these formed the subject matter of the case. ${ }^{172}$ Similarly, in the Nauru case, concerning compensation claimed by Nauru against Australia for damages caused during mining activities when Australia was an administering power, the Court dismissed Australia's argument that the ruling of the Court would unavoidably have an impact on New Zealand and the United Kingdom, which were not parties to the proceedings. Although both these two states had joint authority with Australia to administer Nauru under the Trusteeship Agreement for the Territory of Nauru, the Court held that Australia's responsibility was independent from any responsibility of New Zealand and the United Kingdom, differentiating this case in this way from the Monetary Gold case. ${ }^{173}$

It can be concluded that international judicial bodies cannot disregard the consent-based nature of international judicial proceedings by adjudicating on issues that may affect the rights of states not parties to the proceedings, even if these involve the violation of community interests.

Attention will now be turned to various attempts to initiate judicial proceedings before the ICJ in response to violations of obligations owed to the international community of states as a whole in the aftermath of the Barcelona Traction case.

169 Monetary Gold case (Italy v United Kingdom, United States, France), Pleadings, Oral Arguments and Documents, ICJ Reports (1954), 126 and 131.

170 Charney (1989), op. cit., 67.

171 Commentary to Article 42 of 2001 Final Articles on State Responsibility, (7) in Crawford (2002) 257-8.

172 Case Concerning Military and Paramilitary Activities in and against Nicaragua, (Nicaragua v United States of America), Jurisdiction and Admissibility, Judgment, ICJ Rep. (1984), 431 (88).

173 Case Concerning Certain Phosphate Lands in Nauru (Nauru v Australia), Preliminary Objections, 26 June 1992, ICJ Reports (1992) 240, 261-2. 


\subsubsection{ERGA OMNES CLAIMS BEFORE INTERNATIONALJUDICIAL BODIES}

Despite the significance of the ICJ's ruling in the Barcelona Traction case, there has been uncertainty in relation to whether this recognized a general right to instigate judicial proceedings in the name of community interests or not. More specifically, the question that arose as a result of the Court's obiter dictum was whether the violation of such obligations gave rise to a legal interest to the international community or whether each and every state was empowered with legal standing to judicially demand observance with that obligation. The latter view is supported by the fact that the Court makes clear that 'all States ... have a legal interest' in the protection of obligations erga omnes. ${ }^{174}$ The concept would also become meaningless if the international community as a whole, together with the ambiguity that this term entails, was the only possible enforcer of these obligations. ${ }^{175}$

However, the ICJ has not so far had the opportunity to take a clear stance on this matter. In the East Timor case, the ICJ has dismissed the case on the ground that a third state's rights would be adversely affected. In this case, Portugal initiated proceedings before the ICJ against Australia arguing that the treaty concluded by the latter with Indonesia concerning the exploitation of the natural resources of East Timor, violated both the right of East Timorese to self-determination and the subjective right of Portugal, as the administrating power of East Timor. Furthermore, Portugal complained that Australia's actions constituted an infringement of Security Council Resolutions 384 and 389 with which all states were called on to respect the territorial integrity of East Timor and the right of East Timorese to self-determination and which called on Indonesia to withdraw its troops from the territory of East Timor. ${ }^{176}$ As a consequence, Australia incurred international responsibility both towards the East Timorese people but also towards Portugal. The ICJ, while recognizing the right of East Timorese to selfdetermination as having an erga omnes character, refused to examine the merits of the case ruling that this would unavoidably require it to adjudicate on the lawfulness of the actions of Indonesia, a state that was not a party to the proceedings. More specifically, the Court drew a distinction between the erga omnes character of a norm and the issue of consent to the jurisdiction of the Court. ${ }^{177}$ While the Court did not preclude the entitlement of a third state to complain about the violation of an erga omnes obligation, it emphasized that its ruling would have an impact on a third state that had not consented to its jurisdiction.

The judgment has been criticized as preventing the enforcement of obligations owed to the international community as a whole and as insisting on a bilateral approach to the proceedings. It has been argued, in particular, that since erga omnes obligations by their very nature involve many states, bear legal consequences extending beyond a strict bilateral relationship and are owed to the international community

174 Case Concerning the Barcelona Traction, Light and Power Company, Limited, op.cit., 32, (33).

175 Tams, op. cit., 175.

176 Case Concerning East Timor (Portugal v Australia), 30 June 1995, ICJ Reports (1995) 90, 96 (14-15).

177 Ibid, 102 (29). 
as a whole, each state $u t$ singuli possesses a legal interest in their observance. Even more so, in the case of violations of jus cogens norms there exists a duty to do so. ${ }^{178}$ Simma, by the same token, is of the view that the ruling of the ICJ in the East Timor case, while not adding anything to the concept of obligations erga omnes, does not pose a threat to it either. The Court, having accepted that the right to self-determination is an obligation erga omnes, retained the doctrine of the 'indispensable third party' established in the Monetary Gold case concluding that it could not adjudicate a matter in the absence of a state that would be directly affected by such ruling. ${ }^{179}$

One may observe from this analysis that only if a finding relating to the legal interests of a third state is necessary for the determination of the responsibility of another state will such a third state be regarded as an indispensable state and will thus preclude the examination of the case by the international court. Accordingly, where the legality of the action of a third state is inseparable from the legality of the action of another state, the Court will decline to examine the claim before it. ${ }^{180}$

One crucial point that arises however is whether the ICJ would have accepted Portugal's legal standing to bring an erga omnes claim in the East Timor case had Indonesia recognized the Court's jurisdiction. Moreover, it would be interesting to see how the ICJ would approach a claim made by Portugal that the treaty between Australia and Indonesia infringed a jus cogens norm and whether the Court would accept Portugal's standing to invoke the invalidity of the treaty and the responsibility of the states concerned. This is particularly so in view of the fact that the 1969 VCLT provides that the invalidity of a treaty can only be invoked by states that are parties to it. If one accepts, as the earlier analysis has shown, that the violation of peremptory norms gives rise to obligations that are owed to the international community and that as a consequence every state has a legal interest in their protection, it would be devoid of meaning to prevent such states from asserting its invalidity. While third states would, in principle, have legal standing to raise violations of obligations erga omnes, they would not be able to do so in relation to violations of the most serious nature, that is treaties that infringe norms so fundamental from which no derogation is permitted. Scobbie notes in this regard that a state could seek a declaration that another state infringed a peremptory norm of international law provided of course that 'the jurisdictional link in issue is wide enough'. 181 Moreover, third states, while not entitled to invoke the nullity of the treaty, may have other means of pressure outside the scope of the 1969 VCLT against the implementation of the treaty. The entitlement to use such other means will derive from the erga omnes character of the obligation incorporated in the infringed jus cogens norm. To this end, the concept of erga omnes obligations becomes a shield for the protection of fundamental principles embedded in jus cogens norms. ${ }^{182}$

178 Schulte, op. cit., 537.

179 Simma (1994), op. cit., 298.

180 Schulte, op. cit., 542.

181 Scobbie, op. cit., 1218-9.

182 Ragazzi, op. cit., 206. 
Erga omnes issues were also raised in the proceedings initiated by Australia and New Zealand against France's atmospheric nuclear tests conducted in the South Pacific between 1966 and 1972. ${ }^{183}$ In this regard, the Court reached the conclusion that certain statements of the French government amounted to a unilateral undertaking of ceasing further nuclear tests that was made erga omnes. However, the meaning of the notion used in this case differs from its meaning given in the Barcelona Traction case. While the reference to erga omnes in the latter case was closely associated with the question of enforcement and standing in the terms of a legal interest, in the former case, the reference was restricted only to the circle of states towards which such statement was made. ${ }^{184}$ Despite the fact that the Court did not have the chance to consider the question of the erga omnes effect of the conduct complained of, some of the Judges in the case gave their views on the matter. Judge de Castro, for instance, was of the opinion that states could not rely on a general erga omnes obligation in order to initiate proceedings before the Court and, instead, had to establish that they had suffered an injury to their own rights. ${ }^{185}$ Other judges, however, seemed to accept that the possibility of a general right to standing could be argued in view of the ICJ's ruling on erga omnes obligations. ${ }^{186}$

In other decisions, the Court chose a more careful approach with respect to erga omnes considerations. In the Teheran Hostages case, although the Court highlighted the imperative character of the norms envisaged in the Vienna Convention on the diplomatic and consular relations for the international community as a whole, it restricted the matter as being a dispute between the United States as the injured state and Iran as the wrongdoing state. ${ }^{187}$ Also, in the Nicaragua case, the Court refused to accept that the prohibition of non-intervention had an erga omnes character, thus concluding that the United States, as a third party, had no right to use force in response to armed intervention in another state. In particular, the Court concluded that '[the acts of which Nicaragua is accused] could not justify countermeasures taken by a third State, the United States, and particularly could not justify intervention involving the use of force'. ${ }^{188}$

\subsubsection{CONCLUDING OBSERVATIONS}

The preceding analysis has demonstrated that considerations concerning obligations erga omnes, either arising from specific treaty arrangements or from general international law have not been unknown in the jurisprudence of international courts and other bodies. While the 1966 ruling of the ICJ in the South West Africa case may

183 Case Concerning Nuclear Tests (Australia v France), 20 December 1974, ICJ Reports (1974) 253.

184 Tams, op. cit., 114.

185 Dissenting opinion of Judge De Castro Case Concerning Nuclear Tests, op.cit., 387.

186 Joint Dissenting Opinions of Judges Onyema, Dillard, de Arechaga, Waldock, Case Concerning Nuclear Tests, ibid, 369-70 (118) and Case Concering Nuclear Tests (New Zealand v France), 20 December 1974, ICJ Rep. (1974) 457, 521 (52).

187 See in this regard the ruling of the court in United States Diplomatic and Consular Staff in Teheran (United States of America v Iran), 24 May 1980, ICJ Reports (1980) 3, 41-4.

188 Case Concerning Military and Paramilitary Activities in and against Nicaragua, (1986) op. cit., 127 (249). 
constitute a retrogression in relation to the standing of third states to raise concerns affecting community interests, there is sufficient evidence that shows that such a right was recognized long before the ICJ's dictum in the Barcelona Traction case. Accordingly, this shows that the South West Africa case is not the only ruling that can be relied on. At the same time, however, it has been established that the concept of erga omnes obligations does not confer an automatic right or legal standing on states to initiate judicial proceedings in the event of a violation of an obligation of this nature. Accordingly, the rules concerning the jurisdiction of international courts cannot be disregarded, even in cases that concern the violation of an erga omnes obligation.

Finally, the ICJ's own reference to the legal interest of all states in relation to obligations erga omnes signals a significant legal turning point that supports a general right of standing for initiating proceedings before the ICJ for the protection of community interests. ${ }^{189}$

\subsubsection{Scope and content of obligations erga omnes}

The ICJ's dictum had without doubt a tremendous impact on the further development of community interests. However, other than an express reference to aggression, slavery, racial discrimination and genocide as illustrating some examples giving rise to obligations owed to the international community as a whole, the ICJ did not give a definition of what these obligations are or how they can be identified. This gave rise to claims over the years that all human rights obligations have an erga omnes effect. ${ }^{190}$ What the Court did make however was a reference to the importance of the rights concerned, which bestowed a legal interest on all members of the international community for their protection. ${ }^{191}$

In an effort to establish the criteria that qualify a given obligation as of an erga omnes character, Tams puts forward a material and a structural approach. According to the material approach, erga omnes obligations are characterized by the importance of the rights they protect, although the vagueness of this term may lead to confusion. This adheres to the quality of the protected right. The structural approach, by way of contrast, places the emphasis on the fact that erga omnes obligations possess a 'non-bilateralizable' and 'non-reciprocal' nature as a result of which the obligation must be observed towards all members of the international community. ${ }^{192}$ The problem with the structural approach, however, is that it accepts that every non-bilateralizable obligation would be considered as having an erga omnes character, thus extending its scope to all interdependent and absolute obligations. At the same time, it precludes obligations that have both an erga omnes and a reciprocal character, such as prohibition of aggression. ${ }^{193}$

189 Tams, op. cit., 163.

190 Y. Dinstein, 'The Erga Omnes Applicability of Human Rights', 30 AVR (1992) 16.

191 Case Concerning the Barcelona Traction, Light and Power Company, Limited, op.cit., 32, (33).

192 Tams, op. cit., 129-30.

193 See ibid, 130. 
The importance of the protected rights is, therefore, a distinctive feature of obligations erga omnes. Yet a question arises as to whether all important rights acquire such character or whether a further distinction is required. More specifically, the ICJ itself makes a distinction between basic human rights that possess an erga omnes character and other human rights, indicating that it did not consider that all human rights had an erga omnes effect. ${ }^{194}$ In the East Timor case, the Court identified some factors that may illustrate the erga omnes character of that obligation such as the recognition of the obligation in the UN Charter, in general international law or in universal treaties. ${ }^{195}$

One further significant aspect of obligations owed to the international community as a whole and, consequently, to all states is the fact that derogation from such norms is made very difficult.

Consent therefore plays a significant role in the understanding of the concept of erga omnes rules and of the legal effects that arise for the carriers of an obligation that qualifies as such. Accordingly, if one accepts that erga omnes rules establish obligations empowering all states with a legal interest in their performance, it is necessary to consider what will happen in the event that two or more states decide, with a specific agreement, to derogate from such rules. There is no doubt that, since the obligation is owed to all states, such an agreement would unavoidably affect the interests of all the other members of the international community that were not included in the pact. In these circumstances, the violation of an erga omnes obligation with the consent of some but not all states is not permitted. Consequently, only with the consent of all states to which the obligation is owed will any state be entitled to derogate from such obligations, otherwise their violation will constitute an internationally wrongful act empowering the other states to invoke the responsibility of the wrongdoer. Nevertheless, if one accepts that there can be no derogation from an erga omnes obligation without the consent of all the states concerned, then the legal effect of erga omnes obligations is identical to the legal effect of jus cogens norms, raising the question of how these two notions differ in reality. As Professor Crawford observes:

From the Court's reference to the international community as a whole [ICJ in the Barcelona Traction case], and from the character of the examples it gave, one can infer that the core cases erga omnes are those non-derogable obligations of a general character which arise either directly under general international law or under generally accepted multilateral treaties (e.g in the field of human rights). They are thus virtually coextensive with peremptory obligations (arising under norms of jus cogens). For if a particular obligation can be set aside or displaced as between two States, it is hard to see how that obligation is owed to the international community as a whole. ${ }^{196}$

194 Ragazzi, op. cit., 140-41; ibid, 138.

195 East Timor case, op. cit., 102, (29); Dissenting Opinion of Judge Weeramantry, East Timor case, op. cit., 194. Also see ibid, 153.

196 Third Report on State Responsibility (Crawford), A/CN.4/507 (2000) 46, (106)(a). 
When Russia invaded Afghanistan, for instance, claiming that it had the consent of the Afghan government, the General Assembly, in a resolution adopted in 1980, declared that the sovereignty, territorial integrity and political independence of states constituted a fundamental principle entailed in the UN Charter, which permitted no violation 'on any pretext'. ${ }^{197}$ This is because an obligation falling under this category is owed towards all states as members of the international community as a whole and therefore its violation is the concern of all unless all states had consented to it. As Professor Gaja remarks:

The fact that an act is considered to be wrongful also in the relations between the injuring State and the State specifically injured has little practical meaning so long as the latter State does not put forward any claim. In order to give the provision in the draft articles a greater significance one would also have to assume that no waiver to such a claim is admissible. ${ }^{198}$

Gaja further differentiates the legal consequences to derive from the violation of jus cogens norms and obligations erga omnes. In this regard, the violation of the former leads to the invalidity and illegality of a treaty, while the violation of an erga omnes obligation through the implementation of a specific treaty does not lead to its invalidity and, therefore, it does not have the same legal effect. ${ }^{199}$

Similarly the ILC, examining the differences between these two notions, stressed that:

There is at least a difference in emphasis. While peremptory norms of general international law focus on the scope and priority to be given to a certain number of fundamental obligations, the focus of obligations to the international community as a whole is essentially on the legal interest of all States in compliance - i.e. in terms of the present articles, in being entitled to invoke the responsibility of any State in breach. ${ }^{200}$

Although jus cogens norms and erga omnes obligations overlap, the former entail 'elements of international public policy' and, for this reason, they cannot be derogated from. ${ }^{201}$ It is stressed, however, that it should not be concluded that whenever a rule permits of no exceptions it is thereby of a jus cogens character. ${ }^{202}$

Furthermore, a state cannot evade responsibility and cannot justify the violations of an erga omnes obligation on the ground that it responded to a previous wrongful

197 Keesing's Contemporary Archives, Record of World Events Vol. 26 (1980) 30229, 30236.

198 Gaja (1981), op. cit., 295-6.

199 Ibid, 281.

200 ILC Report on the Work of its Fifty-third Session, 23 April-1 June and 2 July-10 August 2001 (A/56/10 and Corr.1 and 2) 281, (7) in Scobbie, op. cit., 1212.

201 Scobbie, ibid, 1210.

202 Ibid. 
act by another state. ${ }^{203}$ The issue was raised for the first time in the case brought by Bosnia-Herzegovina against Yugoslavia for breaches of the Convention on the Prevention and Punishment of the Crime of Genocide. Yugoslavia submitted a counterclaim concerning violations of the Convention allegedly committed by Bosnia-Herzegovina. ${ }^{204}$

At the same time, as in the case of jus cogens norms, a reasonable question that derives from the notion of obligations erga omnes concerns the legal effect of an objection in relation to the creation of an erga omnes obligation formulated by one or more states. One could argue that, once an obligation has gained an erga omnes character, no state will be able to derogate from it other than under the conditions described earlier. Therefore, in this instance, the moment of creation of the obligation is crucial for the determination of this question. In other words, if one or more states object to the creation of an obligation as having an erga omnes character at the moment of its inception, it would be difficult to see how a norm would acquire such status in the first place. By way of contrast, however, this would have serious ramifications, as no rule would ever develop to have such a character since it is almost impossible to achieve or expect the unanimous agreement of all states of the international community. Quite to the contrary, one would be able to argue that the development of erga omnes obligations results from the fact that the international community has moved away from a solely consent-based understanding of international law that allows the development of certain rules irrespective of the consent of all states. Again, this issue is closely related to the proposition that states are presumed to have accepted international law as a general legal system that is structured on state consensus. ${ }^{205}$

\section{Conclusion}

The preceding analysis intended focusing on the emergence of peremptory norms, obligations erga omnes and community interests in international law. The adoption of Article 53 of the 1969 VCLT, together with the ICJ's pronouncement on obligations in which all states have a legal interest in the Barcelona Traction case, significantly changed the legal scene concerning the very nature of international law. The development of these concepts was unavoidably met with scepticism as they were regarded by some states and commentators as a tool restrictive of the sovereign powers of states and as being irreconcilable with the 'traditional' function of international law that is founded on the coexistence of equal sovereign states without the consent of which no norm can evolve. The recognition of these notions raises significant questions with respect to the nature of international law, as they seem to go beyond merely establishing bilateral relations between states. Accordingly, if international law is construed as a minimal legal system consisting of powerful sovereign states

203 O. Pegna Lopes, 'Counter-claims and Obligations Erga Omnes before the International Court of Justice' 9 EfIL (1998) No. 4, 724.

204 For a review on the case, ibid, 733-5.

205 See, in this regard, analysis in section 2.2. 
that are restrained only to the extent they have accepted, then these norms have no place in such a system. If, by the same token, international law is, in addition, construed to be structured on the basis of collective interests not only owed to, but also binding on, all states and from which no derogation is permitted, then international law seems to resemble a constitutional or quasi-constitutional legal order.

The discussion showed how contemporary legal thinking has progressed from a restrictive perception of interstate relations that are characterized mainly by their bilateral and reciprocal nature, to community interests the protection of which constitutes the concern of all states. It has been shown that these developments played a crucial role in the area of enforcement, although the discussion in this chapter was restricted to the enforcement of community interests and obligations erga omnes by way of initiating proceedings before international judicial bodies.

It has further been established that the obiter dictum of the ICJ had compelling effects on the question of standing of states not affected in their individual rights to bring a claim for the protection of community interests as arising from customary international law. It has also been shown that the question of general standing has been accepted in many cases that preceded the dictum of the ICJ in the Barcelona Traction case, supporting the right of third states to make a claim for the violation of general interests established under specific treaties and under general international law.

Moreover, it has been argued that international courts are not free to disregard the rules concerning their jurisdiction or consent, thus preventing them from considering disputes brought before them that may have an adverse effect on the legal interests of states not parties to the proceedings.

While neither Article 53 of the 1969 VCLT nor the obiter dictum of the ICJ provides a definition of what peremptory norms or obligations owed erga omnes are, both place an emphasis on the importance of the rights they protect. While fears have been expressed about an arbitrary expansion of which obligations qualify as such, it has been shown that it is the quality of the protected rights that play a significant role in their identification.

The examination of these concepts has been deemed necessary for the comprehension of the emergence of another concept, that of countermeasures taken by states other than the injured and which lies at the heart of this book. The recognition of certain norms, which due to the nature of the rights they protect are fundamental for the protection of community interests, has unavoidably raised questions regarding their implementation in the international legal order in the event of their violation. Therefore, a look into the content and scope of jus cogens norms and obligations erga omnes, as these are elaborated in the literature, state practice but more specifically the jurisprudence of the PCIJ and the ICJ, may reveal the justifiability behind the development of the notion of enforcement of these collective interests by way of third-state countermeasures. The next chapter will therefore consider in depth the influence that these developments exercised in the work of the ILC in the codification of the law on state responsibility. 


\section{Community interests in the law on state responsibility}

\section{Introduction}

The recognition of the concept of 'higher' norms of international law from which no derogation is permitted, but also of the concept of legal interests that belong to all states, has influenced to a great extent the work of the ILC on the codification of the law on state responsibility. The analysis in Chapter 1 into these doctrines that have now become an integral part of contemporary international legal thinking was therefore essential in setting the background for the analysis that will follow in this book. Naturally, these developments had a compelling effect on the legal consequences arising from the commission of an internationally wrongful act, with particular emphasis placed on the significance of the rights protected under the infringed norm, the gravity of the violation and also the subjects entitled to invoke the responsibility of the wrongdoing state. More significantly, these developments prepared the ground for the emergence of the concept of countermeasures taken by states other than the injured or solidarity measures, as they are often referred to, the lawfulness of which is focal to this book.

This chapter will pay particular attention to the circumstances under which the ILC engaged with the notion of countermeasures in the name of community interests. This presupposes consideration of another significant concept that also made its appearance in international legal doctrine, including the work on state responsibility, namely, the concept of international state crimes. It will also be shown that in spite of the influence of the concept of higher community interests in the law on state responsibility, the ILC in its Final Articles decided to leave the question of a right to third-state countermeasures to the progressive development of international law. The reluctance of the ILC to incorporate a provision to this effect, concluding at the same time that there existed no sufficient evidence in state practice in support of such a right reflects the controversial character of the issue before it. A detailed analysis into the ILC's findings on state practice, which have been questioned, is undertaken in the next chapter, so here the analysis will focus on how community interests are perceived to have influenced the law on state responsibility.

This analysis is necessary due to the increasing reliance of national and international jurisprudence, state practice and the literature on the Final Articles. 
As pointed out, the Final Articles have become an 'authoritative statement of the rules on State responsibility'. ${ }^{206}$ They not only codify already established international norms regarding state responsibility incorporated in customs or treaties, but also incorporate concepts that have evolved through the progressive development of international law leading the way as to how the law in this particular area could and perhaps should develop in the future. Nevertheless, uncertainty remains in relation to the fate of the Final Articles and in particular as to whether these will be incorporated in an international convention or will be endorsed in a General Assembly resolution. ${ }^{207}$ Despite the fact that the General Assembly, immediately after the completion of the work of the ILC incorporated the Final Articles in Resolution 56/83,208 it did so without prejudice to their ultimate status. Similarly, General Assembly Resolution 59/35, stressing the significance of the Final Articles, called on all states to discuss proposals about the legal future of the Final Articles. ${ }^{209}$ The matter remains unsettled with the General Assembly postponing the discussion until its 66th session. ${ }^{210}$ However, it is necessary that the General Assembly reviews its position on the matter. The incorporation of the Final Articles in an international treaty would enhance their legal status, creating clear binding obligations on states, thus enhancing the effectiveness and certainty of international law and the law on state responsibility. This becomes evident from the wide acceptance and extensive application of another general international treaty, namely the 1969 VCLT, which codified to a large part existing customary rules on the law of treaties. The significance of the 1969 VCLT can hardly be disputed today and, therefore, the incorporation of the Final Articles in

206 See Responsibility of States for Internationally Wrongful Acts, Comments and Information received from Governments, Report of the Secretary-General, 9 March 2007, 62nd session, A/62/63. Also see Responsibility of States for Internationally Wrongful Acts, Compilation of Decisions of International Courts, Tribunals and Other Bodies, Report of the Secretary-General, 1 February 2007, 62nd session, A/62/62.

207 Various arguments have been produced supporting the one or the other solution. It has been argued for instance that while a treaty would be a more legally attractive solution as it would solidify the norms reflected in the articles, the possibility of many states not signing and ratifying it would put in jeopardy the customary character of some of the norms codified by the ILC. By the same token, a General Assembly resolution would lack any legally binding effect. However, supporters of this approach argue that the incorporation of the Articles on State Responsibility in such a resolution would create hopes for the future development of at least some of the provisions as customary rules of international law. For a discussion on the matter see views of Economides, Hafner and Simma in Summary Records of the First Part of the Fifty-Third session, ILCYbk (2001) Vol. I, (21)-(23).

208 Responsibility of States for Internationally Wrongful Acts, General Assembly Resolution 56/83 of 12 December 2001.

209 Responsibility of States for Internationally Wrongful Acts, General Assembly Resolution 59/35 of December 2004; also see Report of the Sixth Committee on the Responsibility of States for Internationally Wrongful Acts, 22 November 2004.

210 Resolution 62/61 adopted by the General Assembly on the Responsibility of States for internationally wrongful acts, adopted on the Report of the Sixth Committee (A/62/446), 8 January 2008. 
an international convention will similarly have a huge impact on the clarity and coherence of the rules on state responsibility.

Before turning next to the question of how community interests were dealt with in the deliberations of the ILC and to the proposals concerning the manner with which such interests would be enforced, it is first important to say a few words about the Commission's own mandate and the concept of state responsibility.

\section{The ILG's mandate to codify the law on state responsibility}

The absence of centralized enforcement mechanisms in international law - as understood in domestic law - has often been the subject of criticism, albeit not necessarily unjustifiably. These weaknesses notwithstanding, the development of the rules on state responsibility, namely the legal consequences imposed on states as a result of their failure to conform to their obligations under international law, has strengthened the integrity of the international legal system. It has further put legal strains on the impunity of states that act in disregard of their international commitments, while at the same time it has ensured that the defaulting state is protected from excessive, abusive or unrestricted reaction by the injured or any other state. Accordingly, the lack of institutionalized enforcement mechanisms in international law makes it even more necessary to define the legal regime applicable in cases of violation of the rules of international law, including certain limitations that would restrain states from arbitrarily exercising their powers against smaller and weaker states. Moreover, the codification of the law on state responsibility is central to the compliance of states with their international obligations and the reinforcement of the binding character of the international legal order.

The international responsibility of states was a concept deeply rooted in the theory of international law and upheld in international state practice and international jurisprudence. More specifically, it is accepted that the commission of an internationally wrongful act creates new international legal relationships that differ from the ones existing before the commission of such act and which entail the accountability of the wrongdoer. Already in 1938, the PCIJ affirmed in the Phosphates in Morocco case that, whenever a state is guilty of an internationally wrongful act against another state, then international responsibility is established 'immediately as between the two states'. ${ }^{211}$ In what ways responsibility today affects states other than those that are bound by bilateral and reciprocal relations is central to this book. Yet, the diversity of opinions and the uncertainty of the law on state responsibility, on the one hand, and the failure of previous attempts to see the regime of state responsibility as a distinct field of international law,

211 Phosphates in Morocco case, Preliminary Objections, 14 June 1938, PCIJ (1938) Series A/B, No. 74, 28 in World Court Reports (1936-42) Vol. IV (ed. Hudson) 325. Also see in Second Report on State Responsibility (Ago), YbILC (1970) Vol. II, 177, 179, (12). 
on the other, delayed further development on the study concerning state responsibility. ${ }^{212}$

The topic regained significance after the end of World War II, when, in 1953 realizing the significance of such a codification in contemporary international law, the General Assembly established the ILC that was empowered to codify international law, including the rules governing the law on state responsibility. In the years that followed, the first Special Rapporteur, Mr Amador, took the view that state responsibility was not restricted to the duty of wrongdoing states to offer reparations, but also extended to international criminal responsibility. However, he confined responsibility to violations concerning the treatment of aliens. His views were met with criticism since many states opposed the idea of 'criminal' state responsibility and the attempts to limit state responsibility merely to injuries caused to the property and person of aliens thus circumventing other substantial areas of state responsibility. ${ }^{213}$

The second Special Rapporteur, Mr Ago, emphasized that the codification of state responsibility should concern responsibility resulting from the violation of international obligations, irrespective of their nature, origin or object.214 Responsibility for the commission of an internationally wrongful act also arose irrespective of the source of the infringed obligation, whether customary or conventional. ${ }^{215}$ In this regard, Mr Ago made a distinction between 'primary' rules of international law, that is to say, rules that impose certain obligations on states in the international plane, and 'secondary' rules, in other words, complementary rules that determine the legal consequences that arise when a 'primary' rule has been infringed. ${ }^{216}$ Only the latter set of rules falls within the sphere of state responsibility. ${ }^{217}$

At an early stage, both Mr Ago and the ILC focused their attention on, among other things, the forms and degrees of state responsibility in the light of the significance of the rules giving rise to the international obligations of states and in view of the seriousness of the violation of such rules. Equally important was the question of the subjects entitled to invoke the responsibility of another state. The ILC was tasked to determine whether a breach established a legal relationship merely between the injured and the defaulting state or as to whether, in cases of

212 First Report on State Responsibility (Ago), YbILC (1969) Vol. II, 125, 126, (2).

213 Ibid, 127 (6).

214 Ibid.

215 Report of the Commission to the General Assembly, YbILG (1976) Vol. II, Part Two, 69, 180, (5); Fifth Report on State Responsibility (Ago), 8,(19).

216 Fifth Report, ibid, 4 (1). Orakhelashvili notes that this distinction was not intended to distinguish the substance of the norm from its effects and legal consequences. This has significance in the context of peremptory norms the legal consequences of which were also to be viewed as of a peremptory character. The alternative would result in having a peremptory norm with ordinary legal consequences. In this regard, each peremptory norm entails the duty of other states not to recognize a situation created as a result of such violation. Orakhelashvili (2006), op. cit., 80-2.

217 Report of the Commission (1976), op. cit., 71 (68). 
serious breaches of international law, it could give rise to legal relationships between the defaulting state and a group of states or the international community as a whole. Mr Ago, for instance, correlated legal obligations with corresponding subjective rights. He noted in this regard that: '[A]s distinct from what is said to be the situation in municipal law, there are certainly no obligations incumbent on a subject which are not matched by an international subjective right of another subject or subjects, or even ... of the totality of the other subjects of the law of nations.' ${ }^{218}$ According to this interpretation, the violation of norms establishing community interests widens the circle of states affected in their subjective rights and entitled to invoke the responsibility of the wrongdoing state.

Furthermore, it was realized that the determination of the various degrees of responsibility would unavoidably also have an impact on whether a state had a right to seek reparation and/or to impose sanctions against the defaulting state. $^{219}$

With these preliminary observations, the examination is next focused on the role that the content of the international obligation breached has played in the law on state responsibility, and also in the determination of the legal consequences applicable as a result.

\section{Content of the obligation breached and subjects entitled to invoke state responsibility}

Influenced by the developments regarding jus cogens norms and obligations erga omnes, the ILC was called on to consider whether the type of responsibility and of legal consequences to emerge after the commission of an internationally wrongful act depended on the importance of the infringed obligation in the light of its content and the seriousness of the breach. ${ }^{220}$ While a wrongdoing state would still incur responsibility irrespective of the content of the infringed obligation, it had to be determined whether there existed a single regime of responsibility or whether different legal consequences applied in the light of the content of the infringed obligation. ${ }^{221}$

Indeed, there was early recognition that both the significance of the obligation and the seriousness of the breach were relevant factors that must be taken into account in determining the legal consequences to apply in the event of a wrongful act. ${ }^{222}$ It would otherwise be meaningless to distinguish wrongful acts on the basis of their content, if the same legal consequences were to be applied for every internationally wrongful act. ${ }^{223}$

218 Third Report on State Responsibility (Ago), YbILC (1971) Vol. II, Part One, 199, 220-21 (65).

219 Report of the Commission to the General Assembly, YbILC (1969) Vol. II, 229, 233 (79-82).

220 Fifth Report on State Responsibility (Ago), op. cit., 5 (9).

221 Ibid, $24-5,(72-3)$.

222 Ibid, 5 (9), 26(79).

223 Ibid, 27 (83). 
The distinction between responsibility for the violation of obligations of great significance to the international community as a whole, such as the prohibition of aggression, genocide and apartheid, and responsibility for breaches concerning obligations of less general importance, paved the way for the appearance of the notion of state crimes, which will be discussed later. ${ }^{224}$

Nevertheless, the content of the infringed obligation is not only necessary for the distinction between wrongful acts and legal consequences, but also for the determination of the subjects entitled to invoke the responsibility of the wrongdoing state. ${ }^{225}$ While in most cases of violations of international law it is not difficult to identify the state entitled to invoke the responsibility of the wrongdoing state, problems arise when so-called 'extra-state' interests are being infringed. ${ }^{226}$ This led to the question of whether such right was merely recognized in relation to the states directly affected and injured by the infringement or whether there were cases in which this right should also be recognized in relation to other states as well. ${ }^{227}$

Support for the latter in the law on state responsibility was drawn in this regard from the distinction made by the ICJ in the Barcelona Traction case in relation to community and other, 'ordinary', interests. According to Mr Ago, this distinction resulted in a confirmation of the varying character of legal consequences to emerge from the violation of these fundamental community interests and of the broadening of the circle of states with a legal interest to react to such violations. In this regard:

[The] responsibility flowing from the breach of those obligations is entailed not only with regard to the state that has been the direct victim of the breach (e.g. a state which has suffered an act of aggression in its territory); it is also entailed with regard to all the other members of the international community. Every state, even if it is not immediately and directly affected by the breach, should therefore be considered justified in invoking the responsibility of the state committing the internationally wrongful act. ${ }^{228}$

This coincides with the view that although traditional international law has been hesitant in recognizing rights in relation to third states, contemporary international law:

[S] eems to admit increasingly a 'constructive injury' to a state, either as a result of its participation in multilateral rule-making, or as a result of the

224 Ibid, 26 (80).

225 Ibid, 5 (7).

226 Fourth Report on State Responsibility (Riphagen), YbILC (1983) Vol. II, Part One, 3, 21-2 (115).

227 Fifth Report on State Responsibility (Ago), op. cit., 28 (88).

228 Ibid, 29 (89). 
recognition of extra-state interests being protected by the primary rule of international law. ${ }^{229}$

The ILC, relying on state practice and the literature, distinguished its study on the subjects entitled to invoke state responsibility in the light of the views held on the matter before World War II and the views that developed after the end of the war. For the purposes of this book, it is essential to consider in some detail how legal thinking approached issues relating to both the significance of certain obligations and the states possessing a legal interest in their protection.

\subsection{Early approaches to responsibility and standing}

During the 19th century and until the outbreak of World War I, there was little in the literature to suggest differentiation between wrongful acts and legal consequences on the basis of the content of the infringed obligations. On the contrary, some authors had implicitly ruled out such differentiation by holding that reparation constituted the only legitimate response to the commission of a wrongful act, whatever the content of the obligation. ${ }^{230}$ Those writers, however, who distinguished various forms of reparation such as restitution, redress for moral and material damage, satisfaction or preventative measures for the non-repetition of the breach, did not do so on the basis of the content of the obligation but solely on the ground that the injured state had the right to choose among various forms of reparation. ${ }^{231}$

In this environment, Bluntschli, a Swiss expert of international law and supporter of the view that the injured state could even resort to punitive measures in response to serious violations of international law, argued that when the interests of the international community were under threat, all states were entitled to safeguard and restore the international legal order.232 This resembles Grotius' authoritative early writings according to which sovereign states have the right to demand punishment not only for wrongdoing directed against them, but also for violations of 'the law of nature or of nations in regard to any persons whatsoever'. ${ }^{233}$ However, there was a general suspicion towards the acceptance of this position by other authors of international law. ${ }^{234}$ As remarked, this 'lone but highly authoritative voice of Bluntschli' whose ideas a century ago coincide with 'the most advanced

229 Third Report on State Responsibility (Riphagen), YbILC (1982) Vol. II, Part One, 22, 36-7 (92).

230 D. Anzilotti, Teoria generale della responsabilita dello stato nel diritto internazionale (1902) in Fifth Report on State Responsibility (Ago), op. cit., 40-1 (122).

231 See analysis in Fifth Report, ibid, 41 (123).

232 J.C. Bluntschli, Das moderne Völkerrecht der civilizierten Staaten als Rechtsbuch dargestellt (Beck: 1872) in ibid, 41 (124).

233 H. Grotius, De iure belli ac pacis libri tres (1646/1925) Book II, Chapter 20, para. 40 cited in Tams, op. cit., 48-9.

234 R. Phillimore, Commentaries upon International Law, Vol. I, 3rd edn (1879) 442 cited in Tams, ibid, 49. 
ideas of the authors of today'235 did not have a great impact on the development of legal opinion during the period under consideration.

In the period between 1919 and 1939, some authors took the view that the content of the obligation had an impact on the subjects entitled to put forward an international claim against the wrongdoing state. Hence, Root and Peaslee maintained that international law should make a distinction between breaches that affect merely the injured states and breaches that affect interests of the international community and the punishment of which any state is entitled to seek, ${ }^{236}$ preparing the way for the development of the notion of state crimes. Some of the advocates of this theory, namely Pella, Saldana, de Vabres and others, supported the adoption of a code that would list all the serious breaches of international law and the legal consequences-sanctions attached to them, although they conditioned this on the establishment of an international criminal court. ${ }^{237}$

Although such views were not generally endorsed, it becomes evident that a doctrine supporting the distinction between a category of less serious international violations subject to the traditional regime of responsibility and a category of the most serious, even qualified as criminal violations of international law subject to a much stricter regime of penal sanctions, gradually begins to emerge. ${ }^{238}$

At the same time, the conclusions of the 1930 Codification Conference provide a very characteristic reflection of the prevailing opinion of states on the matter under consideration held in the period post-World War II. While having accepted that any violation of the obligations relating to the treatment of aliens entailed the international responsibility of the state, there was nothing in the replies of the representatives of the participating states to associate the legal consequences as a result of a wrongful act with the content of the breached obligation. ${ }^{239}$ Neither did the participating states regard the content of the obligation as having any significance on the determination of the state entitled to invoke the responsibility of the wrongdoing state. ${ }^{240}$ Hence, any distinction concerning the categories of internationally wrongful acts, the forms of responsibility applicable and the subjects entitled to respond to a wrongful act were issues independent of the content of the obligation infringed.

235 See Bluntschli, op. cit., 259 in Fifth Report (Ago), op. cit., 41, (124).

236 Root, op. cit., 7-9; J.A. Peaslee, 'The Sanction of International Law', AfIL (April 1916) Vol. 10, No. 2, 328, 335-6. However, Peaslee was in support of the idea that these collective interests should be protected through institutionalised mechanisms rather than individual measures.

237 Q. Saldana, 'La Justice Penale Internationale', Recueil des Cours (1925) (Hachette: 1927) Vol. 10, 227 et seq.; V.V. Pella, La Criminalite Collective des Etats et le droit penal de l'avenir, 2nd edn (Imprimérie de l'État: 1926); D. de Vabres, Les Principes modernes du droit penal international (Sirey: 1928) 418 et seq. in Fifth Report on State Responsibility (Ago), op. cit., 45 (133)-(134).

238 Fifth Report, ibid, 45 (133).

239 League of Nations, Conference for the Codification of International Law, Bases of Discussion for the Conference drawn up by the Preparatory Committee, Vol. III, 20 in ibid, 30 (93).

240 Fifth Report, ibid, 30 (94). 
Yet during this period, aggression was regarded as a violation of a more serious character, described in the draft Treaty of Mutual Assistance prepared by the League of Nations in 1923, as an 'international crime'. Furthermore, the 1924 Geneva Protocol for the settlement of international disputes refers to war of aggression as a violation of the solidarity of the members of the international community and again as an international crime. While these documents make no reference to the regime of responsibility to apply when the prohibition of aggression is violated, it would be contradictory if states had only wished to distinguish crimes from other violations of international law if they did not mean to attach to these more serious offences a heavier regime of responsibility as well. The Covenant of the League of Nations itself provided for a special regime of responsibility in case of breach of the obligation not to resort to a war of aggression and especially for the imposition of sanctions against the aggressor by all member states. $^{241}$

These developments paved the way for a change in legal thinking, particularly in the aftermath of World War II, as the following section will illustrate.

\subsection{Approaches to responsibility and standing after World War II}

The end of World War II signified fundamental changes in the domain of state responsibility and gave new impetus for the distinction between aggression, the use of force and violations of international humanitarian law as serious violations of international law and other, ordinary, violations. ${ }^{242}$ With the significant developments that followed in the context of self-determination, independence and decolonization new rules made their appearance, while the concept of peremptory norms with which the analysis in the first chapter dealt enhanced the understanding that the violation of certain norms is unavoidably more serious than others. This led the Special Rapporteur Mr Ago to speak of 'a different regime of responsibility' to apply in the event of violation of these fundamental norms from which no derogation is permitted. ${ }^{243}$ Likewise, the recognition of the existence of such essential rules for the international community could not leave unaffected the determination of the subjects empowered with the right to respond to their infringement. ${ }^{244}$ However, the type of action and the subjects empowered to respond to such serious violations of international law remained matters both highly controversial and deeply contentious.

Lauterpacht, on his part, referred to 'international delinquencies' resulting from ordinary violations that gave rise to a right for pecuniary compensation and

241 Ibid 30-1 (96). Covenant of the League of Nations, 28 June 1919, 13 AfIL (1919) Supp. $128,361$.

242 Fifth Report, ibid, 31, (97).

243 Ibid.

244 Ibid, 31-2, (99) and 32, (100). 
'international crimes' that gave rise to a graver form of responsibility and permitted coercive measures such as the conduct of war, reprisals or sanctions as envisaged in the UN Charter. ${ }^{245}$ Levin also distinguished between simple breaches of international law and international crimes that turned against the 'very foundations and essential principles of the legal order of international society'. ${ }^{246}$ Similarly, Jessup, like Root in 1916, raised the question as to whether there was a need to consider violations against the peace and order of the international community as a 'violation of the right of every nation' with which all states are regarded as having been injured. ${ }^{247}$ According to this school of thought, a separate category of more severe internationally wrongful acts amounting to crimes existing in the international plane should be established, one that would accordingly bear more severe legal consequences than any other violation of international law, hence attaching to them a punitive character. Nevertheless, the supporters of this theory again associated the existence of serious offences with the existence of an international criminal court.

On similar lines, the State Institute of Law of the Academy of Sciences of the Soviet Union stressed that the commission of certain wrongful acts amounted to 'assaults upon the fundamental principles of international relations and thus encroach upon the rights and interests of all states'. ${ }^{248}$ Moreover, authors such as Verzijl expanded the concept of state crimes not only with respect to aggression, but also to violations of the laws of war and crimes against humanity. ${ }^{249}$ Schindler wrote that colonization and racial discrimination constituted violations erga omnes justifying even non-forcible third-party reprisals, ${ }^{250}$ while Brownlie characterized as an international crime any breach of the rules of jus cogens. ${ }^{251}$ Graefrath and Steiniger identified various categories of internationally wrongful acts and, in particular, aggression and threat to the peace by forceful maintenance of a racial or a colonial regime, other violations of sovereignty and violations of other conventional or customary law obligations. ${ }^{252}$

245 L. Oppenheim, International Law: A Treatise, 6th edn (ed. Lauterpacht, Longmans, Green \& Co.: 1947) 307 in Fifth Report, ibid, 45 (136).

246 L.B. Levin, Otvetstvennost gosudarstu v sovremennom mezhdunarodnom prave (Mezhdunarodnye Otnosheniya: 1966) 105 in Fifth Report, ibid, 45 (136).

247 P. Jessup, A Modern Law of Nations: An Introduction (Macmillan: 1948) 11 in Fifth Report, ibid, 45-6 (136).

248 Soviet Law Institute: State Institute of Law of the Soviet Academy of Sciences, Mezhdunarodnoe pravo (Gosudarstvennoe Izdatelstvo Yuridicheskoi Literatury: 1957) 420 in Fifth Report, ibid, 48 (140).

249 J.H.V. Verzijl, International Law in Historical Perspective (Sijthoff: 1973) Vol. VI, 741 in Fifth Report, ibid, 49 (141).

250 Schindler, 'La Principe de non intervention dans les guerres civiles', Interim Report, Annuaire de l'Institut de Droit International (1973) Vol. 55, 483 in Fifth Report, ibid, 49-50 (141).

251 I. Brownlie, Principles of Public International Law (OUP: 1966) 389-90.

252 B. Grafrath and P.A. Steiniger, 'Kodifikation der völkerrechtlichen Verantwortlichkeit', 8 Neue fustiz (1973) 227 in Fifth Report on State Responsibility (Ago) op. cit., 26 (77). 
There was a strong academic opinion supportive of a distinction of internationally wrongful acts in the light of the significance of the interests protected under the infringed norm. It is evident from this analysis that:

$[1] \mathrm{n}$ the internationalist literature of various countries and of various legal systems, ideas have moved substantially ahead. The positions which in older doctrine represented the isolated voices of certain especially forward-looking thinkers have become more and more frequent and increasingly firm, to the point that in modern works they represent a solidly established viewpoint and significantly, one which is not contested. ${ }^{253}$

It thus becomes indisputable that, by the 1970s, a basic unity of opinion emerged in international legal theory and practice regarding the general awareness that contemporary international law required the distinction between two types of internationally wrongful act in the light of the content of the obligation breached. While all international obligations must be respected, there are certain obligations such as aggression that due to the interests that they protect are recognized as being of a more fundamental character for the fulfilment of the goals of the international community, namely international peace and security. The commission of these acts is no longer confined to the establishment of a bilateral relation between the wrongdoer and the wronged state, but it is also extended to the establishment of a relation that involves all the members of the international community. This is also consistent with the development of the concepts of peremptory norms and obligations owed to the international community as a whole elaborated in the first chapter, which exercised an immense impact on the secondary rules concerning state accountability.

In the light of these developments, the ILC endorsed the view that the form of responsibility depended very much on the significance of the infringed obligations affirming that under certain circumstances the commission of a wrongful act could extend the circle of affected states not only to those directly injured but also to other states. This was predicated on the condition that the nature of the infringed obligation was one which was attached to either a group of states or to all members of the international community. ${ }^{254}$

These developments signified the evolution of another concept, that of state crimes as reflective of violations of the most serious nature and as entailing legal consequences of a graver character.

\section{State crimes in the law on state responsibility}

The notion of state crimes in what was later to become Article 19 in the Draft Articles on the Law on State Responsibility was not new in international law.

253 Fifth Report, ibid, 50 (142).

254 Report of the Commission (1976) op. cit., 76 (4). 
As already discussed, it appeared in the 1923 Draft Mutual Assistance Treaty prepared by the League of Nations and the 1924 Geneva Protocol for the Pacific Settlement of International Disputes. It was also referred to in many acts of the General Assembly such as the 1970 Declaration on Principles of International Law concerning Friendly Relations and Cooperation among States and the 1975 Definition of Aggression. 255

The concept of state crimes with an erga omnes effect also appeared in many academic writings. According to these, the commission of an international crime created new obligations on states, such as a duty to refrain from supporting the unlawful situation ex post either by recognizing its result as legal or by rendering aid or assistance in maintaining such a result. States also had a duty to assist those specially affected by the breach and to participate in collective action for the protection of these fundamental community interests. ${ }^{256}$

The ILC incorporated the concept of state crimes in Draft Article 19 adopted in its first reading in 1996.257 While uncertainty remained as to the action that could and should be taken in response to the violation of these fundamental interests, the ILC, by adopting Draft Article 19 concerning the responsibility of states for the commission of crimes, opened the way to further developments regarding the implementation and enforcement of community interests. It has often been noticed that the distinction made under the Draft Article between international delicts and international crimes and the categorization of responsibility on the basis of the importance of the infringed right, the subjects entitled to respond with sanctions and the scope and kind of sanctions, strengthened the effectiveness of responsibility. ${ }^{258}$

Nevertheless, during the debates in the ILC not all states were supportive of the inclusion of state crimes in the Draft Articles. On the contrary, there was great reluctance to do so. Some states argued that there could be no clear distinction between crimes and delicts based on their gravity as this would require an examination of the primary rule itself, something that could not fall within the ambit of examination of the rules on state responsibility. Concerns were also expressed in relation to the fact that the term 'crime' bore punitive connotations with it and as such it should be precluded, something that the ILC at that stage did not accept.259 Other states pointed to the fact that a state, unlike individuals, could not be punished and that the victims of such punishment would be the nationals belonging to the 'criminal' state. There were also fears that a determination that a crime had

255 See, in this regard, Protocol for the Pacific Settlement of Disputes (League of Nations), 2 October 1924, http://www.unhcr.org.refworld/docid/40421a204.html; Declaration on Principles of International Law concerning Friendly Relations and Co-operation among States and the 1975 Definition of Aggression, 26 October 1970, Resolution 2625 (XXV).

256 Fourth Report on State Responsibility (Riphagen), op. cit., 10 (50).

257 Draft Article 19 can be found in Crawford (2002),op. cit., 348.

258 Report of the Commission to the General Assembly, YbILC (1988) Vol. II, Part Two, 1, 104, 105.

259 Report of the International Law Commission on the Work of its Forty-seventh Session, 2 May to 21 July 1995 (A/50/10), 48 (258). 
been committed would empower strong states to resort to countermeasures entailing much risk for abuse while raising the issue that even when a crime is committed not all states have the same entitlements in responding to such violations. Other states suggested that the individual accountability for violations of fundamental interests should be strengthened instead. The further point was made that the 'universalization' of the notion of the injured state entailed the risk of multiple claims with a threat for escalation of the conflict. ${ }^{260}$ The discussion also brought to light the question as to who was entitled to determine that a crime had been committed, with some members suggesting that such an authority should be placed on a third-party settlement procedure so that powerful states would not abuse such powers borne from countermeasures. ${ }^{261}$

At the same time, while there was little evidence as to the legal consequences that should ensue as a result of the commission of an international crime, it was clearly understood that not all international crimes gave rise to identical legal consequences. ${ }^{262}$ Within the ILC, there was some discussion about establishing a 'minimum common element' of legal consequences that would apply to all international crimes. ${ }^{263}$ One such element was the erga omnes character of the infringed obligation that gave every other state the right to demand from the wrongdoing state the performance of the obligation concerned. It was also held at the time that the commission of an international crime empowered the organized international community such as the UN to deal with the situation, while the principle of nonintervention in the domestic affairs of another state became ineffective. ${ }^{264}$ In the following sections, consideration will be given to the question of whether these views prevailed and to the extent to which they are reflected, if at all, in the Final Articles adopted in 2001.

Regarding the legal consequences arising as a result of an international crime there was a general understanding in the ILC that the commission of such a wrongful act, such as aggression, entailed consequences of a more severe nature which could give rise to a right to individual or collective self-defence. ${ }^{265}$ As already seen, the subject matter of the breached obligation had an impact on the regime of responsibility since the commission of an international crime caused injury to

260 Ibid, 50 (274)

261 Report of the International Law Commission on the work of its Forty-fourth session, YbILC (1992) Vol. II, Part Two, 1, 17, 25 (168).

262 However, it was also accepted that some legal consequences applied to all international crimes. Fourth Report or State Responsibility (Riphagen), op. cit., 11 (58).

263 Ibid, $10(51)$.

264 Ibid, 12 (61).

265 See analysis in Second Report on State Responsibility (Riphagen) YbILC (1981) Vol. II, Part One, 79, 91-2 (101) and (103). Aggression, for instance, was considered an international crime whose legal consequences derived from the UN Charter empowering states to individual or collective self-defence and Security Council action. Yet, some in the ILC favoured the adoption of a specific provision that would outline all the legal consequences to emerge as a result of aggression, including countermeasures, provided, of course, that these complied with the rules of quantitative proportionality, jus cogens and the UN Charter. This was, however, not generally accepted. Fourth Report on State Responsibility (Riphagen) op. cit., 11 (55). 
all states in deviation from the traditional bilateralist approach of interstate affairs. ${ }^{266} \mathrm{Mr}$ Riphagen, the third Special Rapporteur on state responsibility advocated a clear determination of the legal consequences to emerge in the case of international crimes and of the means of their enforcement, placing the emphasis, as Mr Ago had, on the international community as the main body to deal with such violations. ${ }^{267}$ The protection of fundamental community interests however had to be adjusted to the principle of sovereign equality of states as the 'original basis of international law' ${ }^{268}$

Although the notion of state crimes was introduced in the ILC's Draft Articles on State Responsibility in 1976 with the provisional adoption of Article 19, it was not until 1996 that the substantive consequences of state 'crimes' were actually formulated. During the discussions that took place on the matter, Mr ArangioRuiz held the position that the nature of a wrongful act as a crime would reasonably aggravate the substantive and instrumental legal consequences to arise for the defaulting state, which included the recognition of a right to all states to resort to countermeasures. ${ }^{269}$

This was reflected in the 1996 Draft Articles, in which the ILC incorporated special consequences to derive from the commission of a state crime and, more specifically, the removal of the specific restrictions concerning the obligation of the wrongdoing state to make restitution in kind and to satisfaction. In particular, the restrictions provided under Draft Article 43 according to which the defaulting state would not be obliged to make restitution if this placed on it a great burden disproportionate to the benefit restitution would bring to the injured state was removed. It was the ILC's position that a state having committed a crime should not be able to benefit from the fruits of its wrongful conduct. ${ }^{270}$ In the light of this position, the loosening of the specific restriction was not considered to be contrary to the requirement of proportionality as the restoration of the previous situation in the case of a crime could rarely be disproportionate. More controversially, the ILC decided to remove the restriction that prohibited, in international delicts, restitution which could seriously jeopardize the political independence or economic stability of the wrongdoer. With respect to the requirement under Draft Article 45 that satisfaction does not impair the dignity of the defaulting state, the ILC noted that by committing the crime the state concerned 'had itself forfeited its dignity'. ${ }^{271}$ Despite this, the ILC considered it necessary that the requirement that the claim for damages was proportionate to the gravity of the crime should remain. As for the other legal consequences provided under Draft Articles 41 to 45 and,

266 Second Report on State Responsibility (Riphagen) ibid, 92 (102).

267 Third Report on State Responsibility (Riphagen) op. cit., 48.

268 One could, of course, today disagree with Mr Riphagen that the concept of peremptory norms and of community interests today constitute 'something like a corpus alienum'. Second Report on State Responsibility (Riphagen) op. cit., 82 (29).

269 In Seventh Report on State Responsibility (Arangio-Ruiz) YbILC (1995) Vol. I, 83 (62).

270 Report of the International Law Commission on the Work of its Forty-eighth Session, 6 May to 26 July 1996 (A/51/10), Vol.II, Part Two, 1, 72 (3).

271 Ibid, 72 (6). 
more specifically, the duty for cessation of the wrongful act, reparation, restitution in kind, compensation and satisfaction, these were equally applicable in international delicts and international crimes.

This analysis shows that a graver regime of responsibility was established in the event of a commission of an international crime, which imposed particularly burdensome obligations on the defaulting state and which could be described as punitive in character and as infringing fundamental principles of international law such as state equality. The concerns that states expressed in this respect were well founded, leading the ILC to abandon the notion of state crimes in the second reading of the Draft Articles. The concerns expressed over the notion of state crimes notwithstanding, this did not impose an impediment in the understanding that community interests needed to be effectively protected under the rules on state responsibility. While the fate of the concept of state crimes will be further explored in later sections, the examination is next turned to a fundamental concept in this book, that of countermeasures, particularly when taken by states other than the injured.

\section{Countermeasures as enforcement of international law}

\subsection{The progressive development of countermeasures}

International law recognizes that in certain circumstances the responsibility of a state for the violation of its obligations will be precluded, thus rendering, for as long as they persist, the obligations concerned inoperative. ${ }^{272}$ This principle finds prominent place in the law on state responsibility and in the Final Articles, although the attention in this analysis is confined to the notion of countermeasures as a circumstance precluding the wrongfulness of a given conduct.

Whenever these circumstances exist, the legal obligation affected does not cease to exist, as when a treaty is terminated, neither does it cease to have legal effect, even temporarily, as when a treaty is suspended. Therefore, an essential distinction must be made regarding the legal consequences to emerge from the violation of an international agreement such as termination and suspension in the event of a material breach and the legal consequences to arise from the violation - any violation - of international norms, including conventional norms, entailed under the law on state responsibility. This issue is separately considered in Chapter 4 .

Within the deliberations of the ILC, countermeasures were soon recognized as exceptions under which a finding of wrongfulness would be precluded. The notion of countermeasures gained particular significance as a mechanism of enforcement of international law. Countermeasures can be defined as peaceful measures taken by states in violation of their obligations under international law in response to an international wrongdoing committed by another state. In these exceptional circumstances, the wrongfulness of the act, and consequently the responsibility of the 
state resorting to countermeasures, is precluded. The lack of an adequate and effective institutional framework by which the respect for international obligations can be safeguarded becomes even more apparent and compelling in this particular area of international law. Through countermeasures, individual states, acting unilaterally, are empowered to take the law into their own hands and implement international law, a power that exposes small and weak states to the abuse of powerful states. It was therefore essential for the ILC to 'devise ways and means which, by emphasizing the best of lex lata or careful progressive development, could reduce the impact of the great inequality revealed among States in the exercise of their faculte (and possibly obligation) to apply countermeasures, which is such a major cause of concern.' 273

Countermeasures must be distinguished from acts of retorsion that, although unfriendly, are not otherwise unlawful (unlike countermeasures). It has also been concluded by the ILC that countermeasures may be reciprocal, but are not necessarily confined to reciprocal measures. ${ }^{274}$

In the early debates that took place on the codification of the law on state responsibility, the ILC referred to the concept as 'sanctions' or even 'reprisals'. Mr Ago, for his part, used the term 'sanctions' to mean the infliction of punishment or the securing of performance of the obligation breached, as a result of the infringement of the subjective rights of another state. ${ }^{275}$ In view of the serious ramifications involved, only legitimate sanctions could fall under the circumstances precluding a finding of wrongfulness if certain conditions were met. Accordingly, the injured state, or even other subjects of international law, was entitled to resort to such action under exceptional circumstances on the condition that the response was commensurate to the injury suffered. ${ }^{276}$

In 1979 the ILC, in its report to the General Assembly replaced the term 'sanctions' with that of 'countermeasures'. ${ }^{277}$ The use of this term was preferred to that of 'sanctions' in both contemporary legal thinking and the work of the ILC as sanctions were associated with action authorized by an international body or organization. ${ }^{278}$

During this time the ILC also accepted that countermeasures, as a means of punishing the wrongdoing state or securing compliance with its obligations, had been implicitly recognized in international law provided that certain requirements

273 Third Report on State Responsibility (Arangio-Ruiz) YbILC (1991) Vol. II, Part One, 1, 7-8 (4).

274 Report of the International Law Commission (2001), op. cit., 129, (5).

275 Eighth Report on State Responsibility (Ago), YbILC (1979) Vol. II, Part One, 3, 39 (79). At this stage in the work of the International Law Commission, the term 'sanctions' is used interchangeably with 'reprisals'. It is only later that both these terms gave way to the term that is most known today, 'countermeasures'.

276 Ibid, 39-40 (79)-(82).

277 Report of the Commission to the General Assembly, YbILC (1979) Vol. II, Part Two, 1, 87, 106 (1) and 118-9 (12)-(14).

278 Third Report on State Responsibility (Arangio-Ruiz) op. cit., 10 (15). 
were met. ${ }^{279}$ In particular, countermeasures could only be resorted to after a prior demand for reparation has been made and they should be proportionate to the offence, while any obligations regarding the peaceful settlement of disputes should be respected. ${ }^{280}$

Outside the ILC, the notion of sanctions had made its appearance in the arbitration proceedings in the Naulilaa case between Germany and Portugal. ${ }^{281}$ The Tribunal, before considering the lawfulness of certain acts committed by the German authorities, justified by the latter as reprisals to an internationally wrongful act previously committed by Portugal, wished to establish when and in what circumstances reprisals were to be deemed legitimate. According to its ruling:

[T] he latest doctrine, and more particularly German doctrine, defines reprisals in these terms: "Reprisals are an act of taking the law into its own hands by the injured state, an act carried out after an unfulfilled demand in response to an act contrary to the law of nations by the offending state. Their effect is to suspend temporarily, in the relations between the two states, the observance of a particular rule of the law of nations. They are limited by the experiences of mankind and the rules of good faith, applicable in the relations between states. They would be illegal if an earlier act, contrary to the law of nations, had not furnished the motive." 282

In this particular instance, the tribunal held that even if Portugal had indeed previously committed a wrongful act, the imposition of reprisals by Germany would again be unlawful since no prior demand for reparation had been made. ${ }^{283}$

State practice, too, recognized that the legitimate application of sanctions precluded the wrongfulness of the act and the responsibility of the state. During the Codification Conference in 1930, the Preparatory Committee accepted that reprisals could be justified in certain circumstances, an issue that no government disputed. In the 'Basis of Discussion' drawn by the Committee for the Conference, it was finally concluded that, 'a state is not responsible for damage caused to a foreigner if it proves that it acted in circumstances justifying the exercise of reprisals against the state to which the foreigner belongs'. ${ }^{284}$ Some decades later, and, more specifically, in 1968, the representative of the Dutch government in the Sixth Committee of the General Assembly stated that: '[A]ny state, no matter to

279 Although many states had expressed their concerns over the entitlement of states to 'punish' other states, as it will be later discussed.

280 Report of the Commission to the General Assembly (1979) op. cit., 118, fn 595.

281 Case concerning the Responsibility of Germany for Damage Caused in the Portuguese Colonies of South Africa (Portugal v Germany) - The Naulilaa Incident, Arbitral Decision of 31 July 1928, 2 Reports of International Arbitral Awards (1928) 1025-26.

282 Ibid.

283 Ibid.

284 League of Nations Conference, Conference for the Codification of International Law, Bases of Discussion for the Conference drawn up by the Preparatory Committee, Vol. III, 128 and Supplement to Vol. III, 4 in Eighth Report on State Responsibility (Ago) op. cit., 41-2 (88). 
what region of the world it belongs, may find itself in the position of suffering damage from illegal acts on the part of another state and that such a state, for that reason, would be justified in taking measures of non-violent reprisal.' 285

The preclusion of wrongfulness in the case of legitimate sanctions is also upheld in the literature, sometimes referring to it as 'sanctions', at other times as 'reprisals' and at yet others as 'measures of self-protection'. Undoubtedly, the emergence of the prohibition of the use of force as one of the most fundamental principles of international law after the end of World War II, as envisaged in Article 2(4) of the UN Charter, altered the position concerning the legitimacy of armed reprisals. ${ }^{286}$ The prohibition of the use of armed force in circumstances other than self-defence and Security Council authorization highlighted the necessity for alternative mechanisms for the enforcement of international law, strengthening in this manner the relevance and significance of countermeasures.

\subsection{Conditions and functions of countermeasures}

The acceptance of countermeasures in the law of state responsibility was accompanied by certain concerns and considerable reservations. In what was described as the most controversial aspect of state responsibility, ${ }^{287}$ countermeasures were dealt with in Chapter III of the Draft Articles provisionally adopted in the first reading in 1996. According to the general commentary, countermeasures were justified in response to a previous violation of the rights of the injured state and might be necessary in order to ensure the compliance of the wrongdoing state.

Countermeasures, however, did not constitute a 'wholly satisfactory remedy' but rather a 'rudimentary' system for two main reasons. First, because the judgment for their justification is formed by the same state relying on them (unilateral assessment of both whether there has been an infringement and whether the reaction is lawful) and, second, because of the actual inequality of states in respect of military, political and economic strength. ${ }^{288}$ For these reasons, some states opposed the incorporation of countermeasures in the Draft Articles and argued that to rely on the principle of proportionality as a way of limiting any possible excessiveness of such measures would not be of much assistance as the exact content of the principle was not yet universally agreed and determined. The ILC, however, decided to include countermeasures in the Draft Articles as it found that there existed enough evidence in customary law that countermeasures are permitted as a lawful response to an unlawful conduct, emphasizing at the same time that the restrictions and limitations for resorting to such measures should not be ignored.289 Countermeasures, 'a reflection of the imperfect structure of the international

285 S. Swan, 'Netherlands State Practice for the Parliamentary Year 1969-70' I NYIL (1970) 171 in Eighth Report, ibid, 43 (90).

286 Eighth Report, ibid, 42 (89).

287 Report of the International Law Commission (1996) op. cit., 66 (1).

288 Ibid.

289 Ibid, 66 (2) 
community', ${ }^{290}$ were also supported by many states. As pointed out, 'in any society a certain degree of coercion had to be tolerated, provided it did not go beyond certain limits' and that 'at the present stage they were the only means whereby international law could be implemented when an international obligation was violated'. ${ }^{291}$ It was also the position that countermeasures should serve only for the cessation of the wrongful act and not as a means of punishment since the international community was comprised of states that were legally equal between them. ${ }^{292}$ They should further aim to restore the legal relationship between the injured state and the wrongdoer.

To this effect, countermeasures are instrumental in character and they come as part of the implementation of state responsibility for the purpose of inducing the wrongdoing state to comply with its obligations. ${ }^{293}$ Their purpose is limited to inducing the wrongdoing state to cease its unlawful conduct and to offer reparation to the injured state for as long as the wrongdoing state is not complying with its obligations. Countermeasures must also not violate obligations towards third, innocent parties while they are not unlimited in scope. Rather, they have to comply with the requirement of proportionality and they must be reversible in their effects. Likewise, certain obligations, because of their nature, do not allow their non-performance by way of countermeasures such as those owed to the international community as a whole and those arising from peremptory norms.

The recognition that countermeasures could turn into a powerful weapon in the hands of states was the driving force behind the urge to impose the strictest conditions in the use of such measures. It was imperative that such measures were subjected to restrictions and limitations to ensure that they would only be used whenever necessary in response to another infringement. Draft Article 47 provided that countermeasures entitled the injured state 'not to comply with one or more of its obligations towards the wrongdoing state', in order to achieve the permissible functions and aims of such measures, in particular cessation or reparation. Anything exceeding these functions would be unlawful, particularly the infliction of punishment on the wrongdoer. ${ }^{294}$ Moreover, in order to ensure that countermeasures would not be used as a shield for possible abuses, they could only be resorted to after failure of the wrongdoer to comply with its obligations under Draft Articles 41 to 46 concerning cessation, reparation, restitution in kind, compensation, safeguards for non-repetition and satisfaction. In addition to these restrictions, the injured state had a duty to enter into negotiations with the wrongdoing state unless of course urgent action was necessary and to submit the dispute before any dispute settlement procedure existing between the parties. At the same time, the acting state was under an obligation to ensure that its action was not out of proportion to the degree of

290 Report of the Commission (1992), op. cit., 19 (122).

291 Ibid, 20-21 (131).

292 Ibid, 20 (127).

293 Report of the International Law Commission (2001) op. cit., 325-6 (3).

294 Report of the International Law Commission (1996) op. cit., 67 (2). 
gravity of the internationally wrongful act and the effects on the injured state. Such action should also not be inconsistent with the rules concerning the use or threat of force or impose extreme economic and political conditions in violation of the territorial integrity or political independence of the wrongdoing state.

Quite significantly, countermeasures should be in compliance with the rules concerning diplomatic immunities and basic human rights, with obligations owed erga omnes and with peremptory norms of international law. ${ }^{295}$ The latter was affirmed by Gaja according to whom it would be 'illogical' to allow the violation of imperative rules in response to a previously committed wrongful act, even if that act itself was in violation of rules possessing a peremptory character. As noted, 'the very existence of such a category of norms implies that there is a general interest in international society that they should be respected'. 296 Similarly, Lattanzi rejected the possibility of infringement of obligations owed to the international community as a whole by way of countermeasures since: '[T] he violation of an obligation to the detriment of one State in such a case simultaneously represents a violation of the same obligation to the detriment of all those to whom the rule applies. It would be inadmissible for the sanction imposed on one State to constitute the violation of an obligation towards another State. '297 According to Gaja, countermeasures in such cases are not permitted as 'the rights of innocent States would then necessarily be infringed.' 298

Finally, countermeasures had to be necessary in order to induce the wrongdoing state to comply with its obligations. This prerequisite meant, first, that the injured state should only resort to countermeasures if other means failed or proved ineffective and, second, that countermeasures should be used reasonably, in good faith and at the injured state's own risk. Effectively, the injured state was empowered to judge whether the necessity for countermeasures had arisen. In this regard: 'The necessity of countermeasures diminishes in inverse proportion to the achievement of their legitimate aims.' ${ }^{299}$ The burden of establishing the necessity for countermeasures was, therefore, on the injured state.

Having considered the legal restrictions of the entitlement to resort to countermeasures, the next section considers in some depth the subjects entitled to resort to countermeasures and how the notion of countermeasures taken for the protection of collective interests evolved within the law on state responsibility.

\subsection{Subjects entitled to resort to countermeasures}

A crucial question that appeared in the discussions of the ILC concerned the subjects entitled to apply countermeasures in response to another wrongful act and

295 Ibid, 64.

296 Gaja (1981), op. cit., 297.

297 F. Lattanzi, 'Sanzioni internazionali' XLI Enciclopedia del diritto (1989) in Third Report on State Responsibility by Mr. Arangio-Ruiz, 35 (121).

298 In Third Report, ibid, 35 (121).

299 Report of the International Law Commission (1996) op. cit., 68, (6). 
whether this power should be restricted to directly injured states or not. The consideration of this specific issue became essential in the light of the view advanced by some writers that not all the injured states were entitled unilaterally to resort to countermeasures. 300 This was in light of the fact that under Draft Article 19 the notion of the injured state was widely defined and therefore in the event of the commission of an international crime all states were regarded as injured states. The issue was raised in fear that a general faculté to resort to countermeasures would pose a threat to the certainty in the enforcement of the law and would lead to reactions not restricted to ensuring the compliance of the wrongdoer. ${ }^{301}$

While all states may have an interest in the respect of international law generally, this does not mean that all states are entitled to demand performance or even resort to countermeasures whenever a violation of an international norm occurs. ${ }^{302}$ The issue, however, is particularly important with respect to obligations erga omnes. There was a general reluctance to widening the circle of states empowered to resort to such powerful means in safeguarding fundamental interests of the international legal order. In the light of the risks entailed in allowing individual third states to apply sanctions in response to a breach that does not directly affect them, Mr Ago for instance supported institutionalized responses. In particular, he stressed that the task of determining the existence of a breach of an obligation of fundamental significance for the international community as a whole and of deciding the measures that should be taken in response should be vested not in individual states but in international institutions and organizations, such as the UN. ${ }^{303}$

In later discussions, Mr Riphagen acknowledged that under certain circumstances bilateralism did not apply particularly in the event of violation of 'a fundamental interest which is not solely an interest of an individual State'. ${ }^{304}$ This was related to the notion of international crimes envisaged in Draft Article 19, which outlined different legal consequences in the event of the commission of conduct of this nature. As pointed out by Mr Riphagen, the distinction between international delicts and international crimes would be of little significance if it did not imply different legal consequences. Under Draft Article 14, an international crime entailed all the legal consequences of an internationally wrongful act and, additionally, such rights and obligations deriving from its nature as criminal and accepted by the international community. These might entail a new collective right of every other state to require the wrongdoer to comply with its obligations, but they could also extend beyond a demand to 'undo' the wrongful act qualified as an international crime, provided that such consequences were decided at a community level. ${ }^{305}$

300 Fourth Report on State Responsibility by Mr Arangio-Ruiz, YbILC (1992) Vol. II, Part One, 1, 46 (142).

301 Ibid, 46 (142).

302 Fourth Report on State Responsibility (Riphagen), op. cit., 21 (113).

303 Eighth Report on State Responsibility (Ago) op. cit., 43-44 (91-92).

304 Preliminary Report on State responsibility (Riphagen) YbILC (1980) Vol. II, Part One, 107, 119 (62).

305 Ibid, $121(70)$. 
With respect to the right of third states to take countermeasures in particular, Mr Riphagen, like his predecessor, insisted on the authorization of such action at a collective level. He drew support for this from the fact that the action authorized against South Africa as a result of its unlawful presence in South West Africa was a collective decision made by the Security Council, despite the fact that the implementation of this collective decision was left to individual states, although it can be doubted, as it will be established in this book, whether such measures can only be authorized by an international organization or institution. ${ }^{306}$

Mr Arangio-Ruiz, on his part, while acknowledging the dangers that unilateral resort to countermeasures could envisage, noted that refusing such right amounted to denying erga omnes obligations from any binding effect, the violation of which would bear no consequences and no regime of liability for the wrongdoer. He went on to say:

The only real peculiarities of the situations determined by the presence of a plurality of injured States, that is to say, by the fact that the infringed rule is an erga plurimos or erga omnes rule - is that the rights and facultes of the various injured States must be determined in concreto and implemented with a view to the pursuit of the totally or partially common legal interest infringed by the breach. ${ }^{307}$

At the same time, Mr Arangio-Ruiz pointed out that the degree of involvement of injured states would vary in accordance with the nature and extent of the injury suffered. ${ }^{308}$ Specific attention was given in this regard to the various distinctions made between 'directly' and 'indirectly' injured states, specially affected, or even third states. ${ }^{309}$ It was acknowledged that according to the traditional understanding of international law international relations are structured in such a manner that their violation affects only one or more states even in the case of multilateral treaties that seem rather to establish multibilateral legal relationships. This was also the case in relation to multilateral treaties giving rise to integral rights and obligations such as peace, disarmament or environmental treaties. ${ }^{310}$ By the same token, the practice and literature of international law indicate the existence of rules that simply 'do not fit the pattern of bilateralism just described. These are the rules

306 Ibid. See analysis in chapter 3.

307 Fourth Report on State Responsibility (Arangio-Ruiz), op. cit., 46-7 (143).

308 Third Report on State Responsibility (Arangio-Ruiz), op. cit., 26 (89).

309 While the concept of 'third' states was regarded as misleading, the reference to non-directly affected or injured states was argued also to be inaccurate and vague. An injured state was not merely the one that had suffered an unjust physical damage. It was rather the state whose right had been violated; this infringement constituted the injury of the state in question and that was in conformity with the definition of an internationally wrongful act according to which an international obligation is equivalent to an international right. Fourth Report on State Responsibility (Arangio-Ruiz), op. cit., 43 (127).

310 Ibid, 44 (131). 
which, in the pursuit of "general" or "collective" interests, create obligations, compliance with which is in the legally protected interest and, in that sense, a legal right of all the States to which the rule applies'. ${ }^{311}$ As Spinedi commented in this regard:

These rules impose on every State obligations towards all the other States in each of which the corresponding subjective right is vested. A breach of these obligations simultaneously injures the subjective rights of all the States bound by the rule, whether or not they have been especially affected - apart, of course, from the subjective right of the State that committed the breach. The term "erga omnes obligation" is generally used to denote the obligations in question. ${ }^{312}$

Nevertheless, even the violation of an erga omnes obligation does not always affect states in an identical manner. As pointed out, while there may be no difference in the fact that all states are injured, there can be difference as to the way that each state has been injured. For instance, if a coastal state closes a canal within its jurisdiction that is connecting two parts of the high seas, then all the states possess a general entitlement under international law to transit. However, not all the states will be affected in the same way. More precisely, states whose ships have been prevented from crossing the canal and have suffered a material damage will be affected in a different way from the states that have a general right to innocent passage. 313 Thus, a differentiation between injured and other states in the light of the nature and the extent of the injury suffered starts to emerge in the deliberations of the ILC. ${ }^{314}$

These conclusions further formulated the rules on state responsibility. It is therefore now necessary to see how these developments influenced the ILC in its consideration of state crimes and solidarity measures in its Final Articles on state responsibility.

\section{Jus cogens norms, erga omnes obligations and third states in the 2001 Final Articles on State Responsibility}

\subsection{State crimes and serious breaches of peremptory norms}

At the second reading of the Draft Articles on State Responsibility adopted in 1996 Professor Crawford, appointed as Special Rapporteur, retained the distinction between primary and secondary norms of international law placing particular emphasis on the latter, as codification of the primary rules would be very difficult

311 Ibid.

312 Translated from French. M. Spinedi, 'Les consequences juridiques d'un fait internationalement illicite causant un dommage a l'environnement' in F. Francioni and T. Scovazzi (eds) International Responsibility for Environmental Harm (1991) 75 in ibid, 44 (131).

313 Fourth Report, ibid, 45 (136).

314 Ibid, 46 (138). 
to achieve due to the innumerable treaty and customary international obligations. $^{315}$ In view of the existence of some limited normative hierarchy in international law, Professor Crawford acknowledged that there exist various forms and degrees of state responsibility based on both the significance of the rules imposing obligations on states and the seriousness of the violation of such rules. Consequently, such distinction had to be reflected in the final articles on state responsibility.

Nevertheless, one of the most contentious areas with which Professor Crawford was faced was the inclusion of Draft Article 19 concerning state crimes. Professor Crawford concluded that there existed a deep division among states as to the inclusion of the notion of state crimes in Draft Article 19, which as it stood made no reference to any specific characteristics that would clearly distinguish delicts from crimes, such as, for instance, a special system of enforcement or substantive consequences. Moreover, Draft Article 19 did not specifically define those acts that constitute a crime, but merely provided that a crime 'may result' from violations of the obligations referred to under paragraph 3. These extended to obligations essential for the maintenance of international peace and security, selfdetermination of people, widespread violations of obligations essential for the protection of the human being and the preservation of the human environment. Ambiguity also existed with respect to the determination of whether the commission of a crime finally occurred as this was made dependent on the 'rules of international law in force', without further explanation. ${ }^{316}$ The Draft Articles, therefore, did not provide for any special procedure for determining whether a crime had been committed or what consequences should ensue, since such proposals were rejected by ILC in 1995 and 1996. ${ }^{317}$

Likewise, Professor Crawford observed that the definition of crime as reflected in Draft Article 19 provided for an additional element of gravity that was not always existent in the elements of specifically defined internationally wrongful acts. For example, the reference to widespread violations of obligations essential for the protection of human beings added an element that did not exist, for instance, in the definition of genocide. It is not widespread genocide that it is prohibited but genocide in general and irrespective of the degree or scale of such violation.

One further criticism exercised against the inclusion of state crimes in the Final Articles related to the legal consequences deriving from the commission of a crime, which in the Draft Articles did not appear to be distinguishable from the consequences resulting from a delict. Furthermore, under Draft Article 40, following the commission of a crime all other states were considered as injured states and, as such, they were entitled to seek reparation and to resort to countermeasures, a move that entailed risks for abuse. Professor Crawford was also critical of the

315 First Report on State Responsibility (Crawford) (1998) UN Doc. A/CN.4/490 (15).

316 First Report on State Responsibility by Mr James Crawford, Addendum 1 (1998), A/CN.4/490/ Add.1, (49).

317 Ibid (51). 
decision to remove the restrictions placed on the exercise of restitution or satisfaction whenever a crime was involved. ${ }^{318}$

In the light of these concerns, Professor Crawford concluded that there existed no judicial practice supporting the existence of a distinction between state crimes and delicts, despite the recognition that international law consists of different norms that go beyond a strict bilateral relationship and that have a different hierarchy. ${ }^{319} \mathrm{He}$ further observed that the reference to a 'criminal' element could prove misleading. For all these reasons, Professor Crawford recommended the deletion of Draft Article 19, without prejudice, however, to the future development of international law on the matter.

Instead, there was support for the substitution of the provision on state crimes with a provision regarding serious breaches of peremptory norms, such as aggression, genocide, apartheid and denial of self-determination, since they 'shock the conscience of mankind'. ${ }^{320}$ However, this proposal also met the negative reaction of some states that viewed the proposal as a remnant of the notion of state crimes. ${ }^{321}$ It is noteworthy that nowhere in the articles does the ILC attempt to give a definition of jus cogens, relying instead on Article 53 of the 1969 VCLT. This, however, led Professor Pellet to argue that:

[T] he 1969 text defines peremptory norms only in terms of their consequences in matters of treaty law, which is not very rational from the standpoint of the law of international responsibility: that amounts to saying that when a rule renders a conflicting treaty invalid, its breach entails particular consequences in matters of responsibility; this is a not very useful combination of two quite distinct branches of law. ${ }^{322}$

However, despite the differences between the law on treaties as reflected in the 1969 VCLT and the law on state responsibility, the two branches of international law overlap and complement each other. ${ }^{323}$ Moreover, the concept of peremptory norms is also reflected in customary international law and, therefore, is a concept not limited to the law of treaties. ${ }^{324}$

Chapter III of Part 2 of the articles concluded in 2001, and more particularly Articles 40 and 41, provides for specific consequences arising from serious violations of obligations under peremptory norms. In the light of these provisions, however,

318 For detailed analysis on the concerns voiced against the inclusion of the notion of state crimes in the Final Articles on State Responsibility see ibid (52) et seq.

319 First Report on State Reponsibility by Mr James Crawford, Addendum 2 (1998), A/CN.4/490/ Add. 2, (71).

320 Fourth Report on State Responsibility (Crawford) op. cit., (47).

321 See ibid (43).

322 A. Pellet, 'The New Draft Articles of the International Law Commission on the Responsibility of States for Internationally Wrongful Acts: A Requiem for States' Crime?' 32 N $I L$ (2001) 55, 64.

323 This was highlighted by the ICJ in the Case Concerning the Gabcikovo-Nagymaros Project (Hungary/ Slovakia), 25 September 1997, ICJ Reports (1997) 7.

324 See analysis in Chapter 1, section 3.1. 
not all the breaches of jus cogens entail aggravated legal consequences but only those that are of a serious nature; in other words, those that constitute gross or systematic infringement of such norms. However, in the author's opinion, reference to an additional element, that of the seriousness of the violation of such norms, imposes an unnecessary legal constraint that finds no support in state practice, the literature or the jurisprudence. The violation of jus cogens norms, irrespective of their intensity, suffices to be serious enough to entail the necessary legal consequences for the wrongdoer but also to give rise to specific obligations to all other states of the international community. This is particularly so in the case of genocide which seems to carry by definition an element of seriousness and gravity. However, it is acknowledged that the reference to 'serious' violations of peremptory norms intends to distinguish isolated incidents from a given practice.

Article 40 places the emphasis not only on the fact that certain norms are given priority over others, but also on the fact that all states have a legal interest in their preservation. It is imperative, if the distinction between serious and less serious violations of international law is to be meaningful, to attach additional consequences to these violations for which all states are entitled to invoke the responsibility of the wrongdoing state. In this context, Article 41 sets out the specific consequences arising as a result of a serious violation of a peremptory norm, which, however, are directed not against the wrongdoing state but rather, against all other states. Article 41 establishes, therefore, a duty on states to cooperate in order to bring an end to the wrongful act by lawful means, not to recognize as lawful the situation that will result from the violation and not to render aid or assistance to the wrongdoing state. ${ }^{325}$ These consequences are additional to the consequences deriving from Article 48 concerning violations of jus cogens norms that cannot be qualified as serious, and obligations established for the collective good either of a group of states or the international community as a whole. According to Article 48(2), any state entitled to invoke the responsibility of the wrongdoing state under that provision may claim the cessation and non-repetition of the wrongful act and reparation in the interest of the injured state or the beneficiary of the obligation concerned. ${ }^{326}$

As already noted earlier, and in view of the concerns of states regarding the introduction of a punitive element in the law on state responsibility, the legal consequences entailed in Articles 41 and 48 do not aim to impose punishment, a notion at odds with the principle of sovereign equality, but rather merely reflect the gravity of the breach. ${ }^{327}$

\subsection{The injured state and states other than the injured}

The Final Articles endorse a significant distinction between 'injured' and 'other' states, in deviation from the position previously reflected in the Draft Articles

325 Report of the International Law Commission (2001), op. cit., 277.

326 Crawford (2002) op. cit., 276.

327 Fourth Report on State Responsibility (Crawford), op.cit., (45). 
adopted in the first reading that made no such distinction, in recognition that not all states may be affected in identical ways in the event of a violation of an international norm. An injured state is the state whose individual right has been impaired (Article 42(a)), the state that has been specially affected by the infringement of a collective obligation (Article 42(b)(i)) or whenever the violation of a collective obligation radically changes the position of all the other states in relation to its performance (integral or interdependent obligations) (Article 42(b)(ii)). ${ }^{328}$

Article 42(a) deals with obligations arising in the context of a bilateral, delictual relationship between the state to which an obligation concerning an act or omission is owed and the state that carries the duty not to violate the obligation in question. This form of relationship is a central characteristic of traditional international law: any third state is precluded from bringing a claim in case of violation of obligations of this nature. Obligations of a bilateral nature, however, are not only found in bilateral treaties or bilateral customs. It is thus possible that a multilateral treaty for instance, despite the plurality of the states that are parties to it, creates a bundle of multiple bilateral relations between different sets of member states. In these cases, despite the plurality of the states that are parties to the treaty and the fact that they are all bound by the same rules, the treaty creates a bundle of obligations of a bilateral character, with one state party being the carrier of the obligation set by the treaty and the other the carrier of the right. It is also noteworthy that such bilateral relationships are not necessarily established as between all the parties.

An example of a multilateral treaty establishing rights and obligations between two states is the Vienna Convention on Diplomatic and Consular Relations: once a state accepts having a foreign diplomatic mission within its territory, it is bound to provide the mission all the rights and protections provided under the Convention. Although the Convention is a multilateral treaty, only the state whose rights and privileges have been infringed will be able to make a claim against the wrongdoing state. This is in spite of the significance of compliance with the terms of the Convention for the international community as a whole recognized by the ICJ in the Teheran Hostages case. According to the Court, violation of the obligations under diplomatic immunities law could be detrimental for the 'security and wellbeing of the complex international community of the present day, to which it is more essential than ever that the rules developed to ensure the ordered progress of relations between its members should be constantly and scrupulously respected'. ${ }^{329}$ Still, only the state whose individual rights have been infringed will be entitled to make a claim under the Convention.

The Convention on the Law of the Sea offers another example of a multilateral treaty establishing multiple bilateral obligations. ${ }^{330}$ The violation of a bilateral obligation contained in a multilateral treaty necessarily has a bilateral character

328 Report of the International Law Commission (2001) 296.

329 United States Diplomatic and Consular Staff in Teheran, op. cit., 43. Also see Chinkin (1993), op. cit., 137.

330 K. Sachariew, 'State Responsibility Multilateral Treaty Violations: Identifying the "Injured State” and its Legal Status' 35 Netherlands International Law Review (1988) 273, 277. 
itself, meaning that the dispute arises between the two parties actually involved, with the one being the author state and the other the injured state. All the other parties to the treaty are not affected and thus they are third states to the dispute. As a consequence, if a violation of the Convention on the Law of the Sea occurs concerning the right to innocent passage, only the coastal state may bring a claim against the flag state.

Article 42(b), on the other hand, deals with the violation of collective obligations that specially affects the state concerned, or radically changes the position of all the other states. In the latter case, the rule concerned creates 'indivisible' rights and obligations. ${ }^{331}$ Under these circumstances, there is an expectation of performance of the obligation that is a precondition for the fulfilment of the objectives set by the norm. The fulfillment and performance towards one state, is fulfillment and performance towards all. As pointed out, the notion of interdependent obligations envisaged in the Final Articles should be construed narrowly to cover 'obligations which operate in an all-or-nothing fashion, such that each state's continued performance of the obligation is in effect conditioned upon its performance by each other part'. ${ }^{332}$ In this regard, interdependent obligations are obligations whose performance relies on the compliance of all the other parties, such as obligations arising from disarmament treaties. ${ }^{333}$ They must however be distinguished from integral obligations the performance of which is unrelated with their performance by another party, such as for instance obligations deriving from human rights treaties.

Article 60 of the 1969 VCLT that deals with interdependent obligations provides that any state which is a party is entitled to invoke the material breach and to suspend the treaty in question, thus threatening the treaty structure in its entirety. A disarmament treaty is a good example of obligations of this kind. Here, each state undertakes the obligation to reduce its military capability on the assumption that the other states members to the agreement will do the same. Breach of such an obligation would destabilize the balance aimed to be established by the treaty and would result in the radical change of position of every other state party to the treaty. Human rights treaties are therefore not interdependent. On the contrary, 'human rights obligations are incremental, and human rights treaties do not operate in an all-or-nothing way.' 334 As a consequence, a state cannot rely on the infringement committed by another state to avoid the implementation of its own obligations regarding the protection of human rights.

Chapter 1 and the preceding sections demonstrated that while international law is still characterized predominantly by state relations of a bilateral nature,

331 E. Weiss Brown, 'Invoking State Responsibility in the Twenty-First Century' 96 AfIL (2002) 798, 800-1.

332 Crawford, Peel and Olleson, op. cit., 974.

333 'Fragmentation of International Law: Difficulties Arising from the Diversification and Expansion of International Law', Report of the Study Group of the International Law Commission, Finalized by Martti Koskenniemi, United Nations General Assembly, A/CN.4/L.682, 13 April 2006, (262).

334 Crawford, Peel and Olleson, op. cit., 974. 
contemporary international law has also moved towards the recognition of certain international rules the observance of which lies within the interest of all states. These developments led to an expansion of the circle of the subjects entitled to invoke the responsibility of a defaulting state as will be shown in later sections.

It is accordingly imperative to identify not only the subjects entitled to invoke the responsibility of another state but also their capacity for doing so, in other words whether they are injured states under Article 42 or states other than the injured under Article 48. The distinction is significant as it entails different rights and entitlements in each instance. More specifically, while one state may be specifically and materially injured, others may have suffered nothing more than a 'moral' damage. In the latter case, their interest comes as a result of the fact that an obligation owed to a group of states established for the collective interest (erga omnes partes) or an obligation owed to the international community as a whole (erga omnes) has been violated. Yet, the violation of collective interests does not preclude the possibility that a state may still be injured in its individual rights empowering that state even to resort to countermeasures, an entitlement that is disputed in relation to non-injured states.

Professor Crawford advocated the distinction by noting that:

We cannot make progress in developing the idea of a public international law (rather than a private spectre of international law), unless we distinguish between the primary beneficiaries, the right holders, and those states with a legal interest in compliance. ${ }^{335}$

This position is now reflected in Articles 42 and 48 of the 2001 Final Articles. In the case of Article 48, the state has a 'legal interest' in the compliance of the wrongdoing state without necessarily having to prove that the obligation is individually owed to it or that it is specially affected by the violation. ${ }^{336}$ Although it is accepted that there are certain obligations the significance of which concerns a wider spectrum of states, be it a group of states or the international community as a whole, the damage suffered by each state is not always the same. It will vary according to whether the rule involved an obligation owed to a state individually or as a member of a wider group of states. In the former case, the injury caused is of a more 'direct' nature, while in the latter case, although the legal interest is never disputed, the injury only comes as a result of a rule established for the general good. The difference has legal ramifications as only the injured state is entitled to all the remedies provided under the Final Articles. In contrast, non-directly injured states enjoy only limited rights in relation to action they may be entitled to take against the wrongdoing state. ${ }^{337}$

335 Crawford (2000), op. cit., 17 in Scobbie, op. cit., 1205.

336 Scobbie, ibid, 1207.

337 Sicilianos makes the point that Article 48 could be interpreted as allowing the gravest of measures such as the resort to 'lawful measures' even for minor violations of erga omnes obligations. 
Article 48 distinguishes between obligations owed to the international community as a whole as proclaimed in the obiter dictum of the ICJ in the Barcelona Traction case - genocide is often cited as an example - or to a group of states established for the protection of a collective interest. The latter includes regional agreements on security, protection of human rights within a specific region or regional systems established for the protection of the environment. It incorporates obligations erga omnes partes, thus obligations created for the protection of a common interest. Obligations falling under this category differ from obligations the violation of which radically changes the position of every state in the treaty in that they 'tend to promote extra-state interests, are not of a synallagmatic nature and fall outside the interplay of reciprocity. A breach of human rights by state A, however serious it may be, in no way changes the position of other states regarding compliance with their own obligations in the same area.'338

Under Article 48 states are affected by a given infringement based not on their individual capacity but rather because they are members of a group of states or the international community to which the obligation is owed. In the first case, two requirements must be met: the state must be a member of that group and the obligation must aim to protect a collective interest. The second category concerns obligations owed to the international community as a whole and no further requirements need be satisfied. This provision concerns not merely the violation of jus cogens norms but also the violation of erga omnes obligations. The ILC avoided using the phrase 'legal interests' as it appears in the Barcelona Traction case since this would leave no room for distinction between the injured states under Article 42 and states other than the injured under Article 48. ${ }^{339}$

Terms such as 'non-directly injured' and 'third states' have frequently been used in the literature and the work of the ILC. They have been used to indicate those states whose legal interest is established not in the context of a bilateral relationship but in the spectrum of a multilateral relationship borne either within general international law or within the law of treaties. In its Final Articles, the ILC chose to refer to 'states other than the injured', in an attempt to remove the possibility of any misconceptions as to the meaning of such phraseology.

Once the criteria of Article 48 are fulfilled, the state invoking the responsibility of the wrongdoing state may do so not only by demanding cessation of the internationally wrongful act but also by demanding reparation 'in the interest of the injured State or of the beneficiaries of the obligation breached'. This is another indication of moving away from the traditional perception of international law, which found expression in bilateralism. In relation to this, it has been argued that to allow a third state not individually affected by a breach of this kind to claim

A.L. Sicilianos, 'The Classification of Obligations and the Multilateral Dimension of the Relations on International Responsibility' 13 EfIL (2002) 1127, 1141.

338 Ibid, 1135.

339 Report of the International Law Commission (2001), op. cit., 319 (2). 
reparation when the injured state itself has waived its right to do so is without precedent in international law. ${ }^{340}$

Despite these developments, Article 44(a) of the Final Articles introduces a specific admissibility requirement for the invocation of state responsibility, thought by some to stand against the very notion of erga omnes obligations and jus cogens norms. More specifically, Article 44(a) provides that the responsibility of the state cannot be invoked unless in agreement with any applicable rule regarding the nationality of claims. This provision has been viewed by some commentators as being in conflict with Article 48 by making it impossible for a state to act where its nationals are not the victims of a certain violation. ${ }^{341}$ While the ILC in its commentary on Article 44(a) noted that the question of the nationality of claims will be dealt with within the framework of diplomatic protection, it has been characteristically pointed out that the latter is in apparent conflict with the provisions on state responsibility. ${ }^{342}$ This is due to the fact that diplomatic protection requires a link between the national whose rights have been infringed and the state exercising protection on their behalf. This is illustrated by the overlap between diplomatic protection and state responsibility since 'a State acting on behalf of one of its nationals [is] nonetheless invoking State responsibility'. ${ }^{343}$

However, in the debates of Draft Article 1 on Diplomatic Protection it was pointed out that: 'Under international law, obligations concerning human rights were typically obligations erga omnes. Any State could request cessation of the breach, whether the persons affected were its own nationals, nationals of the wrongdoing State, or nationals of a third State. Thus, any requirement of nationality of claims appeared to be out of place when human rights were invoked.'344 Moreover, the commentary to Draft Article 1 on Diplomatic Protection notwithstanding, Article 44(a) is subject only to those cases where the requirement of nationality of claims is applicable and therefore not all cases of invocation of state responsibility will raise such questions.

The significance of Article 48 lies in the clear intention of its drafters to move away from the ruling of the ICJ in the South West Africa case and to affirm a public interest approach as confirmed in its obiter dictum in the Barcelona Traction case. ${ }^{345}$ As the analysis in Chapter 1 revealed, in the former case the Court refused to examine the claims brought by Liberia and Ethiopia against South Africa on the ground that they lacked a special material interest regarding South Africa's practices over South West Africa in violation of the mandate. Furthermore, the

340 Scobbie, op. cit., 1214.

341 Ibid, 1217.

342 Ibid, 1201.

343 Report of the International Law Commission on the Work of its Fifty-second Session, 1 May to 9 June and 10 July to 18 August 2000 (A/55/10) 50, (286).

344 First Report on Diplomatic Protection by Mr J.R. Dugard, Special Rapporteur, UN Doc. A./CN.4/506 (7 March 2000) and Addendum, UN Doc. A/CN.4/506/Add.1 (20 April 2000) in Scobbie, op. cit., 1216.

345 Dawidowicz, op. cit., 341. 
Court rejected that there existed an actio popularis in international law or a right of any member of the international community to take legal action whenever an issue of public interest was at stake. ${ }^{346}$ Article 48 is therefore significant as it establishes a clear legal link between states and violations of this nature and an unequivocal legal interest in the protection of the norms breached by invoking the responsibility of the defaulting state. The position reflected in Article 48 is in line with the previous conclusions of the ICJ in its Advisory Opinion in the Reservations to the Genocide Convention case. It can be deduced from the Court's Opinion that the Convention intended to ensure the rights of all individuals irrespective of their nationality, thus extending the circle of states entitled to invoke the responsibility of the wrongdoing state and to make a claim before international judicial bodies beyond the state of nationality. ${ }^{347}$ This leads to the question central to this book, whether states other than the injured may demand cessation of the wrongful act that attacks collective interests by way of countermeasures. As already shown, this is an issue that remains unsettled in the Final Articles.

\subsection{Countermeasures by states other than the injured}

One of the most disputed aspects of the law on countermeasures was the entitlement of third states to resort to countermeasures. As seen from our earlier discussion on state crimes, under Draft Article 19 as adopted at the first reading of the Draft Articles on State Responsibility countermeasures were open effectively to all states, if an international crime had been committed. At the second reading of the Draft Articles, the ILC, wary of the implications that the recognition of such a general right could have in the preservation of the international legal order, decided not to include such a right with respect to states other than the injured. The omission of express reference to the right of states other than the injured as defined in Article 48 to resort to countermeasures constitutes a controversial issue in the Final Articles. As will be discussed later, Article 54 recognizes the right of states other than the injured to invoke the responsibility of another state for violation of obligations that fall within the meaning of Article 48 and to resort to lawful measures to ensure cessation of the wrongful act and reparation. However, the provision avoids the use of the term 'countermeasures'. The reference to 'lawful measures', in its place, has sparked divergent interpretations as to its exact meaning and scope, while at the same time not ruling out future developments in this respect. ${ }^{348}$ In its commentary on Article 54, the ILC notes that countermeasures by states other than the injured state were still very much disputed while state practice was 'embryonic'. ${ }^{349}$ The action of states other than the injured was rather confined to securing the cessation of the breach and reparation on behalf of the

346 South West Africa cases, Second Phase, op. cit., 47 (88). Also Weiss Brown, op. cit., 804.

347 Reservations to the Genocide Convention, op. cit., 23.

348 Pellet, op. cit., 79.

349 Crawford (2002), op. cit., 302. 
injured state or the beneficiaries by other means permissible under international law. It was therefore feared that codifying and establishing such a right would open Pandora's Box, such that powerful states could behave in an arbitrary way as the law's executors and enforcers.

It should be noted, however, that the decision not to include an express right to solidarity measures did not reflect the view of Professor Crawford. On the contrary, Professor Crawford advocated the inclusion of countermeasures in protection of general interests in two situations. First, whenever a state was invited to resort to such countermeasures by the state directly injured on the basis and scope of the given consent, and, second, in the absence of an injured state, whenever an obligation owed to the international community was infringed. ${ }^{350}$ In the end, neither of these suggestions was adopted. Despite this, one can see from the Final Articles and especially from the commentaries to Articles 22 and 54 that the issue was not intended to be conclusively settled. In particular, the commentary on Article 22 provides that:

Article 54 leaves open the question whether any State may take measures to ensure compliance with certain international obligations in the general interest as distinct from its own individual interest as an injured State. While Article 22 does not cover measures taken in such a case to the extent that these do not qualify as countermeasures, neither does it exclude that possibility. ${ }^{351}$

Furthermore, Article 41(3) on the consequences to ensue as a result of serious breaches of peremptory norms provides that it is without prejudice to other consequences which may be entailed under international law. As Alland observed, this suggests that: 'П]nternational law allows the possibility for ("non-injured") states to take countermeasures of general interest following breach by any state whatever of an obligation arising under a norm of jus cogens. ${ }^{352}$ This becomes evident in cases of indirect violations of peremptory norms through the execution of the terms of a given treaty, which, although prima facie innocent, contributes to the commission of such violations, as elaborated in Chapter 1.353 The question, of course, remains as to the lawfulness of countermeasures taken in the name of collective interests that do not however qualify as peremptory norms.

Alland criticized the wording used in Article 54 concerning 'lawful measures' as not reconcilable with the 'saving' remarks concerning countermeasures of general interest, made regarding Articles 22 and 41(3). As he points out, it is quite remarkable that such countermeasures in response to serious violations of peremptory norms were left 'outside', if international law recognizes the existence of such a right.

350 Third Report on State Responsibility (Crawford), Addendum 4, op. cit., (413).

351 Report of the International Law Commission (2001), op. cit., 183 (b).

352 Alland, op. cit., 1232.

353 Section 3.1.3. 
Furthermore, he stressed that Article 22 can by no means be reconciled with Article 54: the former clearly states that it concerns 'wrongful acts' of a state, while the latter speaks about 'lawful' measures. According to this interpretation, there is a fundamental difference between acts of retorsion and countermeasures ${ }^{354}$ and that, concomitantly, there are substantial reasons to believe that the ILC has precluded, at least for the time being, the concept of countermeasures by states other than the injured. As he points out, with its decision not to include a principle allowing countermeasures for the most serious violations of international law, the ILC gave preference to 'the absence of any consequences for the most serious wrongful acts' as against the admittedly 'subjectivism of a decentralized response in defence of general interests', should institutional action fail. ${ }^{355}$ Nevertheless, Professor Alland's interpretation does not agree either with the intention of the ILC or with the Final Articles and their commentary. Accordingly, in the light of the commentary to Article 54 this provision does not, at least currently, incorporate a right to third-state countermeasures but neither does it preclude it should such a norm permissive of third-state countermeasures evolve in the future (an interpretation also in accordance with the commentary on Article 22 quoted earlier). It is also suggested that a countermeasure that fulfils the predefined conditions of legality does not constitute an unlawful but rather a lawful measure itself, an interpretation that would enable third-state countermeasures to fall within the scope of Article 54 in future.

Nevertheless, the question of whether the conclusions of the ILC concerning the lack of sufficient state practice in support of countermeasures taken in the name of collective interests are satisfactory will be explored in the following chapter. It is necessary, however, to stress that while we cannot ignore the driving force behind the ILC's decision not to recognize at the present time a right to solidarity measures, neither can we overlook the changing nature of the international legal system. There is little doubt that the concerns voiced by many states regarding the abuse of such entitlement by powerful states at the expense of the rights of states to sovereignty and equality bear real merit and must necessarily be taken into account in outlining the most stringent conditions for the right to resort to such measures. However, the analysis in the preceding and current chapter has demonstrated that the international legal order establishes a community that is no longer an abstract idea, but a community founded on common structures and legal principles from which no derogation is allowed. These principles constitute the minimum denominator shared by all states and, therefore, the infringement of any of these legal principles is an attack on the legal interests of every state. No matter how strong the idea of state sovereignty remains in international legal reality, there has been an undisputable force according to which these principles must be respected by all, even by states that have opposed their development. As already seen, this is reflected in the notion of jus cogens norms. It has also been

354 Alland, op. cit., 1233.

355 Ibid, 1239. 
demonstrated that in addition to peremptory norms from which no derogation is allowed, there are other norms that establish collective rights and obligations with an erga omnes effect, making their observance essential for the international community of states as a whole.

In the light of the immobility and inflexibility of institutionalized law enforcement in the international legal order as revealed from the primarily political role of the Security Council and the unfair power balance within the Security Council, it is imperative that the international community finds effective mechanisms to fight international injustices that 'shock the conscience of mankind'. It is not possible in today's world to stay impassive, but also legally incapable, when genocide or torture is committed. The argument in support of a right to solidarity measures becomes even stronger in the light of the danger of leaving serious violations of international law to go unnoticed. ${ }^{356}$ If the international community is currently unable to agree on the existence of institutional mechanisms entitled to the implementation and respect of international law, then the gap should be filled with the recognition of an entitlement to third states to take countermeasures. Nevertheless, the recognition of such a right should only come with the most stringent conditions to ensure that countermeasures are not turned into a powerful weapon to the detriment of international law and subject to manipulation by the existing superpowers. As characteristically pointed out by the Dutch representative to the Sixth Committee of the General Assembly: '[T]he respectable and laudable object of preventing the abuse of reprisals would be served, better than by their abolition, by underscoring the conditions to which their exercise is subject.' 357 The issue of proportionality, therefore, merits separate examination in the last chapter.

\section{Conclusion}

The main purpose of this chapter was to provide a thorough analysis of the ILC's work on the codification of the law on state responsibility in view of the great impact that this work has had and will have in the future development of international law. Most importantly, the examination aimed to show how the emergence of the notion of collective interests influenced the development of the rules on state responsibility and also the rules concerning the enforcement of international law, particularly when fundamental interests come under attack. Undoubtedly, one of the most interesting and intriguing features of the ILC's work has been the realization that not all internationally wrongful acts have the same significance or the same legal effects and that as opposed to simple breaches, there are others which cannot leave unaffected the international community in its entirety. This had an impact on the nature of responsibility with the recognition of additional legal

356 For a similar argument, see A. de Guttry, 'Some Recent Cases of Unilateral Countermeasures and the Problem of their Lawfulness in International Law', 7 IYIL (1986-1987)169, 170.

357 Statement dated 13 December 1968, 1 N $I L$ (1970) 171. The reference here must relate to countermeasures not involving military action. See, in this regard, ibid, 170-71. 
consequences in the event of serious violations of peremptory norms and also on the circle of states entitled to invoke the responsibility of the wrongdoing state.

It has further been explained that the attempt to incorporate the notion of state crimes in the Final Articles was eventually abandoned, due to the concerns voiced by states that the notion was introducing punitive elements into the law on state responsibility and it was taking away something from the principle of sovereign equality of states. This did not prevent the ILC recognizing that states were affected in many different ways as a result of the violation of an international norm, a recognition reflected in Articles 42 and 48 of the Final Articles. Quite significantly, it was accepted that under certain circumstances, states may invoke the responsibility of another state even if they have not been injured in their individual rights. In such circumstances, states act for the purpose of safeguarding obligations with an erga omnes effect but also obligations established for the collective interest of a group of states. This significant development further enhanced the notion of community interests.

Nevertheless, the enforcement of such interests remained a controversial issue. In fear that a general right to countermeasures would be subject to abuse, the ILC decided not to include an express reference to a right to solidarity measures. Instead, it recognized the right of states to resort to 'lawful measures', having concluded in the meantime that there currently exists no customary rule in support of a right to solidarity measures. These conclusions remain all the more significant since the question of solidarity measures is, according to the ILC, the subject of the progressive development of international law. In other words, the ILC has postponed any final settlement on the issue leaving it to states themselves to decide whether to accept or reject such a right in the future. The fact that the ILC did not take a final stance on the matter opens the door to yet more controversy and legal uncertainty. At the same time, there is compelling and amounting evidence that the ILC may have erred in its findings on the existence of state practice and opinio juris to support a right to solidarity measures and this is thoroughly explored in the next chapter.

Before turning to Chapter 3, however, it is imperative to note that the General Assembly must take a clear decision on the future and status of the Final Articles. In the light of their significance and their wide use by states, commentators and courts, their authority must not be compromised by legal uncertainties and, therefore, an international agreement is required to give legally binding effect to the articles, giving at the same time opportunity for further clarification on those issues that remain ambiguous.

With these concluding remarks, attention is next turned to state practice and opinio juris as evidence in support of a right to countermeasures taken in the name of collective interests. 


\section{Countermeasures in the name of community interests in state practice}

\section{Introduction}

It has been established that the incorporation of the concepts of peremptory norms and obligations owed to the international community and to a group of states have prevailed in international legal doctrine as fundamental to the accomplishment of community and collective interests. These developments have influenced issues relating to judicial standing and the enforcement of such interests through judicial channels, but also the subjects entitled to invoke the responsibility of a state that infringes such norms and the legal consequences arising in the event of a violation. Having shown that states not individually injured may initiate proceedings before international courts and other bodies for the protection of community interests and also interests owed to a group of states, the main purpose of Chapter 3 will be to consider whether states may enforce such interests through the implementation of countermeasures.

The significance of this examination lies in what Article 53 of the 1969 VCLT and the obiter dictum of the ICJ in the Barcelona Traction case omit to say: the way by which peremptory norms and obligations erga omnes may be implemented and enforced. Neither Article 53 nor the Court's dictum provide for the safeguard of community interests through judicial proceedings; furthermore, neither do they expressly recognize an automatic right to countermeasures by states other than the injured, ${ }^{358}$ contrary to some authors' belief. ${ }^{359}$ At the same time, the preceding analysis made clear that international organizations such as the UN do not have exclusive authority over the protection of community interests. Moreover, the enforcement of international law, especially whenever fundamental community interests are threatened, is frustrated by the selectivity often exercised at an institutional level and also by the fact that the Security Council has a very restrictive mandate, namely the maintenance of international peace and security, rather than the enforcement of fundamental community interests generally. ${ }^{360}$ In the

358 Tams, op. cit., 204.

359 G. Erasmus, 'Third States and Sanctions in Public International Law - the Position of South Africa', 30 AVR (1992) 128, 133-4. Also see Tams, op. cit., 203.

360 Dawidowicz, op. cit., 335. 
light of these realities, a legal entitlement to ensure observance with such norms and obligations is conferred on states, ${ }^{361}$ even though the manner by which they are entitled to do so is not specified. The same applies in relation to the enforcement of interests owed to a group of states collectively, such as, for instance, interests emanating from the European Convention on Human Rights. The Final Articles, as discussed in Chapter 2, do little to resolve determinatively the question arising with respect to the lawfulness of countermeasures taken by states other than the injured, leaving the matter in legal limbo.

This chapter focuses predominantly on an analysis of relevant state practice and opinio juris in support of a right to countermeasures taken by states other than the injured. What is essentially at the heart of this study is whether states not injured in their individual but rather in their collective rights are entitled to take countermeasures against the defaulting state for the preservation of the international ordre public and in response to serious violations of interests of this nature. ${ }^{362}$ This means that in the absence of a clear and unequivocal rule recognizing such right, the investigation will concentrate on the practice of states. It is state practice that will tell us whether the required, inter alia, opinio juris exists for the formulation of such a customary rule. ${ }^{363}$ In the light of the decentralization of the international legal system and the outlawing of the use of force and punitive, even if peaceful, action in contemporary state affairs, the enforcement of community interests by way of countermeasures and by violating specific obligations under international - as opposed to national - law is of particular significance. As explained in Chapter 2, countermeasures are self-executing measures in the sense that they are applied by the individual states because no other mechanisms to remedy a certain wrongdoing exist or, even if such mechanisms do exist, they are often ineffective or inadequate, especially where immediate action needs to be taken. Despite the fact that the entitlement of injured states to impose countermeasures is now widely accepted in international legal thinking, the lawfulness of countermeasures taken in the protection of collective interests remains unsettled. As seen from the findings of the ILC, there is arguably controversy with respect to the acceptability and legitimacy in international law of countermeasures taken by states that have suffered no direct injury to an interest not individually owed to them. Yet, as the analysis in this chapter aims to establish, on many occasions states have reacted strongly to aggression, genocide and other gross human rights violations while they have also given their support to national liberation movements fighting for their right to selfdetermination and against apartheid, racism and colonization. ${ }^{364}$ This support illustrates the commitment of many states to react to violations of obligations owed

361 Tams, op. cit., 201.

362 There is a growing opinion that the element of 'seriousness' is an essential requirement for the justification of third-state countermeasures. See analysis in Dawidowicz, op. cit., 347-8.

363 C. Warbrick, 'The Theory of International Law: Is there an English Contribution?' in W.E. Butler (ed.), Perestroika and International Law, (Martinus Nijhoff: 1990) 41, 47-8.

364 Tams, op. cit., 212. 
to the international community or to a group of states, often in violation of the principle of non-interference in the domestic affairs of another state. ${ }^{365}$ At the same time, it was elaborated in Chapter 2 that a compelling opinion exists in the literature according to which all states may resort to coercive action whenever fundamental interests are seriously imperilled. ${ }^{366}$

From the analysis that follows it will be shown that these and other examples provide concrete evidence that there is more to be said regarding the existence of a customary norm permitting the use of solidarity measures in international affairs than the conclusions of the ILC on the matter. It will further be established that there is a wealth of examples in state practice and opinio juris in support of such a right that go beyond the limited number of examples referred to by the ILC. Finally, the increasing state interdependence in economic and trade affairs - the WTO offers just one such example - makes it more likely, as the next chapter will show, that the imposition of a certain measure will be in breach of an international obligation arising in a specific legal context (lex specialis or self-contained regime). This makes the consideration of the right to solidarity measures all the more important.

It is also necessary at the outset to distinguish countermeasures from other conduct such as retorsion that, although unfriendly in nature, does not infringe any international rules. Nevertheless, it will be demonstrated that such retorsive action may provide evidence regarding the determination of states not only not to tolerate but also to take specific, even if lawful, action in response to serious violations of international law. This is evidenced from the increasing concern for human rights violations in other countries as reflected in the inclusion in treaties of 'human rights clauses' discussed later, the conditionality of foreign aid and assistance on human rights improvements and the categorization of states according to their human rights records or their support of terrorist activities. It will be argued that these cases provide further legal ground for the argument that states not directly affected are entitled to make a claim and invoke the responsibility of the wrongdoing state that has infringed fundamental interests of the international community or other collective interests, even if no direct injury is involved. Moreover, such measures are often taken in addition to countermeasures, revealing the intention of states to exhaust all possible, lawful and non-lawful, coercive means at their disposal in order to induce the compliance of the defaulting party with its obligations under international law. Furthermore, in the absence of documentation and supporting evidence it is often difficult to assess the lawfulness of certain action, which may move between retorsion and countermeasures. For all these reasons,

365 See for instance Declaration of G77 Foreign Ministers, Seventh Annual Meeting (1983) and Declaration of G77 Foreign Ministers, Sixth Annual Meeting (1982) cited in ibid, 212.

366 See Chapter 2, section 3.1. Also see W.E. Hall, A Treatise on International Law, 8th edn (A. Pearce Higgins: 1924) 65-6. Hall, in particular, argued that all states are entitled to take appropriate action necessary whenever there is a gross violation of interests of 'serious importance'. This was particularly so in the absence of an 'organized authority' empowered to enforce international law. 
such examples of state practice are not excluded from the scope of the present study.

This chapter also considers statements and calls made by non-directly injured states to impose countermeasures against another state even if no action were taken thereafter, as reflective of opinio juris in support of a right to third-state countermeasures.

The assessment of state practice and opinio juris is, however, no easy task. On the contrary, such study comes with a number of inherent difficulties, as state practice is often inconclusive, conflicting or ambiguous. Moreover, states often avoid clearly identifying the legal basis of their action or they attempt to justify their conduct on covert legal grounds. Neither is it always easy to determine whether a specific norm has been infringed and therefore uncertainty remains as to whether certain conduct amounts to retorsion or third-state countermeasures. Also significantly, uncertainty may exist in relation to whether a given wrongful act entails violation of fundamental collective interests that would entitle a state other than the injured to invoke the responsibility of the wrongdoer and to resort to such means of enforcement of international law as countermeasures. ${ }^{367}$ Another difficulty present in this study is that often it is not clear whether the action is attributed to private actors or to the state, making it difficult to recognize whether the action constitutes a countermeasure under international law.

With these preliminary observations in mind, and before considering state practice in depth, attention is now turned to some considerations regarding the implementation of economic measures as a means of coercion in international affairs and how these have been used at a national, regional and international level.

\section{Economic measures as a means of coercion}

The legitimacy of sanctions in a broader sense for the purpose of inflicting hardship (punitive or other) on the targeted state, irrespective of whether imposed in violation of certain international obligations (countermeasures) or not, has often been brought into question. Having developed in a legal system with its roots deeply founded on the principles of sovereign equality of states and non- interference in domestic affairs, the imposition of coercive measures by one state against another was perceived as an 'attack' on the foundations of the system itself. As noted in earlier sections, it was inconceivable that in a non-hierarchical international legal order a state equal with all others could impose such measures at all.

In addition, the effectiveness of sanctions, especially those of an economic nature, was, and remains today, disputed. The particularly burdensome and punitive sanctions inflicted on Germany after its defeat in World War I, ${ }^{368}$ have often been blamed for not reintegrating the country into the international community, enhancing in this way a concealed menace that led to the outbreak of World War II with

367 Dawidowicz, op. cit., 349-50.

368 Elagab, op. cit., 29. 
its catastrophic results for humanity. Furthermore, the sanctioning system provided under the League of Nations was not sufficient to prevent forceful acts, such as the bombardment and occupation of Corfu in 1923 by Italy, which argued that its action did not amount to war, or the invasion and occupation of Manchuria by Japan some 10 years later. ${ }^{369}$ The system could be triggered only in case of war committed by a member state, but not in response to violations short of war. Neither was there an organized system to impose sanctions, the application of which was left to member states themselves. ${ }^{370}$ The sanctions' regime provided under the Covenant of the League of Nations was invoked only on one occasion, namely against Italy for invading Ethiopia in 1935-36, albeit with no success.

In the years that followed World War II and up until the end of the Cold War era, the debate on the issue of economic measures evolved around two substantially different and conflicting schools of thought. The first of these opinions reflected the view of western states that, alarmed by the communist threat, showed willingness in certain cases to use economic measures against what they considered to be an expression of communist expansion in the world through serious violations of the most fundamental principles of international law. This is demonstrated, inter alia, by the economic measures imposed by western states against the Soviet Union for its intervention in Poland in the 1980s. The other trend represented the position of countries belonging to the Soviet bloc, which, wary of foreign intervention in what they regarded as falling within their exclusive jurisdiction, opposed any notion of economic coercion. Economic sanctions were initially conceived as an instrument that fell within the powers of the Security Council under Chapter VII for the maintenance of international peace and security. Nevertheless, practice soon showed that the antiparathesis of east and west prevailed. What the one side proposed would be vetoed by the other except where, and this rarely happened, no conflicting interests existed, such as, for instance, in the case of the arms embargo imposed against South Africa in 1977. As Mayall observed, the trend during the Cold War period was 'clearly towards using sanctions as a symbol of "alliance", European or even Third World solidarity rather than as an instrument of international order'. ${ }^{371}$

The decision to enter into trade exchanges with another state belongs entirely within the discretion of each state. In the absence of an international agreement, there is nothing to oblige states to engage in economic or other relations with other states. ${ }^{372}$ The United States' position on this matter was always firm, as is revealed by the decades-long imposition of an embargo against Cuba. More specifically, the US government has always maintained that in the lack of any treaty

369 S. Neff, 'A Short History of International Law' in Evans (2006) op. cit., 29, 47.

370 Shaw, op. cit., 1216-17.

371 J. Mayall, 'The Sanctions Problem in International Economic Relations: Reflections in the Light of Recent Experience' 60 International Affairs (1984) No. 4, 631, 633.

372 C. Eagleton, International Government, 3rd edn (Ronald Press: 1957). Also see L. Picchio-Forlati and A.L. Sicilianos, Economic Sanctions in International Law (Martinus Nijhoff: 2004) 101. 
commitment states possess an inherent right to exercise full control over their trade relations and to take decisions concerning the exports and imports of goods with other countries at will. ${ }^{373}$

In the cases where no specific international obligation is involved, state practice offers abundant examples of especially economic responses to serious violations of fundamental principles of international law. Accordingly, when the Suez Canal crisis broke out in 1956 as a consequence of the decision of the Egyptian government to nationalize the Canal, the United States distanced itself from the attack undertaken against Egypt by both the United Kingdom and France. Wary that such action encouraged Soviet aggression and, more importantly, undermined the role of the UN and the most fundamental principles of the UN Charter such as the prohibition of the use of force, the United States attempted unsuccessfully to resolve the matter within the UN. Although the United States found itself on the opposite side to its traditional allies, it was determined to use its economic power in order to put an end to the aggressive policies of France and the United Kingdom against Egypt. To this end, the United States made the provision of loans and aid in oil supplies very much needed by both countries conditional on a ceasefire. ${ }^{374}$ On other occasions, the United States did not hesitate to deny military assistance based on human rights considerations in countries such as Argentina, Brazil, Chile, El Salvador, Ethiopia, Guatemala, Nicaragua, the Philippines, South Korea and Uruguay. ${ }^{375} \mathrm{~A}$ similar approach was undertaken by European countries within the framework of regional organizations such as the EU. In particular, and in the context of the latter's external relations with third countries, the EU institutions introduced clauses on human rights considerations according to which the continuation of the cooperation between the EU and these states is made conditional on respect for human rights. This issue is considered thoroughly later.

Nevertheless, the application of economic measures against another state has not been without difficulties or controversy. On the contrary, it is often argued that Article 2(4) of the Charter prohibits not only armed force but also economic force. ${ }^{376}$ However, this view does not seem to prevail either in the literature or in state practice. States have frequently resorted to their economic advantages to induce certain conduct. The EU itself uses trade and economic benefits 'in exchange' for respect for fundamental rights. The prohibition of economic coercion may, however, arise in another context, that of non-intervention and the prohibition of the use of economic, political or other measures in order to exert pressure on the sovereign rights of another state for the purpose of securing advantages of any kind. This principle finds expression in Article 2(7) of the UN Charter

373 Foreign Boycotts, David H. Small, Assistant Legal Adviser for Near Eastern and South Asian Affairs, US Department of State, Digest of US Practice in International Law (1976) 575-80, 577.

374 R.R. Bowie, Suez 1956: International Crises and the Role of Law (OUP: 1974) 61-5.

375 G.C. Hufbauer et al., Economic Sanctions Reconsidered: History and Current Policy (Institute for International Economics, Washington, DC: 1985) 461.

376 K. Ferguson-Brown, 'The Legality of Economic Sanctions against South Africa in Contemporary International Law' 14 SAYIL (1988-89) 59, 66-7. 
and in the 1970 Declaration on Friendly Relations and its customary character can hardly be disputed. In this context, what is prohibited is not any economic coercion, but rather coercion that intends to subordinate the sovereign rights of another state. ${ }^{377}$ In this respect, states that have been responsible for serious violations of community interests such as for instance genocide, torture or racial discrimination have always relied on the principle of non-interference in their domestic affairs to block international outcry and reaction. The analysis that follows intends to illustrate that such serious violations may no longer find justification in international law and that states are entitled to use their economic power, even in violation of specific obligations, to induce the compliance of the wrongdoing state.

\section{Foreign policy and human rights}

During the 18th century, US foreign policy was much more reserved concerning support of universal moral values due to fears that the United States would be viewed as an imperialistic power. ${ }^{378}$ With the protection of human rights at home having a dominant role, it was hoped that the American example would exercise influence over other states. In the years that followed World War II, special focus was given to the anti-communist struggle, even if that meant establishing alliance with countries that supported repression and committed human rights violations themselves. Human rights concerns gave way to national security considerations with the former US Secretary of State, Henry Kissinger, noting that: ' $[\mathrm{T}$ t is dangerous for us to make the domestic policy of countries around the world a direct objective of American foreign policy ... The protection of basic human rights is a very sensitive aspect of the domestic jurisdiction of ... governments. ${ }^{379}$ However, our analysis will demonstrate that the United States has in many instances, although not every, used economic coercion, even in violation of specific legal commitments in response to serious infringements of community interests.

The monolithic obsession to restrain communism in the world to the disadvantage of human rights and other fundamental principles of international law elsewhere came to a halt when US foreign policy was reformulated to include human rights issues. Since 1973, US Congress, to its credit, pressed for the inclusion of internationally recognized human rights in the foreign policy agenda. In particular, during the period 1974-78 several legislative measures were adopted to link foreign security and economic assistance with human rights, among them, Section 32 of the 1973 Foreign Assistance Act, which associated economic

377 Ibid, 69.

378 D. Forsythe, Human Rights and World Politics, 2nd edn (University of Nebraska Press: 1989) 102.

379 US House of Representatives, International Protection of Human Rights, The Work of International Organizations and the Role of U.S. Foreign Policy, hearings before the Subcommittee on International Organizations and Movements of the Committee on Foreign Affairs, House of Representatives, 93rd Congress, First Session (Washington, DC: 1973) 507. 
and military assistance to foreign governments with respect for human rights. In addition, the 1974 Foreign Assistance Act amended Section 502B according to which the president should withhold security assistance from governments that were flagrantly violating human rights, subject to the exception of 'extraordinary circumstances' imperative for the protection of vital national interests. ${ }^{380}$

At the same time, one of the principal objectives of ex-President Jimmy Carter was the promotion and protection of human rights for the establishment of a new world order. It was the administration's belief that human rights considerations should form a substantial part of US foreign policy regarding bilateral relations with other states and policy issues, concerning such issues as arms sales and foreign aid. ${ }^{381}$ Human rights considerations became a central issue of concern for that administration whose commitment to human rights was 'absolute'. 382 According to that view, the United States possessed both a 'legal right' and responsibility under the UN Charter and international law to react to human rights violations, ${ }^{383}$ although American foreign policy was not always disassociated from national interests. ${ }^{384}$ It can be deduced from this that a certain opinio juris existed for the implementation of measures for protecting essential community interests. It needs, however, to be pointed out that many of the measures associating benefits and other assistance with the protection of human rights were adopted at a national level at the discretion of the US government through legislative acts and executive orders and not because or in violation of specific international legal obligations. Having said that, it will be established that the United States has often resorted to solidarity measures, enhancing both state practice and opinio juris in support of such a right under customary international law.

Canada, for its part, stressed that 'as a matter of legal and commercial policy' economic sanctions should be imposed only under a Chapter VII Security Council resolution or by states acting collectively in reaction to fundamental violations of international law and peace and security, in pursuance of a UN resolution,

380 See Racial Discrimination, US Representative Albert Sherer, Digest of US Practice in International Law (1976) 163-6, and Economic and Military Assistance: Legislative Restrictions, Digest of US Practice in International Law (1976) 170. Also see Arms Export Act, International Security Assistance and Arms Export Control Act of 1976, 22 USC 2151, Public Law 94-329, 94th Congress, H.R. 13680, 30 June 1976, 90 Stat. 729 and International Financial Institutions Act, International Financial Institutions Act, P.L. 95-118 in Economic and Military Assistance: Legislative Restrictions, Digest of United States Practice (1977) 221, 222-3. Yet, when Turkey invaded Cyprus in 1974 the United States, in violation of both its domestic and international legal obligations continued providing the former with both military and economic assistance. For a thorough legal analysis of the administration's refusal to suspend assistance to Turkey see E.T. Rossides, 'Cyprus and the Rule of Law' 17 Syracuse fournal of International Law and Commerce (1991) No. 1.

381 D. Kommers and G. Loescher (eds) Human Rights and American Foreign Policy (University of Notre Dame Press: 1979) 212.

382 President Carter's Inaugural Address, 20 January 1977, New York Times, 21 January 1977.

383 Ibid.

384 See statement of Foreign Secretary Cyrus Vance in J. Salzberg and D. Young, 'The Parliamentary Role in Implementing International Human Rights: A U.S. Example' 12 TILf (1977) 251, 269-74. 
including a resolution by the General Assembly. According to the Canadian government, while international law gave states discretion to impose economic measures in response to 'objectionable' conduct of another state, economic sanctions constituted derogation from the general principle concerning friendly relations among states and, therefore, any decision for their application was not to be taken 'lightly'. ${ }^{385}$ While it may be argued that the Canadian government insisted on the express authorization of such action in accordance with the rules of international law, it can be inferred that Canada would resort to coercive measures in violation of international law even in the light of General Assembly resolutions. This is significant since the General Assembly is not empowered under the UN Charter to take legally binding decisions. Accordingly, the determination of Canada to follow the recommendations of the General Assembly even, as indicated already, in violation of the principle concerning the friendly relations among states, may be reflective of support of solidarity measures, decided, however, within a collective context.

In another memorandum issued in 1985 by Canada, it was noted that retaliatory action in violation of international law was justified if it came in response to another international illegal act. Stressing again that sanctions violate customary rules of international law as reflected in the 1970 United Nations Declaration on Principles of International Law Concerning Friendly Relations and Cooperation among States, it was noted that: ' $[1] \mathrm{t}$ is the purpose behind certain economic measures that serves as the essential criterion to separate legally permissible conduct from illicit conduct.' ${ }^{386}$ While no explicit reference is made to whether states not directly injured may be entitled to implement such economic measures, the reference to the purpose of the measures may provide evidence that the statement refers to the right of third states to resort to solidarity measures. This is because in such circumstances the purpose of such measures, namely the protection of essential community interests, would justify the unlawfulness of such action. This interpretation is also supported by the fact that the Canadian statements made in 1983 clearly referred to the right of third states to adopt coercive measures, as an injured state would not need authorization from the Security Council or the General Assembly to do so.

The Netherlands, by way of contrast, following a mandatory decision of the Security Council in 1968 to impose sanctions against Southern Rhodesia, introduced the so-called Sanctions Bill to fill in the legal loopholes in the national legislation for the implementation of the Security Council mandate. As noted in the Explanatory Memorandum, the Bill was intended to be used as a tool towards the national implementation of international decisions, recommendations or agreements concerning the maintenance of international peace and security or the furtherance of the interests of the international legal order. When asked to define the phrase 'international accords' the Dutch government stressed that it did

385 Economic Sanctions, memorandum issued on 15 April 1982 by the Canadian Legal Bureau, CYIL (1983) 311.

386 Economic Sanctions, memorandum dated 3 June 1985, CYIL (1986) 387-8. 
not want to exclude from the scope of the Bill accords, which, although they did not constitute a decision of a certain international organization, were taken within the framework of an international organization. Under the explanation given, 'decisions' taken by the EEG Council for common action or under European political cooperation could also fall into this category. ${ }^{387}$ The Bill allowed the application of measures for, inter alia, gross violation of human rights and breaches of the international legal order that could threaten international peace and security. ${ }^{388}$ While no reference is specifically made in relation to the exercise of countermeasures by states other than the injured, it may be deduced that the Dutch government was committed to implement such international decisions taken, as in the case of Canada, in a collective context, even if this meant violation of specific international obligations towards the targeted state.

\section{European Community action}

Human rights considerations and the observance of fundamental principles of international law could not be discarded from the ambit of the EU, the institutions of which on some occasions did not hesitate to resort to countermeasures in response to serious infringements of international law, even despite the fact that none of the EU member states had been individually affected. One crucial question that arises in this respect is on what legal grounds the EU, which in the 1980s was essentially structured on the common economic interests of its member states rather than on common foreign policy strategic goals, was allowed to take countermeasures in disregard of its own obligations under international law. Moreover, such action has been questioned as falling outside the exclusive competences of the Community institutions and as being targeted against states not members of the EU. This problem, which raises questions especially in the context of international and European law, ${ }^{389}$ was particularly apparent in the action taken by the European Community against Argentina in the 1980s but also against Yugoslavia in the 1990s discussed below.

In this context, the 1987 Single European Act and the 1992 Treaty on European Union (TEU) have dramatically reoriented Community internal policies. They have also had a great impact on the external policies of the EU, especially on issues of defence, security and human rights, on which the exercise of countermeasures by the European institutions can arguably now rely. ${ }^{390}$

The incorporation of Articles 6 and 7 in the Treaty on European Union and the particular weight the EU attaches to human rights considerations in its external relations are all indicative of the increasingly growing interdependence between the EU and fundamental interests owed to all states. This is evidenced by

387 "The meaning of "international accords" in draft Article 2 of the 1976 Sanctions Bill", 9 NYIL (1978) 235-7.

388 Sanctions Bill, Bijl. Hand. II 1975/76-14006 No. 3, 8.

389 C. Chinkin, 'The Legality of the Imposition of Sanctions by the European Union in International Law' in M. Evans (ed.), Aspects of Statehood and Institutionalism in Contemporary Europe (Dartmouth Publishing Company Ltd: 1996) 183, 185.

390 Ibid, 186. 
the numerous 'human rights clauses', the clear interconnection of human rights with unilaterally granted benefits and trade preferences, the emphasis given by the European Court of Justice (ECJ) to human rights as an integral part of the general principles of law and the political conditions including respect for human rights as preconditions for accession to the organization.

The legal framework applicable in the case of implementation of measures decided at Community level in the form of embargoes, withdrawal of unilaterally afforded benefits or suspension of treaties concluded by the Communities, often varies according to whether there exists a Security Council resolution authorizing or even imposing such measures. In the former case, the decision of the Security Council will as, a matter of general rule, prevail in accordance with Article 103 of the UN Charter that provides that the obligations deriving therefrom should prevail over all other international treaty obligations. Nevertheless, the recent ruling of the ECJ in the Kadi and Al Barakaat cases elaborated later may indicate that EU member states may be called to disregard such obligations for the purpose of upholding fundamental interests safeguarded under the European treaties such as respect for fundamental human rights.

Until 1970 the implementation of UN measures was largely perceived as falling within the domain of the EU member states and thus no regulations were adopted in order to give them legal effect at Community level. This, however, changed in 1970 with the establishment of European political cooperation, institutionalized in 1987 with the Single European Act. European political cooperation intended to enhance the cohesion and unity of the member states regarding issues in the interests of the Community such as external policies and to establish, subject to the consensus of all member states, a 'common European identity in their foreign affairs'. ${ }^{391}$ According to this system, it was through Council regulations, adopted after the political consultation of the member states in the context of European political cooperation that UN sanctions were given effect. With the adoption of the Treaty of the European Union such measures can now take effect under the Common Foreign and Security Policy pillar and the European Community. This practice is now reflected in Article 301 (formerly Article 228a). ${ }^{392}$ This Article provides for measures adopted by the Council whenever: ' $\Pi] \mathrm{t}$ is provided, in a common position or in a joint action adopted by the Treaty on European Union relating to the common foreign and security policy, for an action by the Community to interrupt or to reduce, in part or completely, economic relations with one or more third countries. '393 Furthermore, the Amsterdam Treaty, while not amending this provision, introduced a new article, Article 300(2), under the European Community treaty. According to this provision, the application of an agreement may be suspended with a decision taken by the Council (by qualified majority or unanimity according to the matter under consideration) without the consultation

391 Ibid, 186-7.

392 EU consolidated versions of the Treaty on EU and of the Treaty establishing the EC, OJ C 321 E/1, 29 December 2006.

393 Ibid. 
of the European Parliament and without referring to a decision taken under the Common Foreign and Security Policy. ${ }^{394}$

Difficulty is raised with respect to economic measures imposed in violation of existing treaties or other international commitments and in the absence of Security Council authorization. As noted, such measures do not necessarily aim at restoring international peace and security, as do UN measures, but rather they 'constitute a deliberate reaction against international law violations by other States'. ${ }^{395}$ They can only be justified if they are provided under a treaty or a rule of customary international law, such as countermeasures. Nevertheless, as will be shown later, the European Community was reluctant to take coercive action against Uganda in response to the gross violations of human rights taking place within its territory in the late 1970s. The fact that the European Community continued its payments to the brutal regime of Idi Amin finds explanation as noted 'in the limited possibilities for reaction which general international law offered'. ${ }^{396}$ This is due to the fact that under the law of treaties a specific agreement can be suspended or terminated on the ground of human rights considerations only if the treaty so provides or if the human rights violations go against the very object and purpose of the treaty. ${ }^{397}$ Nevertheless, violations of specific treaty commitments can be justified as countermeasures under the law on state responsibility, as the analysis in this chapter establishes. Decisions of this nature that infringe specific treaty provisions must, therefore, be distinguished from acts of retorsion. This is the case of withdrawal of unilaterally awarded benefits and many such examples can be found at Community level. Since such benefits constitute the exercise of sovereign rights, their withdrawal does not constitute an internationally wrongful act. ${ }^{398}$

The issue differs with respect to measures taken in violation of specific conventional or other international obligations. The controversial nature of this problem has driven the Community to incorporate human rights clauses when negotiating agreements with third states. This admittedly affords the Community institutions flexibility granting them the right to terminate or suspend a treaty towards a state that does not conform to such principles, without having to rely on general international law for the non-performance of an agreement. ${ }^{399}$ As noted in this regard, a human rights clause 'does not seek to establish new standards in the international protection of human rights. It merely reaffirms existing commitments which, as

394 Treaty of Amsterdam amending the Treaty on European Union, the Treaties establishing the European Communities and related acts, Official fournal C 340, 10 November 1997. Also see E. Paasivirta and A. Rosas, 'Sanctions, Countermeasures and Related Actions in the External Relations of the EU: A Search for Legal Frameworks' in E. Cannizzaro (ed.), The European Union as an Actor in International Relations (Kluwer: 2002) 207, 209.

395 Ibid, 210.

396 E. Riedel and M. Will, 'Human Rights Clauses in External Agreements of the EC' in P. Alston (ed.), The EU and Human Rights (OUP: 1999) 723.

397 Ibid, 724.

398 Paasivirta and Rosas, op. cit., 212.

399 B. Brandtner and A. Rosas, 'Human Rights and the External Relations of the European Community: An Analysis of Doctrine and Practice' 9 EfIL (1998) 468, 474. 
general international law, already bind all states as well as the EC in its capacity as a subject of general international law', although it was acknowledged that such a clause derived its legitimacy from an international agreement. ${ }^{400}$ Still, quite importantly, Brandtner and Rosas seem to suggest that a reaction by other states against a wrongdoing state would be justified as a duty that derives from human rights norms.

From the examination of the state practice that follows, it will be established that suspension or termination of a treaty has often been justified not on the provisions of the treaty itself but rather on rules of customary international law, such as fundamental change of circumstances or impossibility of performance as a result of a state emergency or civil war. ${ }^{401}$ It is therefore suggested that Community institutions may also rely on a customary rule allowing countermeasures taken in the name of collective interests. Riedel and Will argue that since the European Community is not a party to human rights treaties, it would 'possibly' be entitled to take reprisals (countermeasures) only for 'violations of the minimum standards of human rights protection recognized in customary international law as valid erga omnes. ${ }^{402}$ Undoubtedly, the main challenge here will be to prove that there indeed exists a right to countermeasures by a state other than the injured under customary international law and this is what the following sections aim to establish.

\section{Responses to violations of collective interests in state practice}

The assessment of state practice requires the division of the various examples into two categories of case study. The first category includes examples from state practice that, although they do not involve the infringement of specific international obligations arising either from treaty or custom, are nonetheless illustrative of the determination of states to exert economic and other pressure against states in response to serious violations of fundamental community and collective interests. In some of these cases, states had expressed their intention and willingness to resort to countermeasures when no direct injury was involved and even if no such action were actually taken in the end. In addition, in some of the examples considered in this category it was not possible to establish beyond any doubt the lawfulness of the action under international law. Quite significantly, the decision of states to resort to retorsive measures should not be construed as an opinio juris against solidarity measures. On the contrary, it will be argued that in many of the incidents that will be considered in this section states had exhausted all possible means at their disposal. This was often achieved through lawful measures but also measures in violation of specific international rules, in response to serious violations of interests owed either to the international community as a whole or to a group of states.

400 Ibid, 475.

401 Riedel, Will, op. cit., 724-5.

402 Ibid, 726. 
The second category considers state practice that, in the author's opinion, provides evidence concerning the enforcement of interests owed to the international community as a whole or to a group of states through the implementation of countermeasures by states other than the injured. As the analysis will demonstrate, the implementation of countermeasures by such states is well developed by state practice and opinio juris, satisfying the essential legal requirements for the claim that a customary rule of international law on the right to solidarity measures has now come into existence. At the same time, this category also engages with state action that although justified as third-state countermeasures, their categorization as such may be disputed on other grounds. In this regard, such action has given rise to questions not in relation to whether it infringes a specific norm of international law, but rather as not fulfilling one of the other conditions of solidarity measures, namely the fact that they must be a response to the violation of community and collective interests. Despite this, it will be argued that such incidents reflect the existence of a legal belief on the part of states that their action was aimed at the protection of community interests and that they enhance the argument that under customary international law solidarity measures are permissible.

The results of the current research in either category are cited by way of chronological order rather than significance.

\subsection{State action not amounting to countermeasures}

\subsubsection{Soviet action against Israel (1956)}

In November 1956 the Soviet Union refused to grant export licences to the Soviet Petroleum Export Corporation for the shipment of petroleum to Israeli importers, in spite of the existence of a contract concluded between the Corporation and the Israeli companies in November 1955, later extended in May 1956, and another contract concluded by the same parties in July 1956. The decision of the Soviet Union came as a response to the Israeli invasion in the Sinai Peninsula in October 1956 and to Israel's aggression against Egypt in the Suez Canal crisis. ${ }^{403}$ Israel brought the case before the Soviet Foreign Trade Arbitration Commission, set up under Soviet law to adjudicate disputes of a contractual and other civil law nature arising in relations between subjects of various states during the conduct of foreign trade. The Corporation justified its decision not to honour its contractual commitments by invoking grounds of force majeure. ${ }^{404}$

According to international law, a state-owned enterprise may invoke force majeure whenever the performance of its treaty commitments towards a private party is not possible due to a government order or decision of the controlling state, for

403 See R. Lillich, Economic Coercion and the New International Economic Order (Mitchie Company: 1976) 24; M. Domke, 'The Israeli-Soviet Oil Arbitration', AfIL 53 (October 1959) No. 4, 787.

404 USSR's Prohibition of Shipment of Petroleum due to Israel's Aggression against Egypt, Digest of US Practice in International Law (1970) 861. 
reasons not foreseen at the time of conclusion of the agreement. In this event, the state-owned company is treated by law as a private enterprise and thus discharged of its obligations under the treaty, if certain conditions are met. ${ }^{405}$

Due to lack of further evidence, however, it was not possible to determine whether the decision of the Soviet Union was in violation of specific international legal commitments towards Israel. Therefore, it cannot be conclusively determined whether the Soviet Union's refusal to provide the export licences constituted countermeasures under international law. Nevertheless, the incident shows the reaction of a third state, here the Soviet Union, not directly affected by the aggressive policies of another, Israel, to inflict a certain economic burden for violating a fundamental principle of international law owed to all states, namely the prohibition of the use of armed force. The position would substantially change had the Soviet Union possessed a specific obligation under customary or conventional international law to export petroleum to Israel or to conduct trade and commercial activities with it.

In addition to the Soviet Union's decision not to issue the petroleum export licences, the government proceeded to cut off diplomatic relations with Israel by recalling its ambassador, a measure that does not infringe specific international obligations. ${ }^{406}$

\subsubsection{The Bonn Declaration (1978) and the hijacking incident (1981)}

In a significant move against acts of terrorism through aircraft hijacking, the heads of state and government of the seven most industrialized countries of the world issued in 1978 the so-called Bonn Declaration for the purpose of taking action against states involved in such conduct. ${ }^{407}$ The Declaration called for immediate action against a state that refused to extradite or prosecute individuals involved in the hijacking of aircraft or to return such aircraft by halting 'all incoming flights from that country or from any country by the airlines of the country concerned'.

The legality of the measures authorized under the Declaration were, however, put into question as imposing obligations on states that had not given their consent to the Declaration. According to this view, the Declaration could not give rise to legal obligations regarding the return of the hijacked aircraft or the prosecution or extradition of individuals. Such obligations could only emerge from a customary rule of international law having an erga omnes character, or from the Tokyo

405 C. Scott Maravilla, 'The Ability of a State-Owned Enterprise to Declare Force Majeure Based Upon Actions of the State' Journal of International \& Comparative Law at Chicago-Kent (2002) Volume 2,82 .

406 Suez Canal Crisis, Letter by Soviet Prime Minister Nikolai Bulganin to Israeli Prime Minister David Ben-Gurion, 5 November 1956.

407 At the time these states were: Canada, France, Italy, Japan, the UK, the US and West Germany. 
Convention on Offences and Certain other Acts Committed on Board Aircraft ${ }^{408}$ and the Hague Convention for the Suppression of Unlawful Seizure of Aircraft, provided, of course, that the targeted state was party to these instruments. ${ }^{409}$ Therefore, a state not party to any of these international agreements could not be held internationally responsible, even more so because the Declaration did not constitute part of the agreements establishing special enforcement mechanisms in the event of their violation. Moreover, Busuttil argued that since the two conventions had not been universally endorsed, it was difficult to say that they reflected customary norms of international law. ${ }^{410}$ Accordingly, the mere fact of refusing to comply with any of the terms of the Declaration did not establish the responsibility of the state. ${ }^{411}$ Neither did the participating states intend to strengthen the Declaration with a legally binding effect, as a result of which it was doubtful if it created any legal obligations even as between them. ${ }^{412}$

Counter to this view, it can be argued that the Bonn Declaration provides evidence of state support of a right to suspend obligations arising from aviation agreements in response to violations of obligations erga omnes. From the wording of the Declaration, it becomes apparent that the participating states were determined to take action against any state that refused to extradite or prosecute individuals involved in hijacking. This was the case irrespective of the nationality of the aircraft involved in the hijacking and the nationality of the individuals affected therefrom or the territory on which such hijacking took place and irrespective of whether that state had accepted the Declaration. ${ }^{413}$ This reflects the belief of the participating states that the commission of such acts violated obligations owed to all states.

Chamberlain suggests, in this regard, that although it was difficult to conclude that the obligations entailed in the Hague and Montreal Conventions regarding extradition and prosecution were part of customary international law, ${ }^{414}$ 'certain principles of customary international law can be formulated on the basis of these Conventions as well as of other international instruments', such as UN and International Civil Aviation Organization (ICAO) resolutions. ${ }^{415}$ Therefore, according to him, all states possessed a duty under customary international law not to allow their territories to be used as safe havens for terrorists and individuals involved in acts of hijacking, provided that their refusal to extradite or prosecute

408 Tokyo Convention on Offences and Certain Other Acts Committed on Board Aircraft, 14 September 1963, 704 UNTS 219; J. Busuttil, 'The Bonn Declaration on International Terrorism: A Non-Binding International Agreement on Aircraft Hijacking' 31 ICLQ(1982) 474, 476.

409 Hague Convention for the Suppression of Unlawful Seizure of Aircraft, 16 December 1970, 10 $\operatorname{ILM}(1971)$ 133; Busuttil, ibid, 477.

410 Busuttil, ibid, 480. Also K. Chamberlain, 'Collective Suspension of Air Services with States which Harbour Hijackers' 32 ICLQ(1983) 616, 620.

411 Busuttil, ibid, 481.

412 Ibid, 487.

413 Bonn Declaration, 1978 (II) Pub. Papers 1308, reprinted in (1978) 17 ILM 1285.

414 Convention for the Suppression of Unlawful Acts against the Safety of Civil Aviation, signed in Montreal, 23 September 1971, 974 UNTS 177; Chamberlain, op. cit., 617.

415 Chamberlain, ibid, 629. 
was not the result of technical difficulties but rather of intentional systematic failure to do so. ${ }^{416}$

However, the fact that all states have a certain duty not to allow their territory to be used for such purposes does not necessarily imply that in case of its violation all states have an interest in reacting. Chamberlain argues, in this regard, that if the wrongdoing state is a party to any of the conventions just mentioned, then other states that are parties would be entitled to take retaliatory measures against it under general international law, as that state would be in breach of an international obligation owed to all the parties to the Conventions. He finds it difficult to support the legitimacy of retaliatory measures against a state that is not party to these Conventions, however, unless the other states were directly affected by the violation. ${ }^{417}$

The Declaration reveals that the states concerned had a belief that acts of aircraft hijacking infringed obligations owed to all states, entitling them to the response proclaimed in the Declaration. It can therefore be concluded from this that the intention of states to cease the performance of aviation agreements in such circumstances offers another example of state practice and opinio juris in support of a right to third-state countermeasures. ${ }^{418}$ It is well established that declarations can be used as precedents as they may reflect the existence of legal norms and principles or they may assist in creating new norms of customary international law. ${ }^{419}$

Legal considerations regarding the Bonn Declaration have arisen from the decision of the seven participating states to implement its provisions against Afghanistan. In March 1981, a Pakistani aircraft was hijacked and taken to Afghanistan. The participating states condemned the Afghan government's failure to cease giving refuge to the hijackers as in flagrant violation of the obligations arising from the Hague Convention, to which Afghanistan was a party. They also considered a suspension of all flights to and from Afghanistan as provided under the Bonn Declaration unless Afghanistan complied with its obligations. ${ }^{420}$ Indeed, this position was reaffirmed at the Ottawa meeting of the G7 where it was proposed suspending all flights from and to Afghanistan, were Afghanistan to fail to comply with its obligations under the 1970 Hague Convention. ${ }^{421}$ During the meeting it was emphasized that aircraft hijacking and hostage taking were flagrant violations of fundamental human rights and international law, including the 1970 Hague Convention, and that they also threatened aviation safety. It is notable that the decision was aimed at the protection of collective interests, namely air safety established under the relevant Conventions.

416 Ibid, 630.

417 Ibid.

418 Tams, op. cit., 226.

419 D.J. Harris, Cases and Materials on International Law, 6th edn (Sweet \& Maxwell: 2004) 56.

42081 Department of State Bulletin, No. 2053, August 1981, 16.

421 Ottawa Statement on International Terrorism, 21 July 1981, available at http://www. g7.utoronto.ca/summit/1981 ottawa/terrorism.html; Keesing's (1981) 31231. 
In December 1981, and in the light of no further progress, France, the United Kingdom and West Germany, the only countries having air agreements with the country, decided to denounce their air services agreements with Afghanistan. This decision was reached in response to Afghanistan's failure to prosecute or extradite those responsible for the hijacking of the Pakistani aircraft. The decision was to have effect from December 1982, after giving 1 year's notice, in accordance with the terms of the aviation agreements. ${ }^{422}$ Chamberlain, in particular, criticizes the politically cautious position of France, the United Kingdom and West Germany not to denounce the respective agreements with Afghanistan with immediate effect. ${ }^{423}$

The adoption of the Bonn Declaration and the determination of states to implement the declaration through the suspension and denunciation of aviation agreements in response to a serious violation of international aviation safety enhance the argument concerning the recognition of third-state countermeasures for the protection of collective interests under customary international law. Declarations of this kind provide evidence of state practice and also of the legal belief of states on the rules of international law and therefore can be used as evidence for the existence of a customary rule. The fact that in the case of Afghanistan the denunciation of the relevant aviation agreements was not in violation of international law or of the agreements themselves should not undermine the legal significance of this incident as adding to the state practice and on the opinio juris on the matter.

\subsubsection{US action against Iraq (1980)}

This incident arose in early 1980 as a result of an attack on an Israeli kibbutz by the Arab Liberation Front, which Iraq allegedly supported. The United States, in response to this attack, decided to suspend an agreed sale to Iraq of $\$ 208$ million worth of turbine engines, thus subjecting it to coercive measures on the ground of terrorist involvement. These trade restraints lasted until 1982 and, in 1984, the United States imposed a further embargo on chemical exports to Iraq that could be used for the development of chemical weapons. ${ }^{424}$

The US decision, although not widely referred to in the literature, may indeed offer another example of third-state countermeasures in response to serious violations of international law. Nevertheless, it is not entirely clear whether the agreed

422 Keesing's (1982) 31545; Chamberlain, op. cit., 628. Also see Frowein, (1994) op. cit., 418; Keesing's (1978) 29293; Keesing's (1981) 31071.

423 Chamberlain, ibid, 632.

424 In Hufbauer, Schott and Elliott, Sanctions Reconsidered: Supplemental Case Histories, 2nd edn (Institute for International Economics, Washington, DC: 1990) 526 and in J. Petman, 'Resort to Economic Sanctions by Not Directly Affected States' in Picchio-Forlati and Sicilianos, op. cit., 366. Also see 'Terrorism: Laws Cited Imposing Sanctions on Nations Supporting Terrorism', Fact Sheet for the Honourable Frank R. Lautenberg, United States Senate, United States General Accounting Office, April 1987, available at http://archive.gao.gov/d28t5/133073.pdf. 
sale was the object of a private contract or whether it constituted an agreement between the United States and Iraq, in which case the suspension would be in breach of international law and, therefore, would fall within the definition of countermeasures. Furthermore, in order for the action taken against Iraq to qualify as solidarity measures it would have to be shown that these had been taken as a response to the serious violation of an obligation owed to all states, including the United States. As the attack did not injure the United States directly, the latter would need to establish that Iraq, by supporting terrorism, was in violation of specific norms that create obligations erga omnes. It could be argued, in this respect, that international terrorism threatens international peace and security and violates fundamental principles, such as human rights and, as such, involvement in terrorist activities entitles all states to invoke the responsibility of the wrongdoing state. Still, the United States would have to establish that Iraq's conduct was a serious violation of fundamental interests of international law. ${ }^{425}$

While the United States could establish a legal interest to take coercive action in this incident, uncertainty remains as to whether the suspension of the turbine engine sales and the chemical ban were in breach of treaty obligations towards Iraq. Accordingly, due to the doubts that exist relating to whether certain state obligations had been infringed by the United States in the particular case, since Iraq was not a party to GATT, it is regarded as necessary to include this example in that category of cases not clearly illustrating state practice in support of thirdstate countermeasures. ${ }^{426}$ In any event, the significance of this incident should not be undermined as it reveals the determination of a state not directly injured by a given wrongful act to take such measures necessary for the protection of collective interests, namely protection from international terrorism.

\subsubsection{Denmark against Turkey (2000)}

The interstate application brought before the European Court of Human Rights by Denmark against Turkey in 2000 may provide some useful conclusions in relation to the right of states to exercise non-forcible coercion, not necessarily of an economic character, in response to serious violations of legal interests owed to all states. Although the case was later settled with the agreement of the two parties, and despite the fact that the violations occurred against a Danish national, thus giving Denmark the status of an injured state, it is worth looking at the specific terms of the settlement.

The complaint of the Danish government concerned allegations that a Danish national detained in Turkey was subjected to ill treatment in violation of Article 3 of the European Convention on Human Rights. In the settlement that followed, a declaration made by the Turkish government was incorporated as an integral part of the settlement. In the declaration, Turkey acknowledged that there

425 Dawidowicz, op. cit., 347-8.

426 For GATT membership, see http://www.wto.org/english/theWTO_e/gattmem_e.htm. 
were occasional and individual cases of torture and ill treatment in the country while announcing a series of legislative and other measures on its part to decrease such violations. Turkey expressed its commitment to continue improvement measures in the field of human rights, and especially against torture, and to cooperate with international organs and mechanisms in order to deal with these problems. Moreover, Turkey undertook to participate in a number of projects concerning the training of police officers especially in relation to investigation and human rights issues while the two countries decided to establish a continuous political dialogue between their governments that would also involve human rights considerations. ${ }^{427}$

The example is stimulating because Denmark did not confine itself to remedies regarding the particular dispute but went even further by requiring, as part of the settlement, certain reassurances that general torture practices in Turkey would stop. Even more interesting, Denmark undertook financially to support a bilateral project, the purpose of which would be the training of Turkish police officers in order to achieve further knowledge and practical skills in the field of human rights'. ${ }^{428}$

While this incident does not fall within the category of third-state countermeasures, the legal conclusions arising therefrom cannot be overlooked. Despite the fact that the settlement reached by the two countries was not imposed in violation of international law, but, rather, in conformity with the provisions of the European Convention for the protection of human rights and for the settlement of disputes, Denmark's demand went beyond just seeking a remedy for the direct injury inflicted on it. Instead, acting as an interested party for the safeguarding of rights owed to a group of states (erga omnes partes), Denmark pursued, and obtained, a legal commitment by Turkey that it would respect its obligations concerning the prohibition of torture, owed to all states being parties to the Council of Europe and to the international community as a whole.

\subsection{Countermeasures by states other than the injured in state practice}

The ILC, in its 2001 Final Articles restricted its reference to state practice supporting a right to solidarity measures to a limited number of examples than those that, in fact, exist. This led it to the conclusion that there is no sufficient state practice and opinio juris to establish the existence of a customary rule on the matter. This may find explanation in the ILC's intention to finally reach a compromise between states and bring to a conclusion its work on state responsibility, a work that lasted more than four decades. Most importantly, the controversial nature of third state countermeasures and the objections of some states to incorporate such right in the Final Articles played a determinative role in the ILC's decision.

427 Denmarkv Turkey, Friendly Settlement of 5 April 2000, Application No. 34382/97.

428 Ibid. 
The purpose of the following analysis is to provide evidence that countermeasures in the collective interest have frequently been used by states and that they are well established in international law. ${ }^{429}$ The consideration includes clear examples of third-state countermeasures, but also makes reference to specific examples that, although referred to by the ILC or the literature as third-state countermeasures, may give rise to questions as to whether there was a breach of a collective interest in the first place. Moreover, in some of these examples states resorting to coercive action did not clarify the legal grounds on which they claimed an entitlement to resort to such action. In other words, they did not justify the reasons that the initial wrongdoing entitled them to respond with countermeasures, such as in the case of the coercive action against Poland and the Soviet Union in the early 1980s. The decision to include these examples in the category of state practice in support of solidarity measures relied on the fact that these examples reflect the legal belief of states that they were responding to an infringement that affected community interests and, therefore, their legal belief that countermeasures of this nature are recognized under international law.

Finally, our analysis includes examples of state practice that, although justified on other legal grounds such as fundamental change of circumstances, should have been justified as third-state countermeasures.

The wealth of examples in state practice examined in this section does not justify the conclusions of the ILC on the right to solidarity measures. In addition to the fact that the ILC considered only a very limited number of examples in its commentary on Article 54, these were limited to a very narrow period of time and, in particular, they concerned incidents that took place in the last three decades. Although this analysis will not extensively consider early practices going back to the 19th century or even before that, it is regarded as essential to refer to one such example concerning countermeasures in response to slavery. The reference to this early example is necessary not only for the invaluable conclusions that can be derived therefrom, but also to illustrate that much more evidence in support of third-state countermeasures exists than the ILC acknowledged.

This will be followed by consideration of another example arising from the period during World War II, while the plethora of the examples examined here relate to state practice that occurred after the end of World War II.

\subsubsection{Slavery and the United States-Great Britain Mixed Commission (1853)}

The first example to be considered concerns four significant cases brought before the United States-Great Britain Commission, established in the light of a convention concluded on 8 February 1853 to adjudicate claims by a mixed commission, in which the United States demanded damages and compensation 
against Great Britain. In particular, the United States complained against the decision of British authorities to free a number of slaves who were on board American vessels that belonged to American nationals.

In four separate developments in the early 19th century, the vessels Enterprise, Hermosa, Creole and Lawrence with a number of slaves on board were, due to bad weather conditions or for other reasons of necessity, induced to enter British jurisdiction in the West Indies. In all four cases, the British authorities freed the slaves despite the fact that the vessels carried the American flag and belonged to American nationals.

The Enterprise was forced to enter British jurisdiction in 1835. The British government rejected American claims for compensation on the ground that slavery was prohibited in its territories and it was neither in its 'interests' nor acceptable under its 'moral sentiments'. ${ }^{430}$ It was further the British assertion that slavery was in violation of the law of nature, recognized by many states. ${ }^{431}$ The United States, for its part, argued among others that no state could be forced by another state to change its laws and that such a matter fell within the jurisdiction of each state. ${ }^{432}$ Rejecting the view that slavery was prohibited under the law of nations, the United States argued that: ' $[\mathrm{N}]$ o one nation ... has a right to ... procure an eminent good by means that are unlawful, or to press forward to a great principle by breaking through other great principles that stand in the way.' ${ }^{33}$ The British representative, responding to US claims, pointed out that to accept the rights of slave owners would be a denial of both the laws existing in English territories at the time and the laws of nature. If that were the case, then 'it would be to make international law a partial tyrant rather than an equal arbitrator between nations'. ${ }^{434}$ It was, moreover, stressed that the domestic laws applicable within British jurisdiction concerning the prohibition of slavery were in compliance, rather than in violation of, international law. ${ }^{435}$

The Umpire was called to consider whether slavery had been abolished at the time the Enterprise sought refuge in Bermudas. If a norm prohibiting slavery existed, then the conduct of the British authorities to free the slaves onboard Enterprise would not give rise to the responsibility of Great Britain. If, however, no such norm existed, then Great Britain would incur responsibility towards the United States for infringing its obligation to respect and protect the property of

430 J.B. Moore, History and Digest of the International Arbitrations to which the United States has been a Party', Vol. 4 (Washington, DC, US Government Printing Office: 1898) 4349. It is noteworthy that in two similar cases, and in particular in Comet and Encomium, which sought refuge in British jurisdiction in 1830 and 1834 respectively, the British government accepted the claims for compensation, since at the time slavery was still permitted under British laws.

431 Ibid, 4359-60, 4366.

432 Ibid, 4360-61.

433 Sir William Scott (Lord Stowell), Le Louis case, 2 Dod. 238 cited in ibid, 4360-61.

434 Ibid, 4369.

435 Ibid, 4370. 
foreign nationals and to provide refuge in British ports to foreign vessels caught in distress.

While acknowledging that slavery violated principles of humanity and justice, the Umpire held that at the time of the specific incident, slavery was still common in many countries, including British dominions where it had not been entirely abolished and, therefore, it was not in violation of the laws of nations. ${ }^{436}$ The Umpire finally concluded that, in freeing the slaves of a vessel caught in distress, Great Britain had acted in violation of international law.

Similar findings were made in the case of Hormosa, concerning another American vessel that sought refuge in British jurisdiction in 1840, and in the case of Creole in $1841 .{ }^{437}$

Significantly, the Umpire reached a different conclusion in the Lawrence case. This case concerned an American vessel that in 1848 sprang a leak and therefore sought refuge in Sierra Leone, at the time under British control. Amid seizure of the cargo onboard Lawrence by British authorities, its owners claimed compensation. However, the Umpire held that the vessel was equipped for and engaged in the slave trade and that therefore its owners could not seek compensation or protection of their interests. According to the Umpire, at the specific time that this incident occurred, the slave trade was prohibited by all civilized states as being in violation of the law of nations, ${ }^{438}$ distinguishing in this manner this case from the previous rulings.

As noted later by Mr Ago, the ruling on Enterprise would have today been different. In this regard:

$[\mathrm{T}]$ here is no doubt that between the date of the Umpire's decision and the present day, a profound change has occurred in the rules of international law concerning the question to which this case related. We should be forced to take a different decision from Umpire Bates by the fact that slavery and the slave trade are no longer merely - as Bates noted at the time - practices prohibited by the law of "civilised nations": they have become practices banned by a humanitarian rule of international law which is considered by the international community as a whole, as fundamental and, we believe, "peremptory". States have reciprocally undertaken to combat such practices by all the means at their disposal. This is therefore a rule which, in our opinion, would prevent us, even as far as the past is concerned, from finding a source of international responsibility in conduct which has in the meantime become not only "lawful"... but also "due": the refusal to grant protection to individuals engaging in a practice which is unanimously condemned, and action designed to prevent this practice from attaining its inhuman goals. ${ }^{439}$

436 Ibid, 4373.

437 Ibid, 4373 et seq. In the case of Creole, crew members were forced to navigate to British jurisdiction after a rebellion by the slaves.

438 Ibid, 4372 et seq.

439 Fifth Report on State Responsibility (Ago) op. cit., 17-8 (49). 
This case makes a significant legal contribution to the argument in support of countermeasures by states other than the injured for the purpose of upholding fundamental interests of the international community. In this instance, the government of Great Britain had suffered no direct injury or direct violation of its rights in seeking to seize the vessel and its cargo on the ground that it engaged in the slave trade. In this way, Great Britain was acting in the protection of community interests even if its action were in violation of the rights of the United States for the protection of property belonging to its nationals. As is evident from the discussions in the Enterprise case, the action was found to be a violation of American rights and, therefore, the conduct of the British authorities to seize the vessel and its cargo constituted a violation of international law, amounting in this respect to countermeasures by a state other than the injured.

\subsubsection{Coercive action against Japan (1940-41)}

The next example that falls within the scope of this examination concerns a number of coercive measures taken by the United States against Japan in response to its aggressive policies in the wake of World War II. More specifically, in the period 1940-41, Japan was at war with China. In 1940 the United States, concerned about possible advances of the Japanese in Indo-China, implemented a number of measures such as restrictions on the export of aviation fuel, iron and steel scrap in order 'to deter aggression'. ${ }^{440}$ Even in the absence of further documentation for an assessment as to whether these measures were in violation of specific treaty commitments, it can be said that the freezing of Japanese assets imposed in 1941 by the United States was in violation of international law. More specifically, the freezing of assets involves interference with the property rights of another state and therefore it is a wrongful act under international law. ${ }^{441}$

440 R. Renwick, Economic Sanctions (Center for International Affairs, Harvard Studies in International Affairs) No. 45, 62. For more on this incident see Department of State Bulletin (25 December 1950) 1004; Keesing's (1951) 11171, 11260; L. Damrosch, 'Enforcing International Law through Non-Forcible Measures', 269 RdC (1997) 109; Huffbauer, Schott and Elliott, Sanctions Reconsidered: History and Current Policy (1990) 110-14. For the economic measures decided in the early 1940s see Executive Order 8389 Protecting Funds of Victims of Aggression, 10 April 1940; Executive Order 8785 Freezing the Assets of Certain European Countries, 14 June 1941; Executive Order 8832 - Freezing Japanese and Chinese Assets in the United States, 26 July 1941 also cited in A. Kuhn, 'Foreign Funds Controls and Foreign Owned Property', 35 AfIL (Oct., 1941) No. 4, 651-54.

441 Dawidowicz, op. cit., 351. On the unlawfulness of freezing of foreign assets, also see Tams, op. cit., 209. That the freezing of assests is in violation of international law can also be inferred from the early conclusions of the ILC according to which the obligation of states to enter into negotiations prior to taking countermeasures could not prejudice the right to take interim measures of protection necessary, including the freezing of assets. See in this regard Report of the Commission (1996) op. cit., 69 (4). Also see D. Bederman, 'Counterintuiting Countermeasures', 96 AfIL (2002) 817, 825 and N. White and A. Abass, 'Countermeasures and Sanctions' in Evans (2006), op. cit., 509, 513. Moreover, according to Williams the freezing of assets 'was one of the most notable of the "methods short of war" employed against the Axis during and after the 


\section{The problem of enforcement in international law}

Indeed, these measures were seen by Japan as a threat to its existence. ${ }^{442}$ The United States action therefore enhances state practice and opinio juris in support of a right to third-state countermeasures for the protection of community interests, namely, protection of international peace and security.

\subsubsection{US measures against North Korea and China (1950)}

In this incident, the United States authorized unilaterally coercive action against both China and North Korea in response to their invasion of South Korea in 1950. This involved an order for the freezing of their assets, a measure that as seen earlier is in contravention of international law and requires legal justification. ${ }^{44}$ Accordingly, the interference with another state's property rights could only be justified as a countermeasure. Bearing in mind that the action taken by the United States came in response to an 'act of aggression' in violation of the principles safeguarded under the UN Charter and that the United States was not a direct victim of this aggression, it supports the argument that the action under consideration amounted to solidarity measures.

\subsubsection{Organization of American States (OAS) against the Dominican Republic (1960)}

In 1960, at the Sixth Meeting of Consultation, the OAS decided to take action against the Dominican Republic in the light of its alleged subversive and aggressive acts against Venezuela, its involvement in the attempted assassination of the Venezuelan president and in serious human rights violations. ${ }^{444}$ Such action was authorized in a resolution with which all OAS member states had to comply under the Treaty of Rio de Janeiro. ${ }^{445}$ The resolution condemned the Trujillo regime for acts of aggression and intervention against a foreign country, while it authorized the implementation of a number of measures against the Dominican Republic. This action was justified under Articles 6 and 8 of the Treaty that authorized the OAS to act accordingly whenever the territorial integrity or political independence of any American state was affected by any situation that posed a threat to

summer of 1940'. B. Williams, 'The Coming of Economic Sanctions into American Practice', 37 AfIL (July, 1943) No. 3, 386, 391.

442 Renwick, op. cit., 62-3. Also see Keesing's (1941) 4715.

443 For an analysis on this incident see Dawidowicz, op. cit., 351.

444 Sixth Meeting of Consultation of Ministers of Foreign Affairs Serving as Organ of Consultation in Application of the Inter-American Treaty of Reciprocal Assistance, San José, Costa Rica, 16-21 August 1960, Final Act, OAS Off. Rec. OEA/SER.C/II6 (1960). Also see Z. Selden, Economic Sanctions as Instruments of American Foreign Policy (Praeger: 1999) 117.

445 The resolution is available at http://www.oas.org/consejo/MEETINGS $\% 20 \mathrm{OF} \% 20$ CONSULTATION/Actas/Acta \% 206.pdf. 1947 Inter-American Treaty of Reciprocal Assistance, available at http://www.oas.org/juridico/english/Treaties/b-29.html;M.Akehurst, 'Enforcement Action by Regional Agencies with Special Reference to the Organization of American States' XLII BYIL (1967) 175, 188-9. 
the peace in the continent. 446 The measures initially involved cutting off diplomatic relations, partial interruption of economic relations and an export ban of military equipment to the Dominican Republic. The ban was later extended to the prohibition of exports of petroleum and petroleum products and lorries. The measures against the Dominican Republic, which were unprecedented as the OAS had never before imposed sanctions against another member state, ${ }^{447}$ were to have effect for as long as the country constituted a threat to the peace and security of the hemisphere.

In accordance with Articles 53 and 54 of the UN Charter, the Secretary-General of OAS reported the action to the Security Council. Article 53 in particular provides that 'no enforcement action shall be taken under regional arrangements or by regional agencies without the authorization of the Security Council'. ${ }^{448}$ The Soviet Union argued that under Article 53 only the Security Council was entitled to authorize the application of enforcement action by regional organs against any other state and, for this reason, the OAS was not empowered to take any action against the Dominican Republic. ${ }^{449}$ In the light of this interpretation, the measures authorized by the Organization were in violation of international law and could provide evidence of coercive peaceful action for safeguarding an interest owed not only to the member states of the OAS, but to all states. Although the United States' response was that Article 53 precluded only forcible action and not economic, commercial and other peaceful measures, this was not the position taken by the United States during the drafting of the UN Charter. ${ }^{450}$

Moreover, it was argued, among other things, that the specific measures fell within the sovereign discretion of states and that the enforcement action referred to in Article 53 related to action that 'would be illegal unless based on a Security Council resolution', ${ }^{451}$ suggesting that they were not in breach of international law and, therefore, they did not amount to countermeasures. However, even if such measures did not require the approval of the Security Council, the Dominican Republic, like many other members of the OAS such as Brazil, Haiti, Nicaragua and the United States, were signatory parties to GATT. Accordingly, the authorization and implementation of at least some of the measures such as the export ban on petroleum and lorries and the interruption of economic activities with the Dominican Republic would be in violation of obligations arising from the latter

446 Nevertheless, it needs to be mentioned that the Bogota Conference of 1948 which led to the drafting of the OAS Charter intentionally did not incorporate the notion of sanctions for human rights violations except whenever international peace was threatened. Akehurst, ibid, 192, 205.

447 Ibid, 192.

448 Charter of the United Nations, 26 June 1945, 1 UNTS 16.

449 L.I. Claude, 'The OAS, the UN and the United States' 547 International Conciliation (1964) 1, 49.

450 Ibid.

451 A. Levin, 'The Organization of American States and the United Nations' in B. Andemicael, Regionalism and the United Nations (Oceana Publications: 1979) 165-66. 
agreement, providing evidence in support of a right to countermeasures by states other than the injured.

The OAS member states, although acting on the basis of a treaty authorization, and in particular the Treaty of Rio de Janeiro, were third states to the violations that were allegedly committed by the Dominican Republic. Their reaction in defending principles established for the collective interest of the OAS (erga omnes partes) and the international community (erga omnes) has therefore particular relevance in the context of this study.

\subsubsection{Action against Greece (1967)}

On 21 April 1967 a military coup emerged in Greece resulting in the overthrow of the democratically elected government and its substitution with a dictatorial regime. To establish its powers the regime proceeded to adopt numerous measures aimed at suppressing any political opposition or reaction. With the Royal Decree of April 1967, a state of emergency was declared and certain constitutional provisions were suspended. In June 1967 the Standing Committee of the Consultative Assembly of the Council of Europe passed a damning resolution against Greece. In particular, the resolution deplored the situation in the country as in 'grave violation of human rights'. As a result, Greece could be expelled from the organization while the resolution called on the signatory states to the European Convention on Human Rights, on the basis of what was then Article 24, to refer the so-called Greek case to the European Commission of Human Rights. ${ }^{452}$ Significantly, the resolution provided that the Council 'holds itself ready to make a declaration at the appropriate time on the right of Greece to remain a member of the Council of Europe'. ${ }^{453}$

A few months later, and in compliance with the resolution, Denmark, Norway and Sweden initiated proceedings against Greece before the Commission. They argued that the Royal Decree was in violation of the Convention. In particular, the decree was in breach of the freedom from arbitrary arrest and detention, the right to a fair trial, the right to private and family life, the freedom of thought,

452 The resolution is reproduced in Council of Europe, Directorate of Information, Doc. B (67) 37 (26.6.67).

453 In Keesing's (1967) 22454; European Convention for the Protection of Human Rights and Fundamental Freedoms, 4 November 1950, 213 UNTS 221. Article 32(3) of the European Convention on Human Rights provided that the Committee of Ministers decides by majority of two-thirds 'what effect shall be given' to its finding that a state is in violation of its Convention obligations and that such a decision is of a binding character for the re-structuring of the control machinery under the European Convention on Human Rights see Protocol No. 11 to the Convention for the Protection of Human Rights and Fundamental Freedoms, restructuring the control machinery established thereby, Strasbourg, 11.V.1994, ETS No. 5. Under the new rules, the former powers of the Committee of Ministers under Article 32 mentioned above have been amended. Moreover, Article 8 of the Statute of the Council of Europe provided that whenever a member state seriously violates its obligations to respect human rights and the rule of law it may be suspended of its rights of representation and it may be called by the Committee of Ministers to withdraw from the Organization. The Statute is available at http://conventions.coe.int/Treaty/ EN/Treaties/Html/001.htm. 
conscience and religion, the freedom of expression, the right to peaceful assembly and association, the right to an effective domestic remedy and the right not to be discriminated against on the basis of political beliefs. They also claimed that Greece had improperly invoked Article 15 that allowed for derogations from the Convention as there existed neither a war nor public emergency threatening the life of the nation; neither were the measures adopted and their continued application under the Royal Decree 'strictly required by the exigencies of the situation'. Just days later, the Netherlands filed similar proceedings against Greece. Greece reacted by stating that the claims against it were 'unjust' and threatened to break all trade exchanges with the Scandinavian countries. ${ }^{454}$

The proceedings filed against Greece are relevant in the scope of this examination as they raise the question whether Denmark, the Netherlands, Norway and Sweden possessed a right to file proceedings against Greece under either the Convention or international law, particularly since they were not directly affected by the human rights situation in Greece. In turn, this relates to whether or not the action against Greece amounted to countermeasures by non-injured states.

On the basis of former Article 24 of the Convention any contracting party was entitled to bring a claim before the Commission for alleged violations by another party, irrespective of the fact that the alleged violation was not directed against the nationals of the state bringing the action. In this regard, no special interest had to be established. Therefore, under the Convention, the member states were indeed entitled to seek judicial review by referring a case of infringement to the bodies established under the Convention for the protection of the rights entailed herewith (erga omnes partes).

In relation to the question whether such a contracting state would be bringing an action under former Article 24 as an injured state or not, the Commission had previously concluded that:

A High Contracting Party, when it refers an alleged breach of the Convention to the Commission under Article 24, is not to be regarded as exercising a right of action for the purpose of enforcing its own rights, but rather as bringing before the Commission an alleged violation of the public order of Europe. ${ }^{455}$

The Commission found in this case that Greece was in violation of its obligations emanating under the European Convention on Human Rights, including its obligation not to infringe Article 3 concerning the prohibition of torture and inhuman and other degrading treatment. ${ }^{456}$ Once a complaint arrived before the Commission, the Commission had to examine it and try to reach an amicable settlement of the dispute among the parties involved. In the absence of a consensus, the Commission had to refer its conclusions on the facts and on the alleged

454 Keesing's (1967) 22454.

455 Pfunders case (Austria v Italy), European Commission on Human Rights, 4 Yearbook of the European Convention on Human Rights (1961) 117, 140.

456 Greek case, Commission's Report, 12 Yearbook of the European Convention on Human Rights (1969). 
violations of the Convention to the Committee of the Council of Ministers that could decide to send the case to the Court. However, at the time under consideration, Greece had not accepted the jurisdiction of the Court and, as a result, the case could not be referred to it without its consent. Whenever a case could not be referred to the Court, former Article 32 gave the Council of Ministers some adjudicatory jurisdiction to determine the dispute, although this capacity was criticized as the Committee of Ministers constitutes a political rather than a judicial body. ${ }^{457}$ Once the Committee of Ministers concluded under this power that there had been an infringement of the Convention, it could order the violating party to take all the appropriate measures suggested by the Commission to comply with its obligations and could set a deadline by which date the state should conform. Among others, the Committee of Ministers could request the Greek government to abolish the Royal Decree Act that established the state of emergency and suspended the Constitution. In the event of non-compliance, former Article 32 (3) provided that 'the Committee of Ministers shall decide ... what effect shall be given to its original decision and shall publish the Report'. This included a right to expel the wrongdoing party for infringing 'the principles of the rule of law and of the enjoyment by all persons within its jurisdiction of human rights and fundamental freedoms'.

It is clear from this analysis that the four states acting against Greece were not acting on the ground that there had been an infringement against rights individually owed to them. While the alleged violations took place thousands of miles away, none of their nationals or their other interests had suffered any kind of direct injury from Greece's action. On the contrary, Greece's own nationals were the direct victims of the violations. The four states rather took the action in defence of certain values established for the collective interest of the states that were parties to the Council of Europe. Their action, therefore, falls under what now constitutes Article 48(a) of the Final Articles. Moreover, the proceedings before the Commission were founded on express provision under the European Convention on Human Rights and, therefore, such action was in accordance with, rather than in violation of, international law. ${ }^{458}$

Nevertheless, the significance of the claim brought by the four states must not be underestimated. On the contrary, it reaffirms the position that states have a legal interest in the safeguard of fundamental community and collective interests and they are entitled to invoke the responsibility of the wrongdoing state through judicial means for the preservation of the ordre public.

It is also not without significance that Greece, feeling the pressure of the proceedings against it, took the decision to withdraw from the Council of Europe. Although this was not the reaction the applicant states had wished for, it does

457 T. Buergenthal, 'Proceedings Against Greece under the European Convention of Human Rights' 62 AfIL (1968) No. 2 441, 446.

458 Tams, op. cit., 71-2. The Committee of Ministers powers towards a recalcitrant party are today also regulated under the Rules of the Committee of Ministers for the supervision of the execution of judgments and of the terms of friendly settlements, adopted by the Committee of Ministers on 10 May 2006 at the 964th meeting of the Ministers' Deputies. 
reveal the pressure that the dictatorial regime in Greece faced in the international arena, something that would not have happened had no such action been instigated in the first place.

Similar action was taken in the early 1980 s by France, the Netherlands and Scandinavian states against the military regime that assumed power in Turkey. Again it was stressed that the Convention is a 'constitutional instrument of European public order in the field of human rights', ${ }^{459}$ which goes beyond merely establishing bilateral commitments between its member states. Rather, it creates objective obligations entitling all states to seek their observance. ${ }^{460}$

The reaction against Greece did not cease at the Council of Europe. The situation also had an impact on Greece's relations with the European Economic Community with which it was bound by an Association Agreement since 1962. 461 The agreement provided among others a common external tariff, elimination of quantitative restrictions on trade, free movement of persons, services and capital, while Greece was entitled to obtain loans from the Community. ${ }^{462}$

The European Parliament, in reaction to the military coup d'état, passed what was later described as an unprecedented resolution expressing its solidarity with the Greek people who were 'suffering in defense of the ideals of freedom and democracy'. ${ }^{463}$ The Parliament also made clear that for as long as Greece lacked democratically elected institutions the Association Agreement was at stake and it would not be implemented fully unless Greece respected its obligations under the European Convention on Human Rights. The coup d'état also provoked a number of formal parliamentary questions to the Commission of the European Communities. ${ }^{464}$ In addition, and as will be shown, the Parliament had made repeated calls to the European Commission to suspend or terminate the Association Agreement with Greece. This could reflect a certain opinio juris that the performance of obligations emanating from international treaties could be stopped in response to violations of fundamental interests, even if there was no express provision in the treaties in this regard and even if no direct injury was involved. The specific invitation made by the Parliament to stop the performance of the Association Agreement may enhance the argument that there is sufficient state

459 In Chrisostomos et al. v Turkey, HRLf 12 (1991) 113, (121) in Frowein (1994) op. cit., 360.

460 Frowein, ibid, 360.

461 Association Agreement between EC and Greece, Journal Officiel des Communautés Européennes (1963) No. 6 (January-March) 293/63. The Agreement came into effect on 1 November 1962. See Keesing's (1963) 19260.

462 V. Coufoudakis, 'The European Economic Community and the "Freezing" of the Greek Association, 1967-1974’ 16 Journal of Common Market Studies (1977-78) 114, 116.

463 Resolution sur l'association entre la C.E.E. et la Grèce (2 June 1967) Of (1967) No. 10, 2058. Also Parlement Européen, Debats: Compte Rendu in Extenso des Seances, Vol. VI/67, No. 91, 11-20 (1967).

464 For instance see Written Question No. 108 of 14 July 1967 (Question ecrite No. 108/97 de M. Seifriz a la Commission des CE: Accord d'Association CEE-Grece), Fournal Officiel, No. 243 du 07/10/1967, 3; Reply by the Commission of the European Communities of 22 September 1967, Of (1967) No. 243/2 of 7 October, 2. 
practice and opinio juris in support of a right to countermeasures in the name of collective interests.

In addition to the Parliament's reaction, the European Commission decided to carry out those parts of its Association Agreement with Greece that involved specific obligations as in the areas of trade and tariffs and to associate those areas that still required negotiations and were not bound by specific legal duties with political reform in Greece. 465 Moreover, the suspension of further negotiations on the harmonization of agricultural policy, labour movement and development loans had an adverse effect on the Greek economy. ${ }^{466}$ Uncertain as to how to deal with the situation that emerged in Greece, the European Commission nevertheless rejected claims for the renunciation or suspension of the agreement. In doing so, the European Commission relied on legal grounds in view of the absence of specific clauses in the agreement. ${ }^{467}$ This was a reflection of the difficulty the European Economic Community found itself in, in their effort to influence the situation in Greece. ${ }^{468}$ The European Commission was reluctant for legal reasons to suspend or terminate the Association Agreement in the absence of express provision, despite calls from the European Parliament to do so. ${ }^{469}$

What needs to be determined, however, is whether the European Economic Community had the competence to 'freeze' certain parts of the agreement since the latter entailed no specific provision that could be accommodated with the situation that emerged as a result of the coup, apart from some reference in the preamble to the need to strengthen peace and liberty. This led the Community at a later stage to place particular weight on the democratic governance of states with which the European Community is bound through Association Agreements. ${ }^{470}$ However, in this instance, the political criteria of the Greek association could only be drawn by inference, while it remained unclear what the European Economic Community could do in case of their violation. ${ }^{471}$

As already seen, there was a certain degree of hesitation on the European Commission's part to proceed with the suspension or termination of the treaty, which under Article 60 of the 1969 VCLT is permitted in case of a material breach, or for any of the reasons provided under such treaty.

This has led to confusion as to whether the European Commission's reaction against Greece breached certain obligations under the Association Agreement and therefore amounted to third-state countermeasures.

Buergenthal, for instance, recognized that were Greece to be expelled from the Council of Europe, the European Economic Community itself would be under

465 Coufoudakis, op. cit., 117-18. Also see Keesing's (1970) 24170.

466 Coufoudakis, ibid, 118-19.

467 Ibid, 128.

468 Ibid, 127.

469 Ibid, 128.

470 Ibid, $120-21$.

471 Ibid, 121. 
tremendous pressure to suspend its Association Agreement with Greece. However, he went on to note that:

[E]ven if the Community should for legal reasons be unable to comply with a demand for the complete suspension of the Association Agreement, it is clear that Greece would be economically harmed by a Community policy which limited co-operation with Greece exclusively to a grudging compliance with the clearly-defined obligations of the Association Agreement and left unexecuted the wider aims of this treaty. ${ }^{472}$

In his opinion, it would have been very difficult to suspend the Association Agreement in its entirety because apart from a general reference in the preamble of the agreement to the safeguarding of peace and liberty by the parties, there was no other clause on which such action could be based.

By the same token, it could be argued that the decision of the European Commission to reject a $\$ 10$ million loan for development, despite the fact that the request had already been approved by the European Investment Bank, did infringe the terms and aims of the agreement, as is also admitted by Buergenthal. ${ }^{473}$ Since the object of the Association Agreement was to enhance trade and economic relations among the parties for the purpose of the development of the Greek economy, an argument could be made that this decision was in violation of the objectives of the agreement, thus enhancing the argument in favour of third-state countermeasures. ${ }^{474}$

This view is endorsed by Dawidowicz according to whom the response of the European Economic Community provides yet another example in support of a right to solidarity measures. In his assessment, the decision of the Community institutions to suspend financial assistance to Greece was in violation of Protocol 19 of the Association Agreement. ${ }^{475}$ Since the Association Agreement and the Protocol did not include human rights violations as a ground for their suspension or an express denunciation clause, the measures taken could only be explained as third-state countermeasures. ${ }^{476}$

Greece's response could re-enhance the point as according to the junta these measures were in violation of the Association Agreement, questioning their legality under international law. ${ }^{477}$

Finally, it is noteworthy that when the Community institutions were called almost a decade later to take coercive action against Uganda, it was pointed out that the measures against Greece were justified in the light of the fact that the preamble of

472 Buergenthal, op. cit., 449.

473 New York Times, 29 September 1967, 14, col. 3, 14. See ibid, 448.

474 For the object of the Agreement see Keesing's (1961) 18168.

475 Protocole No. 19, Protocole Financier, Fournal Officiel des Communautés Européennes (1963) No. 6 (January-March) 340/63.

476 Dawidowicz, op. cit., 355.

477 Coufoudakis, op. cit., 126. 
the Association Agreement made reference to the protection of human rights. ${ }^{478}$ However, the passing reference to human rights could not be taken as permitting the Community to suspend or denounce the treaty and, therefore, its action could only be justified as countermeasures taken in the name of community interests. ${ }^{479}$

While the European Economic Community did not directly rely on an argument concerning solidarity measures, a consideration of the action it gave effect to indicates that such action was in violation of specific treaty commitments and, therefore, is significant for the purposes of this study.

\subsubsection{The Arab oil embargo (1973)}

\subsubsection{AN INTRODUCTION TO THE ARAB-ISRAELI CONFLICT}

Since the Arab-Israeli war of 1947, many Arab countries have engaged in an economic offensive against Israel and other states supporting it. It is on this ground that in 1957 Arab states refused overflight and landing rights to Air France over their territories because of its involvement in financially enhancing the Israeli film industry. ${ }^{480}$ In a statement made by the Secretary of the Arab League, it was stressed that the Arab states targeted only those firms that were assisting in the strengthening of Israel's economy, war efforts and its expansionist and aggressive objectives. ${ }^{481}$ However, due to lack of further information on this measure, it has not been possible to assess its lawfulness under international law.

In 1967 Israel, citing security reasons in the context of anticipatory self-defence, launched a military attack, invaded and occupied parts of Egyptian, Jordanian and Syrian territory. It was argued that the attack constituted an unlawful use of force not justified under Article 51 concerning self-defence as there had not been a previous armed attack to which Israel had to respond or an imminent threat to its security. ${ }^{482}$ Despite UN calls for cessation of this aggressive policy, Israel continued to occupy these territories by force.

In 1973 and after years of unsuccessful negotiations new hostilities broke out between Egypt and Syria, on the one hand, in an effort to regain their territories and Israel, on the other. During the conflict, the United States provided Israel with military equipment such as jet fighter planes and equipment to replace Israel's losses. ${ }^{483}$ It was against this background that states injured by Israel's actions,

478 Oral Question No. H-300/76 by Sir Geoffrey de Freitas and Oral Question No. H-306/76 by Mr Patijn published in the Annex to Official Journal of the European Communities (Of) No. $214-$ Debates of the European Parliament of 10 March 1977.

479 Dawidowicz, op. cit., 355-6.

480 M. P. Doxey, Economic Sanctions and International Enforcement (OUP: 1971), 29.

481 Ibid.

482 I.F.I. Shihata, 'Destination Embargo of Arab Oil: Its Legality Under International Law' in J.J. Paust and A.P. Blaustein, The Arab Oil Weapon (Oceana Publications, Inc./Dobbs Ferry: 1977) 97, 107. See The Situation in the Middle East, Security Council Res. 252 (1968); Security Council Res. 267 (1969); Security Council Res. 271 (1969).

483 Paust and Blaustein, ibid, 9-10. 
such as Egypt and Syria, and other states, not directly injured, such as Algeria, Bahrain, Iraq, Kuwait, Libya, Qatar and Saudi Arabia, decided on oil reductions for a number of states directly or indirectly supporting Israel. The deployment of what was later to be known as the 'Arab Oil Weapon' as an economic means of coercion raised many concerns about its legality under international law. The first question of importance is as to whether any, and, if so, which, Arab states were entitled to take any action against Israel, since not all of them were affected by Israel's policies in the same way. And, second, whether third states such as the Netherlands, Portugal, Rhodesia, South Africa and the United States ${ }^{484}$ could be subjected to economic measures and especially countermeasures and, if so, on what legal grounds in view of the fact that they were not directly involved in the dispute and by whom. Since countermeasures are only allowed in response to a violation of international law and must be directed against the defaulting state, it is imperative to identify whether these states, by supporting Israel, were themselves committing a wrongful act.

\subsubsection{LEGALITY OF THE OIL MEASURES IN INTERNATIONAL LAW}

There can be little doubt that action by an injured state against the wrongdoer is justified. Had other states not individually affected by Israel's unlawful use of force taken unilateral peaceful measures against it in violation of their own obligations, it would only enhance the argument in favour of third-state countermeasures in response to flagrant violations of international law, namely aggression, the unlawful use of force and deprivation of the right to self-determination. The question that also requires consideration here, however, is whether these states could impose countermeasures against not the direct aggressor, but rather against third states to the dispute. As shown earlier, for countermeasures to be lawful they must come as a response to another internationally wrongful act. Therefore, it would have to be established that the United States and the other states had violated a specific international obligation, an essential element of the notion of countermeasures by an injured or even a third state. In addition, such violation must involve a norm that is owed to the international community of states as a whole.

As frequently stated by the Arab states the measures were aimed at the liberation of the Arab territories occupied by Israel and the restoration of the rights of Palestinians. Orakhelashvili argues in this regard that the prohibition of the use of force, irrespective of its purpose and unless taken in accordance with the UN Charter, is peremptory in character. This position is also confirmed from the debates of the ILC on the concept of jus cogens in the 1960s. ${ }^{485}$ It can thus be argued that the United States and the other states, in providing assistance to Israel,

484 See Arab Communique, Conference of Arab Oil Ministers, Kuwait, 17 October 1973 in ibid, 42.

485 On the objectives of the oil embargo see Arab Resolution, Conference of Arab Oil Ministers, Kuwait, 17 October 1973 in ibid, 44, 45. On the peremptory nature of the prohibition of armed force see Orakhelashvili, op. cit., 161. Also see ILCYbk (1966) Vol. II, 248 and Shaw, op. cit., 126. 
were violating their customary obligation not to provide aid or assistance in the commission of an internationally wrongful act and especially in the violation of a norm with a peremptory character that creates obligations erga omnes, such as agression, use of force and the violation of the right to self- determination. As elaborated in Chapter 2, this principle today finds expression in Article 41 of the Final Articles. This duty is owed to all states collectively and its violation would entitle all states to invoke the responsibility of the wrongful state. The imposition of the oil embargo by the Arab states could as a result be indicative of practice supportive of third- state countermeasures. Of course, it remains to consider whether the Arab states, in imposing the embargo, had breached international law, a question to which the attention is now turned.

Paust and Blaustein have argued that the exercise of economic coercion by the Arab countries was in violation of the UN Charter and of the most favoured nation treatment clause under GATT, which prohibits discriminatory practices among the member states and the imposition of export restrictions. ${ }^{486}$

It needs to be noted that among the states participating in the embargo, only Kuwait and Egypt were parties to the GATT. While Egypt, as the directly injured state in the dispute could have made a valid defence under Article XXI, it is more likely that Kuwait's action was tantamount to countermeasures taken in response to a violation owed to the international community as a whole, namely the duty not to support the infringement of a peremptory norm. In any event, no attempt was made by any of the parties involved to bring up the matter in GATT. ${ }^{487}$

In relation to the legitimacy of the Arab measures with the bilateral trade agreements concluded between the United States and Iraq, Oman and Saudi Arabia, only the first agreement concluded with Saudi Arabia seems prima facie to raise the issue of the illegality of the oil embargo. More specifically, this agreement concluded in 1933 provided that the two countries accord to each other unconditional most favoured nation treatment on the import, export and other duties and charges on commerce and navigation. ${ }^{488}$ Nothing in the treaty seemed to allow prohibitions or restrictions on any of the grounds given by Saudi Arabia when imposing the embargo against the United States, therefore strengthening the argument that at least the measures decided by Saudi Arabia were in contravention of the obligations under the treaty concerned.

Shihata, on his part, supporting the legitimacy of the Arab measures argued that these were taken 'in an attempt to secure an objective of the highest international order: The restoration to the lawful sovereigns of illegally occupied territories

486 J. Paust, A. Blaustein, 'Commentary: The Arab Oil Weapon - A Threat to International Peace' in Paust and Blaustein, op. cit., 71-2.

487 S. Neff, 'Boycott and the Law of Nations: Economic Warfare and Modern International Law in Historical Perspective' 59 BYIL (1988) 113, 137 fn 106.

488 Provisional Agreement between the United States of America and the Kingdom of Saudi Arabia in regard to diplomatic and consular representation, juridical protection, commerce and navigation, signed November 71933 in Paust and Blaustein, op. cit., 356-7. 
and the restoration of the rights of peoples deprived of self-determination.' 489 Although not expressly worded, this justification seems to be equivalent to the argument in support of third-state countermeasures for the infringement of superior norms of the international legal order.

What is indeed noticeable, however, is that the United States had never officially accounted the Arab measures to be in breach of international law. ${ }^{490}$

In relation to the legitimacy of economic measures taken by states not directly injured by another state, Shihata argued that such measures, apart from deriving authority from state practice and the fact that there was no rule of international law prohibiting them, were all the more legitimate if they aimed at safeguarding respect for international law. ${ }^{491}$ Therefore, emphasis is placed on the legitimacy of the objective itself. Supporting the view that the oil measures deployed by the Arab states were not in violation of any customary or conventional rule of international law, he emphasized that:

A general and absolute prohibition on the use of economic measures for political purposes in the international sphere is still an idealist's dream. Before it hardens into a rule of international law, enforcement machinery must develop for the protection of the militarily weaker states, which may happen to have a relatively great economic power. Precluding such states from the use of their economic power in the settlement of political disputes before a general ban is imposed on armaments and in the absence of an effective collective security system could not serve the interests of international justice. It would only help the development of what President Roosevelt once described as "a one-way international law which lacks mutuality in its observance and therefore becomes an instrument of oppression". ${ }^{492}$

While no express reference to the right to third-state countermeasures is made, it seems to be implicit in what we have just said that unilateral coercive action taken in response to serious violations of international law is not only prohibited, but also recognized under international law.

\subsubsection{CONCLUDING OBSERVATIONS}

It has already been pointed out that the wrongfulness of countermeasures arises only when certain legal conditions are met. Accordingly, it has been established that the US and other states' support for Israel was in violation of their obligation not to render aid or assistance to a state that is responsible for the violation of one

489 Shihata, op. cit., 130.

490 Ibid, 131. Also R. Lillich, 'Economic Coercion and the International Legal Order' in Paust and Blaustein, op. cit., 157.

491 Shihata, ibid, 124.

492 Ibid, 132. 
of the most fundamental principles of international law, namely, the prohibition of the use of armed force. As a consequence, these states could be subjected to countermeasures under international law. This, however, raises another crucial question concerning the subjects entitled to resort to such countermeasures, bearing in mind that not all states were affected in the same way by the wrongful act in question. In the author's opinion, this case, which is not mentioned in the commentary to Article 54 of the Final Articles, offers a significant example of state practice supportive of third-state countermeasures, at least with respect to the measures adopted by Kuwait and Saudi Arabia and for this reason it deserves more attention in the future.

\subsubsection{Unilateral coercive action against Portugal (1973)}

This example concerns the calls made by the Organization of African Unity (OAU) for the imposition of a trade embargo against Portugal in 1963, 1964 and 1973, in reaction to Portugal's refusal to respect the right to self-determination in the territories under its control. ${ }^{493}$ The General Assembly had also condemned Portugal's practices as a 'threat to the well-being of humanity and to international peace', ${ }^{494}$ while in 1965 it called states to implement a trade embargo against Portugal. ${ }^{495}$

Ghana, initially the only member state of GATT that implemented a trade embargo invoked the national security clause as justification for the trade measures it implemented against Portugal. However, by 1973 many members of the OAU had also become members of GATT and therefore, their support to the imposition of coercive measures against Portugal revealed their support to thirdstate countermeasures. ${ }^{496}$

\subsubsection{US embargo against Uganda (1978)}

In 1971 Idi Amin took power in Uganda signalling a period of a brutal dictatorship with 8 years of extermination, torture and economic exhaustion for the people of Uganda. In the light of these atrocities, African states remained silent, with few exceptions, under the pretext of the principle of non-intervention in the

493 Resolutions adopted by the first ordinary session of the Assembly of Heads of State and Government, Territories under Portuguese Domination, Cairo, 17-21 July 1964, AHG/Res. 10(I), availableathttp://www.africa-union.org/root/au/Documents/Decisions/hog/bHoGAssembly1964. pdf. This is also cited in Dawidowicz, op. cit., 399.

494 Question of Territories under Portugese Domination, General Assembly Resolution 2107 (XX), 21 December 1965, (3) and (7) (e). For more on the calls made by both the General Assembly and the Organization of African Unity to implement economic and diplomatic measures against Portugal see G. Simons, Imposing Economic Sanctions: Legal Remedy or Genocidal Tool? (Pluto Press: 1999) 81-83.

495 Question of Territories under Portuguese Adminsitration, General Assembly Resolution 2107 (XX) (7) (e), 21 December 1965.

496 Dawidowicz, op. cit., 399-400; Keesing's (1970) 23904. 
internal affairs of another state, fearing that possible involvement would turn against them like a boomerang. ${ }^{497}$ They also feared that American involvement and intrusion in the affairs of a small African country like Uganda by way of economic sanctions bore a risk of similar action against them in the future.

The US government had not been favourable towards the notorious regime and its serious and persistent violations of human rights from the very beginning. As early as 1973 the US government announced a series of measures. Among them were the closure of the embassy in Kampala, the suspension of its economic assistance to Uganda and its refusal to renew it unless there were improvement in the human rights situation in the country, the opposition to international development loans to Uganda and the ban on munitions export and control over other sensitive materials. ${ }^{498}$ While most of these measures did not involve a violation of international law, it is likely that the munitions export ban was in breach of the United States' obligations under GATT, particularly the provisions regarding non-discrimination and export restrictions. ${ }^{499}$

Despite these efforts, there was some reservation with respect to the employment of unilateral countermeasures against Uganda. Even the Carter administration was hesitant due to its own trade and economic concerns and the possibility of other countries using economic means for the pursuit of political goals against the United States. Reluctant to set an unwanted precedent, the Carter administration stressed that any boycott action taken by the US government would be in violation of its obligations under the GATT. This governmental line found expression in the statement made by the Assistant Secretary of State for Congressional Relations Douglas J. Bennet according to whom:

Boycott actions are not consistent with the principles of the General Agreement on Tariffs and Trade (GATT), to which the United States is committed as the basis for international commercial relations. Whenever these principles [of GATT] are set aside, their overall authority as a protection for our own international trade interests is undermined. Therefore, as a general matter, we are extremely reluctant to take actions which contradict these principles. ${ }^{500}$

Behind this position laid a well-rooted belief of American policymakers tracing back to the 19th century and according to which the United States, as a major

497 R. Ullman, 'Human Rights and Economic Power: The United States Versus Idi Amin' 56 Foreign Affairs (1977-78) 529, 530.

498 Diplomatic Relations and Recognition, Digest of United Practice in International Law (1973) 11-13; S. Fredman, 'Comment: U.S. Trade Sanctions Against Uganda: Legality Under International Law' 11 Law \& Policy in International Business (1979) 1149, 1159.

499 See Articles XI and XIII of the General Agreement on Tariffs and Trade (1947). Uganda became a party to GATT in October 1962. The Agreement is available at http://www.wto.org/english/ docs_e/legal_e/gatt47_e.doc.

500 Cited in Ullman, op. cit., 534. 
trade power, should refrain from associating trade with political ends. This trend was strengthened after World War II where economics and politics were construed as two different spheres, the one being autonomous from the other. This was necessitated by the fact that the influence of politics in trade and economic matters had in the past had catastrophic consequences for international stability, peace and security, a prominent example being the last world war. It was perceived that economic measures should be applied only in response to economic violations unless they were authorized by the Security Council, while human rights violations should find cure through political and legal means such as denunciation. ${ }^{501}$

Furthermore, there was a need on the part of the US government to differentiate the Ugandan case from other US imposed embargoes against Cambodia, Cuba, North Korea and Vietnam, which rather relied on national security reasons and enforcement of UN decisions. ${ }^{502}$ Moreover, the American government did not consider that there existed such extraordinary circumstances to justify countermeasures. 503

Nevertheless, US Representative Pease stood firm on the Ugandan case. 'If we adopt sanctions against Uganda', he said, 'we would be establishing a new principle in our trade policies. We will indicate that we recognize limits of decency beyond which other governments may not go in their treatment of their own citizens. We will demonstrate that in special cases the Congress will use its authority to insist upon corporate responsibility where it may otherwise be lacking. ${ }^{504}$

In 1977 American foreign policy changed considerably, becoming more actively and substantially involved in order to terminate Amin's rule. ${ }^{505}$ It had become clear by then that the main source of Uganda's foreign capital (which was later used to sustain the regime) derived from coffee exports abroad and, in particular, to the United States. By the same token, the Ugandan coffee going to the United States constituted only 7\% of coffee imports in the country. For this reason, Congress concluded that to take action through boycotting Ugandan coffee would not severely harm the American economy. It was further realized that where military force could not be taken due to the general prohibition of the threat or use of force, it was the exertion of economic pressure that bore any chances of bringing the brutal regime in Uganda to an end. ${ }^{506}$ It was also clearly understood that inaction regarding the atrocities that took place in Uganda meant acceptance of Amin's remaining in power.

501 Ibid, 535.

502 Fredman, op. cit., 1160.

503 Ibid.

504 Pease' Statement at the US House of Representatives, H.R. Con. Res. 426, 95th Cong., 1st Session (1977) in ibid, 1162.

505 R. Nurnberger, 'Why Sanctions never Work: In the Case of the Late Idi Amin, They Clearly Helped Drive him from Power - Almost' 17 The International Economy (Fall 2003) Issue 4, 71.

506 Ullman, op. cit., 531. 
In 1978 US Congress issued a declaration of policy that was incorporated in Section 2151 of Title 22 of the US Code Annotated on Foreign Relations and Intercourse. According to the declaration, the protection of the liberties, economic prosperity and security of the American people were 'best sustained and enhanced in a community of nations which respect individual civil and economic rights and freedoms and which work together to use wisely the world's limited resources in an open and equitable international economic system' ${ }^{507}$ This was particularly so in the growing interdependence of nations largely owed to technological, economic and political advancements.

On 7 October 1978 Congress passed a law entitled 'Multilateral and Bilateral Action to Halt Atrocities in Cambodia and Uganda' with the twin aims of dealing with the humanitarian situations that emerged there and abolishing the brutal regimes that ruled in the two countries. ${ }^{508}$ More specifically the law pointed to the 'systematic and extensive brutality' taking place in Cambodia and Uganda that both required 'special notice and continuing condemnation by outside observers'. In order for any action to be effective and substantial, as the influence of the United States alone was very limited, the US government was urged to seek multilateral support through the UN and other international bodies and to encourage action by states with stronger links with the two countries mentioned. Furthermore, Congress directed the president to ban the export of military, paramilitary and police equipment to Uganda and to impose visa restrictions for any Ugandan government official wishing to enter the United States for military, paramilitary or police training purposes. The lifting of these measures was made conditional on a determination by the State Department that the Ugandan government had conformed to the rule of law and international human rights. Finally, the law authorized the submission to the Security Council of a draft resolution for a mandatory arms embargo on Uganda to be implemented by all the UN member states. ${ }^{509}$

Only a few days later Congress, having concluded that the government of Uganda under the power of General Idi Amin had committed genocide against the Ugandan people, adopted Public Law 95-435 according to which Uganda's serious misconduct permitted 'an exceptional response by the United States'. Thus, Congress called on the United States to build up a policy by which it would disassociate itself from any state having committed what the United States described as the international crime of genocide. For this reason, it was decided that the direct or indirect importation of any products grown, produced or manufactured in Uganda by any corporation, individual, institution or group would be banned 'until the President determines and certifies to the Congress that the

507 Foreign Relations Act, United States Code Annotated, Title 22, Chapter 32, Subchapter I, Part I, Section 2151, Foreign Relations and Intercourse, Congressional findings and declaration of policy. 50822 USC s. 2151 (1978).

509 Uganda Act 1, Pub. L. 95-426, 1978 HR 12598, Title VI, section 610, 7 October 1978, 92 Stat. 989; to also be found in Section 2151, United States Code Annotated. 
Government of Uganda is no longer committing a consistent pattern of gross violations of human rights'. ${ }^{510}$ It was further decided to prohibit trade export of goods to Uganda. The export ban also extended to cover articles, materials or supplies such as technical data or other information that fell within the US jurisdiction or exported by any person which was subject to US jurisdiction. Congress further urged the US president to encourage an international response to the human rights violations in Uganda, such as the infliction of economic restrictions by other states of the international community. In addition to these measures, Congress included Uganda in the list of states that would be denied any assistance, monetary or otherwise, along with Cambodia, Cuba and the Socialist Republic of Vietnam. ${ }^{511}$

On 10 October 1978 President Jimmy Carter authorized the imposition of a trade ban on Uganda and in February 1979, the embargo against Uganda took effect with Executive Order 12117 for as long as the Ugandan government did not cease its practices of gross violations of human rights. ${ }^{512}$

These measures were in violation of the US obligations under GATT to which Uganda was also a member state, especially of its duty not to impose any export restrictions and quotas in their economic relations. It is worth pointing out that the US government did not attempt to justify its action on the basis of the exemptions provided under the GATT, such as for instance under Article XXI which authorizes exceptions from the agreement on grounds of national security. On the contrary, the government justified its action as a result of the genocide committed by the Ugandan government against its own people. ${ }^{513}$

EEC member states, by way of contrast, took a more cautious stand towards Uganda, owing to their concerns that they had to comply with treaty commitments towards that country. In particular, it was noted on several occasions that the EEC member states were bound by the Lomé Convention in which there was no provision authorizing coercive action in view of gross human rights violations. Moreover, it was emphasized that as with all the other ACP countries they had to fulfil their obligations deriving from an international agreement. ${ }^{514}$ The Ugandan case was differentiated from the situation that emerged in Greece as a result of

510 Uganda Act 2, Pub. L. 95-435, 1978 HR 9214, section 5, 10 October 1978, 92 Stat. 1052; to be found in Section 2151, United States Code Annotated.

511 Uganda Act 3, Pub. L. 95-424, 1978 HR 12222 section 602; to also be found in Section 2151, United States Code Annotated, Title 22.

512 Executive Order, Executive Order No. 12117, Feb. 6, 1979, 44 F>R. 7937, Implementation of Import Restrictions Imposed Against Uganda; to be found in Section 2151, United States Code Annotated.

513 Embargo Act, Uganda Embargo Act, 22 USC, s. 2151 (1978). Also Third report on State Responsibility (Crawford) Addendum 4, UN doc. A/CN. 4/507/Add. 4 (2000) 14.

514 Human Rights in Uganda, Written Question No. 941/76, (De M. Van Der Hek au Conseil: Les Droits de l'Homme en Ouganda), Of C214/1 (7 September 1977); Oral Question No. H-300/76 by Sir Geoffrey de Freitas and Oral Question No. H-306/76 by Mr Patijn published in the Annex to Official Journal of the European Communities Of 214 - Debates of the European Parliament of 10 March 1977, 71. 
the military coup in 1967. It will be recalled that in that case the EEC had 'frozen' its relations with Greece under the Association Agreement. It was noted in this regard that in the Greek case the Association Agreement contained in the preamble reference to the basic principles of the Community such as human rights, which was not the case with the cooperation agreements with Third World countries. ${ }^{515}$

However, while the Council of Ministers and the Commission were reluctant to suspend the Lomé Convention on human rights grounds as there was no express provision envisaged in the Convention itself, 516 it was decided to redirect some of the development assistance provided under the Convention. As a result of this decision Uganda received only $5 \%$ of the assistance due to it, effectively suspending the implementation of the Lomé Convention. As there was nothing in the agreement to justify the reduction of development aid, the decision offers another example of third-state countermeasures. ${ }^{517}$ This conclusion seems to be enhanced by Commissioner's Cheysson statement that the Convention did not allow action against Uganda on human rights grounds or suspension of the development assistance. ${ }^{518}$ Neither did a fundamental change of circumstances exist that could justify the non-performance of the Convention. Accordingly, the suspension of the development assistance was in breach of the Lomé Convention and, therefore, can be justified as another example of third-state countermeasures.

Only a few months after the implementation of the American countermeasures, and as a result of the Tanzanian invasion of Uganda which had the support of Ugandan exiles and dissidents, Amin was forced to flee the country. Although many associate Amin's loss of power to the Tanzanian invasion and not to the US trade embargo, it was noted that the US stand was not without effect in bringing down the inhuman regime of Idi Amin.

In conclusion, the US action constitutes an invaluable precedent for the use of unilateral measures in violation of specific international obligations (countermeasures), such as GATT, imposed by a state not directly injured in response to serious violations of international law such as genocide and other serious human rights infringements. Similarly, the decision of EEC member states to reduce assistance to Uganda despite the express terms of the Lomé Convention enhances state practice in support of solidarity measures. These examples reveal the intention and determination of the United States and the European Economic Community,

515 Oral Question No. H-300/76 by Sir Geoffrey de Freitas and Oral Question No. H-306/76 by Mr Patijn published in the Annex to Official Journal of the European Communities Of $214-$ Debates of the European Parliament of 10 March 1977, 71.

516 The Commission, in particular, making reference to the ACP Partnership Agreement commented that the Community was 'bound to honour the commitments entered into vis-à-vis every one of those States under the Convention of Lomé'. See Answer of 6 March 1978, Of (1978) No. C 74/18 (28 March 1978).

517 Dawidowicz, op. cit., 359. Also see Tams, op. cit., 210-11.

518 Statement by C. Cheysson, Commissioner on Development Cooperation, 8 July 1980 in Europe, Vol. 28, No. 2495, 11, cited in Tams, op. cit., 211. 
despite initial legal reservations, to take action, even in violation of international law, in the rise of 'special' circumstances.

\subsubsection{Action against the Central African Republic (1979)}

Following a military coup by Colonel Bokassa in the Central African Republic in 1966, there was a wave of serious human rights violations including torture. The situation lasted until the French military intervention in 1979. During this period, while France and the European Community initially retained normal military and financial ties with the regime, the position changed after the murder of 85 children who were participating in a demonstration against the use of school uniforms. ${ }^{519}$ The bloodshed was widely condemned and resulted in the severance of relations between France and the European Community, on the one hand, and the Central African Republic, on the other. ${ }^{520}$

The European Community, while not proceeding to the official suspension of the Lomé I Convention nonetheless decided to suspend development aid to the country. ${ }^{521}$ According to Dawidowicz, this de facto suspension found no justification in the terms of the Lomé I Convention as the European Community did not rely on specific clauses concerning either a fundamental change of circumstances or denunciation provided under Article 92.522 As in the case of the freezing of development aid to Greece by the European Economic Community in the late 1960s, the decision taken at a Community level against the Central African Republic could provide another example in support of solidarity measures. This could be based on the argument that the decision opposed the aims and objectives of the Lomé I Convention for the development of the contracting parties through strengthening, inter alia, infrastructure and sustainable agriculture.

In addition to the measures just cited, France announced the suspension of bilateral economic aid in 1979. In this particular instance and unlike the Lomé I Convention binding on the European Community and the Central African Republic, there was no specific agreement by which France was under a legal duty to provide such aid. Therefore, this specific measure could be categorized as retorsion rather than countermeasures. ${ }^{523}$ However, France also announced the suspension of the 1960 Agreement Concerning Technical Military Assistance in

519 See, in this regard, the reply of the Commission of the European Communities to Written Question No. 115/78, by Mr Adams, (Question ecrite No. 115/78 de M. Adams a la Commission: Empire Centrafricain) Of C (1978) 199/27 (21 August 1978); Central African Empire, Written Question No. 943/77 by M. Adams to the Commission of the European Communities (Question ecrite No. 943/77 de M. Adams a la Commission: Empire Centrafricain, Of (1978) C 74/17 (28 March 1978).

520 Dawidowicz, op. cit., 360.

521 For more on the incident, see Keesing's (1979) 29750. Also see Question ecrite No. 115/78 de M. Adams a la Commission: Empire Centrafricain, Of(1978) C 199/27 (21 August 1978).

522 ACP-EEC Convention (Lomé I), 28 February 1975, 12 CMLR 4633; Dawidowicz, op. cit., 360-61.

523 Dawidowicz, ibid, 361. 
force between itself and the targeted state. ${ }^{524}$ Again, the decision did not rely either on specific human rights or denunciation clauses and, accordingly, it provides another example of third-state countermeasures. ${ }^{525}$

It becomes clear that at least some of the action authorized against the Central African Republic was taken by states not directly injured in response to a serious violation of fundamental human rights norms with an erga omnes effect, even in contravention of specific obligations under international law.

\subsubsection{US action against Libya (1979)}

The United States held a cautious approach towards Libya amid allegations of the latter's involvement in international terrorism. The relations between the two countries deteriorated in 1979 when the United States implemented a number of measures against Libya, including export controls on goods and technology that could be used for military purposes. ${ }^{526}$ In 1985 the United States, again concluding that Libya was supporting state-sponsored terrorism announced an import embargo on petroleum products. ${ }^{527}$ Since Libya was not a signatory party to GATT, however, and in the absence of any other agreement binding between them, these measures cannot fall within the category of countermeasures.

Nevertheless, in response to the terrorist attacks in Rome and Vienna airports in 1985 blamed on Libya, the United States decided in January 1986 to prohibit the sales of air transportation that involved a stop in Libya. ${ }^{528}$ Moreover, the US government announced blocking all property interests of the Libyan government and agencies in the country. ${ }^{529}$ As noted earlier, this measure involves interference with the property of a foreign state that in the absence of specific justification would be a violation of international law. As such, this specific measure adds to the state practice and opinio juris relating to solidarity measures, in response to the commission of international terrorism that threatens international peace and security and which could arguably be said as having an erga omnes character.

\subsubsection{Netherlands' action against Surinam (1980)}

In February 1980 the government of Surinam was overthrown in a military coup led by Colonel Bouterse. The Netherlands, responding to the serious human rights

524 Agreement Concerning Technical Military Assistance, 821 UNTS 266 (27 January 1961).

525 Dawidowicz, op. cit., 361.

526 Export Administration Act of 1979 and Arms Export Control Act, 23 UST 4269, TIAS No. 7535.

527 International Security and Development Cooperation Act of 1985, Public Law No. 99-83, 22 U.S.C. 2151.

528 Federal Aviation Act of 1958. Public Law No. 85-726, Aug. 23, 1958, 72 Stat. 731. The Act can be found in 'Terrorism: Laws Cited Imposing Sanctions on Nations Supporting Terrorism', op. cit.

529 International Emergency Economic Powers Act, Public Law No. 95-223, 50 U.S.C. 1701. The Act can be found in 'Terrorism: Laws Cited Imposing Sanctions on Nations Supporting Terrorism', ibid. 
violations taking place on the territory of Surinam, announced the suspension of the 1975 Treaty on Development Cooperation binding between the two states, which provided for Dutch financial assistance to Surinam.

In doing so, the Netherlands circumvented the normal procedures provided under the treaty invoking as justification the principle clausula rebus sic standibus (fundamental change of circumstances), which would have immediate and direct effect. ${ }^{530}$

A state that relies on this doctrine must first establish that the changed circumstances constituted an essential basis for the consent of the contracting parties when concluding the treaty but also that the changed circumstances radically altered the obligations to be performed under the treaty. It has been argued in this regard that the suspension of the treaty by the Netherlands could not be justified on the ground of change of circumstances since the condition for respect of human rights did not constitute the basis of the agreement between the two countries. ${ }^{531}$ Accordingly, the Dutch reliance on fundamental change of circumstances was rather dubious in this instance and, therefore, its action could be justified as thirdstate countermeasures instead. ${ }^{532}$

Quite significantly, the Dutch government attempted to justify its action on the fact that the Surinamese actions were in violation of the 1966 International Covenant for Civil and Political Rights to which both countries were signatories, in particular the right to life and the freedom from torture that establish obligations erga omnes. ${ }^{533}$ Since the Netherlands was not under the circumstances an injured state in the sense of Article 42 of the Final Articles, this example sets another significant precedent of state practice supportive of action for the protection of collective interests. This is in spite of the fact that the argument put forward by the Dutch government in order to justify its decision did not rely on a right to third-state countermeasures, but rather on the ground of fundamental change of circumstances. It is for this reason that the ILC itself, in the commentary to Article 54 of the Final Articles, distinguished this example from other cases that clearly set a precedent in favour of countermeasures by states other than the injured. The consideration of this example is, therefore, important as it indicates the willingness of states to resort to unilateral coercive action for the protection of collective interests, even when they have done so on the basis of other legal justifications. Most importantly, as the preceding analysis showed the requirements of fundamental change of circumstances were not in this instance met and therefore providing evidence that the Dutch action constituted action taken by a third state in response to the breach of fundamental community interests.

530 Okafor-Obasi, op. cit., 98-9. Also Hufbauer et al. (1985) op. cit., 726.

531 Chinkin, (1996) op. cit., 196.

532 Dawidowicz, op. cit., 405.

533 Okafor-Obasi, op. cit., 100. 


\subsubsection{Action against Liberia (1980)}

The next example providing evidence of a right to third-state countermeasures concerns the action authorized by the Economic Community of West African States (ECOWAS) in response to the military coup by Sergeant Doe in Liberia. ECOWAS decided not to allow Sergeant Doe to participate in the fifth summit conference. Liberia responded that this act challenged its sovereign rights. ${ }^{534}$ Dawidowicz notes in particular that a derivative right of the membership of any state to international organizations is its right to vote and, as a corollary to this, the state's right to participate in the meetings of the organization. ${ }^{535}$ It can therefore be concluded from this that the decision to suspend Liberia's right to participate in the proceedings amounted to a suspension of its membership rights, a measure that found no justification under the ECOWAS Treaty.

Moreover, the European Community announced the suspension of development assistance towards Liberia that, as in the Central African Republic case, was in violation of the aim and objectives of the Lomé I Convention. ${ }^{336}$

\subsubsection{The Soviet invasion in Afghanistan (1980)}

Attention is now turned to another interesting example set in state practice concerning the relations between the United States and the former Soviet Union during the 1970s and 1980s. In 1975 the United States passed the so-called Trade Act according to which the president would not be able to grant most favoured nation status to the Soviet Union unless it was shown that the latter had ceased to impose restrictions on the emigration of its nationals. The Soviet Union in response denounced its 1972 Trade Agreement with the United States on the ground that the Trade Act was in violation of the 1972 Agreement and a serious interference in its domestic affairs. ${ }^{537} \mathrm{In}$ addition to the question whether the non-granting of most favoured nation status was an act contravening the obligations of the United States under the 1972 Trade Agreement, it must be further established whether the other conditions concerning the lawfulness of solidarity measures have been met. In this regard, it will have to be established that the Soviet Union government, by imposing such restrictions on its nationals, committed a serious violation of fundamental interests owed to the international community of states as a whole and that, therefore, the infringed obligation possesses an erga omnes character. This is necessary in order to include this example within the category of countermeasures imposed by not directly injured states. For this purpose, it would have to be established not only that nationals have a right under international law to flee

534 Keesing's (1980) 30407.

535 For an analysis see Dawidowicz, op. cit., 362-3. Also see Article 5 of the Treaty of the Economic Community of West African States, 28 May 1975, 1010 UNTS 17.

536 Statement by C Cheysson, Commissioner on Development Cooperation, 8 July 1980 in Europe, Vol. 28, No. 2495, 11, cited in Tams, op. cit., 211.

537 Keesing's (1975) 26993 and (1976) 27642. 
their country as part of the right to freedom of movement, but also that this right establishes obligations owed to the international community as a whole. While this right is not absolute empowering states to impose certain restrictions in cases of emergency or national security, it could be argued that the freedom of movement constitutes a basic human right within the meaning of erga omnes obligations. Restrictions that actually abolish this right enable third states to invoke the responsibility of the wrongdoing state. In this case, the United States' conduct reveals its belief that it was responding to a violation of a community interest, even in violation of its obligations under the 1972 Agreement and, as such, qualifies as another example of third-state countermeasures.

Only a few years after this incident, the invasion of the Soviet Union in Afghanistan in December 1979 provoked the immediate reaction of the US government that decided the implementation of a number of coercive measures. These measures were taken before the adoption of a General Assembly resolution pursuant to which the Soviet Union was called to withdraw its troops from Afghanistan. The measures announced by the US government were justified on grounds of national security and the foreign policy interests affected by the Soviet invasion. ${ }^{538}$ It needs to be stressed, however, that not all measures resorted to by the US government were inconsistent with international law and, as such, they qualify as acts of retorsion rather than solidarity measures.

Among the measures that were in violation of specific international obligations was the withdrawal of ratification by the US Senate of the SALT II treaty that had already been successfully negotiated between the United States and the Soviet Union. Both states had at the time taken the position that states were bound under customary international law to refrain from resorting to action that would conflict with the object and purpose of an agreement that had been signed but not as yet ratified, a principle that is also reflected in the 1969 VCLT. ${ }^{539}$ Therefore, this measure falls within the category of countermeasures. The United States further decided to curtail Soviet fishing rights in American waters in violation of the 1976 US-USSR Agreement concerning Fisheries off the Coasts of the United States 540 and to restrict Aeroflot flights to the country. ${ }^{541}$

The United States also authorized the suspension of the export of grain that exceeded the amount that it had been legally committed to sell. ${ }^{542}$ In particular,

538 Economic Sanctions - Invasion of Afghanistan (1979); Polish Repression (1981), Cumulative Digest of International Law (1981-88) III, 2967-2979.

539 Obligations Prior to Ratification (SALT II Treaty), Digest of US Practice in International Law (1980) 398. For more information, see Keesing's (1980) 30234.

540 Union of Soviet Socialist Republics, Digest of US Practice in International Law (1980) 601-602. Keesing's (1980) 30234.

541 Hufbauer et al. (1985) op. cit., 655.

542 For a view that the specific decision to limit grain export to eight million metric tons of wheat and corn was required in order not to infringe the United States-Soviet Grain Agreement of 1975, see H. Moyer and L. Mabry, Export Controls as Instruments of Foreign Policy: The History, Legal Issues and Policy Lessons of Three Recent Cases (International Law Institute: 1988) 30-31. 
following the Soviet invasion, the Department of Commerce was instructed to terminate shipments to the Soviet Union of agricultural products including wheat and corn with the exception of the shipment of up to 8 million metric tons of wheat and corn provided for by the 1975 Agreement between the US and the USSR on the Supply of Grain. ${ }^{543}$ The decision of the US government resulted in the freezing of 17 million tons of grain, greatly impacting American farmers.

This decision is not, however, unlawful, ${ }^{544}$ unless it is established that the United States had unilaterally undertaken a commitment to provide more grain than what was already agreed under the specific terms of the 1975 Agreement. In such a case, its refusal to provide more grain would be a breach of a unilateral obligation towards the Soviet Union and, therefore, another example of countermeasures. This view is advocated by Sicilianos according to whom the suspension was in contravention of unilateral legal undertakings by the United States for the provision of a higher quantity of wheat and corn. ${ }^{545}$ It could also be argued that this measure was in violation of the Trade Agreement between the United States and the USSR concluded in 1972 (cited earlier), which provided, inter alia, equal trading access to the USSR and substantial grain purchases. ${ }^{546}$ It is accordingly likely that the reduction of grain quantities infringed specific treaty commitments undertaken by the United States, offering yet more evidence in support of a right to exercise coercive measures in response to the disregard of fundamental interests protected under the norm prohibiting the use of armed force against another state.

In addition to these, the United States announced a number of other measures. These included the boycott of the Moscow Olympics and an embargo on all exports intended for the Olympics with the exception of medical supplies, although these measures amounted to retorsion. Moreover, the United States authorized the suspension of exports of high technology and sensitive products, the prohibition and further restrictions on phosphates for fertilizers ${ }^{547}$ and restrictions on the import of Soviet ammonia. Further to this, the Department of Commerce suspended all outstanding validated licences and new applications that were pending regarding the sale of oil, gas field technology and other products. ${ }^{548}$ To the extent that these measures breached the object and purpose of the 1972 Trade Agreement between the two countries, they can be categorized as solidarity measures.

543 Hufbauer et al. (1985) op. cit., 884. Keesing's (1976) 27641.

544 Dawidowicz, for instance, in the light of lack of evidence supporting that the United States had unilaterally undertaken to increase the quantity of wheat and corn to be sent to the USSR, describes this particular measure as an act of retorsion rather than a third-state countermeasure. Dawidowicz, op. cit., 364.

545 A.L. Sicilianos, Les Réactions décentralizées à l'illicité: des contre-mesures la légitime défense (1990) 158 cited in Dawidowicz, ibid, 364.

546 Keesing's (1972) 25585.

547 Petman, op. cit., 363.

548 Hufbauer et al. (1985) op. cit., 603-604. 
It is interesting to note that the Legal Adviser of the US State Department, Roberts B. Owen, rejected the Soviet claims that the invasion of Afghanistan was justified under the 1978 Treaty of Friendship, Goodneighborliness and Cooperation between the USSR and Afghanistan. According to the Soviet arguments, under this agreement the parties undertook the obligation to protect the security, independence and territorial integrity of the two countries, although the treaty also provided for respect for national sovereignty and the principle of non-interference in the domestic affairs of the other. The US government, by the same token, argued that the Soviet invasion violated international law and the UN Charter. President Jimmy Carter, referring to the Soviet intervention in Afghanistan emphasized that:

Such gross interference in the internal affairs of Afghanistan is in blatant violation of accepted international rules of behavior ... Soviet efforts to justify this action on the basis of the United Nations Charter are a perversion of the United Nations ... the Soviet action is grave breach to peace. ${ }^{549}$

With specific reference to one of the paramount principles of the UN Charter, it was stressed that the USSR had an obligation under Article 2(4) to refrain from the use or threat of force against the territorial integrity or political independence of any state. Pointing out that no treaty could prevail over obligations arising from the UN Charter it was further noted that:

4. Nor is it clear that the treaty between the USSR and Afghanistan, concluded in 1978 between the revolutionary Taraki Government and the USSR, is valid. If it actually does lend itself to support of Soviet intervention of the type in question in Afghanistan, it would be void under contemporary principles of international law, since it would conflict with what the Vienna Convention on the Law of Treaties describes as a "peremptory norm of general international law" (Article 53), namely, that contained in Article 2, paragraph 4 of the Charter.

5. Moreover, the Soviet action conflicts with the terms of the Soviet-Afghan Treaty, since it is a violation of Afghanistan's national sovereignty. ${ }_{5}^{50}$

549 Soviet Invasion of Afghanistan, Digest of US Practice in International Law (1979) 34.

550 Ibid, 35. By way of comparison, it is noteworthy to point out here that when on 20 July 1974 Turkey used similar force to intervene in Cyprus and occupy one-third of its territory, there was no similar reaction by the US government despite the striking resemblance of both these two examples. More specifically, Turkey had justified its action on the Treaty of Guarantee of 1959-60 in response to the Greek-inspired coup against the democratically elected president, Archbishop Makarios. Not only the US did nothing to prevent the invasion or demand its cessation but it also continued providing Turkey with military and economic assistance in violation of both US and international law. For some more information, see Selden, op. cit., 128. 
In justifying the action against the Soviet Union, President Carter noted that the Soviet aggression was a national threat to the United States. ${ }^{551}$ Although he admitted that he did not expect that the measures would force the USSR out of Afghanistan, he pointed out that they were aimed at making the Soviets pay a price for their aggression and at deterring them from future aggression. He subsequently emphasized that the aim of the United States in resorting to these measures was to convince the Soviets by peaceful means that they could not invade a foreign country with impunity and that they should bear the consequences of their action. ${ }^{552}$

Moreover, in his statement before the General Assembly in January 1980, US Ambassador McHenry noted the following:

For this body to remain silent in the face of open aggression would be for the members of the United Nations to condone a violation of the only principles that small nations can invoke to protect themselves from self-aggrandizement by larger and more powerful states. It is not the United States whose freedom is most threatened by Soviet indifference to the Charter; the small and nonaligned countries, like Afghanistan, are most imperiled. ${ }^{553}$

The UK government acted on the same footing, describing the Soviet invasion in Afghanistan as an 'unprovoked act of aggression' that posed 'a serious threat to world peace'. ${ }^{554}$ Canada condemned the atrocities and the gross human rights violations committed by the Soviets against the people of Afghanistan, while the Canadian Prime Minister Joseph Clark supported the implementation of measures as a means to impose pressure on the USSR to withdraw from Afghanistan. 555 In particular, in January 1980 Canada announced the suspension of Soviet fishing rights in its Exclusive Economic Zone provided under the 1976 Agreement on Mutual Fisheries Relations between Canada and the Soviet Union. ${ }^{556}$ The suspension, which took place within 3 weeks after the Soviet invasion, was not provided under the terms of the Agreement that only allowed denunciation of the agreement after the passage of 6 years from its conclusion and then only after giving 12 months' notice. ${ }^{557}$ In a similar move, New Zealand also announced the suspension of the Soviet Union's fishing rights provided under the 1978 Agreement on Fisheries between the two countries. ${ }^{558} \mathrm{As}$ in the Canadian case, the suspension was not justified under the treaty or any denunciation provisions, thus qualifying

551 Afghanistan sanctions in Hufbauer et al. (1985) op. cit., 658.

552 Soviet Invasion of Afghanistan, Digest of US Practice in International Law (1980) 31.

553 Soviet Invasion of Afghanistan, Digest of US Practice in International Law (1979) 43.

554 Coercion and Use of Force Short of War-Unilateral Acts Intervention, 29 BYIL (1980) 473.

555 Hufbauer et al. (1985) op. cit., 660. Also Afghanistan, 25 CYIL (1987) 432.

556 Agreement on Mutual Fisheries Relations between Canada and the Soviet Union 1132 UNTS 139 (19 May 1976).

557 Dawidowicz, op. cit., 365.

558 Keesing's (1980) 30241; New Zealand-USSR Agreement on Fisheries, 1151 UNTS 277 (4 April 1978). 
the suspension as countermeasures taken in the protection of collective interests, namely international peace and security.

At the same time, the General Assembly and the European Community Council of Ministers condemned in unequivocal terms the Soviet invasion as interference in the internal affairs of Afghanistan and also as infringing fundamental principles of international law. ${ }^{559}$ While the Community adopted measures that affected agriculture, food and humanitarian aid and commercial policy and left open the possibility of further measures in the area of export credits, these did not amount to countermeasures. ${ }^{560}$

Other western countries were reluctant to impose countermeasures against the Soviet Union in violation of their treaty obligations, although it is suggested that it was the economic benefit that was the determinative factor for not taking action against the Soviet Union. The European Economic Community, for instance, replaced the United States in the sales of grain to the Soviet Union, ${ }^{561}$ although the initial reaction of the organization and that of Argentina, Australia and Canada to the Soviet invasion was that they would support the US grain embargo. ${ }^{562}$ In a common statement days after the Soviet invasion, they asserted that they would not attempt to replace the grain that would have been sent to the Soviet Union before the measures announced by the United States. ${ }^{563}$ In later interpretations, the representatives of these countries, with the exception of Argentina, said that the statement "was viewed as a commitment not to allow sales to the USSR to exceed "normal" or "traditional' levels". ${ }^{564}$ Argentina, by way of contrast, argued that it had no legal basis to interfere in the activities of private traders and thus rejected invitations to join in the economic coercive measures. ${ }^{565}$

Nevertheless, the European Parliament did urge the Commission to consider economic, financial and commercial measures against the Soviet Union. ${ }^{566}$

What can be concluded from this foregoing discussion is that at least some of the Canadian, New Zealand and US action against the Soviet invasion of Afghanistan amounted to countermeasures taken by states other than the injured in the name of collective interests, more specifically in response to the unlawful use of force against another country. The prohibition of the use of force is one of the

559 The situation in Afghanistan and its implications for international peace and security, General Assembly resolution 35/37 (20 November 1980); EC Bulletin (1980) No. 1, Vol. 13, points 1.1.3-1.1.11; Matters concerning Western Asia: Situation in Afghanistan, United Nations Yearbook, Volume 34 (1980) 296 seq.

560 EC Bulletin (1980) No. 1, Vol. 13, points 1.1.7-1.1.10. Also see Dawidowicz, op. cit., 364.

561 Petman, op. cit., 363.

562 Keesing's (1980) 30235.

563 Ibid.

564 Afghanistan Sanctions, 'An Assessment of the Afghanistan Sanctions: Implications for Trade and Diplomacy in the 1980s', Congressional Research Service, Library of Congress, 1981. Prepared for the House Committee on Foreign Affairs, 97 Cong., 1st Session, Washington in Hufbauer et al. (1985) op. cit., 659-60.

565 Hufbauer, ibid, 660.

566 Resolution on the Soviet Intervention in Afghanistan, Of (1980) No. C34/28. 
most fundamental principles in contemporary international law the respect for which creates obligations owed to all states of the international community. Subsequently, all states have a paramount interest in the protection of the rule and, therefore, they are not unaffected in the event of its infringement. It is in this context that the action just cited could be justified. The fact that other states did not join in similar action cannot lead to the conclusion that they did so because they opposed the possibility of taking countermeasures in cases of serious violations of erga omnes obligations. Rather, it seems that economic and other considerations existed that interfered in their decision not to respond with more forceful measures against the Soviet Union in this instance.

\subsubsection{International reaction to the Teheran hostage crisis (1980)}

Hostage taking has been frequently used as a means for the achievement of mainly political goals, imposing in this manner a threat not only to the lives of the individuals involved but also to international peace and security and, therefore, of concern to the international community as a whole. The Security Council's resolutions in the Teheran hostages crisis are indicative of this international concern. The dispute arose between the United States, as an injured state, and Iran on 4 and 5 November 1979 when armed groups seized the premises and the staff working at the time in the American Embassy in Teheran and in the American consulates in Tabriz and Shiraz. The hostage takers had been protesting against the earlier decision of the United States to allow the former Shah of Iran to seek medical treatment in that country. While these events were initially instigated by non-state actors, the Iranian government was held responsible for its tolerance, encouragement and failure to act duly in order to prevent and terminate them. ${ }^{567}$

In reaction to the attacks against the US Embassy and personnel the Security Council took immediate action by calling for the immediate release of the hostages while leaving open the possibility of further measures under Articles 39 and 41 of the UN Charter should Iran fail to comply. 568 Ultimately, these measures were never authorized due to the exercise of the Soviet veto.

In view of the Security Council's failure to take more coercive action against Iran, the Foreign Ministers of the European Economic Community issued a statement on 14 April 1980 in which they stressed that the Iranian government continued to be in flagrant violation of international law. In the statement, it was made clear that Iran had ignored the calls of both the Security Council and the ICJ to comply with its international obligations. ${ }^{569}$ On 22 April 1980 the EEC Foreign Ministers decided to initiate their national procedures for imposing an arms embargo against Iran in accordance with former Article 223 of the EEC

567 United States Diplomatic and Consular Staff in Teheran, op. cit., 44.

568 Islamic Republic of Iran-USA, Security Council Res. 457 (1979); Security Council Res. 461 (1979).

569 On the Teheran Hostages, 29 BYIL (1980), 409. 
Treaty, despite the lack of Security Council authorization, for its continued disregard of international law in what they determined would constitute a threat to international peace and security. ${ }^{570}$ On 17 May they decided to apply the measures provided under the draft Security Council resolution of 10 January, in spite of the fact that this resolution was never adopted. It is significant to note that the specific resolution provided for a total trade embargo against Iran and, therefore, the determination of the EEC states to give it effect provides evidence of support of coercive measures taken in the name of community interests even in violation of international law. In any event, under this later decision all contracts concluded with Iran after 4 November 1979 were to be suspended, which would bring the EEC member states in violation of their treaty commitments. ${ }^{571}$

The United Kingdom reacted to the Teheran hostage crisis with the adoption on 15 May 1980 of the Iran (Temporary Powers) Act that came into force 2 days later. ${ }^{572}$ Section $1(1)$ of the Act authorized the Queen to take such decisions about contracts with Iran concerning services or goods as she regarded necessary due to Iran's violation of international law in the hostage crisis. The wording of the Act reflects the intention of the United Kingdom to resort even to countermeasures as a third party against Iran. The Act was adopted 2 weeks before the ICJ's judgment on the Teheran Hostages case according to which the seizure of the diplomatic staff constituted a violation of 'obligations essential to the international community as a whole'. ${ }^{573}$ In justifying the decision to take action against Iran, the Minister of State, Foreign and Commonwealth Office, Douglas Hurd, made reference to an earlier ruling issued by the ICJ on the case, one which the United Kingdom regarded as binding in international law. Furthermore, the UK action against Iran came 3 days before the embargo authorized by the European ministers of foreign affairs. ${ }^{574} \mathrm{~A}$ few days later the UK government adopted two orders by which it imposed a prohibition on the conclusion and performance of any new contracts with Iran, although these measures did not affect already existing contracts and, therefore, did not amount to countermeasures. ${ }^{575}$ The position of the UK government regarding the justifiability of the measures decided against Iran was that Iran could not continue disregarding basic principles of international law. ${ }^{576}$ According to one view, the UK Act amounted to 'lawful measures' as in

570 Ibid, 477.

571 The Community and the Member States and the Events in Iran, Bulletin of the EC (1980) No. 4, 20-26.

572 'An Act to enable provision to be made in consequence of breaches in international law by Iran in connection with or arising out of the detention of members of the embassy of the United States of America', in On the Teheran Hostages, op. cit., 413.

573 United States Diplomatic and Consular Staff in Teheran, op. cit., 42-4 (91-92).

574 On the Teheran Hostages, op. cit., 413.

575 Iran Sanctions, The Export of Goods Control (Iran Sanctions) Order and the Iran (Trading Sanctions) Order, 29 May 1980 in Statutory Instruments, London, 1981, 2579 and 2585 in Picchio-Forlati and Sicilianos, op. cit., 102, fn 4.

576 On the Teheran Hostages, op. cit., 413-4. 
Articles 22 and 54 of Final Articles. ${ }^{577}$ Nevertheless, the United Kingdom's reaction is not without legal significance as it illustrates the determination of a state not injured by a certain wrongdoing to respond to serious violations of obligations owed erga omnes, while indicating its intention to resort to any action necessary for the cessation of the wrongful act.

With respect to the position of Canada, the Secretary of State for External Affairs, Mark MacGuigan, stressed that the seizure of the diplomatic staff and the premises of the American Embassy constituted grave breaches of international law that called 'for an unequivocal response from the international community'. ${ }^{578}$ Referring to the Security Council resolutions on the matter, the first of which was adopted even by the Soviet Union, he drew attention to the threat posed to the international community as a result of the hostage crisis. With respect to the Soviet veto, he said:

The cynical Soviet veto, however, cannot obscure the fact that the international community, both then and now, condemns the hostage affair. In addition to the overwhelming support given to the Security Council resolutions on Iran, this condemnation from the international community has been reiterated by the International Court of Justice which, first in December and then again in May, ordered Iran to restore the embassy to the U.S.A. and to free the hostages. These unequivocal judgments by the UN and the International Court of Justice fully satisfy the international community in applying economic sanctions against Iran. 579

Canada, and in the light of action taken by EEC countries, Japan and Australia, called for the implementation of the measures provided under the vetoed resolution, which provided for the implementation of trade, transport, finance and diplomatic measures. The government justified its decision on its concern to uphold a fundamental rule of international law which is vital to the conduct of international relations.' 580

Even though Canada seemed to rely on the ICJ rulings and the UN resolutions to justify its own action against Iran, it is necessary to determine whether these could be relied on for the implementation of countermeasures. In relation to the UN resolutions it is noted that no legally binding resolution was adopted authorizing the application of peaceful coercive measures against Iran. As for the ICJ ruling, it is essential to remember that this creates obligations only towards the parties submitting the dispute before it. Moreover, the ICJ cannot authorize the implementation of countermeasures, as its role is confined to adjudicate on what

577 Picchio-Forlati and Sicilianos, op. cit., 102, fn 3.

578 Iranian Economic Sanctions Act, CYIL (1981) 372.

579 Ibid, 373.

580 Ibid, 374. 
the law is and not to exceed these judicial powers. Yet, its ruling may have significance for the determination that an internationally wrongful act has been committed. In any event, it seems from this that Canada was determined to proceed with a number of coercive measures against Iran. Although it is not clear whether these measures actually infringed specific obligations, this example is significant as it lends support for third-state reaction in response to the violation of fundamental community interests and it reflects a belief held by these states that such response would be justified.

As for the United Kingdom's response, although this was actually confined to 'lawful' measures, it seems that the door was left open to further action if 'regarded necessary'. The emphasis placed on the seriousness of the wrongful act committed by Iran is indicative of the significance attributed by the United Kingdom to the respect for international law and the international implications that arose from the forceful seizure of the diplomatic premises.

However, it is necessary to identify the rules violated by Iran's actions, or rather omissions, and also which states were entitled to react, if at all, by the implementation of economic measures and, even more significantly, countermeasures. One could, therefore, argue in this regard that the obligations arising from the general law of diplomatic immunities are of a bilateral nature as between the receiving and sending states and that as a consequence no other state is entitled to invoke the responsibility of the defaulting state. While this is correct, one could turn to the way that the diplomatic immunities were disregarded in the particular case by Iran, namely the use of force against the American diplomatic premises and personnel. Had the Iranian government chosen to respond to alleged US violations of diplomatic law by declaring the American diplomats as persona non grata then no other state would be entitled to react to such a decision. It is, therefore, suggested that it is to the unlawful use of force that Canada, the United Kingdom and the other European Economic Community countries were responding, even though they were not directly involved in the dispute. Moreover, while it is true that the 1961 Vienna Convention on Diplomatic Relations establishes multiple bilateral relations, it could be argued that the Convention aims at the protection of certain collective interests owed to all states parties to it, establishing accordingly an interest on all states parties to invoke the responsibility of the wrongdoer and even to resort to countermeasures. ${ }^{581}$ The decision, particularly of the EEC member states, to suspend all treaties concluded with Iran after November 1979 seems to fall within the category of third-state countermeasures as implying their intention to take action that may be in violation of specific commitments under international law and, for this reason, it is regarded important for the purposes of the current examination. 582

581 See in this regard Vienna Convention on Diplomatic Relations, 18 April 1961, 500 UNTS 95.

582 For the view that the EEC measures did not amount to countermeasures, see Dawidowicz, op. cit., 402-403. 


\subsubsection{Imposition of martial law in Poland and Soviet involvement (1981)}

When in December 1981 the Polish government ordered, with the alleged encouragement, advice and technical assistance of the Soviet Union, the application of martial law in the country for the repression of trade unions, political dissidents and civil rights, the United States expressed its profound condemnation and concern for the situation that emerged as a result. Immediately after the decision of the Polish government, President Ronald Reagan, in the absence of a Security Council resolution, gave instructions for the suspension of the most significant elements of the country's economic relationships with Poland. The decision was justified as a reaction to the violation of the UN Charter (although not specifying which principles exactly had been violated), the Helsinki Final Act (not a legally binding instrument although, in certain cases, it reflects customary norms of international law) and the Gdansk Agreement of 31 August 1980 with the leaders of the Solidarity movement. ${ }^{583}$ At the same time the US government called on Poland to release all the political dissidents whose only offence was to exercise their civil and political rights 'enshrined in many international documents to which [Poland] was a party'. ${ }^{584}$ While the shipment of food aid continued on the condition that this was received by the Polish people themselves, all shipments of agricultural and dairy products were suspended until their distribution could be monitored by independent agencies.

Furthermore, the United States stopped the renewal of the Export-Import Bank's line of export credit insurance to Poland; opposed the extension of any new credits and Poland's membership of the International Monetary Fund; and recommended allying countries to impose restrictions on their high technology exports to Poland. These measures, however, did not contravene specific treaty or other obligations of the United States towards Poland and, therefore, they do not fall within the category of countermeasures. In exchange for the lifting of these measures, President Reagan called on the Polish government to release all those arbitrarily held in prison, to cease the violence against the Polish population, to lift martial law and to restore the internationally recognized and protected, inalienable rights of the Polish people to freedom of speech and association.

In addition to this action, the US government announced that it would suspend aviation privileges in the United States to Polish airlines and that it was in the process of suspending the fishing rights of Poland within American waters. With respect to Poland's civil aviation privileges the United States announced the suspension of the 1972 US-Polish Air Transport Services Agreement on 26 December 1981.585 The Civil Aeronautics Board informed LOT (Polskie Linie Lornicze) about the suspension of the foreign air carrier permit issued to LOT. LOT protested against the suspension on the ground that the President's decision was in

583 Economic Sanctions - Invasion of Afghanistan (1979); Polish Repression (1981), Cumulative Digest of International Law (1981-88) III, 2967-2979.

584 Keesing's (1982) 31454.

585 For a list of all the measures adopted by the US government see Export Administration Act of 1979 and Arms Export Control Act, 23 UST 4269, TIAS No. 7535. 
violation of the 1972 Agreement, which did not permit of its immediate suspension or termination and which was effective until March 1982. More specifically, the Agreement provided that the operating permission granted to the airlines of the two parties could be withheld, suspended or revoked on the ground that the targeted airline did not satisfy the standard procedures of the aeronautical authorities of the state applying the suspension. Moreover, the Agreement could be suspended or denounced on the ground that the airline failed to comply with the regulations of the suspending state regarding admission and departure of air services or that the suspending state believed that the designated airlines of the other party were not owed or controlled by it. It can, therefore, be seen that the Agreement permitted no suspension or termination on grounds other than the ones provided by it and made no specific reference to human rights violations. Furthermore, the suspension or termination of the Agreement could take effect only after the consultation with the other party, with the exception of Article IV(A)(2) of the Agreement relating to entry and exit regulations, something that the United States had failed to do. It is noted that the state of emergency as a result of the imposition of martial law did not seem to provide a satisfactory legal ground for justifying the United States in suspending the Agreement without satisfying the condition of consultation, neither did it directly affect US interests. ${ }^{586}$ Moreover, under the Agreement denunciation could only take effect after giving 12 months' notice.

The suspension of the Polish civil aviation rights by the United States had a great economic impact on Polish tourism. If justification of the US decision within the Agreement cannot be supported, it is necessary to determine whether such action could be justified under any other legal ground of general international law. While consideration was given to circumstances that could render the Agreement void, such as being in violation of a jus cogens norm, it was concluded that no such grounds could be proven as existing in the particular case. Furthermore, it was noted that the suspension of the Agreement could not rely on a material breach or fundamental change of circumstances recognized under the general law of treaties as valid reasons for the suspension of a treaty. ${ }^{587}$ The US decision should, therefore, be examined in the context of the general law on state responsibility and, in particular, countermeasures. The difficulty in this regard would be to identify the internationally wrongful act committed by Poland for which the United States, as a non-directly injured state, would be entitled to complain, either by resorting to countermeasures or otherwise.

In justifying its decision, the US government pointed to the 'exceedingly serious world events'. In particular:

Clearly, under such circumstances, there resides in the President and the Executive [b]ranch of the U.S. Government ample authority to suspend

586 M. Malamut, 'Aviation: Suspension of Landing Rights of Polish Airlines in the United States - 93 CAB Reports 479 (1981)' 24 Harvard International Law Journal (1983) 190, 191-3.

587 Ibid, 196-7. 
application of an Executive Agreement between the United States and a foreign country, whether or not such suspension is provided for under the specific terms of the Agreement. ${ }^{588}$

Other states such as Switzerland and the United Kingdom also ceased performance of their respective aviation agreements with Poland, a measure that again was not justified under any of the provisions of these agreements. ${ }^{589}$

In 1982, and following the adoption of further repressive measures by the Polish government, the United States suspended Poland's most favoured status on the ground that it failed to meet the import percentage required under the GATT. President Reagan stressed that the United States would not remain passive to Poland's 'outrages', adding that 'their crime will cost them dearly in their future dealings with America and free peoples elsewhere'. ${ }^{590}$ He further stressed that, by these measures, the US government intended 'to put powerful doubts in the minds of the Soviet and Polish leaders about this continued repression ... The whole purpose of our actions is to speak for those who have been silenced and to help those who have been rendered helpless.' 591

The imposition of martial law in Poland and the suspension of human rights caused reaction in Europe as well. In a statement issued in January 1982 by the Foreign Ministers of the European Community member states, the situation was condemned as an infringement of the 'most elementary human and citizens' rights, contrary to the Helsinki Final Act, the UN Charter and the Universal Declaration of Human Rights', the significance of which went beyond merely Polish borders. 592 However, in announcing the steps it was ready to take the European Community adopted a more careful approach limiting measures on considering credit, economic and food assistance to Poland. ${ }^{593}$ Due to disagreements among the member states, the measures were limited to the import of luxury goods and thus expected to have only symbolic significance. ${ }^{594}$ Despite this, it was made clear that the EC countries would seek consultation and close cooperation on developments with the United States. When examining at a later stage what further action to take they requested the Permanent Representatives Committee and the Commission to study the economic measures already resorted to by the United States, their scope and the impact on the economy and trade of

588 United States-Poland: Suspension, Cumulative Digest of US Practice in International Law (1981-88) II, 2180, 2182.

589 Tams, op. cit., 214.

590 Washington Post, 24 December 1981, Al in Hufbauer et al. (1985) op. cit., 686.

591 President Ronald Reagan, 29 December 1981 in Hufbauer, ibid, 701.

592 The Community and Poland, Final Communiqué of 4 January 1982, Bulletin of the EC (1981: 12) 12-13 (1.4.2).

593 Ibid. Also State Trading Countries - Poland, Bulletin of the EC (1982: 1) 2.2.38; State Trading Countries - USSR, Bulletin of the EC (1982: 2) 2.2.44; Keesing's (1982) 31453.

594 Keesing's, ibid. 
EC member states. ${ }^{595}$ Moreover, the European Council announced the termination on the basis of special terms of foodstuff sales to Poland while the exports under normal terms would remain unaffected. 596

At a NATO level, it was stressed that the massive violations of human rights and fundamental civil liberties were in breach of the UN Charter, the Universal Declaration of Human Rights and the Helsinki Accords. ${ }^{597}$

The problematic aspects in this case arise not only as to whether the United States and other countries possessed the right to resort to countermeasures in response to a violation of international law not injuring them in their individual rights, but also because it could be argued that Poland's actions did not amount to a breach of obligations erga omnes. As already stressed, one of the legal conditions of third-state countermeasures is that they must come in response to a previously committed internationally wrongful act concerning the violation of collective or community interests.

Accordingly, the US action in particular must be looked at in the light of Poland's obligations while answer must be given to the question as to whether, by imposing martial law in the country, Poland was acting in violation of norms possessing an erga omnes character that could trigger the invocation of its responsibility by any other state. While it is true that in contemporary international law human rights violations do not fall within the exclusive jurisdiction of states, it has already been argued in Chapter 1 that not all human rights obligations have an erga omnes character. Accordingly, not all human rights violations would entitle all states to invoke the responsibility of the wrongdoer, unless, of course, otherwise provided. This is reflected in the reference in the Barcelona case to 'basic' human rights having an erga omnes nature, as distinguished, as already suggested, from other human rights not possessing such qualification. ${ }^{598}$ It could, therefore, be argued that the infringement of trade union rights could not give rise to any entitlement on the part of the United States unless they were in breach of international obligations owed to the international community as a whole or established for the collective good of a group of states. France, for instance, was reluctant to follow suit in this instance, claiming that the situation in Poland was an internal matter. ${ }^{599}$ However, it could be argued that the serious repression and extinction of fundamental human rights such as the right to liberty and the right to a fair trial are 'basic' human rights establishing obligations erga omnes.

It is true that this incident lacks clarity in respect of the legal ground on which Poland's violations would have infringed an interest owed to the international community as a whole. Nevertheless, this example may substantiate the claims that these rights had already become part of customary international law and that

595 State Trading Countries - Poland, Bulletin of the EC (1982: 1) 2.2.38.

596 Ibid.

597 Malamut, op. cit., 197, fn 41.

598 Case Concerning the Barcelona Traction, Light and Power Company, Limited op. cit., (34), (35), (91).

599 Tams, op. cit., 214. 
the right to a fair trial, freedom of expression and to liberty all establish a legal interest owed to the international community as a whole. ${ }^{600}$ This conclusion can also be inferred from the reliance on the Helsinki Final Act and the Universal Declaration, two non-legally binding instruments, for justification of the action taken against Poland.

In conclusion, the action against Poland offers important evidence that the gross and systematic violation of fundamental human right elements create a legal interest to all states in their protection.

In parallel with the measures adopted against Poland, the United States called on the Soviet Union to allow the restoration of basic rights in Poland and warned it that the United States would 'have no choice but to take further concrete political and economic measures affecting our relationship'601 in the event that the repression in Poland continued. Several days later, the United States announced that it would extend the economic measures to the Soviet Union for its role and interference in the situation in Poland. In a statement issued on 29 December 1981, it was pointed out that:

The Soviet Union bears a heavy and direct responsibility for the repression in Poland. For many months the Soviets publicly and privately demanded such a crackdown. They brought major pressures to bear through now-public letters to the Polish leadership, military manoeuvres and other forms of intimidation. They now openly endorse the suppression which has ensued. ${ }^{602}$

According to the United States, the Soviet Union was in breach of its obligations under the Helsinki Final Act (although this is not a legally binding instrument) and the UN Charter, without, however, expressly clarifying the legal principles or provisions violated as a result. ${ }^{603}$

Among the first steps taken was the suspension of landing rights in the United States by the Soviet airline, Aeroflot. Aeroflot had at the time been granted permission under Section 402 of the Federal Aviation Act of 1958 to conduct two roundtrips a week between Moscow and New York/Washington, DC. This was made conditional on 'all applicable provisions of any treaty, convention, or agreement affecting international air transportation now in effect or that may become effective during the period this permit remains in effect, to which the United States and the U.S.S.R. shall be parties' ${ }^{604}$ The two countries were bound by a bilateral agreement, namely the US-USSR Civil Air Transport Agreement of 1966 that required a 6-month notice for its suspension. According to the Agreement, the

600 Ibid, 233.

601 Economic Sanctions - Invasion of Afghanistan (1979); Polish Repression (1981), Cumulative Digest of International Law (1981-88) III, 2968.

602 For more on the US reaction see Keesing' s (1982) 31456.

603 Ibid.

604 Economic Sanctions - Invasion of Afghanistan (1979); Polish Repression (1981), Cumulative Digest of International Law (1981-88) III, 2970. 
service to be operated by designated carriers should be approved by both parties. Although numerous intergovernmental agreements had taken effect since the conclusion of the 1966 Agreement in order to determine the service levels, the last of these intergovernmental agreements had expired in 1979 with the common understanding that future agreement would determine the acceptable pattern of service. However, these negotiations never took place. It was, therefore, the position of the US government that since no further agreement existed on the schedules, frequency and capacity of flights conducted by Aeroflot, the latter was conducting its flights at the discretion of the US government. ${ }^{605}$ As noted, the suspension of Aeroflot's flights in response to the Soviet Union's involvement in the situation in Poland was not in violation of the Aviation Agreement as there was no guaranteed level of service under the agreement at that moment. At the same time, reference was made to the world events that preceded the decision on the suspension of Aeroflot's rights that, as noted, were of compelling significance. ${ }^{606}$ Nevertheless, it could be argued that the permission granted under the Federal Aviation Act of 1958 provided an extension of the agreement between the two states and, therefore, the US restrictions were in breach of its treaty commitments towards the Soviet Union. In this regard, the determination of a third state, in this instance of the United States to respond with coercive action against involvement in the serious suppression of fundamental human rights enhances further the argument in support of a general rule permitting solidarity measures.

Other measures decided against the Soviet Union included the suspension of issuance or renewal of export licences for high tech items such as electronic equipment and computers, the closure of the Soviet Purchasing Commission office in New York and the suspension of negotiations on the extension of the grain agreement between the two countries. Also, the suspension of negotiations for a new maritime agreement and the imposition of stricter requirements for port access to all Soviet vessels in the light of the forthcoming expiration of the US-USSR bilateral maritime trade agreement and as from that day. The United States also decided on the expansion of restrictions and controls on the export of oil and gas equipment and pipe layers to the Soviet Union, initially imposed in 1978 in response to human rights violations, to include commodities and technical data for transmission or refinement of petroleum or natural gas for energy usage. Finally, the United States announced their intention not to renew ending US-Soviet agreements, as for example the agreements on energy, science and technology. ${ }^{607}$ To the extent that these measures were not in violation of the 1972 Trade Agreement between the two countries noted earlier, they could be categorized as retorsion, although it may be that at least some of the export restrictions contravened the aim and purpose of that Agreement.

605 Ibid.

606 Ibid, 2971.

607 Ibid, 2969. 
At the same time, the United States put pressure on the countries participating in the construction of a new natural gas pipeline to withhold their cooperation with the USSR. However, France, Japan and West Germany refused to suspend the project. ${ }^{608}$ In January 1982 the United States ceased export licences for the export of components for gas compressor turbines needed for the construction of a pipeline deal between the Soviet Union and western European firms. ${ }^{609}$ It seems that some European states were reluctant to proceed with more determinative measures against the Soviet Union not on legal concerns, but rather on economic considerations. ${ }^{610}$ This conclusion is rather strengthened by the fact that not only did certain European states, including France and West Germany, not suspend already existing agreements with the USSR, they also proceeded with the conclusion of new ones. 611

In addition to these measures, in February 1982 the European Council decided to reduce its imports from the Soviet Union. ${ }^{612}$ This took effect with Council Regulation 596/82 with which the Council decided to suspend the preferential treatment of goods imported from the USSR that were exempted from quantitative restrictions according to previous Council regulations, because Community interests required so, although no further explanation was given. ${ }^{613}$ However, it needs to be noted that this concession had previously been unilaterally granted to the Soviet Union and, therefore, it could be argued that with its suspension no international obligations were infringed on the part of the European Economic Community. The EEC member states based their action on former Article 113. Greece, for political reasons denied participating in any kind of trade and other measures against the USSR. Accordingly, the regulation noted that Greece was not to join in the implementation of the measures against the USSR on grounds referring to economic and trade difficulties faced by it. ${ }^{614}$ Furthermore, it is noted that the EEC action against the USSR did not entail the violation of trade agreements within GATT context. ${ }^{615}$

The United Kingdom, by way of contrast, announced restrictions on the movement of Soviet and Polish diplomats and that there would be no new financial aid to Poland, measures that were not however inconsistent with international law. The UK government commented that these measures 'are not really sanctions as

608 Keesing's (1982) 31453.

609 Washington Post, 30 December 1981, A1 in Hufbauer et al. (1985) op. cit., 697.

610 Keesing's (1982) 31458.

611 Ibid, 31459.

612 State Trading Countries - USSR, Bulletin of the EC(1982: 2) 2.2.44.

613 Council Regulation (EEC) No. 596/82 of 15 March 1982 amending the import arrangements for certain products originating in the USSR, Of (1982) L72/15.

614 P.J. Kuyper, 'Community Sanctions against Argentina: Lawfulness under Community and International Law' in D. O'Keeffe and H.G. Schermers (eds) Essays in European Law and Integration (Kluwer: 1982) 141, 147.

615 Ibid, 165. 
such but a signal to the Polish and Soviet authorities of Allied disapproval. We believe this is just as strong a signal as the US measures.' ${ }^{\prime} 16$

In spite of action taken, particularly that of the United States, countries including France, Italy and West Germany continued their agreements with the Soviet Union. As a result, and by the summer of 1982, the US government announced the extension of the ban on oil and gas equipment sales to foreign subsidiaries of US firms and foreign companies that produced equipment under US licence. ${ }^{617}$ This decision, which was criticized by many European states as having extraterritorial effect, ${ }^{618}$ need not be examined here as it falls outside the scope of this book.

While the action taken against both Poland and the former Soviet Union show the willingness of states to resort to unilateral coercive action in protection of community interests, caution must be exercised so that any action taken by third states is the response to a breach of an obligation erga omnes. In these cases, the wrongful acts committed by the two states, particularly those by the Soviet Union, that empowered states not directly affected to react were not clearly identified. However, particularly in the case of Poland, the reaction was the result of serious human rights violations after the imposition of martial law in the country. Accordingly, the suspension of its aviation rights in violation of the 1972 Agreement binding between the United States and Poland constitutes countermeasures taken by a non-injured state for the purpose of safeguarding fundamental community interests, namely, the protection of human rights possessing an erga omnes character.

\subsubsection{US action against Nicaragua (1982)}

From the beginning of the 1980s, relations between the United States and Nicaragua were strained because of the alleged intervention of Nicaragua in the domestic affairs of neighbouring countries by providing military equipment to rebel groups and by trying to destabilise foreign governments. The United States, in particular, accused Nicaragua of intervention in neighbouring countries and of aggressive policies aimed at destabilizing the governments in Costa Rica, El Salvador, Guatemala and Honduras. ${ }^{619}$

In 1981 the United States government, in response to these violations, confirmed the indefinite suspension of all economic aid to Nicaragua provided under an economic aid package concluded between the two states in 1980.620 This specific measure, however, was not held by the ICJ, in the proceedings initiated by Nicaragua against the United States, to be in violation of the 1956 Treaty of

616 Washington Post, 16 February 1982, A1 in Hufbauer et al. (1985) op. cit., 689.

617 Hufbauer, ibid, 697.

618 Ibid, 697-8.

619 Keesing's (1982) 31616.

620 Keesing's (1981) 30977. 
Friendship, Commerce and Navigation and Protocol binding on the two states and, therefore, it could not be characterized as a countermeasure. ${ }^{621}$

A year later, the United States, by Proclamation No. 4941 established a quota on the import of sugar, a measure that had a direct impact on Nicaragua's exports of the product to the American market. ${ }^{622}$ This came in response to Nicaragua's alleged interference in the sovereignty of neighbouring countries that constituted a serious violation of a fundamental obligation. ${ }^{623}$ In 1984 a GATT panel was invited to look at Nicaragua's claims that the US action was in violation of its GATT obligations as it was taken for political rather than economic reasons and therefore it was unjustified as discriminatory. Not only did the United States not attempt to rebut Nicaragua's allegations, but also confirmed that its decision, although it had trade implications, was not taken for trade considerations. It refused to justify its action under any exception clauses or in the context of GATT. It rather stressed that the specific dispute could not be resolved in the context of GATT, without producing further arguments for this purpose. It is merely noted that the United States only contested that 'its action was fully justified in the context in which it was taken' ${ }^{2} 24$ The panel, restricted by its own terms of reference, found it sufficient to examine the dispute on the basis of GATT, accepting Nicaragua's claims, without, however, looking into the question of whether the US conduct could be justified under a right to countermeasures for the protection of fundamental interests of the international community. ${ }^{625}$

This example clearly falls within the concept of solidarity measures and, therefore, within the scope of this examination, as the United States did not hesitate to violate its trade obligations under GATT in response to violations that fell outside the GATT system. Nevertheless, it is necessary to establish that Nicaragua's actions constituted a serious breach of fundamental interests. This is an essential condition for the legality of countermeasures in order to remedy the fears of vulnerable states that such measures will not be subjected to abuse. Before one can therefore incorporate this example as indicative of state practice in support of third-state countermeasures, it must first be determined whether Nicaragua had infringed its international obligations and, if so, whether the infringed obligations had an erga omnes character.

It seems that the United States was particularly concerned about the increasing Soviet influence over Nicaragua, ${ }^{626}$ which by itself would not involve a violation of an interest owed to the international community as a whole. This is particularly so in view of fundamental international law principles according to which states are entitled to non-interference in their domestic affairs, with the exception of serious

621 Case Concerning Military and Paramilitary Activities in and against Nicaragua, (1986), op. cit., 138, (276).

622 Keesing's (1982) 31570.

623 Dawidowicz, op. cit., 379.

624 GATT Basic Instruments and Selected Documents, United States - Imports of Sugar from Nicaragua, Report of the Panel adopted on 13 March 1984, BISD/31S/67L/5607, (3.11).

625 Ibid.

626 Guttry, op. cit., 172. 
violations of human rights and free enjoyment of the political, economic and social system they wish to establish. However, the US action was a response to unlawful use of force by Nicaragua and, therefore, the imposition of quota on the import of sugar establishes another precedent in support of countermeasures by states other than the injured in response to a serious violation of international law that affected the legal interests of all states.

US reaction, however, did not cease there. In 1985 the US government issued Executive Order No. 12513 entitled 'Prohibiting Trade and Certain Other Transactions Involving Nicaragua'. The Order was justified on grounds of the unusual and extraordinary threat to national security and foreign policy as a result of Nicaragua's aggressive policies in Central America of subverting its neighbouring countries, destabilizing military buildup and enhancing its military and security ties with Cuba and the USSR. The Order prohibited all imports of goods and services from and all exports to Nicaragua. At the same time, all Nicaraguan aircarriers were banned from engaging in any transportation from or to the United States, while all vessels of Nicaraguan registry were prevented from entering US ports. ${ }^{627}$ Moreover, the United States gave 12 months' notice for the termination of the 1956 US-Nicaragua Treaty of Friendship, Commerce and Navigation and Protocol between the two states, a measure, however, that was in accordance with the provisions of the Treaty and in particular with Article XXVI, para 3. ${ }^{628}$

Nicaragua, for its part, argued that the trade embargo was in violation of the UN Charter, the Charter of the Organization of American States, GATT and the 1956 US-Nicaraguan Treaty of Friendship, Commerce and Navigation and Protocol. This was terminated by the United States, invoking arguments that the policies and actions of the Nicaraguan government were incompatible with normal commercial relations between the two countries. The treaty excluded from its scope conduct taken in the light of 'essential security interests' and, thus, the US action could be justified on express treaty provisions. The United States was reacting to Nicaragua's use of force in violation of the UN Charter against its neighbours, Costa Rica and Honduras, by entering their territory and supporting armed bands and rebels.

In a subsequent complaint filed by Nicaragua against the United States within the GATT context concerning the trade embargo, a GATT panel was actually unable to examine the merits of the case because the United States had invoked the security clause under Article XXI. However, the panel, not really convinced by the US justification, noted in its 1986 report that irrespective of whether the US action was justified under Article XXI, such boycotts contradicted the very purposes of GATT for non-discriminatory treatment and freedom from obstacles

627 Economic Sanctions - Nicaragua, Cumulative Digest of International Law (1981-88) III, 2979.

628 United States Diplomatic Note concerning economic sanctions, 24 ILM (1985) 811-816; United States notification of trade embargo, GATT doc. L/5803; United States - Trade Measures Affecting Nicaragua, Report by the Panel, L/6053, 13 October 1986, available at http://www.worldtradelaw.net/reports/ gattpanels/nicembargo.pdf. Also see Guttry, op. cit., 173. 
to trade practices. ${ }^{629}$ It is true that the national security clause must comply with the principle of good faith. ${ }^{630}$

The US embargo was further condemned as violating the Declaration on the Friendly Relations among States and the Charter of Economic Rights and Duties of States. Nicaragua also found support from the Coordinating Bureau of the Non-Aligned Countries, the member states of the Latin American Economic System and the member states of the Caribbean Community, ${ }^{631}$ although Denmark was one of the very few states that stressed that 'unilateral economic sanctions do not violate general international law'. ${ }^{632}$ Furthermore, at a UN level the Security Council and the General Assembly characterized the US action against Nicaragua as an unlawful exercise of economic coercion in violation of the Declaration on Friendly Relations and of GATT, ${ }^{633}$ although as Dawidowicz notes, there was no claim that such measures could only be resorted to by the UN. ${ }^{634}$

It is remarkable that when the dispute was brought by Nicaragua before the ICJ, the Court failed to examine the US termination of the 1956 Treaty on Friendship, Commerce and Navigation in the context of the law of countermeasures. That was despite the fact that the Court acknowledged Nicaragua's own wrongful acts and, in particular, the use of force in violation of Article 2(4) of the Charter. Instead, the Court stressed that a state was entitled to cease trade relations with a certain state only insofar as there was no treaty or other commitment under international law. ${ }^{635}$ Examining further whether the US decision to terminate the treaty could be justified under Article XXI of GATT, the Court held that in the absence of evidence from the United States, the embargo did not fulfil the condition of necessity for the protection of essential security interests as provided under that provision. ${ }^{636}$

The trade embargo, viewed in the context of general international law rather than that of a regime lex specialis such as the GATT, has legal significance for the purposes of the current examination. Although the US government did not rely in this instance on a right to respond to serious violations of collective interests by way of countermeasures, but rather on grounds of national security as it was already entitled to do under GATT, many states considered its action as unlawful

629 GATT Doc. L/6053 (1986) ibid,18.

630 Guttry, op. cit., 175.

631 Dawidowicz, op. cit., 380. Declaration on the Friendly Relations among States, op. cit.; also see Charter of Economic Rights and Duties of States, General Assembly Resolution 3281 (XXIX) of 12 December 1974.

632 See statement in United Nations Security Council Official Records, Doc S/PV 2578, 9 May 1985 (95) also cited in Dawidowicz, ibid, 381, fn 258.

633 US-Nicaragua Security Council res. 562 (1985).

634 Dawidowicz, op. cit., 382.

635 Case Concerming Military and Paramilitary Activities in and against Nicaragua (1986) op. cit., 138 (276). For a critical evaluation of the Court's judgment, see Frowein (1994) op. cit., 374 et seq.

636 Case Concerning Military and Paramilitary Activities in and against Nicaragua, ibid, 141, (281-82). Also see Frowein, ibid, 375. 
economic coercion. 637 This is further evidenced by GATT panel's report of 1986 that viewed the US trade embargo as an infringement of the US obligations under GATT. This may offer yet another example of third-state countermeasures although some authors have concluded that the 'motivation' behind the implementation of the embargo excludes this incident as a measure of this nature. ${ }^{638}$

\subsubsection{The Falklands crisis (1982)}

When in April 1982 Argentina invaded the Falkland Islands, the Security Council, acting on its Chapter VII powers, described Argentina's action as a breach of the peace and demanded it to cease hostilities immediately and to withdraw from the islands, while it called on the two countries involved in the conflict to resolve their differences by diplomatic means. ${ }^{639}$ However, no compulsory, military or economic action under Chapter VII was authorized. The United Kingdom, which was directly injured, called on other states to respond to this violation and, indeed, members of the European Economic Community, Australia, Canada and New Zealand implemented a number of economic measures such as the ban on all imports of Argentinean products.

In this regard, the EEC Council determined that the serious situation created by the invasion of the Falkland Islands required immediate and uniform response by all member states of the Communities. As a result, with Regulation 877/82 and later with Regulations 1176/82 and 1254/82, it decided on 16 April 1982 to suspend the import of all products originating from Argentina, including the suspension of two agreements regarding textiles and mutton and lamb, invoking both former Articles 113 and 224.640 Article 113 provided for a common commercial policy, while Article 224 imposed a duty on member states to consult one another for the purpose of preserving the common market, particularly when

637 See in this regard the position taken by Algeria, India, Mexico and Peru in United Nations doc. S/PV 2578, (9 May 1985) (9), (19), (66), (186), available at http://documents-dds-ny.un.org/ doc/UNDOC/GEN/NL8/500/29/pdf/NL850029.pdf?OpenElement; by Bolivia, Ethiopia, Madagascar and Ukraine in United Nations doc. S/PV 2579, (10 May 1985), (24), (47), (61), (75), available at http://documents-dds-ny.un.org/doc/UNDOC/GEN/NL8/500/15/pdf/NL 850015.pdf?OpenElement; by Argentina and Guyana in United Nations doc. S/PV 2580 (10 May 1985) (40), (44), (96), (147), available at http://document-dds-ny.un.org/doc/UNDOC/ GEN/NL8/500/32/pdf/NL850032.pdf?OpenElement. For detailed analysis on this, see Dawidowicz, op. cit., 381.

638 Dawidowicz, ibid, 382-3.

639 Falkland Islands (Malvinas) Security Council res. 502 (1982).

640 Council Regulation (EEC) No. 877/82 in $O \mathcal{F}$ (1982) L/102/1 (16 April 1982); Council Regulation $1176 / 82$ in $O \mathcal{f}(1982) \mathrm{L} / 136 / 1$ (18 May 1982). The treaties can be found in $O f(1979) \mathrm{L} / 298 / 2$ (26 November 1979), Treaty concerning textiles, and Arrangement in the form of an exchange of letters between the European Economic Community and the Argentine Republic on trade in mutton and lamb, Of (1980) L/275/14 (14 October 1980); Council Regulation (EEC) extending the suspension of imports of all products originating in Argentina, No. 1254/82, Of(1982) L/146, 1-1 (24 May 1982). 
affected by measures taken by a member state in compliance with its obligations for the maintenance of international peace and security. ${ }^{641}$ As noted in the preambular paragraph of the regulation: '[T]he interests of the Community and the Member States demand the temporary suspension of imports of all products originating in Argentina.' 642 These measures were in violation of obligations emanating from GATT but also in violation of the two agreements regarding textiles and mutton and lamb that required a notice of 3 and 12 months respectively for their suspension. They were, however, required because as noted a territory associated with the Community had been occupied by the use of force. ${ }^{643}$ Accordingly, their sole aim was to compel the withdrawal of Argentinean forces from the Falklands. ${ }^{644}$

With a subsequent decision of the representatives of the governments of the member states of the European Coal and Steel Community, the imports of all Argentinean products falling under the specific agreement were also suspended. ${ }^{645}$ On no occasion did the EEC Council express hesitation about the legitimacy of such action in international law, in contradiction to their stand towards the regime of Idi Amin only a few years earlier.

Nevertheless, some member states distanced themselves from the implementation of the measures provided for under these regulations. Denmark seemed to oppose the idea that trade means could be used for political purposes on the basis of Article 113. Instead of challenging the regulations before the EGJ, the judgment of which could undermine significantly such EEC measures, it preferred to announce that since it lacked the legal basis for implementing this form of action it was imperative to enact national legislation giving effect to the measures against Argentina. ${ }^{646}$ Ireland and Italy, by way of contrast, relied on former Article 224 not to apply the measures. ${ }^{647}$ Zoller, in particular, comments that this fact is

641 Former Article 113 (now Article 133) constitutes the legal basis for the uniform commercial policy of the EC member states, while former Article 224 (now Article 297 of the EC Treaty) in particular attempts to reconcile obligations falling under the EEC and obligations arising under the UN Charter. See Treaty Establishing the European Community, Of(2006) C 321 E/37 (29 December 2006); Council Regulation (EEC) No. 877/82 of 16 April 1982 suspending imports of all products originating in Argentina, Of (1982) L102/1. For the text of these agreements see Council Regulation (EEG) No. 2557/79 of 30 October 1979 concerning the conclusion of the Agreement between the EEC and the Argentine Republic on trade in textile products, Of (1979) No. L298/1; Council Regulation (EEC) No. 2642/80 of 14 October 1980 laying down conditions for the application of protective measures in the sheepmeat and goatmeat sector, $O \mathcal{F}(1980) \mathrm{L} 275 / 4$.

642 In Kuyper (1982), op. cit., 142.

643 Ibid, 152.

644 Community solidarity in the Falklands Conflict, Bulletin of the EC(1982) No. 4, 7.

645 Council Regulation (EEG) No. 877/82 of 16 April 1982 suspending imports of all products originating in Argentina, Of (1982) L102/1, 3.

646 Kuyper (1982), op. cit., 149-50.

647 Ibid. Former Article 224 has been invoked by member states to justify not only the imposition of sanctions against a third state, but also unilateral deviations from sanctions taken on the basis of former article $113 \mathrm{EC}$, such as was the case of Ireland and Italy in the EC sanctions against Argentina. For a European law perspective, see analysis by P. Koutrakos, Trade, Foreign Policy and 
evidence that the EEC measures were not adopted by the Community as an international organization or by a Community institution, but rather as a result of the collective decision of the member states. ${ }^{648}$

Argentina, for its part, claimed that the EEC action against it was in violation of the UN Charter, the GATT and the Charter of Economic Rights and Duties of States. The EEC's action was also criticized by other GATT parties, ${ }^{649}$ which argued that the measures were taken for political reasons and not on bona fide economic grounds. ${ }^{650}$ With respect to the argument that the EEC measures were in violation of the UN Charter this rests on the incorrect assumption that the implementation of economic measures, such as in the case of authorization of the use of armed force, falls within the monopoly of the Security Council. ${ }^{651}$

Regarding Argentina's claims that the EEC measures were in violation of GATT, ${ }^{652}$ it was argued that such measures could fall under the security clause according to which action could be justified for the protection of essential security interests, the determination of which is left to the member states. In fact, the European Economic Community and the other states imposing trade sanctions on Argentina claimed that while these measures affected the latter's rights under GATT, they were justified by reference to the national security exception under Article XXI GATT. Nevertheless, according to Dawidowicz, Article XXI did not apply in this particular instance and therefore, the EEC measures were in violation of this agreement. ${ }^{653}$ More specifically, the justification of the suspension of the two agreements between the European Economic Community and Argentina on the trade of textile products, on the one hand, and of mutton and lamb, on the other, under the security exceptions of GATT was rather tense. While the first treaty was concluded on the basis of Article 4 of the Multi-Fibre Agreement within the GATT, the relationship was more tenuous concerning the second agreement on mutton and lamb. As noted: '[T] hough it is a type of self-limitation

Defence in EU Constitutional Law: The Legal Regulation of Sanctions, Exports of Dual-use Goods and Armaments (Hart Publishing: 2001) 86.

648 E. Zoller, Peacetime Unilateral Remedies: An Analysis of Countermeasures (Transnational Publishers, Inc., Dobbs Ferry: 1984) 104. It is argued by White and Abass that the confusion between state and institutional practice, namely measures taken by international organizations such as the EEC/ EU, on third- state countermeasures does not corroborate the existence of a right to third-state countermeasures. White and Abass, op. cit., 526-7.

649 GATT Communique - Trade Restrictions affecting Argentina applied for Non-economic Reasons, 18 May 1982, GATT doc. L5319/Rev.1; Trade Restrictions affecting Argentina applied for Non-economic Reasons, 30 April 1982, GATT doc. L5317; also see the position of Spain and Brazil, Minutes of Meeting, 22 June 1982, GATT doc. C/M/157, 5-6.

650 See Ministerial Declaration on Dispute Settlement Procedures, adopted on 29 November 1982, L/5424, Basic Instruments and Selected Documents, Supplement No. 29, 9. Also in Keesing's (1983) 32169A.

651 Kuyper (1982), op. cit., 152.

652 See GATT Communique, op. cit.; Trade Restrictions affecting Argentina applied for Non-economic Reasons, 15 June 1982, L/5336; Position taken by Spain and Brazil, Minutes of Meeting, 22 June 1982, GATT doc. C/M/157, 5-6; Report on Work since the Thirty-Seventh Session, 12 November 1982, L/5414, 17.

653 Dawidowicz, op. cit., 368. 
agreement which is common in the framework of GATT, it does not find a legal basis within GATT itself or in any instrument based on the GATT' ${ }^{654}$ Furthermore, it was stressed that the security exceptions did not necessarily apply to all agreements concluded within GATT as an organization and that in any case the European Economic Community could not be regarded as the injured party to the dispute. ${ }^{655}$

Significantly, in a joint statement made by EC member states, Australia and Canada, it was noted that their action was justified by their 'inherent right of which Article XXI of the General Agreement is a reflection', while the European Community representative argued that 'inherent rights constituted a general exception to the GATT' ${ }^{656}$ This suggests that states assumed a right existing under general international law to resort to the action they did irrespective of the national security exceptions provided under GATT. It is suggested by Dawidowicz, in particular, that the reference to 'inherent rights' extends to a customary right to third-state countermeasures that amounts to a general exception to GATT. ${ }^{657}$

Other commentators concluded that the EEC action did not constitute a countermeasure. Kuyper, in particular, examining whether the EEC measures could be justified as reprisals or countermeasures, is not convinced beyond any doubt that there exists a right on states not directly injured by a certain wrongdoing to violate their own international obligations in the form of reprisals. He bases his view in the light of the ILC's conclusions at the time, according to which preference was given to the collective protection of fundamental community interests rather than to allowing states or a group of states acting unilaterally to enforce international law. ${ }^{658}$ According to him, third-state reprisals tend to disregard the role of the UN system in the maintenance of international peace and security and entail risks for the European Economic Community itself regarding similar situations against which it does not wish to bring any collective action. ${ }^{659}$ As Kuyper points out, the entitlement of the European Economic Community to resort to reprisals against Argentina created difficulties not only because 'the EEG would set itself up as some minor policeman of this world' but also due to the fact that:

$[\mathrm{T}]$ hird party reprisals are looked at askance in international law, although it has been shown above that there are indications in state practice and in the doctrine which tend to support a right to reprisal by third states, if the target

654 Kuyper (1982), op. cit., 154.

655 Ibid.

656 Joint statement by the European Community, Australia and Canada, 'Trade Restrictions Affecting Argentina Applied for Non-Economic Reasons', GATT doc. L 5319/Rev. 1 (5 May 1982) (1) (b) and GATT doc. C/M/157, 10, available at http://www.wto.org/gatt_docs/English/ SULPDF/90440042.pdf.

657 Dawidowicz, op. cit., 370.

658 Kuyper (1982), op. cit., 158.

659 Ibid, 159, 162-3. 
state has infringed very fundamental rules of international law, such as the prohibition of the use of force. ${ }^{660}$

He thus takes the view that the EEC action was justified under the right of collective self-defence contained in Article 51 of the UN Charter, since the United Kingdom had an established right to individual self-defence as the victim of the unlawful military conduct of Argentina. According to him, this solution is more preferable as it incorporated the EEC action within the UN system and did not alienate it from it. ${ }^{661}$ Zoller also suggests that the EEC action relied rather on a right to collective self-defence. She justifies this by the fact that when addressing the issue before GATT, the measures were referred to as measures taken by the Community and its member states on the basis of their 'inherent rights', a phrase used in Article 51 to refer to the right to self-defence. ${ }^{662}$ However, it is significant to note that the notion of collective self-defence was never expressly referred to within the debates in GATT and was not relied on as justifying the action taken against Argentina. 663

In addition to the EEG measures, West Germany imposed a trade embargo against Argentina and suspended its civil aviation agreement a move it justified not on collective self-defence but rather on a general right to suspend the treaty even if this was not expressly provided for under the treaty. ${ }^{664}$ This justification provides yet another clear example of third-state countermeasures. Norway, for its part, prohibited imports from the targeted state, ${ }^{665}$ while Belgium, France, the Netherlands and West Germany banned arms sales to Argentina. Belgium, in particular, affirmed the right of individual states to resort to unilateral peaceful coercive measures outside the framework of the UN whenever a grave breach of the United Nations Charter occurs. ${ }^{666}$ Canada, greatly concerned by the use of force by Argentina as a means for settling a dispute over a territory, recognized the United Kingdom's right to self-defence. It was on this basis that Canada decided to impose a ban on exports of war material and on all military shipments to Argentina and introduced restrictions on the import of Argentinean goods to Canada. ${ }^{667}$ New Zealand, for its part, announced an import and export ban and the suspension of a civil aviation agreement with Argentina. ${ }^{668}$

660 Ibid, 165.

661 Ibid, 158.

662 Zoller, op. cit., 104-5.

663 Tams, op. cit., 216.

664 Hufbauer et al. (1985) op. cit., 718; Dawidowicz, op. cit., 373.

665 Financial Times, Latin American Markets, 10 May 1982, 3; Financial Times, 13 July 1982, 14 in Hufbauer, ibid, 719.

666 See Belgium's statement on behalf of the European Community, UN doc. S/PV 2363, 23 May 1982, (131-32), available at http://documents-dds-ny.un.org/doc/UNDOC/GEN/ NL8/200/43/pdf/NL820043.pdf?OpenElement.

667 Argentina - Attack on Falkland Islands, House of Commons Debates (Canada), CYIL (1983) 359-60.

668 Keesing's (1982) 31533; Also see A. de Mestral, 'Canadian Practice in International Law during 1982' 21 CYIL (1983) 337 and 'Australian Practice in International Law, 1981 to 1983', 10 AYIL (1983) 573. 
More interestingly, the United States, like Argentina a member of the Organization of American States (OAS), decided on the implementation of numerous measures with considerable economic and political effects that contributed to the outcome of the dispute. ${ }^{669}$ Apart from the logistical and material assistance it was providing to the United Kingdom, the United States suspended all military exports and security assistance to Argentina, withheld the certification of Argentina's eligibility for military sales, suspended the Export-Import Bank credits and guarantees and suspended the Commodity Credit Corporation guarantees. The US government justified its position by reference to the principles of law and the peaceful settlement of disputes in consequence of Argentina's refusal to accept a compromise. The US Secretary of State, in particular, referred to the need to take action in the light of the use of unlawful force for the resolution of disputes, rejecting at the same time that the US military would engage in the hostilities. ${ }^{670}$ This has legal significance for the question of solidarity measures as the US measures did not rely on a self-defence argument and, therefore, they could only find justification in general international law.

Many states, however, especially within the inter-American system, viewed these measures as in violation of the OAS principles and international law. By Resolution I adopted during the 20th Consultation of Ministers of Foreign Affairs and by a great number of OAS member states a few weeks only after the dispute, the EEC and US measures were deplored since they were neither authorized by the Security Council nor were they consistent with the UN and OAS Charters or the GATT. The United States was called on to lift the coercive measures and to cease any material assistance to the United Kingdom in conformity with the principle of solidarity recognized under the Inter-American Treaty of Reciprocal Assistance. ${ }^{671}$ In another resolution adopted by the OAS Inter-American Economic and Social Council it was declared that the economic measures against Argentina were in breach, inter alia, of Article 19 of the OAS Charter. Article 19 provides that: 'No state may use or encourage the use of coercive measures of an economic or political character in order to force the sovereign will of another state and obtain from it advantages of any kind.'672

Acevedo takes the view that the US decision to implement unilateral withdrawal of benefits from Argentina was unlawful on the grounds on which it relied, namely, to force Argentina to accept contrary to its own wish a compromise on the conflict and which was punitive in nature. ${ }^{673}$ Furthermore, Acevedo points to the justification used for the suspension of the Export-Import Bank credits and guarantees in

669 A. Acevedo, 'The U.S. Measures against Argentina Resulting from the Malvinas Conflict' 78 AfIL (1984) 323.

670 See Haig's Statement, Secretary of State, 30 April 1982, New York Times, 1 May 1982, 8, col.5 in ibid, 340. Also see Keesing's (1982) 31709.

671 Inter-American Treaty of Reciprocal Assistance (Rio) (modified by the 1975 Protocol of San José), 2 September 1947, 21 UNTS 77, available at http://www.oas.org/juridico/english/ Treaties/b-29.html; in Acevedo, ibid, 338.

672 In Acevedo, ibid, 331, fn 23.

673 Ibid, $337-8,341$. 
Public Notice 805, which relied on the US policy and national interest. ${ }^{674}$ Yet, at the OAS Economic and Social Council meeting held in October 1982, the US government rebutted the suggestion that it had been involved in the adoption of coercive measures against Argentina. As noted:

The United States had no legal obligation to keep up the benefits that it withdrew from Argentina, nor did it violate any existing agreement with that country. The measures the United States adopted were not intended to obtain advantages of any kind; quite to the contrary, their purpose was to demonstrate the consistency of the United States vis-à-vis the principle of peaceful settlement of disputes. The measures taken by the Government of the United States demonstrated the United States' adherence to the basic principles of international law and were fully in keeping with its international obligations, and particularly with the pertinent resolution adopted by the United Nations Security Council. ${ }^{675}$

According to Acevedo this legal argumentation seemed contradictory in many respects. ${ }^{676}$ More specifically, it denied the existence of US coercive measures against Argentina, something that went beyond the statement of the Secretary of State on the matter. It further contradicted the purpose of Public Notice 805, the purpose of which was to advance US policy and national interests and, lastly, it denied that there had been any violation of an agreement existing between the two states, thus implying that the UN and OAS Charters and GATT were not agreements between Argentina and the USA. ${ }^{677}$

Indeed, the US measures were in violation of the obligations of the United States under GATT. It is relevant here to note the US reliance on the Security Council resolution passed on the dispute to justify its action. The Security Council had adopted no mandatory resolution on the matter and, therefore, the US action lacked legal basis in that respect. Accordingly, their effort to safeguard fundamental interests of international law could only rely on solidarity measures. The action decided against Argentina reveals, therefore, the determination on the part of the US government to respond with economic and other measures to a serious violation of the international legal order, even if no direct injury was sustained by it.

With respect to the EEC collective non-forcible measures, these offer another example of peaceful coercive remedies taken outside the context of a Security Council mandate and in violation of specific treaty obligations. This was made in an acknowledgment that the unlawful use of force could not leave other states unaffected, even if

674 Ibid, 341.

675 See Piedra's Statement, US Representative to the Inter-American and Social Council (translated by Acevedo from the Spanish version as reported by the Associated Press on 21 October 1982), reproduced in OAS Department of Public Information, Servicio Informativo, 22 October 1982, at 1 in ibid, 342 .

676 Acevedo, ibid, 342.

677 Ibid, 342. 
again the EEC and its member states, with the exception of the UK, were not the direct victims of attack by Argentina. The EEC action has nevertheless raised questions as to whether it could be justified as countermeasures or as part of the exercise of the right to collective self-defence, making the distinction between them necessary. ${ }^{678}$

It can be deduced that while the legal basis of particularly the European Community action is not entirely clear, moving between a claim of collective selfdefence and solidarity measures, the reaction of the OAS and GATT indicates that the action could not be justified under a right to self-defence or under the national security clause. Significantly, the reaction of OAS member states in support of Argentina did not rely on a general objection of countermeasures of this nature, but rather on the support given by American states to the Argentinean territorial and sovereign claims over the Falklands. This is of legal importance as the stance that these states have taken does not reflect their protest against a rule permitting solidarity measures, but even in the unlikely case that it did, it would not by itself be sufficient to prevent the formulation of a customary rule to that effect. ${ }^{679}$

\subsubsection{Non-forcible action against the Soviet Union for the destruction of a civil aircraft in flight (1983)}

In September 1983 the USSR shot down and destroyed a South Korean aircraft that had strayed into Soviet airspace, killing all the people on board, which included nationals of several states. The USSR justified its act by the allegation that the aircraft had been involved in spying against it, although later it was proved that the aircraft was a civilian and unarmed Korean Airlines plane.

The United States responded to this 'heinous' act with a number of measures concerning aviation rights of Aeroflot in the United States. In particular, the government announced the suspension of Aeroflot's right to sell tickets, the prohibition of US airlines from selling tickets for transportation with Aeroflot and the prohibition of US airlines from carrying traffic to, from or within the United States where an Aeroflot flight is on the ticket. Moreover, the government instructed US airlines to suspend any interline service arrangements with Aeroflot and decided on the prohibition of American Airlines from accepting tickets issued by Aeroflot for air travel to, from or within the United States. According to the US government, since there were no agreed services under the 1966 US-USSR Civil Transport Agreement the USSR had no right to have the Aeroflot services in the United States maintained. This legal justification is similar to the one advanced previously by the United States in relation to the action taken against the USSR for its involvement in the repression in Poland in 1981.680

678 Dawidowicz, op. cit., 373.

679 For the role of dissidence in the formation of customs see Dissenting Opinion of Judge Tanaka, South West Africa cases (Second Phase), op. cit., 291.

680 United States-USSR: Suspensions, Cumulative Digest of US Practice in International Law (1981-88) II, 2190. 
While there were American nationals among the passengers killed, thus entitling the United States to action as an aggrieved state, the US government placed particular emphasis on the fact that the Soviet action was in violation of fundamental community interests. In particular, it was stressed that the shooting was a violation of both general international law concerning the prohibition of the use of force and also of the ICAO concerning the signal, warning and guidance procedures for the interception of civilian aircrafts. ${ }^{681}$ President Reagan demanded that the Soviet Union give a full explanation of the circumstances of the shooting, an apology and reparations for the families of the victims. He further stressed that the intention was not to take vengeance against the Soviet Union but rather to ensure non-repetition of such act. ${ }^{682}$

For its part the USSR did not deny the existence of a rule prohibiting the use of force, but rather attempted to justify its action on the basis of another customary norm, in particular the norm concerning the treatment of aircraft that were involved in an espionage mission. ${ }^{683}$

In a draft resolution by the Security Council, subsequently vetoed by the USSR, it was stated that the Soviet action was in violation of 'elementary considerations of humanity'. ${ }^{684}$ Moreover, the ICAO Council referred to the shooting as a serious violation of international law. ${ }^{685}$ However, in the absence of collective action at a UN level, certain other states including Canada, Japan, Spain, the United Kingdom and West Germany and other NATO countries (with the exception of France, Greece and Turkey) announced a 2-week prohibition on all Soviet Aeroflot flights from and to their territories. ${ }^{686}$ The suspension of civil aviation rights was initially based on a recommendation made by the International Federation of Airline Pilots in the light of which a number of national pilot associations suspended flying to the USSR for a period of up to 60 days. ${ }^{687}$ While this decision was not taken directly by state authorities, the suspension was attributed to the states of the national pilot associations taking part in the action. ${ }^{688}$ Moreover, this decision was in violation of specific aviation agreements with the Soviet Union. France and Germany for instance acknowledged

681 The Legal Analysis of Soviet Actions, prepared by Patrick J. Norton, Assistant Legal Adviser for East Asian Affairs, and by Mary Beth West, Assistant Legal Adviser for European Affairs, 15 September 1983, in Destruction of Civil Aircraft in Flight, Cumulative Digest of US Practice in International Law (1981-88) II, 2199-2209.

682 Washington Post, 6 September 1983, A4 in Hufbauer et al. (1985) op. cit., 740.

683 Legal Argumentation in International Crises: The Downing of Korean Airlines Flight 007, 97 HLR (1984) 1198.

684 In M. Kido, 'The Korean Airlines Incident on September 1, 1983, and Some Measures Following it' 62 Journal of Air Law and Commerce (1997) 1049, 1052. Also see Petman, op. cit., 362.

685 International Civil Aviation Organization Consideration 22 ILM (1983) 1149-51.

686 Hufbauer et al. (1985) op. cit., 739, 741.

687 Action taken by the International Federation of Airline Pilots, 6 September 1983, 22 ILM (1983) 1218-19. Also see Dawidowicz, op. cit., 374.

688 Dawidowicz, ibid, 374. Also see Keesing's (1983) 32513-16. 
that such suspension of their respective bilateral aviation agreements with the USSR was not provided for. ${ }^{689}$

While some of the states that supported the suspension were injured states, such as Canada, Japan, South Korea, Sweden, the United Kingdom and the United States, and therefore justified in taking countermeasures, other states such as Finland, France, Germany, Spain and Switzerland had suffered no direct injury. Therefore, their action could only be justified in the context of solidarity measures. ${ }^{690}$ Moreover, their action came despite continuing debates to resolve the dispute at a UN level. Importantly, in 1984, the ICAO Council, making particular reference to the shooting incident highlighted that 'such use of force constitutes a violation of international law, and invokes generally recognised legal consequences'. ${ }^{691}$

It can be concluded from the analysis just undertaken that the suspension of aviation rights decided at least by some of the states mentioned in that analysis, amounted to countermeasures taken in response to a serious violation, namely the unlawful use of force, by states that were not directly affected by the violation.

\subsubsection{Countermeasures against the apartheid regime in South Africa (1960-64 and 1986)}

\subsubsection{INTRODUCTORY NOTE}

The problem of race segregation in South Africa had extensively occupied the discussions at the UN in the 1960s resulting in the adoption of several resolutions, especially by the General Assembly, in condemnation of the racial policies of the South African regime. Many states also insisted on a harsher reaction with the implementation of several economic and trade measures against the country. In 1977, amid growing international unrest concerning apartheid, the Security Council acting under Chapter VII of the UN Charter imposed a mandatory embargo on arms, ammunitions, weapons and military equipment to South Africa. The embargo was imposed as a reaction to the apartheid policies of South Africa that imposed a threat to international peace and security. ${ }^{692}$ Apartheid was also a violation of the right to self-determination, later incorporated in the 1970 General Assembly Declaration on Principles of International Law Concerning Friendly Relations and Co-operation among States, according to which people have a right to be ruled by a government without distinction as to race, creed or colour. 693 While the Declaration does not create legally binding effects, the right to self-determination not only finds expression in customary international law, but

689 Dawidowicz, ibid, 375.

690 Ibid. Also see Keesing's (1983) 32514; 'National Actions Taken in Response to the Destruction of the Korean Air Lines Aircraft', 22 ILM (1983) 1197, 1199, 1201, 1205, 1218.

691 Resolution adopted by ICAO Council on 6 March 1984, 23 ILM (1984) 937, (4).

692 South Africa Security Council Res. 418 (1977).

693 See Ferguson-Brown, op. cit., 61-2. 
it also establishes obligations erga omnes as the ICJ ruled in the Barcelona Traction case. According to the findings of the ICJ, the South African practices of racial segregation and the denial of fundamental human rights were 'a flagrant violation of the purposes and principles of the UN Charter' ${ }^{694}$

The following sections consider in some depth the international reaction against apartheid and the efforts made to bring such policies to an end. It will be shown that states supported not only in words but also in practice unilateral coercive peaceful measures against South Africa, responding not as injured states but rather as states that were upholding fundamental interests of the international community as a whole.

\subsubsection{THE INDIAN REACTION (1946)}

In 1946, immediately after the end of World War II, India was the first state to take the path of trade measures against South Africa for its apartheid policies and for what it characterized as an issue that touched the conscience of the world. ${ }^{695} \mathrm{It}$ raised the matter before the General Assembly, arguing that with the 1946 Asiatic Land Tenure and Indian Representation Act passed by the South African government imposing complete segregation on trade and residence, South Africa had repudiated the Capetown Agreement between the two countries. ${ }^{696}$ South Africa, in response, argued that since the question concerned not Indian nationals but rather Indian nationals of South Africa, the issue fell within its domestic jurisdiction allowing for no outside interference. However, reference was also made to the Capetown Agreement whose object according to South Africa was to encourage emigration back to India and to improve the life of those who remained. ${ }^{697}$ It has not been possible to assess the nature of the measures imposed by India and, in particular, whether they were in violation of international law. However, from South Africa's response it may be deduced that India was a third party as the discriminatory measures were imposed against South African citizens, even if they were of Indian origin. Unfortunately, no more information could be obtained on this incident and therefore the legality of the Indian response and its categorization as a solidarity measure could not be confirmed.

694 Legal Consequences for States of the Continued Presence of South Africa in Namibia, op. cit., 57, (131).

695 L. de Villiers, In Sight of Surrender: The US Sanctions Campaign against South Africa, 1946-1993 (Praeger: 1995) 1.

696 Capetown Agreement, 1927, Foint Communiqué issued by the South African and Indian Governments, February 21, 1927, available at http://www.anc.org.za/ancdocs/history/people/gandhi/appendix.htm. In an exchange of letters between representatives of the Indian and South African governments, it was pointed out that Indians and their successors would be able to live and trade freely in South Africa, in the areas in which they were living. See Letter dated J7 uly 1914, from Gandhi to Gorges, http://www.anc.org.za/ancdocs/history/people/gandhi/appendix.htm

697 Letter of Indian Government of 22 June 1946 to be discussed in first session by General Assembly, UN Yearbook (1946-47) 144; Keesing's (1946) 8325. 


\subsubsection{REACTION OF AFRICAN STATES}

In the conference conducted by independent African states in Addis Ababa in the summer of 1960, African states were called on to react to the 'shameful' racial discrimination policies of South Africa and to take various measures in response. These included the imposition of trade embargoes on all African products, the closure of their ports to all South African vessels, the prohibition of vessels carrying their flags from using South African ports and the refusal of landing and overflight rights to aircraft owned by South Africa. The decision taken is significant as it establishes the legal belief of the African states that they could enforce the protection of fundamental human rights even by violation of their treaty and other obligations under international law. A month after the adoption of this resolution, Ghana was the first state to implement the decision by imposing a total embargo on all South African products and to close its ports and airports to South African planes and ships. It even required South Africans entering its territory to declare their opposition to apartheid and, if refused, denied them entry. ${ }^{698}$ Indonesia, Kuwait, Malaysia, Nigeria, Pakistan, Sierra Leone, Tanganyika and Uganda also decided on the implementation of a trade embargo in 1960, while some of these states also imposed an air ban and restrictions on port use against planes and vessels with a South African flag. ${ }^{699}$

The Organization of African Unity (OAU) extended these measures in 1963 recommending the termination of diplomatic and consular relations, port and airport closure and prohibition of South African aircraft from using the air space of African states. ${ }^{700}$ Cameroon, Ivory Coast, Libya and Sudan, for instance, closed their ports and airports to Portugal and South Africa. Uganda, in addition to those countries, announced the ban on the export of goods to South Africa. ${ }^{701}$ The General Assembly also reacted to the apartheid policies through the adoption of Resolution 1761 in 1962 according to which South Africa was declared to be in serious violation of international law and recommended the implementation of a trade embargo against it. ${ }^{702}$

Hungary, for its part, announced in July 1963 the cessation of trade relations with South Africa, India imposed a ban on landing and related facilities to South African aircraft, Indonesia decided on closure of its ports, a measure followed by Kuwait, while the Philippines imposed a ban on the import of mahogany. ${ }^{703}$ Sierra Leone also announced a trade and commerce ban on

698 See New Tork Times, 25 June 1960, col. 6; 30 July 1960, 1 col. 1.

699 Keesing's (1963-64) 19699.

700 Ibid, 19463, 19468. Also see Resolution of Organization of African Unity on Apartheid and Racial Discrimination, available at http://www.africa-union.org/root/au/Documents/Decisions/ hog/aHoGAssembly1963.pdf.

701 Keesing's (1963-64) 19699.

702 On South Africa (Apartheid) General Assembly Resolution 1761 (6 November 1962).

703 Keesing's (1963) 19757. 
South Africa together with a prohibition of all South African vessels and aircraft from entering its jurisdiction. ${ }^{704}$

As many of these states, including South Africa, were members of GATT, any trade restrictions would have to be justified in the light of one of the saving clauses of GATT and, in particular, under Articles XIX-XXI. However, none of these states tried to justify its action in the light of any of these provisions and, therefore, their actions could not be justified under GATT, but rather as third-state countermeasures. ${ }^{705}$

\subsubsection{CALLS FOR THE IMPOSITION OF AN OIL EMBARGO \\ AGAINST SOUTH AFRICA}

Despite the mandatory Security Council Resolution 418 (1977) authorizing the implementation of an arms ban against South Africa, the Security Council fell short of authorizing a mandatory oil embargo against the regime. The reluctance for such further action was due to the opposition of mainly western European states that were mainly concerned about the interests of their oil industries, ${ }^{706}$ rather than the unlawfulness of such measure under international law. Such an oil embargo was regarded as complementary to the arms ban and as essential for coercing the regime into ceasing its discriminatory policies. Despite the reluctance of western states, the Arab states were determined to implement an oil embargo against South Africa. Therefore, in the Summit Conference of Arab States held in Algiers in 1973 a total oil embargo was decided on. This was followed by calls made by the Special Committee against Apartheid for national parliaments to give effect to such an embargo against South Africa. ${ }^{707}$ The General Assembly had on a number of occasions called on UN member states to implement a petroleum ban against the country. ${ }^{708}$ In December 1975, the General Assembly reinforced its call on all states 'to take the necessary measures' for an embargo in the supply of petroleum and petroleum products and raw materials to South Africa. ${ }^{709}$

The same call was repeated in 1976, 1977 and 1979.710 In 1980 the General Assembly, while urging the adoption of a mandatory Security Council resolution, positively commended those states that had already implemented such an oil embargo even in the absence of a Security Council resolution. It also urged other

704 Keesing's (1961) 18186.

705 Tams, op. cit., 90; Dawidowicz, op. cit., 353.

706 E.S.Reddy, 'A Review of United Nations Action for an Oil Embargo against South Africa', with special reference to the work of the Special Committee against Apartheid, Director, United Nations Centre against Apartheid, Brussels, 30-31 January 1981, available at http://www.anc. org.za/un/reddy/oilembargo.html.

707 Ibid.

708 See, in this regard, General Assembly Resolution 1899 (XVIII) of 13 November 1963.

709 General Assembly Resolution 3411 G (XXX) of 10 December 1975.

710 General Assembly Resolution 31/6 of 26 October 1976; General Assembly Resolution 32/105 of 14 December 1977; General Assembly Resolution 34/93 of 12 December 1979. 
states 'to take effective legislative and other measures to ensure the implementation of such an oil embargo against South Africa as well as embargoes already imposed by States, individually or collectively'. ${ }^{711}$ The resolution demonstrates support for unilateral coercive measures taken by third states in the name of community interests. It was adopted by 123 states, including many members of GATT such as Egypt, Finland, Haiti, Norway, Pakistan, Sri Lanka and Sweden. Attempts at implementing an oil embargo were also taken at the level of the OAU.712 Interestingly, Nigeria proceeded to the nationalization of the assets of British Petroleum that was providing South Africa with oil, a measure commended by the Special Committee against Apartheid. ${ }^{713}$

The calls for the implementation of an oil embargo against South Africa show a general acceptance of unilateral coercive measures in the absence of mandatory Security Council resolution to that effect. In conclusion, these attempts can be used as further evidence of both state practice and opinio juris in recognition of a right to solidarity measures.

\subsubsection{US REACTION}

In an in-depth examination of the US policy on the apartheid regime in South Africa it is observed that never before had the United States been so successful in protecting human rights abroad and leading the racist regime to its slow death. This was achieved by means of both sustaining regional diplomacy and taking into consideration strategic interests in the African continent and adopting a more dynamic approach through the implementation of unilateral coercive peaceful measures. It is argued in this regard that nothing was as effective as a threat to the structures of apartheid policies as the economic measures taken by the United States alone in the mid-1980s, not even the multilateral oil and arms embargoes against South Africa imposed by the UN in the 1960s and 1970s. ${ }^{714}$ Only when a firmer approach was adopted by the United States, at the time one of the closest trading partners and major investors in South Africa and in combination with the formulation of strong opposition within South Africa itself, was the regime induced to bring these policies to an end. ${ }^{715}$ The US decision to take action influenced other economic powers such as Japan and the United Kingdom to do the same. Similarly, other smaller states followed with the adoption of what they described as 'symbolic gestures'. ${ }^{716}$ The incentive behind the American measures

711 General Assembly Resolution 35/206 of 16 December 1980.

712 Reddy, op. cit.

713 Ibid.

714 P. Baker, 'Getting It Right, U.S. Policy in South Africa' in Liang-Fenton D. (ed.) Implementing U.S. Human Rights Policy (2004) 86.

715 Baker, ibid 93.

716 Villiers, op. cit., xiv. 
was not to overthrow the regime but rather to reinforce domestic forces fighting apartheid. ${ }^{717}$

Nevertheless, the US government was not always in favour of a stronger line with measures of an economic character against South Africa. When in 1976 the Security Council adopted Resolution 392 calling on the South African government to cease the violence against the African majority and to eliminate its apartheid policies that were in flagrant violation of human rights, the United States supported the resolution in the context of Chapter VI rather than the mandatory powers provided under Chapter VII. At the same time, the US government made clear that it could not support enforcement action in what they regarded at the time under consideration as a matter falling within the domestic jurisdiction of another state. ${ }^{718}$

Ten years later, with the strengthening at a domestic level of the voices in support of action against South Africa and with the United Kingdom proceeding with limited sanctions in response to more extensive measures announced by the Commonwealth countries, the US Congress in an overwhelming vote overturned President Reagan's veto against the implementation of economic measures in response to these discriminatory practices. In this way, the US Congress went beyond its mere role of review in the formulation of foreign policy and South Africa received 'the strongest psychological and economic blow it had ever received from the international community'. ${ }^{719}$

With the Comprehensive Anti-Apartheid Act of 1986,720 direct air flights between the United States and South Africa ceased, in violation of the Agreement between the two countries relating to Air Services between their Respective Territories signed in 1947. ${ }^{721}$ More specifically, the right of any South African designated aircarrier to provide services under the 1947 Agreement was revoked whilst all US aircarriers were prohibited from continuing their services to South Africa. The American decision was taken pursuant to Article $\mathrm{XI}(\mathrm{B})$ of the Agreement, which established the right of any party to request consultation with the other party at any time. Accordingly: '[W] hen the procedure for a consultation provided for in paragraph $(\mathrm{B})$... has been initiated, either contracting party may at any time give notice to the other of its desire to terminate this agreement.' 722 Article XI further established that the termination of the agreement would take effect only 1 year after the date of receipt of the notice of termination. However, several days after the US government announced its intention to terminate the

717 Baker, op. cit., 104.

718 Racial Discrimination, US Representative Albert Sherer, Digest of US Practice in International Law (1976) 163-66, 165.

719 Baker, op. cit., 89.

720 Anti-Apartheid Act, The Comprehensive Anti-Apartheid Act of 1986, Pub. L. 99-440, 100 Stat. 1086, 22 U.S.C. 5001 et seq., enacted 2 October 1986.

721 Petman, op. cit., 371.

722 See United States-South Africa: Termination, Cumulative Digest of US Practice in International Law (1981-88) II, 2183-2189. 
Agreement, it revoked the operating permit of South African Airways and restricted the operating service of US aircarriers with South Africa in accordance with Section 306 of the Act. This decision was accordingly in clear violation of the 12-month notice requirement established under Article XI of the Agreement between the United States and South Africa.

In contesting the lawfulness of the US action, South African Airways filed a petition before the US Court of Appeals for the District of Columbia Circuit, arguing that Section 306 did not authorize immediate revocation of its permit. It also argued that in any event, no revocation could be permitted before the end of the 1-year period after the notice for termination had been given. It was thus the submission of the South African airline that the Final Order authorizing these measures against it was, inter alia, in violation of the 1947 Agreement. In making its case before the Court the US government argued that the Court should refrain from adjudicating the case before it because the dispute involved the implementation of international agreements and a foreign policy issue that fell within the powers of the Executive Branch. The Court held that the Congress intended to give Section 306 immediate effect and priority over the 1947 Agreement or any other conflicting domestic law. It further stressed that the Congress had the right to denounce international treaties. ${ }^{723}$ It can be deduced from this analysis that the suspension of the 1947 Agreement was in violation of the United States' obligations under international law, providing yet another significant example of state practice in support of solidarity measures.

With respect to the other measures adopted under the Comprehensive Anti-Apartheid Act, new investments in South Africa were banned with the exception of investments made in firms owned by blacks. Loans going to the private sector and to the South African government were also prohibited except for those needed for humanitarian purposes. Imports from South Africa to the United States were prohibited while the US government was banned from buying South African goods and services and from promoting tourism to South Africa. There was also a prohibition against the export of products while US nationals were banned from making new investments in South Africa either directly or indirectly. ${ }^{724}$

This example provides strong evidence that human rights concerns gained primacy over economic and geostrategic interests. ${ }^{725}$ The only way for the

723 South African Airways case (South African Airways v Dole) 817 F. 2 d 119 (D.C. Cir. 1987), cert. Den., 108 S.CT. 229. Also see United States-South Africa: Termination, Cumulative Digest of US Practice in International Law (1981-88) II, 2185-7. It needs to be said that in opposing the inclusion of aviation sanctions in the Anti-Apartheid Act, the American administration drew the attention to the fact that such decision would be in violation of the 1947 Agreement with South Africa, and that as a result the United States would have to solve the dispute through arbitration. In that case, it was mentioned, the US would be in danger of being obliged to award damages.

724 Law Restatement, Restatement of the Law. The Foreign Relations Law of the United States, Vol. 1 (American Law Institute Publishers: 1987) 382.

725 Baker, op. cit., 92. 
South African government to escape from its economic isolation was by complying with the requirements of the Act or, even more remotely, with a decision by both Houses of the US Congress. The lifting of these measures was made conditional on the release of Nelson Mandela from jail, the repeal of the state of emergency and the release of all detained persons. The Act also provided for the enhancement of the democratic process with the participation of the political parties banned by the regime, the repeal of the Great Areas Act and the Population Registration Act and the initiation of good faith negotiations with genuine representatives of the black population. ${ }^{726}$ In the event that no compliance had occurred within a period of 12 months, additional sanctions could be imposed such as the banning of importation from South Africa of strategic materials, steel, diamonds, food, agricultural products and giving military assistance to countries violating the arms embargo against South Africa.

The diplomatic and consular relations between the two countries, however, were not terminated. On the contrary, the US government continued diplomatic negotiations with South Africa with the aim of encouraging and influencing it towards ultimate change. ${ }^{727}$

The contribution of the US sanctions towards political change and reform in South Africa with the final abolition of the apartheid regime is not without merit and for this reason it constitutes a significant example of state practice in support of a right to solidarity measures. If none of these measures had been taken, the apartheid regime would most possibly still be in place or have ended in violence. ${ }^{728}$ While the intention of these measures was not to overthrow the regime but rather to reinforce domestic forces fighting apartheid, it was pointed out that, 'Even the law's most ardent supporters pointed out that there was no precedent for a ruling elite relinquishing power without force and that sanctions rarely are enough to dislodge a regime that is militarily secure.' 729

Although the South African example must be viewed in the framework of the surrounding circumstances and its specific characteristics due to both the external and internal changes occurring at the time, it remains undisputed that if no economic measures had been taken this would have allowed the racist regime to continue to commit its atrocities with impunity. ${ }^{730}$ In his conclusion about the effect of US sanctions on the historic regime transformation that would follow in the next years, de Villiers argues that: 'US and other punitive measures significantly dictated the form, substance, timing, and pace of these reforms. ${ }^{.731}$

For his part, Nelson Mandela, in his first speech before the US Congress after his release from prison, took the opportunity to express his gratitude for the

726 Villiers, op. cit., 125-6.

727 Baker, op. cit., 94.

728 R. Mullerson, Human Rights Diplomacy (Routledge: 1997) 114.

729 Baker, op. cit., 98, 104.

730 Ibid, 92.

731 Villiers, op. cit., 207. 
adoption of the 'historic' Comprehensive Anti-Apartheid Act, 'which made such a decisive contribution to the process of moving our country forward towards negotiations'. ${ }^{732} \mathrm{He}$ insisted that the measures should remain in place until the goals of the Act, namely the abolition of apartheid, were met.

The measures continued until 1993 when relations between the United States and South Africa were finally restored with the signature of the National Peace Accord between the government of South Africa and opposition groups, following which the conditions for the termination of the sanctions were finally met.

In a concluding note, it has been remarked that:

South Africa was not invaded by an outside power and did not descend into full-scale internal war, but it underwent a political transformation from apartheid to democracy that was every bit as radical as that of Afghanistan after the Taliban and that of Iraq after Hussein. The South African state could have collapsed but did not. It thus presents a rare instance of regime change-indeed, it was a system change - that resulted in a dramatic improvement of human rights. Critical external intervention was applied successfully and in a timely way, without the use of military force. ${ }^{733}$

This quotation is a representation of the power of unilateral coercive peaceful measures as a remedy for serious infringements of interests in which all states have a legal interest. It is also a reflection of the necessity of enforcing such fundamental interests by means short of armed force and, therefore, of the necessity to recognize a right to solidarity measures in international law.

\subsubsection{REACTION OF THE DUTCH GOVERNMENT}

When the Dutch government recommended a number of measures concerning oil supplies to, imports from, and investments in South Africa, the Advisory Committee on Questions of International Law was requested to examine the lawfulness of these measures within the UN Declaration on Principles of International Law Concerning Friendly Relations and Co-operation among States. According to the report of the Committee prepared in 1982 and entitled 'Measures against South Africa and the Non-intervention Duty', the duty of nonintervention should not be viewed in isolation but, on the contrary, should be examined in the light of other rules of international law. Since apartheid was regarded by an overwhelming majority of states as a flagrant violation of the human rights of the non-white population of South Africa, it could not be protected within the ambit of the rule of non-intervention.

732 Address of Nelson Mandela to the Joint Session of the Houses of Congress of the United States of America, 26 June 1990, available at http://www.anc.org.za/ancdocs/history/mandela/1990/ sp900626.html

733 Baker, op. cit., 109. 
The report further examined the question as to whether intervention needed to be at the initiative of the international community as a whole or whether it could be resorted to by individual states. In the light of the Committee's conclusions:

[1] can be established that the Charter was never intended to confer exclusive powers upon the Security Council. Although binding decisions in respect of (military) enforcement measures are a prerogative of the Security Council in the Charter, it does not follow that the general rules of international law relating to the right to take measures against unlawful acts are thereby invalidated. Clear proof of this can be found in the right, also recognized by the Charter, of individual and collective self-defense. ${ }^{734}$

Here no clear distinction is made between retorsion and countermeasures. However, it could be implied from the Committee's conclusions that economic and trade restrictions such as those recommended by the Dutch government would not be unlawful in such circumstances. This may reflect a certain legal belief that even if such measures were in violation of specific obligations, they would nonetheless be justified under international law as countermeasures. This conclusion is supported by the fact that if the measures recommended by the Dutch government were of a retorsive character then the government would be under no need to consider their lawfulness since retorsion by definition consists of measures that infringe no rules of international law. The reference in the Committee's report must accordingly relate to third-state countermeasures that under other circumstances would entail a breach of the principle of nonintervention in the affairs of another state, yet are justified here as a response to a gross violation of interests owed to all states. This is further evident from the fact that the Committee supported unilateral coercive measures in the absence of Security Council authorization and of direct injury, a reference that would not be necessary had the action recommended against South Africa involved no violation of international law.

These findings are further enhanced by the fact that in the Memorandum of Reply to the First Chamber concerning the Bill on the application of sanctions against states and territories, ${ }^{735}$ it was recognized that special circumstances could exist to justify measures other than those authorized by the Security Council for the protection of the international legal order. ${ }^{736}$ Interestingly, in a note sent by the Dutch Minister for Foreign Affairs to the Second Chamber in 1979 relating to the question of the oil embargo against South Africa, it was noted that the obligations of the Netherlands under the EEC, the Benelux Economic Union and

734 Measures against South Africa and the Non-intervention Duty, Advisory Committee on Questions of International Law, 14 NYIL (1983) 246, 248.

735 Memorandum of Reply to the First Chamber Concerning the Bill on the Application of Sanctions against States and territories, 8 NYIL (1977) 205.

736 Intervention and Self-help, 12 NYIL (1981) 168-170. 
GATT posed an obstacle to its taking unilateral commercial action against South Africa. The only exception referred to was the existence of a mandatory Security Council resolution in which case the Netherlands, according to the note, would be entitled to derogate from its other treaty obligations. ${ }^{737}$ However, it seems to be also suggested that in the case of a possible consent of the other parties to the treaties just mentioned, the imposition of measures, even third-state countermeasures, would be feasible. As already noted in section 3 of this chapter, the Sanctions Bill introduced in 1976 to enable the Dutch government to conform with its obligations at the international level did not differentiate between lawful measures, on the one hand, and countermeasures, on the other. It could, therefore, be implied that the possibility of even third-state countermeasures was not excluded.

The note concludes that what has just been mentioned should be taken into consideration for an evaluation of the 'political effect of an oil embargo by the Netherlands', making no reference, however, to the legitimacy of a unilateral decision of the Netherlands to proceed with the imposition of the oil embargo in general international law. In other words, what is examined in the note is the justification for the Dutch action under specific treaty regimes but not under the general law on state responsibility and the rules concerning the lawfulness or unlawfulness of third-state countermeasures.

Furthermore, the possibility of the imposition of measures in accordance with the Netherlands's obligations under the EEC and its other obligations is left open. More notably, this is confirmed in the Statement of the Dutch prime minister in the Second Chamber of 26 June 1980, which stressed that any action against South Africa, although desired, would have to be in concordance with the country's obligations towards its economic treaty partners. ${ }^{738}$

\subsubsection{CANADIAN MEASURES AGAINST APARTHEID}

The Canadian government, in spite of initial hesitation towards economic action, announced a number of measures to oppose apartheid, including measures of an economic character. These included cessation of official trade support and investment, cessation of the Program for Export Market Development and the global insurance policies written by the Export Development Corporation concerning South Africa and broadening of the UN arms embargo in order to include high technology items. Quite significantly, the government announced abrogation of the double taxation agreements, and introduction of a voluntary ban on loans to South Africa and its agencies. Moreover, Canada announced a voluntary ban on the sale of crude oil and refined products by asking Canadian companies not to sell these products to South Africa, while it imposed an embargo on air transport between Canada and South Africa although there was no bilateral agreement on which previous traffic rights were based. On the contrary, direct air transport 
between the two countries was limited to occasional charters. With this measure reciprocal air service of charter flights ceased until apartheid was abolished. ${ }^{739} \mathrm{It}$ seems that with the exception of the abrogation of the double taxation agreements all the other measures decided by the Canadian government were not in contravention of international law.

\subsubsection{OTHER ACTION}

European Community member states imposed unilateral coercive measures against South Africa that did not rely on a Security Council resolution adopted under Chapter VII of the UN Charter, thus giving another example of state practice in support of third-state countermeasures. In particular, the Foreign Ministers decided to impose among others an arms embargo, freezing of international security and sporting agreements and cessation of oil exports. ${ }^{740}$ These measures were extended to a ban on the import of iron, steel and gold coins. ${ }^{741}$ As far as the export and import restrictions were concerned, these amounted to third-state countermeasures, particularly in the absence of a Security Council resolution authorizing them.

Furthermore, at a Commonwealth level, at the meeting of heads of governments in Nassau in 1985 special attention was given to the discriminatory practices in South Africa. It was agreed during the session that the continuation of apartheid, the unlawful occupation of Namibia and South Africa's aggressive policies posed 'a serious challenge to the values and principles of the Commonwealth' ${ }^{742}$ In view of these developments, it was decided to impose a ban on oil sale and export, a ban on aviation links, a prohibition on the import of agricultural products, the termination of double taxation agreements and cessation of all trade with South Africa. The same call was made a year later at the meeting of the Commonwealth in London in 1986. In the light of Commonwealth calls, Australia announced the suspension of its aviation agreement with South Africa in violation of an express requirement to provide a 12-month notice, providing another example in support of third-state countermeasures. ${ }^{743}$

The measures authorized at a Commonwealth level, intended to coerce the South African regime into compliance, even in breach of specific obligations emanating from international law, provide evidence of state practice and opinio juris that such measures were lawful or were becoming lawful under international law by way of countermeasures. The calls to impose aviation and trade restrictions

739 For the measures against South Africa see Apartheid, 24 CYIL (1986) 407-12.

740 Political and Institutional Matters, European Community Bulletin (1985) No. 9, para. 2.5.1 (10 September 1985).

741 Political and Institutional Matters, European Community Bulletin (1986) No. 9, para. 2.4.2 (16 September 1986).

742 The Commonwealth Accord on Southern Africa (Nassau, 20 October 1985) reproduced in Keesing's (1986) 34647.

743 Union of South Africa and Australia, Exchange of Notes constituting an Agreement relating to air services, Cape Town, 26 September 1958, 335 UNTS 127 (2 April 1970), 121. 
reveal the position of states that in the absence of effective institutional action, unilateral peaceful coercive measures against serious violations of international law are permissible under the right to third-state countermeasures. ${ }^{744}$

\subsubsection{CONCLUDING OBSERVATIONS}

The preceding analysis has demonstrated that in many instances going back to the 1960s states did not hesitate to authorize coercive measures against South Africa in response to discrimination against the black population in the country, even in the absence of a Security Council resolution. Most significantly, states have resorted to specific action that was in contravention of international law, which offers more evidence that state practice and opinio juris support the existence of a right to solidarity measures. The examination also included calls and recommendations made at various institutional, regional and international levels for the strengthening of economic coercion against South Africa, even in breach of international obligations.

Apartheid was a practice strongly deplored and condemned by the vast majority of countries. At the same time, it is also important to note that in international politics often other interests, mainly of an economic nature, come into play, resulting in inaction even in response to the most serious violations of international law. This element should not be ignored when examining whether or not states support a right to react when the most valued principles of the international community as a whole are endangered. In any event, the silence or inaction of states should not be considered as evidence against a right in the name of fundamental community interests.

\subsubsection{US action against Panama (1988)}

After a military coup in Panama in 1988, the United States responded to the human rights crisis in the country and the abolition of democratic rule, by ceasing military and economic aid to Panama. Since there were no express treaty obligation imposing upon the United States a duty to continue such assistance, this decision constituted an act of retorsion rather than a countermeasure. ${ }^{745}$ In April 1988 however, the United States further extended its action against Panama by declaring that the situation in Panama amounted to an extraordinary threat to the national security of the United States. This was achieved through the freezing of all assets belonging to Panama in the United States, but also through the suspension of payment of an amount of $\$ 7 \mathrm{~m}$ to the Panama Canal Commission in the light of the Panama Canal Treaty between the United States and Panama. ${ }^{746}$ Both measures were in violation of specific obligations, the former relating to the prohibition of interfering with the property of a foreign state and the other

744 Dawidowicz, op. cit., 377.

745 Ibid, 383. Also see M. Nash, 'Contemporary Practice of the United States Relating to International Law', 82 AfIL (1988) 566-69, 571-77.

746 Panama Canal Treaty, 1280 UNTS 3 (1 October 1979); Keesing's (1980) 30047-48. 
relating to the non-performance of obligations undertaken by the United States under the Panama Canal Treaty.

It is now well established that serious violations of fundamental human rights no longer fall within the exclusive jurisdiction of states as the preceding analysis has shown. States have often exerted economic pressure in violation of international law on recalcitrant states for the purpose of safeguarding community and collective interests. Nevertheless, questions remain in relation to the right of third states to react in order to restore or to induce democratic governance in another state. In the author's opinion, this remains a highly controversial issue in the light of the principle in customary and UN Charter law that states are entitled to choose among others their own political system and also of the number of states that adhere to authoritarian rule, such as many African and Arab countries. ${ }^{747}$ For this reason, unilateral coercive measures taken for the purpose of overthrowing foreign governments or for imposing a certain political system must be treated with caution. This is because states must not be given an opportunity to abuse the law on countermeasures by using them as a mechanism of imposing their values on the rest of the world. Countermeasures must then be applied only after the most stringent conditions are met, namely that there has been a breach of genuinely erga omnes legal interests owed to a group of states or to the international community as a whole, something disputed in relation to the right to democratic governance.

To the extent that the action taken by the United States was a response to serious human rights violations, then this can qualify as countermeasures taken in the name of collective interests. In any event, this incident provides further evidence of state practice and opinio juris that third states may respond to serious violations of fundamental community interests by implementing coercive, yet peaceful measures.

\subsubsection{The Iraqi invasion of Kuwait and EEC response (1990)}

The next example from state practice in support of a right to countermeasures by states other than the injured concerns the action authorized by several states as a result of the Iraqi aggression and invasion in Kuwait in the summer of 1990. On 2 August 1990 the Security Council, acting under its Chapter VII powers of the UN Charter adopted Resolution 660 by which it demanded Iraq's immediate withdrawal from Kuwait and decided to meet again for the determination of further action that might prove necessary, although no concrete action was decided at that point.

In the light of these developments, the Ministers of Foreign Affairs representing the member states of the European Community met on 4 August 1990 in the context of the European Political Cooperation (EPC), where they condemned Iraq in the strongest terms, demanding the immediate and unconditional withdrawal of its troops from the territory of Kuwait. They rejected as unfounded the grounds on

747 On arguments supportive of a right to democratic governance in international law see T.M. Franck, 'The Emerging Right to Democratic Governance', 86 AfIL (1992) 46; G.H. Fox, B. Roth. Democratic Goverance and International Law (Cambridge University Press: 2000). 
which Iraq based its military aggression against Kuwait and emphasized that they would work towards a consensus within the Security Council for the imposition of mandatory and comprehensive sanctions should Iraq fail to comply with Resolution 660. In addition, they decided to impose an embargo on all oil imports from Iraq and Kuwait, to freeze Iraqi assets existing in the territories of Community member states, to place a prohibition on arms and other military equipment sales to Iraq, to suspend all technical and scientific cooperation with Iraq and to suspend the application of generalized preferences to Iraq. ${ }^{748}$ This decision came while negotiations within the Security Council were still ongoing and even before a formal Security Council resolution authorizing any kind of sanctions was adopted, ${ }^{749}$ although it actually took effect after the adoption of Security Council Resolution 661 (1990) of 6 August. ${ }^{750}$ With this resolution, the Security Council authorized economic, trade, finance and arms sanctions. The EEC measures, and in particular the freezing of Iraqi assets, were in violation of international law and, therefore, qualify as unilateral peaceful measures taken in the name of international peace and security.

In compliance with the EPC's decision, on 8 August the Commission presented to the Council various proposals for the adoption of measures against Iraq and for their extension to Kuwait with the aim of preventing the aggressor from benefiting from its unlawful actions. The proposals concerned the prohibition of the import into Community territory of crude oil and refined petroleum products coming from either Iraq or Kuwait. Moreover, they provided for the suspension of the generalized tariff preferences for products coming from Iraq in accordance with Council Regulations No. 3896/89, No. 3897/89 and 3898/89, and for the suspension of Council Regulation No. 3899/89, concerning levy reductions. It is noteworthy that these proposals do not rely for their legitimacy on Security Council resolution 661. Rather, in the explanatory memorandum emphasis is given to the statement of 4 August made by the Community and its member states in the framework of political cooperation. The memorandum also took notice that:

$[\mathrm{T}]$ he serious situation caused by Iraq's invasion of Kuwait resulted in Resolution 660 (90) of the United Nations Security Council and led to the statement by the Community and its Member States of 4 August 1990 which unreservedly condemned Iraq's invasion of Kuwait and called for

748 European Political Cooperation - Invasion of Kuwait by Iraq, Bulletin of the European Communities (1990) No. 7/8 (1.5.11). The EPC provided merely coordination among the member states to the EC on matters of foreign relations, for which the member states retained their full sovereign powers and did not transfer such competences to the European institutions like they did with a wide number of economic issues. See Title III of Single European Act, Of (1987) L169/1. For more information on the EPC, see T. Stein, 'European Political Cooperation as a Component of the Foreign Affairs System’ 43 ZaoRV(1983) 49; J.S. Nuttall, 'Interaction between European Political Cooperation and the European Community' 7 Tearbook of European Law (1987) 211. The EPC was replaced by Title $\mathrm{V}$ of TEU which provided for a CFSP.

749 S. Bohr, 'Sanctions by the United Nations Security Council and the European Community' 4 EfIL (1993) 256, 258. See European Political Cooperation - Invasion of Kuwait by Iraq, EC Bulletin (1990) No. 7/8 (1.5.11).

750 Iraq-Kuwait, Security Council Resolution 661 (6 August 1990). 
the immediate and unconditional withdrawal of Iraqi forces from Kuwait's territory, and also led to the decision to take economic action against Iraq, in accordance with the relevant provisions of the Treaties of the Communities. ${ }^{751}$

Following the Commission's recommendations, the EU Council decided the same day to prohibit trade between the Community, Iraq and Kuwait with Regulation 2340/90. Taking cognizance of Security Council Resolutions 660 and 661 and of the sanctions authorized therein, the Regulation aimed to ensure the uniform implementation of the trade measures against Iraq and Kuwait. ${ }^{752}$ Consequently, all trade with Iraq, including imports and exports, and all activities and commercial transactions were banned. It is important to point out that the Regulation, although aiming to comply with the Security Council decisions, did not rely on Article 224 concerning united action by the Community member states in compliance with their obligations for the maintenance of international peace and security, but rather on Article 113 concerning a common commercial policy. ${ }^{753}$ This could be perhaps interpreted as revealing the intention of the Community to take action irrespective of Security Council authorization.

Moreover, with Regulation 3155/90 the European Community imposed restrictions on air services, while there was a prohibition on commodities covered under the European Coal and Steel Community (ECSG). ${ }^{754}$ In this way, the member states of the European Community decided on the uniform application of economic and other measures against Iraq and Kuwait, measures that were decided at a Community level and not unilaterally by individual states. ${ }^{755}$

In addition to the measures decided at a European Community level, the United States announced on 2 August 1990, that is 4 days before the adoption of Security Council Resolution 661, a trade embargo against Iraq and the freezing of its economic assets. During the same period, Japan and Switzerland also

751 Proposal for a Council Regulation (EEC) prohibiting the introduction into the territory of the Community of crude oil and refined petroleum products or their derivatives originating in or last exported from Kuwait, COM (90) 375, Brussels, 8 August 1990; Proposal for a Council Regulation (EEC) prohibiting the introduction into the territory of the Community of crude oil and refined petroleum products or their derivatives originating in or last exported from Kuwait, COM (90) 376, Brussels, 8 August 1990; Proposal for a Council Regulation (EEC) suspending for 1990 the levy reductions for certain agricultural products originating in Iraq, COM (90) 391 final, Brussels, 8 August 1990; Draft for a decision of the representatives of the governments of the member states meeting within the Council suspending for 1990 the generalized tariff preferences for certain iron and steel products originating in Iraq, COM (90) 391 final, Brussels, 8 August 1990.

752 Council Regulation (EEC) No. 2340/90 of 8 August April 1990 preventing trade by the Community as regards Iraq and Kuwait, Of (1990) L213/1.

753 Chinkin (1996) op. cit., 199.

754 See Council Regulation (EEC) No. 2340/90, op. cit.; Council Decision of 8 August 1990 preventing trade as regards Iraq and Kuwait (90/414/ECSC), Of (1990) L213/3.

755 Chinkin (1996), op. cit., 198. 
announced the freezing of Iraqi assets while Japan also banned the export of products coming from Kuwait and Iraq. ${ }^{756}$

The states resorting to such measures did not rely on their right to collective self-defence, implying that they were acting in accordance with a right to thirdstate countermeasures. The fact that these states were acting in the light of Kuwait's consent as injured states, while important, it is not a determinative factor as there may be instances where no injured state exists. Moreover, in cases where fundamental interests are owed to a group of states or to the international community as a whole, it may be questioned whether the consent of the injured state is a necessary requirement at all. ${ }^{757}$

\subsubsection{EC measures against Haiti (1991)}

The next example relevant to the scope of this examination relates to the military coup that took place in Haiti in 1991, which resulted in the ousting of the democratically elected President Jean-Bertrand Aristide. The OAS responded immediately by requesting its member states to impose economic sanctions. In May 1992 the OAS decided to step up the trade sanctions against Haiti and, in particular, to ban from all ports in the hemisphere ships delivering oil and other commercial cargoes to Haiti, to ban commercial flights from transporting goods and to cease the issuing of travel visas. ${ }^{758}$ These restrictions were also in violation of GATT to which Haiti has been a member since 1950 .

In another context, the Committee of Ministers of the African, Caribbean and Pacific Group of States recommended that states parties to the Lomé IV Convention suspend trade with Haiti, also a party to this Convention, although there was initial hesitation as to the legality of such action under the Convention. ${ }^{759}$

EC states, in the context of EPC, decided, in the absence of any Security Council authorization, to impose a trade embargo in infringement of the Lomé Convention, which, although it made reference to human rights, did not incorporate a right to democracy.

This case has been criticized not so much regarding whether such action without Security Council authorization was permissible or not but, rather, as in the case of Panama, because the violation of an international obligation having an erga omnes character on Haiti's part was doubtful. According to this position military

756 Letter dated 6 August 1990 from the Charge d'Affaires A.I. of the Permanent Mission of Italy to the United Nations addressed to the Secretary-General, United Nations doc. S/21444 (6 August 1990); Letter dated 5 August 1990 from the Permanent Representative of Japan to the United Nations addressed to the Secretary-General, United Nations doc. S/21449 (5 August 1990); Transmitting note from Switzerland concerning measures to implement Security Council resolution 661 (1990) on sanctions against Iraq, United Nations doc. S/21585 (7 August 1990); cited in Dawidowicz, op. cit., 385.

757 For a different view, see Dawidowicz, ibid, 386.

758 See Charter of the Organization of American States (Bogota Charter), 30 April 1948, 119 UNTS 3; Keesing's (1992) 38905.

759 Keesing's, ibid. 
coups fall within the domestic jurisdiction of states and, while the Lomé Convention made reference to human rights, it is difficult to find that a right to democracy was also incorporated under this provision. ${ }^{760}$ This incident, however, provides evidence that the notion of third-state countermeasures for the purpose of protecting fundamental community interests, is not as controversial as concluded by the ILC in the Final Articles. Quite significantly, this incident is significant in so long as it provides evidence of third-state action in response to serious human rights violations, which, as noted elsewhere, give all states a legal interest in their protection.

\subsubsection{Countermeasures against Yugoslavia (1991)}

In many of the cases considered so far, apart from measures resorted to by individual states there have been measures decided at an institutional level such as international and regional organizations. The next example concerns unilateral economic countermeasures against Yugoslavia imposed by the EU among others and discusses the legal basis on which such measures are decided on.

With the outbreak of the ethnic conflict in the former Social Federal Republic of Yugoslavia the international community was faced with one of the worst humanitarian crises ever since the end of World War II. In a statement issued in July 1991 in the context of the EPC, the EC and its member states expressed their deep concern for the increasing violence in Yugoslavia and called for the immediate initiation of negotiations between the conflicting parties. ${ }^{761}$ It was made clear in the statement that any peace effort should give due respect to human rights including the right of minorities and the right of people to self-determination and full consideration of the UN Charter principles and other norms of international law relating to the territorial integrity of states.

Prior to and in the absence of any Security Council authorization, ${ }^{762}$ the Community and its member states agreed to apply an embargo on armaments and military equipment that would have effect in the whole of the territory of Yugoslavia and called on other states to do the same. This did not preclude the possibility of military action in the event of any further breach of the ceasefire. It was also decided to suspend the second and third financial protocols with Yugoslavia for so long as there was no normalization of the situation. ${ }^{763}$

The first Security Council resolution on Yugoslavia was not passed until September 1991 which confirmed and approved the Community action. ${ }^{764}$

760 Chinkin (1996), op. cit., 201.

761 European Political Cooperation - Yugoslavia, Bulletin of the EC (1991) No. 7/8, Vol. 24 (1.4.3) .

762 Bohr, op. cit., 256-8.

763 European Political Cooperation - Yugoslavia, EC Bulletin (1991) No. 7/8, Vol. 24, (1.4.3).

764 The term 'Yugoslavia' is used in the text of all the Security Council resolutions from September 1991 until May 1992. 
More specifically, in Resolution 713 the Security Council expressed its full support for the efforts already made by the member states of the EC along with the states participating in the Conference on Security and Cooperation in Europe for a peaceful and comprehensive settlement in Yugoslavia. The Security Council also commended the decision to suspend the delivery of all military weapons and equipment to Yugoslavia. This is significant as it indicates the Security Council's approval of unilateral coercive measures taken in the absence of UN authorization. At the same time, the Security Council acting within its powers under Chapter VII authorized an embargo on all military material and equipment to Yugoslavia. ${ }^{765}$ Quite significantly, Resolution 713 concerned only authorization for the imposition of an arms embargo rather than the imposition of trade restrictions in contravention of the 1983 Cooperation Agreement with Yugoslavia as will be analyzed in the subsequent paragraphs. ${ }^{766}$

The embargo, however, did not prevent the worsening of the situation and for this reason in November 1991 the EG and its member states decided to proceed with further coercive action. Highlighting the seriousness of the crisis with the 'indiscriminate bloodshed' and 'the unacceptable threats and use of force against the population of Dubrovnik', the EC adopted the so-called 'Yugoslav countermeasures'. In the midst of the worsening situation EC member states announced a number of measures including the restoration of quantitative restrictions for textiles; the exclusion of Yugoslavia from the generalized system of preferences; and the suspension of benefits under the Phare Programme, a measure that was not, however, inconsistent with any treaty. ${ }^{767}$ Furthermore, the EC expressed its determination to work for consensus within the Security Council for the imposition of an oil embargo. These measures were given effect by a number of regulations and decisions passed by the EU Council within the scope of the EEC and the ECSC.

In particular, on the basis of Regulation No. 3300/91, the EU Council decided to suspend the trade concessions under the 1983 Cooperation Agreement between the EEC and the Socialist Federal Republic of Yugoslavia. This decision was made giving cognizance to the radical change of circumstances as a result of the hostilities taking place in the territory of Yugoslavia and their impact on trade and economic relations. With Council Decision 91/586/ECSC, the 1983 Cooperation Agreement and its Protocols, in addition to the Agreement concerning the ECSC existing between them, were suspended with immediate effect.

The denunciation of the Agreement between the member states of the ECSC and Yugoslavia came with Council Decision 91/587/ECSC while the denunciation of the 1983 Cooperation Agreement between the EEC and Yugoslavia came with Council Decision 91/602/EEC. The trade concessions granted under the ECSG were suspended with Decision 91/588/ECSC with reference made to

765 Socialist Federal Republic of Yugoslavia Security Council Res. 713 (1991) (6).

766 Dawidowicz, op. cit., 406.

767 European Political Cooperation - Yugoslavia, EC Bulletin (1991) No. 11, 91, (1.4.4). 
Resolution 713 and to the peace threat as a consequence of the situation in Yugoslavia. The country was also expelled from the list of beneficiaries of the Community's generalized tariff preferences scheme in 1991, on the ground that 'the situation which obtains in Yugoslavia no longer enables this country to remain on the list of beneficiaries of generalized tariff preferences' ${ }^{768}$ With Regulation No. 3301/91, the EU Council decided to impose quantitative restrictions on textile products originating in Yugoslavia.

In the period from April to May 1992 the Commission, on request from the Ministers of Foreign Affairs, decided on a number of measures to be taken against the Republics of Serbia and Montenegro and sent the list with the suggested measures to the Council. ${ }^{769}$ On 27 May the member states agreed to impose a total trade embargo against Yugoslavia, a prohibition on all export credits and the suspension of scientific and technical cooperation, while disagreement occurred with respect to an air transportation moratorium and an oil embargo. It was only 2 days later that the Security Council passed Resolution 757 (1992) by which it decided to ban all imports and exports, air transport from and to Serbia and Montenegro, transport and financial services and scientific, technical and cultural cooperation. The decision of the EC member states to authorize such trade measures even before Security Council authorization reflects the determination of states to take unilateral coercive peaceful action in the protection of fundamental community interests.

In this regard, while the Community action taken in this instance in the form of legally binding instruments referred to relevant Security Council resolutions, the legal justification on which the regulations and decisions rely seems to vary. Although no express mention is made in the regulations just discussed, decisions and statements by EG policymakers to the right of third-state countermeasures, it

768 Council Decision of 11 November 1991 suspending the application of the agreements between the European Community, its member states and the Socialist Federal Republic of Yugoslavia (91/586/ECSC, EEC), Of (1991) L315/47; Council Regulation (EEC) No. 3300/91, Of (1991) L 315/1; Council Regulation (EEG) No. 3301/91 of 11 November 1991 on the arrangements for imports of certain textile products originating in Yugoslavia, Of (1991) L315/3; Council Regulation (EEC) No. 1155/92 of 28 April 1992 amending Regulation No. 3301/91 on the arrangements for imports of certain textile products originating in Yugoslavia, Of (1992) L122/1; Council Decision of 11 November 1991 denouncing the Agreement between the member states of the European Coal and Steel Community and the Socialist Federal Republic of Yugoslavia (91/587/ECSC), Of (1991) L315/48; Council Decision of 11 November 1991 suspending the trade concessions provided for by the Agreement between the member states of the European Coal and Steel Community and the Socialist Federal Republic of Yugoslavia (91/588/ECSC), Of (1991) L315/49; Council Decision of 11 November 1991 withdrawing Yugoslavia from the list of the beneficiaries of the Community generalized tariff preferences scheme for 1991 (91/589/ ECSC), Of (1991) L315/50; Council Regulation (EEG) No. 3302/91 of 11 November 1991 withdrawing Yugoslavia from the list of beneficiaries of the Community generalized tariff preferences scheme for 1991, Of (1991) L315/46; Council Decision of 25 November 1991 denouncing the Cooperation Agreement between the EEC and the Socialist Federal Republic of Yugoslavia (91/602/EEG), Of (1991) L325/23.

769 Agence Europe No. 5728 of 13 April 1992, 3; Agence Europe No. 5734 of 22 May 1992, 6; cited in Bohr, op. cit. 
is clear that the action taken did not rely on such a resolution, as Resolution 713 only authorized the imposition of an arms embargo. On the contrary, the Community action at times even precipitated UN action.

Furthermore, there is nothing to indicate that the Community institutions acted in accordance with the Security Council resolutions because they had a legal obligation to do so. It is thus suggested that the EC is only legally bound by the UN Charter to the extent that it codifies general rules of international law. 770 The possibility of a conflict between an obligation under Community law and under the UN Charter to which all EG member states are parties is intended to be resolved by the inclusion in the Treaty of Rome of Article 297 (former Article 224). According to this provision, derogation from the EC Treaty is permitted in order to carry out obligations it has accepted for the purpose of maintaining peace and international security'. Therefore, EC member states can take economic or other measures in compliance with their other obligations under international law for the maintenance of international peace and security, after consultation between them in order to ensure that the common market will not be adversely affected by measures taken by a member state unilaterally. However, Article 297 does not preclude Community action in the form of sanctions within its exclusive competences on common commercial policy. ${ }^{771}$ Since the EC is not the addressee of Security Council resolutions neither does it take over the obligations of its member states under other international legal instruments such as the UN Charter, Article 297 ensures the compliance of EC member states with other international responsibilities, which the EC cannot disregard. ${ }^{772}$ Furthermore, Article 307 of the Treaty of Rome (formerly Article 234) aims to remedy a conflict between Community law and public international law with the cooperation between the EC and its member states.

As already explained, the immediate suspension of the 1983 Cooperation Agreement between the EEC and Yugoslavia concerning trade and cooperation was justified on the ground of a 'radical change' to the conditions of the agreement. ${ }^{773}$ Subsequently, the EC member states decided on the denunciation of the agreement despite the fact that 6 months' notice was required. ${ }^{774}$

In the Racke case brought before the ECJ, the lawfulness of Council Regulation (EEG) No. 3300/91 of 11 November 1991 with which the trade concessions

770 Bohr, ibid, 264-5.

771 Ibid, 266.

772 Ibid, 268.

773 Council Decision of 11 November 1991 suspending the application of the Agreements between the European Community, its member states and the Socialist Federal Republic of Yugoslavia (91/586/ECSC, EEC), Of (1991) L315/47.

774 The Cooperation Agreement can be found in Council Regulation (EEC) No. 314/83 of 24 January 1983, Of (1983) L 41/1. For the decision on suspension and termination see Council Regulation (EEC) No. 3300/91 of 11 November 1991, Of (1991) L 315/1; Decision of the Council and the Representatives of the Governments of the Member States of 11 November 1991, Of (1991) L 315/47; and Council Decision of 25 November 1991, Of (1991) L 325/23. 
established by the Cooperation Agreement were suspended with immediate effect, was put into question. ${ }^{775}$ The Agreement provided, inter alia, the reduction of custom duties on imports into the Community of wine of fresh grapes not exceeding a specific tariff quota. Although the force of the Agreement was to have an unlimited period, it was also agreed that it could be denounced by giving 6 months' notice to the other party. It was mainly argued by the applicants that the Cooperation Agreement contained no human rights clauses and, therefore, it had no non-execution clauses, as a consequence of which its suspension could not be justified. The Community, by way of contrast, argued that the suspension of the Agreement was justified under customary international law on the ground of rebus sic stantibus (fundamental change of circumstances).

The Racke case highlights the difficulties that arise as a result of the nonexecution of an agreement between two states, irrespective of the reasons behind it. This is because the pacta sunt servanda rule constitutes one of the most fundamental principles of international law. 776 Nevertheless, the Court upheld the lawfulness of the Council regulation in dispute regarding the unilateral suspension of the Cooperation Agreement on the ground of fundamental change of circumstances. More specifically, the Court pointed to the wide-ranging objectives of the Cooperation Agreement, including, among other things, the promotion of economic and social development and the welfare of the populations of the contracting parties, finally holding that the maintenance of peace in Yugoslavia constituted an essential element of the consent of the parties when concluding the Agreement. As a consequence, the disintegration of the country created a fundamental change of circumstances that justified the suspension of the Agreement in question. ${ }^{777}$

While some reference was made to the right of retorsion confusing the notion with that of countermeasures, the Community institutions did not rely on the concept of third-state countermeasures as a circumstance precluding the wrongfulness of their decision. ${ }^{778}$ The reliance on the concept of fundamental change of circumstances could possibly weaken the argument that the Community at the time was acting with the concrete belief that it possessed a right to resort to countermeasures in response to a situation that raised concerns in the international community as a whole, even if it were not directly affected.

However, questions arise as to whether the requirements of fundamental change of circumstances were indeed satisfied in this instance. As Chinkin points out, it would be difficult to prove in this case the existence of the two elements necessary to establish fundamental change of circumstances as a valid ground for the suspension or denunciation of the treaty under consideration. More specifically,

775 Racke v Hauptzollamt Mainz, Judgment of 16 June 1998, Case C-162/96, European Court Reports I (1998) Part 6, 3655.

776 B. Brandtner and A. Rosas, 'Trade Preferences and Human Rights' in Alston (1999) op. cit., 699, 703-704.

777 P.J. Kuijper, 'The Court and the Tribunal of the EC and the Vienna Convention on the Law of Treaties 1969' 25 Legal Issues of European Integration (1998) No. 1, 20.

778 See Dawidowicz, op. cit., 406. 
while it would be possible to argue that peace in Yugoslavia constituted a precondition for the continuation of the Cooperation Agreement, it would be difficult to prove that the internal hostilities radically changed the EC's obligations under the treaty. She notes, in this regard, that: 'Under the Vienna Convention impossibility of performance is more generally seen as applicable to situations where the subject matter of the treaty has ceased to exist rather than loss of political authority by one of the treaty parties. ${ }^{779}$ Moreover, and irrespective of whether or not in the present case there indeed existed such a change of circumstances as to justify the denunciation of the agreements, one wonders whether this could be used as an excuse for any threat to the peace and security and any humanitarian crisis. It follows that any discussion on the law on countermeasures would become pointless and there would not even be a need to rely on such justification since treaties would be able to be denounced or suspended on the ground of fundamental change of circumstances. The author is, therefore, of the view that the claim of fundamental change of circumstances must be used with constraint and that acceptance of such justification must meet some very strict legal conditions. It is thus imperative that the international legal order finds appropriate means to address humanitarian crises within the law on state responsibility itself and especially through resort to countermeasures even by states that have not themselves suffered any direct injury. In conclusion, legitimate questions emerge in relation to whether the suspension of the 1983 Agreement could not qualify as a solidarity measure.

At a GATT level, Yugoslavia argued that the EC sanctions imposed against it, by not applying uniform treatment to the entire territory of Yugoslavia infringed the most favoured nation treatment clause under GATT and, as a consequence, it requested the establishment of a panel to look into the case. EG member states, however, invoked Article XXI regarding national security as justification for their decision to suspend and denounce the 1983 Cooperation Agreement with Yugoslavia. ${ }^{780}$ The GATT Council declined to look into the substance of the claim as it found that FRY could not automatically be regarded as having succeeded the Social Federal Republic of Yugoslavia as a contracting party. ${ }^{781}$ It could be argued that in the light of the fact that the EEC member states had suffered no direct injury in this instance, their reliance on the argument of national security would be weak, thus enhancing again the argument that their action amounted to solidarity measures.

The economic measures adopted by both the Security Council and the EC from 1992 to 1995 aimed at inducing Yugoslavia to accept a settlement in Bosnia. The responsibility for the enforcement of the measures adopted by the EC, the West European Union and other institutions was given to the Sanctions Assistance Mission established for this purpose. The final result of this coordinated action

779 Chinkin (1996) op. cit., 197.

780 Trade Measures Taken by the European Community against the Socialist Federal Republic of Kugoslavia Communication from the European Communities, 2 December 1991, GATT doc. L/6948.

781 Paasivirta and Rosas, op. cit., 212. 
was the termination of support for Bosnian-Serb forces by the regime under Slobodan Miloševič. It is often argued that the sanctions imposed against Yugoslavia during that period played a significant role in the decision of the 'most immoderate leadership'782 under Miloševič to enter into negotiations.

This incident offers another significant example of the determination of third states to respond to serious violations of fundamental community interests through the enforcement of unilateral peaceful coercive measures, even though EC member states did not unequivocally rely on a justification of third-state countermeasures. The reluctance of the EC in this regard has been criticized as the legal justifications it relied on, particularly that concerning the fundamental change of circumstances, did not really meet the requirements of international law. ${ }^{783}$

Quite distinctive from the EC action, on 11 November 1994 the United States decided unilaterally to refuse compliance with Security Council Resolution 713, which it itself had voted for and which provided for a weapons embargo against Yugoslavia. ${ }^{784}$ In this regard, they ceased the arms embargo against BosniaHerzegovina causing the concern of other NATO allies such as the United Kingdom. ${ }^{785}$ Some months later, and in particular in August 1995, Congress voted in favour of a cessation of the arms embargo against Bosnia, 'an unambiguous de jure violation of the UN Charter and the relevant resolutions'. ${ }^{786}$ This action came several months before the Security Council decided to lift the arms embargo against the former Yugoslavia in November 1995.787 This the United Kingdom and France described as 'worrying'. ${ }^{788}$ At a NATO level there was a call to 'continue to enforce fully and totally all UN Security Council resolutions which form the basis of [NATO's] involvement in former Yugoslavia'. ${ }^{789}$ A similar call was made by members of the Western European Union. ${ }^{790}$

It is most interesting that the United States refused to comply with clear legal obligations emanating from a mandatory Security Council resolution adopted under Chapter VII of the Charter, and in particular from Resolution 713. The lifting of the arms embargo may provide yet another example of countermeasures taken in the name of collective interests, provided that the US decision relied on the gross violations of human rights, such as genocide, taking place in the territory of Bosnia-Herzegovina, and also on a serious threat to international

782 E. Luttwak, 'Toward Post-Heroic Warfare' 74 Foreign Affairs (1995) No. 3, 109, 118; D. Cortright, 'Powers of Persuasion: Sanctions and Incentives in the Shaping of International Society' 38 International Studies (2001) No. 2, 113, 119.

783 Dawidowicz, op. cit., 407.

784 Security Council Resolution 713, 25 September 1991. See Keesing's (1994) 40287.

785 Simons, op. cit., 103. As noted by French Foreign Minister Alain Juppé, this was 'the first time that a country like the United States has unilaterally exonerated itself from a United Nations Security council resolution that it has voted for'. Sunday Times, 13 November 1994.

786 Simons, op. cit., 104.

787 Security Council Resolution 1021, 29 November 1995.

788 Keesing's (1994) 40287.

789 Ibid.

790 Ibid. 
peace and security. At the vote before the United States Senate for the unilateral breaching of the arms embargo it was pointed out that the embargo was in breach of Bosnia's right under article 51 of the Charter to self-defence. ${ }^{791}$ However, it is not entirely clear whether the United States justified their decision on a claim to third state countermeasures or as part of their own right to assist BosniaHerzegovina to defend itself. In view of the other states' objection and negative reaction to the decision of the United States to proceed to the unilateral lifting of the arms embargo an argument could be made to the effect that these states did not consider that the specific measure could be justified under the right to individual or collective self-defence.

\subsubsection{Peaceful coercive measures against Nigeria (1995)}

When the democratic elections held in Nigeria in 1993 were invalidated as a result of which the military regime of General Abacha came to power, there was bloodshed between political activists and the regime with serious violations of human rights and the execution of prominent figures opposing the regime. The United States and member states of both EC and Commonwealth resorted to a number of retorsive measures such as travel and arms restrictions. ${ }^{792}$ In addition to these measures, EC member states decided to freeze Nigerian assets without, however, giving effect to this decision in the light of the fact that such assets had already been transferred to Swiss banks. ${ }^{793}$ Similarly, member states of the Commonwealth discussed the freezing of assets and the imposition of aviation restrictions, although again, no actual decision was taken to this effect. ${ }^{794}$ The US Congress, for its part, proposed a flight ban although, again, it did not implement this decision. Calls and the recommendations decided at these institutional levels against Nigeria, even if not actually given effect, may be expressive of the determination of states to resort to coercive measures in violation of their international obligations in order to protect fundamental human rights norms and interests owed to the international community as a whole. ${ }^{795}$

Moreover, the decision of the Commonwealth in 1995 to suspend Nigeria from the Commonwealth, arguably adversely affected its voting rights. In the light of the fact that the Commonwealth could be considered as an international organization, the decision to suspend Nigeria amounted to a violation of the 1971 Singapore Declaration of Commonwealth Principles and the 1991 Harare Commonwealth Declaration. ${ }^{796}$ This could provide another example of state

791 Ibid, 40017.

792 See Dawidowicz, op. cit., 387.

793 Keesing's (1995) 40758.

794 Commonwealth Proposes Further Measures against Military Regime in Nigeria, 2 Commonwealth Currents 3 (1996); and also 3 Commonwealth Currents 7 (1996).

795 Dawidowicz, op. cit., 387.

796 For more information on the legal status of these declarations, see Duxbury A., 'Rejuvenating the Commonwealth - the Human Rights Remedy', 46 ICLQ(1997) 344, cited in ibid, 388. 
practice and opinio juris in support of a right to solidarity measures and, therefore, it is necessary to include it within the scope of the present examination.

\subsubsection{Unilateral coercive action against Burundi (1996)}

Following the assassination of the first democratically elected president of Burundi in 1993 after a military coup, civil war broke out, as a result of which many people died. The international community, while deploring the situation, avoided any coercive action at an institutional level. However, the worsening of the crisis in 1996 led some African states to impose trade restrictions against Burundi. These restrictions were decided at the second Arusha Summit that took place in July 1996 for the purpose of restoring democratic rule in Burundi. ${ }^{797}$ Among the states that imposed a trade embargo Kenya, Rwanda, Tanzania, and Uganda, like Burundi, were members of GATT and consequently, these measures were in violation of their obligations arising from GATT.

These states did not rely on any of the saving clauses provided under Article XXI of GATT to justify their action. ${ }^{798}$

At the same time Rwanda and Zaire were bound by the 1976 Convention establishing the Economic Community of the Great Lake Countries and, accordingly, the measures against Burundi could amount to a violation of the obligations arising from this Convention. ${ }^{799}$ While the Convention provided for a 3-year notice for its denunciation, this condition was not satisfied before the imposition of the measures taken by these two states. Burundi, for its part, claimed that the action against it was in violation of the UN Charter, the Charter of the OAU and general international law. ${ }^{800}$ According to Tams and Dawidowicz, this is yet another example of state practice in support of third-state countermeasures in international law. ${ }^{801}$

\subsubsection{US action against Sudan (1997-2005)}

The United States, through the adoption of Executive Order 13067 in 1997, announced trade restrictions and an investment ban as a result of Sudan's interference in Uganda and also, in the light of the worsening human rights situation in Sudan, with allegations of slavery and religious repression. ${ }^{802}$ While Sudan was

797 Joint Communiqué of the Second Arusha Summit, United Nations doc. A/51/264-S/1996/620; cited in Dawidowicz, ibid, 389.

798 Dawidowicz, ibid, 389.

7991092 UNTS 49 (17 April 1978) in ibid, 390.

800 Letter dated 25/09/96 from the Permanent Representative of Burundi to the United Nations addressed to the Secretary-General and the President of the Security Council, United Nations doc. S/1996/788 and Letter dated 25/08/96 from the Permanent Representative of Burundi to the United Nations addressed to the President of the Security Council, United Nations doc. S/1996/690.

801 Tams, op. cit., 222; Dawidowicz, op. cit., 390.

802 This example is cited in Dawidowicz, ibid, 391. 
not a member of GATT, and therefore these measures did not amount to a violation of specific treaty commitments, the freezing of Sudanese assets was in violation of general international law. ${ }^{803}$ Sudan complained against these measures, which it described as 'unjust'. ${ }^{804}$ It is of significance that since the asset freezing was not included in the mandatory sanctions imposed against Sudan by Security Council Resolution 1054 adopted in 1996, the United States freezing was in violation of international law, thus offering further evidence of the existence of a right to solidarity measures. ${ }^{805}$ The asset freezing continued until 2005 when the Security Council adopted another resolution imposing further sanctions against Sudan and authorizing, inter alia, the freezing of its assets. ${ }^{806}$

\subsubsection{Coercive action against Burma/Myanmar (1997-2005)}

In the light of the serious human rights crisis in Burma/Myanmar as a result of the long-established military rule in the country and the oppression of political dissidents, and parliamentary results, the international community responded with a number of measures against the regime. While many of the restrictions imposed such as the travel bans and the suspension of the generalised system of preferences $^{807}$ were acts of retorsion, the decision of the EC to proceed in 2000 with the freezing of Burmese assets, a decision supported by 21 further states, was in violation of international law. ${ }^{808}$ As noted in earlier cases, the freezing of assets is conduct in violation of international law and therefore the action resorted to in this instance is another example of third-state countermeasures. ${ }^{809}$

\subsubsection{Collective action against Yugoslavia (1998)}

Following further worsening of the humanitarian situation in the Federal Republic of Yugoslavia (FRY) in 1998 the Security Council decided to impose an arms embargo under its Chapter VII competence, while not excluding the possibility of additional measures should a peaceful settlement of the conflict in Kosovo fail. The EU Council, through common positions and regulations decided to implement additional measures

803 Dawidowicz, ibid, 391. Also see Keesing's (1997) 41900.

804 Keesing's, ibid.

805 Security Council Resolution 1054 adopted on 26 April 1996.

806 Security Council Resolution 1591 adopted on 29 March 2005.

807 Common Position on Burma/Myanmar 96/635/CFSP (28 October 1996), Of L 287/1 (8 November 1996); and European Community Bulletin No. 12 (1996), para. 1.4.40; Council Decision of 27 April 1998 concerning the further extension of Common Position 96/635/CFSP on Burma/Myanmar, Of L 138/5 (9 May 1998).

808 Council Regulation (EC) No. 1081/2000 of 22 May 2000, prohibiting the sale, supply and export to Burma/Myanmar of equipment which might be used for internal repression or terrorism, and freezing the funds of certain persons related to important governmental functions in that country Of L 122/29 (22 May 2000).

809 Dawidowicz, op. cit., 392. 
in order 'to obtain from the Government of the FRY the fulfilment of the requirements of UNSG Resolution 1160 (1998) and of the said common positions'. ${ }^{10}$ Resolution 1160 did not, however, authorize states to resort to such additional measures in order to bring about the compliance of the FRY with its international obligations, other than the arms embargo. ${ }^{811}$ Russia was against any proposals for the imposition of economic measures on the country. As a consequence, Canada, the EU, Japan and the United States decided to apply unilateral measures. ${ }^{812}$

The EU Council, with common positions adopted on 7 May and 29 June 1998 within its powers under the Common Foreign and Security Policy, decided to freeze all Yugoslav assets abroad and to impose a flight ban, which for some states, such as France, Germany and the United Kingdom, meant violation of their bilateral aviation agreements with the targeted country. 813 This was implemented by Regulation 1901/98 where the Council noted that the FRY had not stopped its indiscriminate violence and brutal repression against its own population. The Council further emphasized that the situation in Kosovo amounted to serious violations of human rights and international humanitarian law and that the government had failed to take steps towards a settlement and regional peace and security. ${ }^{814}$ The regulation provided that any aircraft operated directly or indirectly by a Yugoslav carrier or a carrier which had its main place of business or

810 Council Regulation (EG) No. 1901/98 of 7 September 1998 concerning a ban on flights of Yugoslav carriers between the Federal Republic of Yugoslavia and the European Community, Of (1998) L248/1; Common Position of 19 March 1998 defined by the Council on the basis of Article J. 2 of the Treaty on European Union on restrictive measures against the Federal Republic of Yugoslavia, Of (1998) L95/1; Common Position of 7 May 1998 defined by the Council on the basis of Article J.2 of the Treaty on European Union concerning the freezing of funds held abroad by the Federal Republic of Yugoslavia and Serbian Governments, Of (1998) L143/1; Common Position of 8 June 1998 defined by the Council on the basis of Article J.2 of the Treaty on European Union concerning the prohibition of new investment in Serbia, Of (1998) L165/1; Council Regulation (EG) No. 926/98 of 27 April 1998 concerning the reduction of certain economic relations with the Federal Republic of Yugoslavia, Of (1998) L130/1; Council Regulation (EC) No. 1295/98 of 22 June 1998 concerning the freezing of funds held abroad by the governments of the Federal Republic of Yugoslavia and the Republic of Serbia, Of (1998) L178/33; Council Regulation (EC) No. 1607/98 of 24 July 1998 concerning the prohibition of new investment in the Republic of Serbia, Of (1998) L209/16.

811 Security Council Resolution 1160 (1998).

812 See UK Parliament Kosovo Crisis, 'The Kosovo Crisis after May 1997 - Sanctions', Fourth Report, Select Committee on Foreign Affairs, available at http://www.publications.parliament. uk/pa/cm 199900/cmselect/cmfaff/28/2809.htm

813 Common Position of 7 May 1998 defined by the Council on the basis of Article J.2 of the Treaty on European Union concerning the freezing of funds held abroad by the Federal Republic of Yugoslavia and Serbian governments, Of (1998) L143/1; Common Position of 29 June 1998 defined by the Council on the basis of Article J.2 of the Treaty on European Union concerning a ban on flights by Yugoslav carriers between the Federal Republic of Yugoslavia and the European Community, Of (1998) L190/3.

814 Council Regulation (EG) No. 1901/98 of 7 September 1998 concerning a ban on flights of Yugoslav carriers between the Federal Republic of Yugoslavia and the European Community, Of (1998) L248/1. 
registered office in the FRY would be banned from flying between the latter and the EC, thus revoking all existing and new operating authorizations to Yugoslav carriers. This prohibition was limited to landing and taking off rights. With a subsequent Council Regulation the ban was expanded to cover the takeoff or landing in the territory of an EC member state of any civil aircraft that had taken off from or was going to land in the territory of the FRY. ${ }^{815}$ The implementation of the flight ban was later challenged in the Bosphorus and Ebony cases, thoroughly examined within the scope of the last chapter, as infringing fundamental human rights such as the right to property.

The Regulation raised significant issues of the legality of the measures under international law, especially in view of existing Air Services Agreements between EU member states and the FRY. One such example relates to the Air Services Agreement concluded in 1959 by the government of the United Kingdom and the then government of the Federal People's Republic of Yugoslavia. ${ }^{816}$ The Agreement specifically provided that, in the event of any dispute relating to its interpretation or application, it should first be attempted to resolve such dispute with negotiation between the parties. Should such negotiations fail then the parties were entitled ('may') to request the resolution of the dispute by an arbitration tribunal. Even more significantly, Article 17 of the Agreement allowed the termination of the treaty by either party by giving notice to the other party. In such an event, the termination of the treaty would become effective only 12 months after receipt of the notice.

There apparently existed a real impediment concerning the lawfulness under international law of possible implementation by the UK government of Council Regulation 1901/98 through the adoption of the UK Yugoslavia (Prohibition of Flights) Regulations 1998 that was passed a few days after the Council Regulation was entered into force and which gave immediate effect to it. ${ }^{817}$ The requirement

815 Council Regulation (EC) No. 1064/1999 of 21 May 1999 imposing a ban on flights between the European Community and the Federal Republic of Yugoslavia and repealing regulation (EC) No. 1901/98, Of (1999) L129/27; Council Regulation (EC) No. 2151/1999 of 11 October 1999 imposing a ban on flights between the territories of the Community and the Federal Republic of Yugoslavia other than the Republic of Montenegro and the Province of Kosovo and repealing regulation (EG) No. 1064/1999, Of (1999) L264/3.

816 UK-FPRT Agreement of 1959, Agreement between the Government of the United Kingdom of Great Britain and Northern Ireland and the Government of the Federal People's Republic of Yugoslavia concerning Air Services, London, February 1959, Treaty Series No. 10 (1960) Presented to Parliament by the Secretary of State for Foreign Affairs by Command of Her Majesty, March 1960. This Agreement continued to be binding between the UK and the FRY and was the subject of a meeting between representatives of the two countries which took place on 14 October 1996 for the purpose of considering the position of their bilateral agreements. See Command Paper, First Supplementary List of Ratifications, Accessions, Withdrawals etc. for 1998, Treaty Series No. 28 (1998), Command Paper presented to Parliament by the Secretary of State for Foreign and Commonwealth Affairs by Command of Her Majesty, July 1998, Stationery Office.

817 The Yugoslavia Regulations 1998 were later revoked with Yugoslavia Regulations 1999, Statutory Instrument 1999 No. 2018, available at http://www.legislation.hmso.gov.uk/si/si1999/19992018. htm in accordance to Council Regulation (EC) No. 1064/1999 of 21 May 1999 imposing a 
of 12 months' notice was indeed a matter of concern for the British government as is revealed by the response given by the Secretary of State to the Committee on Foreign Affairs enquiry on the matter. Initially, the UK government was very reluctant to introduce the ban on flights conducted by Serbian airlines immediately as required by the Council regulation. ${ }^{818}$ In a confidential memo sent to all EU member states, the UK government contended that it possessed no right under international law to resort to 'reprisals' and, in particular, not to comply with existing treaty obligations due to the fact that the human rights violations in Kosovo did not affect EU member states directly. ${ }^{819}$ However, in the light of fierce criticism, especially from its European partners, the UK government reversed its decision and decided to enforce the ban immediately. The Secretary of State, while acknowledging the legal implications of giving immediate effect to the ban in contravention of the Air Service Agreement, especially Article 17, pointed out that the continuing repression in Kosovo and the humanitarian crisis justified the immediate ban of flights. ${ }^{820}$ Asked about the legal grounds on which the 1959 Agreement was to take precedence over the Council Regulation imposing the air ban, the Secretary of State replied that the agreement between Yugoslavia and the United Kingdom, which preceded the former's accession to the EC, had not been left unaffected. While accepting that the UK government still had a legal obligation to abide by its obligations under the agreement, it was stressed that:

There was always a balance to be struck between our legal obligation under the 1959 ASA ... and the need to bring Milosevic to comply with his obligations. That balance had tilted sharply by September given the worsening humanitarian situation on the ground in Kosovo, and in particular the reports of serious human rights abuses committed by the FRY and Serbian security forces. As my statement of 16 September makes clear, I concluded that, on moral and political grounds, Milosevic had forfeited the right to the 12 months' notice period which would normally apply under the terms of the ASA. ${ }^{821}$

ban on flights between the European Community and the Federal Republic of Yugoslavia and repealing regulation (EC) No. 1901/98, Of (1999) L129/27.

818 UK Secretary of State's statement, House of Commons Debates, 24 July 1998, c. 184. The UK government was faced with the possibility of proceedings before the ECJ in the event that it declined to conform with its obligations under Community treaties. See article by Butler in The Independent, 16 September 1998.

819 K. Butler 'Cook reviews "unethical" policy on Serbia after EU outrage'; The Independent, 16 September 1998.

820 UK Foreign Policy Report, First Report from the Foreign Affairs Committee, Session 1998-99, Foreign Policy and Human Rights, Response of the Secretary of State for Foreign and Commonwealth Affairs, EU Ban on Yugoslav Flights, Cm 4229, 6 available at http://www.fco. gov.uk/Files/kfile/FACresponse 019899,0.pdf.

821 Letter to the Chairman of the Committee from the Foreign Secretary on the Yugoslavia Flight Ban, 30/11/1998, Appendix 32 (emphasis added), available at http://www.publications. parliament.uk/pa/cm199899/cmselect/cmfaff/100/100ap46.htm. 
It is significant to highlight the fact that in this instance the UK government seems to have taken the view that there does not exist in international law a legal right of states not directly injured by a certain breach to resort to countermeasures, no matter if the breach may affect fundamental interests of the international community as a whole. Nevertheless, as noted, the United Kingdom's position in this instance seems to be at odds with its decision to impose a freeze on Yugoslav assets, a move in contravention of international law, but also with the position it held in several other cases examined earlier in which it had no hesitation in implementing countermeasures as an indirectly injured state. ${ }^{822}$

Similar concerns were also expressed by Greece, which invoked its bilateral agreement with Yugoslavia for its failure to give immediate effect to the decision of the EU Council, as reflected in its common positions and subsequently in the Regulations. ${ }^{823}$ Irrespective of the legal debate as to the legal force of common positions adopted under Title V TEU, especially when these are vaguely phrased, it was pointed out that sanctions decided at a Community level are required to be uniformly applied by all members of the EC. As noted by President Santer: '[D] ecisions taken by the fifteen Member States have to be applied by fifteen. If one or more countries refuses to play the game, it strips the decision to impose sanctions of any meaning.' ${ }^{2} 24$

Despite these difficulties it was argued that the EU, by resorting to the flight ban, despite the fact that in this way many bilateral agreements existing between the FRY and individual member states would be affected, 'broke new ground'. ${ }^{825}$ When the flight ban and, in particular, Council Regulation 1901/98, was challenged before the Belgian Cour d'Appel de Bruxelles, the latter ruled in favour of the legality of the regulation on the following grounds:

- ces mésures respondent à une violation antérieure du droit international;

- cette violation autorisé les contre-mesures;

- ces contre-mesures ne sont pas d'une illicité absolue;

- elles sont proportionnées à la violation initiale du droit international;

- leur mise en oevre est précédé d'une sommation adressé à l'État responsible de mettre fin à la violation initiale du droit international. ${ }^{826}$

Despite some states' reluctance, the reaction against Yugoslavia particularly through the freezing of assets but also through the immediate suspension of bilateral agreements concerning aviation rights provides further evidence of state practice and opinio juris of a right to unilateral coercive action for safeguarding fundamental community interests.

822 Dawidowicz, op. cit., 393.

823 See Agence Europe, 7286, 25-26 August 1998, 2; The European, 14-20 September 1998, 6.

824 European Voice, 17-23 September 1998, 15 in Koutrakos, op. cit., 88.

825 Paasivirta and Rosas, op. cit., 214.

826 Jugoslovenski Aerotransport v l'État Belge, Cour d'Appel de Bruxelles (9ème Chambre), decision of 10 June 1999 (No. 1998/KR/528) [1999] J.T. 693 in ibid, 215. 


\subsubsection{Legal issues arising from extradition agreements (1989 and 1991)}

Not infrequently many European and other states, including the United Kingdom, Canada and the Netherlands, have been faced with questions of conflict between two international, conventional or customary, norms of international law, one of which relating to human rights considerations.

The issue was raised among others in the well-known Soering case where the applicant, a German national who was accused of murder in the United States, had been arrested in the United Kingdom and was due for extradition to the United States in order to stand trial there. However, the European Court of Human Rights ruled that there were substantial cumulative reasons to believe that should the extradition be carried out, the applicant faced a real risk of exposure to an infringement of Article 3 of the European Convention on Human Rights regarding the prohibition of torture and inhuman treatment. Hence, although the prohibition of extradition to a place where an individual would be subjected to torture was not specifically spelled out in the Convention, this did not mean that such a prohibition was not inherent in Article 3. Judge De Meyer, in his concurring opinion said that extraditing an individual to a place where they would be exposed to torture or to the death penalty would be 'repugnant to European standards of justice and contrary to the public order of Europe'. ${ }^{827}$

The significance of this case lies in the fact that the United Kingdom and the United States were bound by the 1972 Extradition Treaty and should extradition be refused the United Kingdom would be acting in violation of its treaty obligations, giving rise to its international responsibility. The United Kingdom was thus confronted with the dilemma of whether to implement one international commitment while violating another. In the end, the United Kingdom sought and received assurances from the United States that Soering would not be tried on capital murder charges and subsequently extradited Soering to the United States. ${ }^{828}$ In this instance, the claim before the European Court of Human Rights was that compliance with the United Kingdom's obligations under the 1972 Treaty would result in the risk of subjecting the individual to torture, the prohibition of which is a peremptory norm of international law. Moreover, the prohibition of torture holds prominent place in the European Convention on Human Rights, which as analyzed earlier establishes an objective legal regime. As noted by Orakhelashvili: ' $[\mathrm{T}]$ he Court upheld the overriding effect of Article 3 and by implication tolerated some dangers to legal stability and the routine expectations of the States concerned.' ${ }^{2} 29$ This was particularly so in view of the fact that the 1972 Treaty was not in itself in violation of peremptory norms of international law, however, its implementation would be a violation of a prohibition of 'superior limitation'. ${ }^{830}$ This example seems to provide further support, of a judicial nature, for a right to

827 Soering v UK, 11 EHRR (1989), 439.

828 R. Lillich, 'The Soering Case' 85 AfIL(1991) No. 1, 128, 141.

829 Orakhelashvili, op. cit., 32-3.

830 Ibid, 32-3. 
countermeasures in the sense that states are entitled to refuse performance of their treaty and customary obligations in order to uphold a norm of fundamental character of international law.

Similar questions were raised in the case Short $v$ Netherlands where the applicant, an American citizen, was wanted by the US authorities for murder. The United States and the Netherlands were bound by the NATO Status of Force Agreement regarding extradition issues. However, the Netherlands was also bound by the Sixth Protocol to the European Convention on Human Rights under which the death sentence was prohibited. Refusing to extradite Short, the Netherlands justified its decision on the ground that: ' $[1] \mathrm{n}$ view of the great importance which must be attributed to the right not to suffer the death penalty, the weighing of the various interests in this case must inevitably result in a decision in Short's favour.' 831

The significance of the questions that these cases raise is invaluable. This is because both the Netherlands and the United Kingdom, while acting in agreement with specific treaty obligations, namely those arising from the European Convention on Human Rights, did so even though their action would be in contravention of another treaty obligation. In both the last cases, the two countries required to fulfil their extradition obligations towards the United States were third countries, not directly injured by a certain infringement or even by the possibility of an infringement. Rather, the Netherlands and the United Kingdom were acting for the protection of collective interests that had been established within the context of the Council of Europe and also under customary international law (prohibition of torture), upholding in this way the public order even in disregard of other treaty commitments.

\subsubsection{Unilateral coercive action against Zimbabwe (2002-2008)}

In the last few years, the Zimbabwean regime of Robert Mugabe has been engaged in serious human rights violations repressing political activity and opposition in the country through a wave of killings and intimidation. ${ }^{832}$ As a result, many countries at regional and universal level decided to implement a number of measures against Zimbabwe in response to these serious human rights violations. In particular, at an EU level it was decided in 1998 to impose an arms embargo and to introduce a travel ban, measures which, in the absence of specific treaty commitments, constitute only acts of retorsion. Moreover, the EC decided to suspend financial and development assistance provided under the Cotonou Agreement, which replaced the Lomé Conventions. ${ }^{833}$ The Cotonou Agreement makes express reference to the ability of member states to resort to appropriate measures in the

831 C.D.S v The State of the Netherlands, Supreme Court, 30 March 1990, RvdW (1990) No. 76, MRT (1990) 225; NJ (1991) No 249; also cited in NYIL (1991) No. 22, 433.

832 Keesing's (2002) 44600.

833 Keesing's, ibid. 
event of violation of human rights, democratic principles and the rule of law. ${ }^{834}$ Accordingly, these restrictions were justified within the scope of the Convention and, therefore, they did not amount to countermeasures.

In addition to these measures, it was decided to freeze Zimbabwean financial assets, a measure in violation of international law. This was followed by the majority of central and eastern European states with links to Cyprus, the EU, Lichtenstein and Malta. ${ }^{835}$ This measure infringed Zimbabwe's rights under general international law rather than under the African, Caribbean and Pacific Group Agreement (ACP Agreement) and, therefore, it could be justified as a third-state countermeasure. ${ }^{836}$ At a Commonwealth level, it was decided that Zimbabwe should be expelled from the Commonwealth, a measure that arguably amounts to suspension of membership rights such as voting as already seen in the case of Nigeria. ${ }^{837}$ The United States followed suit by also freezing Zimbabwean assets in 2003 and the same example was followed by the United Kingdom. ${ }^{838}$ These measures were later extended by EC member states and the United States amid further deterioration of the situation in Zimbabwe. ${ }^{839}$

\subsubsection{US action against Syria (2003-2004)}

In the light of Syria's occupation of the Lebanon and its alleged support of terrorism, the United States imposed through the adoption of the Syria Accountability and Lebanese Sovereignty Restoration Act, economic measures against Syria. These entailed the right to prohibit aviation rights, an export embargo and the freezing of Syrian assets. 840

While the export embargo did not infringe specific treaty commitments as Syria is not a member state to GATT, the freezing of its assets was in contravention of its rights under international law and, as such, it falls within the category of solidarity measures. ${ }^{841}$

834 Partnership Agreement between the ACP and the European Community of 23 June 2000 (Cotonou Agreement), Of (2000) L $317 / 3$ (15 December 2000). For the EC measures, see Council Common Position of 18 February 2002, 2002/145/CFSP (18 February 2002), Of (2002) L 50/1; Council Regulation (EG) No. 310/2002 of 18 February 2002, Of (2002) L 50/4.

835 See analysis in Dawidowicz, op. cit., 394-5.

836 Tams, op. cit., 224-5.

837 Dawidowicz, op. cit., 396.

838 'Blocking Property of Persons Undermining Democratic Processes or Institutions in Zimbabwe', Executive Order 13288, 6 March 2003 Federal Register, Vol. 68, No. 46; Keesing's (2002) 44541.

839 Council Common Position 2006/51/CFSP of 30 January 2006 renewing restrictive measures against Zimbabwe, Of (2006), L 26/28 (31 January 2006); Council Decision of 17 February 2005, extending the period of application of the measures provided for by Decision 2002/148/EC concluding consultations held with Zimbabwe under Article 96 of the ACP-EC Partnership Agreement Of (2005) L 48/28 (19 February 2005).

840 See Syria Accountability and Lebanese Sovereignty Restoration Act of 2003, HR 1828, 12 April 2003, Public Law 108-175 (12 December 2003) cited in Dawidowicz, op. cit., 396-7.

841 Dawidowicz, ibid, 397. 


\subsubsection{Action against Belarus (2004-2006)}

The human rights crisis that prevailed in Belarus resulting in the repression of political opponents and forced disappearances provoked international condemnation and criticism. The European Parliament deplored the situation calling on the Council and EU member states to freeze the assets of President Lukashenko. ${ }^{842}$ The Council of Ministers for its part reiterated the call for the freezing of economic assets. ${ }^{843}$ While no such decision to freeze assets was given effect at an EU level, the incident is significant as it reveals the determination of states to proceed with third-state countermeasures in response to serious violations of human rights. ${ }^{844}$ In parallel to the EU activity, the United States announced in 2006 the freezing of assets, a measure that amounts to a third-state countermeasure. ${ }^{845}$

\subsubsection{The ruling of the ECf in Kadi and $\mathrm{Al}$ Barakaat (2008)}

The recent rulings of the ECJ in Kadi and Al Barakaat concerning EU action taken in compliance with UN law but nevertheless in violation of fundamental human rights, and therefore community interests, are of particular relevance to the question of countermeasures by states not directly affected and therefore require special attention. The conclusion of the Court that the regulation adopted to give effect to relevant Security Council resolutions was in violation of fundamental human rights norms may imply a right of EU member states and institutions not to comply with these resolutions whenever such compliance would be tantamount to the breach of fundamental collective interests protected under EU law.

The applicants claimed that freezing their assets without allowing the possibility of their challenging the decision made against them was in violation of their right to property, their right to be heard and their right to judicial review. ${ }^{846}$ The Court was called on to consider whether the obligations emanating from the UN Charter prevailed over all other obligations, including those arising from EU law and human rights norms (whether treaty or customary in nature). The question is particularly relevant for the purposes of this examination relating to whether states could refuse to comply with Security Council resolutions adopted under Chapter VII of the UN Charter in order to uphold fundamental community interests such as the protection of human rights. In such a case, the decision could offer another example of solidarity measures.

842 European Parliament Resolution on Belarus, European Union Bulletin No. 3, 10 March 2005, 1.2.4.

843 General Affairs and External Relations, 2687th Council Meeting, Council of the European Union, External Relations, Brussels, 7 November 2005, 13622/05, available at http://ue.eu.int/ueDocs/ cms_Data/docs/pressData/en/gena/86850.pdf.

844 Dawidowicz, op. cit., 398.

845 Executive Order 'Blocking Property of Certain Persons Undermining Democratic Processes or Institutions in Belarus', US Department of the Treasury, available at http://www.treas.gov/ offices/enforcement/ofac/programs/belarus/belarus.pdf. Also see ibid, 398.

846 Kadi and Al Barakaat International Foundation v Council of the European Union and Commission of the European Communities, Joined Cases C-402/05 P and C-415/05 P, Judgment 3 September 2008. 
The difficulty with these cases relates to the prima facie conflict between two essential community interests, the protection of international peace and security, on the one hand, and the protection of fundamental human rights, on the other. However, such conflict seems to be at best fictitious, as the Security Council, in fulfilling its primary responsibility under the UN Charter, must abide by its principles, one of which is the protection of human rights. ${ }^{847}$

For the purposes of the current examination, and in the light of settled law, conduct that infringes fundamental principles of Community law should be annulled. ${ }^{848}$ The growing expansion of Security Council powers in maintaining international peace and security may in practice entail a risk to fundamental human rights. The Advocate-General stressed that, in his opinion, the powers of the Security Council in this regard should not be used to 'silence' the protection of human rights as embodied in Community law. Quite significantly, the AdvocateGeneral pointed out that the rules of public international law would determine the legal consequences to emerge as a result of implementation of Community principles at the expense of a Security Council resolution. ${ }^{849}$ This would unavoidably suggest that the lawfulness of a Community act would have to be determined also in the light of any general international rules concerning the right of third states to impose countermeasures by way of non-performance of other international obligations in response to a violation of a fundamental community right.

The Court itself upheld in the cases under consideration the principle that Community acts should still be subjected to judicial review even if taken in compliance with Security Council resolutions and emphasized that because of the autonomous character of the EU, its principles could not be disregarded on the ground of compliance with obligations arising from other international agreements. ${ }^{850}$ This could imply a right of the EU member states to countermeasures for protecting fundamental community interests, in violation of obligations arising from a given Security Council resolution, and even in the absence of direct injury. Ultimately the Court, while acknowledging that its limited competences did not allow it to exercise judicial review over Security Council resolutions, stressed that implementing such resolutions should not ignore the fundamental principles on which the EU is founded. ${ }^{851}$

Having established the unlawfulness of the contested regulation with human rights principles safeguarded under Community law, the Court ordered the

847 For relevant bibliography, see Katselli, op. cit., 301; G. Verdirame, 'Breaches of the European Convention on Human Rights resulting from the conduct of international organizations', 2 EHRLR (2008), 209; F. Megret and F. Hoffmann, 'The UN as a Human Rights Violator? Some Reflections on the United Nations Changing Human Rights Responsibilities', 25 HRQ (2003) 314.

848 Germany v Council, Case C-122/95 (1998) ECR I-973.

849 Kadi v Council of the European Union and Commission of the European Communities, Opinion of Advocate General Mr Maduro, 16 January 2008, Case C-402/05 P, (34) and (39).

850 Kadi and Al Barakaat v Council and Commission, (3 September 2008), op. cit., (303).

851 Ibid, (305). 
substitution of the contested regulation with another regulation that would ensure respect for individual human rights.

The ruling of the Court is significant as it implies that Community principles should prevail over other obligations emanating from other international agreements. While the Court's ruling was an attempt to reconcile the implementation of Security Council resolutions with fundamental Community interests, the question remains as to what will be the outcome if no such reconciliation can be achieved. The Court's ruling seems to imply violation of obligations emanating from Security Council resolutions, in an effort to protect essential collective principles protected under EU law. Although the Court made no express reference to the concept of countermeasures by states other than the injured, its decision could provide further support for the existence of state practice and opinio juris in favour of measures of this nature.

\section{Legal assessment of state practice and opinio juris}

There is little doubt that the problem of enforcement of international norms raises significant questions that lie at the heart of the nature and function of international law. This is particularly so with respect to interests the preservation and respect for which are fundamental for a group of states or the international community as a whole. The problem of implementation of these norms was central to this study, owing to the different views expressed within the ILC regarding the recognition of a rule permitting countermeasures taken in the collective interest by states that are not directly injured. In the absence of a treaty rule establishing a general right to resort to countermeasures for the protection of collective interests and interests owed to the international community as a whole, attention in this chapter was unavoidably turned to whether state practice and opinio juris establish the existence of a customary rule of international law to this effect.

Significantly, the ILC, in a final attempt to conclude the codification of the law on state responsibility that had been pending for more than four decades, held that there was no sufficient support relating to a customary rule permitting thirdstate countermeasures. According to its conclusions, the existing practice of states was selective and not of a general character and, therefore, it could not provide adequate evidence for the establishment of a customary rule. The decision of the ILC, however, not to incorporate the concept of solidarity measures in the Final Articles came somewhat as a surprise. This is very much due to the fact that under the Draft Articles on State Responsibility adopted in the first reading in 1996 all states were entitled to resort to countermeasures as a means of reaction to the commission of international crimes. ${ }^{852}$ Moreover, during the discussions in the ILC there was never a general or strong opposition to the concept with many states providing their support for the recognition of the right of states not directly injured to exercise unilateral coercive peaceful measures for inducing the wrongdoer to 
comply with its international obligations. ${ }^{853}$ Significantly, the ILC's conclusions relied on a very limited number of cases and its study lacked the depth and detail that were imperative in the light of the significance that the enforcement of fundamental collective and community interests has in international law.

The analysis in this chapter has sought to demonstrate that the findings of the ILC did not conclude or exhaust the subject, which reveals many examples of conduct resorted to by third states in violation of international law, justified by the protection of obligations owed to a group of states or the international community as a whole. Furthermore, the analyses here have shown that, in a significant number of cases in which states did not proceed with the actual implementation of measures of this nature, they demonstrated an intention to do so, through calls and recommendations particularly at a regional and international level.

This section will, therefore, provide some general conclusions that can be drawn from this analysis, but first attention will be turned to a consideration of the two basic elements required for the creation of custom, namely state practice and opinio juris. This is necessary to establish whether the examples discussed earlier in the chapter meet these requirements and therefore support a conclusion in favour of solidarity measures.

\subsection{Elements of customary mules of international lawe}

Article 38 of the Statute of the ICJ refers to custom as 'evidence of a general practice accepted as law'. Custom therefore consists of two interdependent elements: state practice, that is what states do, and opinio juris sive necessitatis, that is their belief that they have an obligation to behave in a certain way. ${ }^{854}$

For state practice to exist there must be some form of continuity, consistency, generality and repetition, although practice need not be uniform or prolonged. In the Asylum case, the ICJ ruled that practice must be 'constant and uniform', short of any uncertainty and contradiction, fluctuation, discrepancy or inconsistency. ${ }^{855}$ This was later upheld in the North Sea Continental Shelf cases, according to which practice must be uniform and extensive. ${ }^{856}$ In view of the difficulty of achieving uniformity in state affairs, the ICJ modified this requirement in its ruling in the Military and Paramilitary Activities in and against Nicaragua case so that state practice need not be uniform but must be consistent. 857

State practice can be reflected in treaties, in the decisions of national and international judicial bodies and in diplomatic correspondence or protests. It can also be found in national legislation, in the practice of international organizations, in

853 See analysis in Tams, op. cit., 244, 247-8.

854 Shaw, op. cit., 72 et seq.

855 Asylum case (Colombia/Peru), Judgment of 20 November 1950, ICJ Reports (1950) 266, 277.

856 North Sea Continental Shelf cases (Federal Republic of Germany v Denmark and the Netherlands), ICJ Reports (1969) 3, (74).

857 Case concerning Military and Paramilitary Activities in and against Nicaragua, (1986), op. cit., 98 (186). 
policy statements, press releases, executive decisions and also in the comments of states made in various international fora, including the ILC. ${ }^{858}$

State practice alone, however, is not sufficient to satisfy the requirements of custom, as it must always be accompanied by opinio juris. ${ }^{859}$ The ICJ has defined the psychological element as the belief of states that certain practice is 'obligatory by the existence of a rule of law requiring it'. ${ }^{860}$ Difficulties may arise in relation to proving the existence of opinio juris, that is, the belief that a certain state activity is in accordance with the law. For practical reasons, the opinio juris requirement has been expanded to include not only the belief that a certain conduct is required by law but, also, that it is becoming law. ${ }^{861}$ This element differentiates custom from moral or political principles, as it requires 'an aspect of legality about the behaviour and the acting state will have to confirm that this is so, so that the international community can easily distinguish legal from non-legal practices' ${ }^{862}$

Evidence of the essential state practice and opinio juris can also be established through General Assembly resolutions. This is because such resolutions constitute 'collective pronouncements of States', ${ }^{863}$ and provide support for the existence of state practice and also for the legal belief of states on international legal principles and rules. 864

In the light of these preliminary observations, it will now be considered whether the examples analyzed in this chapter satisfy the requirements for the establishment of a customary norm that confers a right on states to exercise unilateral coercive peaceful action in response to serious violations of collective interests, in the absence of individual injury.

\subsection{Some conclusions from the analysis of state practice}

This last consideration has dealt with a number of cases that, in the author's opinion, establish that the question of solidarity measures is not a newly conceived issue in the practice of international law and that such practice and opinio juris support the existence of a customary rule that permits enforcement of collective and community interests by such means. The study has not been confined to the examples referred to by the ILC in its commentary on countermeasures by states other than the injured and in recent academic commentary but, rather, it has tried to complement these by reference to some more examples not previously considered. The preceding discussion did not aim to exhaust the topic, a task almost impossible in view of the plurality of the actors and the multilevelled nature

858 Harris, op. cit., 23.

859 Shaw, op. cit., 75.

860 Case concerning Military and Paramilitary Activities in and against Nicaragua, (1986), op. cit., 108-9, (207); Case concerning North Sea Continental Shelf Cases (1969), 44, (77).

861 Shaw, op. cit., 87.

862 Ibid, 88.

863 Harris, op. cit., 55.

864 Ibid, 57. 
and depth of international state relations. Nevertheless, it has been shown through detailed analysis of national legislation, official statements, debates and discussions taking place in national parliaments and also before international organizations, national and international decisions and statements, that there is ample evidence of state practice and opinio juris that confirms the existence of a customary norm on solidarity measures. The significance of enforcement of such essential interests, but also the window of opportunity left open by the ILC's reference to the progressive development of international law on the matter make such detailed analysis necessary.

Truly, the preceding analysis has at times revealed the reluctance of states to resort to third-state countermeasures in the absence of relevant authorization by the Security Council. Such was the case when, for instance, US Congress decided to impose aviation restrictions against South Africa in response to apartheid. In that particular case, the US government was concerned that such a measure would be in violation of its obligations towards South Africa and for this reason tried, unsuccessfully, to block Congress from applying such countermeasures. The EEC had similar reservations in violating its commitments towards Uganda, despite the international outcry regarding the atrocities taking place in that country in the 1970s. The same scepticism was expressed by the EEC in relation to the situation in Greece, although this did not eventually prevent the Community from taking action in response to the human rights violations there. The UK government itself, in finally consenting to join other EU member states in taking coercive action against the FRY stated that its decision was based on 'moral and political grounds', implying that it was not acting in the belief that it was acting in accordance with the law, as required by opinio juris. At the same time, the analysis has shown that states have often opted to implement coercive but nonetheless lawful measures in response to serious violations of fundamental collective interests as opposed to countermeasures.

Given this analysis, some concerns exist as to whether certain cases were indeed a response to a previous violation of international law and, if so, whether such violation concerned an obligation in which a group of states or all states had a legal interest. White and Abass have observed in this regard that the state practice on which the ILC based its conclusions regarding the lawfulness of countermeasures of collective interests does not in all cases reveal a response to a violation of an erga omnes obligation. ${ }^{865}$ Such concerns have been expressed in relation to the action taken against Poland and the Soviet Union as a result of the implementation of martial law in Poland in 1981 or against Haiti in 1991.

Having said that, the examination provides compelling evidence that in many situations states not only did not hesitate to resort to countermeasures in protection of fundamental collective and community interests, even if no direct injury were involved, they also held the belief that this was the only way to induce the wrongdoing state to comply with international law. The measures adopted

865 White and Abass, op. cit., 520. 
against the Dominican Republic, the oil embargo imposed by Kuwait and Saudi Arabia against the United States for its support to Israel and its aggressive policies and the embargo against Uganda provide but a few examples of solidarity measures. Similarly, the action taken against the Soviet Union for its invasion in Afghanistan, the trade restrictions imposed against Nicaragua and the US lifting of the arms embargo against Bosnia-Herzegovina, provide further evidence of state practice and opinio juris in support of the right to solidarity measures. Such measures were given effect in violation of specific treaty and customary obligations and in the absence of Security Council authorization. While the consideration did not focus on early examples of state practice, the reference to the seizure of American vessels engaged in slavery and the freeing of slaves by British authorities in the 19th century highlights the point that such practices were not unknown in international law and that solidarity measures may already have been recognized as a customary right. Similarly, the coercive measures taken by the United States against Japan in the early 1940s in response to the latter's aggressive policies further illustrate the point that the concept of solidarity measures is not a contemporary development and that practice is not confined to that evolved after the end of World War II. This is something that is worth further exploration in future studies.

With the emphasis placed, however, on practice after World War II, it has been established that states have frequently resorted to action amounting to countermeasures in response to serious violations such as the commission of genocide, torture, apartheid, terrorism, hostage taking and aggression. While doubts remain with respect to the entitlement of states to impose countermeasures in response to violations of the right to democratic governance as the analysis concerning the action against Haiti has shown, it has been demonstrated that systematic and gross violations of fundamental human rights through the abolition of democratic rule have given rise to measures of this nature. This is evident from the action taken among others against Greece, the Central African Republic, and Liberia. Countermeasures have also been resorted to in protection of the right to selfdetermination such as the action taken against Portugal and South Africa. In addition, reference has been made to instances where states were faced with the dilemma of respecting their obligations emanating from fundamental human rights norms even in violation of other treaty obligations, such as in cases regarding the extradition of individuals to countries where they faced a risk of being subjected to torture or other cruel and inhuman treatment. Particularly relevant for the subject under consideration is the conflict that may arise between the implementation of Security Council resolutions and obligations concerning the protection of human rights, as evident from the recent ruling of the ECJ in Kadi and Al Barakaat. This is further illustrated from the United States' refusal to comply with the Security Council mandatory arms embargo against Bosnia-Herzegovina.

The analysis has further demonstrated numerous other instances where states, through statements before regional and international bodies, have called for or recommended the implementation of countermeasures, even if in the end no action were taken to that effect. This has been evident, for instance, from the repeated calls made by the General Assembly and the OAU for the implementation of an 
oil and a total trade embargo against South Africa in the 1960s and 1970s. Also significant are the General Assembly's calls to impose a trade embargo against Portugal and the calls of the EEC to implement a total trade embargo against Iran in the Teheran hostage crisis and against Iraq for its invasion of Kuwait. Evidence of state practice and opinio juris can further be deduced from the Bonn Declaration concerning action against states that failed to prosecute or extradite individuals responsible for aircraft hijacking. The legal significance of these examples should by no means be ignored as they support the argument that states have demonstrated both practice but also their legal belief that such conduct is in accordance with the law or is becoming law. ${ }^{866}$

Significantly, in many of the cases where states resorted to countermeasures, such as when the EEC decided in the 1980s to take action against Argentina, Poland or the Soviet Union, the issue of legitimacy under international law was never raised as an obstacle by the states resorting to such action.

An additional factor that needs to be taken into consideration when legally assessing these examples is that often the human rights or foreign policy of states was drafted in the light of their economic, political or geostrategic interests. This consideration has frequently contributed to the reluctance of states to protect community values by unilateral peaceful means when these were threatened by intransigent states and therefore it should not be construed as evidence of opinio juris against the existence of a right to third-state countermeasures.

Moreover, it has been shown that even in those cases where states restricted their action to coercive but not unlawful measures, they did so not necessarily because they opposed the notion of third-state countermeasures. The legal significance of these examples is invaluable as they demonstrate the determination of states, even if third parties, to interfere against serious violations of obligations in the protection of which they possess a legal interest. States have often resorted to retorsion together with countermeasures, resorting to all means at their disposal for the safeguard of such fundamental interests.

In some of the cases referred to earlier, states did not rely on a right to solidarity measures but instead used other justifications such as fundamental change of circumstances or national security clauses provided under specific treaty arrangements such as GATT. It has been shown, however, that, at least in some of these cases, a justification on third-state countermeasures was more appropriate.

Quite significantly, during the discussions before the ILC, the Czech Republic pointed out that although institutionalised responses were preferable, it recognized that such was unrealistic for the time being, leaving open the question of a unilateral right to third-state countermeasures. ${ }^{867}$ Similarly, the Nordic countries

866 Harris, op. cit., 55-6.

867 On the position of the Nordic Countries see state comments on Draft Article 47 in State Responsibility, Comments and Observation received from Governments, ILC, Fiftieth Session, A/CN.4/488, 134. Also see Spinedi (1989) op. cit. 70. Interestingly, in 1981 the Federal Republic of Germany made the following statement: 'if rules of international law are violated in the observation of which the community of States as a whole has a vested interest, third States, although 
expressed no reservations concerning a right to third-state countermeasures. Quite notably, during the early debates concerning the inclusions of the notion of state crimes, Australia, the United States, Bulgaria, Indonesia and the Federal Republic of Germany did not object the admissibility of countermeasures taken in response to violations of this nature. ${ }^{868}$

It can therefore be concluded that the state practice as analyzed here is not isolated but, on the contrary, has flourished through the years, particularly after the incorporation of the concept of obligations erga omnes in international legal thinking revealing consistency and repetition. ${ }^{869}$ Accordingly, state practice is neither 'sparse' nor 'embryonic'. Moreover, it has been illustrated that often such practice has been supported by developed as well as developing countries establishing the general acceptance of a norm permitting for third-state countermeasures. This is illustrated by decisions and recommendations of the OAS, by the OAU, by the EU and by the League of Arab States. ${ }^{870}$ Such general and consistent practice is evident, for instance, from the numerous occasions of freezing of foreign assets, which have also been accompanied by the required opinio juris. Only in a few exceptional circumstances have states, when resorting to countermeasures, tried to justify their conduct on moral or political reasons and not on legal grounds. On the contrary, in most cases states acted bearing in mind that such action would be in contravention of their international commitments under GATT, EEC law, general international law such as the prohibition of interfering with another state's property or bilateral trade and aviation agreements. It is also not without legal significance that in many of the cases discussed earlier, there was no general protest from other states, with few exceptions such as for instance in relation to the coercive measures imposed against Argentina during the Falklands. As noted, however, such protest was due to the fact that other American states considered that Argentina had valid territorial claims over the islands and not because they opposed a customary rule on solidarity measures. As noted in this regard, the absence of protest is indicative of the legal belief held by these states that such conduct was required by law. ${ }^{871}$

In conclusion, our analysis has demonstrated extensive evidence of state practice and opinio juris in support of a right to take countermeasures by states other than the injured as an integral part of customary international law.

not immediately involved, might well be entitled to take countermeasures or to participate in such measures.' Comments of Governments on part 1 of the draft articles on State responsibility for internationally wrongful acts, YbILC (1981), vol. II, Part One, 71, 75.

868 State comments on Draft Article 47, ibid, 135.

869 In support of this conclusion, see Tams, op. cit., 232-40; Dawidowicz, op. cit., 408-415.

870 Also see Dawidowicz, ibid, 409-15.

871 Ibid, 358. Furthermore, according to MacGibbon, 'a protest constitutes a formal objection by which the protesting state makes it known that it does not recognize the legality of the acts against which the protest is directed, that it does not acquiesce in the situation which such acts have created or which they threaten to create, and that it has no intention of abandoning its own rights in the premises.' See, in this regard, I.C. MacGibbon, 'Some Observations on the Part of Protest in International Law' 30 BrIL (1953) 293, 298. 


\section{Conclusion}

The concept of solidarity measures has emerged through the necessity of enforcing fundamental interests of international law owed to a group of states collectively or to the international community in its entirety. ${ }^{872}$ Unlike national law where the enforcement of its rules is achieved through central institutions and procedures, restricting the entitlement of individuals to resort to private means of self-help, the international legal order is reliant on such means of self-help, particularly so for the protection of interests that it regards as important. Yet, the necessity of enforcing such fundamental interests has stumbled on the admittedly justified fears that recognition of a right to countermeasures by states other than the injured will be open to abuse. ${ }^{873}$ Such fears, however, should not be allowed to suppress contemporary developments on the matter, as the fear of arbitrary use of international law is inherent in all aspects of state affairs without placing a halt on the creation of new norms. Moreover, any discussion on solidarity measures must take into account the conditions of their lawfulness and, therefore, any claim of a state that it is acting in protection of collective and community interests must always be assessed within that legal framework. Accordingly, the state that abuses the right to solidarity measures will be itself the subject of international responsibility, with all the legal consequences that this entails.

Quite significantly, the practice examined in this chapter has demonstrated that states have on numerous occasions responded to serious violations of obligations with an erga omnes and erga omnes partes effect, an important requirement for the lawfulness of conduct of such nature. ${ }^{874}$ Nevertheless, while this element is necessary to prevent abuse and further conflict in interstate relations, it is submitted that it is inherent in some types of wrongful act, such as those concerning the violation of peremptory norms of international law, including, for instance, the commission of genocide, aggression, slavery and apartheid. ${ }^{875}$ The seriousness of a wrongful act will, however, be necessary to ensure that states do not resort

872 K. Frahm, 'Comment: The Erga Omnes Applicability of Human Rights', 30 ARV (1992) 34; G. Gaja, 'Obligations Erga Omnes, International Crimes and Fus Cogens: A Tentative Analysis of Three Related Concepts' in Weiler, Cassese and Spinedi (1989) op. cit., 155-6; Elagab, op.cit. T. Meron, 'International Law in the age of Human Rights', $301 R d C$ (2003) 296; Annacker, op. cit., 160; J. Delbruck (ed.), 'The Impact of the Allocation of International Law Enforcement Authority on the International Legal Order' in Allocation of Law Enforcement Authority in the International System (1995) 152-3.

873 D.N. Hutchinson, 'Solidarity and Breaches of Multilateral Treaties', 59 BYIL (1988) 151, 202.

874 Dawidowicz, op. cit., 347. Also see, in this regard, J. Frowein, 'Collective Enforcement of International Obligations', 47 ZaoRV (1987) 77; C. Dominice, 'The International Responsibility of States for Breach of Multilateral Obligations', 10 EfIL (1999) 360-61; C. Hillgruber, 'The Right of Third States to take Countermeasures' in C. Tomuschat and J.M. Thouvenin (eds) The Fundamental Rules of the International Legal Order: Jus Cogens and Obligations Erga Omnes (2006) 268; Sicilianos (2002), op. cit., 1127; Alland, op. cit., 1221.

875 Also see discussion in Chapter 2. 
to such powerful means whenever isolated violations of fundamental interests occur.

The analysis in the preceding sections has demonstrated that a customary rule concerning a right to countermeasures by not directly injured states for the protection of collective interests has evolved in international law. This has been achieved through general, consistent and continuous practice, accompanied by the necessary opinio juris, opening the way for the effective enforcement of fundamental collective legal interests. While the foregoing analysis does not exhaust the topic, it provides concrete evidence, contrary to the conclusions of the ILC, that states have often exerted economic, trade and other non-forcible pressure against those that have infringed obligations owed either to a group of states collectively or to the international community as a whole. This work comes to complement the existing literature on the matter and also to enrich this with further analysis and more examples that give rise to a claim regarding the customary character of the right to solidarity measures.

While the analysis so far focused on the emergence of fundamental interests in international legal theory, practice and the jurisprudence, attention will next focus on the interrelationship between the right to solidarity measures and obligations arising from other legal, so-called special and self-contained regimes. 


\section{Self-contained regimes, solidarity measures and the fragmentation of international law}

\section{Introduction}

The discussion so far has demonstrated that the recognition of fundamental community interests and interests owed to a group of states has been closely interlinked with issues relating to their enforcement, either through initiating proceedings before judicial bodies or through the implementation of countermeasures. Having established in particular the existence of a customary rule that permits the enforcement of such interests through countermeasures by states that have suffered no direct injury, it will be considered next whether such right may be imperilled by alternative enforcement mechanisms provided under specific treaties or so-called self-contained regimes. In other words, this chapter will consider the question of whether states may contract out from the enforcement of obligations erga omnes under general international law by concluding special agreements that preclude the intrusion of enforcement mechanisms other than those, and for the reasons, specifically provided under them.

In recent years, international law has come face to face with a wide, both in scope and content, expansion of primary and secondary norms, a proliferation of general and special legal regimes and a growing number of international judicial bodies entrusted with the duty to resolve disputes arising in the international legal arena. In a highly anarchical society such as the international one, such growth of norms, regimes and institutions could not but be welcomed as promoting and enhancing the rule of international law. Yet the ability of these special or selfcontained regimes, to promote through their own institutions and mechanisms respect for their own norms, has not toned down voices of concern and scepticism with respect to their position in the framework of general international law.

In the course of this analysis, it will be shown that states may be faced with a conflict of norms or a conflict of enforcement mechanisms emanating from different legal regimes, restricting their ability to implement countermeasures under general international law and, subsequently, their ability to safeguard community and collective interests.

The scope of the present chapter is accordingly focused on the relationship between lex specialis and lex generalis enforcement regimes, with particular emphasis placed on the position of self-contained regimes within the general system of international law viewed from two different perspectives. 
First, whether such self-contained regimes preclude totally or partially the application of the general rules on state responsibility for the violation of their rules, thus permitting only the remedies expressly provided for by such regimes. Second, and more significantly, whether a violation of a rule of general international law, for example, a violation of a jus cogens norm or an obligation erga omnes, may justify countermeasures through the non-performance of obligations established within such specific regimes. As already seen in Chapter 3, concerning state practice in support of solidarity measures, states have frequently disregarded their obligations emanating from specific agreements or self-contained regimes in response to serious violations of community and collective interests. This has often been the subject of criticism as endangering the unity and coherence of international law. The dilemma for the state here is clear: to observe its legal undertakings under a specific agreement at the expense of fundamental community interests or interests established for the collective good of a group of states or to infringe its treaty commitments for the purpose of safeguarding such interests. In the former case, the state is in compliance with international law; in the latter, it is at least prima facie, in apparent violation of it.

The question gains particular significance in the context of the WTO due to the rapidly and widely increasing trade areas covered by its agreements, thus leaving little space for the application of countermeasures under general international law. Similarly, questions are raised with respect to the integrity of the international legal system as such since while a certain conduct may be justified under general rules, it may be prohibited under others. International judicial bodies may also reach, as they have done so in the past, different legal conclusions on similar facts threatening in this manner legal security, but also consistency in terms of equal application of the law. Finally, states may be faced with international responsibility for conduct that while unlawful under one set of rules, it is justified under others.

In the light of the significance of countermeasures in general, but also of countermeasures in the collective interest in particular as means of international legal enforcement, the interrelationship of secondary rules emanating from different legal regimes is of great relevance and, therefore, it will be considered thoroughly in the following sections.

However, before looking in depth into the question of the relationship between specific and general enforcement legal regimes, it is necessary to examine the interaction, if any, between the law on state responsibility and the law on treaties as both constituting leges generales. This consideration will assist in the comprehension of how the legal consequences that arise from the law on state responsibility, such as countermeasures complement the rules emanating from the law of treaties. It will further clarify the legal basis on which state action may rely on enhancing in this way the integrity of the rule of law. This is particularly so since, as the analysis in the previous chapter has shown, states have often attempted to justify their conduct on grounds emanating interchangeably from the law on treaties and the law on state responsibility. It is, therefore, timely to consider the interaction between these two fields of international law and to consider under 
what circumstances state responsibility, and countermeasures in particular, may be resorted to as opposed to consequences emanating from the law of treaties.

\section{Relationship between the law on treaties and the law on state responsibility}

The relationship between the law on treaties and the law on state responsibility was thoroughly dealt with in the dispute that broke out between Hungary and Czechoslovakia in the Gabčikovo-Nagymaros case. ${ }^{876}$ The dispute evolved around claims concerning the implementation of an agreement entered by the two states in 1977 for the construction and operation of a system of barrage and locks on that part of the Danube shared by them as both international river and boundary. ${ }^{877}$ The project provided for the construction and installation of two hydroelectric power plants on the Hungarian Nagymaros sector, on the one hand, and on the Czechoslovakian Gabčikovo sector, on the other, and consisted of a large indivisible complex of installations and structures that had to be implemented in an integrated and joint manner. In view of increasing environmental concerns at a domestic level, the Hungarian government decided in May 1989 to suspend and finally abandon the works at the Nagymaros sector and those works at Gabčikovo attributed to it, notwithstanding that, by that time the works at Gabčikovo had to a great extent been completed, the works at Nagymaros had hardly begun. ${ }^{878}$

In 1991 Czechoslovakia, in response to Hungary's decision adopted an alternative project known as 'the provisional solution', otherwise known as Variant C. This latter plan provided for the diversion of the River Danube within Czechoslovakia's boundaries without Hungary's consent. As a result, in 1992, before the actual operation of Variant C, Hungary announced the termination of the 1977 Treaty existing between the two countries. The work on the damming of the Danube was completed a few months after Hungary's denunciation of the Treaty, resulting in significant reduction of water flow. ${ }^{879}$

The fact that Hungary and Czechoslovakia were not legally bound by the 1969 VCLT when they signed the 1977 Treaty notwithstanding, and in the absence of specific provisions under the latter treaty concerning denunciation or withdrawal, the Court held that the conduct of the two parties should be evaluated under the scope of Articles 60-62 of the VCLT. These articles reflect existing customary rules of international law and they are therefore binding on the two states. At the same time, the Court called for consideration of the two parties' conduct under the law on state responsibility.

876 Case Concerning the Gabčikovo-Nagymaros Project (1997) op.cit., 7.

877 Treaty Concerning the Construction and Operation of the Gabčikovo-Nagymaros System of Locks, 16 September 1977, 32 ILM (1993) 1247.

878 D. Reichert-Facilides, 'Down the Danube: The Vienna Convention on the Law of Treaties and the Case Concerning the Gabčikovo-Nagymaros Project' 47 ICLQ(1998) No. 4, 837, 838-9.

879 Ibid, 839-40. 
Hungary's unwillingness to comply with some of its treaty obligations unavoidably made the completion of the project impossible, ${ }^{880}$ however, it was justified on reasons of ecological necessity that had forced Hungary to initially suspend and abandon certain works of the Gabčikovo-Nagymaros Project and finally terminate its treaty with Czechoslovakia. In this regard, the Court held that this ground should be viewed under the scope of the law on state responsibility according to which necessity, if proven as existent, would preclude the responsibility of the defaulting state on the international plane. Nevertheless, since this ground was invoked in an attempt to justify the suspension and termination of the 1977 treaty, reference to the law of treaties was unavoidable.

Concerned about a possible misconception between the two branches of international law when evaluating the legality of the suspension or termination of a treaty as in the present case, the Court wished to draw a distinguishing line between the law on treaties and the law on state responsibility.

Accordingly, while the law on treaties determines, inter alia, whether a treaty is in force and the grounds on which a treaty may lawfully be suspended or terminated, the law on state responsibility evaluates the legal consequences to derive as a result of unlawful suspension or termination of the treaty, ${ }^{881}$ in the absence of any agreement to the contrary. In other words: '[W] hile once conduct incompatible with the law of treaties has been established, potential ensuing responsibility should be assessed according to the law on state responsibility.' 882 This is in accordance with Article 73 of the 1969 VCLT according to which 'the provisions of the present Convention shall not prejudge any question that may arise in regard to a treaty from a succession of States or from the international responsibility of a State or from the outbreak of hostilities between States.' While the 1969 VCLT is concerned with the genesis of a treaty obligation, its very existence, content and its subjects, it does not provide rules concerning compliance with it. Rather, the issue of conformity with customary or conventional rules is covered by the general rules on state responsibility. As Professor Crawford concludes, the ILC Articles on State Responsibility provide 'the general secondary law of international obligations, in the same way that the Vienna Convention provides the general secondary law of treaties' ${ }^{883}$

Against this background and with respect to Hungary's claim for the existence of environmental necessity, the Court highlighted that necessity, falling within the scope of state responsibility, could not validly be invoked as a reason for the suspension or termination of the 1977 Treaty. In this regard, the Court stressed that a treaty may only be terminated or suspended for one of the reasons referred to in Articles 60-62, namely, for material breach, impossibility of performance or

880 Case Concerning the Gabčikovo-Nagymaros Project (1997), op.cit., (48).

881 Ibid (47).

882 K. Wellens, 'The Court's Judgment Concerning the Gabčikovo-Nagymaros Project (Hungary/ Slovakia): Some preliminary reflections' in Wellens (1998), op. cit., 768.

883 Crawford (2000), op. cit. 
fundamental change of circumstances. ${ }^{884}$ These articles provide an exhaustive list of the circumstances under which a treaty may be lawfully terminated or suspended. Possible acceptance of additional grounds for the lawful suspension and termination of treaties other than those already provided could put at risk 'the security of treaty regimes'. ${ }^{885}$ Consequently, Hungary could not invoke necessity as a ground for the termination or even suspension of the 1977 Treaty and, as a result, this ground was dismissed.

A justified invocation of a state of necessity could, however, be used as a ground for precluding state responsibility for the temporary non-performance of treaty obligations and for as long as necessity existed. Accordingly, the only effect that necessity may have is that it makes the treaty ineffective and 'dormant, but unless the parties by mutual agreement terminate the Treaty - it continues to exist. As soon as the state of necessity ceases to exist, the duty to comply with treaty obligations revives.' ${ }^{8} 86$ Accordingly, although non-performance of a treaty obligation may look like suspension, it is not.

While Hungary's suspension or termination of its treaty with Czechoslovakia could not rely on necessity, its decision to suspend certain works of the project could be justified under the state of necessity as a circumstance precluding wrongfulness provided under the law on state responsibility. Nevertheless, Hungary would still be legally bound to perform its treaty obligations as soon as the state of necessity ceased to exist. 887

This is the main difference between suspension and termination of a treaty, on the one hand, and non-performance of treaty obligations, on the other. In the former case, the treaty ceases to have legal effects and to be in force, whereas in the case of non-performance the treaty remains legally binding on all the parties involved that still have to resume their obligations as soon as the ground precluding wrongfulness vanishes. As Professor Crawford noted on the matter, the existence of circumstances precluding the international responsibility of a state, such as necessity or countermeasures, render, for as long as they persist, the international obligation 'inoperative'. ${ }^{888}$ Yet, the obligation does not cease to exist, a point that has often been highlighted as of great significance. In the words of Fitzmaurice:

some of the grounds justifying non-performance of a particular treaty obligation are identical with some of those causing or justifying the termination of a treaty. Yet ... the two subjects are quite distinct, if only because in the case of termination ... the treaty ends altogether, while in the other [case] ... it does not in general do so, and (if a paradox is permissible) the non-performance

884 Case Concerning the Gabcikovo-Nagymaros Project (1997) op. cit., (47).

885 P. Okawa, 'International Court of Justice: Recent Cases, Case concerning the GabčikovoNagymaros Project (Hungary/Slovakia)' 47 ICLQ(1998) 688, 692.

886 Case Concerning the Gabčikovo-Nagymaros Project (1997) op. cit., (101).

887 Ibid.

888 Second Report on State Responsibility (Crawford) Addendum 2, op. cit., (222) 
is not only justified, but "looks towards" a resumption of performance so soon as the factors causing and justifying the non-performance are no longer present. ${ }^{889}$

Zoller observes in this regard that while suspension or termination has, as a result the cessation of the legal effects of the treaty (and in the case of suspension for as long as this situation is persistent), non-performance does not result to the same effect. She illustrates this difference with an example. Accordingly, whenever a treaty is suspended the interest stops running, while in non-performance the interest continues to be calculated. 890

Moreover, it has been very characteristically pointed out that:

by confirming that the consequences of illegal termination, and in particular whether they could be excused, had to be determined by reference to the law of State Responsibility, the judgment implicitly lays to rest some of the arguments that had been advanced in the literature that States parties to the Vienna Convention had forfeited the right to rely on the broader excuses precluding wrongfulness under the law of state responsibility. ${ }^{891}$

In addition to this, the 1969 VCLT confirms, rather than deviates from, customary international law and, consequently, a state may still rely on principles of customary international law, complementary to any other treaty provisions that may be applicable, and even if such principles are not expressly provided by a given treaty. This can take the form of retaliatory measures such as the temporary non-performance of specific treaty obligations, by reference to the rules on state responsibility. ${ }^{892}$

It can therefore be concluded that the law on treaties and the law on state responsibility, although different in nature and different in scope, are not completely unrelated. More specifically, the two branches of international law, the rules of which are 'of the utmost significance for the overall functioning of international law', should not be interpreted in a 'counterproductive way', but on the contrary, must be construed as coexisting in harmony. ${ }^{893}$

In this regard, the Court should follow an integrative approach in relation to these different branches of law and such an attempt should not be rendered impossible by the mere existence of Article 73 of the VCLT. In support of this position and as evident from the analysis in Chapter 3, states often try to justify the breach of their international obligations in the light of the law on treaties and the law on state responsibility. ${ }^{894}$ Accordingly, it seems that it is not really possible

889 Fourth Report on the Law of Treaties (Fitzmaurice), op. cit., 41 in Second Report on State Responsibility (Crawford) Addendum 2, op. cit.,(224).

890 Zoller, op. cit., 89.

891 Okawa (1998), op. cit., 692.

892 Zoller, op. cit., 92-3.

893 Wellens, 'The Court's Judgment Concerning the Gabčikovo-Nagymaros Project (Hungary/ Slovakia): Some preliminary reflections' in Wellens (1998), op. cit., 793.

894 Ibid, 794. 
to separate the law on treaties from the law on state responsibility. With this in mind:

the law on State responsibility not only 'touches and interacts' with other branches of general international law, but constitutes the decisive body of rules governing non-compliance with any other legal obligation, and thus 'permeates' all sets of general, conventional and customary primary rules. The law on state responsibility occupies a quasi-constitutional place in the international legal order. ${ }^{895}$

Furthermore, the fact that two (or more) states decide to conclude a treaty means that this treaty will apply in their relations as lex specialis, regulating their rights and their obligations. Nevertheless, the existence of a treaty between two parties does not exclude the application of other branches of international law. As the ICJ held in its 1971 Namibia Opinion, 'an international instrument has to be interpreted and applied within the framework of the entire legal system prevailing at the time of the interpretation ... the corpus iuris gentium has been considerably enriched, and this the Court, if it is faithfully to discharge its functions, may not ignore.' 896 This is further explored later.

Nevertheless, according to some authors, the decision of the Court in the Gabcikovo-Nagymaros case to adopt a strict interpretation in relation to the grounds allowed for the suspension or termination of a treaty sacrificed 'substantive justice' over 'legal security'. The former may call for the possibility to introduce new grounds under which a treaty may be suspended or terminated other than those already provided in Articles 60-62 of the Convention. As the supporters of this opinion argue, this becomes even more compelling in cases where the continuance of a treaty imposes a particularly heavy burden on the treaty parties. ${ }^{897}$

Nevertheless, the analysis here illustrates that the two branches of international law complement one another, creating legal harmony and outlining clearly the legal boundaries of state conduct. This is particularly significant in evaluating the legality of certain state action that amounts to countermeasures under the law on state responsibility and which must be distinguished from other possible legal justifications.

\section{Lex specialis, self-contained regimes and general international law}

Now that the interrelation of the law on state responsibility and the law on treaties has been clarified, it is imperative to examine the interrelation between the law on state responsibility and the law on treaties as leges generales, on the one hand, and specific legal regimes, on the other.

895 Ibid.

896 Legal Consequences for States of the Continued Presence of South Africa in Namibia, op. cit., 31-32 (53).

897 Reichert-Facilides, op. cit., 842; Okawa (1998), op. cit., 692. 
The issue raises interesting questions since the incorporation of collective and community interests in the main body of international law, as elaborated in Chapters 1 and 2 has not prevented states from still possessing a pivotal role in the formulation of international norms, including rules on enforcement. As already noted in Chapter 1 in this regard, 'international law is a law of cooperation, not subordination' founded on state consent. Since each state determines what the law binding on it will be the international legal system consists of multiple legal relationships that vary in scope and content according to the states involved. ${ }^{898}$

In an inherently pluralistic society such as the international one, seeking ultimate unity in the law generally and in the law of enforcement particularly is perhaps an untenable goal. ${ }^{899}$ For this purpose, the system has enacted procedures of dispute resolution and interpretative methods whenever a conflict between norms or obligations occurs, such as the general principle that the posterior rule prevails over an earlier one. What is more, in this system, states are entitled to enter into specific agreements in deviation from the general rules of international law, such as the law on state responsibility or the law on treaties, and which although may reinforce and strengthen the rights of states, they may often create a legal regime that essentially affords states weaker protection. It is therefore well established in international law that even though such agreements may not infringe jus cogens norms, the lex specialis rule will prevail over the lex generalis. ${ }^{900}$

Often, the specific rule is seen within the general legal framework within which it exists and as an elaboration of the general rules. At other times, however, the specific rule is incompatible with the general rules that it sets aside..$^{901}$

It has, therefore, long been recognized that states, when entering into agreements may choose to specify the legal consequences to derive from the infringement of their obligations under such agreements or even to set up their own dispute settlement procedures and establish their own enforcement mechanisms. This may be so even in derogation not only of the general rules of the law on treaties concerning the suspension and termination of treaties, but also of the general rules of the international responsibility of states. Therefore, these specific regimes, irrespective of whether customary or conventional, often complement, substitute or depart from general provisions. ${ }^{902}$

The lex specialis maxim has its roots in the widely consensual structure of international law and on the fact that general international law is 'dispositive',

898 J. Pauwelyn, 'The Role of Public International Law in the WTO: How far can we go?' 95 AffIL (2001) 535, 536.

899 'Fragmentation of International Law', Report (2006), op. cit., (16).

900 Ibid. (56).

901 Ibid, (56-7).

902 Pellet, op. cit., 56. Obligations of a specific character are usually established by treaties, although even a special custom could prevail over a general rule established by treaty. See, in this regard, Report of the International Law Commission on the Work of its Fifty-sixth Session, 3 May to 4 June and 5 July to 6 August, 2004 (A/59/10), 288 (313). 
construed as meaning that it can largely be derogated from. ${ }^{903}$ The lex specialis has also been used as a means for the resolution of norm conflicts" 904 and as a 'technique of legal reasoning' that aims to bring legal certainty and clarity into the relations among states. ${ }^{905}$

The lex specialis rule raises significant questions as to how it relates with general rules of international law. This is particularly important as international law consists of several general and specific legal regimes establishing certain rights and imposing specific obligations that are often independent from one another and which stand autonomously in the international legal order. While the norms of these separate legal regimes frequently interact and seem to be complementary, sometimes they collide. Of course, specific rules do not exist in a legal hole, on the contrary, they must be interpreted taking into consideration the legal framework within which they exist and operate..$^{906}$

Yet, there is little said about the possible dangers from conflicts arising with respect to irreconcilable norms of international law belonging to different legal regimes and on which different legal consequences may apply.

Within the deliberations of the ILC on the codification of state responsibility, Mr Riphagen made the point that international law is separated between various interrelated subsystems in accordance to the function that each one of them fulfils. A treaty may establish a distinctive subsystem with its own secondary rules to be set in motion whenever its provisions are infringed by any of the parties and which cannot be overruled by other subsystems. The existence of such a treaty subsystem, however, does not necessarily preclude the application of the rules of customary international law regarding the international responsibility of states. This is so because the treaty subsystem may itself collapse, 'in which case a fallback on another subsystem may be unavoidable'. ${ }^{907}$

On the same footing, the study group looking into the question of fragmentation of international law, discussed further later, described general international law as 'omnipresent' existing behind special rules and regimes. ${ }^{908}$ Nevertheless:

the interrelationship between the subsystems may be complicated by the fact that a particular set of actual circumstances may be relevant for more than one subsystem. Here the measure of organization of the relationship becomes particularly important: if it is not possible to allocate the situation to one or the other system, the more organized system prevails until it fails as such. ${ }^{909}$

903 Report of the International Law Commission (2004), ibid, 286 (309).

904 Ibid, 285 (305).

905 'Fragmentation of International Law', Report (2006), op. cit., (119).

906 Ibid, (120).

907 Third Report on State Responsibility (Riphagen) op. cit., 30-31, (54).

908 Report of the International Law Commission (2004) op. cit., 287 (311).

909 Third Report on State Responsibility (Riphagen) op. cit., 30-31 (54). 
While it is possible that the same wrongful act violates rules belonging to different subsystems and therefore a combination between these subsystems and their legal consequences may be unavoidable, ${ }^{910}$ difficulty seems to arise whenever a specific conduct is lawful under a certain legal regime or subsystem and unlawful under another. It is to the interrelationship of the various legal systems existent in the international arena and the various legal consequences to emerge therefrom that attention is next turned to, with particular emphasis given on the implementation of countermeasures under the general law on state responsibility within specific or self-contained regimes.

First, however, it is essential to consider what 'self-contained' regimes are. The term, which is understood to express a subcategory of lex specialis, ${ }^{911}$ appeared in the ruling of the ICJ in the dispute that broke out between Iran and the United States in relation to the seizure of the US Embassy and its diplomatic and consular staff in Teheran. In the proceedings initiated by the United States before the Court, the Iranian government tried to defend itself and justify the events in the embassy by relying on alleged previous interventions in Iranian internal affairs by the United States, such as the latter's involvement in the coup d'état of 1953 and the overthrow of the lawful national government. Nevertheless, the Court rejected this argument, stressing that no countermeasures were permissible in the field of diplomatic relations for the violation of a norm of the same kind. The only countermeasures that could be resorted to were those provided for by diplomatic law itself and, in particular, that of declaring a diplomat or a consular official as persona non grata, the breaking off of the diplomatic relations and the closure of the mission. While the sending state has an obligation under general international law to respect the laws and regulations of the receiving state and not to interfere in its domestic affairs, the violation of these obligations does not justify a similar response in disregard of the privileges and immunities accorded by diplomatic law by the receiving state. According to the Court:

$[\mathrm{T}]$ he rules of diplomatic law, in short, constitute a self-contained regime which, on the one hand, lays down the receiving State's obligations regarding the facilities, privileges and immunities to be accorded to diplomatic missions and, on the other, foresees their possible abuse by members of the mission and specifies the means at the disposal of the receiving State to counter any such abuse. These means are by their very nature, entirely efficacious. ${ }^{912}$

Here, the notion of self-contained regimes is understood as a set of specific legal consequences applicable in the relations between two (or more) states as opposed to the general consequences provided under the law on state responsibility. ${ }^{913}$

910 Ibid, 32 (69).

911 Report of the International Law Commission (2004), op. cit., 288 (314).

912 United States Diplomatic and Consular Staff in Teheran, op. cit., 40.

913 'Fragmentation of International Law', Report (2006) op. cit., (124). 
The same holds true in relation to human rights treaties according to which one state cannot rely on human rights violations committed by another member state as justification for its own failure to meet its human rights commitments.

According to the classical perception of international law regarding 'self-contained' regimes, a regime is autonomous from international law if it meets two conditions. First, that its norms should not be applied or relied on by other institutions existing outside the regime and, second, that it is 'self-sufficient' in the sense that it does not need to rely on any other rules apart from the ones incorporated in it. ${ }^{914}$ This seems to refer to a wider understanding of self-contained regimes as providing a thorough system of primary and secondary rules, with their own dispute settlement bodies and procedures. ${ }^{915}$ Whether, however, a truly self-contained regime, in total independence from general international law may exist will be questioned.

The term appeared also in the work of the ILC on the codification of the law on state responsibility. Mr Riphagen, who often used the terms self-contained and objective regimes or subsystems in parallel, made a distinction between general consequences of internationally wrongful acts and those included within special regimes. The legal consequences emanating from the law on state responsibility, including the right to countermeasures would be applicable to every internationally wrongful act, 'except to the extent that the legal consequences of such a breach are prescribed by the rule or rules of international law establishing the obligation or by other applicable rules of international law'. ${ }^{916}$ The lex specialis would prevail over the lex generalis, leaving only a residual role for the latter, meaning that in the event that the subsystem collapses or does not contain an adequate regime of legal consequences, the general rules will take over. ${ }^{917}$

Simma, on his part, describes a self-contained regime as one that precludes 'more or less totally the application of the general legal consequences of wrongful acts, in particular the application of the countermeasures normally at the disposal of an injured party'. ${ }^{118}$

If this is the case, then the need to narrow down as much as possible the existence of such regimes becomes apparent as the enforcement of international law would otherwise be severely jeopardized, especially with respect to violations that do not fall within the scope of these specific regimes. Moreover, the need to resort to unilateral measures provided by general international law becomes even more pressing in the event that the wrongdoer fails to comply with the decisions of the institutions provided under the 'special regime' or where the violation persists despite the initiation of the regime's proceedings.

914 T. Melescanu, 'The European Union and the General International Law', available at http:// ebooks.unibuc.ro/StiintePOL/recenzie/7.htm

915 'Fragmentation of International Law', Report (2006) op. cit., (128).

916 Third Report on State Responsibility (Riphagen), op. cit., 27.

917 In B. Simma, 'Self-contained Regimes' 16 NIIL (1985) 111, 116.

918 Ibid, 117 (emphasis added). Also see L. Bartels, 'Article XX of GATT and the Problem of Extraterritorial Jurisdiction, The Case of Trade Measures for the Protection of Human Rights' 36 (2) Journal of World Trade (2002) 394, fn 160. 
In such an event, the affected state will be able to resort to action permitted under international law in order to secure and protect its rights and legal interests. Nevertheless, according to Mr Arangio-Ruiz, such 'external' measures not provided under the regime should be regarded as exceptional and to be only directed against wrongful acts of such gravity that put in danger principles highly valued. ${ }^{919}$ Due to these considerations, Mr Arangio-Ruiz, adopting a different line from the former Special Rapporteur Mr Riphagen, preferred not to include in the draft articles on state responsibility 'special' restrictions on measures affecting obligations deriving from self-contained regimes. The general principles regarding the legal consequences of an internationally wrongful act should be able to resolve any issue to be arisen from treaties establishing 'self-contained' regimes. This was even so, whenever the legal consequences of an internationally wrongful act 'were determined by other rules of international law'. ${ }^{920} \mathrm{Mr}$ Arangio Ruiz defended this position on the ground that states, by introducing such special regimes aimed not to diminish the already existing mechanisms of protection, but rather to reinforce them. ${ }^{921}$

The ability of states still to rely on the general rules on state responsibility, including their right under customary international law to resort to countermeasures, even if they conceded their sovereign rights in the interest of specific or self-contained regimes, is of particular significance for the purposes of this examination. It has been demonstrated earlier that the establishment of such regimes cannot entirely extinguish the general framework of international law and the general rules on state responsibility, which remain in the background.

It is for this reason that the term 'self-contained regimes' has been criticized as imprecise as no regime can be seen in isolation from general international law as, first, the latter plays a determinative normative role in the creation of such regimes and, second, it becomes active again whenever the special regime collapses. ${ }^{922}$

Professor Dupuy supports the view that the doctrine about self-contained regimes is misleading. ${ }^{923}$ Okafor-Obasi adds that a self-contained regime is a system created by a group of sovereign states in terms of full equality, which provides its own rules concerning implementation, enforcement and other remedies. Due, however, to the equality of treaty and customary norms, states may resort to measures provided under either field, namely conventional or customary international law in order to remedy a violation. Even more so, a state may eventually resort to general international law if such system fails. For these reasons, no system under international law can genuinely be regarded as 'self-sustained'. ${ }^{24}$ The Study Group itself proposed the substitution of the term 'self-contained' regimes

919 Fourth Report on State Responsibility (Arangio-Ruiz), op. cit., 41 (116).

920 Ibid, 42 (123).

921 Ibid, 42 (123)-(124).

922 Report of the International Law Commission (2004), op. cit., 290 (318-9).

923 M.P. Dupuy, 'The Danger of Fragmentation or Unification of the International Legal System and the International Court of Justice' 31 N.Y.U.F.Int'l L. E Pol. (1999) 791, 797.

924 Okafor-Obasi, op. cit., 36. 
with that of 'special' regimes. ${ }^{925}$ However, for the avoidance of confusion, the analysis that follows refers to such regimes both as 'self-contained' and 'special', highlighting at the same time that they can never be completely detached from the general body of international law.

\subsection{Application of countermeasures and principles under general international law zithin self-contained regimes}

The analysis that follows aims to highlight how general rules of international law, including the rules on state responsibility and countermeasures, may 'intrude' selfcontained regimes. Following Simma's footsteps, the examination focuses on the application of general rules by reference to the law on diplomatic immunities, the EU and human rights treaties.

\subsubsection{The law on diplomatic immunities}

It has been noted already that in the Teheran Hostages case, the ICJ precluded the implementation of countermeasures within the law on diplomatic immunities. Having concluded that the rules on diplomatic immunities established a selfcontained regime, the Court held that the infringement of diplomatic immunities and privileges could not be remedied by infringement of the same rules. This conclusion was criticized by Simma, according to whom diplomatic law is all about reciprocity. Nevertheless, even if it is accepted that the regime on diplomatic immunities does not allow their violation by way of countermeasures in response to a similar breach nothing can preclude countermeasures in the form of nonperformance of obligations emanating from other fields. Consistent with this view, diplomatic law can be construed as a self-contained regime only in a narrow sense, since it does not preclude the application of other remedies provided under general international law but only imposes certain limitations ratione personae and ratione materiae. ${ }^{926}$ As a result, a violation of diplomatic immunities would still entitle a state to resort to countermeasures insofar as these are limited by the principle of proportionality and they do not violate norms of jus cogens character or humanitarian obligations. ${ }^{927}$

\subsubsection{The EU as a self-contained regime}

It is a common position today that the law under the EU is an autonomous legal order that arguably establishes a self-contained regime with its own effective

925 'Fragmentation of International Law', Report (2006) op. cit., (152) (5).

926 Simma (1985), op. cit., 121.

927 Ibid, 120-1; Also comment by Reuter, Summary Records of the Meetings of the Thirty-sixth Session, YbILC (1984) Vol. I., 264 (30); K. Zemanek, 'The Unilateral Enforcement of International Obligations' 47 ZaoRV(1987) 32, 40. 
judicial and to some extent enforcement mechanisms to deal with violations. ${ }^{928}$ In this context, the ECJ has rejected a right 'on the part of member States from taking justice into their own hands' through resort to countermeasures by not fulfilling their Community obligations. ${ }^{929}$ More specifically, it has been the persistent position of the ECJ that the member states have forfeited their right to take unilateral measures under general international law. ${ }^{930}$

Yet, EU treaties do not cease to constitute treaties under international law. Therefore, the applicability of the general rules of international law on state responsibility and the rules on the law on treaties cannot be entirely precluded even with the express will of the member states participating in the Community structure. This will gain particular significance in the event that this structure collapses or its own remedies are inadequate to respond to persistent violations of Community law. Accordingly, there are authors who support the view that the faculté of states to resort to countermeasures under general international law remains if the EU enforcement mechanism has been used to no avail. As noted: 'Through such a fundamental change of circumstances any treaty system excluding the applicability of certain general legal consequences and/or countermeasures will fall back on the general regime.' ${ }^{931}$

As further pointed out by Mr Arangio-Ruiz it should not be concluded that whenever a state avails itself of remedies in the context of such self-contained regimes, it permanently abandons its rights and faculties of unilateral reaction under general international law. Although the state concerned will have primary responsibility to use the means awarded to it by the specific regime, it will still be entitled to utilize the measures provided under general international law. The extent to which it may be able to do so will be determined in the light of 'availability and effectiveness of the remedies envisaged by the treaty-based "regime". 932

Accordingly, the Community legal order remains part of general international law. ${ }^{933}$ Moreover, the right to countermeasures provided under customary international law does not cease to exist, particularly whenever the Community mechanisms fail to resolve the dispute. ${ }^{934}$ Consequently, general international law in relation to legal consequences is not entirely precluded from applying at a

928 See, for example, the powers of the Commission under Articles 226-228 EC Treaty and the suspension measures against the member state that fails to comply with its Community obligations under Article 7 of the Treaty on European Union; Article 7 (ex Article F.1) of TEU. Treaty on European Union (Maastricht Treaty), 7 February 1992, 31 ILM (1992) 247.

929 See Commission v Grand Duchy of Luxembourg and Commission v Kingdom of Belgium, Cases 90 and 91/63, European Court Reports (1964) 625.

930 See analysis in Fourth Report on State Responsibility (Arangio-Ruiz) op. cit., 35-6 (98).

931 Simma (1985), op. cit., 127.

932 Fourth Report on State Responsibility (Arangio-Ruiz) op. cit., 40 (114).

933 A. Rosas, 'The European Union and International Dispute Settlement' in L. Boisson de Chazournes, C. Romano and R. Mackenzie (eds) International Organizations and International Dispute Settlement: Trends and Prospects (Transnational Publishers, Inc.: 2002) 49, 51.

934 Fourth Report on State Responsibility (Arangio-Ruiz), op. cit., 36 (100). 
Community level, at least whenever all the other remedies provided for by the system have been exhausted without success.

The fact that the European treaties are not to be read in isolation of general international law is further reflected in Article 6 of the Treaty on the European Union (TEU) that now falls within the jurisdiction of the ECJ. More particularly, Article 6(1) provides that the principles of liberty, democracy, respect for human rights and fundamental freedoms and the rule of law, common to all the member states, constitute the foundation of the EU. Paragraph 2 of the same article provides that the respect of human rights as safeguarded by the European Convention on Human Rights and, by the common constitutional principles of the member states, constitute general principles of Community law. Hence, it is demonstrated that EU law is not to be read in isolation from other fundamental principles of general international law. The significance of this provision, especially of paragraph 1, is further reflected in Article 7 TEU, which provides that if the principles covered under paragraph 1 are infringed by any member state then the European Council may decide to suspend some of the rights deriving from the TEU. Some authors have argued that this enhances the argument regarding the 'selfcontainment' of the Community legal order. Nevertheless, the connotation of Article 7 with Article 6(1) is of great significance since it reveals that the action taken by member states is not monitored 'solely within the context of Community law, but against the broader background of international human rights principles'. ${ }^{935}$

As the analysis in Chapter 3 reveals, the EU on a number of occasions has reacted to 'external' violations, such as the violation of the rule prohibiting the use of armed force or the violation of human rights commitments, through nonperformance of obligations emanating from Community law. Such was the case against Argentina in the 1980s, Greece in the 1970s and Yugoslavia in the 1990s. The intrusion of secondary rules under the general law on state responsibility at Community level is further evidenced from the measures implemented by the United Kingdom against Argentina during the Falklands crisis. In this instance, while the UK action was in violation of obligations arising under Community law, none of the other member states protested or claimed that such obligations prevailed over a right to self-defence, or even countermeasures, under general international law. This weakens the argument that the application of countermeasures other than those expressly provided under the EU or for reasons that fall outside the Community context is entirely excluded

A state party to a self-contained regime, such as the EU, cannot be expected to continue performance of its obligations towards a wrongdoing state on the ground that the regime provides only for limited justifications of non-performance or suspension relating only to violations of obligations arising under that specific regime. Alternatively, this would amount to imposing a duty to that state to trade with the

935 A. Rosas, 'The European Union and International Human Rights Instruments' in V. Kronenberger (ed.) The European Union and the International Legal Order: Discord or Harmony? (T.M.C. Asser Press: 2001) 53, 60. 
occupier of its territory or with the violator of its rights and its interests as these are widely construed.

Finally, the intrusion of general international law, including customary rules, into Community law was clearly indicated in the Racke case. ${ }^{936}$ As discussed in Chapter 3, the ECJ relied on the customary rule of fundamental change of circumstances to justify a Community regulation that was in violation of the 1983 Agreement concluded between the EEG and the Socialist Federal Republic of Yugoslavia.

\subsubsection{Human rights treaties}

While certain human rights treaties provide adequate enforcement mechanisms to remedy any violation of their provisions, and the European Convention on Human Rights offers one such example, most treaties, especially those in the UN context, lack a compulsory sanctioning or enforcement mechanism. Hence, the implementation of such treaties relies on the discretion of their member states.

Quite distinct is the problem of enforcement of human rights norms through the implementation of countermeasures by non-performance of rights and obligations emanating from such human rights regimes. The European Convention on Human Rights, for instance, makes clear that countermeasures of reciprocal nature are precluded as the Convention creates a series of objective obligations. ${ }^{937}$ This would apply to most human rights treaties that establish integral obligations owed to all the other states parties and, therefore, their violation is precluded. Accordingly, if countermeasures by not performing obligations arising from such human rights treaties are precluded, the question arises as to whether the violation of such rules would permit the implementation of remedies that fall outside the closed 'circuit' of self-contained regimes, and are provided under the law on state responsibility.

Even if such human rights regimes provide for their own secondary rules and enforcement mechanisms in the event of violation of their norms, the applicability of general enforcement mechanisms would still not be entirely precluded. Simma is of the view that if the mechanisms provided in such specific regimes, which have to be given priority, have been exhausted without the compliance of the violating state, then the general rules on state responsibility will come into play to fill the legal gap. He says in this regard:

It has yet to be proved that such a 'decoupling' of human rights treaties from the enforcement processes of general international law was actually intended by the negotiating States. As long as such proof is not furnished one has to stick to the premise that multilateral treaties for the protection of human rights, like all other treaties, embody correlative rights and duties between the

936 Racke v Hauptzollamt Mainz, (1998), op. cit.

937 Pfunders case, op. cit., 140. 
contracting parties ut singuli, resulting in a duty on each party to fulfill its obligations vis-à-vis all the others, and conversely, in a right for each party to demand compliance from every other party and, if necessary, to enforce it through countermeasures. ${ }^{938}$

Similarly, Cassese notes that:

It would be contrary to the spirit of the whole body of international law on human rights to suggest that the monitoring systems envisaged in the Covenant and the Protocol should bar States parties from 'leaving' the self-contained regime contemplated in the Covenant and falling back on the customary law system of resort to peaceful countermeasures. ${ }^{939}$

Consequently, states are not prevented from resorting to the general mechanisms of enforcement in relation to human rights treaties, even if these establish 'selfcontained' regimes. This is particularly so if under a specific regime there is no provision for remedies. In such an event, the rules of general international law will once again take over. ${ }^{940}$ However, even when specific remedies are provided, the specific rule does not extinguish the general rule but rather makes it 'temporarily' and as long as there is agreement to, inoperative. It suspends its effects but only for as long as the special rule has not successfully been challenged or disputed. Furthermore, Pauwelyn notes in this respect that while states may "contract out" of one, more or, in theory, all rules of international law (other than those of jus cogens) ... they cannot contract out of the system of international law' ${ }^{941}$

It was in this context that the PCIJ ruled in the Chorzow Factories case that the omission of the parties to a specific convention to include an obligation to make reparation in the event of an infringement did not preclude such right, as it constituted a 'principle of international law'. The Court went further to add that: 'Reparation therefore, is the indispensable complement of a failure to apply a convention and there is no necessity for this to be stated in the convention itself.' ${ }^{942}$

A similar approach was adopted in the Advisory Opinion on the Namibia case where the ICJ held that in relation to the right to terminate a treaty nothing could preclude the application of a general rule of international law unless specifically

938 Simma (1985), op. cit., 133.

939 A. Cassese, International Law (OUP: 2001) 208.

940 Pauwelyn (2001), op. cit., 541, fn 44. Also, Lauterpacht noted as early as 1949: 'It is the treaty as a whole which is law. The treaty as a whole transcends any of its individual provisions or even the sum total of its provisions. For the treaty, once signed and ratified, is more than the expression of the intention of the parties. It is part of international law and must be interpreted against the general background of its rules and principles'. H. Lauterpacht, 'Restrictive Interpretation and the Principle of Effectiveness in the Interpretation of Treaties', 26 BrIL (1949) 48, 76.

941 J. Pauwelyn (2003) Conflict of Norms in Public International Law. How WTO Law Relates to Other Rules of International Law (CUP: 2003) 37.

942 Chorzow Factories, (Merits), op. cit., 29 P. Mavroidis, 'Remedies in the WTO Legal System: Between a Rock and a Hard Place' 11 EfIL (2000) No. 4, 763, 764. 
precluded by a specific treaty. ${ }^{943}$ This position was reaffirmed in the ELSI case. ${ }^{944}$ The Iran-US Claims Tribunal confirmed this approach by stating that although lex specialis would prevail over lex generalis, 'the rules of customary law may be useful in order to fill in possible lacunae of the law of the Treaty, to ascertain the meaning of undefined terms in its text or, more generally, to aid interpretation and implementation of its provisions. 945

The European Court of Human Rights itself has, in many instances, relied on general principles of international law in order to fill in the legal lacuna and to harmonize, to the extent possible, the obligations emanating from the European Convention on Human Rights with such rules and principles. ${ }^{946}$

In conclusion, human rights treaties, even if they set up their own primary and secondary rules and provide for their own dispute settlement and enforcement mechanisms, cannot be read in isolation of general international law that continues to surround them. This has particular relevance in relation to their enforcement through the implementation of countermeasures provided under general international law. This is particularly so whenever a state party to such treaties continues to engage in gross human rights violations in which case resort to general international law is necessary for the cessation of such conduct provided of course that the human rights obligations of the state remain intact. ${ }^{947}$

\subsection{Application of countermeasures and principles under general international law within the WTO}

\subsubsection{The WTO example}

Compliance with the rules of general international law and the relationship between special regimes, on the one hand, and countermeasures, on the other, also gains significance in another context, that of the WTO.

The WTO, a system that provides for specific rules and sets up its own dispute settlement mechanisms, may deviate, by common agreement of its member states, from the 1969 VCLT and the rules on state responsibility. While reliance on nonWTO law by the WTO judicial panels when interpreting the meaning of WTO rules or filling procedural gaps is quite a common phenomenon, the position differs with respect to the legitimacy of countermeasures within the WTO system for violations of obligations outside the system, such as for instance

943 Legal Consequences for States of the Continued Presence of South Africa in Namibia, op. cit., 47 (96).

944 Elettronica Sicula S.p.A. (ELSI) (United States of America v Italy), Judgment of 20 July 1989, ICJ Reports (1989) 15, 47, (96) in Pauwelyn (2001), op. cit., 542.

945 Amoco Int'l Fin. Corp. v Iran, 15 Iran-US Claims Tribunal Reports (1987) 189, (112) in Pauwelyn, ibid, 541-2, fn 48.

946 See McElhinney v Ireland, No. 31253/96, Judgment of 21 November 2001, ECHR (2001) XI, (36); Al-Adsani v United Kingdom, No. 35763/97, Judgment of 21 November 2001, ECHR (2001) XI, (55); Fogarty v United Kingdom, No. 37112/97, Judgment of 21 November 2001, ECHR (2001) XI, (36). Also cited in 'Fragmentation of International Law', Report (2006) op. cit., (161-64).

947 'Fragmentation of International Law', ibid, (190). 
jus cogens norms or obligations erga omnes. This is specifically so in view of the fact that a WTO member state may only deviate from its obligations under that treaty on grounds of national security and the general exceptions provided under Articles XX and XXI of GATT. Otherwise, the uniformity and effectiveness of trade regulations would arguably be endangered if member states were entitled to refuse to comply with their treaty commitments under the WTO. Counter to this lies the view advocated in this book that the effectiveness of enforcement of international law in general and of community and other collective interests in particular would be substantially undermined if states were not allowed to cease performance of their obligations emanating from lex specialis or self-contained regimes.

Accordingly, controversy exists in relation to whether countermeasures for violations that fall outside the WTO system by not performing WTO obligations should be permissible and could be used as justification. Some authors have argued that such countermeasures would be unlawful. ${ }^{948}$ Others, including this author, would argue that such countermeasures would be in accordance with general international law and therefore justified. The division in opinion, nevertheless, highlights the problem that depending on the forum before which a claim is raised the wrongfulness of a certain act, and therefore the responsibility of the state will vary, threatening the integrity of the international legal order.

It must be noted in this regard that the WTO, like other special or selfcontained regimes, is not isolated from the general body of international law, as it will be explored further later. Quite significantly, with the increasing competences of the WTO in a wide number of areas, precluding resort to countermeasures in response to violations not concerning WTO obligations would imperil substantially the enforcement of international law. As already discussed, in a largely decentralized legal order such as the international one, countermeasures come as a means of private justice and self-help to ensure the compliance of the wrongdoing state with its international obligations. This is of particular gravity whenever community and collective interests are at stake.

It remains, therefore, to examine whether the WTO treaty indeed bans the application of countermeasures provided under general international law taken either in addition to other remedies already provided for by the covered agreements or as an instrument of political and economic coercion for achieving goals outside the limited scope of the WTO. For this reason, it is imperative to understand the legal nature of the WTO, its competences and jurisdiction but also the enforcement mechanisms provided therein. This will be examined in view of the applicable law within the WTO.

\subsubsection{Legal nature and jurisdiction of the WTO}

The WTO, apart from containing a body of legal rules indicating the rights and obligations of its member states, sets up its own enforcement mechanisms and

948 See analysis in J. Pauwelyn (2003) 'A Typology of Multilateral Treaty Obligations: Are WTO Obligations Bilateral or Collective in Nature?' 14 EfIL (2003) No. 5, 907, 945, fn 135. 
dispute settlement procedures. These procedures are contained in the Understanding on Rules and Procedures Governing the Settlement of Disputes (hereinafter DSU) and are to be distinguished from those mechanisms that were provided under the GATT. In particular, the WTO gives the right to all member states to have automatic recourse to the ad hoc judicial panels and the standing Appellate Body. These bodies have the power to make legally binding recommendations and suggestions of the way that the state found to be in breach of its WTO obligations could bring its acts in conformity with its treaty undertakings and the recommendations made by the adjudicating bodies. 949 The conclusions of these panels may then be veiled with legal effect once they are referred to and adopted by the Dispute Settlement Body (DSB).

The DSB is the body before which parties can raise issues relating to the implementation of the panels' reports. The establishment of the panels, the adoption of their reports by the DSB and the authorization of retaliation by means of trade sanctions have an automatic effect 'unless there is a consensus against it. ${ }^{950}$ In other words, the consensus of the member states is not a precondition for initiating the dispute settlement mechanism. This is considered granted, if no state expressly indicates its view to the contrary, thus deviating from the regime under GATT which was structured on the basis of the positive consensus rule.

Furthermore, the DSU makes the dispute settlement mechanism under the WTO of a compulsory nature. While under the GATT it was provided that, member states 'may' authorize the 'appropriate' suspension of concessions on the ground of the 'seriousness' of the circumstances, under Article 22.6 of the DSU the DSB is obliged ('shall') to grant such authorization for the suspension of concessions or other obligations. This is particularly so whenever the defaulting state has failed to comply with and implement the recommendations and rulings within the set time limits. Such authorization is not conditional on the 'seriousness' or the 'appropriateness' of the situation, provided that the suspension is 'equivalent to the level of the nullification or impairment' in accordance with Article 22.4. ${ }^{951}$ Furthermore, whenever an infringement is found and no agreement for compensation is reached, the complaining state may seek the authorization of the DSU to 'suspend concessions or other obligations under the covered agreements' 952 or, in other words, to have recourse to countermeasures although this term nowhere appears in the DSU. Once again, the authorization to resort to countermeasures (which in the context of the WTO can only be bilateral) is automatic and may only be refused if there is an agreement by the member states against such measures.

949 Mavroidis, op. cit., 788.

950 J. Pauwelyn, 'Enforcement and Countermeasures in the WTO: Rules are Rules - Toward a More Collective Approach' 94 AfIL No. 2 (2000) 335, 336.

951 S. Charnovitz, 'Rethinking WTO Trade Sanctions' 95 AfIL (2001) Vol. 95 No. 4, 792, 803.

952 Ibid, 792. 
With the inclusion of specific procedures and remedies for dealing with violations of its rules with the ultimate purpose of inducing conformity (as opposed to any concept of punishment), ${ }^{953}$ the WTO is arguably significantly strengthened and re-enforced as an autonomous legal order that exists in parallel with other regimes provided under international law.

It is, therefore, not without logic that Article 3.2 of the DSU regards the WTO dispute settlement system as a 'central element in providing security and predictability to the multilateral trading system', one that protects the rights and obligations of its member states.

Yet different opinions exist in relation to whether WTO member states may only resort to the measures provided under the WTO agreements in response to violations that incur within the WTO legal order or as to whether WTO member states may also resort to measures provided under the law on state responsibility. This is distinct from the question of whether states are entitled to take WTO countermeasures in response to external violations, such as for instance the commission of genocide, examined later.

As noted earlier, some authors believe that unless a multilateral treaty sets up a self-contained regime or specifically provides so, a state is not limited to the measures and mechanisms provided under the infringed treaty, but may also apply 'extra-contractual' measures. Other authors, contrariwise, reject the idea of imposition of measures outside the scope of the infringed multilateral treaty. Sachariew, for instance, opposes the possibility of application and implementation of measures outside those already provided by the infringed treaty as he finds it difficult to understand how such measures would be able to be applied without, or even against, the consent of the other members to the treaty. Furthermore, he believes that such a possibility would be difficult to reconcile with the principle of proportionality if each state to the multilateral treaty decided to apply countermeasures ut singuli. ${ }^{954}$

With respect to the nature of the WTO, and its relation to other rules of international law including those concerning enforcement, it has been argued that:

WTO law is a specific subsystem of international law with specific rights and obligations, specific claims and causes of action, specific violations, specific enforcement mechanisms and specific remedies in case of their violation. The WTO dispute settlement system is also concerned with the distinct but parallel question of the limited jurisdiction and incapacity of the WTO adjudicating bodies to apply and enforce norms other than those of the WTO.955

Therefore, the WTO entitles the judicial panels to adjudicate only on those matters specifically defined and included in the covered agreements thus granting them limited jurisdiction, while in a case of conflict with other norms of international

953 Ibid, 794.

954 Sachariew, op. cit., 286.

955 G. Marceau, 'WTO Dispute Settlement and Human Rights' 13 EfIL (2002) No. 4, 753, 755. 
law, to give priority to the rights and duties deriving from these agreements as a regime of lex specialis. The WTO judicial panels have jurisdiction to examine complaints made by a member state that a certain benefit afforded to it directly or indirectly under the WTO agreements 'is being nullified or impaired' by the action of another member state that fails to meet its treaty commitments. ${ }^{956}$ At the same time, in considering whether a state is in compliance with its obligations emanating from the WTO, the WTO judicial panels are not entitled to take into account justifications that may exist under general international law. This may place a state in a difficult situation where its conduct may be unlawful under WTO, but lawful under general international law.

Nevertheless, the limited jurisdiction of the WTO judicial panels does not limit the applicable law for the determination of the issues before them. On the contrary, and in the absence of an express provision, the DSB, the judicial panels and the appellate body can resort to and rely on all sources of international law in determining the cases brought before them. This is, however, conditioned on the requirement that reliance on general international rules does not add or diminish the rights and obligations provided in the covered agreements (Articles 3.2 and 19.2 of DSU respectively). Accordingly, whenever the rights and obligations protected under the WTO agreements are threatened by such other rules of international law that are applicable in the WTO dispute settlement procedure, then priority should according to WTO law be given to an interpretation in agreement with the WTO treaty as establishing a regime lex specialis. This would be the case even if doing so would effectively mean an interpretation in violation of the obligations arising from other international legal instruments. ${ }^{957}$ While the WTO judicial panels often refer to other rules of international law, they have never given them priority over the rules provided under the WTO covered agreements. ${ }^{958}$

In consequence, the agreements establishing the WTO provide for limited jurisdiction while the DSU provides for specific remedies that the panels and the appellate body are entitled to recommend and suggest (Article 19 of DSU). Hence, the WTO adjudicating bodies do not have the authority to examine claims that fall under another system of international law, such as, for example, claims concerning the violation of human rights or other obligations owed to the international community as a whole. ${ }^{959}$

It can be concluded then that international law consists of various legal systems that are not necessarily linked between them. While a measure may be unlawful in one of these systems, it may be lawful in another. Although states members to the WTO will always be responsible for fulfilling their obligations under other

956 Article 1.1 of DSU.

957 L. Bartels, 'Applicable Law in WTO Dispute Settlement Proceedings' 35 (3) Fournal of World Trade (2001) 499, 518-9. See Hormones Case - EC Measures Concerning Meat and Meat Products (Hormones), WT/DS26/AB/R, January 1997, (125).

958 'Fragmentation of International Law', Report (2006), op. cit., (444).

959 Marceau, op. cit., 762-3. 
systems of international law, 'they cannot use the WTO remedial machinery to enforce them'. ${ }^{960}$ It is accordingly argued that: 'The drafters of the WTO treaty never wanted to provide non-WTO norms with direct effect in WTO law, nor allow states to benefit from free use of the WTO remedial mechanism to enforce rights and obligations other than those of the WTO treaty.' 961

One must also not forget that under Article 23, regarded one of the fundamental provisions of the DSU, the power to determine a violation of the covered agreements under WTO and to decide on countermeasures rests on the WTO judicial bodies. ${ }^{962}$ This provision prohibits unilateral action in response to violations of obligations provided under the WTO treaties. Instead, this competence and the competence to deal with WTO violations is transferred to the WTO adjudicating bodies, precluding the application of the general rules of international law on countermeasures. ${ }^{963}$

Furthermore, Article 23 restricts the use of countermeasures as follows:

(7) The necessary prior authorization of the membership before the (winning) Members can use retaliatory sanctions (Article 22(2)-22(6) of the DSU) once all the prior procedural safeguards have been respected.

(9) The level of countermeasures is also regulated and WTO arbitrators are given exclusive jurisdiction to determine a level of suspensions of obligations having trade effects equivalent to the level of nullification of benefits (a criterion distinct from the 'appropriate' or 'proportionate' benchmark under general international law).

It thus seems so far that the remedies permitted under the WTO treaty concern the obligation for cessation, non-repetition and satisfaction only with very strict conditions on the right to countermeasures. This suggests according to many that the member states wanted to preclude an open-ended right to countermeasures and wanted to transfer to the settlement mechanisms the responsibility to do so. ${ }^{964}$

960 Ibid, 775.

961 Ibid, 778.

962 Article 23 reads as follows: '(2) Members shall: (a) not make a determination to the effect that a violation has occurred, that benefits have been nullified or impaired or that the attainment of any objective of the covered agreements has been impeded, except through recourse to dispute settlement in accordance with the rules and procedures of this Understanding, and shall make any such determination consistent with the findings contained in the panel or Appellate Body report adopted by the DSB or an arbitration award rendered under this Understanding.'

963 The issue was addressed in the Panel Report in US-Certain EC Products para. 6.133: 'In short the regime of counter-measures, reprisals or retaliatory measures has been strictly regulated under the WTO Agreement. It is now only in the institutional framework of the WTO/DSU that the United States could obtain a WTO compatible determination that the European Communities violated the WTO Agreement, and it is only in the institutional framework of the WTO/DSU that the United States could obtain the authorization to exercise remedial action.' In Marceau, op. cit., 760, fn 22. 964 Ibid, 773. 
Distinct to the restriction of responses for violations that occur within the WTO lays the question of responsibility for temporarily ceasing the performance of obligations provided under the WTO in response to external violations. From what it has been discussed earlier, it becomes evident that the WTO judicial panels will hold that state responsible irrespective of any other justifications that may be present under general international law.

In a recent dispute between Mexico and the United States brought before the WTO panels, Mexico justified its decision to introduce tax on soft drinks and other beverages in order to secure the compliance of the United States with its obligations under a distinct international agreement, that of NAFTA. ${ }^{965}$ In particular, Mexico relied on Article XX(d) of GATT 1994 that allowed a WTO member state to maintain measures that are necessary to secure compliance with laws or regulations not inconsistent with GATT, but, importantly, on the basis of countermeasures under general international law. The WTO judicial panel, however, rather than considering whether Mexico's action could be justified under the general law on countermeasures used the ILC's conclusions on the question of countermeasures in order to interpret Article XX(d) of GATT and in order to determine whether that Article allowed action on the grounds put forward by Mexico. Having found that Article $\mathrm{XX}(\mathrm{d})$ did not allow such action, the panel found Mexico as responsible for violating its trade commitments towards the USA. ${ }^{966}$ In addition to that, the judicial panel pointed out that the notion of countermeasures under general international law was not unknown to the drafters of the trade organization. It referred in this regard to India's proposal when negotiating the International Trade Organization (ITO) Charter to include a provision allowing discriminatory measures when 'this is the only effective measure open to it to retaliate against discrimination practiced by that Member in matters outside the purview of the [nternational Trade] Organization'. 967 This proposal was, however, never accepted.

Accordingly, with the expanding competences of organizations such as the WTO, the right to countermeasures under general international law, either in response to ordinary breaches or in response to violations of a more fundamental nature, is seriously imperilled. Although the principle that international agreements must be respected holds prominent place in international law, it is equally imperative to protect the right of states to resort to countermeasures, especially in a decentralized legal order whose Achilles' heel lies on the lack of means of enforcement and implementation of its rules.

The judicial bodies of such special regimes, due to their restricted powers and jurisdiction, will have primary responsibility to apply the law of the specific regime. Koskenniemi and Leino, therefore, believe that it cannot be asked by specific

965 United States v Mexico, WT/DS308, Report of the Appellate Body in Mexico - Tax Measures on Soft Drinks and Other Beverages, 6 March 2006.

966 Ibid, (77).

967 Ibid, (175). 
bodies such as the WTO bodies to expand their competences in order to enable them to adjudicate on matters of general international law. Rather, this will only be accomplished with the establishment of strong institutions to represent noneconomic interests. ${ }^{968}$ However, although the establishment of such institutions would be most welcomed, it is unlikely that states are willing to entrust such institutions with enforcement powers. This, in turn, reveals once again the necessity of unilateral countermeasures under general international law, particularly for the protection of fundamental community interests.

The preceding observations notwithstanding, the WTO remains a treaty under international law and, as such:

$[\mathrm{T}]$ he WTO agreement cannot, therefore, be applied in isolation from other rules of international law. Just as private contracts are automatically born into a system of domestic law, so treaties are automatically born into the system of international law. Much the way private contracts do not need to list all the relevant legislative and administrative provisions of domestic law for them to be applicable to the contract, so treaties need not explicitly set out rules of general international law for them to be applicable to the treaty. 969

The WTO stands in the international legal order as an integral part of general international law and it is thus influenced and developed by its rules and principles, including those concerning state responsibility and countermeasures. ${ }^{970}$ As noted, the relationship between the WTO and general international law constitutes a mutual relationship of enrichment. ${ }^{971}$ Consequently, even if the WTO judicial bodies' competences are limited by the covered agreements, in assessing the content of such rights and obligations emanating from the agreements they must take due regard to the overall normative context of general international law. ${ }^{972}$

The impact of the general rules on state responsibility on specific legal regimes was also examined by the ICJ in the Nicaragua case. This ruling has often been criticized due to the Court's failure to determine what the United States as a third state could do in view of the recognition that Nicaragua had frequently violated international law by militarily incurring into the territory of neighbouring countries (Costa Rica and Honduras) and by supporting armed bands and rebels. While the Court did not accept that Nicaragua's action amounted to an armed attack that would justify the right to collective self-defence, it held that the trade

968 M. Koskenniemi and P. Leino, 'Fragmentation of International Law? Postmodern Anxieties' 15 Leiden Fournal of International Law (2002) 553, 574.

969 J. Pauwelyn (2003(c)), 'How to Win a World Trade Organization Dispute Based on Non-World Trade Organization Law? Questions of Jurisdiction and Merits' 37 (6) Journal of World Trade (2003) 997, 1001.

970 'Fragmentation of International Law', Report (2006), op. cit., (169).

971 Pauwelyn (2001), op. cit., 552. Also see ibid, (169).

972 'Fragmentation of International Law', ibid, (170). 
embargo imposed by the United States against Nicaragua infringed the 1956 Treaty on Friendship, Commerce and Navigation concluded between the two countries. By this determination the Court, as noted in Chapter 3, left no room for examining the US action in the light of Nicaragua's own wrongdoing and, in particular, the violation of its obligations under the UN Charter. In considering Article XXI of GATT as a possible justification of the US measures, the Court emphasized that the party should prove that such action was necessary to its essential security interests. The Court went on to conclude that from the circumstances of the particular case no such necessity emerged. ${ }^{973}$ However, this conclusion also received criticism, as according to one view the Court should have examined the trade embargo in the light of the law on countermeasures. As noted in this regard:

It cannot be correct, it is submitted, to exclude all those treaty commitments from a possible application of the right of reprisals which are conditioned by specific exception clauses, as the security clause in the respective Treaty. It would be going much too far to see this as a self-contained regime in the sense the International Court of Justice has used this notion in the Tehran Hostages case. Trade agreements in the widest sense are the area where peaceful reprisals must apply in the first place if this area of law on State responsibility should not become obsolete. ${ }^{974}$

The problem grows in significance since, in most cases, treaties allow derivations from the treaty obligations only for reasons closely associated with and established by the treaty, restricting in this manner the general use of countermeasures. Zoller, in particular, argues that precluding states parties to a certain treaty from responding to an external violation by violating their obligations under the treaty would render international law ineffective. If one construed treaties, whether bilateral or multilateral, as 'locked circles' that prohibit both measures outside the treaty for violations within the treaty and measures within a treaty for violations occurring outside such treaty, this would amount to the alienation of international law by creating several legal regimes existing in parallel but with absolutely no relationship between them. As she rightly remarks, treaties 'would have a legal life of their own independent of their surroundings. States after being their creators, would become their prisoners, the Pygmalions of international law.' 975 Zoller continued that irrespective of their nature, customary or conventional, international rules are interrelated and together form the existing international legal order. To demand states to refrain from resorting to countermeasures for the violation of any of their rights would not only endanger the unity of the international legal order as the treaty would become unconnected with the rest of the corpus of international norms, but it would also remove 'the indirect guarantee of compliance

973 For an analysis of the ruling, see Frowein (1994), op. cit., 372.

974 Ibid, 376 and 426.

975 Zoller, op. cit., 85-6. 
which the treaty embodied. Such a situation would be detrimental to both customary and treaty law'. ${ }^{976}$

In 1977, US Representative Pease was arguing, in support of US measures against Uganda even in violation of the country's obligations under GATT, that there existed 'higher principles involved than blind adherence to free trade dogma' and that this agreement should not be deemed as 'sacrosanct and inviolable'. ${ }^{977}$ The position that state action cannot be confined within a specific treaty is also reflected in the statement of the French Prime Minister Briand who, rejecting Germany's arguments that France could not resort to sanctions outside the Versailles Treaty, said that there still existed other sanctions under international law. ${ }^{978}$

This view seems to also apply, as noted earlier, with respect to other international agreements such as those concerning the protection of human rights. Thus, according to the conclusions of the American Law Institute, a state party to an international human rights agreement has at its disposal not only the remedies provided under these agreements but also the remedies provided under general international law in the event of the commission of an internationally wrongful act. ${ }^{979}$ Frowein says, in this respect, that to preclude action other than that provided under a specific treaty would be to afford weaker protection when needed, especially regarding human rights violations. ${ }^{980}$ Of course, such action would not be possible to entail nonperformance of obligations arising from human rights treaties themselves, due to the special character of such treaties as establishing integral regimes and due to the erga omnes character of the obligations protected under them. ${ }^{981}$

At the WTO level, this position is reflected in the Gasoline case according to which 'the General Agreement is not to be read in clinical isolation from public international law' ${ }^{982}$ As Pauwelyn observes:

It is true that the DSU has to be considered as lex specialis and that it can - and in certain areas, does - deviate from general international law. If any ambiguity were to persist in the DSU, however, as to whether a breach of WTO rules activates the secondary obligation of cessation, recourse should be made to residual international law rules. These rules make clear beyond doubt that in case wrongful act is found, the state concerned has to stop that conduct. The DSU determines, in turn, the means by which the prevailing WTO

976 Ibid, 87.

977 Pease' Statement at the US House of Representatives, H.R. Con. Res. 426, 95th Cong., 1st Session (1977) in Fredman, op. cit., 1162.

978 See Briand, Repert. Prat. Française, I, No. 235, 131 in Zoller, op. cit., 88.

979 Law Restatement, Restatement of the Law. The Foreign Relations Law of the United States, Vol. 2, 1987, 174 in Frowein (1994), op. cit., 399-400.

980 Frowein, ibid, 400.

981 'Fragmentation of International Law', Report (2006), op. cit., (154) and (248)-(249).

982 Gasoline case - United States - Standards for Reformulated and Conventional Gasoline, WT/DS2/AB/R, 20 May 1996, 17. 
member is authorized to obtain fulfillment of that secondary legal obligation of cessation. ${ }^{983}$

In addition to this, the WTO judicial bodies have themselves many times referred to the general principles of international law and customary international law, and to other treaties, while Article 3.2 of the DSU provides that the agreements under the WTO must be interpreted 'in accordance with customary rules of interpretation of public international law'. Furthermore, the power of the WTO panels to refer to other sources of international law for an objective application of the agreements under the WTO is safeguarded under both Articles 11 and 7.2 of the DSU.

In the light of this, the WTO is not strictly speaking a self-contained regime as other rules of international law such as the rules on state responsibility, rules relating to the judicial settlement of disputes, the rules regarding the conclusion, termination, suspension or application of treaties and the rules on how to resolve conflicts between legal norms are applicable.

In conclusion, to say that the WTO law precludes the application of rules of general international law would amount to saying that the WTO is viewed as 'a self-contained regime' while general public international law is viewed, according to Pauwelyn 'as a fragmented system with sealed-off compartments'. ${ }^{984}$ In addition, even self-contained regimes do not totally and permanently deviate from the general legal regime, but only to the extent that there is express agreement to the contrary. As Simma points out:

$[\mathrm{T}]$ he general regime of State responsibility can only be again called to the foreground after all remedies provided in the 'subsystem' have been exhausted without any positive results and when further tolerance of the imbalance of costs and benefits caused by non-performance can no longer bona fide be expected from an injured party. ${ }^{985}$

It can be concluded from these considerations that general international law constitutes a reference point on which self-contained regimes or other specific rules always rely. While states may agree, by entering into specific agreements or establishing self-contained regimes, to deviate from general international law, they cannot deviate from the system of international law in its entirety that remains in the background. This is significant as the rules of general international law and, in particular, the rules on enforcement remain active, especially when the remedies provided under such regimes fail to meet their objectives. This is even more so when the obligations breached concern legal interests owed either to the international community as a whole or to a group of states. To prohibit states from ceasing the performance of their obligations emanating from such specific regimes would be to deprive them of a powerful tool to effectively secure the compliance

983 Pauwelyn (2000), op. cit., 341.

984 Pauwelyn (2003 (c)), op. cit., 1029.

985 Simma (1985), op. cit., 128-9. 
of the wrongdoing state with its international commitments. Nevertheless, it has been shown that reliance on the customary right to countermeasures may cause friction in relation to obligations emanating from other legal regimes. This may have the effect of incompatible or inconsistent solutions threatening as a result the integrity of the international legal order.

\subsubsection{The general and security exceptions under Articles XX and XXI of GATT}

Article XX of GATT exempts from the prohibition of trade restrictions among others measures taken for the protection of human life or health. While such measures are justifiable for the protection of human life or health within the territory of the responding state, this becomes less clear with respect to measures taken to protect human life or health in another member state's territory.986 The latter requires a distinction between restrictions of products themselves produced in a manner contravening human rights and measures taken against products that, although not produced in a manner violating human rights, are produced by a member state that violates human rights generally. It is suggested that in this latter category one should speak about 'sanctions' and not about 'trade restrictions' as provided by Article XX. ${ }^{987}$

As noted earlier, countermeasures by way of not performing WTO obligations in response to a wrongful act under general international law such as genocide are not permitted within the WTO context and they seem to be precluded from the blessing of Article XX. ${ }^{988}$ This was also confirmed in a Ministerial Declaration made in 1982 according to which GATT contracting parties undertook the commitment to 'abstain from taking restrictive trade measures, for reasons of a non-economic character, not consistent with the General Agreement'. ${ }^{989}$

While Article XX safeguards trade restrictions on products that have been produced in a process and method that infringes human rights or health, it exempts from its scope the enforcement of trade measures that take the form of countermeasures. Such countermeasures are not allowed within the context of the WTO, even if these are to be permitted under the general rules on state responsibility. This is qualified by the condition that there has not been an agreement to authorize such countermeasures on the basis that such an agreement does not put at risk the rights and obligations of third parties.

Article XXI, by the same token, allows exceptions from the obligations arising under the WTO treaties on grounds of national security. While WTO member states enjoy discretion when invoking security reasons to justify conduct irreconcilable with their obligations, in the sense that the judicial panels are not entitled to look into whether a threat to national security interests indeed existed and the

986 Bartels (2002), op. cit., 355.

987 Ibid, 357-8.

988 Ibid, 361.

989 Ministerial Declaration on Dispute Settlement Procedures, adopted on 29 November 1982, L/5424, Basic Instruments and Selected Documents, Supplement No. 29. Also in Keesing's (1983), 32169A. 
justifiability of the measures taken in response to the threat, states need to exercise their discretion in good faith. ${ }^{990}$ In the light of the wide scope of the notion of 'essential national security' emerging 'in time of war or other emergency in international relations' it could be claimed that serious violations of human rights such as genocide fall within the ambit of this provision. ${ }^{991}$ As the analysis in the preceding chapter demonstrated, WTO states have often invoked this provision in justification of trade restrictions imposed in response to serious violations of community and collective interests, even if there existed no threats to national security stricto sensu.

Despite the significance of these issues arising from a possible conflict between an entitlement to respond to serious violations such as genocide and specific agreements that preclude the general regime of responsibility, it seems that in the context of the WTO judicial panels the specific rules will prevail.

Having considered extensively how the relationship between specific and general legal consequences is dealt with within special or self-contained regimes, the examination is next turned to how this issue is addressed within the Final Articles on State Responsibility.

\section{Lex specialis and self-contained regimes in the 2001 Final Articles on State Responsibility}

In its commentary on Article 50 of the Final Articles entitled 'Obligations not Affected by Countermeasures', the ILC recognizes the right of states to enter into specific agreements to preclude countermeasures, as a regime lex specialis. Reference is made to this end to the WTO and to the fact that under Article 23 of the DSU a member state may suspend concessions or other obligations under the WTO agreements only with the prior authorization of the DSB. It is pointed out that:

This has been construed both as an 'exclusive dispute resolution clause' and as a clause 'preventing WTO members from unilaterally resolving their disputes in respect of WTO rights and obligations'. To the extent that derogation clauses or other treaty provisions (e.g. those prohibiting reservations) are properly interpreted as indicating that the treaty provisions are 'intransgressible', they may entail the exclusion of countermeasures. ${ }^{992}$

This found expression in Part 4 under Article 55 according to which the articles on state responsibility:

[D]o not apply where and to the extent that the conditions for the existence of an internationally wrongful act or the content or implementation of the

990 See D. Akande and S. Williams, 'International Adjudication on National Security Issues: What Role for the WTO?' 43 VJIL (2003) No. 2, 365, 386 and 389.

991 Brandtner and Rosas (1999), op. cit., 706.

992 Crawford (2002), op. cit., 290-91. 
international responsibility of a State are governed by special rules of international law.

The ILC, in its commentary on this provision, acknowledges the right of states to enter into specific agreements that will depart from other applicable rules of international law concerning the legal consequences arising from the violation of a primary rule. It seems from this, that the ILC precludes the application of the general rules on the law on state responsibility whenever specific rules precisely and expressly determine the legal consequences to derive as a result of their breach.

Article 55, however, remains silent with respect to the application of the general law on state responsibility within a specific regime in response to a violation of an obligation that exists outside that regime. More specifically, Article 55 does not prohibit the non-performance of WTO obligations, for instance, in response to gross human rights violations or violations emanating from other agreements. All Article 55 restricts is the implementation of countermeasures by ceasing the performance of obligations within a specific regime, in response to violations of other obligations emanating from the same regime, unless otherwise provided. Yet as already explained, even in this instance states will still be able to resort to general international law should all other remedies specifically provided for fail.

From a general international law standpoint, the violation of obligations deriving from special regimes by way of countermeasures in response to a violation that occurred outside such regimes will be lawful. This coincides with the concept of countermeasures that have an inherent element of unlawfulness although, due to certain circumstances, the wrongfulness of the act and the responsibility of the implementing state will be precluded. However, the preceding analysis has shown that particularly the judicial bodies provided under the WTO have been reluctant to give way to a right to countermeasures under general international law. This approach entails the danger of upgrading the lex specialis to superior law in which the intrusion of general international law is totally precluded, thus endowing the specific legal regime with absolute nature.

If countermeasures for reasons falling outside a specific treaty are precluded then there would be a conflict between the notion of countermeasures, which by definition permits as lawful the violation of any obligation (with limited exceptions) of international law, and Article 55 of the Final Articles. How could countermeasures ever be applied if prevalence is unequivocally always given to the self-contained regime?

This point gains particular significance in light of the increasing competences in trade matters of the WTO. Hence, the argument according to which WTO rules have an impact 'on almost all other segments of society and law'993 could not be more relevant, especially in the light of the effects of liberalization of trade on 
environmental or human rights concerns. If the entitlement of states to resort to countermeasures in the form of trade restrictions is taken away, even for the most serious internationally wrongful acts, then states are left with few powers to enforce international law and such fundamental community or collective interests.

This, however, has significance not only whenever a breach of a jus cogens norm is involved, but also for breaches of a less serious nature. If it is recognized that the WTO in particular imposes uniform state behaviour in more and more trade areas, then it diminishes significantly the sphere of state action. The same applies if one accepts that the WTO obligations can only be suspended, terminated or not performed in response to the violation of another WTO obligation and only under the procedures provided by the WTO agreements. In such an event, the role of countermeasures under the general rules on state responsibility becomes meaningless, with the enforcement of international law significantly weakened.

\section{On the risk of fragmentation of international law}

One of the increasingly interesting areas that has recently attracted the attention of the ILC, and which will be at the scope of the current section, is that of fragmentation of international law. In the absence of a clear separation of powers in the international legal order, international law comprises several autonomous legal regimes and norms that, as discussed already, may at times clash between them, endangering the integrity of international law.

The fragmentation of international law is not a new phenomenon. The conflict between west and east during the Cold War period prevented the development of the international legal order into a coherent system of norms. Although aspirations about the 'completeness' of international law revived with the abolition of the walls between the two worlds, international law was once again faced with fragmentation, but this time because of a new enemy, namely the rapid proliferation of independent legal systems. ${ }^{994}$

In its 52nd session held in 2000, the ILC decided to include within its longterm work the problem of fragmentation of international law, acknowledging its increasing importance for the consistency and unity of international law. ${ }^{995}$ In the study pursued by Mr Gerhard Hafner annexed to the 2000 ILC report, 996 the problem of fragmentation appeared as the result of the lack of homogeneity and organization of international law that until the present day consists of several 'erratic' legal regimes, systems and subsystems. Despite the contribution of these regimes to the progression of the international legal order, they may also cause friction among norms belonging to different legal systems, often having the effect

994 Koskenniemi, and Leino, op. cit., 559.

995 Report of the International Law Commission (2000), Annex, op. cit., 143.

996 G. Hafner, 'Risks Ensuing from Fragmentation of International Law' ILC Report on the Work of its 52nd Session, Official Records of the General Assembly, 55th session, Supplement No. 10 (A/55/10), Annex. 
of creating obligations on states that are incompatible and irreconcilable between them. ${ }^{997}$ This unavoidably raises the responsibility of a state that, unable to conform to its parallel obligations, is caught up between several international rules and legal systems that most of the times lack of a hierarchical nature. ${ }^{998} \operatorname{In} 2002$ the study group established by the ILC during its 54th session to investigate the scope of the question under consideration defined the term 'fragmentation' as indicative of the effects of the 'expansion and diversification of international law'. ${ }^{999}$

Such fragmentation may be owed to the lack of central instruments of dispute resolution threatening in this manner the integrity of international law, the emergence, in addition to the synallagmatic obligations provided under traditional international law, of obligations owed to individuals and the international community as a whole and the existence of competitive rules. Moreover, the widening of the scope of international law with the increase of the actors in the international arena but also of enforcement mechanisms especially provided for under specific regimes, the existence of several parallel secondary norms that often prevail over the general rules on state responsibility or even the law on treaties, may also cause conflict. ${ }^{1000}$ In addition, the lack of both a clear hierarchy of norms and homogeneity in the international legal order, the proliferation of international judicial bodies often having jurisdiction over the same matters, the parallel development of often conflicting legal norms and the emergence of a pluralism of legal regimes also exacerbate the problem. ${ }^{1001}$ Furthermore, the accommodation of new principles and new ideas of a 'constitutional' nature in the body of international law has only added to the confusion.

Such inconsistency has appeared for instance within the context of the ad hoc International Tribunal for the Former Yugoslavia (ICTFY) and the ICJ. In this regard, there has been different approach in the rulings of the ICJ and the ICTFY on specific questions of law. In its 1996 Advisory Opinion on The Legality of Threat or Use of Nuclear Weapons, the ICJ ruled that armed reprisals should be proportionate. However, not long after this ruling the ICTFY was concluding that such reprisals were entirely prohibited. ${ }^{1002}$ Problems may also be created as a result of

997 Ibid, 321-2.

998 Report of the International Law Commission on the Work of its Fifty-fourth Session, 29 April-7 June and 22 July-16 August 2002 (A/57/10) 240/(506).

999 See Committee of Legal Advisers on Public International Law (CAHDI), 24th Meeting, Bratislava, 9-10 September 2002 on the ILC Report on the Work of its 54th Session (29 April-7 June and 22 July-16 August 2002). Prepared by Professor Bruno Simma, (61).

1000 Hafner, op. cit., 326-31.

1001 Koskenniemi and Leino, although not rejecting the problem, very pointedly argue that international law has never been unified so that to risk a possible fragmentation at this instance. However, the term 'fragmentation' should be construed as revealing the situation where there exist conflicting legal norms that may undermine the coherence of international law. See Koskenniemi and Leino, op. cit., 576.

1002 Legality of the Threat or Use of Nuclear Weapons, op. cit., 246 (46); The Prosecutor v Martič, Decision of 8 March 1996, Case No. IT-95-11-R61, International Tribunal for the Former Yugoslavia, Trial Chamber I in Koskenniemi and Leino, op. cit., 562-3. 
hierarchy between international judicial bodies, as evidenced from the Ćelebici case. In this case, the Appeals Chamber of the ICTFY highlighted that there was no hierarchy between itself and the ICJ and that it was autonomous from the ICJ. 1003

Furthermore, in the Belilos case, the European Court of Human Rights gave prevalence to the specific provisions of the European Convention on Human Rights on the issue of reservations over the provisions of general international law on the same matter. ${ }^{1004}$ In the Lockerbie case, the ICJ said that Libya should comply with its obligations under Article 103 of the UN Charter even if these were in contravention with other obligations and, in particular, with the 1971 Montreal Convention.

As discussed thoroughly in earlier sections, a conflict may appear with respect to both primary norms, if there are more such norms regulating the same subject, and secondary norms, if an internationally wrongful act incurs several consequences existing in various systems and subsystems of international law. Undoubtedly, the existence of multiple enforcement mechanisms, each one of which claims to be the most appropriate for the resolution of a given dispute on the basis of the rules within which it exists and is structured on, tends to enhance rather than diminish the already 'disintegrated nature of international law'.1005 However, problems emerge when competing enforcement mechanisms diminish, as explained, the protection of international law.

In its 2002 report, the Study Group highlighted that among other things further consideration should be given to the function and scope of lex specialis norms and the problem of self-contained regimes, but also the interpretation of treaties in the light of other relevant rules of international law in view of contemporary developments and the concerns of the international community. ${ }^{1006}$ In its 2003 report the Study Group highlighted the need to investigate the conditions of the establishment of self-contained regimes, their scope of application towards general international law and the circumstances under which there is a 'fallback' to the general rules. ${ }^{1007}$

Against this notion, there are arguments supporting the idea that the plethora of specific legal regimes contributes to the enhancement of the international legal order, whose main defect has always been its unenforceability. A study undertaken in 1996 by the Netherlands Yearbook of International Law concluded that such specific systems, with their own rules and mechanisms, strengthened

1003 Celebiči case, The Prosecutor v Delalic et al., Decision of 20 February 2001, Case No. IT-96-21-A, International Tribunal for the Former Yugoslavia, Appeals Chamber.

1004 Belilos v Switzerland, No. 10328/83 Judgment of 29 April 1988, 1988 ECHR, (Ser. A) No. 132.

1005 Hafner, op. cit., 332.

1006 Report of the International Law Commission (2002) op. cit., (512).

1007 Report of the International Law Commission (2004) op. cit., 290 (319). 
compliance with the primary rules they establish. ${ }^{1008}$ As Koskenniemi and Leino point out:

The ICJ, a human rights body, a trade regime or a regional exception may each be used for good and for ignoble purposes and it should be a matter of debate and evidence, and not of abstract 'consistency', as to which institution should be preferred in a particular situation. The universalist voices of humanitarianism, human rights, trade or the environment should undoubtedly be heard. But they may also echo imperial concerns, and never more so than when they are spoken from high positions in institutions that administer flexible standards that leave the final decision always to those speakers themselves. ${ }^{1009}$

Along the same lines and in relation to the proliferation of international judicial bodies, Professor Abi-Saab remarks that it constitutes a 'healthy phenomenon ... in a system that has notoriously suffered, throughout its existence, from the dearth (not to say lack) of objective determinations'. ${ }^{1010}$ However, he also highlights the necessity to preserve the unity of the overall system within which special regimes are conceived and created. He thus precludes that there can exist entirely selfcontained regimes as otherwise such regimes would not be part of the general legal system, but rather they would themselves become legal orders of their own, 'a kind of legal Frankenstein, or Kelsen's "gang of robbers"'. 1011

Indeed, in the extensive report prepared by the study group and finalized by Professor Koskenniemi in 2006, it is stressed that:

Fragmentation moves international law in the direction of legal pluralism, but does this ... by using the resources of general international law, especially the rules of the VCLT, customary law and 'general principles of law recognised by civilised nations'. ${ }^{1012}$

Kirchner, on his part, identifies two dimensions of conflict resolution in international law. The first, which the 1969 VCLT seems to follow, relates to a conflict of laws approach. The second concerns a public law approach that aims to bring coherence in the process of 'constitutionalization' of the international legal order by reconciling the phenomena of fragmentation, on the one hand, and constitutionalization, on the other, with a view of establishing 'an overall public

1008 K. Wellens, 'Diversity in Secondary Rules and the Unity of International Law: Some Reflections on Current Trends' in L.A.N.M. Barnhoorn and K. Wellens, Diversity in Secondary Rules and the Unity of International Law (Martinus Nijhoff: 1995) 3, 28.

1009 Koskenniemi and Leino, op. cit., 578-9.

1010 G. Abi-Saab, 'Fragmentation or Unification: Some Concluding Remarks' 31 N.Y.U.F.Int'l.L. \& Pol. (1999) 919, 925.

1011 Ibid, 926.

1012 'Fragmentation of International Law', Report (2006) op. cit., (492). 
law approach'. ${ }^{1013}$ He believes that this reconciliation can be achieved with the incorporation in the corpus of international law of constitutional notions such as jus cogens norms and the moving away from a dogmatic perception of international law as being of a contractual nature merely involving public entities. ${ }^{1014}$

At the same time, the rules of interpretation provided under the 1969 VCLT, and in particular under Article 31(3)(c) and reflected in customary international law, play a determinative role in the resolution of conflicts. This was recently raised before the ICJ in the Oil Platforms case. ${ }^{1015}$ In this case, the ICJ was called to examine the lawfulness of certain forcible measures taken by the United States against Iran with the 1955 Treaty of Amity concluded between these two states. As the jurisdiction of the ICJ relied on a compromissory clause provided under the Agreement, the question raised was whether the ICJ should confine its examination on the specific terms of the treaty or whether it could also rely on the general rules on the use of force. This ruling allowed placing the 1955 Agreement in the general context of international law and not in isolation from it. This is particularly important as the ICJ was able, in interpreting the Agreement, to take into consideration a fundamental principle of international law widely acknowledged as possessing the character of jus cogens, that of the prohibition of the use of armed force. The application of Article 31(3)(c) has, therefore, been described by some authors as a bridge connecting different international legal regimes, arguably offering a remedy to the emerging risk of compartmentalization of international law. ${ }^{1016}$

Undoubtedly, the problem of fragmentation of international law will only increase in significance, especially with the awarding of more contractual freedom to states in the absence of a unified code of conduct in the event that a conflict between two or more specific and general legal regimes occurs.

This gains particular significance for the enforcement of international law, especially through countermeasures by states other than the injured. While states may deviate from general rules through the adoption of specific agreements or even through the creation of self-contained regimes, these should not be construed as totally independent from the normative environment in which they inescapably exist. As seen, countermeasures constitute a powerful tool of implementation of international rules, particularly those of great significance for the international community, since they aim to protect community and collective interests. Consequently, to restrict the right to countermeasures by ceasing performance of obligations under specific agreements or even self-contained regimes, as states have many times done in the past, would be tantamount to preventing states from using the only means at their disposal, in the absence of any other means, to

1013 Kirchner, op. cit., 54.

1014 Ibid, 63-4.

1015 Case Concerning Oil Platforms, op. cit.

1016 For a thorough analysis of the position of self contained regimes within the framework of international law see B. Simma and D. Pulkowski, 'Of Planets and the Universe: Self-Contained Regimes in International Law', 17 EJIL (2006) No. 3, 483. 
secure respect for the rule of international law. For these reasons, the right to countermeasures constitutes an integral part of the international legal order that is essential for the implementation of its rules, particularly so when community interests are at stake.

\section{Conclusion}

The notion of self-contained regimes has often been used to describe the existence of autonomous legal regimes that establish their own primary and secondary norms conferring rights and obligations on states and providing for their own legal remedies in the event of a breach. Moreover, this term has been used to indicate legal regimes that set up their own dispute settlement bodies and enforcement mechanisms in independence of the rules of general international law. However, as the preceding analysis established, no such regime can be seen in total isolation from the general body of international law to which it continues to be an integral part.

The issue becomes relevant for the purposes of this book as it reveals the existence of a rather strenuous relation between obligations emanating from such self-contained regimes and countermeasures provided under general international law, particularly those taken in the name of fundamental community interests. As the emphasis is increasingly placed on the prevalence of the rules emerging from such regimes, the scope and content of countermeasures generally and solidarity measures particularly becomes diminished. This is even more so in the context of the WTO the competences of which are rapidly expanding to a wide range of trade areas, precluding at the same time the implementation of countermeasures under general international law.

However, the 'exclusivity' of such regimes in relation to the other rules of international law and in terms of international enforcement has frequently been called into question. This is due to the fact that specific norms evolved within such specific regimes are formed between certain states to serve certain purposes - and those purposes only. This means that the organs, judicial or other, provided under these self-contained regimes are not empowered to resolve a dispute arising before them by reference to other applicable rules of international law existing outside such legal regimes. This makes the application of international law fragmented, while it significantly weakens its effective enforcement.

Nevertheless, it has been established that no regime is truly self-contained neither can it 'stand' on its own, as it never ceases to be part of the general international legal system that remains in the background. In the light of the proliferation of self-contained or special regimes, general international law still plays a fundamental role and exercises a huge impact on such regimes or obligations emanating from lex specialis. This is so since general international law not only remains in the background by providing the principles on which a special regime is founded, but by also filling the legal gaps whenever such special regimes fail or collapse.

Furthermore, the need to implement general international law, even when this is explicitly prohibited by specific rules, becomes apparent whenever the only 
means of protection available to a state injured by a certain wrongdoing or even a state acting in the name of community and collective interests lie in the context of such special regimes. In this respect, the rules on state responsibility as reflected in customary international law, and particularly the right to resort to countermeasures, still influence the relations of states even if these are regulated by such special regimes. ${ }^{1017}$

As already explained, to suggest that the obligations emanating from special regimes will prevail, leaving no room for the application of other means of enforcement provided under general international law, would be tantamount to endowing such specific obligations with a peremptory character. This would result in diminishing significantly, to the extent of extinction even, the application of countermeasures under general international law.

In addition to this, the practice of states reveals that, most of the time, countermeasures taken in response to a given wrongdoing involve violations of obligations arising from such specific rules. This issue becomes particularly relevant in the context of the current examination. More specifically, the right to solidarity measures would become devoid if states were precluded from not performing obligations that derive within the context of specific legal regimes. This is because it is usually with the non-performance of obligations falling within such regimes that countermeasures become more effective.

The aforegoing arguments notwithstanding, the difficulties that may arise from a situation where certain conduct may be lawful under one legal regime but unlawful under another raise separate questions that must not be undermined or ignored. It has, therefore, been shown in this chapter that it is essential that these legal concerns are addressed in a manner so that the unity of international law, whether always existent or just starting to emerge, is not to be impaired.

In their recent article, Simma and Pulkowski, giving cognizance to the increasing role of self-contained regimes in the international legal system have described such regimes as planets that exist in the universe. According to them: 'Life on the planet becomes more interesting than the fate of the universe'. However, in the author's view, while the significance of self-contained or special regimes in enhancing the rule of law must not be undermined, it is important that the emphasis is placed on the universe, to use Simma and Pulkowski's words, and on the universal justice of general international law.

With these conclusions, attention is next turned on the legal restrictions of countermeasures and, in particular, on the principle of proportionality as a means of restricting abusive exercise of such measures.

1017 'Fragmentation of International Law', Report (2006), op. cit., (194). 


\section{The principle of proportionality}

\section{Introduction}

It has been stressed throughout this work that in a decentralized legal system in which, as a general rule, no compulsory enforcement mechanisms are available, countermeasures become important because they enable the state whose rights and interests have been infringed to remedy the violation and its unlawful consequences. This is achieved by inducing the wrongdoing state to cease its wrongful conduct and to offer reparation for the injury suffered. This is even more so for securing compliance not only with the rules of general international law, but also with fundamental community interests. However, the fact that the determination of whether a violation that would justify countermeasures in the first place has indeed occurred is made unilaterally by the state resorting to them makes countermeasures vulnerable to abuse. For this reason, the international legal system has attached certain conditions for the lawfulness of countermeasures, examined in section 5.2 of this chapter. In this framework, proportionality, which is at the focus of examination of this last chapter, comes as one condition of lawfulness, among others that intend to restrain the powers of states when resorting to countermeasures. Proportionality finds proper application regarding violations of customary international law as in treaty law states can agree to anything, provided, of course, that this is not in conflict with jus cogens norms. ${ }^{1018}$

In domestic law, when a state takes action in order to prevent or punish the commission of a certain criminal act, it must ensure that its organs abide by specifically defined rules and principles. The aim of such rules extends primarily to the protection of fundamental, inalienable human rights and the observance of the rule of law applicable in a just state. Such action must not be taken arbitrarily or in abuse of powers entrusted by law and it must be the result of pressing necessity without which the legitimate objective cannot be achieved. However, the fact that certain action was necessary does not mean that the specific action finally chosen was also proportionate. Proportionality possesses a prominent position in national legal systems where the state and the individual stand in an apparent 
relationship of inequality. The notion has developed out of the need to regulate and restrict as much as possible the interference of state mechanisms in the sphere of individuals concerning their rights, whether deriving from the private or public sector and with the purpose of balancing individual freedoms and community interests. ${ }^{1019}$

In international law, by the same token, proportionality may arise in three contexts: as an integral element of the primary norm, in the law of the use of force and in the law of state responsibility. Since the current work is focused on the secondary rather than the primary rules of international law, the first category regarding proportionality as part of the primary rule will be excluded from the scope of the current examination.

Having clarified that, proportionality in the international legal system derives its significance from the principle of sovereign equality of states and plays a crucial role not only in the law concerning the use of force (jus ad bellum and jus in bello) but also in the law of countermeasures. Proportionality, therefore, becomes relevant in international law whenever the legal balance in the relationship between states has been disturbed because of a certain wrongdoing. Proportionality is used as a means of evaluation of whether the response to the wrongful act, forcible or not, fulfils specific standards of legality or whether it is excessive. Since often, both the initial wrongful act and the response concern the violation of different international legal norms, the function of proportionality lies in the sphere of balancing different conflicting legal interests. ${ }^{1020}$ In that sense, proportionality does not resemble reciprocity in that the legal balance cannot be regained by mere application of equivalence because the rights and obligations in question are different in kind. ${ }^{1021}$ At the same time, proportionality seems to have been increasingly influenced by current trends regarding humanitarian considerations.

Although proportionality is synonymous to something that is balanced, equipoise, measured, reasonable and symmetrical, there is ambiguity regarding its exact scope and content. ${ }^{1022}$ Despite the fact that proportionality is not a notion independent from the intensity, means, objectives, degree, extent, legal consequences, seriousness and the principles at stake as a result of the initial act and the act taken in response, different opinions remain regarding how proportionality should be assessed. This is particularly so with respect to the concept of proportionality in the law of countermeasures especially in response to violations of collective and community interests. While considerable attention has been given over the years to the content of proportionality when applied in the law of use of force lato sensu, the principle of proportionality in relation to the law of countermeasures has

1019 D. Feldman, 'Proportionality and the Human Rights Act 1998' in E. Ellis (ed.) The Principle of Proportionality in the Laws of Europe (Hart: 1999), 117, 118.

1020 W. Van Gerven, 'The Effect of Proportionality on the Actions of Member States of the European Community: National Viewpoints from Continental Europe' in E. Ellis, op. cit., 37, 58.

1021 Zoller, op. cit., 50.

1022 Van Gerven, op. cit., 47-8. 
significantly remained underdeveloped. Much of the expressed hesitation, for example, in recognizing a right to states other than the injured to resort to countermeasures is the fear that their use may lead to abuses.

In the light of the thesis advanced in this book that customary international law recognizes a right to third-state countermeasures, it is imperative that the legal standards by which proportionality is determined are clearly defined. By contrast, the lack of consensus with respect to proportionality in this field makes the search for predictability much more difficult and subjective, while it endangers not only the feeling of justice but also these basic values of international peace and security as it leaves the door wide open to more arbitrary and unjustified violations of international law. ${ }^{1023}$ The degree of control and review of the legitimacy of countermeasures depends on how precisely the principle of proportionality is formulated, ${ }^{1024}$ particularly in the absence of central compulsory institutions and mechanisms for their review.

Accordingly, the crucial question that one needs to address is what countermeasures must be proportionate to. Several theories have been developed in this regard, with some placing emphasis on a strict relation between the breach and the response and with others turning their attention to the aims pursued or the interests at stake in each case. Bearing in mind the observations made thus far, this chapter will attempt to shed some light on the various conceptions formulated regarding the content of proportionality. Brief consideration will be given on how proportionality is understood in the context of the EU and national legal systems, as this is essential for comprehending the substantive elements of the notion generally. The examination will, however, primarily concentrate on proportionality as applied in the law of the use of force and the law of countermeasures and on the question of whether proportionality does or should coincide in these two areas of international law. Moreover, this chapter will attempt to touch on the question as to whether the nature of the infringed obligation and, more specifically, whether of a bilateral nature or erga omnes, has, or should have, any bearing on the assessment of proportionality. This is essential in the light of the position that contemporary international law recognizes a right to solidarity measures.

\section{The principle of proportionality in the law of the EU}

The question of proportionality was not excluded from the context of the EU. Although the Treaty of Rome makes only a brief reference to the principle, proportionality was subsequently developed through the case law of the ECJ as a

1023 Bowett observes, in this regard that: 'The principle that, while the critical decision to act must be subjective, the legality of the action must be subsequently evaluated by objective and impartial standards, applies in the case of a State resorting to self-defense and ought to be of general application to any form of coercion'. D. Bowett, 'International Law and Economic Coercion' in R. Lillich, Economic Coercion and the New International Economic Order (Mitchie Company: 1976) 87, 98.

1024 Van Gerven, op. cit., 61. 
general principle of law. ${ }^{1025}$ Proportionality in European law is used as a tool of judicial review concerning not only Community but also national measures of administrative and legislative character. ${ }^{1026}$ In applying the proportionality rule, the Court has identified three elements, in particular the suitability and the necessity of the measure under review and the absence of a disproportionate character. A measure meets the requirement of suitability whenever the means employed are suitable for the fulfilment of the legitimate goal, while it is necessary whenever the adverse consequences of the measure on a legally protected interest are justified in the light of the importance of the pursued goal. ${ }^{1027}$

The criterion of proportionality varies according to whether the Court is called to review the proportionality of a specific Community measure or the proportionality of a certain national measure. In the former case, what is under review is a private vis-à-vis a public interest and, in particular, the rights of the individuals affected by the Community measure, on the one hand, and Community interests, on the other. In this event, and although proportionality seeks to protect the rights of individuals, the proportionality of the measure is weighted on the basis of whether it is manifestly inappropriate to achieve its objectives or not. Whenever, however, it is the compatibility of a national measure with the fundamental freedoms established under Community law that is under scrutiny, in the balance of proportionality there exists a national vis-à-vis a Community interest. The test in this case is much stricter and proportionality is measured by way of necessity. What matters here is whether the less restrictive measure has been opted for or not. ${ }^{1028}$

Although there are several factors taken into account when determining proportionality, such as the nature of the action taken, the degree of discretion of the authority taking the decision, the effects of the action and the type of the interests affected, the objective of the measure and the interests the measure aims to protect, the existence of alternative measures and the urgency of the situation, what is essentially in the focus of the ECJ is a balance between the objectives sought and the impact of the measure on individual rights. Tridimas notes in this regard that 'in Community law, far from dictating a uniform test, proportionality is a flexible principle which is used in different contexts to protect different interests and entails varying degrees of judicial scrutiny'. 1029

1025 Internationale Handelsgesellschaft v Einfür- und Vorratsstelle Getreide, Case 11/70, European Court Reports (1970), Part II, 1125; Nold v Commission, Case 4/73, European Court Reports (1974), Part I, ECR 491, 513-14; United Kingdom v Council, Case C-84/94, European Court Reports I (1996), Parts 11-12, 5755; Hauer v Rheinland-Pfalz, Case 44/79, European Court Reports (1979), Part 3, 3727.

1026 F.G. Jacobs, 'Recent Developments in the Principle of Proportionality in European Community Law' in Ellis, op. cit., 1, 2-3; T. Tridimas, 'Proportionality in Community Law: Searching for the Appropriate Standard of Scrutiny' in Ellis, op. cit., 65, 66.

1027 Tridimas, ibid, 68.

1028 Ibid, 66.

1029 Ibid, 69. 
The issue of proportionality was also raised in the light of UN sanctions imposed against Yugoslavia in the 1990s. In the Bosphorus case, one of the main concerns raised was whether the measures taken by Ireland in compliance with Regulation 990/93 were in violation of fundamental Community interests. ${ }^{1030}$ The dispute arose as a result of an Irish ministerial order in the light of which one of two aircraft belonging to JAT, the Yugoslav national airline, but leased, fully managed and controlled by the Turkish Bosphorus Airline was impounded. When the case was referred to the ECJ for a preliminary ruling, Bosphorus Airline, which had agreed the payment of the rent into blocked accounts in order not to circumvent the sanctions, argued that the Regulation infringed its right to peaceful enjoyment of its property and its freedom to contact commercial activities and that it was disproportionate and manifestly unnecessary.

The EGJ, having concluded that the rights in question did not have an absolute character, held that the essential interests of the international community to cease the war in Bosnia-Herzegovina supervened over the rights of Bosphorus. In any event, the impounding of the aircraft was neither inappropriate nor disproportionate. ${ }^{1031}$

Similar questions were raised in the Ebony Maritime case. ${ }^{1032}$ The case in question concerned a tanker, Lido II, flying the Maltese flag that had left Tunisia having as its destination Rijeka in Croatia and carrying a cargo of petroleum products. When, due to bad weather, the vessel decided to change its destination to Montenegro, it was coerced by NATO and WEU forces to sail back to Brindisi where it was handed to the Italian authorities. The latter ordered the impounding of the vessel and the confiscation of its cargo in compliance with the national measures taken to give effect to EC Regulation 990/93. The ECJ, while stressing that it belonged to the discretion of the member states to choose the penalties to be imposed for the violation of the regulation, emphasized that a penalty had to be effective, proportionate and dissuasive. It was accordingly up to the national court to decide whether the confiscation of the cargo irrespective of the degree of involvement fulfilled these conditions. To determine this due consideration should be given to the objective of the regulation, which, in this case, was to bring to an end the humanitarian crisis caused by the war in the region.

1030 Bosphorus v Minister for Transport, Energy and Communications, Ireland and the Attorney-General, Case C-84/95, European Court Reports I (1996), Part 1, 3953.

1031 Ibid (67) and (69). A similar approach was taken by the ECtHR when the case was brought before it. In particular, the Court found that the protection of human rights within the European Union was 'equivalent' to the protection offered under the European Convention on Human Rights and agreed with the ECJ that the interference with the complainant's right to property was not manifestly 'deficient'. On the question of proportionality, the Court held that the means used and the general interests pursued were not disproportionate. Accordingly, the interference with the applicant's right to a peaceful enjoyment of its property was not in violation of article 1 of Protocol 1 of ECHR. Bosphorus Hava Yollari Turizm ve Ticaret Anonim Sirketi v Ireland, Application No. 45036/98, Grand Chamber Judgment, 30 June 2005, (149-50) and (155-57).

1032 Ebony Maritime and Boden Navigationv Prefetto della Provincia di Brindisi and Others, Case C-177/95, European Court Reports I (1997), Parts 1-2, 1111. 
The two cases reveal that the ECJ, in assessing proportionality, gave significant weight to the public interest at stake. Proportionality was, therefore, assessed on the basis of the objective of the restrictive measures under scrutiny, on the one hand, as opposed to the interests and rights affected, on the other.

\section{The concept of proportionality in national law}

This section will briefly consider the elements taken into consideration for assessing proportionality under French, German and UK law. While this examination is by no means exhaustive, it intends to show some of the fundamental aspects of the notion of proportionality that may be useful for the application of this principle in the international legal context.

German law has influenced the development of proportionality under EU law. In particular, German law associates proportionality with the suitability of the measure for the fulfilment of the pursued objective, its necessity in the absence of other means available for the achievement of the pursued objective, and the lack of excessiveness/disproportionality with regard to the negative effects the measure creates. ${ }^{1033}$ More precisely, in order to evaluate whether the measure under scrutiny is necessary and proportionate, there is first a weighing of the means used, the aims pursued and the interests the measure seeks to protect and, subsequently, these are weighed towards another interest that is safeguarded by another rule. The means used for the achievement of the specific objective are then examined with respect to whether they impose an excessive burden on that other interest. ${ }^{1034}$

In France, proportionality gradually developed as a notion that takes into consideration the motives, the purpose and the content of administrative action along with the balancing of interests, the existence of any discretionary powers and the importance of the protected interests. ${ }^{1035}$

British courts, by way of contrast, rely on the test of unreasonableness according to which the court will only interfere with a decision if no reasonable public authority could have adopted it. ${ }^{1036}$ The problem with this approach is that it is equally applicable to all cases irrespective of the nature of the rights involved in each particular case. ${ }^{1037}$

Despite this general approach, British courts are required to apply proportionality in cases where an issue under Community law arises or whenever a right protected under the European Convention on Human Rights is involved. With the coming into force of the 1998 Human Rights Act, UK courts must refer to Strasbourg case law, although they are not obliged to follow it. ${ }^{1038}$ As far as

1033 Van Gerven, op. cit., 44-5.

1034 Ibid, 45.

1035 Ibid, 51-2.

1036 The Rt Hon. Lord Hoffmann 'The Influence of the European Principle of Proportionality upon UK Law' in Ellis, op. cit., 107, 109.

1037 P. Craig, 'Unreasonableness and Proportionality in UK Law' in Ellis, ibid, 85, 99-100.

1038 Feldman, op. cit., 121. Human Rights Act, Section 2. 
proportionality is formed in the light of the Strasbourg decisions, then the assessment of proportionality will rely on three factors. The first relates to the nature of the right to be affected with the interference: while some rights can be restricted, others cannot. The second has to do with the justification, in other words the reasons of the interference. Such reasons may vary from protection of the public order to protection of morals. The third factor concerns the source and form of the interference. ${ }^{1039}$

With these considerations in mind, attention is next turned on the role of proportionality in the law of use of armed force.

\section{Proportionality in jus ad bellum and jus in bello}

\subsection{Introduction}

There was a time in history when a state possessed a 'right to every thing that can secure it from such a threatening danger, and to keep at a distance whatever is capable of causing its ruin'. ${ }^{1040}$ As Dinstein put it: 'Once it was believed that when the cannons roar, the laws are silent.'1041 Nevertheless, the adoption of the UN Charter together with the formulation of international humanitarian law not only restrict the circumstances under which the use of force is justified, but also regulate the conduct and the means allowed during an armed conflict.

It is necessary, however, to make a clear distinction between the law of the use of force (jus ad bellum) and the law of armed conflict (jus in bello). While the former relates to whether a state possesses a right to use force against another state, the latter concerns the rules applicable in war and more precisely the manner in which a war can be conducted. Both fields are restricted by the principle of proportionality, although in each case proportionality is assessed based on different criteria.

The resort to force (jus ad bellum), whether taken in self-defence or after Security Council authorization, must not be disproportionate to the legitimate ends of force'. ${ }^{1042}$ Proportionality, in this case, is determined based on the reasons of using armed force, in other words, whether or not a specific forceful response is for repelling an armed attack. Here the purpose of proportionality is to allow a state to defend itself while eliminating to the extent possible the adverse effects to international peace and security and to the international community as a whole. ${ }^{1043}$

Proportionality in jus in bello, by way of contrast, is related to the rule that during an armed conflict the parties involved do not have unlimited freedom as to the

1039 Ibid, 137-9.

1040 E. Vattel, The Law of Nations or the Principles of Natural Law Sections 16-18 in K.R. Stevens, Border Diplomacy: The Caroline and McLeod Affairs in Anglo-American-Canadian Relations, 1837-1842 (University of Alabama Press: 1989) 25.

1041 Y. Dinstein, The Conduct of Hostilities under the Law of International Armed Conflict (CUP: 2004) 1.

1042 J.G. Gardam, Necessity, Proportionality and the Use of Force by States (GUP: 2004)10-11.

1043 Ibid, 16. 
means and methods they may use and the injury they may inflict on the enemy. ${ }^{1044}$ Here, instead, proportionality is built on humanitarian considerations and a further distinction is made according to which proportionality is viewed under a different lens when concerning combatants and civilians. ${ }^{1045}$ Quite significantly, the fact that proportionality is consistent with jus ad bellum does not preclude responsibility if a response is not at the same time proportionate in jus in bello and vice versa. ${ }^{1046}$

The determination of proportionality in the law of the use of force and the law of armed conflict gains all the more significance, especially in view of the risks envisaged from a possible escalation of the conflict and its tragic effects in respect of loss of lives and destruction caused. Proportionality in this context aims to formulate the scope and intensity of, and the effects to derive from, the use of force in general.

\subsection{Jus ad bellum}

The right to self-defence does not give unlimited powers to the state invoking it. The fact that a state has been the victim of an armed attack does not entitle it to resort to more force than necessary to achieve the lawful objective, namely the repeal of the attack. That the use of force must comply with the principle of proportionality is a principle well established in international law. Proportionality in this respect is not confined to the context of a strict relationship between initial attack and response, since there may be occasions where an equivalent or even identical use of force may not suffice to bring termination of the wrongful act. ${ }^{1047}$ In addition, proportionality looks at what is necessary to secure the objectives pursued, namely to halt and repel the attack. ${ }^{1048}$ In this regard, the proportionality of a given forcible conduct will be assessed in light of its ability to bring about the desired result. ${ }^{1049}$

Accordingly, any action taken in response to an unlawful attack must be restricted in terms of both intensity and magnitude to what is necessary for the fulfilment of the set objectives. It may also be argued that the injured state may

1044 Ibid, 17.

1045 Ibid, 14, 16-17.

1046 Ibid, 11. Also see Legality of the Threat or Use of Nuclear Weapons, op. cit., 245 (42).

1047 K.H. Kaikobad, 'Self-defence, Enforcement Action and the Gulf Wars 1980-88 and 1990-91' 63 BIIL (1992) 299, 316.

1048 Eighth Report on State Responsibility (Ago) Addendum, YbILC (1980), Vol. II, Part One, 69. Also see Dissenting Opinion of Judge Schwebel, Case Concerning Military and Paramilitary Activities in and against Nicaragua, (1986), op. cit., 367 (212).

1049 Eighth Report on State Responsibility (Ago) Addendum ibid, 69. This view is endorsed by Greig (1976) op. cit., 887 in Kaikobad, op. cit., 316-7; M. McDougal and F. Feliciano, The International Law of War: Transnational Coercion and World Public Order (Martinus Nijhoff: 1994) 241-42. 
take such action as necessary to guarantee that its territorial integrity is not threatened again in the future. ${ }^{1050}$

Yet, no unanimity exists on the matter as some authors place the emphasis on the initial danger, ${ }^{1051}$ while others on the injury inflicted. ${ }^{1052}$ Kaikobad suggests that evaluating proportionality is not an easy task. This is because there are a number of other factors to be taken into consideration such as the nature and scale of the attack but also the 'vital interests' at stake, thus giving a certain degree of relativity and subjectivity to the notion of proportionality. ${ }^{1053}$

\subsection{Jus in bello}

Otherwise known as international humanitarian law, jus in bello comprises norms the purpose of which is to balance the military necessity, on the one hand and humanitarian considerations, on the other. While jus in bello has been formulated out of the need to restrict to the extent possible human suffering during an armed conflict, it has also been accustomed to the realities that emerge during war. ${ }^{1054}$

The requirement of proportionality as an essential component of the law of armed conflict can be traced not only in customary international law but also in conventional law, in particular in Article 51(5)(b) of Protocol I adopted in 1977. ${ }^{1055}$ According to this provision, an attack expected to cause incidental loss of, and injury to civilian life and which would be excessive in relation to the military advantage anticipated will be disproportionate. ${ }^{1056}$

Three factors seem to be relevant in determining the content of proportionality in jus in bello, namely, the selection of the target, the means and methods of the attack and whether unnecessary loss of civilian life has been carried out in comparison to the military advantage pursued. Yet, the weakening of the military advantage of the enemy may not be an adequate or satisfactory criterion in determining proportionality. It is noted in this respect that short-term effects may arguably not be sufficient to lead to the conclusion that a certain response was proportionate or not. On the contrary, long-term effects on population or environment must also be taken into consideration while proportionality should be assessed on a case-by-case basis rather than cumulatively. ${ }^{1057}$

1050 C. Wicker, 'The Scope of Proportionality in the Right of Self-defence and in the Law of International Counter-measures', A dissertation submitted to the University of Durham for the degree of LLM in International and European Legal Studies (2002) 18.

1051 D. Bowett, Self-defence in International Law (Manchester University Press: 1958) 269.

1052 R. Higgins, Problems and Process: International Law and How to Use It (Clarendon: 1994) 231.

1053 Kaikobad, op. cit., 317.

1054 Dinstein (2004), op. cit., 17.

1055 Protocol Additional to the Geneva Conventions of 12 August 1949 and Relating to the Protection of Victims of International Armed Conflicts (Protocol I) 1977, Laws of Armed Conflicts 423, $430-1$.

1056 Ibid.

1057 J.G. Gardam, 'Proportionality and Force in International Law' 87 AfIL (1993) No. 3, 391, 409. 


\subsection{Proportionality in state practice and judicial revieze}

The dispute between the United States and Great Britain over the Caroline Incident is considered to have set the structures for the development of the principles of necessity and proportionality under the UN Charter. ${ }^{1058}$ The incident was evoked in 1837 when British forces set the Caroline, an American vessel that was docked in American waters, on fire. The vessel had been allegedly involved in providing war assistance to rebels who were at the time fighting against British colonialism in Canada. As a consequence, one American citizen lost his life. Although the US president described the incident as a serious violation of American territory, he confined action to strengthening border controls and to seeking reparation. ${ }^{1059}$ When, however, a British subject was later arrested by the state of New York for his involvement in the incident, the British government responded immediately demanding for his release. It was specifically noted that the act with which he was charged had a public character and it was necessary to defend the territories and the subjects of Great Britain. ${ }^{1060}$

In its response, the US government asserted that the principle of the inviolability of the territory of a foreign state could only be legitimately violated and therefore justified, if it were the result of 'absolute necessity'. Although the American government clearly questioned the necessity of the British response, it demanded the British government to show that it had done nothing 'unreasonable or excessive', in other words, disproportionate and that its action was not only necessary but it also did not go beyond that necessity. ${ }^{1061}$

Although the two notions of necessity and proportionality are closely related, they are two separate and independent concepts. Accordingly, as already pointed out, the fact that the necessity for certain action is proved does not automatically mean that the action is also proportionate either to the injury suffered or to the aim pursued. The British government was requested to demonstrate that the attack on the vessel was justified, in other words, that it was necessary to use force. It was also required to show that the action taken was the most appropriate for achieving its purpose, which is associated with the question as to whether the force used were proportionate. From the US response, it can also be inferred that there was some reference to jus in bello as questions emerged regarding the manner in which the attack was carried out, as to whether alternative action was unavailable and the fact that it was indiscriminate.

The British government responded that its action was necessary and limited to that necessity. ${ }^{1062}$ However, and although the necessity for action has also been

1058 The Caroline Incident, 29 British and Foreign State Papers (1840-41) 1129 and 30 British and Foreign State Papers (1841-42) 195. Also see Gardam (2004) op. cit., 40.

1059 Stevens, op. cit., 1372-3, 1376-7.

1060 Correspondence of Mr Fox to Mr Webster, March 1841 in British and Foreign State Papers (1840-41) Vol. 29, 1127.

1061 Ibid, 1138.

1062 Lord Ashburton to Mr Webster in British and Foreign State Papers (1841-42) Vol. 30, 196. 
disputed, ${ }^{1063}$ the question that remains is whether the particular action taken, in its extent and severity, was the most appropriate under the circumstances in order to cease the aggressive activities in which the vessel was allegedly engaged and as to whether alternative milder means would not be sufficient.

In the Corfu Channel case, which concerned a dispute between Albania and the United Kingdom, Albania argued that minesweeping undertaken by the British Navy without its consent was a violation of its sovereignty. The minesweeping took place a few weeks after the explosion of two mines in the North Corfu Channel resulting in the destruction of two ships belonging to the British Navy and the loss of many lives. ${ }^{1064}$ Although the ICJ refused to recognize a right of intervention in the territory of another state for collecting evidence, it held that the way with which the operation for the minesweeping was carried out was not 'out of proportion to the requirements of the sweep'. ${ }^{1065}$ It seems that the Court, in its consideration of the British action and as to whether it conformed to the requirement of proportionality, took into account the objective of the operation, namely the minesweeping of the area.

In the Case Concerning Military and Paramilitary Activities In and Against Nicaragua, the ICJ was called to consider, among other things, whether American military assistance to groups acting in and against Nicaragua was proportionate. ${ }^{1066}$ Having rejected that the US action was carried out in self-defence in the absence of an armed attack on Nicaragua's part, the Court concluded that, in any event, such action, including the mining and attacking of Nicaraguan ports and oil installations was neither necessary nor proportionate. ${ }^{1067}$ As the Court acknowledged, the exercise of the right to self-defence must be subject to proportionality and necessity, 'a rule well established in customary international law.'1068 The Court therefore upheld that proportionality in self-defence is linked to what is required to repel the attack and that, accordingly, the US action was not in proportion to the act that provoked it, namely, the aid and assistance provided by Nicaragua to the Salvadorian contras. 1069

1063 Stevens, op. cit., 35-6.

1064 Corfu Channel case, Merits, op. cit., 4.

1065 Ibid, 35.

1066 Case Concerning Military and Paramilitary Activities in and against Nicaragua (1984), op. cit., 392; Case Concerning Military and Paramilitary Activities in and against Nicaragua, (1986), op. cit., 14.

1067 Case Concerning Military and Paramilitary Activities in and against Nicaragua, (1986), ibid, 122 (237). According to the Court the alleged support of the armed opposition in El Salvador, Honduras and Costa Rica by Nicaragua could not justify countermeasures by a third state, neither did it amount to armed attack to justify collective self-defence. Further, the US action could be justified in response to Nicaragua's intervention in the internal affairs of states other than the United States. In responding further to the US allegations that that there were extensive human rights violations in Nicaragua the Court dismissed the use of force as being an appropriate means to address such violations. See paras 249, 268.

1068 Case Concerning Military and Paramilitary Activities in and against Nicaragua, (1986), ibid, 94 (176).

1069 Also see analysis in Gardam (2004), op. cit., 158. 
Concerns were further expressed with respect to the conformity of the use of nuclear weapons with the principle of proportionality, a question raised before the ICJ in the Legality of the Threat or Use of Nuclear Weapons case. ${ }^{1070}$ In its Advisory Opinion, the Court, having concluded that there was no customary or conventional rule of international law prohibiting the threat or use of nuclear weapons, focused its attention on the law of the UN Charter and the law of armed conflict. In its view, these were the most relevant fields for the determination of whether the use or threat of nuclear weapons was permitted, in view of the particularly catastrophic consequences to derive therefrom.

Reaffirming the principle that the right to self-defence was subject to the rules of proportionality and necessity as ruled in the Nicaragua case, the Court stressed that proportionality, by itself, did not outlaw the use of nuclear weapons as the response should be viewed in the light of the armed conflict (jus in bello). With specific reference to international humanitarian law, the Court highlighted that this finds expression in the Hague Conventions of 1899 and 1907, which include the Regulations Respecting the Laws and Customs of War on Land, and the Geneva Conventions of 1864, 1906, 1929 and 1949 and the Additional Protocols of 1977.

These instruments make clear that the right of belligerents to inflict injury on the enemy is significantly restricted with as a result the limitation of the means that can be used during armed conflict, while the civilian population is immune from acts of reprisal. It is derived from these instruments that certain types of weapons are prohibited if they inflict unnecessary suffering in comparison to the pursued legitimate military objectives and make difficult the distinction between combatants and non-combatants. For the Court, the prohibition of superfluous injury or unnecessary suffering on combatants constitutes a 'cardinal principle', which, as a consequence, bans certain weapons, irrespective of whether this is specifically provided under a treaty or not. ${ }^{1071}$

The Court deduced that the body of rules of international humanitarian law and the obligations arising therefrom applied also to the use or threat of nuclear weapons (jus in bello) and that the use or threat of nuclear weapons should comply with Articles 2(4) and 51 of the UN Charter ( jus ad bellum). However, the Court felt unable to conclude with certainty that the use of nuclear weapons would be incompatible with the rules of humanitarian law (jus in bello), although it did recognize that nuclear weapons bore such characteristics that made them 'scarcely reconcilable' with the rules prohibiting unnecessary suffering and indiscriminate attacks. At the same time, the Court highlighted the right of each state to protect itself, thus leaving it to be inferred that the right to self-defence would prevail over humanitarian law should the need emerge.

Undoubtedly, the Opinion left a feeling of disappointment since it did not mitigate the fears of a possible nuclear war by setting the most stringent conditions for

1070 Legality of the Threat or Use of Nuclear Weapons, op. cit.

1071 Ibid, 257 (78), (79). 
the permissibility of nuclear weapons in the light of the considerations and prohibitions under the law of armed conflict. As Dinstein further observes, the inability of the Court to resolve the matter as to whether the use of nuclear weapons 'in an extreme circumstance of self-defence, in which the very survival of a State would be at stake' 1072 would be permissible is difficult to accept. This is because 'it appears to be utterly inconsistent with the basic tenet that LOIAC (jus in bello) applies equally to all belligerent States, irrespective of the merits of their cause pursuant to jus ad bellum'. ${ }^{1073}$

The use of nuclear weapons raises concerns both in respect of unnecessary suffering but also of indiscriminate attacks against civilians and civilian losses. Most important, the Court with its opinion leaves a legal gap with which the requirement of proportionality, so important in both jus ad bellum and, especially, in jus in bello, is circumvented. ${ }^{1074}$ Although one can see the justification of nuclear weapons under certain circumstances in the law of the use of force where proportionality is measured in accordance with the military objective to repel the initial attack, it is difficult to see how their use can be reconciled with the law of armed conflict. This is particularly so as many of the rules provided under humanitarian law are considered to have a peremptory character.

\section{Proportionality in the law of countermeasures}

\subsection{In search of international enforcement}

The general prohibition of the use of force as a means of settling state disputes has not eliminated the threats and dangers with which the international community is faced. Countermeasures, in particular, may become such a strong weapon in the hands of those states using them that the imposition of the most stringent conditions regarding their use is an essential prerequisite if they are not to become an instrument of vengeance. This is particularly so since as noted the main characteristic of the international legal community is the non-existence of central compulsory judicial and enforcement mechanisms. It was acknowledged by Mr Arangio-Ruiz that:

$[\mathrm{T}]$ he matter has been rightly recognized as also being of great importance in legally controlling resort to non-forcible measures. Although less dramatic

1072 See in this regard the conclusions of the Court, ibid, 263 (97).

1073 Dinstein (2004), op. cit., 78.

1074 On indiscriminate attacks see Dissenting Opinion of Judge Higgins, Legality of the Threat or Use of Nuclear Weapons, op. cit., 586 and 588 (17) and (24). For the position that contemporary international law does not provide for an exception when the life of the nation is threatened, see Dissenting Opinion of Judge Shahabudeen, Legality of the Threat or Use of Nuclear Weapons op. cit., 377 Dissenting Opinion of Judge Koroma, Legality of the Threat or Use of Nuclear Weapons, op. cit., 556, 560-3. 
and harmful, such measures can be equally detrimental to the preservation of friendly relations and the development of cooperation among States. ${ }^{1075}$

In a community structured on the basis of sovereign equality of states no state can claim that it has been entrusted with world enforcement and punitive powers as against the rest. The notion of proportionality comprises an integral part of the law of countermeasures. No response can be regarded as lawful if it is disproportionate, as with it the rights of the wrongdoing state and the international community as a whole are aimed to be protected. The wrongdoing state is protected because proportionality secures that there will be no violation of its own rights in respect of the aims set, the means used and the effects to be derived from the response. The international community is also protected because proportionality provides an indication when a certain act ceases to be a reestablishment of legality, and seeks to achieve goals that are unlawful per se, for instance the punishment of the wrongdoer. The latter can never be a legitimate objective, nor can it safeguard international law, peace and security. Quite the contrary, as history has shown with Germany's exclusion from the League of Nations and the imposition against it of heavy compensation demands and sanctions of a punitive character as a result of its role in World War I, the measures against it did not prevent it from further pursuing its aggressive policies. This led to yet more human suffering and devastation borne out of World War II. This is the reason that in the aftermath of World War II the objective was not the punishment but rather the rehabilitation of Germany.

Furthermore, the varied interests of states in the international legal arena, but also the factual inequality of states, make the need for legal restraint even more compelling. This reality is best described in the words of McDougal and Feliciano, who pointed out that:

The 'establishment of a civil society which generally administers the law' has been described as 'mankind's most difficult problem'. In a community of States afflicted with clashing conceptions of the appropriate ends of law and civil society, whose largest arena is a military arena of multiplying devices that promise both infernal destruction and access to the heavens, the establishment of a society generally administering a law adequately expressing the deepest aspirations of the world's peoples for freedom, security and abundance - the establishment, in other words, of a world public order of human dignity - is truly a problem of the most heroic proportions. ${ }^{1076}$

It is the varied perception of the world order by states that make them fear foreign intervention and strongly upkeep the notion of sovereignty that they refuse to abandon. It is for these reasons that contemporary international law confines itself

1075 Third Report on State Responsibility (Arangio-Ruiz), op. cit., 18 (52).

1076 M. McDougal and F. Feliciano, Law and Minimum World Public Order (YUP: 1961) 261. 
at establishing a minimum order that prohibits unauthorized coercion and violence. As early as 1958 Professor Brierly pointed out that what differentiated municipal from international law was not the lack of sanctions in international law, but the fact that the sanction mechanisms under municipal law are organized and systematic, while in international law there is a lack of an organized sanctionimposing system. As a consequence: 'The true problem for consideration is therefore not whether we should try to create sanctions for international law, but whether we should try to organize them in a system.' ${ }^{1077}$

In the absence of such a centralized international legal system, states are empowered to become the guardians of their own rights and are entitled to resort to unilateral, peaceful measures in order to induce termination of the wrong committed against them and the compliance of the wrongdoing state with its obligations that derive as a result. Nevertheless, the international community is now called on to face new challenges with respect to serious violations of fundamental interests owed to the international community as a whole or to a group of states. The lack of compulsory judicial and enforcement mechanisms has put at risk the very effectiveness of international law and has fed a controversial debate as to whether states not injured are or should be entitled to take action in the form of countermeasures in order to bring to an end these violations.

At the same time, the acceptance of a right to solidarity measures has not been without its sceptics. Professor Koskenniemi argues, for example, that in view of the unwillingness of states to commit themselves to clear-cut definitions of notions such as erga omnes obligations, serious breaches or the fundamental interests of the international community, which may in the future trigger 'automaticity' of action and their preference for flexible terminology allowing them discretion for the protection of their national interests should such a need arise in the future, makes the danger of abuse of solidarity measures apparent. It is therefore imperative that resort to such measures is restricted. ${ }^{1078}$

Undoubtedly, the entitlement of all states to resort to such measures raises significant questions regarding proportionality. In the light of the ILC's conclusion that there currently exists no rule allowing solidarity measures in international law, the question of proportionality of such measures was neglected. It is, thus, imperative, in view of the significance of the matter, to consider whether the notion of proportionality as advanced in the Final Articles regarding countermeasures by injured states could apply to assess the proportionality of solidarity measures. It does not matter that the ILC did not acknowledge the existence of such a right, unlike the conclusions of this study. The fact that it left the subject to the progressive development of international law, but also the frequent resort to such measures by states, makes such consideration essential to ensure that the

1077 J. Brierly, 'Sanctions in International Law' in H. Lauterpacht and M.H.C. Waldock (eds) The Basis of Obligation in International Law and Other Papers of the late James Leslie Brierly (OUP: 1959) 202 in ibid, 296, fn 71.

1078 Koskenniemi (2001), op. cit., 349-50, 355. 
dangers of abuse are eliminated. For this purpose, and in order to mitigate the fears of many states regarding authorization of countermeasures by states other than the injured, it is necessary to reduce, to the extent possible, the risks of abuse by those states that are favoured in terms of military and economic strength.

\subsection{Legal constraints of countermeasures}

Leaving aside for the time being the question of whether countermeasures by a state other than the injured are permissible or not, it should not be forgotten that countermeasures, constituting an internationally wrongful act themselves, exceptionally entitle a state whose rights have been violated to suspend the performance of its own obligations towards the wrongdoing state. The purpose of such nonperformance is, according to Article 49 of the Final Articles, to induce the compliance of the wrongdoing state regarding cessation and reparation. ${ }^{1079}$ The Final Articles also acknowledge that countermeasures need not be reciprocal in character, deviating in this way from the maxim an eye for an eye, since reciprocity, while it could at times comply with the principles of necessity and proportionality, could also collide with them in given circumstances, thus endangering fundamental principles of international law.

Countermeasures, which must not involve the use of force, must be temporary in character, a principle affirmed by the ICJ in the Gabcikovo-Nagymaros case. As already seen in Chapter 4, the Court in that case differentiated between the suspension or termination of a treaty as a consequence of a material breach as provided under Article 60 of the 1969 VCLT, on the one hand, and suspension of the performance of obligations by way of countermeasures under the law on state responsibility, on the other. Countermeasures are therefore taken for the fulfilment of a certain aim and must be terminated as soon as this aim is accomplished. ${ }^{1080}$ Furthermore, for the legality of countermeasures to remain uncontested, they must solely be directed against the wrongdoing state, they must not be aimed at inflicting punishment, while their effects must be reversible as far as possible. The latter means that if the state resorting to countermeasures has to select between many effective measures, it must select those that would allow resumption of the performance of the obligations once they are terminated. ${ }^{1081}$

Moreover, the Final Articles make clear that countermeasures are prohibited with respect to obligations arising from the UN Charter concerning the prohibition of the threat or use of force, obligations regarding the protection of fundamental human rights, obligations of a humanitarian nature banning reprisals and obligations arising from jus cogens norms. ${ }^{1082}$ The universal significance of human rights,

1079 Report of the International Law Commission (2000), op. cit., 51 (296).

1080 Case Concerning the Gabčikovo-Nagymaros Project (1997) op. cit., (47); Crawford (2002), op. cit., 282-3.

1081 Ibid, 283.

1082 Ibid, 288. 
as this is reflected from the several international instruments existing for their protection, could also not leave unaffected the development of countermeasures.

Special Rapporteur Professor Crawford had also proposed a further provision prohibiting extreme political or economic coercion that aimed to endanger the territorial integrity or political independence of the wrongdoing state or which would amount to interference in its domestic affairs, ${ }^{1083}$ a proposition not finally followed by the ILC. Instead, in the commentary of final Article 50(1)(b) concerning the requirement of respect of international human rights, reference is made to the International Covenant on Economic, Social and Cultural Rights, which provides for a distinction between exercising economic and political pressure for compliance with international law and inflicting suffering on vulnerable groups within the targeted state. ${ }^{1084}$ It can, therefore, be inferred from this that particularly burdensome countermeasures will be assessed in the context of the obligations requiring respect for fundamental human rights.

Article 50(2) of the Final Articles further provides that a state resorting to countermeasures is still under a duty to fulfil its obligations under any dispute settlement procedure existing between itself and the wrongdoing state that is related to the dispute in question and under diplomatic and consular law.

It is within this context that proportionality should be assessed, as the considerations just analyzed narrow significantly what it may be done by way of countermeasures and they make the scope of proportionality very small. As it can be inferred, a state whose rights or legal interests have been violated is limited by certain conditions as to what it can do in response, excluding the restrictions mentioned earlier. Proportionality provides what the state is entitled to achieve and keeps the notion of countermeasures clear from punitive elements. ${ }^{1085}$ This is exactly where the principle of proportionality gains significance. As Professor Crawford has pointed out, proportionality is the sine qua non of the legality of countermeasures, ${ }^{1086}$ while it serves to restrict the intensity and nature of unilateral power that legitimizes what in other circumstances would be illegitimate and therefore safeguarding the own rights of the defaulting state. ${ }^{1087}$ At the same time, it aims to bring legal certainty and predictability in international relations by setting the conditions with which excessiveness of a certain action can be measured and assessed.

Furthermore, proportionality draws a line between the internationally wrongful act and the countermeasures resorted to, while it may be related to the purpose pursued by the latter. As the ILC observes in its commentary to Article 51 of the Final Articles a disproportionate response may have been unnecessary in inducing

1083 Report of the International Law Commission (2000), op. cit., 52 (301).

1084 Crawford (2002), op. cit., 289.

1085 Zoller, op. cit., 135.

1086 Report of the International Law Commission (2000), op. cit., 53, (305).

1087 E. Cannizzaro, 'The Role of Proportionality in the Law of International Countermeasures' 12 EJIL (2001), 889, 890. 
the compliance of the wrongdoer with its international obligations, namely cessation and reparation. Yet proportionality may render unlawful countermeasures that although necessary to bring the compliance of the defaulting state were not proportionate. ${ }^{1088}$

One of the main concerns regarding countermeasures in general and proportionality in particular is that they are assessed by the state resorting to such measures. The view has therefore been taken that proportionality should be more precisely formulated. ${ }^{1089}$ Here again emerges the question as to what countermeasures must be proportionate. While earlier sections dealt with an overview of proportionality in the context of EU, national legal systems and the law of armed conflict, the following sections will focus on the content of proportionality in the law of countermeasures. An additional question that will be raised is how proportionality would or should be assessed, in the context of solidarity measures.

\subsection{Concept of proportionality in the work of the ILC}

The prohibition of the use of armed force as a means of resolution of international disputes, as reflected in customary international law but also in Article 2(4) of the UN Charter and General Assembly Resolution 2625 on the Friendly Relations of States, ${ }^{1090}$ played a determinative role in the further development of the concept of countermeasures. One of the main concerns in view of the decentralized character of the international legal order, however, has been the outlining of the legal restraints of countermeasures. As pointed out by Mr Riphagen, no matter how serious the initial wrongdoing, the offender has certain rights that no one can violate in response. In his opinion, this rule constitutes a negative statement of the rule of proportionality according to which:

$[\mathrm{T}]$ he author state does not, by the mere fact of committing any breach of any obligation, become an 'outlaw'. Rather, the rules of international law determine the legal consequences of the breach, i.e. the possible responses, including the new obligations of the author State. These responses are not necessarily strictly proportional to the breach. They may involve legal consequences having a serious impact on the sovereignty of the author State, as, for example, in the case of a response against aggression committed by the author State. But the point is that even the most serious 'international crime' (in the sense of art. 19 of part 1 of the draft) does not in itself - i.e. automatically - deprive the author State of its sovereignty as such. ${ }^{1091}$

1088 Crawford (2002), op. cit., 296.

1089 Report of the International Law Commission (2000), op. cit., 56 (333).

1090 General Assembly Resolution on Friendly Relations 2625 (1970), op. cit.

1091 Second Report on State Responsibility (Riphagen), op. cit., 86 (60). 
At the ILC, it was acknowledged that the application of countermeasures as a response to a prior breach in order to preclude the wrongfulness and therefore the responsibility of the responding state should be commensurate to the injury suffered by the initial offence. ${ }^{1092}$

For Mr Riphagen, however, the source (i.e. customary, conventional or other), the content, the purpose and the object of an obligation that has been infringed cannot but influence the legal consequences of the breach (qualitative proportionality). Moreover, the factual circumstances under which a breach occurred are also relevant for the response such as the seriousness of the wrongful act and its effects on the interests of another state. Such circumstances may aggravate or extenuate the responsibility of the author state, in other words, the legal consequences deriving from the wrongful act (quantitative proportionality). It is accordingly imperative to find equivalence between the actual effects of the internationally wrongful act and the actual effects of the legal consequences. Therefore:

A manifest 'quantitative disproportionality' between breach and legal consequences should be avoided, but, while this principle can appear in a set of general draft articles on State responsibility, a further elaboration must be left to the States, international organizations or organs for the peaceful settlement of disputes which may be called upon to apply those articles. ${ }^{1093}$

Mr Riphagen further suggested that when assessing the lawfulness of specific countermeasures, it is important to take into account the seriousness of the violation, on the one hand, and the seriousness of the sanction taken, on the other, although there can be 'no perfect correlation' between breach and response in international law. ${ }^{1094}$ Nevertheless, 'translating quantity in terms of quality and vice versa', as characteristically was pointed out, is not an easy task. This is especially when the new legal relationship established because of the initial wrongful act does not merely establish an obligation for restitutio in integrum, but also authorizes the injured state to resort to countermeasures or even creates a right or a duty for third states to adopt a non-neutral position towards the defaulting state. ${ }^{1095}$

In 1969 the ILC identified two factors that were significant for determining proportionality. The first related to the greater or lesser importance of the infringed norms to the international community, while the second concerned the greater or lesser seriousness of the breach. ${ }^{1096}$

It was suggested in this regard that in determining the legal regime of responsibility, that is the legal consequences arising because of an internationally wrongful

1092 Eighth Report on State Responsibility (Ago), op. cit., 40 (82).

1093 Third Report on State Responsibility (Riphagen), op. cit., 46 (1).

1094 Second Report on State Responsibility (Riphagen), op. cit., 84-5 (49).

1095 Preliminary Report on State Responsibility (Riphagen), op. cit., 128 (95).

1096 In Second Report on State Responsibility (Riphagen), op. cit., 84 (47). 
act, it was not enough to draw a list of the new legal relationships and categorize such legal consequences in a scale of strength. Neither was it satisfactory when choosing which legal consequences are more appropriate in each particular case to merely draw proportionality in the light of the breach and the response. This led Mr Riphagen to propose that in addition to the scale of consequences in accordance to their strength, a substantive criterion was also required and, in particular, a scale of values affected from both the breach and the response. ${ }^{1097}$ Nevertheless, a scale of values necessarily fell within the ambit of the primary rules, something that the Commission repeatedly precluded in Part 1 of its Draft Articles, with the exception, perhaps, of Article 19 and with what it named as 'international crimes'. However, as Mr Riphagen noted, even in the case of international crimes there existed different legal consequences to be chosen from for each particular situation. ${ }^{1098}$

For determining the legal consequences to be applied in a case of a violation and of estimating proportionality, Mr Riphagen recommended to do so by way of approximation taking into account a scale of possible responses, on the one hand, and the general rule of proportionality between the actual breach and the actual response, on the other. At the same time, he acknowledged that the seriousness of the situation created as a result of the violation might entail a stronger and more serious response. To achieve that, Mr Riphagen suggested three restrictions in relation to the protection given to the object of the response by the rules of international law; the connection between the object of the breach and the object of the response; and the existence of a form of international organization lato sensu covering the situation. According to him, these requirements provided for flexibility when determining the question of proportionality.

Nevertheless, it was also suggested that the wrongful act might, in fact, be of such negligible significance so 'its breach' does not entail all the legal consequences provided by the secondary rules for that particular act. As Mr Riphagen remarked, 'the mirror-image of this immediate appreciation of a particular set of factual circumstances is the principle of law called the principle of proportionality'. ${ }^{1099}$

When Mr Arangio-Ruiz later examined the issue of proportionality, the attention was turned to the determination of the real objective of countermeasures in each particular case. ${ }^{1100}$ However, when defining the notion of proportionality in relation to countermeasures, Mr Arangio-Ruiz, unlike his predecessor, rejected that it was appropriate to refer to terms such as 'manifestly disproportionate', since there was a risk of introducing subjective and ambiguous elements into the notion. Instead, he opted for terms such as 'out of proportion' or simply

1097 Preliminary Report on State Responsibility (Riphagen), op. cit., 129 (98).

1098 Ibid.

1099 Third Report on State Responsibility (Riphagen), op. cit.,32 (65).

1100 See in this regard Report of the Commission (1992), op. cit., 31 (215). Also see analysis in Third Report (Arangio-Ruiz), op. cit., (37) et seq. 
'disproportionate'. As for the criteria required for the assessment of proportionality Mr Arangio-Ruiz stressed that it would not suffice to take into account merely the damage caused by the wrongful act (quantitative element). An additional, qualitative element should also be taken into consideration and, more specifically, the importance of the interest/right protected by the infringed rule, and the seriousness of the breach. As a consequence, Mr Arangio-Ruiz proposed Draft Article 13 according to which: 'Any measure taken by an injured State under articles 11 and 12 shall not be out of proportion to the gravity of the internationally wrongful act and of the effects thereof.'1101

The next Special Rapporteur, Professor James Crawford, turned his attention to the aims to be pursued by countermeasures ascertaining that it was necessary to legally restrict these. Emphasis was therefore given to the coercive character of countermeasures. Accordingly, the ILC accepted as lawful countermeasures whose purpose is strictly to bring compliance with the obligations of the wrongdoing state borne out of its wrongful act. This view is reflected in Article 49 of the Final Articles, according to which, an injured state is entitled to resort to countermeasures only for inducing the wrongdoer to comply with its obligations, namely, the cessation of the wrongful act, the provision of safeguards of non-repetition and reparation for the injury caused (Part 2 of the Final Articles).

Article 51 of the Final Articles provides that: 'Countermeasures must be commensurate with the injury suffered, taking into account the gravity of the internationally wrongful act and the rights in question.' Cannizzaro notes, in this regard, that despite the change of perception regarding the nature of countermeasures, Article 51 does not correspond to this change because in effect it envisages a relationship between breach and response. ${ }^{1102}$ Therefore, if the ILC wished to focus on the coercive nature of countermeasures, then it should have defined proportionality as a relation between the intensity of the constraint and the gravity of the initial breach. Moreover, Cannizzaro argues that it is improper to put all countermeasures under the same category, namely that they all aim at the coercion of the wrongdoing party, as it does not give flexibility or establish a link between the aim pursued and the means used. ${ }^{1103}$

In addition to this, White and Abass note that, if proportionality were assessed on the basis of the injury caused, this would imply that the purpose of countermeasures is to punish the recalcitrant state, something explicitly precluded under the Final Articles and that, as a result, there seems to be a contradiction in the position of the ILC. ${ }^{104}$ Although the author shares these thoughts, it is also important to stress that proportionality cannot be completely disassociated from the initial breach.

1101 Fourth Report on State Responsibility (Arangio-Ruiz), op. cit., 35.

1102 In Crawford (2002), op. cit., 294. Also see Bederman (2002), op. cit., 822.

1103 Cannizzaro (2001), op. cit., 893-4.

1104 White and Abass, op. cit., 516. 


\subsection{Development of proportionality in the laze of countermeasures}

Reprisals, as measures short of war taken by one state against another, made their appearance in the second half of the 19th century. ${ }^{1105}$ According to Oppenheim, reprisals constituted 'such injurious and otherwise internationally illegal acts of one State against another as are exceptionally permitted for the purpose of compelling the latter to consent to a satisfactory settlement of a difference created by its own international delinquency'. 1106

The question of proportionality was discussed in the Naulilaa incident between Germany and Portugal in 1928, although the concept of proportionality as outlawing reprisals which were disproportionate to the act that provoked them was not previously unknown to academic commentary. ${ }^{1107}$ The Arbitration Tribunal established in this case with the agreement of the two states parties to the dispute was called to determine whether the reprisals taken in that course were grossly disproportionate.

The incident between the two countries was evoked when, in October 1914, some members of a Portuguese frontier post in Naulilaa killed three German officers and wounded two others. In retaliation, the governor of German South-West Africa ordered German forces to attack and destroy forts and posts in the Portuguese territory that were as a result abandoned and later looted by the native population. The two countries reached an agreement for the establishment of an arbitration tribunal in accordance with the terms of the Treaty of Versailles to try claims concerning acts of the German government since July 1914 and before Portugal's accession to the war. The Tribunal, having concluded that the Portuguese action to kill the German officers was a mistake and as a result did not constitute a wrongful act, held that reprisals constituted an act of self-help of the injured state in retaliation to a violation of international law and that it had to comply with proportionality. More specifically, the Tribunal stressed that reprisals:

$[\mathrm{H}]$ ave for object to suspend momentarily, in the relations between the two states, the observance of such or such a rule of international law. They are limited by the rules of humanity and good faith applicable in the relations of state to state....They tend to impose on the offending state reparation for the offence or the return to legality and avoidance of new offences. This definition does not require that the reprisal be proportioned to the offence. ${ }^{108}$

The Tribunal further noted on the question of proportionality that according to the German doctrine of reprisals, these did not need to be proportionate to

1105 Gardam (2004), op. cit., 46.

1106 Cited in Gardam (2004), op. cit., 46.

1107 In Zoller, op. cit., 125.

1108 Case Concerning the Responsibility of Germany for Damage Caused in the Portuguese Colonies of South Africa (Portugal v Germany) - The Naulilaa Incident, op. cit., 951. 
the offence. Nevertheless, the Tribunal did acknowledge an existing disagreement among authors on the issue and that the majority viewed that there needed to be a proportion between the offence and the reprisal as a condition of legitimacy. ${ }^{109}$ It went further to note that:

(2) The necessity of a proportionality between the reprisal and the offence appears to be recognized in the German reply. Even if one admits that international law does not require that reprisals be measured approximately by the offence, one must certainly consider as excessive, and consequently illicit, reprisals out of all proportion to the act which has motivated them. In the present case ... there was an evident disproportion between the incident of Naulilaa and the six acts of reprisal which have followed it. ${ }^{110}$

The emphasis placed by the Tribunal lies on the lack of equivalence between the initial wrongdoing and the reprisals. The conclusions of the Tribunal that proportionality was a prerequisite for the legality of reprisals reflected the opinion of writers of the time according to which 'reprisals must be in proportion to the wrong done and to the amount of compulsion necessary to get reparation'. 111 However, the state practice that followed the Naulilaa incident was not always consistent to this approach according to which proportionality had a restraining power. One of the reasons identified for this was the lack of agreement regarding the aims of reprisals, 'an established referent against which to measure the reprisal action'. ${ }^{1112}$ It is, therefore, observed that if what was aimed for by the reprisals was retribution then the gravity of the offence could be a relevant factor in evaluating proportionality. If, however, the aim of the reprisals were to induce the wrongdoing state to offer reparation, then the injury suffered would be essential in assessing proportionality.

Zoller has taken the view that proportionality becomes relevant whenever the response to the wrongful act goes beyond the suspension or termination of a right or obligation equivalent to the right or obligation that had initially been infringed. In this context, proportionality brings harmony which is not based as noted on mathematical approximation, but rather, on relative equality. ${ }^{1113}$

Proportionality in relation to countermeasures was the subject of examination by the Arbitration Tribunal established with the agreement of the United States and France in the Case Concerning the Air Services Agreement of 27 March 1946. ${ }^{1114}$

1109 Ibid, 1026.

1110 Ibid, 953.

1111 H. Lauterpacht (ed.), Opperheim's International Law: A Treatise, Vol. II, Disputes, War and Neutrality, 7 th ed., 141 in Gardam (2004), op. cit., 47.

1112 Ibid, 48.

1113 Zoller, op. cit., 131.

1114 Case Concerning the Air Service Agreement of 27 March 1946 between the United States of America and France, Decision of 9 December 1978, ILR 54 (1979) 304. 
The dispute broke out between the parties when France refused to allow a PanAm aircraft travelling from the United States to Paris with change of gauge in London to disembark its passengers and freight, while suspending future PanAm flights to Paris. France argued, in particular, that the decision of PanAm to use smaller aircraft for the route from London to Paris was in violation of the 1946 Agreement. In response the USA, for as long as the French authorities enforced the restrictions against PanAm, ordered two French airlines to file the schedule of their flights. A few days later, they prohibited Air France from operating certain flights to the United States. Both orders were passed under Part 213 of the US Civil Aeronautics Board's Economic Regulations. In the meantime, the two countries by common agreement submitted their dispute to an arbitration tribunal requesting it to determine, among other things, whether the US orders were lawful and proportionate.

In assessing the lawfulness of the US action the tribunal noted that it would have to base its conclusions on the aim actually pursued and whether that was confined to reciprocity, quicker settlement of the dispute, or prevention of future violations by other states. ${ }^{115}$ The tribunal reaffirmed in this regard the rule that countermeasures should be equivalent to the breach although it acknowledged that proportionality could be assessed only by approximation. Significantly, it was pointed out that it was not only necessary to consider the injuries suffered by the said companies but also 'the importance of the questions of principle arising from the alleged breach'. ${ }^{1116}$

The tribunal stressed that a mere comparison of the losses the parties in the dispute suffered or would have suffered did not suffice for the determination of whether the US action was proportionate. Rather, it gave emphasis to the interests and principles at stake by the initial action of France and its impact on the general air transport policy of the United States and on a large number of international agreements with states other than France concerning changes of gauge in third countries. What mattered in this regard was the proportionality between the effects of the initial wrongful act and the effects sought by the countermeasures. Zoller further illustrated this point by associating the case before the tribunal with the restriction of civil rights by police for the maintenance of public order. The determinative factor for proportionality in this latter case would be to balance the effects of the exercise of the civil rights and the effects of the implementation of the police measures. As Zoller very characteristically points out, this principle is reflected in the 'aphorism' that: 'The police may not use machine guns to kill birds.' 1117 Subsequently, what proportionality measures is not the breach and the response, but whether the countermeasures resorted to are proportionate to the purpose aimed at and the means used in order to achieve it. ${ }^{118}$ She also stresses 
that equivalence may not always be the right answer since even an equivalent response may indeed be disproportionate and cause more harm. ${ }^{1119}$

Should the US action have been evaluated in the light of measures aiming to compel France to lift the ban imposed on PanAm to land in Paris, the US measures, which resulted to the suspension of any flight between Paris and Los Angeles, would have been disproportionate to the purpose they wanted to achieve. Instead, the United States emphasized the effects of the action taken by it, which it claimed did not exceed the effects that derived as a result of France's initial decision. According to the analysis made by the United States:

France has denied a U.S. carrier its right under the Agreement to provide a West Coast-Paris service; Air France's Paris-Los Angeles service was approximately equivalent in law to the West Coast-Paris service Pan Am proposed to resume. In fact, Air France operated its Los Angeles-Paris round trip service only three times a week while the Pan Am service would have been six times a week. ${ }^{1120}$

Viewed in this context the tribunal did not find that the US response was disproportionate in comparison to the French measures. ${ }^{121}$ It needs to be noted, however, that in this case the countermeasures resorted to fell within the same field and concerned the same routes as the ones affected by the initial measures to which they were a response, although their economic effects on the French airlines were more severe. ${ }^{1122}$

The principle of proportionality was also examined in the Gabcikovo-Nagymaros case. ${ }^{123}$ As already seen in Chapter 4, when, in 1989, Hungary, due to environmental concerns, decided to suspend and finally abandon the works of the project, Czechoslovakia responded by diverting the waters of the River Danube within its boundaries, which it justified as a measure of 'approximate application' of the agreement between them. Looking at the arguments of both parties the Court stressed that with the conclusion of the 1977 Treaty, Hungary had accepted the damming of the Danube and the diversion of its waters but only on the condition of common operation and benefit of the project. Consequently, it had not

1119 Ibid, 136-7.

1120 Reprisals, Retorsion and Sanctions for Breach of Treaty, Digest of US Practice in International Law (1978) 770 .

1121 In his dissenting opinion, Mr Reuter, although he agreed with the legal analysis of the Court on the issue of proportionality according to which this should be assessed not only on the basis of the facts but also in the light of the questions of principle to be born from the facts, added that these questions of principle should also be considered in view of their probable effects. Dissenting Opinion of Judge Reuter, Case Concerning the Air Service Agreement of 27 March 1946 between the United States of America and France, Decision of 9 December 1978, Reports of International Arbitral Awards, Volume XVIII, 417, 448.

1122 Crawford (2002), op. cit., 295.

1123 Case Concerning the Gabcikovo-Nagymaros Project (1997), op. cit. 
forfeited its rights for the equitable and reasonable sharing of the Danube as an international watercourse. The Court, therefore, reached the conclusion that Czechoslovakia, by diverting the waters of the Danube (but not by constructing the works which would put into operation Variant C during which Hungary suffered no injury), had itself committed an internationally wrongful act. Assessing the lawfulness of Czechoslovakia's response, as later succeeded by Slovakia, the ICJ confirmed the principle that countermeasures should be commensurate to the injury caused with due consideration of the rights in question. The Court, with special focus on the right of all riparian states to enjoy in a regime of full and unqualified equality in a commonly shared river, concluded that:

Czechoslovakia, by unilaterally assuming control of a shared resource, and thereby depriving Hungary of its right to an equitable and reasonable share of the natural resources of the Danube - with the continuing effects of the diversion of these waters on the ecology of the riparian area of the Szigetkoz - failed to respect the proportionality which is required by international law. ${ }^{124}$

The criterion adopted in both these two cases was of qualitative rather than quantitative character, placing the emphasis on the nature of the rights involved. Article 51 of the Final Articles is drafted in this framework. Accordingly, what matters for purposes of proportionality is not only the injury suffered and the losses, usually material, caused as a result (quantitative element), but also the significance of the interests involved, not only of the injured state but also of the wrongdoing state, and the seriousness of the breach. ${ }^{125}$

Cannizzaro also distanced himself from the view that proportionality reflects a quantitative relationship between the breach and the response. He believes that 'in a plurality of instruments and tools of self-redress'1126 in the international legal order deriving from the need of states to protect their legal rights and interests, ${ }^{1127}$ emphasis must be placed on the function each response fulfils instead. This function can be normative, retributive, coercive or executive, in other words, different countermeasures, different functions, different measurement of proportionality. This conclusion relies on the proposition that in resorting to countermeasures, states do not pursue one and the same purpose and, in this sense, it is different from the opinion that regards countermeasures as having an instrumental role, namely, to bring compliance with the breached obligation or to obtain reparation. The instrumental perception of countermeasures would unavoidably be construed as a relation between the aims and the means of the action. This, according to Cannizzaro, entails the danger to justify excessive in relation to the original breach 
responses, if proven necessary for the accomplishment of the aim. ${ }^{1128}$ Furthermore, it rejects that countermeasures may seek other than a coercive aim, thus 'wiping out the richness and variety of the different forms in which reactions to wrongful acts may materialize'. ${ }^{1129}$

The proposition that countermeasures are multifunctional in nature seems to correspond with the conclusions of the arbitration tribunal in the Air Services Agreement case, according to which countermeasures may pursue a variety of aims. Accordingly:

The scope of the United States action could be assessed in very different ways according to the object pursued; does it bear on a simple principle of reciprocity measured in economic terms? Was it pressure aiming at achieving a quicker procedure of settlement? Did such action have, beyond the French case, an exemplary character directed at other countries and, if so, did it have to some degree the character of a sanction? ${ }^{1130}$

As a consequence of this mosaic of countermeasures, one should also think in terms of a mosaic of proportionality. Therefore, proportionality should not be conceived as a fixed notion, unchangeable and inflexible, applicable to all situations no matter the differences between them. Proportionality must on the contrary be 'built' on a case-by-case basis. In this respect, the proportionality of a response to the infringement of a bilateral trade obligation cannot be compared with the proportionality required for the response to a violation of an obligation erga omnes. While in the former case, the reciprocal suspension of rights may suffice, in the latter, the reaction may aim at imposing the compliance of the defaulting state with the infringed rule. Furthermore, and despite the fact that the coercive element may be apparent in both cases, it may have different significance where a measure is taken in response to a violation of an erga omnes obligation. ${ }^{1131}$ Professor Brierly, writing in 1925 on the principle of non-interference in the domestic jurisdiction of another state in accordance with Article 15(8) of the Covenant of the League of Nations, emphasized that a simple violation of immigration law could not be placed on an equal footing with a state act that amounted to 'a massacre on a colossal scale even though the victims may be its own nationals'. ${ }^{1132}$ Accordingly, the nature and function of countermeasures in each instance varies significantly.

Cannizzaro, therefore, suggests that the emphasis is placed on the appropriateness of the aim/function of the response (external proportionality) and the

1128 Ibid, 891-2.

1129 Ibid, 892.

1130 Case Concerning the Air Service Agreement of 27 March 1946 between the United States of America and France, op. cit., (78).

1131 Cannizzaro (2001), op. cit., 896.

1132 J.L. Brierly, 'Matters of Domestic Jurisdiction', 6 BYIL (1925) 8, 18. 
appropriateness of the adopted measures in light of the result they want to achieve (internal proportionality). He further proposes to divide the response to several bundles of measures and determine the objective pursued, individually rather than cumulatively, by each one of them. In this regard, if a state in response to a wrongful act proceeds to suspend its reciprocal obligations under the infringed treaty and at the same time freezes the assets and goods of the wrongdoing party, it is suggested that proportionality not be evaluated on the basis of the totality of the measures. Rather, it should be measured in the light of the objectives pursued by each measure. For this purpose, the suspension of the treaty will be judged based on the objective regarding the re-establishment of the legal balance disturbed by the initial wrongful act, while the freezing of assets will be judged on the need for compliance or the obtaining of reparation. That proportionality should be evaluated based on the function of the action is reflected according to Cannizzaro also in the ruling of the ICJ in the Gabcikovo-Nagymaros case. In other words, had Slovakia's action aimed at reversing the effects of the breach and at unilaterally bringing the benefits that would have derived from the completion of the project, its action would have been proportionate. However, the Court based its conclusion on a different legal explanation. More specifically, it judged Slovakia's action in the light of the breached treaty and the proper function of the response. The purpose of the treaty was to create a project the benefits of which would be commonly shared by the two countries and not to grant a right for the unilateral implementation of the treaty and the unilateral exploitation of the river. In conclusion, the diversion of the Danube by Slovakia was not the proper function of the response, which should rather be to restore the balance between the parties and seek reparation. ${ }^{1133}$

In accordance with these considerations, Cannizzaro suggests that the appropriateness of the aim be determined in the light of the infringed rule and the legal consequences of the breach, while the appropriateness of the measures adopted is judged on the basis of the result they want to achieve.

With respect to the functions of countermeasures, Cannizzaro identifies four possible functions: a normative, a retributive, a coercive and an executive function.

Countermeasures with a normative function aim to re-establish the legal balance of the parties involved. Here, the action under scrutiny aims to achieve a balance between the breach and the response and corresponds to the non-performance of the same or equivalent obligation. In a hijacking incident in 1971, India reacted by prohibiting the flying over its territory by Pakistani civil aviation, which resulted in damages greater than the damages caused by the initial infringement. According to Cannizzaro, India justified its action by saying that its response was a reciprocal reaction to Pakistan's action that amounted to the suspension of India's flying rights over Pakistan. Similarly, in the Air Services Agreement case the USA justified its response by saying that the services in question were equivalent in law and thus its action was proportionate. 
In the case of countermeasures with retributive function, there is an assessment of the effects of the breach and the response, with the intention of inflicting a certain cost on the wrongdoer for its breach. Retributive countermeasures arise in the case of unilateral obligations compliance with which does not rely on the performance of a certain other obligation.

In coercive countermeasures, the response aims at inducing the wrongdoer to reverse the effects of its wrongful conduct and to comply with its obligation. What matters here in respect of proportionality is the breach and the need to re-establish the pre-existing situation. Coercive countermeasures become relevant in relation to the violation of obligations owed to the international community. Proportionality is thus not assessed by comparison of the damages caused but rather by what is appropriate in order to bring to an end the violation, as the most fundamental interests of the international community are at stake. However, even countermeasures with this function are subject to limitations, especially whenever human rights issues are involved. ${ }^{1134}$

Finally, with respect to the executive function of countermeasures, it is noted that this aims to secure the benefits that would derive from the infringed obligation even without the cooperation of the wrongdoing state. The injurious effects of the countermeasures must not supervene the benefits to be achieved while the means used must be necessary for the accomplishment of the aim. ${ }^{135}$

Cannizaro finally suggests that the function of proportionality is twofold. First, it serves as an indicator of the means and forms of the response and limits the power of the responding state in the selection of the objective of the response. Second, it restrains the power to select the measure of reaction and imposes a duty that the response is appropriate to the aim pursued and not disproportionate to the initial breach. ${ }^{1136}$

With these observations in mind, and with proportionality gaining different significance in the different legal contexts to which it applies, the attention will finally turn to a critical assessment of the various positions on the scope and content of this principle.

\section{A critical assessment of proportionality in the law on countermeasures}

In view of the great perplexity of the question of proportionality and the varied approaches taken in the matter, we will now make an attempt to clarify the main features of the principle in view of all earlier considerations. First, one needs to examine whether proportionality, as applied in the law of the use of force, can be 'transplanted' to the law on state responsibility.

1134 For a detailed analysis of the four functions of countermeasures see ibid, 910 .

1135 Ibid, 911.

1136 Ibid, 916. 
It has already been pointed out that proportionality in the use of force is closely associated with the objective of the forceful response that in all cases must be confined to repelling the initial attack. On the contrary, the law of state responsibility is built on the assumption that not all the wrongful acts short of the use of force are of the same gravity and seriousness and, thus, not all bear exactly the same legal consequences. Moreover, in the use of force, the seriousness and gravity of the initial wrongdoing, but also the interests at stake have a significant impact on the determination of the response. This can be revealed from the fact that with the exception of authorization from the Security Council, a state may only resort to force in response to a breach of equal gravity, that of an armed attack, acting in individual or collective self-defence. In this sense, the response is reciprocal in kind to the original misdeed. This is owed to the fact that nothing can endanger international peace and security and the international legal system in its entirety so directly as a state that uses armed force to pursue its policies. The attack of another state is by itself a very serious infringement of one of the most fundamental principles of international law that requires determinative action for its cessation, even if it is more intense and extensive than the initial wrongdoing. It is, therefore, suggested that due to the different objectives aimed at and interests at stake proportionality cannot have the same content in the law of armed force and the law of countermeasures.

As to whether proportionality as applied in the law of armed conflict regarding the means and methods of warfare should be applied in the law of countermeasures, one should not forget that jus in bello is not entirely autonomous from jus ad bellum. Even a proportionate response in respect of means and methods will give rise to responsibility if the resort to force was unlawful in the first place or if the force used was disproportionate to the military objective pursued. Again, it is submitted, this criterion does not suffice for assessing proportionality in the law of countermeasures that remains a different branch of international law with different objectives and that provides for different means of achieving such objectives.

Nevertheless, the preceding analysis has helped to establish that proportionality may have different scope and content in the various contexts that it applies, in view of the objectives that a given response aims to achieve. Despite this, and as the analysis of how proportionality is viewed at national and EU law and also in the law on countermeasures, it can be concluded that there are certain features or factors that are common to all these different legal fields. Accordingly, the aims pursued and the suitability or appropriateness of the means used to accomplish the aims of the response characterize proportionality irrespective of the context within which it applies.

It is, therefore, now essential to evaluate more specifically the different positions formed in relation to the content of proportionality in the law of countermeasures. It has been discussed that the criterion used by the tribunal in the Naulilaa incident was one of comparison between the initial wrongdoing and the response. It is doubted, however, as to whether an assessment of equivalence between the breach and the response is preferable especially in light of the well-attested principle that countermeasures must not aim at the punishment of the defaulting state. In the author's view, a mere comparison between the breach and the response 
that is equivalent to the maxim an eye for an eye, attaches a punitive element to countermeasures and thus should be rejected. Furthermore, the position that proportionality should be based on the equivalence between breach and response cannot lead to satisfactory results because, as rightly suggested, this would amount to imposing a heavy burden on the victim state that would be unable to take measures necessary to effectively protect its legitimate rights and interests. ${ }^{1137}$ Nevertheless, the nature of the breach, its gravity and seriousness are factors that must be taken into consideration when determining whether certain conduct complies with the principle of proportionality. Such assessment becomes important in relation to the aims pursued by the response in question but also in considering whether the means used can fulfil these aims.

McDougal and Feliciano noted in this regard that the coercion exercised by one state against another, its intensity and the consequences to derive therefrom are related to the nature and scope of the objectives it sets. In particular, they argued that the degree of coercion is equivalent to the scope of the objective set by the responding state and the value it attaches to this objective. Consequently, the limitation of the degree of the coercion relies on the limitation of the set objectives. ${ }^{1138}$ Zoller, on her part, searched for proportionality in the aims pursued by the countermeasures and the means used to achieve them. Similarly, Cannizzaro placed all the attention on the appropriateness of the aim, not the subjective aim of the state making use of countermeasures but rather the 'legal objective'1139 and on the appropriateness of the measures to accomplish this aim.

Although the author shares the concerns expressed by Professor Crawford who supported the limitation of the objectives of countermeasures, the approach proposed by Cannizzaro is not without merit or significance. In particular, his approach seems to turn the attention in the right direction as it establishes objective criteria for the determination of proportionality and, for this reason, it should have been reflected in Article 51 of the Final Articles. However, and as already acknowledged, this by itself does not suffice since the more serious the initial wrongdoing the more serious and intensive the response may need to be for its cessation. Furthermore, the nature of the rights affected by a certain wrongdoing also needs to be taken into consideration. These elements will be particularly important when assessing the proportionality of countermeasures taken in response to particularly serious violations of international law such as jus cogens norms or obligations erga omnes, whether from the position of an injured state or a state other than that injured.

In the author's view, proportionality does not establish an inflexible standard that applies uniformly in all situations without a further distinction as to the nature of the wrongful act and the objectives of the response. In this respect, proportionality is not entirely free from some subjectivity in the sense that it must be assessed

1137 Ibid, 908.

1138 McDougal and Feliciano (1961), op. cit., 33-4.

1139 Cannizzaro (2001), op. cit., 896, fn 20. 
on a case-by-case basis. This is due to the fact that, as thoroughly argued throughout this book, not all internationally wrongful acts bear the same gravity or significance. This differentiation must be unavoidably reflected on the principle of proportionality. However, despite this realization some objective standards must be drawn in order to narrow down the possibility of abuse by the state resorting to peaceful coercive action. In the author's view, the aims and the means used to achieve such aims, the gravity and seriousness of the wrongful act, the injury suffered and the interests at stake should all be taken into account when deciding whether a certain action was proportionate or not. The theoretical analysis made by Cannizzaro establishes a reasonable approach to the question of proportionality and therefore should be given the attention it deserves.

However, uncertainty remains with respect to the proportionality of solidarity measures and as to whether this will be assessed on a case-by-case basis or whether it will be evaluated on a cumulative basis. Here, resort to such measures by various actors entails an apparent danger of inflicting particularly burdensome measures against the wrongdoing state. The assessment of the proportionality of such countermeasures becomes particularly difficult and it is for this reason that the aim pursued, the gravity and seriousness of the wrongful act, but also the appropriateness of the response to bring about the desired result must be relevant factors to be taken into consideration. This may require the assessment of each individual conduct in the light of the objective it intends to achieve, since a cumulative assessment will prove an untenable way of determining proportionality. In any event, it is worth pointing out that, even when a certain breach does not infringe community interests but affects the bilateral interests of several states, proportionality is assessed on the basis of the action taken by each state individually rather than cumulatively.

Undoubtedly, assessing the proportionality of a response may be difficult and as in the case of the use of armed force, it may entail elements of subjectivity and relativity. Nevertheless, identifying from the outset the primary parameters within which proportionality must be evaluated will reduce the risk of abuse and it will strengthen legal certainty. While the adoption of an absolute uniform standard of proportionality may be impossible to achieve due to the varied nature of wrongful acts and objectives, it is important to assess the proportionality of individual measures in the general framework within which they are taken. For this purpose, and as explained in the preceding sections, it must always be borne in mind that, when resorting to countermeasures, states have a very tight legal framework within which they can move. In this regard, the responding state must safeguard, among other things, fundamental norms of international law such as respect for human rights and peremptory norms of international law. It is within this already narrow circle that the proportionality of a particular conduct will be examined.

\section{Conclusion}

The principle of proportionality has evolved out of the pressing necessity to restrain the use of countermeasures to the maximum extent possible and has 
developed as an essential element of legality of such measures. However, proportionality gains even more significance in the light of an 'anarchical' society, such as the international one, which lacks the mechanisms necessary to monitor its correct implementation by individual states. This, along with the ongoing controversy as to the exact scope of the principle, which is only reflective of the perplexity of the question, elevates proportionality as one of the most difficult problems when it comes to countermeasures. This is only aggravated by the recognition under customary international law of a right to resort to countermeasures in response to violations of obligations erga omnes and peremptory norms, the significance of which extends beyond a merely bilateral relationship between two states since these norms have been established to protect community interests. The same applies with respect to countermeasures taken in response to violations of interests owed to a group of states collectively. The approach adopted by the ILC in Article 51 does not seem to quiet these concerns and therefore reconsideration of the matter, in view of an established right to solidarity measures, may prove essential. 


\section{Conclusion}

The problem of enforcement of international law raises one of the most difficult challenges not only in international legal theory but also in international legal practice. In the light of the prohibition of the use of armed force as a means of settling state disputes, enforcement in international law may take the form of judicial proceedings or, quite significantly, countermeasures through the non-performance of obligations arising from conventional or customary rules. Due to the decentralized character of the international legal order and in the absence of institutions empowered to enforce international law generally, implementation, through the application of countermeasures, is entrusted to each state individually which is called, by its own means, to protect its rights. As noted in the preceding analysis, countermeasures constitute mechanisms of private justice according to which a state whose international rights have been infringed is entitled to respond by refusing to perform its own obligations under international law towards the wrongdoing state. In these circumstances, the wrongfulness of the conduct and as a consequence the responsibility of the responding state is precluded.

The question of enforcement, however, becomes particularly problematic with respect to obligations owed to the international community as a whole and fundamental community interests in the observance of which all states have a legal interest. This gives rise to controversy as to the subjects entitled to invoke the responsibility of the wrongdoing state particularly in the absence of direct or individual injury, but most importantly, to pursue their performance through the implementation of countermeasures. The unilateral assessment both in relation to whether an internationally wrongful act has been committed in the first place and the legal requirements necessary for the lawfulness of countermeasures of this nature make them vulnerable to abuse. Moreover, the powerfulness of solidarity measures and their strong effects on legal stability but also on international peace and security and the friendly relations between states have raised concerns in relation to whether a right to countermeasures by states other than the injured should be recognized in international law.

The significance of enforcement of community interests by way of solidarity measures lies at the heart of this book. This is owed to the fact that, without such enforcement, the protection of essential interests of the international community would be severely undermined, diminishing the effectiveness of international law 
in its entirety. As former UN Secretary-General Kofi Annan recently pointed out: '[W]ithout implementation, our declarations ring hollow. Without action, our promises are meaningless.' 1140 Indeed, the conclusion of an anti-apartheid treaty, a convention prohibiting genocide, torture and slavery or the development of a norm against aggression or a norm safeguarding fundamental human rights and freedoms or the right to self-determination provide no consolation to those racially being discriminated against, tortured or exterminated, if no effective enforcement mechanisms are in place. While no one can disregard the unique nature of the international legal order that is founded on state equality and state consent and the nature of which is still rudimentary, anarchical and primitive, such mechanisms are essential to enhance the respect for the rule of law, particularly so whenever the most fundamental interests of the international community are concerned. The recognition of community interests in international legal doctrine would become meaningless and international law would lose its credibility in the absence of appropriate mechanisms to ensure compliance with its norms. Hence, the necessity of enforcement is epitomized in Sophocles' wise words

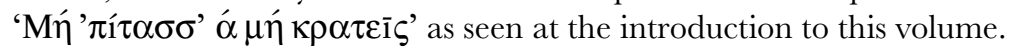

While most of the times most states comply with most international norms, ${ }^{1141}$ the book has attempted to establish that the international community now needs to turn its attention to the problem of enforcement, especially whenever its most fundamental interests are imperilled. Nevertheless, as the study in this book has demonstrated, there has been a certain degree of reluctance in entitling individual third states to implement international law and to induce the wrongdoing state to respect its international commitments. In this regard, many authors, in fear of 'the unilateral, world-ordering politics of a self-appointed hegemon', ${ }^{1142}$ placed their emphasis on collective, institutionalized action as the appropriate answer to the problem of enforcement, as opposed to unilateral coercive action resorted to by individual states. Along the same lines, Mr Annan stressed that states need to make a commitment towards 'collective strategies, collective institutions and collective action'. ${ }^{1143}$ According to this view, the goals of development, security and human rights cannot be advanced by states individually, but rather only as the result of concordant efforts, whilst the UN could play a significant role to this effect. Even more progressively, Mr Annan emphasized the emerging need to establish an international legal duty and responsibility to protect. Although acknowledging that this position was, and still is, very much premature, he pointed

1140 Report of the UN Secretary General, Mr Kofi Annan, 'In Larger Freedom: Towards Development, Security and Human Rights for All', 21 March 2005 (General Assembly, Fifty-ninth Session, A/59/2005) (130).

1141 See T.M. Franck, The Power of Legitimacy among Nations (OUP: 1990).

1142 J. Habermas, 'Interpreting the Fall of a Monument' 4 German Law Fournal (2003) 706 in Koskenniemi (2005) 118.

1143 Report of the UN Secretary General, Mr Kofi Annan, op. cit. (3). 
to this direction in the future, where the international community will have the responsibility to protect people should the national authorities fail to do so. ${ }^{1144}$

Nevertheless, these views unavoidably raise the question as to whether the UN as an international organization possesses the legal capacity and the mandate to assume the role of a supranational government, with the Security Council acting as a world police and the UN Charter being the constitution of the international legal community. The debate on this matter grows deeper as the Security Council assumes more responsibilities in a wide number of areas - terrorism, genocide, war crimes, ethnic cleansing to name but a few - and elaborates more coercive mechanisms against states in the last two decades than ever before in its entire history. Despite these significant developments, however, the Security Council remains a political body with powers that are restricted to safeguarding international peace and security, rather than the power to give effect to and enforce general international law and fundamental community interests.

While there has been a growing opinion in the literature, particularly after the cessation of the Cold War era, to attach a constitutional role to the UN, it must be stressed that the international legal order differs substantially from national legal systems where there are central institutions to observe the rule of law. While the entrustment especially of the enforcement of international law to independent and impartial international institutions and organizations would be the ideal solution in an ideal world, it is currently neither feasible nor desired by states. This is because states are very reluctant to concede too much of their sovereign powers to international institutions that could in the future turn against them with enforcement action. The persistence of the five permanent member states to the Security Council to uphold their veto powers constitutes perhaps the most prominent example illustrating the point under consideration. In consequence, if the Security Council is ever going to undertake a role to enforce international law, fundamental changes will be needed. Accordingly, there must be a legal authorization expanding the powers of the Security Council to that effect, but also, quite importantly, a change in the decision-making procedures so that the international community is equally represented and the UN institutions reinforced. Finally, there must be the determination and will to apply the law equally and to resort to coercive action whenever necessary, circumventing claims of selective enforcement of the law.

Furthermore, as the analysis in Chapter 2 revealed, there were suggestions before the ILC linking the question of enforcement of fundamental community interests with institutional responses and, in particular, with the establishment of an international criminal court. Whilst the establishment of an international criminal court for the prosecution of individuals for the commission of serious violations of international law such as war crimes, crimes against humanity and genocide is today a reality, the punishment of states remains a concept that has found no common ground in international legal doctrine. As thoroughly explained in Chapter 2, 
states are reluctant to allow the intrusion of punitive elements in the interstate relations that are structured on equality. Quite significantly, it was soon understood that the receivers of such punishment would be innocent civilians, the nationals of the wrongdoing state, often victims of atrocities committed by their own government. As a result, these suggestions were not endorsed by the ILC in the conclusion of its work on the law on state responsibility.

This has still left a legal loophole in relation to the enforcement of such fundamental community interests. In this context, and as the book argues, unilateral and peaceful coercive measures by third states become important in the theory and practice of international law. The dilemma here is clear, as there is a need to strike a balance between the necessity not to use the concept of fundamental principles owed to the international community as a shield for international injustice and the need to effectively and determinatively remedy serious infringements of international law that affect every state.

The right of third states that have suffered no direct injury to resort to countermeasures whenever community interests have been infringed has, therefore, been central to the scope of this book. In this regard, it was necessary first to elaborate on how the concept of community interests infiltrated international legal doctrine and introduced fundamental changes as to the nature and function of contemporary international law.

Chapter 1 focused on the development of the notion of peremptory norms of international law, as norms recognized as fundamental by the international community of states as a whole and from which no derogation is permitted unless with the development of a norm of the same character. It was argued in this respect that while the concept of peremptory norms finds expression in Article 53 of the 1969 VCLT, this concept has become an integral part of customary international law and, therefore, no state can refuse compliance with norms that have acquired a peremptory character.

This has caused scepticism among international lawyers and states that viewed the concept of peremptory norms as an attempt to circumvent state consent that lies at the structures of the international legal system. Reservations have also been expressed about compromising the neutral character of international law by introducing ambiguous concepts with moral connotations in an inherently pluralistic international society. The abstract and indeterminate content of these and other concepts such as the 'international community as a whole' have provoked suspicion among commentators who have even seen in these attempts a new form of colonialism and a threat to legal stability. ${ }^{1145}$

Hence, some states and commentators have been extremely reluctant to accommodate such notions as they raise significant questions of international legitimacy: who decides which norms qualify as such and for what reasons? The difficulties to be borne from these legal considerations are not to be underestimated. By the same token, there is still an ongoing theoretical debate on how and on what

1145 Koskenniemi (2005) op. cit., 115. 
criteria one identifies these 'special' primary norms as establishing more fundamental rights than others.

Definitely, if the international legal community is to be construed to be based on state consent, then such concepts appear to go against the consensual character of international law and how international law has been traditionally perceived. Moreover, these principles are viewed as compromising state sovereignty since their violation is not anymore considered to fall within the exclusive domain of any state but, rather, it establishes a legal interest to all members of the international community in their protection.

Nevertheless, as the analysis in Chapter 1 demonstrated, and the discussion in Chapter 2 corroborated, the realization that some interests are so essential for the existence of the international community that hold a superior character in international law has not been a new invention. Contrariwise, the passage from bilateralism to community interests is well rooted in international jurisprudence, the literature and state practice of international law, confirming that international law has progressively developed into something more than just being 'minimal law'. As Chapter 1 attempted to show, these concepts contributed to the progress of international law insomuch that it is now claimed that the international legal order has developed into something more than merely a voluntarist structure between absolute sovereigns. Rather, it seems to resemble more an international public order that is concerned, among other things, about interests intended to protect the common good of mankind. One could argue that some form of constitutional status is now attached to certain rules, although acceptance of these contemporary ideas has not been free from criticism.

Moreover, the endorsement by the ICJ of the notion of obligations erga omnes in the Barcelona Traction case has signified further developments paving the way to third states, not specially affected by a certain breach, to demand their performance. However, one of the most controversial aspects of both the concept of peremptory norms and the concept of obligations owed to the international community as a whole is the fact that they remain silent as to the means of their enforcement in the event of their breach. The issue of enforcement of community interests has been at the focus of recent academic works. This book attempts to add to the existing literature on the matter placing the emphasis, however, on the enforcement of such interests by way of solidarity measures. By doing so, however, the foregoing analysis did not ignore other ways of implementation of fundamental community interests, particularly through the initiation of judicial and other proceedings. The analysis concluded that long before the obiter dictum of the ICJ on obligations erga omnes, there was recognition of the right of third states to seek compliance with interests set to serve certain community and collective purposes establishing general standing in this regard.

Having established the nature and scope of the concept of community interests as recognized in international law, the attention was then turned to the influence that this concept has exercised on the law on state responsibility and on the development of the notion of solidarity measures. It was shown in this regard that the law on state responsibility is built on the understanding that the violation of a 
primary, conventional or customary, norm providing what the obligations of states are, entails new obligations for the defaulting state like the obligation to cease the wrongful act and to offer reparation for the injury caused.

When the ILC first took up the task to codify the law on state responsibility in 1953 , it turned all the attention to violations of the primary rules on the treatment of aliens, thus restricting the scope and content of state responsibility to violations of this kind. Despite this initial approach, it was soon acknowledged that international law consisted of other rules that called for attention and protection in the event of their violation and which incurred the responsibility of the state irrespective of the nature, origin, object or content of the infringed rule. Yet, and as the study on state responsibility progressed, a new concept started to make its appearance in the debates of the ILC: that the violation of primary norms did not always have the same significance, weight or effect due to the importance attached to and the nature of the rights certain primary norms sought to safeguard.

As the concepts of peremptory norms and obligations erga omnes started to preoccupy international legal thinking, they could not leave unaffected the deliberations and the discussions taking place before the ILC on the codification of the law on state responsibility. This was particularly so concerning violations of norms of this character. As the analysis in Chapter 2 illustrated, while the essential nature of many international norms did not extend beyond a relationship of a bilateral nature, others established collective interests, fundamental to the international community as a whole such as the prohibition of genocide. The ILC was, therefore, faced with the question of how to deal with violations of certain primary rules considered as being of a more serious nature due to the significance and the 'superiority' of the interests they seek to protect. It was accordingly essential to determine whether the legal consequences arising from the commission of an internationally wrongful act would be the same in all instances or whether a further distinction was required between legal consequences in the light of the seriousness of the wrongful act and the rights and interests protected by the infringed rule. This led to another significant realization concerning the circle of states entitled to invoke the responsibility of the wrongdoing state and, most important of all, to resort to countermeasures in response to the wrongful act.

The ILC, influenced by the developments concerning jus cogens norms and obligations erga omnes, soon realized that not all internationally wrongful acts were of the same gravity or of the same significance. It was in this context that the concept of state criminal responsibility, previously supported by what it seemed to be a minority of authors, re-emerged and flourished in the debates of the ILC. The ILC made a distinction between international delicts and international crimes reflected in Draft Article 19 and which gave rise to penal sanctions against the recalcitrant state. Although the notion of criminal responsibility was not eventually sustained in the Final Articles, the understanding that not all violations bore the same gravity did not cease to constitute a common ground of understanding.

As thoroughly discussed in Chapter 2, this position is now reflected in Articles 40 and 41 of the Final Articles regarding the legal consequences to derive as a result of serious violations of peremptory norms. 
Article 48 further confirms that there exist certain interests, which, either because they are owed to the international community as a whole or because they are established for the collective interest of a group of states, entitle states other than those which have directly sustained an injury from a given wrongdoing to invoke the responsibility of the defaulting state.

One of the most controversial considerations before the ILC, however, was what could a state other than the directly injured do in response to a violation of this kind, hence raising significant questions of enforcement and implementation. The attention was subsequently turned to the notion of countermeasures that had emerged in the draft articles as a means of self-help taken in response to another, previously committed internationally wrongful act. However, states realized from the beginning the powerful effects of countermeasures and for this reason sought to restrict to the extent possible not only their content but also the states entitled to resort to such measures. As the analysis showed, the ILC itself, wishing to bring its work on state responsibility to completion and in the light of some concerns expressed by states regarding the incorporation of a right to third state countermeasures in the Final Articles, opted not to take a final position on the matter and left further developments in the field open. Accordingly, Article 54 refers to 'lawful measures', a notion that provoked some reaction among commentators, rather than countermeasures by states other than the injured, while in its commentary on the article the ILC concludes that customary international law does not support such a right. Article 54 has accordingly failed to mitigate the concerns regarding the enforcement of fundamental community interests.

Chapter 3 evolved around the findings of the ILC concerning the existence of a right to solidarity measures and provided a critical assessment and detailed analysis of state practice. This assessment led to the conclusion that the reference of the ILC to state practice was brief and inconclusive and that there was a wealth of evidence in support of such a right that had not been considered. The examination in this chapter started with an analysis of foreign policies of various states and the impact that fundamental community interests, such as respect for human rights, have on the formulation of such policies. Due regard was given on the use of economic coercion as a tool for the exercise of pressure against a wrongdoing state to comply with international law and that sometimes took the form of retorsive measures while others the form of countermeasures even if no direct injury existed. It was shown in this regard that states were often determined to respond to serious violations by way of countermeasures and, for this reason, they enacted domestic legislation that would enable them to do so as the examples of Canada and the Netherlands revealed.

The study then proceeded to a consideration of some incidents that, although they did not involve state action in violation of international law, they are still significant for the purposes of this work. Some of the cases discussed here reflected the determination of states to respond to serious violations of fundamental community interests by all means at their disposal, while other cases such as the Bonn Declaration regarding the hijacking of aircraft reflected the legal belief of states that resort to countermeasures even by third states was lawful or becoming lawful. 
This analysis is significant as it provides evidence for the existence of a certain opinio juris necessary for the creation of a customary norm of international law allowing solidarity measures.

The focus of this chapter however turned to evidence of state action in violation of specific legal commitments, supporting a right to solidarity measures in the name of community and collective interests. From the scope of this examination it could not preclude some reference, even if brief, to some early examples from state practice supportive of coercive unilateral action in response to violations of community norms. The decision of the British authorities to free slaves and to seize vessels taking part in slavery in the 19th century, but also the decision of the USA to freeze Japanese assets in response to aggression provide early examples of solidarity measures and perhaps evidence that a right to this effect was already recognized under customary international law.

The examination, however, placed most of the emphasis on state practice as evolved after World War II, according to which, in numerous occasions states had called for the implementation of countermeasures and often had resorted to such measures even if they were not directly injured. That was the case in relation to action taken against the Dominican Republic and Greece, the imposition of the oil embargo against states supporting Israel in its aggressive policies in the 1960s and 1970s, the trade embargo and other coercive measures taken against the Central African Republic, Iraq, Uganda and Yugoslavia, to name but a few. In addition, the study included examples of state practice that although justified on other legal grounds such as fundamental change of circumstances, they could qualify as third-state countermeasures providing further evidence for the existence of such a right under customary international law. At the same time, the study did not preclude from its scope some reservations expressed as to whether certain responses could qualify as solidarity measures. Such concerns were due to uncertainty in relation to the legal grounds on which certain action relied and as to whether community interests had indeed been infringed, entitling third states to coercive measures. Such is the case in relation to the coercive action taken against Poland and the Soviet Union in the early 1980s. It was stressed that for action to qualify as solidarity measures it must be a response to a breach of an obligation owed to the international community of states as a whole or to a group of states. Questions were also raised with respect to whether the abolition of democratic rule could give rise to a right to solidarity measures, as in the author's view, democratic governance does not seem to currently establish a legal interest owed to the international community as a whole. Nevertheless, the preceding analysis has established that gross human rights violations entitle every state to invoke the responsibility of the wrongdoing state and to resort to countermeasures.

The analysis in Chapter 3 further demonstrated that the right to solidarity measures is not a new concept in international law. It was also established that the reluctance of states to often resort to such measures was not owed to their belief that such measures were not allowed, but rather on other considerations such as economic or political interests. Such reluctance could not be taken as establishing an opinio juris against a right to third-state countermeasures. On the contrary, it is argued 
that states have frequently resorted to such countermeasures and, therefore, state practice is neither sparse nor embryonic. As the author concludes, the right to solidarity measures has become part of customary international law, as an essential mechanism of enforcement of fundamental community interests such as the prohibition of genocide, slavery, aggression, torture and the right to self-determination and fundamental human rights.

In the course of this analysis, it was also established that countermeasures by states other than the injured are not only supported by state practice, but they are also required as a derivative effect of the concept of peremptory norms of international law. As particularly argued in Chapter 1, a state bound by a treaty the execution of which indirectly contributes to the breach of a peremptory norm has a legal obligation to cease the performance of the treaty concerned. While this does not lead to the suspension or termination of the treaty as the terms of the treaty do not call directly for a violation of the norm in question, the indirect effects to arise from the implementation of the treaty require its temporary non-performance.

With these conclusions in mind, Chapter 4 dealt with another challenge concerning the enforcement of general international law and community interests and emerging from the proliferation of lex specialis rules and, particularly, selfcontained regimes. The growing number of legal regimes that provide not only for primary rules but they also set up their own dispute settlement procedures, such as the EU and the WTO, and sometimes their own enforcement mechanisms, raise questions concerning the impact of these regimes on the right to countermeasures under the general law on state responsibility. While it is a well-attested principle of international law that specific rules take prevalence over general rules, questions arise whenever the enforcement mechanisms of a specific regime fail or they simply do not exist in the first place. This issue, which lay at the heart of Chapter 4, has even wider ramifications with respect to whether the non-performance of obligations provided under a specific regime by way of countermeasures is permissible in response to violations not related to that specific regime. The significance of the matter becomes apparent in relation to countermeasures, by way of not performing obligations arising under specific agreements such as GATT, in reaction to the violation of genocide or apartheid.

As noted in this regard, if one accepts the view that such general legal considerations do not fall within the jurisdiction of the specific regime and that as a result they cannot be taken into consideration as a defence, then the scope and content of countermeasures as a means of enforcement of international law is significantly narrowed down. However, it was demonstrated that in the absence of other alternatives, resort to countermeasures by not performing obligations emanating from special or self-contained regimes falls at the heart of enforcement of international law generally and community interests particularly. Accordingly, countermeasures that by definition constitute conduct in breach of international law play a pivotal role in the protection of the international legal order. As the examination in Chapter 4 established, the traditional mechanism of enforcement of international law by resort to countermeasures and especially to economic and trade measures cannot be paralyzed because of the existence of specific legal regimes. 
As concluded, it is exactly in this context that countermeasures gain significance and are effective in exerting pressure on the wrongdoing state. This is particularly important whenever the fundamental principles of the international community as a whole are endangered, even if that would seem to compromise interests in the economic or trade sphere.

Nevertheless, as argued, the existence of parallel and often conflicting rules of international law belonging to various legal systems raises non-negligible concerns regarding the integrity of the international legal order. It was shown in this respect that while the proliferation of special legal regimes generally enhances the rule of international law, there are times that its coherence is seriously challenged, particularly insofar as certain state conduct may be lawful under certain rules but unlawful under others.

According to the conclusions of the analysis in Chapter 4, however, to claim that the obligations emanating from self-contained regimes will prevail over all other rules would be tantamount to undermining enforcement in international law, while it would enhance these regimes with a quasi-peremptory character and give them prevalence over substantially 'higher' principles of international law. Finally, as noted, these special and self-contained regimes are not isolated from the body of general international law to which they continue to constitute an integral part.

Having established that customary international law recognizes a right to thirdstate countermeasures in protection of community and collective interests even in violation of obligations arising from specific agreements or self-contained regimes, Chapter 5 dealt with the legal constraints of countermeasures and the principle of proportionality. In realization of the inevitable danger of abuse of such measures, the analysis in this final chapter turned to the legal confines of countermeasures, particularly whenever many states respond, individually or in agreement with other states, to the breach of community interests. It is because of these fears that the ILC decided not to include a right to solidarity measures in the Final Articles. The not so unrealistic fears of abuse of such a right by strong states with respect to whether a serious violation of a jus cogens norm or an erga omnes obligation has occurred and the limits of such reaction, request that the right to resort to countermeasures is restricted.

As Chapter 5 intended to show, the right to countermeasures exists in a very tight legal framework that sets up numerous legal conditions and requirements for the justifiability of such measures. It was emphasized that countermeasures are only allowed in response to a previously wrongful act for the purpose of inducing the wrongdoing state to cease the wrongful act and to comply with the new legal obligations arising as a result of its conduct, such as the duty to offer reparation. Moreover, as the analysis showed, countermeasures must have a temporary character and must not aim at the punishment of the wrongdoing state, a notion at odds with the nature of the international legal system. Quite significantly, countermeasures cannot entail the violation of peremptory rules of international law, the prohibition of the use of armed force or humanitarian rules. It is within these legal confines that the principle of proportionality has developed to ensure that whatever action is taken is not excessive. 
To this effect, proportionality plays an important role in limiting the power of states to resort to countermeasures, particularly in the event of solidarity measures. This finds justification on the realization that the recalcitrant state, by committing a certain violation, no matter how gross this may be, does not cease to be a member of the international community with its own rights and obligations. It is, therefore, through proportionality that not only the rights of the defaulting state are guaranteed, but also that the right to countermeasures for the protection of common interests will not be manipulated by any state.

It follows from the study in this chapter that proportionality should strike a balance between the initial wrongdoing - its gravity, its injurious consequences, and the nature of rights it affects, on the one hand, and the response - the legal aims it seeks to pursue and the means, methods and intensity used to fulfil these aims, on the other. In the author's view, proportionality should not merely be seen as a relationship between the breach and the response, as this would be equivalent to punishment. Instead, the emphasis must be placed on the aims to be accomplished by the countermeasures in question and the appropriateness of the means used to accomplish these aims.

The principle of proportionality has developed through the literature, state practice and judicial review, as a legal instrument of constraint, a tool for determining the legality of a given action. Nevertheless, the proportionality test becomes even more compelling if, in seeking to protect interests owed erga omnes, several states decide to take action against the violator. The assessment of proportionality in this event unfolds to a challenging legal question that raises significant legal considerations. This is due to the fact that, while a given state action examined in isolation may meet the requirement of proportionality, multiple independent state actions, if viewed in their totality, may be disproportionate, thus significantly undermining the rights and interests of the wrongdoing state and seriously damaging the rule of international law. Nevertheless, and as the analysis concluded, countermeasures must be assessed, within the already strict confines in place for their lawfulness on an individual basis in the light of the aim they intend to achieve and which, in any event, must not be the punishment of the wrongdoing state.

This volume has intended to show that without effective enforcement mechanisms in place, the concepts of community and collective interests become devoid of meaning. While the book does not share the view that without enforcement international law is not real law, a view advocated by Austin as already noted at the beginning of this work, enforcement plays a significant role in the realization of the objectives of the international legal system and the international community, the existence of which can hardly be disputed. Taking into account the peculiarities of the international legal order as an order structured on the equality of states and consent, but also as an order that lacks centralized and compulsory enforcement mechanisms, this work has attempted to establish that entrusting states with the power to safeguard fundamental community interests through unilateral peaceful coercive measures has become increasingly necessary. This is due to the fact that the distinction between serious and less serious violations of international law, ordinary norms and norms with a peremptory character and bilateral 
obligations and obligations owed to the international community of states as a whole would bear no significance were international law not to provide for effective mechanisms for their protection. In the absence of state consensus for the establishment of an international organization to respond to such serious violations of international law, solidarity measures become the only means of enforcement of these fundamental interests.

As the preceding analysis established, the policy of 'constructive engagement' for long supported by the United States and according to which the US government approached the world's most notorious dictators by friendly means and 'quiet diplomacy' have proved insufficient to bring the cessation of serious infringements of fundamental norms of international law. Similarly, using 'the carrot as well as the stick approach to encourage favorable trends in the protection of human rights' 1146 has not been successful in convincing those committing genocide, apartheid, torture and aggression to comply with their international obligations. By way of contrast, these approaches have made such oppressive regimes more intransigent, giving them the impression that they could act with impunity.

Compliance with the law and, for that matter, with international law becomes burdensome when such compliance means providing support, directly or indirectly to a regime that engages in practices such as the ones mentioned earlier. In this context, the recognition of a customary norm permitting solidarity measures in violation of other international obligations is dictated by the need to effectively protect and enforce fundamental interests owed to the international community. 


\section{Appendix \\ $\mathrm{UN}$ and other documentation}

\section{United Nations documents on the law on state responsibility}

Report of the Commission to the General Assembly

YbILC (1969) Vol. II, 203, 229.

YbILC (1970) 271, 305.

YbILG (1971) Vol. II, Part One, 244, 275.

YbILC (1972) Vol. II, 219, 323.

YbILC (1973) Vol. II, 161, 165.

YbILC (1974) Vol. II, Part One, 157, 269.

YbILC (1975) Vol. II, 47, 51.

YbILC (1976) Vol. II, Part Two, 1, 69.

YbILG (1977) Vol. II, Part Two, 3, 5.

YbILC (1978) Vol. II, Part Two, 1, 74.

YbILC (1979) Vol. II, Part Two, 1, 87.

YbILC (1981) Vol. II, Part Two, 1, 142.

Comments of Governments on Part 1 of the Draft Articles on State Responsibility for internationally wrongful acts, YbILC (1981). Vol. II, Part One, 71.

YbILC (1982) Vol. II, Part Two, 1, 78.

YbILC (1983) Vol. II, Part Two, 1, 39.

YbILC (1984) Vol. II, Part Two, 1, 99.

Summary records of the meetings of the 37th session, YbILC (1984) Vol. I.

YbILC (1985) Vol. II, Part Two, 1, 19.

YbILC (1988) Vol. II, Part Two, 1, 104.

Comments and observations of governments on Part 1 of the Draft Articles on State Responsibility for internationally wrongful acts, YbILC (1988) Vol. II, Part One, 1.

YbILC (1989) Vol. II, Part Two, 1, 71.

YbILC (1990) Vol. II, Part Two, 1, 68.

YbILC (1991) Vol. II, Part Two, 1, 126.

YbILC (1992) Vol. II, Part Two, 1, 17.

YbILC (1993) Vol. II, Part Two, 1, 34. 
YbILC (1994) Vol. II, Part Two, 1, 136.

ILC Report on the work of its 47th session, 2 May to 21 July 1995 (A/50/10).

ILC Report on the work of its 48th session, 6 May to 26 July 1996 (A/51/10).

ILC Report on the work of its 52nd session, 1 May to 9 June and 10 July to 18 August 2000 (A/55/10).

ILC Report on the work of its 53rd session, 23 April to 1 June and 2 July to 10 August 2001 (A/56/10 and Corr.1 and 2).

ILC Report on the work of its 54th session, 29 April to 7 June and 22 July to 16 August 2002 (A/57/10).

ILC Report on the work of its 55th session, 5 May to 6 June and 7 July to 8 August 2003 (A/58/10).

ILC Report on the work of its 56th session, 3 May to 4 June and 5 July to 6 August $2004(\mathrm{~A} / 59 / 10)$.

\section{Reports of Special Rapporteur, Mr Ago}

First Report, YbILC (1969) Vol. II, 125.

Second Report, YbILG (1970) Vol. II, 177.

First Report, Addendum, YbILC (1971) Vol. II, Part One, 193.

Third Report, YbILC (1971) Vol. II, Part One, 199.

Fourth Report, YbILG (1972) Vol. II, 71.

Fifth Report, YbILC (1976) Vol. II, Part One, 3.

Sixth Report, YbILC (1977) Vol. II, Part One, 3.

Seventh Report, YbILC (1978) Vol. II, Part One, 31.

Eighth Report, YbILC (1979) Vol. II, Part One, 3.

Eighth Report, Addendum, YbILC (1980), Vol. II, Part One, 69.

\section{Reports of Special Rapporteur, Mr Riphagen}

Preliminary Report, YbILC (1980) Vol. II, Part One, 107.

Second Report, YbILG (1981) Vol. II, Part One, 79.

Third Report, YbILC (1982) Vol. II, Part One, 22.

Fourth Report, YbILC (1983) Vol. II, Part One, 3.

Fifth Report, YbILC (1984) Vol. II, Part One, 1.

Sixth Report, YbILC (1985) Vol. II, Part One, 3.

Seventh Report, YbILC (1986) Vol. II, Part One, 1.

\section{Reports of Special Rapporteur, Mr Arangio-Ruiz}

Preliminary Report, YbILC (1988) Vol. II, Part One, 6.

Second Report, YbILC (1989) Vol. II, Part One, 1.

Third Report, YbILC (1991) Vol. II, Part One, 1.

Fourth Report, YbILC (1992) Vol. II, Part One, 1.

Fifth Report, YbILC (1993) Vol. II, Part One, 1. 
Sixth Report, YbILC (1994) Vol. II, Part One, 3

Seventh Report, YbILC (1995) Vol. I.

\section{Reports of Special Rapporteur, Mr Crazeford}

First Report (1998) UN doc. A/CN.4/490.

First Report, Addendum 1 (1998) UN doc. A/CN.4/490/Add. 1.

First Report, Addendum 2 (1998), UN doc. A/CN.4/490/Add. 2.

First Report, Addendum 3 (1998), UN doc. A/CN.4/490/Add. 3.

First Report, Addendum 4 (1998), UN doc. A/CN.4/490/Add. 4.

First Report, Addendum 5 (1998), UN doc. A/CN.4/490/Add. 5.

First Report, Addendum 6 (1998), UN doc. A/CN.4/490/Add. 6.

First Report, Addendum 7 (1998), UN doc. A/CN.4/490/Add. 7.

Second Report (1999) UN doc. A/CN.4/498.

Second Report, Addendum 1 (1999), UN doc. A/CN.4/498/Add. 1.

Second Report, Addendum 2 (1999), UN doc. A/CN.4/498/Add. 2.

Second Report, Addendum 3 (1999), UN doc. A/CN.4/498/Add. 3.

Second Report, Addendum 4 (1999), UN doc. A/CN.4/498/Add. 4.

Third Report (2000) UN doc. A/CN.4/507.

Third Report, Addendum 1 (2000) UN doc. A/CN.4/507/Add. 1.

Third Report, Addendum 2 (2000) UN doc. A/CN.4/507/Add. 2.

Third Report, Addendum 3 (2000) UN doc. A/CN.4/507/Add. 3.

Third Report, Addendum 4 (2000) UN doc. A/CN.4/507/Add. 4.

Fourth Report (2001) UN doc. A/CN.4/517.

Fourth Report, Addendum 1 (2001) UN doc. A/CN.4/517/Add. 1.

Fourth Report, Addendum 2 (2001) UN doc. A/CN.4/517/Add. 2.

Fourth Report, Addendum 3 (2001) UN doc. A/CN.4/517/Add. 3.

Fourth Report, Addendum 4 (2001) UN doc. A/CN.4/517/Add. 4.

\section{Other United Nations documents}

Third Report on the Law of Treaties by Mr Fitzmaurice, Yearbook of the ILC (1958) Vol. II, 20.

Fourth Report on the Law of Treaties by Mr Fitzmaurice, Yearbook of the ILC (1959) Vol. II, 37.

Summary records of the 16th session on the Law of Treaties, Yearbook of the ILC (1964) Vol. I, 1.

Comment by Iraq's representative, Mr Yaseen, 80th Meeting Committee of the Whole, 21 May 1968.

United Nations Conference on the Law of Treaties, Official Records of the United Nations Conference on the Law of Treaties, 1st Session, 80th meeting, Vienna, 26 March-24 May 1968, UN doc. A/CONF.39/11 (1969). Also see United Nations Conference on the Law of Treaties, Official Records, 2nd Session. Vienna, 9 April -22 May 1969 UN doc. A/Conf.39/11/Add. 1. 
Matters concerning Western Asia: Situation in Afghanistan, United Nations Yearbook (1980) 296 seq.

E.S. Reddy, 'A review of United Nations action for an oil embargo against South Africa', with special reference to the work of the Special Committee against Apartheid, Director, United Nations Centre against Apartheid, Brussels, 30-31 January 1981, available at http://www.anc.org.za/un/reddy/oilembargo.html.

Reuter, Summary Records of the Meetings of the 36th session, Yearbook of the ILC (1984) Vol. I., 264 (30).

Letter dated 6 August 1990 from the Charge d'Affaires A.I. of the Permanent

Mission of Italy to the United Nations addressed to the Secretary-General, United Nations doc. S/21444 (6 August 1990).

Letter dated 5 August 1990 from the Permanent Representative of Japan to the

United Nations addressed to the Secretary-General, United Nations doc. S/21449 (5 August 1990).

Transmitting note from Switzerland concerning measures to implement Security Council resolution 661 (1990) on Sanctions against Iraq, United Nations doc. S/21585 (7 August 1990).

Letter dated 25/09/96 from the Permanent Representative of Burundi to the

United Nations addressed to the Secretary-General and the President of the

Security Council, United Nations doc. S/1996/788.

Letter dated 25/08/96 from the Permanent Representative of Burundi to the

United Nations addressed to the President of the Security Council, United Nations doc. S/1996/690.

Final Report on Human Rights and Population Transfer, Special Rapporteur, AlKhasawneh, E/CN.4/Sub.2/1997/23.

First Report on Diplomatic Protection, Special Rapporteur, Mr J.R. Dugard, UN doc. A./CN.4/506 (7 March 2000); Addendum, UN doc. A/CN.4/506/ Add. 1 (20 April 2000).

Report of the 6th Committee on the Responsibility of States for Internationally Wrongful Acts, 22 November 2004, available at http://daccessdds.un.org/ doc/UNDOC/GEN/N04/619/67/PDF/N0461967.pdf?OpenElement.

Summary Records of the First Part of the Fifty-Third Session, ILCYbk (2001) Vol. I.

Report of UN Secretary-General, Mr Kofi Annan, 'In larger freedom: towards development, security and human rights for all', 21 March 2005 (General Assembly, 59th session, A/59/2005).

Report of the Secretary-General, 1 February 2007, 62nd session, A/62/62,

'Responsibility of states for internationally wrongful acts', Compilation of decisions of international courts, tribunals and other bodies.

Report of the Secretary-General, 9 March 2007, 62nd session, A/62/63, 'Responsibility of states for internationally wrongful acts', Comments and information received from governments.

Report of the Study Group of the International Law Commission, finalized by Martti Koskenniemi, 'Fragmentation of international law: difficulties arising from the diversification and expansion of international law', United Nations General Assembly, A/CN.4/L.682, 13 April 2006. 


\section{State official documents, statements, legal positions}

The Caroline Incident, 29 British and foreign state papers (1840-41) 1129 and 30 British and foreign state papers (1841-42) 195.

Correspondence of Mr Fox to Mr Webster, March 1841, British and foreign state papers (1840-41) Vol. 29, 1127.

Letter of Lord Ashburton to Mr Webster, British and foreign state papers (1841-42) Vol. 30, 196.

Briand, Repert. Prat. Française, I, No. 235, 131.

Letter dated 7 July 1914, from Gandhi to Gorges, available at http://www.anc. org.za/ancdocs/history/people/gandhi/appendix.htm.

Letter of Indian government of 22 June 1946, to be discussed in 1st session by General Assembly, UN Yearbook (1946-47) 144.

Suez Canal crisis, Letter by Soviet Prime Minister Nikolai Bulganin to Israeli Prime Minister David Ben-Gurion, 5 November 1956.

State Institute of Law of the Soviet Academy of Sciences, Mezhdunarodnoe pravo (Moscow, Gosudarstvennoe izdatelstvo yuridicheskoi literatury: 1957).

'USSR's prohibition of shipment of petroleum due to Israel's aggression against Egypt', Digest of US Practice in International Law (1970) 861.

'Diplomatic relations and recognition', Digest of United Practice in International Law (1973) 11-13.

'Racial discrimination', US Representative Albert Sherer, Digest of US Practice in International Law (1976) 164-66.

Economic and Military Assistance: Legislative Restrictions, Digest of US Practice in International Law (1976), 170.

Economic and Military Assistance: Legislative Restrictions, Digest of United States Practice (1977) 221.

'Foreign boycotts', David H. Small, Assistant Legal Adviser for Near Eastern and South Asian Affairs, US Department of State, Digest of US Practice in International Law (1976) 575-80.

'Memorandum of reply to the First Chamber concerning the bill on the application of sanctions against states and territories', 8 NYIL (1977) 205.

'President Carter's inaugural address', 20 January 1977, New York Times, 21 January 1977.

'Arab communiqué', Conference of Arab Oil Ministers, Kuwait, 17 October 1973 in Paust, J.J. and Blaustein, P.A., The Arab Oil Weapon (Oceana Publications, Inc.: 1977) 42.

'Arab resolution', Conference of Arab Oil Ministers, Kuwait, 17 October 1973 in Paust, J.J. and Blaustein, P.A., The Arab Oil Weapon (Oceana Publications, Inc.: 1977) 45.

'Pease' statement at the US House of Representatives', H.R. Con. Res. 426, 95th Congress, 1st Session (1977).

'The meaning of "international accords" in Draft Article 2 of the 1976 Sanctions Bill', 9 NYIL (1978) 235. 
'Reprisals, retorsion and sanctions for breach of treaty', Digest of US Practice in International Law (1978) 768-81.

'Memorandum of reply concerning the 1976 Sanctions Bill', 9 NYIL (1978) 235.

'Soviet invasion of Afghanistan', Digest of US Practice in International Law (1979) 34.

'Soviet invasion of Afghanistan', Digest of US Practice in International Law (1980) 31.

Belgium's statement on behalf of the European Community, UN doc. S/PV 2363, paras 131-32.

'Coercion and use of force short of war - unilateral acts intervention', BIIL (1980) $472-75$.

'Obligations prior to ratification (SALT II Treaty)', Digest of US Practice in International Law (1980) 398.

'Union of Soviet Socialist Republics', Digest of US Practice in International Law (1980) 601-602.

'Grain sales to the Union of Soviet Socialist Republics: export restrictions', Digest of US Practice in International Law (1980) 884.

'On the Teheran hostages', 29 BrIL (1980) 409.

'Intervention and self-help', 12 NYIL (1981) 168-70.

'The question of a Netherlands oil embargo against South Africa', 12 NYIL (1981) 240-41.

'Economic sanctions against South Africa', 12 NKIL (1981) 242-43.

'Iranian Economic Sanctions Act', CYIL (1981) 372.

'Haig's statement', Secretary of State, 30 April 1982, New York Times, 1 May 1982, 8, col. 5 .

'Economic sanctions', Memorandum issued on 15 April 1982 by the Canadian Legal Bureau, CYIL (1983) 311.

'Piedra's statement', US Representative to the Inter-American and Social Council (translated by Acevedo D. from the Spanish version as reported by the Associated Press on 21 October 1982), reproduced in OAS Department of Public Information, Servicio Informativo, 22 October 1982, at 1. Acevedo D., 'The US measures against Argentina resulting from the Malvinas conflict', 78 AfIL (1984) 323, 342.

Belgium's Statement on behalf of the European Community on the measures against Argentina, UN doc. S/PV 2363, 23 May 1982, (131-32) available at http://documents-dds-ny.un.org/doc/UNDOC/GEN/NL8/200/43/pdf/ NL820043.pdf?OpenElement.

'Argentina - attack on Falkland Islands', House of Commons Debates (Canada), CYIL (1983) 359-60.

'Measures against South Africa and the non-intervention duty', Advisory Committee on Questions of International Law, 14 NYIL (1983) 246.

'Legal argumentation in international crises: the downing of Korean Airlines flight 007', 97 HLR (1984) 1198.

'United States' diplomatic note concerning economic sanctions', 24 ILM (1985) 811-16.

On the US measures against Nicaragua, see position taken by Algeria, India, Mexico and Peru in United Nations doc. S/PV 2578 (9 May 1985) available 
at http://documents-dds-ny.un.org/doc/UNDOC/GEN/NL8/500/29/ pdf/NL850029.pdf?OpenElement; by Bolivia, Ethiopia, Madagascar and Ukraine in United Nations doc. S/PV 2579 (10 May 1985), paras 24, 47, 61, 75, available at http://documents-dds-ny.un.org/doc/UNDOC/GEN/ NL8/500/15/pdf/NL850015.pdf?OpenElement; by Argentina and Guyana in United Nations doc. S/PV 2580 (10 May 1985) paras 40, 44, 96, 147 available at http://documents-dds-ny.un.org/doc/UNDOC/GEN/NL8/500/32/ pdf/NL850032.pdf?OpenElement.

On the Danish position on unilateral economic sanctions, United Nations Security Council Official Records, Doc. S/PV 2578, 9 May 1985.

Economic Sanctions-Nicaragua, Cumulative Digest of International Law (1981-88) III, 2979.

'USSR - shooting down of Korean airline', CYIL (1985) 388.

'The legal analysis of Soviet actions', prepared by Patrick J. Norton, Assistant Legal Adviser for East Asian Affairs, and by Mary Beth West, Assistant Legal Adviser for European Affairs, 15 September 1983, in Destruction of Civil Aircraft in Flight, Cumulative Digest of US Practice in International Law (1981-88) II, 2199-209.

'United States - Poland: suspension', Cumulative Digest of US Practice in International Law (1981-88) II, 2180-184.

'United States - South Africa: termination', Cumulative Digest of US Practice in International Law (1981-88) II, 2184-189.

'United States - USSR: suspensions', Cumulative Digest of US Practice in International Law (1981-88) II, 2189-195.

'Economic sanctions - invasion of Afghanistan (1979); Polish repression (1981)', Cumulative Digest of International Law (1981-88) III, 2967-979.

'Apartheid', 24 CYIL (1986) 407-12.

'Afghanistan', 25 CIIL (1987) 432.

Address of Nelson Mandela to the Joint Session of the Houses of Congress of the United States of America, 26 June 1990, available at http://www.arc.org.za/ arcdocs/history/mandela/1990/sp900626.html.

'Commonwealth proposes further measures against military regime in Nigeria', 2 Commonwealth Currents 3 (1996); 3 Commonwealth Currents 7 (1996).

Executive Order, 'Blocking property of certain persons undermining democratic processes or institutions in Belarus', US Department of the Treasury, available at http://www.treas.gov/offices/enforcement/ofac/programs/belarus/ belarus.pdf.

\section{European Union legislation}

Council Regulation (EEC) No. 2557/79 of 30 October 1979, concerning the conclusion of the Agreement between the EEC and the Argentine Republic on trade in textile products, $O \mathcal{F}(1979)$ No L298/1.

Council Regulation (EEG) No. 2642/80 of 14 October 1980, laying down conditions for the application of protective measures in the sheepmeat and goatmeat sector, $O \mathcal{F}(1980) \mathrm{L} 275 / 4$. 
Council Regulation (EEG) No. 596/82 of 15 March 1982, amending the import arrangements for certain products originating in the USSR, Of (1982) L72/15.

Council Regulation (EEC) No. 597/82 of 15 March 1982, suspending in respect of Greece certain commercial policy measures applicable to imports originating in the USSR, Of (1982) L72/19.

Council Regulation (EEG) No. 877/82 of 16 April 1982, suspending imports of all products originating in Argentina, Of (1982) L102/1; Council Regulation $1176 / 82$ extending the suspension of imports of all products originating in Argentina, Of (1982) L/136/1 (18 May 1982).

Council Regulation (EEC) extending the suspension of imports of all products originating in Argentina, No.1254/82, Of (1982) L/146, 1-1 (24 May 1982)

Council Regulation (EEG) No. 314/83 of 24 January 1983 on the conclusion of the Cooperation Agreement between the European Economic Community and the Socialist Federal Republic of Yugoslavia.

Title III of Single European Act, Of (1987) L169/1.

Council Regulation (EEG) No. 2340/90 of 8 April 1990, preventing trade by the Community as regards Iraq and Kuwait, Of (1990) L213/1.

Council decision of 8 August 1990, preventing trade as regards Iraq and Kuwait (90/414/ECSC), Of (1990) L213/3.

Council decision of 11 November 1991, suspending the application of the Agreements between the European Community, its member states and the Socialist Federal Republic of Yugoslavia (91/586/ECSC, EEC), Of (1991) L315/47.

Council decision of 11 November 1991, denouncing the Agreement between the member states of the European Coal and Steel Community and the Socialist Federal Republic of Yugoslavia (91/587/ECSG), Of (1991) L315/48.

Council decision of 11 November 1991, suspending the trade concessions provided for by the Agreement between the member states of the European Coal and Steel Community and the Socialist Federal Republic of Yugoslavia (91/588/ECSC), Of (1991) L315/49.

Council decision of 11 November 1991, withdrawing Yugoslavia from the list of the beneficiaries of the Community generalized tariff preferences scheme for 1991 (91/589/ECSC), Of (1991) L315/50.

Council Regulation (EEG) No. 3300/91, Of (1991) L 315/1.

Council Regulation (EEG) No. 3301/91 of 11 November 1991, on the arrangements for imports of certain textile products originating in Yugoslavia, $O \mathcal{F}$ (1991) L315/3.

Council Regulation (EEG) No. 3302/91 of 11 November 1991, withdrawing Yugoslavia from the list of beneficiaries of the Community generalized tariff preferences scheme for 1991, OJ (1991) L315/46.

Council decision of 25 November 1991, denouncing the Cooperation Agreement between the EEC and the Socialist Federal Republic of Yugoslavia (91/602/ EEG), Of (1991) L325/23. 
Council Regulation (EEG) No. 1155/92 of 28 April 1992, amending Regulation No. 3301/91, on the arrangements for imports of certain textile products originating in Yugoslavia, Of (1992) L122/1.

Council Regulation (EC) No. 1901/98 of 7 September 1998, concerning a ban on flights of Yugoslav carriers between the Federal Republic of Yugoslavia and the European Community, Of (1998) L248/1.

Common Positions on Burma/Myanmar, 96/635/CFSP (28 October 1996), Of L 287/1 (8 November 1996).

Council Decision of 27 April 1998 concerning the further extention of Common Position 96/635/CFSP on Burma/Myanmar, Of L 138/5 (9 May 1998).

Common position of 19 March 1998, defined by the Council on the basis of Article J2 of the Treaty on European Union on restrictive measures against the Federal Republic of Yugoslavia, Of (1998) L95/1.

Common position of 7 May 1998, defined by the Council on the basis of Article J2 of the Treaty on European Union, concerning the freezing of funds held abroad by the Federal Republic of Yugoslavia and Serbian governments, Of (1998) L143/1.

Common position of 8 June 1998, defined by the Council on the basis of Article J2 of the Treaty on European Union concerning the prohibition of new investment in Serbia, Of (1998) L165/1.

Council Regulation (EC) No. 926/98 of 27 April 1998, concerning the reduction of certain economic relations with the Federal Republic of Yugoslavia, $O \mathcal{F}$ (1998) L130/1.

Council Regulation (EC) No. 1295/98 of 22 June 1998, concerning the freezing of funds held abroad by the governments of the Federal Republic of Yugoslavia and the Republic of Serbia, Of (1998) L178/33.

Council Regulation (EC) No. 1607/98 of 24 July 1998, concerning the prohibition of new investment in the Republic of Serbia, Of (1998) L209/16.

Common position of 29 June 1998, defined by the Council on the basis of Article J2 of the Treaty on European Union concerning a ban on flights by Yugoslav carriers between the Federal Republic of Yugoslavia and the European Community, Of (1998) L190/3.

Council Regulation (EC) No. 1064/1999 of 21 May 1999, imposing a ban on flights between the European Community and the Federal Republic of Yugoslavia and repealing regulation (EG) No. 1901/98, Of (1999) L129/27.

Council Regulation (EC) No. 2151/1999 of 11 October 1999, imposing a ban on flights between the territories of the Community and the Federal Republic of Yugoslavia other than the Republic of Montenegro and the province of Kosovo and repealing regulation (EG) No. 1064/1999, Of (1999) L264/3.

Council Regulation (EG) No. 1081/2000 of 22 May 2000 prohibiting the sale, supply and export to Burma/Myanmar of equipment which might be used for internal repression or terrorism, and freezing the funds of certain persons related to important governmental functions in that country, Of L 122/29 (22 May 2000). 
Measures against Zimbabwe, Council common position of 18 February 2002, 2002/145/CFSP (18 February 2002), Of 2002 L 50/1; Council Regulation (EG) No. 310/2002 of 18 February 2002, Of (2002) L 50/4.

Council common position 2006/51 / CFSP of 30 January 2006 renewing restrictive measures against Zimbabwe, Of (2006), L 26/28 (31 January 2006); Council decision of 17 February 2005, Of (2005) L 48/28 (19 February 2005).

\section{European Union documents}

Resolution sur l'association entre la GEE et la Grèce (2 June 1967), Of (1967) 10, 2058.

Written Question No. 108 of 14 July 1967 (Question ecrite No. 108/97 de M. Seifriz a la Commission des CEE Accord d'Association CEE-Grece), Journal Officiel, No. 243 du 07/10/1967, 3; Reply by the Commission of the European Communities of 22 September 1967, Of (1967) 243/2 (7 October 1967).

Parlement Europeen, Debats: Compte Rendu in Extenso des Seances, VI/67, 91, 11-20 (1967).

Human Rights in Uganda, Written Question No. 941/76, (De M. Van Der Hek an Conseil: Les Droits de l'Homme en Ouganda), Of C214/1(7 September 1977). Answer of 6 March 1978, Of (1978) C 74/18 (28 March 1978).

Oral Question No. H-300/76 by Sir Geoffrey de Freitas and Oral Question No. H-306/76 by Mr Patijn published in the Annex to Official Journal of the European Communities (OF) 214/71 - Debates of the European Parliament (10 March 1977).

Central African Empire, Written Question No. 943/77 by Mr Adams to the Commission of the European Communities, (Question ecrite No. 943/77 de M. Adams a la Commission: Empire Centrafrican), Of (1978) C 74/17 (28 March 1978).

Reply of the Commission of the European Communities to Written Question No. 115/78, by Mr Adams (Question ecrite No. 115/78 de M. Adams a la Commission: Empire Centrafrican), Of C (1978) 199/27 (21 August 1978).

Resolution on the Soviet intervention in Afghanistan, Of (1980) C34/28. Also EC Bulletin (1980) 1, 13, points 1.1.3-1.1.11.

Statement by C. Cheysson, Commissioner on Development Cooperation, 8 July 1980, Europe, 28, 2495, 11.

Community and the Member States and the events in Iran, Bulletin of the EC (1980) 4, 20-26.

Community and Poland, Final Communique of 4 January 1982, Bulletin of the EC (1981: 12) 12-13 (1.4.2).

State Trading Countries - USSR, Bulletin of the EC (1982) 3, 66.

State Trading Countries - Poland, Bulletin of the EC (1982: 1) 2.2.38.

State Trading Countries - USSR, Bulletin of the EC (1982: 2) 2.2.44.

Community solidarity in the Falklands Conflict, Bulletin of the $E C(1982) 4,7$.

Declaration of G77 Foreign Ministers, Sixth Annual Meeting (1982).

Declaration of G77 Foreign Ministers, Seventh Annual Meeting (1983). 
Political and Institutional Matters, European Community Bulletin (1985) No. 9, para. 2.5.1 (10 September 1985); Political and Institutional Matters, European Community Bulletin (1986) No. 9, para. 2.4.2 (16 September 1986).

European Political Cooperation - Invasion of Kuwait by Iraq, Bulletin of the European Communities (1990) 7/8 (1.5.9), (1.5.11).

Proposal for a Council Regulation (EEC) suspending for 1990 the generalized tariff preferences for certain products originating in Iraq, COM (90) 391 final, Brussels (8 August 1990).

Proposal for a Council Regulation (EEC) suspending for 1990 the levy reductions for certain agricultural products originating in Iraq, COM(90) 391 final, Brussels (8 August 1990).

Draft for a Decision of the Representatives of the Governments of the Member States meeting within the Council suspending for 1990 the generalized tariff preferences for certain iron and steel products originating in Iraq, COM (90) 391 final, Brussels (8 August 1990).

Proposal for a Council Regulation (EEG) prohibiting the introduction into the territory of the Community of crude oil and refined petroleum products or their derivatives originating in or last exported from Kuwait, $C O M(90) 375$, Brussels (8 August 1990).

Proposal for a Council Regulation (EEG) prohibiting the introduction into the territory of the Community of crude oil and refined petroleum products or their derivatives originating in or last exported from Kuwait, $C O M(90)$ 376, Brussels (8 August 1990).

European Political Cooperation - Yugoslavia, Bulletin of the EC (1991) 7/8 (1.4.3). European Political Cooperation - Yugoslavia, EC Bulletin (1991) No. 11, 91 (1.4.4).

Title V of the Treaty on European Union of 7 February 1992.

Agence Europe No. 5728 of 13 April 1992, 3.

Agence Europe No. 5734 of 22 May 1992, 6.

Agence Europe, No. 7286 of 25-26 August 1998, 2.

Council of the European Union, External Relations, Brussels, 7 November 2005, 13622/05, http://ue.eu.int/ueDocs/cms_Data/docs/pressData/en/ gena/86850.pdf.

European Parliament Resolution on Belarus, European Union Bulletin, No. 3, 10 March 2005, 1.2.4.

On Belarus, General Affairs and External Relations, 2687th Council Meeting, Council of the European Union, External Relations, Brussels, 7 November 2005, 13622/05, available at http://ue.eu.int/ueDocs/cms_Data/docs/pressData/ en/gena/86850.pdf

\section{Record of world events}

\section{Keesing's contemporary archives}

(1951) 11171, 11260.

(1961) 18168. 
(1963-64) 19699; 19463, 19468; 19699.

(1963) 19260.

(1967) 22454.

(1970) 24170; 23904.

(1972) 25585.

(1975) 26993.

(1976) 27642.

(1978) 29293.

(1979) 29750.

(1980) 30229, 30236; 30407; 30234; 30241.

(1981) $31071 ; 31231 ; 30977$.

(1982) 31545; 31453, 31454; 31456; 31458-59; 31616; $31570 ; 31533$.

(1983) 32514.

(1992) 38905.

(1994) 40287.

(2002) 44600; 44541.

\section{Parliamentary debates and documents}

US House of Representatives, 'International Protection of Human Rights, The Work of International Organizations and the Role of U.S. Foreign Policy', hearings before the Subcommittee on International Organizations and Movements of the Committee on Foreign Affairs, House of Representatives, 93rd Congress, 1st Session (Washington, DC: 1973) 507.

Afghanistan Sanctions, 'An Assessment of the Afghanistan Sanctions: Implications for Trade and Diplomacy in the 1980s', Congressional Research Service, Library of Congress, prepared for the House Committee on Foreign Affairs, 97th Congress, 1st session (Washington, DC: 1981).

'Iranian Economic Sanctions Act', House of Commons Debates (Canada), CYIL (1981) 372-74.

'Argentina - Attack on Falkland Islands', House of Commons Debates (Canada), CrIL (1983) 359-60.

'Terrorism: Laws Cited Imposing Sanctions on Nations Supporting Terrorism', Fact Sheet for the Honourable Frank R. Lautenberg, United States Senate, United States General Accounting Office, April 1987, available at http:// archive.gao.gov/d28t5/133073.pdf.

'Afghanistan', House of Commons Debates (Canada), CYIL (1987) 432.

UK Parliament Kosovo Crisis, 'The Kosovo Crisis after May 1997 - Sanctions', Fourth Report, Select Committee on Foreign Affairs, available at http://www. publications.parliament.uk/pa/cm199900/cmselect/cmfaff/28/2809.htm

UK Foreign Policy Report, 'First Report from the Foreign Affairs Committee, Session 1998-99, Foreign Policy and Human Rights, Response of the Secretary of State for Foreign and Commonwealth Affairs', Cm 4229, 6, available at http://www.fco.gov.uk/Files/kfile/FACresponse019899,0.pdf 
'Letter to the Chairman of the Committee from the UK Foreign Secretary on the Yugoslavia Flight Ban', 30 November 1998, Appendix 32.

Command Paper, 'First Supplementary List of Ratifications, Accessions, Withdrawals etc for 1998, Treaty Series No. 28 (1998)', Command Paper presented to Parliament by the Secretary of State for Foreign and Commonwealth Affairs by Command of Her Majesty, July 1998, Stationery Office.

House of Commons Debates, 976, col. 1222, 14 January 1980, BIIL 29 (1980), 473. House of Lords Debates, 408, col. 770, 23 April 1980, BYIL 29 (1980), 409, 477. House of Commons Debates, 985, Written Answers, col. 347, 22 May 1980. House of Lords Debates, 408, col. 770, 23 April 1980, BYIL 29 (1980), 413-14. UK Secretary of State's Statement, House of Commons Debates, 24 July 1998, col. 184.

\section{United States' legislation}

Executive Order 8389 - Protecting Funds of Victims of Aggression, 10 April 1940

Executive Order 8785 - Freezing the Assets of Certain European Countries, 14 June 1941.

Executive Order 8832 - Freezing Japanese and Chinese Assets in the United States, 26 July 1941.

1974 Foreign Assistance Act, Digest of US Practice in International Law (1976) 1.

Arms Export Act, International Security Assistance and Arms Export Control Act of 1976, 22 USG 2151, Public Law 94-329, 94th Congress, HR 13680, 30 June 1976, 90 Stat. 729, Digest of United States Practice (1977) 221.

International Financial Institutions Act, International Financial Institutions Act, PL 95-118, Digest of United States Practice (1977) 221.

International Development Act, International Development and Food Assistance Act of 1977, Digest of United States Practice (1977) 221.

A concurrent resolution providing that the President should implement measures to discourage activities which benefit the Government of the Republic of Uganda, House Concurrent Resolution No. 426, 95th Congress, 1st Session (1 December 1977), available at http://thomas.loc.gov/cgi-bin/bdquery/ D?d095:426:./list/bss/d095HC.lst::|TOM:/bss/d095query.html.

Pub. L. 95-435, 1978 HR 9214, section 5, 10 October 1978, 92 Stat. 1052; to be found in Section 2151, United States Code Annotated, Title 22, Foreign

Relations and Intercourse Sections 1251 to 2500 (West Publishing: 1979).

Uganda Act 1, Pub. L. 95-426, 1978 HR 12598, Title VI, section 610, 7 October 1978, 92 Stat. 989; to also be found in Section 2151, United States Code Annotated.

Uganda Act 2, Pub. L. 95-435, 1978 HR 9214, section 5, 10 October 1978, 92 Stat. 1052; to be found in Section 2151, United States Code Annotated.

Uganda Act 3, Pub. L. 95-424, 1978 HR 12222 section 602; to also be found in Section 2151, United States Code Annotated, Title 22.

Embargo Act, Uganda Embargo Act, 22 USC, s. 2151 (1978).

"Multilateral and Bilateral Action to Halt Atrocities in Cambodia and Uganda", 22 USG s. 2151 (1978). 
Executive Order, Executive Order No. 12117, 6 February 1979, 44 F>R. 7937, Implementation of Import Restrictions Imposed against Uganda; to be found in Section 2151, United States Code Annotated.

Foreign Relations Act, United States Code Annotated, Title 22, Chapter 32,

Subchapter I, Part I, Section 2151, Foreign Relations and Intercourse,

Congressional findings and declaration of policy.

Export Administration Act of 1979 and Arms Export Control Act, 23 UST 4269, TIAS No. 7535.

Argentine Republic; Determination under Section 2 (b)(1)(B) of the Export-Import Bank Act of 1945, as Amended and Executive Order 12166, 21 ILM (1982) 684.

International Security and Development Cooperation Act of 1985, Public Law No. 99-83, 22 U.S.C. 2151.

Federal Aviation Act of 1958, Public Law No. 85-726, Aug. 23, 1958, 72 Stat. 731.

International Emergency Economic Powers Act, Public Law No. 95-223, 50 U.S.G 1701.

Anti-Apartheid Act, the Comprehensive Anti-Apartheid Act of 1986, Pub. L. 99-440, 100 Stat. 1086, 22 USG 5001 et seq., enacted 2 October 1986.

Law Restatement, Restatement of the Law, the Foreign Relations Law of the United States, Vol. 1 (American Law Institute Publishers: 1987) 382.

Law Restatement, Restatement of the Law, the Foreign Relations Law of the United States, Vol. 2, 1987, 174.

Syria Accountability and Lebanese Sovereignty Restoration Act of 2003, HR 1828, 12 April 2003, Public Law 108-75 (12 December 2003).

'Blocking Property of Persons Undermining Democratic Processes or Institutions in Zimbabwe', Executive Order 13288, 6 March 2003, Federal Register, Vol. 68, No. 46.

\section{United Kingdom legislation}

'An Act to enable provision to be made in consequence of breaches in international law by Iran in connection with or arising out of the detention of members of the embassy of the United States of America', BYIL 29 (1980) 413.

Iran Sanctions, the Export of Goods Control (Iran Sanctions) Order and the Iran (Trading Sanctions) Order, 29 May 1980 in Statutory Instruments, London, 1981, 2579, 2585.

Human Rights Act 1998, available at http://www.hmso.gov.uk/acts/acts1998/ 19980042.htm

Yugoslavia Regulations 1999, Statutory Instrument 1999 No. 2018, available at http://www.legislation.hmso.gov.uk/si/si1999/19992018.htm

\section{Other national legislation}

Sanctions Bill, Bijl. Hand. II 1975/76-14006 No. 3, 8. The 1976 Sanctions Bill, 8 NYIL (1977) 205. 


\section{Documents of the League of Nations}

Aaland Islands Question, 'Report of the International Committee of Jurists entrusted by the Council of the League of Nations with the task of giving an Advisory Opinion upon the legal aspects of the Aaland Islands Question', LNOJ (Special Supplement No. 3) (October 1920) 17.

League of Nations Conference,Conference for the Codification of International Law, Bases of Discussion for the Conference drawn up by the Preparatory Committee, Vol. III, 128; Supplement to Vol. III, 4.

\section{Newspaper sources}

New York Times, 25 June 1960, col. 6; 30 July 1960, col. 1.

New York Times, 29 September 1967, 14, col. 3.

New York Times, 21 January 1977.

Washington Post, 24 December 1981.

Washington Post, 30 December 1981.

Washington Post, 16 February 1982.

Financial Times, 'Latin American markets', 10 May 1982, 3; Financial Times, 13 July 1982, 14.

Washington Post, 6 September 1983.

Sunday Times, 13 November 1994.

The Independent, 'Cook reviews "unethical" policy on Serbia after EU outrage', Katherine Butler, 16 September 1998.

The Independent, 'Cook in Kosovo Climbdown', Katherine` Butler, 17 September 1998.

\section{Documents of the Council of Europe}

Resolution, Council of Europe, Directorate of Information, Doc. B (67) 37 (26 June 1967).

CAHDI - Committee of Legal Advisers on Public International Law (CAHDI), 24th Meeting, Bratislava, 9-10 September 2002 on the ILC Report on the work of its 54th session (29 April-7 June and 22 July-16 August 2002). Prepared by Professor Bruno Simma.

\section{Documents of the World Trade Organization}

GATT Communique - Trade Restrictions affecting Argentina applied for Non-economic Reasons, 18 May 1982, GATT doc. L5319/Rev.1 and Trade Restrictions affecting Argentina applied for Non-economic Reasons, 30 April 1982, GATT doc. L5317.

Trade Restrictions affecting Argentina applied for Non-economic Reasons, 15 June 1982, L/5336.

Report on Work since the 37th Session, 12 November 1982, L/5414, 17. 
Position taken by Spain and Brazil on the measures against Argentina, Minutes of Meeting, 22 June 1982, GATT Document C/M/157, 5-6.

Joint statement by the European Community, Australia and Canada, 'Trade Restrictions affecting Argentina applied for Non-economic Reasons', GATT doc. L 5319/Rev. 1 (5 May 1982) para. 1b and GATT doc. C/M/157, 10, available at http://www.wto.org/gatt_docs/English/SULPDF/90440042.pdf.

Ministerial Declaration on Dispute Settlement Procedures, adopted on 29 November 1982, L/5424, Basic Instruments and Selected Documents, Supplement No. 29, 9. Also in Keesing's Contemporary Archives, May 1983, 32169A.

United States Notification of Trade Embargo, GATT doc. L/5803; United States - Trade Measures Affecting Nicaragua, Report by the Panel, L/6053, 13 October 1986, 18, available at http://www.worldtradelaw.net/reports/ gattpanels/nicembargo.pdf.

Trade Measures Taken by the European Community against the Socialist Federal Republic of Yugoslavia - Communication from the European Communities, 2 December 1991, GATT doc. L/6948.

\section{Other documents}

Statute of the Council of Europe, available at http://conventions.coe.int/Treaty/ EN/Treaties/Html/001.htm.

Sixth Meeting of Consultation of Ministers of Foreign Affairs Serving as Organ of Consultation in Application of the Inter-American Treaty of Reciprocal Assistance, San Jose, Costa Rica, 16-21 August 1960, Final Act, OAS off. Rec. OEA/ SER, C/II 6 (1960).

Resolution of Organization of African Unity on Apartheid and Racial Discrimination, availableathttp://www.africa-union.org/root/au/Documents/ Decisions/hog/aHoGAssembly1963.pdf.

Resolutions adopted by the first ordinary session of the Assembly of Heads of State and Government, Territories under Portuguese Domination, Cairo, 17-21 July 1964, AHG/Res.10 (I), available at http://www.africa-union.org/root/ $\mathrm{au} /$ Documents/Decisions/hog/bHoGAssembly1964.pdf.

Lucerne Conference of Governmental Experts on the use of Certain Conventional Weapons of 1974, Conference Report, published by ICRC, 1975.

Bonn Declaration, 1978 (II) Pub. Papers 1308, reprinted in (1978) 17 ILM 1285.

Ottawa Statement on International Terrorism, 21 July 1981, available at http: //www.g7.utoronto.ca/summit/1981 lottawa/terrorism.html.

Action taken by the International Federation of Airline Pilots, 6 September 1983, $22 \operatorname{ILM}$ (1983) 1218-19.

'National Actions Taken in Response to the Destruction of the Korean Air Lines Aircraft', 22 ILM (1983) 1197, 1199, 1201, 1205, 1218.

Resolution adopted by ICAO Council on 6 March 1984, 23 ILM (1984) 937; Resolution adopted by ICAO Council, 22 ILM (1983) 1149.

The Commonwealth Accord on Southern Africa (Nassau, 20 October 1985) reproduced in Keesing's (1986) 34647.

Commonwealth Proposes further measures against Military Regime in Nigeria, 2 Commonwealth Currents 3 (1996); and 3 Commonwealth Currents 7 (1996). 


\section{International treaties}

Treaty of Munster (Westphalia), Peace Treaty between the Holy Roman Emperor and the King of France and their respective Allies, 24 October 1648, 1 CTS 271.

1856 Åaland Islands Convention, 15 NRG, 1st series, 788-90.

Capetown Agreement, 1927, Joint Communiqué issued by the South African and Indian Governments, 21 February 1927, available at http://www.anc.org. za/ancdocs/history/people/gandhi/appendix.htm.

Covenant of the League of Nations, 28 June 1919, 13 AfIL (1919) Supp. 128, 361.

Protocol for the Pacific Settlement of Disputes (League of Nations), 2 October 1924, available at http://www.unhcr.org.refworld/docid/4042 la204.html.

South West Africa Mandate, 17 December 1920, LNOJ 1921, 89.

Treaty of Versailles (Treaty of Peace between the Allied and Associated Powers and Germany), 28 June 1919, 16 AfIL (1922) Supp. 1.

Provisional Agreement between the United States of America and the Kingdom of Saudi Arabia in Regard to Diplomatic and Consular Representation, Juridical Protection, Commerce and Navigation, signed 7 November 1933 in Paust,J.J. and Blaustein, P.A., The Arab Oil Weapon (Oceana Publications, Inc.:1977), 356-57.

Charter of the United Nations, 26 June 1945, 1 UNTS 16.

Agreement between South Africa and the United States of America relating to Air Services Between their Respective Territories, signed in 1947.

Convention on the Prevention and Punishment of the Crime of Genocide, 9 December 1948, UNTS, Vol. 78, 277.

Inter-American Treaty of Reciprocal Assistance (Rio) (modified by the 1975 Protocol of San José), 2 September 1947, 21 UNTS 77.

General Agreement on Tariffs and Trade (1947), available at http://www.wto. org/english/docs_e/legal_e/gatt47_e.doc.

Charter of the Organization of American States (Bogota Charter), 30 April 1948, 119 UNTS 3.

European Convention for the Protection of Human Rights and Fundamental Freedoms, 4 November 1950, 213 UNTS 221.

Statute of the Council of Europe, London, 5.v.1949, available at http:// conventions.coe.int/Treaty/en/Treaties/Html/001.htm.

Union of South Africa and Australia, Exchange of Notes constituting an Agreement relating to air services, Cape Town, 26 September 1958, 335 UNTS 127 (2 April 1970), 121.

UK - FPRY Agreement of 1959, Agreement between the Government of the United Kingdom of Great Britain and Northern Ireland and the Government of the Federal People's Republic of Yugoslavia concerning Air Services, London, February 1959, Treaty Series No. 10 (1960) Presented to Parliament by the Secretary of State for Foreign Affairs by Command of Her Majesty, March 1960.

Cyprus-Greece, Turkey, UK, Treaty of Guarantee of the Republic of Cyprus, 16 August 1960, 382 UNTS 3

Vienna Convention on Diplomatic Relations, 18 May 1961, 500 UNTS 95.

Agreement Concerning Technical Military Assistance, 821 UNTS 266 (27 January 1961). 
Tokyo Convention on Offences and Certain Other Acts Committed on Board Aircraft, 14 September 1963, 704 UNTS 219.

Association Agreement between EC and Greece, Fournal Officiel des Communautés Européennes (1963) No. 6 (January-March) 293/63; Protocole No. 19, Protocole Financier, Fournal Officiel des Communautés Européennes (1963) No. 6 (January-March) 340/63.

Vienna Convention on the Law of Treaties, 23 May 1969, 1155 UNTS 331.

Hague Convention for the Suppression of Unlawful Seizure of Aircraft, 16 December 1970, $10 \operatorname{ILM}(1971) 133$.

Convention for the Suppression of Unlawful Acts against the Safety of Civil Aviation, Montreal, 23 September 1971, 974 UNTS 177.

US-Polish Air Agreement, 1972 US-Polish Air Transport Services Agreement, 23 UST 4269, TIAS No. 7535.

ACP-EEC Convention (Lome I), 28 February 1975, 12 CMLR 4633.

Treaty of the Economic Community of West African States, 28 May 1975, 1010 UNTS 17.

Agreement on Mutual Fisheries Relations between Canada and the Soviet Union, 1132 UNTS 139 (19 May 1976).

Convention establishing the Economic Community of the Great Lake Countries of 1976, 1092 UNTS 49 (17 April 1978).

Treaty Concerning the Construction and Operation of the Gabčikovo-Nagymaros System of Locks of 16 September 1977, 32 ILM (1993) 1247.

Protocol Additional to the Geneva Conventions of 12 August 1949 and Relating to the Protection of Victims of International Armed Conflicts (Protocol I) 1977, Laws of Armed Conflicts 423.

New Zealand - USSR Agreement on Fisheries, 1151 UNTS 277 (4 April 1978).

Panama Canal Treaty, 1280 UNTS 3 (1 October 1979).

Agreement between the European Economic Community and the Argentine Republic on Trade in Textile Products, Of (1979) No. L298/2; Arrangement in the form of an exchange of letters between the European Economic Community and the Argentina Republic on trade in mutton and lamb, $O f$ (1980) L/275/14 (14 October 1980).

Treaty of Amsterdam amending the Treaty on European Union, the Treaties establishing the European Communities and related acts, Official fournal C 340, 10 November 1997.

International Covenant on Economic, Social and Cultural Rights, 5 December 1997, E/C/12/1997/8.

Protocol No. 11 to the Convention for the Protection of Human Rights and Fundamental Freedoms, restructuring the control machinery established thereby, Strasbourg, 11.V.1994, ETS No. 5.

Partnership Agreement between the African, Caribbean and Pacific Group of States and the European Community of 23 June 2000 (Cotonou Agreement), Of (2000) L $317 / 3$ (15 December 2000).

EU Consolidated Versions of the Treaty on EU and of the Treaty establishing the EC, Of C 321 E/1, 29 December 2006. 


\section{United Nations resolutions}

\section{Security Council}

The situation in the Middle East (21 May), Res. 252 (1968).

The situation in the Middle East (3 March), Res. 267 (1969).

The situation in the Middle East (15 September), Res. 271 (1969).

The situation in the Middle East (25 September), Res. 298 (1971).

South Africa (4 November), Res. 418 (1977).

Islamic Republic of Iran-USA (4 December), Res. 457 (1979).

Islamic Republic of Iran-USA (31 December), Res. 461 (1979).

Falkland Islands (Malvinas), Res. 502 (1982).

US-Nicaragua, Res. 562 (1985).

Iraq-Kuwait (2 August), Res. 660 (1990).

Iraq-Kuwait (6 August), Res. 661 (1990).

Iraq-Kuwait (25 September), Res. 670 (1990).

Socialist Federal Republic of Yugoslavia (25 September), Res. 713 (1991).

Bosnia and Herzegovina (30 May), Res. 757 (1992).

On the Sanctions against Sudan (26 April 1996) Res. 1054 (1996) and (29 March 2005) Res. 1591 (2005).

Situation in the Federal Republic of Yugoslavia, Res. 1160 (1998).

Termination of the embargo on deliveries of weapons and military equipment imposed by Resolution 713 (1991), Resolution 1021 (1995).

\section{General Assembly}

Question of Territories under Portuguese Administration, Resolution 2107 (XX) para. 7(e), 21 December 1965.

On South Africa (Apartheid), Resolution 1761 (XVII), 6 November 1962. Resolution 1899 (XVIII), 13 November 1963; Resolution 3411G (XXX), 10 December 1975; Resolution 31/6, 26 October 1976; Resolution 32/105, 14 December 1977; Resolution 34/93, 12 December 1979; Resolution 35/206, 16 December 1980.

Declaration on Principles of International Law concerning Friendly Relations and Co-operation among States and the 1975 Definition of Aggression, Resolution 2625 (XXV), 26 October 1970.

Charter of Economic Rights and Duties of States, General Assembly Resolution 3281 (XXIX) of 12 December 1974.

The situation in Afghanistan and its implications for international peace and security, Resolution 35/37, 20 November 1980.

Responsibility of States for Internationally Wrongful Acts, Resolution 56/83, 12 December 2001.

Responsibility of States for Internationally Wrongful Acts, Resolution 59/35, December 2004.

Responsibility of States for Internationally Wrongful Acts, Resolution 62/61 (A/62/446), 8 January 2008. 


\section{Bibliography}

Abi-Saab, G. (1967) 'The Concept of Jus Cogens in International Law', 2 Lagonissi Conference: Papers and Proceedings, Vol. II (Carnegie Endowment for International Peace). 919 .

Acevedo, D. (1984) 'The U.S. Measures against Argentina resulting from the Malvinas Conflict' 78 AfIL 323.

Ago, R. (1989) 'Obligations Erga Omnes and the International Community' in Weiler H.H.J., Spinedi M. and Cassese A. (eds), International Crimes of States: A Critical Analysis of the ILC's Draft Article 19 on State Responsibility (New York: Walter de Gruyter) 237.

Akande, D. and Williams, S. (2003) 'International Adjudication on National Security Issues: What Role for the WTO?' 43 VIIL 2, 365.

Akehurst, M. (1967) 'Enforcement Action by Regional Agencies with Special Reference to the Organization of American States' XLII BYIL 175.

— (1970) 'Reprisals by Third States' 44 BIIL 1.

Alexidze, A.L.K. (1981) 'Legal Nature of Jus Cogens in Contemporary International Law' $172 R d C$ III, 219.

Alland, D. (2002) 'Countermeasures of General Interest' 13 EfIL 5, 1221.

Allott, P. (1990) Eunomia. New Order for a New World (Oxford University Press).

Alston, P. (ed.) (1999) The EU and Human Rights (Oxford University Press).

Anand, P.R. (1986) 'Sovereign Equality of States in International Law' 197 Recueil des Cours (II) 9 .

Anghie, A. and Sturgess, G. (eds) (1998) Legal Visions of the 21st Century: Essays in Honour of Judge Christopher Weeramantry (Kluwer Law International).

Annacker, C. (1994) 'The Legal Regime of Erga Omnes Obligations in International Law' 46 Aus. FIL 131.

Arend, A.C. and Beck, R. (1993) International Law and the Use of Force (Routledge).

Baker, P. (2004) 'Getting it Right, U.S. Policy in South Africa' in Liang-Fenton D. (ed.), Implementing U.S. Human Rights Policy, 86.

Barnhoorn, A.L. (1994) 'Diplomatic Law and Unilateral Remedies' 25 NYIL 39.

Barnhoorn, A.L. and Wellens, G.K. (eds) (1995) Diversity in Secondary Rules and the Unity of International Law (Martinus Nijhoff).

Bartels, L. (2001) 'Applicable Law in WTO Dispute Settlement Proceedings' 35 (3) Journal of World Trade 499.

(2002) 'Article XX of GATT and the Problem of Extraterritorial Jurisdiction, The Case of Trade Measures for the Protection of Human Rights' 36 (2) Fournal of World Trade 353.

Bederman, D. (2002) 'Counterintuiting Countermeasures' 96 AfIL 817. 
Bluntschli, K.J. (1872) Das Moderne Volkerrecht der civilisierten Staaten als Rechtsbuch dargestellt (Beck).

— (2000) The Theory of the State (authorized English translation from the 6th German edition) (Batoche Books, Kitchener). Available at http://socserv2.socsci.mcmaster.ca/ $\sim$ econ/ugcm/3ll3/bluntschli/TheState.pdf.

Bohr, S. (1993) 'Sanctions by the United Nations Security Council and the European Community' 4 EJIL 256.

Boisson de Chazournes, L., Romano, C. and Mackenzie, R. (eds) (2002) International Organizations and International Dispute Settlement: Trends and Prospects (Transnational Publishers, Inc.).

Boornman, J. (1976) 'Economic Coercion in International Law: The Arab Oil Weapon and the Ensuing Juridical Issues' in Lillich R., Economic Coercion and the New International Economic Order (The Mitchie Company, Law Publishers: Charlottesville, Virginia) 268.

Bowett, D. (1958) Self-defence in International Law (Manchester University Press).

_ (1972) 'Economic Coercion and Reprisals by States' 13 VJIL 1, 1.

(1976) 'International Law and Economic Coercion' in Lillich R., Economic Coercion and the New International Economic Order (The Mitchie Company, Law Publishers: Charlottesville, Virginia) 87.

Bowie, R.R. (1974) Suez 1956: International Crises and the Role of Law (Oxford University Press).

Brandtner, B. and Rosas, A. (1998) 'Human Rights and the External Relations of the European Community: An Analysis of Doctrine and Practice' 9 EJIL 468.

_ (1999) 'Trade Preferences and Human Rights' in Alston P. (ed.) 699 The EU and Human Rights (Oxford University Press) 699.

Brierly, L.J. (1925) 'Matters of Domestic Jurisdiction' 6 BYIL 8.

(1959) 'Sanctions in International Law' in Lauterpacht H. and Waldock C.H.M. (eds.), The Basis of Obligation in International Law and Other Papers of the late Fames Leslie Brierly, (Oxford).

Briggs, W.H. (ed.) (1953) The Law of Nations: Cases, Documents and Notes, 2nd edn (Stevens).

Brosche, H. (1976) 'The Arab Oil Embargo and United States Pressure Against Chile: Economic and Political Coercion and the Charter of the United Nations' in Lillich R., Economic Coercion and the New International Economic Order (The Mitchie Company, Law Publishers: Charlottesville, Virginia) 292.

Brownlie, I. (1990) Principles of Public International Law, 4th edn (Oxford University Press).

Buergenthal, T. (1968) 'Proceedings against Greece under the European Convention of Human Rights' 62 AfIL 2, 441.

Bull, H. (1995) The Anarchical Society: A Study of Order and World Politics, 2nd edn (Columbia University Press).

Busuttil, J. (1982) 'The Bonn Declaration on International Terrorism: A Non-Binding International Agreement on Aircraft Hijacking' 31 ICLQ 474.

Byers, M. (1997) 'Conceptualising the Relationship between fus Cogens and Erga Omnes Rules' 66 NFIL 211.

Cannizzaro, E. (2001) 'The Role of Proportionality in the Law of International Countermeasures' 12 EfIL 890.

- (ed.) (2002) The European Union as an Actor in International Relations (Kluwer Law International).

Cassese, A. (1990) Human Rights in a Changing World (Polity Press).

- (2001) International Law (Oxford University Press).

Cassese, A. and Weiler H.H.J. (eds) (1988) Change and Stability in International Law-Making, (Walter de Gruyter).

Chamberlain, K. (1983) 'Collective Suspension of Air Services with States which Harbour Hijackers' 32 ICLQ616. 


\section{Bibliography}

Charney, J. (1989) 'Third State Remedies in International Law' 10 MFIL 57. (1993) 'Universal International Law' 87 AfIL, 529.

Charnovitz, S. (2001) 'Rethinking WTO Trade Sanctions' 95 AfIL 4, 792-832.

Chinkin, C. (1993) Third Parties in International Law (Clarendon Press).

— (1996) 'The Legality of the Imposition of Sanctions by the European Union in International Law' in Evans (ed.) Aspects of Statehood and Institutionalism in Contemporary Europe, (Dartmouth Publishing Company Ltd) 183.

Claude, I.L. (1964) 'The OAS, the UN and the United States' 547 International Conciliation 1.

Cortright, D. (2001) 'Powers of Persuasion: Sanctions and Incentives in the Shaping of International Society' 38 International Studies 2, 113.

Coufoudakis, V. (1977-78) 'The European Economic Community and the "Freezing" of the Greek Association, 1967-1974' 16 Journal of Common Market Studies 114.

Craig, P. (1999) 'Unreasonableness and Proportionality in UK Law' in Ellis E. (ed.) The Principle of Proportionality in the Lawes of Europe (Hart Publishing), 85.

Crawford, J. (1994) 'Countermeasures as Interim Measures' 5 EfIL 65.

(2000) 'Responsibility to the International Community as a Whole', Fourth Annual Snyder Lecture, April, Bloomington School of Law, Indiana University. Available at http://www.lcil.cam.ac.uk/media/lectures/doc/Snyderlect 00(f).doc

- (2002) The International Law Commission's Articles on State Responsibility, Introduction, Text and Commentaries, 1st edn (Cambridge University Press).

Crawford, J., Peel, J. and Olleson, S. (2001) 'The ILC's Articles on Responsibility of States for Internationally Wrongful Acts: Completion of the Second Reading' 12 EfIL 963.

Czaplinski, W. (1997-98) 'Concepts of fus Cogens and Obligations Erga Omnes in International Law in the Light of Recent Developments' 23 Polish Yearbook of International Law 87.

Damrosch, L. (1997) 'Enforcing International Law through Non-Forcible Measures' 269 $R d C 109$.

Dawidowicz, M. (2006) 'Public Law Enforcement without Public Law Safeguards? An Analysis of State Practice on Third-Party Countermeasures and their Relationship to the UN Security Council' BYIL 333.

Delbruck, J. (1992) 'The Erga Omnes Applicability of Human Rights', 30 AVR 16.

_ (1992) 'International Economic Sanctions and Third States' AdV 86.

_ (ed.) (1993) The Future of International Law Enforcement: New Scenarios - New Law? (Duncker \& Humblot).

- (1995) 'The Impact of the Allocation of International Law Enforcement Authority on the International Legal Order' in Delbruck J. (ed.), Allocation of Law Enforcement Authority in the International System (Duncker \& Humblot).

_ (1999) "Laws in the Public Interest" - Some Observations on the Foundations and Identification of Erga Omnes Norms in International Law' in Gotz et al. (eds) Liber Amicorum Gunther Faenicke - Zum 85. Geburtstag.

Dinstein, Y. (1992) 'The Erga Omnes Applicability of Human Rights', 30 AVR 16.

(2004) The Conduct of Hostilities under the Law of International Armed Conflict (Cambridge University Press).

Dolzer, R. (1987) 'Enforcement of International Obligations through Regional Arrangements: Structures and Experience of the OAS' 47 ZaoRV 113.

Dominicé, C. (1999) 'The International Responsibility of States for Breach of Multilateral Obligations' 10 EJIL 2.

Dominicé, C., Patry, R. and Reymond, C. (eds) (1993) Études de droit international en l'honneur de Pierre Lalive (Helbing \& Lichtenhahn).

Domke, M. (1959) 'The Israeli-Soviet Oil Arbitration', AfIL 53 4, 787. 
Doxey, P.M. (1971) Economic Sanctions and International Enforcement (Oxford University Press).

Dupuy, M.-P. (1998) 'International Law: Torn between Coexistence, Cooperation and Globalization. General Conclusions', 9 EfIL 278.

_ (1999) 'The Danger of Fragmentation or Unification of the International Legal System and the International Court of Justice' 31 NYUJInt'lLEPol 791.

- (2005) 'Some Reflections on Contemporary International Law and the Appeal to Universal Values: A Response to Martti Koskenniemi' 16 EfIL 1, 131.

Duxbury, A. (1997) 'Rejuvenating the Commonwealth - The Human Rights Remedy', 46 ICLQ344.

Eagleton, C. (1928) The Responsibility of States in International Law (New York University Press). - (1957) International Government, 3rd edn (Ronald Press).

Elagab, O. (1988) The Legality of Non-forcible Countermeasures in International Law (Clarendon Press).

Ellis, E. (ed.) (1999) The Principle of Proportionality in the Lawes of Europe (Hart Publishing).

Erades, L. (1993) Interactions between International and Municipal Law: A Comparative Case Law Study (T.M.C. Asser Instituut).

Erasmus, G. (1992) 'Third States and Sanctions in Public International Law - the Position of South Africa', 30 AVR 128.

Evans, M. (ed.) (1996) Aspects of Statehood and Institutionalism in Contemporary Europe (Dartmouth Publishing Company Ltd).

- (ed.) (2003) International Law, 1st edn (Oxford University Press).

Falk, R. (1998) Law in an Emerging Global Village: A Post-Westphalian Perspective (Transnational Publishers, Inc.).

Feldman D. (1999) 'Proportionality and the Human Rights Act 1998' in Ellis E. (ed.), The Principle of Proportionality in the Laws of Europe (Hart Publishing), 117.

Ferencz, B. (1983) Enforcing International Law: A Documentary History and Analysis (Oceana Publications, Inc.).

Ferguson-Brown, K. (1988-89) 'The Legality of Economic Sanctions against South Africa in Contemporary International Law' 14 SAYIL 59.

Forsythe, D. (1989) Human Rights and World Politics, 2nd edn (University of Nebraska Press).

Fox, H.G., and Roth B. (2000) Democratic Governance and International Law (Cambridge University Press).

Frahm, K. (1992) 'Comment: The Erga Omnes Applicability of Human Rights' 30 ARV 34.

Francioni, F. and Scovazzi, T. (eds) (1991) International Responsibility for Environmental Harm (Martinus Nijhoff).

Franck, M.T. (1990) The Power of Legitimacy among Nations (Oxford University Press).

- (1992) 'The Powers of Appreciation: Who is the Ultimate Guardian of UN Legitimacy?' 86 AfIL 519. - (1992) 'The Emerging Right to Democratic Governance', 86 AfIL 46.

_ (1993) 'Fairness in the International Legal and Institutional System' $240 R d C 118$.

Fredman, S. (1979) 'Comment: U.S. Trade Sanctions Against Uganda: Legality under International Law' Law \& Policy in International Business 1149.

Frowein, J. (1987) 'Collective Enforcement of International Obligations' 47 Zeitschrift fuir Ausländisches Öffentliches Recht und Völkerrecht 67.

_ (1993) 'International Law Enforcement in Case of Security Council Inaction' in Delbruck J. (ed.), The Future of International Law Enforcement: New Scenarios - New Law? (Duncker \& Humblot) 111.

(1994) 'Reactions by Not Directly Affected States to Breaches of Public International Law' Academie de Droit International, Recueil des Cours, Collected Courses 248 IV, 345. 
Gaja, G. (1981) 'fus Cogens Beyond the Vienna Convention’ 172 RdC III, 271.

- (1989) 'Obligations Erga Omnes, International Crimes and Fus Cogens: A Tentative Analysis of Three Related Concepts' in J. Weiler, A. Cassese, M. Spindei (eds), International Crimes of State: A Critical Analysis of the ILC's Draft Article 19 on State Responsibility (de Gruyter) 151.

_ (1999) 'Should All References to International Crimes Disappear from the ILC

Draft Articles on State Responsibility?’ 10 EfIL 2, 365.

Gardam, G.J. (1993) 'Proportionality and Force in International Law' 87 AfIL 3, 391.

- (2004) Necessity, Proportionality and the Use of Force by States (Cambridge University Press).

Gardner, R.N. (1974) 'The Hard Road to World Order' 52 Foreign Affairs 556.

Gerstenberg, O. (2005) 'What International Law should (not) become. A Comment on Koskenniemi' 16 EfIL 1, 125.

Gotz, V., Selmer, P. and Wolfrum, R. (eds) (1999) Liber Amicorum Gunther Faenicke - Zum 85. Geburtstag (Springer).

Gowlland-Debbas, V. (2001) United Nations Sanctions and International Law (Kluwer Law International).

Graefrath, B. (1989) 'International Crimes and Collective Security' in Weiler J., Cassese A. and Spinedi M. (eds), International Crimes of States: A Critical Analysis of the ILC's Draft Article 19 on State Responsibility (de Gruyter).

Greig, D. (1976) International Law, 2nd edn (Butterworth).

- (2002) " "International Community", "Interdependence" and All That ... Rhetorical Correctness?' in Kreijen G. (ed.), State, Sovereignty, and International Governance (Oxford University Press), 521.

Guttry, de A. (1986-87) 'Some Recent Cases of Unilateral Countermeasures and the Problem of their Lawfulness in International Law' 9 IYIL.

Habermas, J. (2003) 'Interpreting the Fall of a Monument' 4 German Law Fournal 706.

Hafner, G. (2003) 'Risks Ensuing from Fragmentation of International Law' ILC Report on the Work of its 52nd Session, Official Records of the General Assembly, 55th session, Supplement No. 10 (A/55/10), Annex.

Hailbronner, K. (1992) 'Sanctions and Third Parties and the Concept of International Public Order' 30 AVR 2.

Hall, E.W. (1924) A Treatise on International Law, 8th edn (A. Pearce Higgins).

Hannikainen, L. (1988) Peremptory Norms (Jus Cogens) in International Law (Finnish Lawyers Publishing Company).

Harris, J.D. (2004) Cases and Materials on International Law, 6th edn (Sweet \& Maxwell).

Herdegen, M. (1994) 'The ‘Constitutionalization' of the UN Security System’ 27 Vanderbilt Fournal of Transnational Law 135.

Herodotus (1959) The Histories (trans. Aubrey de Selincourt; Penguin).

Higgins, R. (1976-77) 'Derogations under Human Rights Treaties', BrIL 281.

- (1994) Problems and Process: International Law and How to Use It (Clarendon Press).

Hillgruber, C. (2006) 'The Right of Third States to take Countermeasures' in Tomuschat C. and Thouvenin M.J. (eds), The Fundamental Rules of the International Legal Order: Jus Cogens and Obligations Erga Omnes, 268.

Hoffmann, Rt Hon Lord (1999) 'The Influence of the European Principle of Proportionality upon UK Law' in Ellis E. (ed.), The Princeple of Proportionality in the Laws of Europe (Hart Publishing), 107.

de Hoogh, A. (1991) 'The Relationship between Fus Cogens, Obligations Erga Omnes and International Crimes: Peremptory Norms in Perspective' 42 Austrian Fournal of Public International Law 183.

— (1996) Obligations Erga Omnes and International Crimes (Kluwer Law International). 
Hufbauer, J., Schott, J. and Elliott, A. (1985) Economic Sanctions Reconsidered: History and Current Policy (Institute for International Economics).

— (1990) Sanctions Reconsidered: Supplemental Case Histories, 2nd edn (Institute for International Economics).

Hutchinson, N.D. (1988) 'Solidarity and Breaches of Multilateral Treaties', 59 BrIL 151.

Jacobs, G. F. (1999) 'Recent Developments in the Principle of Proportionality in European Community Law' in Ellis E. (ed.), The Principle of Proportionality in the Lawe of Europe (Hart Publishing), 1.

Jennings, Y. R. (1938) 'The Caroline and McLeod Cases' 32 AfIL 1, 82.

Jessup, P. (1948) A Modern Law of Nations: An Introduction (Macmillan).

Johnson, J. (1975) Ideology, Reason and the Limitation of War (Princeton University Press).

- (1981) Just War Tradition and the Restraint of War (Princeton University Press).

Jorgensen, N. (2000) The Responsibility of States for International Crimes (Oxford University Press).

Kaikobad, H.K. (1992) 'Self-defence, Enforcement Action and the Gulf Wars 1980-88 and 1990-91' 63 BYIL 299.

Kamerbeek, J. C. (1978) The Plays of Sophocles: Commentaries VII The Oedipus Coloneus.

Katselli, E. (2005) 'Countermeasures by Non-Injured States in the Law on State Responsibility', European Society of International Law. Available at http://www.esil-sedi.org/ english/pdf/Katselli.PDF.

_ (2007) 'Holding the Security Council Accountable for Human Rights Violations', Human Rights \& International Legal Discourse Vol. 1, Issue No. 2, 301.

Kelsen, H. (1950) The Law of the United Nations. A Critical Analysis of its Fundamental Problems (Stevens).

Khaldun, I. (1981) The Muqaddimah, An Introduction to History (N.J. Dawood).

Kido, M. (1997) 'The Korean Airlines Incident on September 1, 1983, and some Measures Following it' 62 Journal of Air Law and Commerce 1049.

Kingsbury, B. (1998) 'The Concept of Compliance as a Function of Competing Conceptions of International Law' 19 MFIL 345.

Kirchner, S. (2004) 'Relative Normativity and the Constitutional Dimension of International Law: A Place for Values in the International Legal System?' 5 GLf 1, 47.

Klein, P. (2002) 'Responsibility for Serious Breaches of Obligations Deriving from Peremptory Norms of International Law and United Nations Law' 13 EfIL 5, 1241.

Koji, T. (2001) 'Emerging Hierarchy in International Human Rights and Beyond: From the Perspective of Non-derogable Rights' 12 EfIL 917.

Kommers, D. and Loescher, G. (eds) (1979) Human Rights and American Foreign Policy (University of Notre Dame Press).

Koskenniemi, M. (1997) 'Hierarchy in International Law: A Sketch' 8 EfIL 566.

_ (2001) 'Solidarity Measures: State Responsibility as a New International Order?' 71 BYIL 337.

(2005) 'International Law in Europe: Between Tradition and Renewal' 16 EfIL 1, 113.

Koskenniemi M. and Leino P. (2002) 'Fragmentation of International Law? Postmodern Anxieties' 15 Leiden Fournal of International Law 553.

Koutrakos, P. (2001) Trade, Foreign Policy and Defence in EU Constitutional Law: The Legal Regulation of Sanctions, Exports of Dual-use Goods and Armaments (Hart Publishing).

Kreijen, G. (ed.) (2002) State, Sovereignty, and International Governance (Oxford University Press).

Kronenberger, V. (ed.) (2001) The European Union and the International Legal Order: Discord or Harmony? (T.M.C. Asser Press).

Kuhn, A. (1941) 'Foreign Funds Controls and Foreign Owned Property', 35 AfIL (Oct) No. 4,651 . 
Kuijper, P.J. (1998) 'The Court and the Tribunal of the EC and the Vienna Convention on the Law of Treaties 1969' 25 Legal Issues of European Integration 1, 1.

Kuyper, P.J. (1982) 'Community Sanctions against Argentina: Lawfulness under Community and International Law' in O'Keeffe and Schermes (eds). Essays in European Law and Integration (Kluwer Law International) 141.

Lattanzi, F. (1989) 'Sanzioni internazionali' XLI Enciclopedia del diritto.

Lauterpacht, H. (1927) Private Law Sources and Analogies of International Law (Longman, Green).

— (1937) 'Règles générales du droit de la paix' $62 R d C$ IV, 95.

(1949) 'Restrictive Interpretation and the Principle of Effectiveness in the Interpretation of Treaties' 26 BIIL 48.

- (1952) Oppenheim's International Law: A Treatise, 7th edn (Volume II, Disputes, War and Neutrality) (Longman).

Lauterpacht, H. and Waldock, C.H.M. (eds) (1959) The Basis of Obligation in International Law and Other Papers of the late Fames Leslie Brierly, 2nd edn (Oxford University Press).

Levin, B.L. (1979) 'The Organization of American States and the United Nations' in Andemicael, B., Regionalism and the United Nations (Oceana Publications, Inc.).

Liang-Fenton, D. (ed.) (2004) Implementing U.S. Human Rights Policy (United States Institute of Peace Press).

Lillich, R. (1976) Economic Coercion and the New International Economic Order (The Mitchie Company Law Publishers: Charlottesville, Virginia).

— (1977) 'Economic Coercion and the International Legal Order' in Paust J.J. and Blaustein P.A., The Arab Oil Weapon (Oceana Publications) 159. (1991) 'The Soering Case' 85 AfIL 1, 128.

Luttwak, E. (1995) 'Toward Post-Heroic Warfare' 74 Foreign Affairs 3, 109, 118.

Macdonald, R. (1987) 'Fundamental Norms in Contemporary International Law' 25 CYIL 115.

(1993) 'The Principle of Solidarity in Public International Law' in Dominicé C., Patry R. and Reymond C. (eds) Etudes de droit international en l'honneur de Pierre Lalive (Helbing \& Lichtenhahn) 275.

McDougal, M. and Feliciano, F. (1961) Law and Minimum World Public Order (Yale University Press).

(1994) The International Law of War: Transnational Coercion and World Public Order (Martinus Nijhoff).

MacGibbon, C.I. (1953) 'Some Observations on the Part of Protest in International Law' 30 BIIL 293.

McLachlan, C. (2005) 'The Principle of Systemic Integration and Article 31(3)(c) of the Vienna Convention' 54 ICLQ 279.

McNair, D.A. (1957) 'The General Principles of Law Recognized by Civilized Nations' 33 BYIL 1.

- (1961) The Law of Treaties (Clarendon Press).

Malamut, M. (1983) 'Aviation: Suspension of Landing Rights of Polish Airlines in the United States - 93 CAB Reports 479 (1981)’ 24 HILf 190.

Marceau, G. (2002) 'WTO Dispute Settlement and Human Rights' 13 EfIL 4, 753.

Marschik, A. (1998) 'Review Essay: Too Much Order? The Impact of Special Secondary

Norms on the Unity and Efficacy of the International Legal System' 9 EfIL 1, 240.

Matsui, Y. (1994) 'Countermeasures in the International Legal Order' 37 FAIL 1.

Mavroidis, P. (2000) 'Remedies in the WTO Legal System: Between a Rock and a Hard Place' 11 EJIL 4, 763.

Mayall,J. (1984) 'The Sanctions Problem in International Economic Relations: Reflections in the Light of Recent Experience' 60 International Affairs 4, 631. 
Megret, F. and Hoffmann, F. (2003) 'The UN as a Human Rights Violator? Some Reflections on the United Nations Changing Human Rights Responsibilities', 25 HRQ314.

Melescanu, T. (2003) The European Union and the General International Law, available at http://www.unibuc.ro/eBooks/StiintePOL/recenzie/7.htm.

Meron, T. (2003) 'International Law in the age of Human Rights', 301 RdC 296.

de Mestral, A. (1983) 'Canadian Practice in International Law during 1982' 21 CrIL 337. - (1983) 'Australian Practice in International Law, 1981 to 1983', 10 AYIL 573.

Mitchell, D.A. (2001) 'Does One Illegality Merit Another? The Law of Belligerent Reprisals in International Law' 170 Military Law Review 155.

Moore, B.J. (1898) History and Digest of the International Arbitrations to which the United States has been a Party Vol. 4 (US Government Printing Office).

Mosler, H. (1980) The International Society as a Legal Community (Sijthoff).

— (1984) 'International Legal Community' in Bernhardt, R. (ed.), Encyclopedia of Public International Law, Vol. 7 (North-Holland: Elsevier Science Publishers) 309.

Moyer, H. and Mabry, L. (1988) Export Controls as Instruments of Foreign Policy: The History, Legal Issues and Policy Lessons of Three Recent Cases (International Law Institute).

Mullerson, R. (1997) Human Rights Diplomacy (Routledge).

- (2000) Ordering Anarchy: International Law in International Society (Martinus Nijhoff).

Nash, M. (1988) 'Contemporary Practice of the United States Relating to International Law', 82 AfIL 566.

Neff, S. (1988) 'Boycott and the Law of Nations: Economic Warfare and Modern International Law in Historical Perspective' 59 BrIL 113.

(2003) 'A Short History of International Law' in Evans M. (ed.) International Law, $1^{\text {st }}$ edn. (Oxford University Press) 31.

Neuman, O. (2005) 'Talking to Ourselves' 16 EfIL 1, 139.

Noortman, M. (2005) Enforcing International Law: From Self-Help to Self-Contained Regimes (Ashgate Publishing).

Nurnberger, R. (2003) 'Why Sanctions never Work: in the Case of the Late Idi Amin, they Clearly Helped drive him from Power - almost' 17 The International Economy (Fall). Issue 4,71 .

Nuttall, S.J. (1987) 'Interaction between European Political Cooperation and the European Community' 7 rearbook of European Law 211.

O'Connell. M. (2002) 'Debating the Law of Sanctions' 13 EfIL 1, 63.

Okafor-Obasi. O. (2003) The Enforcement of State Obligations to Respect and Ensure Human Rights in International Law (Universität Potsdam).

O'Keeffe, D. and Schermers, G.H. (eds) (1982) Essays in European Law and Integration (Kluwer Law International).

Okowa, P. (1998) 'International Court of Justice: Recent Cases, Case Concerning the Gabčikovo-Nagymaros Project (Hungary/Slovakia)' 47 ICLQ 688.

Oppenheim, L. (1947) International Law: A Treatise, 6th edn (ed. H. Lauterpacht; Longman, Green).

Orakhelashvili, A. (2005) 'The Impact of Peremptory Norms on the Interpretation and Application of United Nations Security Council Resolutions' 16 EfIL 1, 89.

- (2006) Peremptory Norms in International Law (Oxford University Press).

Paasivirta, E. and Rosas, A. (2002) 'Sanctions, Countermeasures and Related Actions in the External Relations of the EU: A Search for Legal Frameworks' in Cannizzaro E. (ed.) The European Union as an Actor in International Relations (Kluwer Law International) 207.

Paust, J.J. and Blaustein, P.A. (1977) The Arab Oil Weapon (Oceana Publications, Inc.).

_ (1977) 'Commentary: The Arab Oil Weapon - A Treaty to International Peace' in Paust, J.J., and Blaustein, P.A., The Arab Oil Weapon (Oceana Publications, Inc.). 
Pauwelyn, J. (2000) 'Enforcement and Countermeasures in the WTO: Rules are Rules Toward a More Collective Approach’ 94 AfIL2, 335.

— (2001) 'The Role of Public International Law in the WTO: How Far Can we Go?' 95 AfIL 535.

- (2003) (a) Conflict of Norms in Public International Law. How WTO Law Relates to Other Rules of International Law (Cambridge University Press).

- (2003) (b) 'A Typology of Multilateral Treaty Obligations: Are WTO Obligations Bilateral or Collective in Nature?' 14 EfIL 5, 907.

_ (2003) (c) 'How to Win a World Trade Organization Dispute Based on Non-World Trade Organization Law? Questions of Jurisdiction and Merits' 37 (6) Journal of World Trade 997.

Peaslee, A.J. (1916) 'The Sanction of International Law' 10 AfIL 2, 335.

Pegna Lopes, O. (1998) 'Counter-claims and Obligations Erga Omnes before the International Court of Justice' 9 EfIL 4, 724.

Pellet, A. (2001) 'The New Draft Articles of the International Law Commission on the Responsibility of States for Internationally Wrongful Acts: A Requiem for States' Crime?' 32 NKIL 55.

Petman, J. (2004) 'Resort to Economic Sanctions by Not Directly Affected States' in Picchio Forlati L. and Sicilianos L.-A., Economic Sanctions in International Law (Martinus Nijhoff Publishers) 371 .

Picchio Forlati, L. and Sicilianos, L.-A. (2004) Economic Sanctions in International Law (Martinus Nijhoff).

Pildes, R. (2002) 'Conflicts Between American and European Views of Law: The Dark Side of Legalism’ 44 VJIL 145.

Posner, E.A. (2003) 'Do States Have a Moral Obligation to Obey International Law?; 55 Stanford Fournal of International Law 1916.

Pulkowski, D. (2006) 'Narratives of Fragmentation: International Law between Unity and Multiplicity'. Available at http://www.esil-sedi.org/english/pdf/Pulkowski.PDF.

Ragazzi, M. (1997) The Concept of International Obligations Erga Omnes (Clarendon Press).

Reichert-Facilides, D. (1998) 'Down the Danube: The Vienna Convention on the Law of Treaties and the Case Concerning the Gabčikovo-Nagymaros Project' 47 ICLQ 4, 837.

Reisman, W.M. (1971) Nullity and Revision: The Review and Enforcement of International Fudgments and Awards (Yale University Press).

Reisman, W.M., Arsanjani, M.H., Wiessner, S. and Westerman, G.S. (2004) International Law in Contemporary Perspective (Foundation Press).

Renwick, R. (1981) Economic Sanctions (Harvard University Press).

Reuter, P. (1989) Introduction to the Law of Treaties (Pinter).

Riedel, E. and Will, M. (1999) 'Human Rights Clauses in External Agreements of the EC' in Alston P. (ed.), The EU and Human Rights (Oxford University Press) 723.

Roberts, A. and Kingsbury, B. (eds) (1993) United Nations, Divided World, 2nd edn (Clarendon Press).

Root, E. (1916) 'The Outlook for International Law', 10 AfIL (Jan.) No. 1.

Rosas, A. (2001) 'The European Union and International Human Rights Instruments' in Kronenberger V. (ed.) The European Union and the International Legal Order: Discord or Harmony? (T.M.C. Asser Press, The Hague) 53.

- (2002) 'The European Union and International Dispute Settlement' in Boisson de Chazournes, L., Romano, C. and Mackenzie, R. (eds), International Organizations and International Dispute Settlement: Trends and Prospects (Transnational Publishers, Inc.) 49. 
Rosenne, S. (1998) 'Some Reflections Erga Omnes' in Anghie A. and Sturgess G. (eds) Legal Visions of the 21st Century: Essays in Honour of Judge Christopher Weeramantry (Kluwer Law International) 509.

Rossides, T.E. (1991) 'Cyprus and the Rule of Law' 17 Syracuse Fournal of International Law and Commerce 1.

Rozakis, L.C. (1976) The Concept of Jus Cogens in the Law of Treaties (North-Holland).

Sachariew, K. (1988) 'State Responsibility Multilateral Treaty Violations: Identifying the 'Injured State' and its Legal Status' 35 Netherlands International Law Review 273.

Salzberg, J. and Young, D. (1977) 'The Parliamentary Role in Implementing International Human Rights: A U.S. Example' 12 Texas International Law fournal 251.

Schachter, O. (1960) 'The Enforcement of International Judicial and Arbitral Decisions' 54 AJIL 1.

Schrijver, N. (1999) 'The Changing Nature of State Sovereignty' 70 BrIL 65.

Schulte, C. (1999) 'The Enforcement of Obligations Erga Omnes before the International Court of Justice, Procedural Law and the East Timor Judgment in Might and Right in International Relations' XXIII Thesaurus Acroasium 531.

Schwarzenberger, G. (1957) International Law as Applied by International Courts and Tribunals, Vol. I (Stevens).

_ (1965) 'International Fus Cogens' 43 Texas Law Review 455.

— (1965) 'The Problem of International Public Policy' 18 CLP.

Scobbie, I. (2002) 'The Invocation of Responsibility for the Breach of 'Obligations under Peremptory Norms of General International Law' 13 EfIL 5, 1201.

Scott Maravilla, C. (2002) 'The Ability of a State-Owned Enterprise to Declare Force Majeure Based upon Actions of the State' Fournal of International and Comparative Law at Chicago-Kent Volume 2, 82.

Selden, Z. (1999) Economic Sanctions as Instruments of American Foreign Policy (Praeger).

Shaw, M. (2008) International Law, 6th edn (Cambridge University Press).

Shelton, D. (2003) 'International Law and Relative Normativity' in Evans M. (ed.), International Law, $1^{\text {st }}$ edn. (Oxford University Press).

Shihata, I.F.I. (1976) 'Arab Oil Policies and the New International Economic Order' in Lillich R., Economic Coercion and the New International Economic Order (The Mitchie Company, Law Publishers: Charlottesville, Virginia) 231.

_ (1977) 'Destination Embargo of Arab Oil: Its Legality Under International Law' in Paust J.J. and Blaustein P.A. The Arab Oil Weapon (Oceana Publications, Inc./Dobbs Ferry) 107.

Sicilianos, A.L. (1993) 'The Relationship between Reprisals and Denunciation or Suspension of a Treaty' 4 EFIL 3, 341.

- (2002) 'The Classification of Obligations and the Multilateral Dimension of the Relations on International Responsibility' 13 EfIL 1127.

Simma, B. (1985) 'Self-contained Regimes' XVI NYIL 111.

(1988) 'Bilateralism and Community Interest in the Law on State Responsibility' in Dinstein Y., International Law in a Time of Perplexity: Essays in Honour of Shabtai Rosenne (Martinus Nijhoff) 821.

- (1993) 'Does the UN Charter Provide an Adequate Legal Basis for Individual or Collective Responses to Violations of Obligations Erga Omnes?' in Delbruck J. (ed.) The Future of International Law Enforcement: New Scenarios - New Law? (Duncker \& Humblot) 125.

— (1994) 'From Bilateralism to Community Interest in International Law' 250 $R d C$ VI, 217. 
Simma, B. and Alston, P. (1992) 'The Sources of Human Rights Law: Custom, Jus Cogens, and General Principles' 12 AYIL 82.

Simma, B. and Pulkowski, D. (2006) 'Of Planets and the Universe: Self-Contained Regimes in International Law' 17 EfIL 3, 483.

Simons, G. (1999) Imposing Economic Sanctions: Legal Remedy or Genocidal Tool? (Pluto Press).

Slaughter, M.A. (1995) 'International Law in a World of Liberal States' 6 EfIL 503.

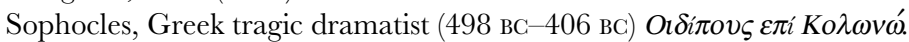

Spinedi, M. (1989) 'International Crimes of State: The Legislative History' in J. Weiler, A. Cassese and M. Spinedi (eds), International Crimes of State: A Critical Analysis of the ILC's Draft Article 19 on State Responsibility (de Gruyter) 1.

- (1991) 'Les consequences juridiques d'un fait internationalement illicite causant un dommage à l'environnement' in Francioni F. and Scovazzi T. (eds) International Responsibility for Environmental Harm, 75.

Stein, T. (1983) 'European Political Cooperation as a Component of the Foreign Affairs System' 43 ZaoRV 49.

- (1992) 'International Measures against Terrorism and Sanctions by and against Third States' 30 AVR 38.

Stevens, R.K. (1989) Border Diplomacy: The Caroline and McLeod Affairs in Anglo-American-Canadian Relations, 1837-1842 (University of Alabama Press).

Sur S. (1988) 'Discussion Statement' in Cassese A. and Weiler H.H.J. (eds.) Change and Stability in International Law-Making (de Gruyter) 128.

Swan, S. (1970) 'Netherlands State practice for the parliamentary year 1969-69' I NYIL 171.

Tams, G. (2005) Enforcing Obligations Erga Omnes in International Law (Cambridge University Press).

Tomuschat, C. (1993) 'Obligations Arising for States Without or Against their Will' 241 $R d C$ IV, 195.

Tomuschat, C. and Thouvenin M.J. (eds) (2006) The Fundamental Rules of the International Legal Order: Jus Cogens and Obligations Erga Omnes (Martinus Nijhoff).

Tridimas, T. (1999) 'Proportionality in Community Law: Searching for the Appropriate Standard of Scrutiny' in Ellis E. (ed.), The Principle of Proportionality in the Laws of Europe (Hart Publishing), 65.

Ullman, R. (1977-78) 'Human Rights and Economic Power: The United States versus Idi Amin' 56 Foreign Affairs 529.

Van Gerven, W. (1999) 'The Effect of Proportionality on the Actions of Member States of the European Community: National Viewpoints from Continental Europe' in Ellis E. (ed.) The Principle of Proportionality in the Laws of Europe (Hart Publishing), 37.

Van Hoof, G.J.H. (1983) Rethinking the Sources of International Law (Deventer).

Vattel, E. (1758) The Law of Nations or the Principles of Natural Law (trans. Charles G. Fenwick).

Verdirame, G. (2008) 'Breaches of the European Convention on Human Rights resulting from the conduct of international organizations' 2 EHRLR 209.

Verdross, A. (1937) 'Forbidden Treaties in International Law: Comments on Professor Garner's Report on the "Law of Treaties", 31 AfIL 4, 571.

- (1966) 'Jus Dispositivum and Fus Cogens in International Law' 60 AfIL 55.

Vereshchetin, V. (1996) 'New Constitutions and the Old Problem of the Relationship between International Law and National Law' 7 EfIL 29.

Verhoeven, J. (1998) 'Jus Cogens and Reservations or "Counter-reservations" to the Jurisdiction of the International Court of Justice' in Wellens K. (ed.) International Law: Theory and Practice, Essays in Honour of Eric Suy (Martinus Nijhoff Publishers) 195. 
de Villiers, L. (1995) In Sight of Surrender: The US Sanctions Campaign against South Africa, 1946-1993 (Praeger).

Vincent, R.J. (1974) Non-intervention and International Order (Princeton University Press).

von Geusau, A.F. (2002) 'Staying the Course: The Concept of Sovereignty in the Work of

Pieter Kooijmans' in Kreijen G. (ed.) State, Sovereignty, and International Governance (Oxford University Press) 635.

Warbrick, C. (1990) 'The Theory of International Law: Is there an English Contribution?' in W.E. Butler (ed.), Perestroika and International Law, (Martinus Nijhoff) 41.

Warbrick, C. and Lowe, V. (eds) (1994) The United Nations and Principles of International Law: Essays in Memory of Michael Akehurst (Routledge).

Warbrick, C., O’ Boyle, M. and Harris, J.D. (1995) Law of the European Convention on Human Rights (Butterworth).

Weil, P. (1983) 'Towards Relative Normativity in International Law' 77 AfIL 419.

Weiler, H.H.J., Cassese, A. and Spinedi, M. (eds.) (1989) International Crimes of State, A Critical Analysis of the ILC's Draft Article 19 on State Responsibility (Walter de Gruyter).

Weiss Brown, E. (2002) 'Invoking State Responsibility in the Twenty-First Century' 96 AfIL 798.

Wellens, K. (ed.) (1998) International Law: Theory and Practice, Essays in Honour of Eric Suy (Martinus Nijhoff).

— (1998) 'The Court's Judgment Concerning the Gabčikovo-Nagymaros Project (Hungary/Slovakia): Some Preliminary Reflections' in Wellens K. (ed.) International Law: Theory And Practice: Essays In Honour Of Eric Suy (Martinus Nijhoff) 765-801.

- (1995) 'Diversity in Secondary Rules and the Unity of International Law: Some Reflections on Current Trends' in Barnhoorn M.N.A.L. and Wellens K. (eds) Diversity in Secondary Rules and the Unity of International Law (The Hague: Nijhoff) 3.

White, N. and Abass, A. (2003) 'Countermeasures and Sanctions' in Evans M. (ed.) International Law, $1^{\text {st }}$ edn. (Oxford University Press) 505.

Wicker, C. (2002) 'The Scope of Proportionality in the Right of Self-defence and in the Law of International Counter-measures', dissertation submitted to the University of Durham for the degree of LLM in International and European Legal Studies.

Williams, B. (1943) 'The Coming of Economic Sanctions into American Practice', 37 AfIL (July) No. 3, 386.

Yenkong Ngangjoh, H. (2004) 'Collective Countermeasures and the WTO Dispute Settlement: Solidarity Measures Revisited’ 2. Available at http://www.njcl.utu.fi/2_2004/ article2.pdf.

Zemanek, K. (1987) 'The Unilateral Enforcement of International Obligations' 47 ZaoRV 32 .

- (2000) 'New Trends in the Enforcement of Erga Omnes Obligations' 4 Max Planck TBUNLI.

Zoller, E. (1984) Peacetime Unilateral Remedies: An Analysis of Countermeasures (Transnational Publishers, Inc.). 


\section{Index}

Aaland Islands, 40, 41, 42

General Peace Treaty, 1856 Aaland

Islands Convention, 40

Abuse, 3, 9, 10, 25, 32, 208, 279, 281, 290

powerful states, by, $6,9,69,87$

countermeasures, of $9,66,72,77,89$, $153,178,208,248,250$

dangers, of, 263

diplomatic missions, of, 219

human rights, 35, 194

reprisals, of, 88

solidarity measures, of, 262

Action popularis, 42, 85

Afghanistan, 50, 173

air services agreement, with, 107

Bonn Declaration, 106

Hague Convention, 106

Internal affairs, of, 140

Soviet invasion, of, 135, 136, 138, 139, 140, 205

Trade Agreement 1972

Treaty of Friendship,

Goodneighborliness and

Cooperation between the USSR

and Afghanistan 1978, 138

African, Caribbean and Pacific Group of

States, 181, 198

Agreements, see also treaties

African, Caribbean and Pacific

Group, 198

air, 107

Air Services, 170, 193, 194, 270, 274, 275

Air Transport, 145, 146, 147, 149

application, of, 100

Association, with

Greece, 119, 120, 121, 122, 131, aviation, 105, 106, 107, 147, 150, 160, $164,165,176,192,207$

bilateral trade, 124 cannot be dispensed with by any, 22

cannot be remedied by an, 28

Capetown, 166,

Civil Transport, 163

concerning Technical Military

Assistance, 132

conclusion, of, 103

cooperation, 131, 183, 185, 186, 187,

Cotonou, 197

created, by 19

demilitarization, 40

EEC and Socialist Federal Republic of Yugoslavia, 225

Extradition, 196

Fisheries, 136, 139

Gdansk, 145

General Agreement on Tariffs and Trade, 127, 130, 159, 162, 236, 238, 289

Grain, 137, 150

human rights, 236

implementation, of, 212

intergovernmental, 150

international, 22, 89, 94, 102, 105, 130, $171,200,201,233,236$

maintenance of international peace and security, 98

maritime, 150

Multi-Fibre, 158

NATO, 197

non-performance, 101

proliferation, of, 8

regional, 83

Russia concluded an, 40

self-contained, 37

South West Africa Mandate, 42

specific, 37, 50, 101, 132, 211, 217, 239, $240,245,290$

Taxation, 175, 176

textiles, mutton and lamb, 156, 157, 158 
third states, with, 101

Trade, 135, 137, 150, 151, 207, 235

Trusteeship

Cameroon 41

Nauru, 45

United States and Iraq, 108

United States and France, 270, 271,272

violation, of 68

WTO, 230, 231, 232, 234, 236, 237, 241,

Aggression, 3, 8, 49, 59, 62, 63, 64, 65, 66, 78, 91, 95, 103, 113, 114, 123, 139, $178,179,205,208,265,282,288$, 289, 292

Air services, see agreements

Al Barakaat Case, 8, 100, 199, 205

Algeria, 123

Amsterdam Treaty, 100

Apartheid, 3, 8, 59, 78, 91, 205, 208, 289, 292

South Africa, 165, 166, 167, 177, 204

Asiatic Land Tenure and Indian

Representation Act 1946, 166

oil embargo, 168, 169,

US, 169, 170, 172

Comprehensive Anti-Apartheid

Act of 1986, 170, 171, 173

Air Services Between their

Respective Territories 1947

Dutch government, 173

non-intervention, 173

Canadian measures, 175

Commonwealth, see also Commonwealth, 176

Argentina, 95, 99, 140, 207, 224

EEC, 157, 158, 159, 160, 163, 206, 224

Falklands, 156,

GATT, 158

United States, 161, 162

suspension of agreements regarding textiles and mutton and lamb

Armed force, 2, 13, 71, 95, 126, 137, 158, 173, 224, 265, 277, 281, 290.

collective self-defence, 3

Israel, 104

Jus cogens, 26, 27, 245,

Proportionality, 254, 279,

UN, 25

Arms, see also embargo, 23, 94, 129, 141, $165,169,172,176,179,183,185$, 188, 189, 191, 192, 198, 205

Ban, 168
Restrictions

Nigeria, 189

sales, 97,160

Assets, 169, 207, 275

freezing, of

Japanese, 113, 288

China and North Korea, 114

Iraqi, 179, 180, 181

Nigerian, 189

Sudanese, 191

Burmese, 191

Yugoslav, 192, 195

Zimbabwean, 198

Syrian, 198

Belarus, 199

Kadi, 199

$\mathrm{Al}$ Barakaat, see also Al Barakaat Case, 199

Panama, 177

Association Agreement

Greece, 119, 120, 121, 122, 131

Australia, 45, 46, 47, 140, 143, 156, 159, 176,207

Aviation, see also air services, 105

International Civil Aviation

Organization (ICAO), 105

Cease performance, of, 106

Restrictions, 189, 204

Safety, 106

Agreements, 107, 147, 150, 164, 165, $176,192,207$

Civil, 275

Federal Aviation Act of 1958, 149,150

Rights, 152, 195, 198

Fuel, 113

Suspension, of, 145, 146, 165

Ban, 176

Bahrain, 123

Belarus, 199

Belgium, 34, 160

Bilateralism, 6, 12, 13, 14, 35, 38, 74, 75, 83, 285

Bluntschli, 60

Bonn Declaration 1978, 104, 105, 106, 107, 206, 287

Brazil, 95, 115

Brownlie, 63

Burma/Myanmar, 191

Burundi, 190

Cambodia, 128, 129, 130

Cameroon, 167 
Canada, 34, 97, 98, 99, 139, 140, 143, $144,156,159,160,164,165,175$, $176,192,196,257,287$

Capacity, 14, 35, 37, 82, 83, 101, 118, 150, 283

incapacity, 230

Caroline Incident, 257

Carter, 97, 127, 130, 138, 139

Central African Republic, 132, 133, 135,205

Charter of Economic Rights and Duties of States, 155, 158

Chile, 95

China, 113, 114

Circumstance precluding wrongfulness, 24, $69,186,214,215$

Civil Aeronautics Board, 145

Coercion, 72, 268, 278

Economic, 93, 94, 95, 96, 123, 124, 155, 156, 228, 264, 287

Non-forcible, 108

South Africa, 177

Unauthorized, 262

Co-existence, 11, 17, 19, 21, 22, 52

Commonwealth, 170, 176, 189, 198,

Harare Commonwealth Declaration 1991, 189

Consent, 2, 13, 14, 15, 20, 22, 23, 24, 27, $37,38,45,46,50,51,52,53,86$, $104,118,134,175,181,186,204$, 212, 217, 230, 258, 269, 282, 284, 285, 291

Constitutional, quasi-constitutional, constitutionalization, $6,33,53$, 116, 119, 216, 224, 242, 244, 245, 283, 285

Convention establishing the Economic Community of the Great Lake Countries 1976, 190

Cooperation, 11, 15, 16, 65, 95, 98, 99, $100,131,134,138,147,151,178$, 179, 183, 184, 185, 186, 187, 196, 217, 261, 276

Coordination, 13

Costa Rica, 152, 154, 234

Cotonou Agreement, 197

Council of Europe, 109, 116, 118, 119, 120,197

Countermeasures, see also solidarity measures

private justice, mechanisms of, 2, 228,291

peaceful, 2, 3, 6, 10, 31, 69, 226

temporary, 2, 263, 290 distinction from retorsion, 2, 69, 87, 92, 93,101, 174, 186, 206

sanctions, 2, 69, 70

self-defence, 2

termination/suspension of treaties, 2, 29, 68

conditions, 8, 69, 71, 72, 87, 88, 103, 125, 135, 148, 178, 208, 248, 260, 264, 290,

reciprocal, 31, 69, 225, 263

proportionate, 250, 257, 261, 264, 265

instrumental, 72, 273

reversible, 72, 263

powerful weapon, 72,88

self-executing, 91

Covenant of the League of Nations, 62, 94, 274

Crawford, 29, 30, 31, 50, 76, 77, 78, 82, 86, 213, 214, 264, 268, 278

Crimes against humanity, 63, 283

Cuba, 94, 128, 130, 154

Customary rule, norm permitting solidarity measures, 7, 8, 89, 102, 103, 163, 201

state practice, 91, 107, 109, 202, 203

opinio juris, 91, 107, 109, 202, 203

Cyprus, 29, 97, 138, 198

Denmark, 43, 108, 109, 116, 117 , 155, 157,

Development progressive, of, 14, 54, 55, 204, 262

Diplomatic immunities, 12, 17, 33, 73, 80, 144, 222

Dispute

resolution, 217, 239, 242

settlement mechanisms, 13, 227, 229

Dominican Republic, 114, 115, 116, 205, 288

Draft article 19, 65, 74, 77, 78, 85, 286

Economic Community of West African States (ECOWAS), 135

Egypt, 95, 103, 122, 123, 124, 169

El Salvador, 95, 152

Embargo

Air transport, 175

Arms, 94, 129, 131, 141, 165, 169, $172,175,176,182,183,185,188$, 189,191, 192, 197, 205

Chemical exports, 107

Economic, 23

Grain, 140 
Trade, 126, 142, 154, 155, 156, 160, 167, 180, 181, 184, 190, 206, 235, 288

oil, 8, 122, 124, 133, 168, 169, 174, 175, 179, 183, 184, 205, 288

Enforcement, see also implementation

Procedures, 1

International law, of, 1, 2, 9, 68, 71, 88, 90, 93, 220, 228, 241, 245, 281, 283, 289

Mechanisms, 1, 8, 10, 32, 35, 36, 37, 56, 105, 210, 217, 223, 225, 227, 228, 230, 242, 243, 246, 248, 260, 262, 282, 289, 291

Judicial, 3, 43

Institutionalized, 56

Erga Omnes

scope, content, effects, of, 37, 38, 49, 50, 53,58

universality, 34

interest, 35, 49, 178

enforcement, 1, 5, 36, 53, 90, 210

locus standi, 39, 45, 47, 48

human rights, 35, 36, 49, 84, 102, 133, $136,148,152$

partes, 14, 82, 83, 109, 116, 117, 208

distinction from jus cogens, 33, 51, 52

Ethiopia, 41, 84, 94, 95

European Coal and Steel Community (ECSC), 157, 180, 183

European Community, see also European Economic Community, 99, 100, 101, 102, 120, 132, 135, 140, 147, 159, $163,176,178,180$

European Convention on Human Rights, 43, 91, 108, 116, 117, 118, 119, 196, 197, 243, 253

European Court of Human Rights, 43, 108, 196, 227, 243

European Court of Justice, 100, 157, 185, 199, 205, 223, 224, 225, 250, 251, 252, 253

European Economic Community, see also European Community, 99, 119, 120, 121, 122, 130, 131, 140, 141, 142, $143,144,151,156,157,158,159$, $160,161,162,163,174,175,178$, 183, 185, 187, 204, 206, 207, 225

European Parliament, 101, 119, 120, 199

European Political Co-operation, 99, 100,178

European Union, 26, 99, 100, 187, 224

Extradition, 8, 104, 105, 196, 197, 205
Falkland Islands, 156, 157, 163, 207, 224

Final Articles on State Responsibility 2001, $3,4,7,31,54,55,66,68,76,77,79$, 81, 82, 83, 84, 85, 86, 87, 89, 91, 109, $110,118,124,126,134,143,182$, 201, 239, 240, 262, 263, 264, 268, $273,278,286,287,290$

Finland, 40, 165, 169

Foreign Assistance Act, 96, 97

Force majeure, 103

Foreign policy, 96, 97, 99, 128, 136, 154, 170, 171, 206

Fragmentation, 9, 210, 218, 241, 242, 244,245

France, 39, 40, 44, 47, 95, 107, 119, 132, $148,151,152,160,164,165,188$, $192,236,253,270,271,272$

Frowein, 36, 236

Fundamental change of circumstances, 6, 62, 102, 110, 131, 132, 134, 146, 186, 187, 188, 206, 214, 223, 225, 283, 284, 288

General Agreement on Trade and Tariffs (GATT), 108, 115, 124, 126, 127, 130, 131, 133, 147, 151, 153, 154, $155,156,157,158,159,160,161$, 162, 163, 168, 169, 175, 181, 187, 190, 191, 198, 206, 207, 228, 229, 233, 235, 236, 238, 289

Genocide, 3, 8, 29, 36, 41, 49, 51, 59, 77, $78,79,83,85,88,91,96,129,130$, 131, 188, 205, 208, 230, 238, 239, 282, 283, 286, 289, 292

Germany, 39, 40, 70, 93, 107, 151, 152, 160, 164, 165, 192, 207, 236, 261,269

Ghana, 126, 167

Great Britain, 40, 110, 111, 112, 113, 257

Grotius, 60

Guatemala, 95, 152

Hague Convention for the Suppression of Unlawful Seizure of Aircraft, 105

Haiti, 8, 115, 169, 181, 204, 205

Helsinki Final Act, 145, 147, 149

Hijacking aircraft, 104, 105, 106, 107, 206, 275,287

Honduras, 152, 154, 234

Human rights, see also fundamental freedoms

basic, 49, 73, 96, 148 
erga omnes character, 49, 152, 236

clauses, 92, 95, 100, 101, 133, 186

foreign security and economic assistance, 96

treaties, 81, 102, 220, 222, 225, 226, 227, 236

Act 1998, 253

Hungary, 167, 212, 213, 214, 272, 273

India, 166, 167, 233, 275

Indonesia, 46, 47, 167, 207

Injury

nature, extent, 75, 76

direct, 7, 14, 39, 82, 92, 102, 109, 113 , $118,119,165,174,187,200,204$, 210, 281, 284, 287

individual, 37, 41, 42, 48, 91, 162, 203, 281

reparation, 2, 248, 268, 286

legal, 4

Interests

Fundamental, 1, 3, 15, 26, 27, 43, 65, $66,74,88,92,99,100,108,113$, $119,135,137,153,162,166,173$, 181, 195, 206, 208, 209, 262, 276, 282, 292

Legal, 39, 44, 45, 47, 53, 83, 87, 108, 154, 178, 209, 221, 237, 249,264

Bilateral, 279

'extra-state', 59, 60, 83

national, 97, 162, 262

Interference, 113, 114, 133, 135, 138, 140, $149,153,166,190,249,254,264$

non-interference, 13, 92, 93, 96, 153,274

unlawful, 13

International Civil Aviation Organization (ICAO), 105, 164, 165

International Court of Justice

consent, 1, 38

standing, 38, 41, 42, 43, 45, 47, 48

hostages case, 80, 141, 142, 143, 222,235

obiter dictum, 4, 35, 49, 53, 83, 84, 90

third states, 7, 44, 45, 46

compliance, with, 45

obligations erga omnes, 11, 17, 33, $34,37,39,41,43,48,49,50,52$, 166, 285

peremptory norm, 28, 29, 32

claim

individually owed, 13
International Covenant on Civil and Political Rights 1966 (ICCPR), 134

International Covenant on Economic, Social and Cultural Rights 1966

(ICESCR), 264

International crimes, 63, 66, 67, 68, 74, 201, 267, 286

International Criminal Court, 61, 63, 283

International Criminal Tribunal for the Former Yugoslavia (ICTFY), 242, 243

International Federation of Airline Pilots (IFAP), 164

International law

Nature, 6, 13, 20, 52, 243

Traditional, 12, 17, 22, 23, 35, 59, 80,242

unity, of, 241, 247,

fragmentation, of, 9, 210, 218, 241, 245

International Monetary Fund, 145

Internationally wrongful acts gravity, of, 73, 268, 277

seriousness, of, 144, 208, 266, 279, 286

Iran, 48, 141, 142, 143, 144, 206, 219, 227,245

Iraq, 107, 108, 123, 124, 173, 178, 179, 180, 181, 206, 288

Ireland, 157, 252

Israel, 103, 104, 122, 123,124, 125, 288

Italy, 39, 44, 94, 152, 157

Ivory Coast, 167

Japan, 39, 94, 113, 114, 143, 151, 164, $165,169,180,181,192,205,288$

fus cogens norms, see also peremptory norms, 1, 10, 11, 17, 20, 21, 22, 23, $24,25,26,27,28,29,30,31,32,33$, $37,42,46,47,50,51,52,53,58,63$, 76, 78, 79, 83, 84, 86, 87, 123, 146, 211, 217, 222, 226, 227, 241, 245, $248,263,278,286,290$

Kenya, 190

Kiel Canal, 39

Koskenniemi, 233, 244, 262

Kuwait, 123, 124, 126, 167, 178, 179, 180, 181, 205, 206

Latin American Economic System, 155

Lauterpacht, Hersch, 62-63

Law of nature, 19, 60, 111

League of Nations, 40, 41, 42, 62, 65, $94,261,274$ 
Lebanon, 198

Legal consequences

Differentiated, 19

Community interests, 4, 5, 7, 10, 12, 21,67

Peremptory norms, 27, 29, 31, 32, 51, $54,58,79,286$

Content, obligation of, 61, 63, 64, 66, 74,77

Gravity, seriousness, 277, 286

subjects, 59, 90

Levin, 63

Lex generalis, 210, 217, 227

Lex specialis, 8, 92, 155, 210, 216, 217, 218 , 219, 220, 227, 228, 231, 236, 239, 240, 243, 246, 289

Liberia, 41, 84, 135, 205

Libya, 123, 133, 167, 243

Lichtenstein, 198

Lome Convention, 130, 131, 132, 135, 181, 182, 197

Malaysia, 167

Malta, 198

Mexico, 233

Most favoured nation treatment, 124, 187

Namibia, 176, 216

Nationality of claims, 84

Naulilaa Incident, 70, 269, 270, 277

Necessity

countermeasures, of, $3,71,73$, 173,234

protection of essential interests, 155 , 173, 208, 282

ecological, 213

environmental, 213

suspension, termination, treaty of, 214

temporary non-performance, 214

military, 256

and proportionality, 257, 258, 259, 263

New Zealand, 45, 47, 139, 140, 156, 160

Nicaragua, 45, 48, 95, 115, 152, 153, 154, $155,202,205,234,235,258,259$

Nigeria, 167, 169, 189, 198

North Atlantic Treaty Organization

(NATO), 148, 164, 188, 197, 252

Norms

Superior, 10, 17, 20, 125, 240, 285, 286 Higher, 54

Primary, 4, 57, 60, 65, 76, 82, 210, 216, $220,227,240,243,244,246,249$, 267, 285, 286, 289
Secondary, 57, 64, 76, 210, 211, 213, 218, 220, 224, 225, 227, 236, 237, $242,243,246,249,267$

hierarchy, 20, 23, 77, 78, 242

North Korea, 114, 128

Norway, 43, 116, 117, 160, 169

Nuclear weapons

proportionality, 242, 259, 260

use, 18, 32,

prohibition, of, 19,

international humanitarian law, 259, 260

Oman, 124

Organization of African Unity (OAU), 126, 167, 169, 190, 205, 207

Organization of American States (OAS), 114, 115, 116, 162, 163, 161, 181, 207

Pakistan, 106, 107, 167, 169, 275

Panama, 177, 178, 181

Peremptory norms, see also jus cogens community interests, 6, 24, invalidity, null, 11, 29, 31 compulsory procedures indirect conflict, 31,86 , serious breaches, 76, 78, 79, 86, 89, 286

Permanent Court of International Justice (PCIJ), 13, 38, 39, 42, 53, 226

Philippines, 95, 167

Poland, 39, 94, 110, 145, 146, 147, 148, 149, 150, 151, 152, 163, 204, 206, 288

Portugal, 46, 47, 70, 123, 126, 167, 205, 206, 269

Qatar, 123

Racial discrimination, 49, 63, 96, 167

Reparation, 2, 27, 57, 58, 60, 68, 70, 72, 77, 79, 83, 84, 85, 164, 226, 248, 257, 263, 265, 268, 269, 270, 273, 275, 286, 290

Reprisals, see also Naulilaa Incident armed, 71, 242

third party, 63, 159

self-help, 269

Restitution in kind, 27, 60, 67, 68, 72, 78

Retaliatory action, 98

Rights, see also human rights subjective, 13, 39, 58, 69, 76

indispensable, third, 19, 22, 26, 43, 45, $46,47,226$ 
integral, 75, 80

indivisible, 81

sovereign, 95, 96, 101, 135, 221

property, 113, 114, 193, 199, 252

Rule of law, 3, 42, 118, 129, 198, 203, 211 , 224, 247, 248, 282, 283

Rwanda, 190

Saudi Arabia, 123, 124, 126, 205

Self-contained regimes, see also lex specialis, 6, 8, 9, 37, 92, 209, 210, 211, 216, 219, 220, 221, 222, 223, 225, 226, 228, 230, 235, 237, 239, 240, 243, 245, 246, 247, 289, 290

World Trade Organisation, see also World Trade Organisation, 92

European Union, see also European Union, 222, 224

Self-determination, 27, 46, 62, 78, 123, $125,126,165,182,282,289$

Sierra Leone, 112, 167

Simma, Bruno, 37, 46, 220, 222, 225, 237, 247

Single European Act 1987, 99, 100

Slavery, 36, 49, 110, 111, 112, 190, 205, 208, 282, 288, 289

Social Federal Republic of Yugoslavia (SFRY), see also Yugoslavia, 182, 187

Solidarity measures

definition, 2, 54,

state practice, opinio juris $6,8,92,98$, $102,103,114,121,122,131,132$, $133,137,150,153,161,162,163$, $165,169,171,172,177,187,190$, 191, 198, 199, 202, 203, 204, 205, 206, 207, 209, 211, 288, 289

self-contained regimes, 247

implementation, enforcement, 3, 208, 281, 285, 292

serious violations, international law, of, $88,108,173$

ILC, 3, 7, 76, 87, 89, 109, 110, 201, $262,287,290$

Risks, 4, 262, 281

Peremptory norms, obligations erga omnes, 5

Proportionality, 9, 250, 262, 265, 279, 280, 291

South Africa, 8, 42, 75, 84, 94, 123, $165,166,167,168,169,170,171$, 172, 173, 174, 175, 176, 177, 204, 205, 206

South Korea, 95, 114, 163, 165
South West Africa, 35, 38, 41, 43, 48, 75, 84, 269

actio popularis, 35

Southern Rhodesia, 98

Sovereign equality, 2, 20, 67, 79, 89, 93, 249, 261

Sovereignty, 13, 15, 16, 19, 50, 63, 87, 138, 153, 198, 258, 261, 265, 285

Soviet Union, 63, 94, 103, 104, 110, 115, $135,136,137,139,140,141,143$, $145,149,150,151,152,163,164$, 204, 205, 206, 288

Spain, 34, 164, 165

Sri Lanka, 169

Standing, 12, 33, 37, 40, 42, 48, 60 judicial proceedings, 5, 7, 12, 17, 45, 90 general, 6, 39, 41, 43, 44, 48, 49, 53, 285 legal, 34, 38, 47, 48

State crimes, 7, 20, 30, 32, 34, 51, 59, 61, $62,63,64,65,66,67,68,74,76,77$, 78, 85, 89, 129, 147, 201, 207, 265, 267, 286

State practice inconclusive, 93, 287

ambiguous, 93,

legal assessment, 201,

State responsibility forms, 57, 61, 77,

subjects, entitled to invoke responsibility, 7, 54, 57, 58, 59, 60, 82, 90, 281

Sudan, 167, 190, 191

Suez Canal, 95, 103

Summit Conference of Arab States, 168

Switzerland, 147, 165, 180

Syria, 122, 123, 198

Tanganyika, 167

Tanzania, 131, 190

The Netherlands, 43, 98, 117, 119, 123, 133, 134, 174, 175, 196, 197, 243, 287

Tokyo Convention on Offences and Certain other Acts Committed on Board Aircraft, 104-105

Trade

Exchanges, 94, 117

Relations, 95, 155, 167

Ban, 130

Restrictions, 168, 174, 176, 183, 190, 205, 238, 239, 241

Treaty, see also agreements

Multilateral, 14, 50, 75, 80, 225, 230, 235 
Disarmament, 75, 81

Innocent, 29, 86

fundamental change of circumstances, $102,110,131,132,134,146$, $186,187,188,206,214,223$, 225,288

material breach, 29, 68, 81, 120, 146, 213, 263

impossibility of performance, 102 , 187, 213

pacta tertiis rule, 13

pacta sunt servanda, 186

Westphalia, of, 20

Invalidity, 22, 28, 47, 51

Suspension, termination, of, 2, 29, 68, $100,102,107,108,120,121$, $132,134,139,140,145,146$, $147,149,152,156,157,158$, $160,163,164,165,171,176$, $185,186,187,195,213,214$, 215, 216, 217, 224, 237, 263, $270,275,289$

Null, 28, 29, 32, 47

Human rights, see also human rights treaties

Treaty on European Union 1992 (TEU), 99, 100, 195, 224

Treaty of Rio de Janeiro, 114, 116

Treaty of Rome, 185, 250

Treaty of Versailles, 39, 40, 269

Turkey, 40, 108, 109, 119, 164

Uganda, 8, 101, 121, 126, 127, 128, 128, 129, 130, 131, 167, 190, 204, 205, 236, 288

United Kingdom, see also Great Britain, 39, 40, 43, 44, 45, 95, 107, 142, 143, 144, 147, 151, 156, 160, 161, 164, 165, 169, 170, 188, 192, 193, 194, 195, 196, 197, 198, 224, 258

United Nations Charter, 6, 8, 22, 50, 63, 71, 95, 97, 98, 100, 114, 115, 123, $124,138,139,141,145,147,148$, $149,154,158,160,165,166,174$, $176,178,182,185,188,189,190$, 199, 200, 235, 243, 254, 257, 259, 263, 265, 283

United Nations General Assembly, 4, 50, $55,57,65,69,70,88,89,98,126$, 166, 167, 168, 203, 205, 206, 265
United Nations Security Council, enforcement, international law, of, 1 , $88,90,115,174,283$

institutionalized responses, 6,75

authorization, 27, 71, 98, 100, 101, $128,142,158,161,162,168$, $175,176,177,178,180,181$, 182, 183, 184, 199, 204, 205, 254, 277

peace, security, 94

sanctions, measures, action, 97, 98, 141, 156, 165, 169, 179, 187, 188, 191

human rights, 199, 200, 205

United States, 44, 48, 94, 95, 96, 97, 107, $108,110,111,113,114,115,122$, 123, 124, 125, 127, 128, 129, 131, 133, 135, 136, 137, 139, 140, 141, $145,146,147,148,149,150,151$, $152,153,154,155,161,162,163$, $164,165,169,170,171,173,177$, 178, 180, 188, 189, 191, 192, 196, 197, 198, 199, 205, 207, 219, 233, 234, 235, 245, 257, 270, 271, 272, 274, 292

Universal Declaration of Human Rights, 147, 148, 149

Use of Force armed, 48 prohibition, 15, 19, 71, 91, 95, 108, 160, $164,254,263$

erga omnes, 124

proportionality, 249, 250, 255, 260, 276,277

unlawful, 28, 140, 144, 154, 155

serious violation, 62, 123, 165

Venezuela, 114

Vietnam, 128, 130

World Trade Organization (WTO), 9, 92, 211, 227, 228, 229, 230, 231, 232, 233, 234, 236, 237, 238, 239, 240, 241, 246, 289

Yugoslavia, see also Social Federal Republic of Yugoslavia, 51, 182, 183, 184, 185, 186, 187, 188, 191, 192, 193, 194, 195, 224, 288

Zaire, 190

Zimbabwe, 197, 198 






